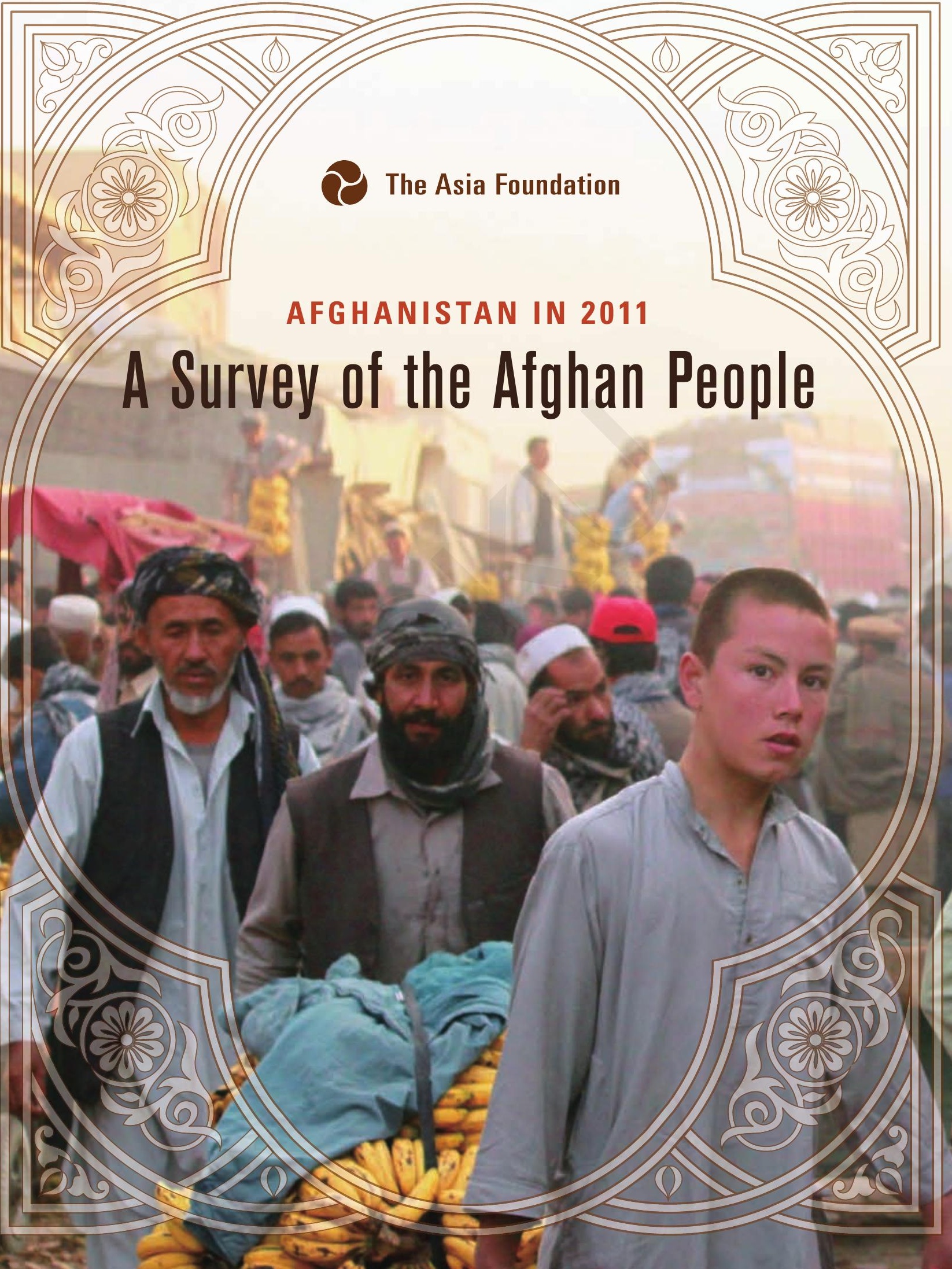




\section{AFGHANISTAN IN 2011 A Survey of the Afghan People}

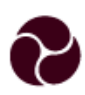

The Asia Foundation 


\title{
Afghanistan in 2011
}

A Survey of the Afghan People

\section{Project Design and Direction}

The Asia Foundation

\author{
Editor \\ Ruth Rennie
}

\author{
Report Authors \\ Mohammad Osman Tariq \\ Najla Ayoubi \\ Fazel Rabi Haqbeen
}

\section{Fieldwork}

Afghan Centre for Socio-economic and Opinion Research (ACSOR), Kabul

\author{
Report Design and Printing \\ The Asia Foundation \\ AINA Media, Kabul
}

\section{(C) 2011, The Asia Foundation}

\section{About The Asia Foundation}

The Asia Foundation is a nonprofit, non-governmental organization committed to the development of a peaceful, prosperous, just, and open Asia-Pacific region. The Foundation supports Asian initiatives to improve governance, law, and civil society; women's empowerment; economic reform and development; sustainable development and the environment; and international relations. Drawing on nearly 60 years of experience in Asia, the Foundation collaborates with private and public partners to support leadership and institutional development, exchanges, and policy research.

With 18 offices throughout Asia, an office in Washington, DC, and its headquarters in San Francisco, the Foundation addresses these issues on both a country and regional level. In 2010, the Foundation provided more than $\$ 98$ million in program support and distributed nearly one million books and journals valued at over $\$ 42$ million.

The Asia Foundation is not an endowed organization, and depends solely on monetary contributions from donors to accomplish its work.

For more information, visit www.asiafoundation.org 


\section{Table of contents}

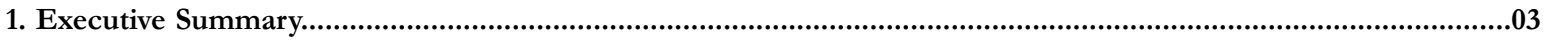

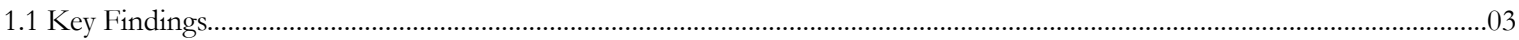

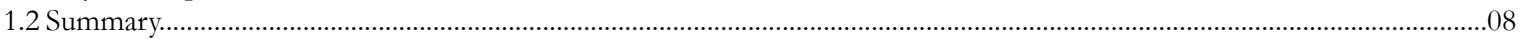

1.3 Restriction on survey field work and replacements of sampling points for security reasons.................................................14

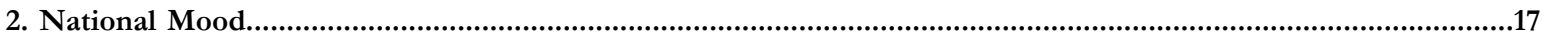

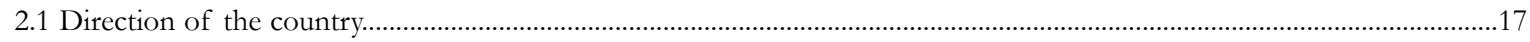

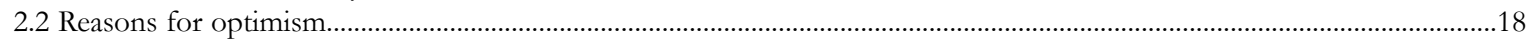

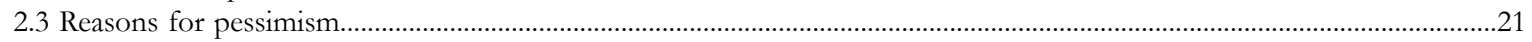

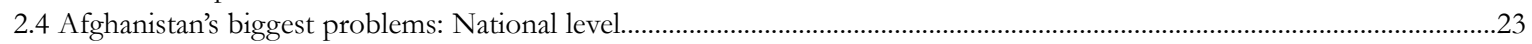

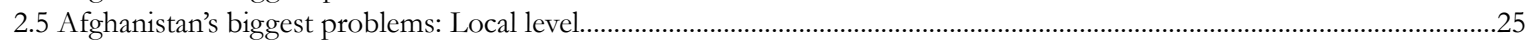

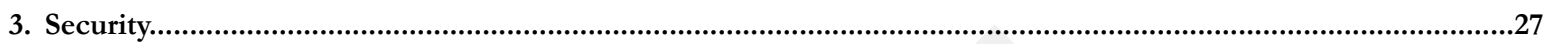

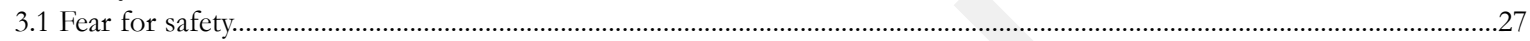

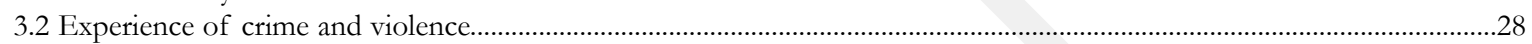

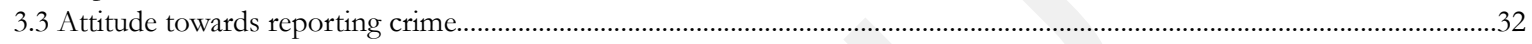

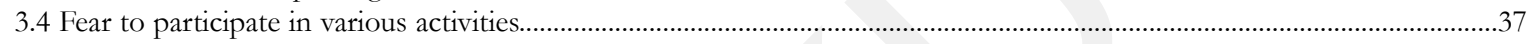

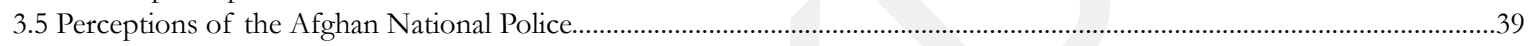

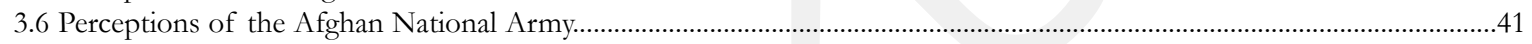

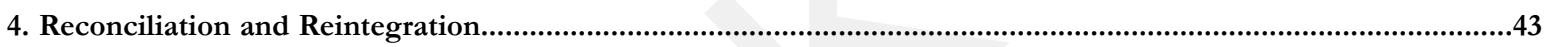

4.1 Perceptions of the government's reconciliation efforts......................................................................................................4

4.2 Reasons why armed opposition groups fight the Afghan government.................................................................................4

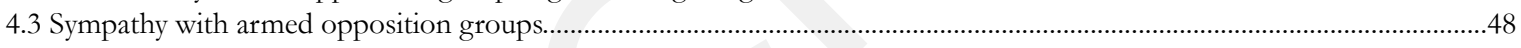

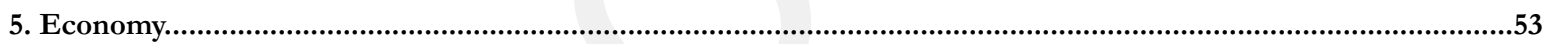

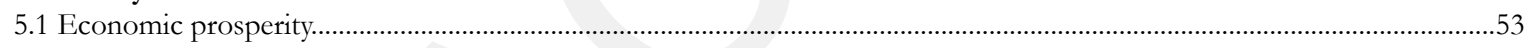

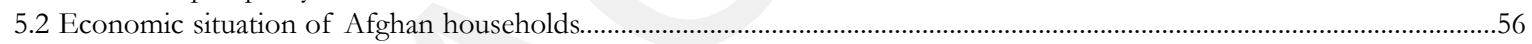

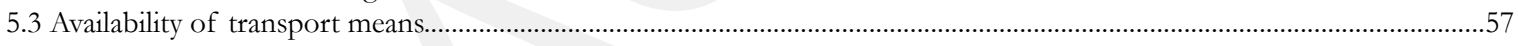

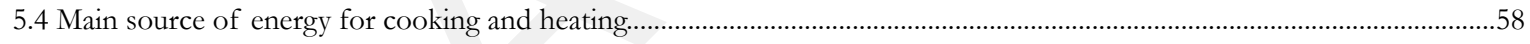

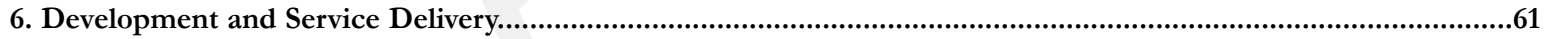

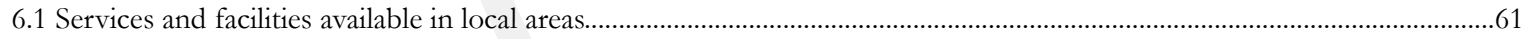

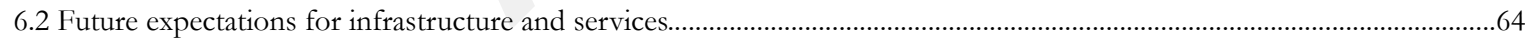

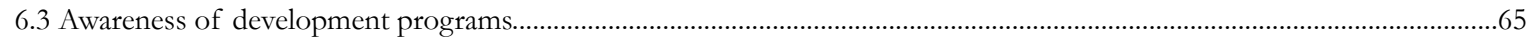

6.4 Development programs and public awareness of foreign aid............................................................................................67

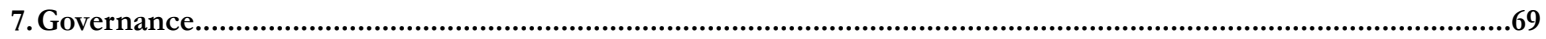

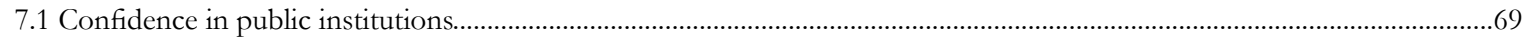

7.2 Satisfaction with the performance of the central government..............................................................................................72

7.3 Satisfaction with central government performance in policy and service delivery......................................................................74

7.4 Important achievements and failings of the central government …………........................................................................75

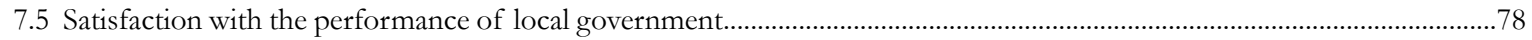

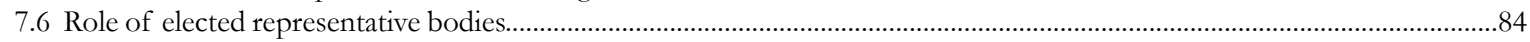

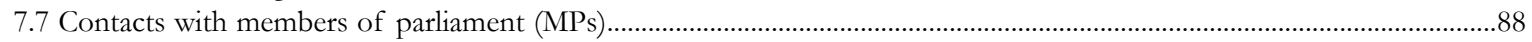

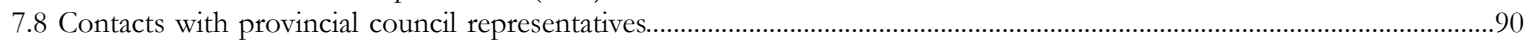

7.9 Role of community development councils................................................................................................................. 
8. Corruption

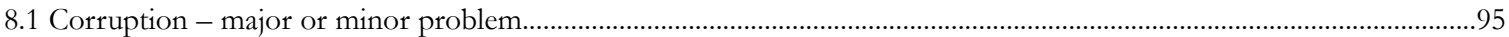

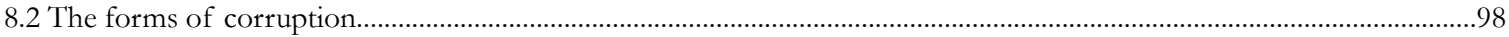

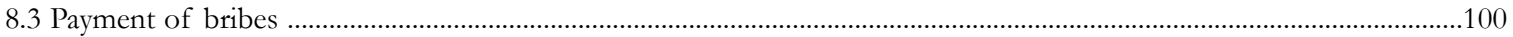

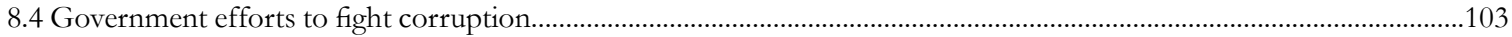

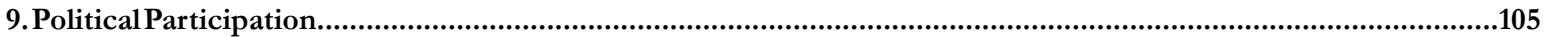

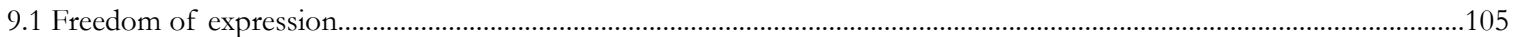

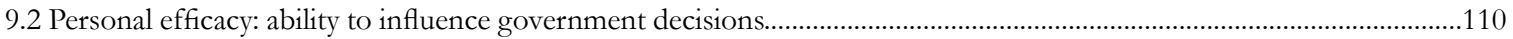

9.3 Consideration of the public interest when making decisions and policies..........................................................................111

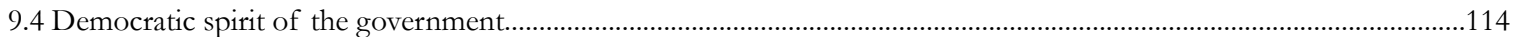

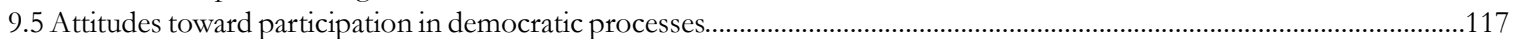

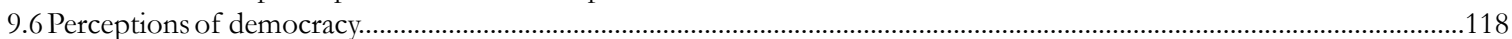

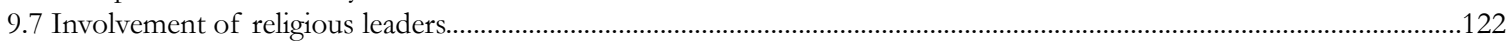

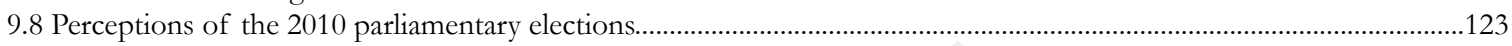

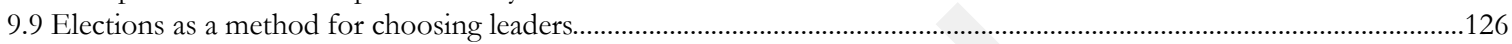

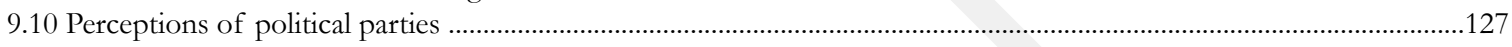

9.11 Constitutional responsibilities of the president and parliament ..................................................................................130

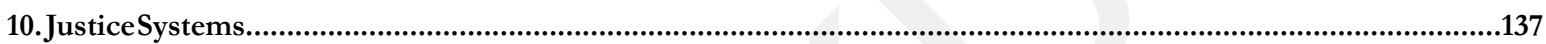

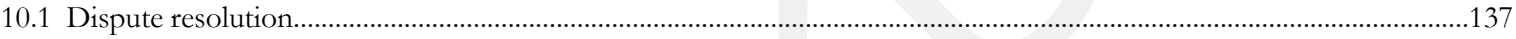

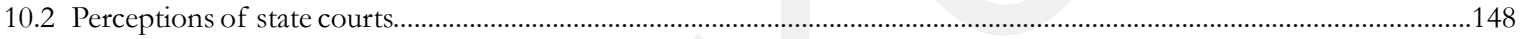

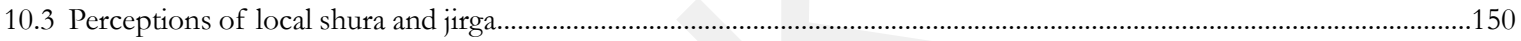

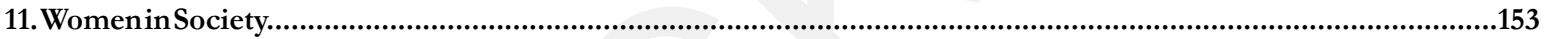

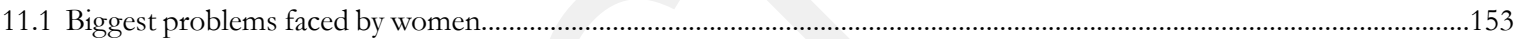

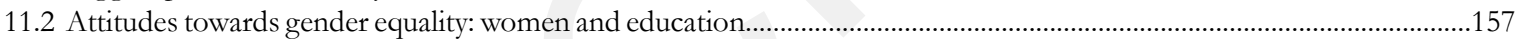

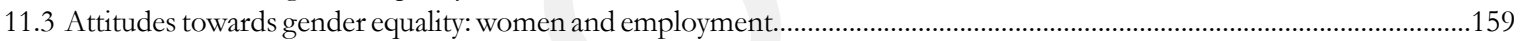

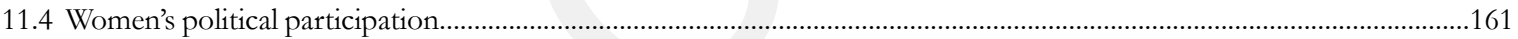

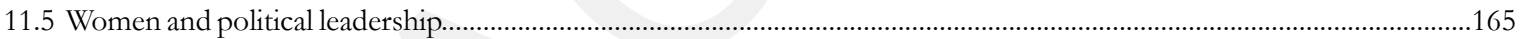

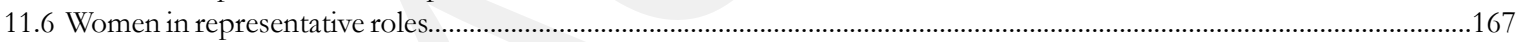

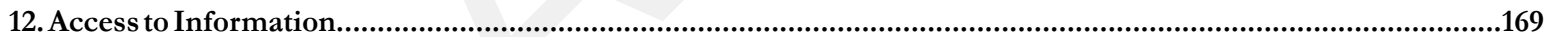

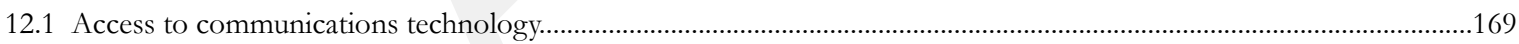

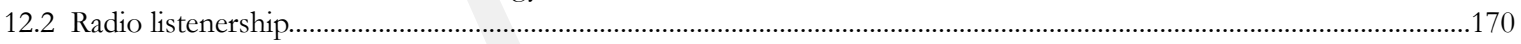

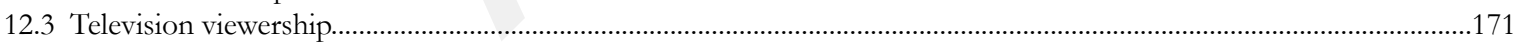

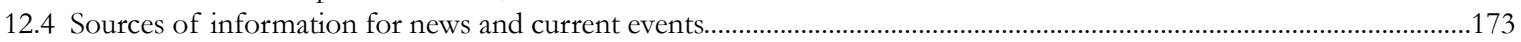

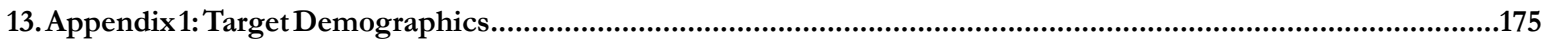

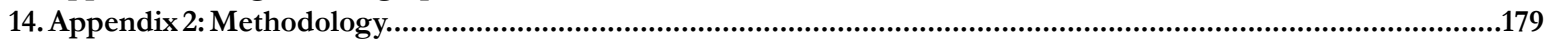

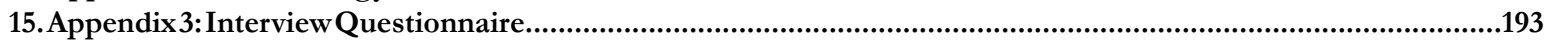

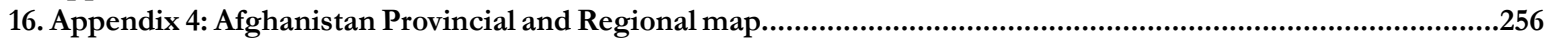




\section{PREFACE}

2011 has been an important and eventful year for the people of Afghanistan. The 12 months since The Asia Foundation conducted its last Survey of the Afghan People have been filled with significant developments, including beginning the initial phases of the planned transition of the country's security to Afghan leadership. As the international community and Afghan citizens alike reflect on the last decade in Afghanistan, the opinions expressed by the people of Afghanistan matter more than ever.

Against this backdrop, The Asia Foundation conducted its seventh nationwide survey of Afghan public opinion, the broadest and most comprehensive poll in Afghanistan. In July 2011, the Foundation interviewed close to 6,500 adult Afghans, face-to-face, across the 34 provinces of Afghanistan.

The survey, as in previous years, provides a sense of the mood and direction of the country. It is both a snapshot of Afghan perceptions at a specific point in time and a tool to measure shifts in public opinion over a longer period of time. The survey aims to gather firsthand opinion of a large sample of Afghan citizens on a variety of contemporary governance and development-related issues so that policymakers and opinion shapers in government, the international community, and the broader Afghan public can utilize valid and reliable data as they make decisions and craft future policy.

In 2011, despite the economic, political, and security challenges facing Afghanistan, close to half of respondents remain optimistic, and say the country is moving in the right direction. The survey suggests that Afghans view the country's economic situation more favorably than in previous years, although unemployment remains one of the country's biggest problems. The majority agree that women should have equal opportunities. The 2011 survey also records the highest levels of access to education and health services, and growing understanding of the role of public institutions. While there is growing public confidence in the Afghan security forces and police, there is at the same time an increased reluctance by the public to fully participate in their own governance - particularly for women - a rising concern of corruption at all levels, and acknowledgement of an increasingly challenging security environment.

The 2011 Survey of the Afghan People is the latest in a series of empirical assessments that The Asia Foundation has conducted across Asia. The Foundation has established a reputation for developing surveys in order to pinpoint citizen concerns and needs, to gauge public support and development progress, and inform important policy debates and development programs.

The survey also represents an investment by The Asia Foundation in building Afghan research capacity. The survey was managed by our office in Afghanistan, working in close collaboration with several Afghan organizations, including Kabul-based Afghan Center for Socio-Economic and Opinion Research (ACSOR) and the Central Statistics Organization of Afghanistan (CSO).

Afghanistan is striving to rebuild, accelerate development, and attain a better future. We hope that the survey findings - which capture the realities, concerns, goals, and expectations of the Afghan people - will help illuminate the situation on the ground and provide useful guideposts for future development efforts by the Afghanistan government and the international community.

David D. Arnold

President, The Asia Foundation

October 2011 


\section{ACKNOWLEDGEMENTS}

The survey remains an impressive team effort that involved local partners and The Asia Foundation staff in Kabul working under the guidance of Country Representative Dr. V. Bruce J. Tolentino, Deputy Country Representative Sheilagh Henry, and Survey Project Manager Jehangir Gabar. Special thanks to Asia Foundation Program Directors Mohammad Osman Tariq, Najla Ayoubi, and Fazel Rabi Haqbeen for their contributions as principal authors of the survey. Staff in San Francisco and Washington, DC also greatly supported the project. We also thank Sudhindra Sharma and Pawan Kumar Sen of Inter Disciplinary Analysts (IDA) for their guidance, and Ruth Rennie for her editorial assistance. Finally, the support of the United States Agency for International Development (USAID) and its team of professionals - particularly Mir Waez Zarif - made this important research and capacity-building tool possible. 


\section{Executive Summary}

\subsection{Key Findings}

Nearly half of the respondents (46\%) in 2011 say that things in the country are moving in the right direction. Thirty-five percent say things are moving in the wrong direction - an increase of 8\% compared to 2010.

The main reason for people's optimism is reconstruction/rebuilding (40\%). Of those who are optimistic, more than a third of respondents in 2011 say it's because of good security (39\%) and 16\% cite improvement in the education system.

At the same time, insecurity is the top reason for pessimism, cited by $45 \%$ of the respondents who say the country is moving in the wrong direction. This is followed by corruption (16\%), bad government (15\%) and unemployment $(13 \%)$.

Insecurity (including attacks, violence and terrorism) is identified as the biggest problem in Afghanistan by over a third of respondents (38\%), particularly in the South East (56\%), East (53\%) and South West (52\%). Unemployment remains the second biggest problem, cited by $23 \%$ of respondents. Corruption is identified by $21 \%$ of respondents making it the third biggest problem in 2011 . Poverty $(12 \%)$, poor economy $(10 \%)$, lack of education $(10 \%)$, presence of the Taliban $(8 \%)$, suicide attacks $(8 \%)$ and interference of foreign countries $(7 \%)$ also continue to be identified amongst Afghanistan's biggest problems.

Unemployment continues to feature amongst the most important problems at both national and local levels with $23 \%$ of respondents identifying unemployment as a problem at the national level and $28 \%$ at the local level. Other major problems at the local level include basic infrastructure and services such as electricity (23\%), drinking water $(20 \%)$, roads $(15 \%)$, education (14\%), insecurity $(14 \%)$ and lack of healthcare/clinics/ hospitals $(12 \%)$, similar to previous years.

More than half of respondents $(56 \%)$ say they fear for their personal safety in their local area. The highest proportions of respondents who report fearing for their safety are in the South East (68\%), West (62\%) and East $(61 \%)$. There have also been significant increases in the incidence of crime and violence experienced by respondents in these same regions since 2010 , with $4 \%, 3 \%$ and $8 \%$, respective increases. There has been a $9 \%$ increase in the incidence of crime in the North West.

Twenty-two percent of respondents report that they or someone in their family have been victims of violence or crime in the past year, which is the highest level recorded to date. The most common form of crime experienced remains physical attack or beating $(36 \%)$ followed by burglary/looting $(12 \%)$ and racketeering and extortion (10\%). Violence resulting from the actions of foreign forces $(8 \%)$ is most commonly reported in the South West (27\%), followed by the South East (9\%), Central/Hazarajat (6\%) and East (5\%). Violence due to militant/insurgent actions (4\%) is cited most often in the East (8\%), Central/Kabul (6\%), North East $(5 \%)$ and South East (5\%). 


\section{4 | Afghanistan in 2011}

The majority of respondents say they would have some level of fear voting in a national election (57\%), participating in a peaceful demonstration (66\%), running for a public office $(63 \%)$, traveling from one part of Afghanistan to another part of the country $(75 \%)$ and encountering international forces (76\%). However, more than half of respondents say they would have no fear participating in resolving problems in their communities (59\%) or encountering officers of the Afghan National Army (ANA) (55\%) or Afghan National Police (ANP) (51\%).

In 2011, support for the government's approach toward negotiation and reintegration of armed opposition groups remains high. Eighty-two percent of respondents support the government's attempts to address the security situation through negotiation and reconciliation with armed opposition. Support for the government's peace and reconciliation efforts and negotiations with the armed opposition is high in all regions and highest in the East (89\%), South West (87\%), North West (85\%) and South East (83\%). Eighty-one percent of respondents also agree with the government providing assistance, jobs and housing to those who lay down arms and want to reintegrate into society.

The proportion of respondents who say they have some level of sympathy with the motivations of armed opposition groups reaches its lowest level in 2011. Support has fallen from 56\% in 2009 and $40 \%$ in 2010 to $29 \%$ in 2011 . However, more than a third of respondents in the East (41\%), South East (41\%), and South West $(37 \%)$ say they have some level of sympathy with armed opposition groups.

In 2011, the majority of respondents report satisfaction with the availability of most basic services, including education for children (73\%), water for drinking (70\%), the ability to move safely in local areas (70\%) and the availability of clinics and hospitals $(57 \%)$. Nearly half of respondents are satisfied with the availability of water for irrigation (45\%). Respondents are least satisfied with the availability of jobs and electricity supply. At the same time, $70 \%$ say the availability of jobs in their local area is bad and $65 \%$ say the same about the supply of electricity.

In 2011, more people report an annual improvement across all areas of economic wellbeing than in previous years, except in relation to electricity supply. Forty-three percent of respondents report improvement of the financial wellbeing of their household (compared to 42\% in 2010 and 31\% in 2009), 35\% report improvement in the quality of their food diet (compared to 33\% in 2010 and $23 \%$ in 2009), and $30 \%$ say the same about the availability of products in the market (compared to $27 \%$ in 2010 and $19 \%$ in 2009). Twenty-two percent of respondents report an improvement in electricity supply but this is reported by more urban (40\%) than rural $(17 \%)$ respondents.

More than half of respondents say they are aware of development projects relating to reconstruction/building of roads and bridges (59\%) and education (57\%) in their local area. Forty-eight percent report awareness of projects related to drinking water supply, 44\% report awareness of healthcare programs, 33\% are aware of programs related to agriculture and $18 \%$ of programs to support industry. 
Slightly more than a quarter of respondents $(27 \%)$ say the United States has provided the most aid for projects implemented in their local area, which is a significant drop from previous years (48\% in 2006, 44\% in 2007, 46\% in 2008 and 41\% in 2009). Respondents also identify Germany (7\%) - particularly in the North East (22\%), Japan (6\%) - particularly in the East (12\%) and South West (10\%), India (4\%) - also in the East $(8 \%)$ and South West (10\%), and the United Kingdom (Britain) $(2 \%)$ - especially in the South West (8\%) as major donors supporting development projects in their local area.

Overall satisfaction with the performance of the national government has remained the same as in 2010 with $73 \%$ of respondents saying the government is doing a good job. The government's performance is judged most positively with regard to the provision of basic public services such as education $(85 \%$ say the government is doing a good job), healthcare (68\%) and security (62\%). Although less than half of respondents say the government is doing a good job in reviving/developing the economy (46\%), creating job opportunities $(36 \%)$ and fighting corruption (35\%), levels of satisfaction with the national government's performance in all these areas have risen slightly since 2010 .

Satisfaction with the performance of other levels of government has also risen in 2011. Respondents are most positive about the performance of their provincial government $(80 \%)$ which is equal to the highest figure recorded in 2007. Sixty-eight percent of rural respondents say that their local authority is doing a good job, which is also just short of the highest figure recorded in 2009 (69\%). Respondents are least satisfied with the performance of municipalities (63\%). However, this figure has risen significantly since 2010 (54\%) to its highest recorded level in 2011.

The 2011 survey records the highest levels of confidence recorded to date in a range of public institutions including provincial governments (67\%), parliament (62\%), the public administration $(62 \%)$ and community development councils (CDC) (68\%). This year for the first time, a majority of respondents express confidence in municipal authorities (55\%) and the state justice system (55\%).

The survey shows that the majority of Afghans think that corruption is a major problem in all facets of life and at all levels of government. A little more than half of respondents say corruption is a major problem in their daily life (56\%) and their local authorities (56\%); these figures have been rising since 2007. Around two thirds say that corruption is a major problem in their provincial government (64\%), and around three quarters think that corruption is a major problem for Afghanistan as a whole $(76 \%)$.

Representative bodies continue to enjoy the confidence of the majority of respondents, including community shura and jirga (70\%), community development councils (CDC) (68\%), provincial councils (67\%) and parliament $(62 \%)$. This year the level of confidence in all these bodies has increased compared to 2010. In 2011, for the first time the majority of respondents are aware of a CDC in their area, particularly in rural areas. Levels of satisfaction with the performance of CDCs also increased slightly in 2011 (81\%) compared to 2009 (78\%). 


\section{6 | Afghanistan in 2011}

Overall, $26 \%$ of respondents say they feel safer to express their opinions this year than last year, while $20 \%$ say they feel less safe. Respondents who say they feel less safe are predominantly in the South East (27\%), North East (21\%) and Central/Kabul (21\%) regions. The major barriers to freedom of expression are identified as poor local security conditions $(37 \%)$, fear for personal safety $(32 \%)$, presence of the Taliban (26\%) and government restrictions on freedom of political opinion $(18 \%)$.

More than two thirds of respondents (69\%) say they are satisfied with the way democracy works in Afghanistan. Satisfaction is highest in the Central/Hazarajat (78\%), West $(76 \%)$ and North West $(75 \%)$. However, $40 \%$ of respondents in the South East, 34\% in Central/Kabul and 31\% in the North East say they are dissatisfied with the way democracy is working. Fifty-three percent of respondents say they can have some level of influence over government decisions, which is the lowest figure recorded to date (declining from $66 \%$ in 2008 to $56 \%$ in 2009 and 54\% in 2010). In 2011, the proportion of respondents who agree that it is unacceptable to talk negatively about the government $(68 \%)$ has risen significantly since $2010(62 \%)$, and support for the government allowing peaceful opposition (81\%) has fallen slightly since 2010 (83\%) although it remains higher than in $2008(78 \%)$ or $2009(77 \%)$.

Just under half of respondents (49\%) say that the 2010 parliamentary elections were free and fair, while an almost equal proportion (46\%) say they were not. The majority of respondents in the Central/Hazarajat (65\%), North West (61\%), North East (54\%) and West (52\%) say the 2010 parliamentary elections were free and fair. But, the majority in the East (52\%), South East (54\%) and Central/Kabul (55\%) regions say they were not free and fair.

Two thirds $(66 \%)$ of respondents say that elections are run by the Independent Election Commission. Twenty-three percent say elections are run by the government, $7 \%$ say elections are run by the international community and $2 \%$ say they are run by a special court.

A quarter (25\%) of respondents say political parties serve the interest of the country as a whole, and 19\% say they represent broad layers of society. Eighteen percent say political parties serve regional interest, 14\% say group/personal interests, $13 \%$ say ethnic interests, $5 \%$ say corporate interests (like those of farmers, workers, businessmen, etc.) and 4\% say political parties serve local interests.

A majority of respondents agree that the constitution should limit the president to serving a maximum of two terms $(73 \%)$ and that the president should not be bound by laws or court decisions that he thinks are wrong $(61 \%)$. A majority also agree that members of parliament should make laws for this country, even if the president does not agree $(70 \%)$. Thirty-three percent of respondents say the most important job of a member of parliament is to make laws for the good of the country, $29 \%$ say it is to listen to constituents and represent their needs and $26 \%$ say it is to deliver jobs or development.

Seventy percent of respondents say religious leaders should be consulted on the problems facing an area, which is the highest figure recorded to date (up from 61\% in 2006,60\% in 2007 to $69 \%$ in 2008 and $67 \%$ in 
2009). Religious leaders (45\%) and government employees (44\%) are the only groups for which more respondents say they consider the Afghan public's interests rather than their own interests, when making decisions and policies. By contrast, more respondents say that members of parliament consider their own interests (40\%) rather than the interests of the Afghan public (33\%). The same is true for ministers in the government, where almost half of respondents (47\%) say they consider their own interests and close to a third (32\%) say they consider the public's interest when making decisions.

A quarter of respondents (25\%) report having approached some authority to help resolve a community problem. The largest proportion of respondents $(66 \%)$ stated that the problem was taken to a local shura or jirga for resolution. Twenty percent of respondents report having taken a personal dispute to an external body for resolution. Slightly more respondents took their case to a shura or jirga (43\%), than to a state court (41\%). Satisfaction with shura/jirga $(83 \%)$ continues to be higher than with state courts $(78 \%)$.

Education and illiteracy (25\%) remain the major problems facing women in Afghanistan, followed by lack of rights, including women's rights $(15 \%)$, domestic violence $(9 \%)$, forced marriage/dowry $(8 \%)$, healthcare $(8 \%)$, poverty $(8 \%)$, women not being able to leave their home $(6 \%)$ and women under the control of men $(6 \%)$. Only $19 \%$ of respondents say there is an organization or institution in their local area where women can go to solve their problems. The institutions identified include the Directorate of Women's Affairs (23\%), women's shura (18\%), Human Rights Office (13\%), District Office (12\%), village shura/elders shura $(12 \%)$ and the courts $(5 \%)$.

In 2011, support for the principles of gender equality remains high, including equal rights under the law regardless of gender, ethnicity or religion (82\%), equal educational opportunities for women (85\%) and women being allowed to stand up for their individual rights (79\%). However, support for women being allowed to work outside the home continues to fall - from $71 \%$ in 2006 to $62 \%$ in 2011 . About one third of respondents $(35 \%)$ say that women should not be allowed to work outside the home.

Radio remains the most accessible media for Afghan households. More than four fifths (81\%) of respondents say they possess a functioning radio in their household, but there is a difference in access between rural (83\%) and urban $(73 \%)$ areas. Other communications technologies such as television, mobile phones and computers are significantly more accessible in urban areas. Just under half $(45 \%)$ of respondents use radio most often to get news and information, while just over a quarter (28\%) use television. One in five respondents $(20 \%)$ depend on friends and family to receive news and information.

Ownership of mobile telephones continues to increase in 2011 compared to previous years. This has meant that two thirds of respondents $(66 \%)$ now have access to this technology, although there is a large divide between urban $(88 \%)$ and rural $(60 \%)$ areas. 


\section{8 | Afghanistan in 2011}

\subsection{Summary}

The proportion of respondents saying that the country is moving in the right direction declined slightly in 2011, but it is still higher than in previous years. Security issues continue to play a predominant role in shaping Afghans' perceptions about the situation in the country and the prospects for the future. Like in 2010, good security is one of the principle reasons for optimism cited by respondents, however in 2011 for the first time it is cited less often than reconstruction and rebuilding. Good security is cited most often in the Central/Hazarajat, North East and North West, which also record the highest levels of optimism overall that the country is moving in the right direction.

The proportion of respondents who believe that the country is moving in the wrong direction, however, has increased in 2011. Insecurity is again the most commonly cited reason for pessimism, and again identified as the most important problem facing Afghanistan, particularly by respondents in the South East, East and South West, and in rural areas.

Increasing concern about the security situation is also reflected in the proportion of respondents who say that they often fear for their safety and that of their families, which has been rising steadily since 2006. Levels of fear for personal safety are also highest in the South East, East, West and South West, which are the same regions that identify insecurity as the main reason for pessimism about the direction of the country. The sense of insecurity also pervades other domains of social and public life. The proportion of people who say they fear to participate in a range of public activities is rising over time and is highest in the same regions that highlight poor security as a reason for pessimism, although there has been a fall since 2010 when the highest levels of fear to participate were recorded.

There has been a significant increase in the proportion of respondents who say that they feel less safe in 2011 to express their political opinions than in 2010. Bad security conditions and fear for safety have consistently been the two most important reasons why people feel they have less freedom to express their political opinion than they did a year ago. The proportion of respondents who specifically cite the presence of the Taliban as the reason for this has been rising steadily since 2008 to its highest recorded figure in 2011, again especially in the South East, East, West and South West regions.

The 2011 survey shows a marked rise since 2010 in the proportion of respondents reporting direct experience of violence or crime in all regions except Central/Kabul, reaching the highest levels recorded in most regions, except Central/Hazarajat and West, since 2008. Respondents identify unemployment and corruption as the biggest causes of crime although insecurity and weak government are also seen to play a role. While the incidence of victimization from militants/insurgents actions has declined significantly in 2011 in almost all regions except the East and the South East, the incidence of victimization from foreign forces and police action has risen in almost all regions compared to 2010 except the East, and the Central/Kabul region. In the East, the fall in reported cases of violence by foreign forces experienced by respondents appears to have been replaced by an increase in the direct experience of violence from insurgent actions, suggesting that the im- 
pact of the ongoing conflict remains significant in this region. Victimization by the actions of foreign forces remains highest in the South West.

Support for the government's peace, reconciliation and negotiation efforts with armed opposition groups remains very high, suggesting that a substantial proportion of the Afghan public is in favor of a political solution to the ongoing conflict in the country, rather than a purely military one. Indeed, support for reconciliation is highest in the East, South West and South East where insecurity is most often identified as a major local problem. However, women continue to report lower levels of support for reconciliation with armed opposition groups suggesting ongoing concern regarding the possible impact on women's lives that may arise through a negotiated settlement with the Taliban, whose regime imposed major restrictions on women's participation in Afghan society at all levels. Support for the efforts to reintegrate armed combatants into Afghan society is also highest in the East, South West and South East where the population is largely Pashtun, and in the North West where the population is predominantly Uzbek. These are also the regions and ethnic groups that record the highest levels of sympathy for armed opposition groups. However, sympathy for armed opposition groups has fallen significantly since 2009 and the proportion of respondents who say they have no sympathy with armed opposition groups has reached its highest recorded level in 2011.

The majority of respondents in all regions, except Central/Kabul and the South East, report overall confidence in government law enforcement agencies. The Afghan National Army (ANA) and the Afghan National Police (ANP) continue to enjoy the highest levels of public confidence of any institution, and public perceptions of the operational capacity of both the ANP and the ANA continue to rise over time. However, the fact that the majority - yet declining percentage of respondents still say the ANP is unprofessional and poorly trained and needs the support of foreign troops to operate again highlights ongoing concerns about insecurity.

In 2011, for the first time reconstruction and rebuilding are cited as the main reason for optimism, particularly in the West, Central/Kabul, South East, South West and East regions, and in urban, rather than rural, areas. Improvements in the education system are also cited by more respondents in 2011, particularly in the South East, North East and Central/Kabul regions. The major reasons for optimism identified in the different regions generally correspond to high levels of satisfaction with the performance of related government services (security in the Central/Hazarajat, North East and North West, reconstruction and rebuilding in the West and East, and improvements in the education system in the South East and Central/Kabul regions), highlighting the link that respondents make between progress in the country and the ability of government to provide essential services and support development.

Satisfaction with the availability of most basic facilities and public service has been increasing over time, reaching its highest levels in 2011 for a range of services including the availability of education for children, clinics, hospitals and medicines, clean drinking water and security. The majority of respondents expect to see further improvements in their local area in these amenities and services. Respondents are least satisfied with 
the availability of jobs and the electricity supply, but satisfaction with these services is higher in 2011 than in previous years. The only amenity for which satisfaction continues to fall in 2011 is water for irrigation.

The majority of respondents say they are aware of development projects in their local area relating to reconstruction/building of roads and bridges and improvements to education including reconstruction/opening of schools, training of teachers etc. However, comparatively few are aware of projects related to improving the electricity supply. Awareness of electricity-related projects is lowest in the West, East and South East, which are also the regions that report the lowest levels of satisfaction with the availability of electricity supply in their local area. There does not seem to be a strong correlation between awareness of different development projects and satisfaction with the related services.

The majority of respondents say the Afghan Government is the primary agency responsible for most development although foreign donors are identified as significant in supporting de-mining and humanitarian programs. The United States remains the most frequently identified donor supporting local development projects in all regions, although the figure has dropped dramatically in 2011 compared to previous years.

Geographically the overall pattern that emerges suggests a heavy concentration of donor assisted development projects focusing on basic infrastructure and public services in certain areas of the country, particularly the East and South West, and to some extent the North West. Indeed, the East and South West also record the highest levels of awareness of security-related projects such as de-mining and demilitarization/disarmament.

Despite clear differences between regions, the proportion of respondents who identify a lack of reconstruction as a reason for pessimism is at its lowest level since 2006. The same is true for respondents who cite a bad economy and unemployment as the biggest problem facing Afghanistan, which also record their lowest levels in 2011, suggesting that Afghans view the country's economic situation more favorably than in previous years. The most significant improvements concern the financial wellbeing of households, quality of the food diet, availability of products in the market and the physical conditions of housing, suggesting that the level of material prosperity is improving for a significant proportion of the Afghan population. However, responses vary greatly by region: improvements are most commonly reported in the East, South East, North East and Central/Hazarajat but comparatively rarely in the Central/Kabul and North West regions. The proportion of respondents who give a positive assessment of the availability of jobs in their local area has been rising steadily since 2008 , which is consistent with the fall in those that identify unemployment as a major national problem. However, respondents continue to report the least improvement in employment opportunities of all services and amenities particularly in the South East, North East and North West.

The 2011 survey demonstrates a clear correlation between perceptions of government performance and public trust in government institutions. This year, levels of confidence in most public institutions have risen, as have positive assessments of the performance of these institutions. 2011 records the highest levels of public confidence since 2008 in a wide range of representative bodies including government ministers, provincial councils, municipalities and community development councils. Although respondents remain least satisfied 
with the performance of municipalities, for the first time, a small majority of respondents say they have confidence in these institutions and there is an increase in satisfaction amongst urban respondents with the performance of their municipal authorities.

The 2011 survey also records the highest levels of positive assessments of national government performance since 2008 in all regions except the South East, North West and Central/Kabul. Confidence in the government justice system also reaches its highest level since 2006. For the first time a majority of respondents say they have some level of confidence in the system. This finding corroborates the increase in positive assessments of the quality and performance of state courts in regards to their accessibility, being fair and trusted, following local norms and being effective at delivering justice and resolving cases in a timely and prompt manner.

Corruption remains a major issue for all public institutions. The proportion of respondents who identify corruption as a reason for pessimism significantly decreased in 2011 to a figure more in line with previous years. However, this drop is not reflected in a fall in concern about corruption as a whole. On the contrary, the survey shows that the majority of Afghans continue to think that corruption is a major problem in all facets of life and at all levels of government. In 2011, for the first time the majority of respondents also say corruption is a major problem in their daily life. The proportion of respondents who say that corruption has increased since last year remains more or less stable; however, reports of corruption directly experienced by respondents are the highest for any year to date for all surveyed institutions. The survey shows that in 2011 the majority of respondents who accessed basic public services such as healthcare, applying for jobs, receiving official documents and dealing with the police or the courts encountered some level of corruption. The majority of respondents say that the government is doing a bad job in fighting corruption.

Although satisfaction with government performance in delivering services is increasing, this is not the case for the performance of democratic institutions. Since 2008 there has been a steady rise in those who say they are dissatisfied with the way democracy works in the country. In 2011, there is a significant increase in the proportion of respondents who agree that it is unacceptable to talk negatively about the government, and more respondents mention government censorship as a reason for feeling less safe to express their opinions than in any previous year since 2008. The proportion of respondents who say they can have some level of influence over government decisions has also been declining steadily over this period. Support for allowing peaceful opposition also fell slightly in 2011 after a significant increase in 2010, which may be a reflection of the increased number of demonstrations held across the country, which in some cases, turned violent.

It is significant that the proportion of respondents who identify peace as a potential benefit of democracy has been rising steadily since 2007, reaching its highest recorded level in 2011. This finding suggests that the ability of the democratic system to ensure security is increasingly important to respondents. On the other hand, the proportion of respondents who say that democracy will bring less corruption has been falling over the same period, suggesting that democracy has so far failed to deliver a reduction in corruption. 
The survey also reveals significant ambivalence about electoral processes. Opinion is almost equally divided between respondents who say that the 2010 parliamentary elections were free and fair and those who say they were not. Respondents identify a range of problems with the most recent elections including buying of votes, cheating in the vote count, men voting on behalf of women, husbands not letting their wives vote, and intimidation against voters or party activists. Despite the doubts about the freeness and fairness of the parliamentary elections, this year sees an increase in confidence in the Independent Electoral Commission. However, this remains well below the confidence level recorded in 2009. The fall in references to democracy and elections as a cause for optimism in 2011 may also reflect the controversy surrounding the 2010 parliamentary elections. A similar drop was recorded in 2009 when the survey was held during the run up to the presidential and provincial elections amidst accusations of fraud in electoral registration. Nonetheless, in 2011 the majority of respondents say they agree that Afghanistan should choose its leaders through regular, open and honest elections, even though the majority of respondents continue to say people should vote the way the community votes, not how they feel individually, although this percentage has been falling since 2008. In 2011, more people than in any previous year say voting should be a question of individual preference.

Views on the performance of political representative institutions also reveal some ambivalence. There is clear agreement for the need for constitutional limitations as to the length of the president's mandate and clarification of the presidential role in law making related to the role of parliament. However, within these parameters, the majority of respondents feel that the president should be free to act without constraints from the legal and judicial system.

Opinions regarding the roles of members of parliament are almost equally divided between those who say an MP's job is to make laws for the good of the country, those who say it is to listen to constituents and represent their needs and those who say delivering jobs or development is their most important responsibility. Although the majority of respondents still give a positive assessment, levels of satisfaction with the performance of MPs in addressing the major problems of their constituencies have fallen steadily since 2006, suggesting increasing disenchantment with the ability of MPs to address local problems through the parliamentary system. However, contact by constituents with elected representative to help resolve local issues continues to increase. The proportion of respondents who report contacting their MP for help in solving problems has doubled since 2006. A similar rise has been recorded in the proportion of respondents who report contacting a provincial council representative for assistance.

The proportion of respondents who say religious leaders should be consulted in public decision-making processes has increased over time to its highest level in 2011, suggesting that an increasing number of people in Afghanistan see the involvement of religious leaders as one of the ways to strengthen governance in the country.

Respondents continue to report crime and violence to a wide range of formal and informal institutions especially the Afghan National Police (ANP) in urban areas and shura/elders and mullahs in rural areas. This largely reflects the accessibility of these institutions and the fact that local shura and jirga remain the most trusted and accessible conflict resolution mechanisms for Afghans, particularly in rural areas. 
Disputes also continue to be taken to a broad range of formal and informal institutions for resolution, including mullahs, malik/khan, shura/jirga, government agencies, the ANP, district authorities and provincial governors. The survey findings suggest that respondents more frequently address common problems such as land disputes to the institutions that are the closest to their local community. Dispute resolution mechanisms that are strongly anchored in local communities, such as mullahs, malik/khan and local shura/jirga are also amongst the most effective in resolving disputes.

There has been little variation in the proportions of respondents taking their disputes to formal state courts or to informal shura/jirga for resolution since 2008, although fewer respondents report using both mechanisms in 2011. Most respondents living in urban areas report that they took their case to formal state courts, while most in rural areas say they approached informal local shura or jirga suggesting again that formal institutions are more accessible to urban residents. Satisfaction with the performance of state courts shows a small improvement in 2011 reaching again the highest levels which were recorded in 2007. A similar rise is also seen in satisfaction with the performance of local jirga/shura. The traditional justice system continues to be seen to perform better than the modern state justice system on all counts.

In 2011, lack of education and/or illiteracy and the lack of rights, including women's rights, are again identified as the biggest problems facing women in Afghanistan. The proportion of respondents who identify lack of education has fallen significantly since 2009. In 2011, a higher proportion of respondents identify the lack of women's rights as the major problem facing women than in 2010, but this remains lower than in previous years. This seems consistent with a general fall in support for women's rights since the survey began. Although support for equal opportunities in education and women standing up for their rights is high, there has been a steady decline since 2006 in the proportion of people who say that women should be able to work outside the home and just under half of the male respondents disagree with this idea.

In 2011, a clear majority of respondents say that women should participate in elections and vote themselves. Support for women in representative political roles also rose in 2011 to levels closer to those recorded in 2007 and 2008, after a significant drop in the election years of 2009 and 2010. However, support for equal representation of men and women in political leadership positions continues to decline.

Radio remains the most accessible media for all Afghan households However, other communications technologies such as television, mobile phones and computers are much more accessible to urban residents than to those living in rural areas, largely thanks to better access to electricity. The most marked increase continues to be in mobile phone ownership, which now reaches two thirds of respondents.

Although radio has remained the most common source of information since 2006, the proportion of respondents who use radio as their main source of information has been falling over this period, whereas those who identify TV as their main source of news and information has been steadily rising. Surprisingly, the proportion of respondents who cite friends and family as their main source of information has also risen over this period. Three times more respondents also say they get their news and information from religious leaders (mosques) in 2010 and 2011 than in previous years. 


\subsection{Restriction on survey field work and replacement of sampling points for security reasons}

In 2011, as in previous years, there were restrictions on the movement of some survey researchers due to logistical challenges, natural disasters and security, which made it impossible for them to reach some of the districts identified through the random sampling process. In 2011, 166 of the 876 sampling points had to be replaced by selecting other sampling points in the same region. Instability and frequent fighting in some provinces caused 95 sampling points to be replaced (57\% of the total replacements); however, restrictions on the movement of survey researchers due to security concerns have decreased considerably since last year. In $2011,11 \%$ of sampling points were replaced compared to $16 \%$ in 2010.

Replacements of sampling points due to security problems (Appendix 2: Methodology) COMPARISON OF 2007, 2008, 2009, 2010 and 2011

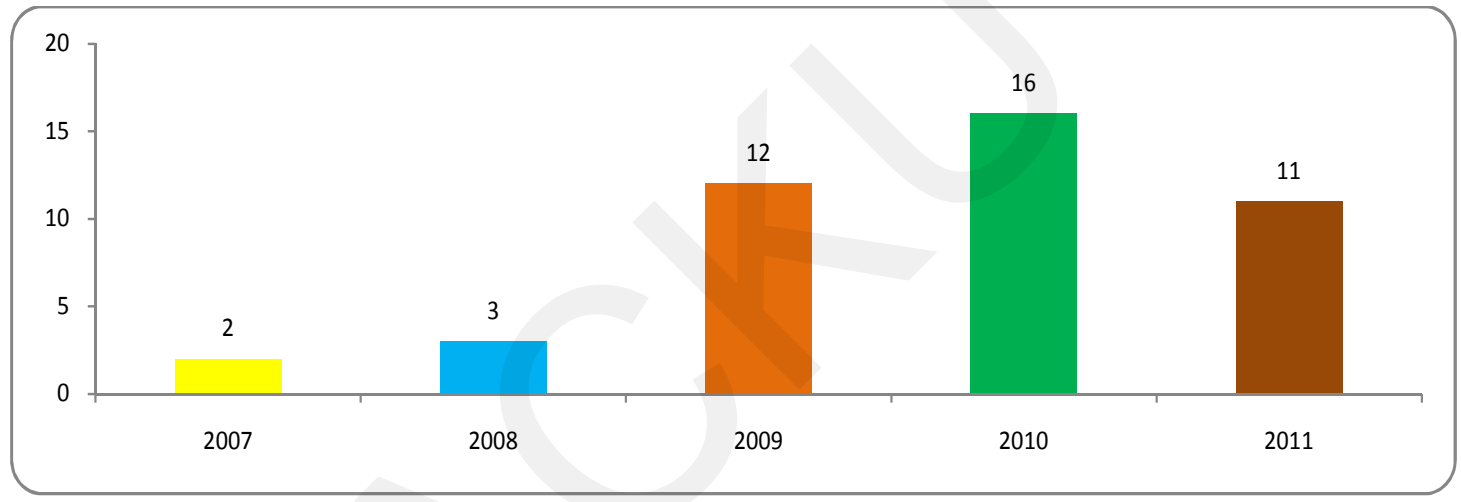

Fig 1.1

Table 1.1: Replacements of sampling points due to various problems (Appendix 2: Methodology) BY VARIOUS REASONS

\begin{tabular}{|l|c|c|c|}
\hline Total Sampling Points 876 & $\begin{array}{c}\text { Count } \\
\#\end{array}$ & $\begin{array}{c}\text { Versus total replacement } \\
\mathbf{( \% )}\end{array}$ & $\begin{array}{c}\text { Versus all sample points } \\
(\%)\end{array}$ \\
\hline Security & 95 & 57 & 11 \\
\hline Village was not found & 30 & 18 & 3 \\
\hline No transportation way & 29 & 17 & 3 \\
\hline Surveyors were not allowed & 7 & 4 & 0 \\
\hline Surveyed before & 3 & 2 & 0 \\
\hline Not qualified for survey & 2 & 1 & 19 \\
\hline Total replacement & 167 & & 1 \\
\hline
\end{tabular}


The replacement of 95 sampling points for security reasons means that the field survey team could not access many areas with high levels of insecurity. This in turn means that the opinions of those living in highly insecure areas are likely to be underrepresented in survey findings.

The deterioration of the security situation in the country began to have a significant impact on the survey fieldwork in 2009. In 2007, only 11 of the 626 sampling points had to be replaced because areas were inaccessible due to security problems (i.e. $\%$ of all sampling points). Nine of the eleven replacements were made in just two regions, the South East and South West. The situation was similar in 2008, when 18 of the 659 sampling points were replaced due to security problems (i.e. $3 \%$ of all sampling points). These replacements were again mainly concentrated in the South East and South West but the other replacements were distributed amongst seven of the eight regions with the exception of the North West.

However, in 2009 the total number of security-related replacements of survey sampling points increased fourfold, from 3\% in 2008 to $12 \%$ in 2009 . One hundred and two of the 823 random sampling points were inaccessible to survey researchers due to insecurity, and replacements were required in all regions. In addition, the number of insecure areas that could not be accessed at least tripled in the South East and the South West and rose even more dramatically in all other regions.

In 2010, the situation deteriorated further. One hundred and thirty eight of the 825 random sampling points were inaccessible to survey researchers due to security problems (17\% of all sampling points). Again, the number of replacements rose significantly in most regions. The region's most affected continued to be the South East, South West and the East. Central/Hazarajat was the only region in which no replacements were made due to security problems.

In 2011, the situation has improved somewhat. Ninety-five of the 876 sampling points had to be replaced due to security reasons (11\% of all sampling points). The regions most severely affected by these restrictions are the South East (23 replacements), East (20 replacements), Central/Kabul (17 replacements) and North West (16 replacements). Eight replacements were made in the South West, seven in the North East, and four in the West. Again, in 2011 no replacements were made for security reasons in the Central/Hazarajat region. In the regions where significant numbers of sampling points had to be changed for security reasons, individual provinces with the maximum changes included Kunarha (15 replacements) in the East, Ghazni (12 replacements) in the South East and Baghlan (11 replacements) in the North West. Samangan, Farah, Zabul, Panjshir and Uruzgan were the only provinces where sampling points did not have to be replaced.

Table 1.2: Actual number of replacements of sampling points due to security problems (See Appendix 2: Methodology) ALL AND BY REGION COMPARISON OF 2007, 2008, 2009, 2010 AND 2011

\begin{tabular}{|c|c|c|c|c|c|c|c|c|c|c|}
\hline Year & $\begin{array}{l}\text { Number of Sample } \\
\text { Points Replaced for } \\
\text { Security Reasons }\end{array}$ & $\begin{array}{l}\text { No. of total } \\
\text { sample } \\
\text { points }\end{array}$ & $\begin{array}{c}\text { Central/ } \\
\text { Kabul }\end{array}$ & East & $\begin{array}{c}\text { South } \\
\text { East }\end{array}$ & $\begin{array}{l}\text { South } \\
\text { West }\end{array}$ & West & $\begin{array}{c}\text { North } \\
\text { East }\end{array}$ & $\begin{array}{l}\text { Central/ } \\
\text { Hazarajat }\end{array}$ & $\begin{array}{c}\text { North } \\
\text { West }\end{array}$ \\
\hline 2007 & 11 & - & 1 & 0 & 6 & 3 & 1 & 0 & 0 & 0 \\
\hline 2008 & 18 & - & 1 & 2 & 6 & 5 & 2 & 1 & 1 & 0 \\
\hline 2009 & 102 & 882 & 13 & 14 & 18 & 17 & 14 & 11 & 2 & 13 \\
\hline 2010 & 138 & 885 & 10 & 21 & 28 & 24 & 12 & 23 & 0 & 20 \\
\hline 2011 & 95 & 876 & 17 & 20 & 20 & 8 & 4 & 7 & 0 & 16 \\
\hline
\end{tabular}


Table 1.3: Actual number of replacements of sampling points due to various problems (See Appendix 2: Methodology) BY REGION

\begin{tabular}{|l|c|c|c|c|c|c|}
\hline $\begin{array}{l}\text { Number of Sampling } \\
\text { Points replaced for } \\
\text { various reasons }\end{array}$ & Security & $\begin{array}{c}\text { No transportation } \\
\text { way } \\
\#\end{array}$ & $\begin{array}{c}\text { Village was } \\
\text { not found } \\
\#\end{array}$ & $\begin{array}{c}\text { Surveyors were } \\
\text { not allowed } \\
\#\end{array}$ & $\begin{array}{c}\text { Surveyed } \\
\text { before } \\
\#\end{array}$ & $\begin{array}{c}\text { Not qualified } \\
\text { for survey } \\
\#\end{array}$ \\
\hline Central/Kabul & 17 & 2 & 4 & 6 & 3 & 1 \\
\hline East & 20 & 0 & 2 & 0 & 0 & 0 \\
\hline South East & 23 & 0 & 0 & 0 & 0 & 0 \\
\hline South West & 8 & 0 & 2 & 0 & 0 & 0 \\
\hline West & 4 & 2 & 3 & 0 & 0 & 0 \\
\hline North East & 7 & 16 & 11 & 1 & 0 & 0 \\
\hline Central/Hazarajat & 0 & 7 & 8 & 0 & 0 & 1 \\
\hline North West & 16 & 2 & 0 & 0 & 0 & 0 \\
\hline Total & 95 & 29 & 30 & 7 & 3 & 2 \\
\hline
\end{tabular}

In 2011, in two provinces, Paktika and Zabul, the deterioration of the security situation restricted the freedom of movement, making it unsafe to employ female interviewers. This meant that no women were included in the sample in these provinces. It should also be noted that there has been a steady decline in the number of women respondents since 2006 and 2007, when half of the respondents were women. In 2011, only $43 \%$ of the respondents are women, while $57 \%$ of the respondents are men. This is a $14 \%$ difference in the gender split, and a $7 \%$ decrease in female representation from 2007, which may be reflected in the survey results.

Percentage of men and women respondents of 2006, 2007, 2008, 2009, 2010 and 2011

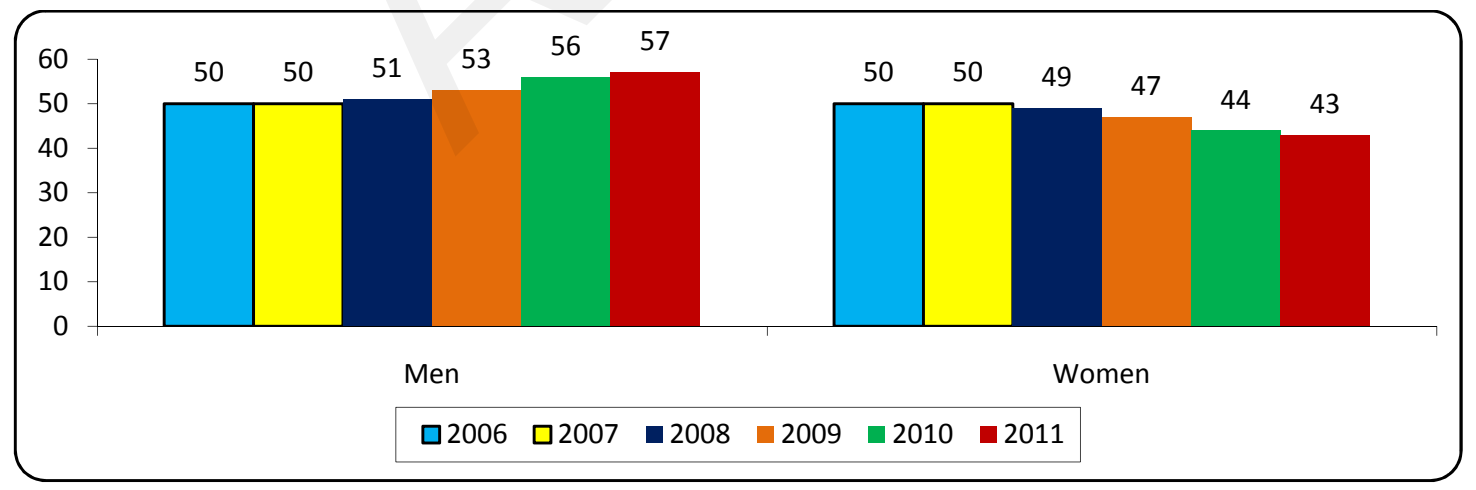

Fig. 1.2 


\section{National Mood}

\subsection{Direction of the country}

The 2011 Survey of the Afghan people, the seventh in the series, attempted to measure how Afghan citizens assess their country's situation in general. Respondents were asked whether they think things in Afghanistan today are going in the right direction or the wrong direction. Nearly half of respondents (46\%) say things in the country are moving in the right direction while 35\%, the highest proportion since the start of the survey, say things are moving in the wrong direction. A significant proportion of people have mixed opinions (some things are moving in the right and some in the wrong direction) (17\%).

Generally speaking, do you think things in Afghanistan today are going in the right direction, or do you think they are going in the wrong direction? (Q-2 base-6348)

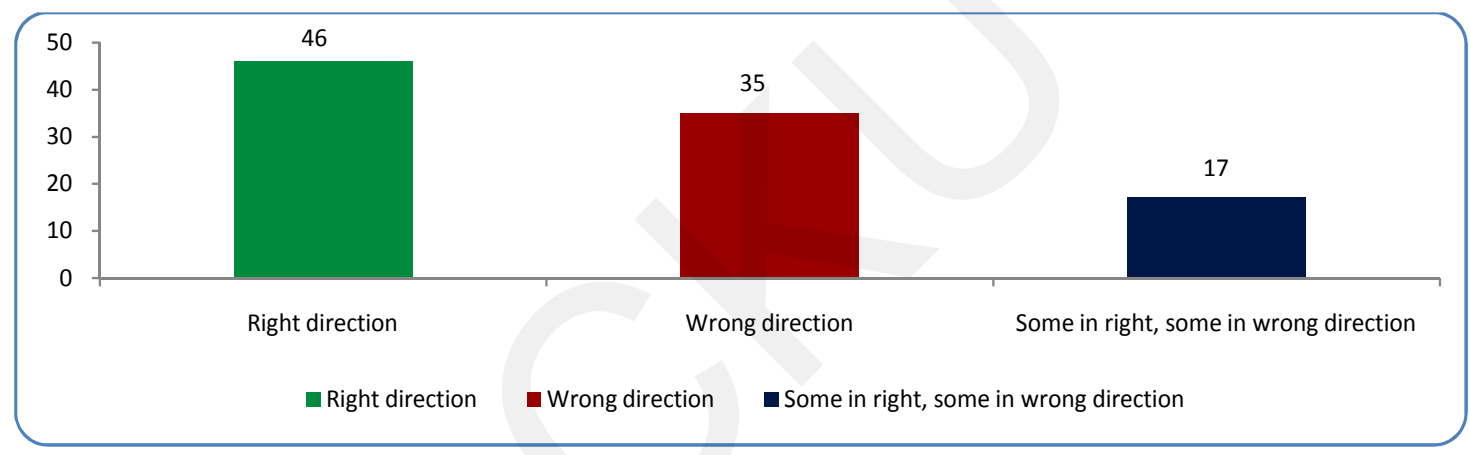

Fig 2.1

Both Afghan men and women responded the same way about the direction of change in Afghanistan. A similar proportion of men (47\%) and women (46\%) say things are moving in the right direction. Meanwhile over a third of men (37\%) and just under a third of women (32\%) say things are moving in the wrong direction. Interestingly, more respondents in rural areas (48\%) say things are moving in the right direction than respondents in urban areas (40\%), whereas more respondents in urban areas (42\%) say things are moving in the wrong direction than respondents in rural areas (33\%). There is little variation across ethnic groups. Slightly more Hazara (50\%) say things are moving in the right direction than Tajik (47\%), Uzbek (46\%) and Pashtun (45\%). More Pashtun (37\%), Tajik (34\%) and Uzbek (33\%) than Hazara $(27 \%)$ respondents say things are moving in the wrong direction.

Respondents in the lowest earning bracket are more positive than other groups. Just over half (51\%) of low income earners (earning less than 2,000Afs per month) say things are moving in the right direction, compared to $43 \%$ of middle-income (earning between 3,000 and 5,000Afs per month) and 46\% of high income earners (10,000Afs and above per month). As income increases, pessimism also slightly increases. Just under a third 
of respondents in the lowest income group $(32 \%)$ say things are moving in the wrong direction, compared to just over a third in the middle (34\%) and high (37\%) income groups.

A clear majority of people in the Central/Hazarajat (59\%), North East (55\%), North West (52\%) and South West (51\%) say that the country is moving in the right direction compared to under half in the West (47\%), East (46\%) and South East (39\%). On the other hand, the largest proportion of respondents in the Central/ Kabul region (47\%) says that things in the country are going in the wrong direction.

The proportion of respondents saying that the country is moving in the right direction has declined slightly in 2011 (from $47 \%$ in 2010 to $46 \%$ in 2011), but it is still higher than other years. However, the proportion of those who say that the country is moving in the wrong direction has increased by $8 \%$ in 2011 compared to 2010 (from $27 \%$ in 2010 to $35 \%$ in 2011). There has also been a decline in the proportion of those who have mixed views about their country's direction (from $22 \%$ in 2010 to $17 \%$ in 2011), suggesting that more people have formed a definite negative view about the direction of change.

This data, however, should be read with some caution given that some survey sampling points were replaced in highly insecure areas (see Chapter 1, 1.3 Restriction on survey field work and replacement of sampling points for security reasons).

Generally speaking, do you think things in Afghanistan today are going in the right direction, or do you think they are going in the wrong direction? (Q-2) COMPARISON BETWEEN 2006, 2007, 2008, 2009, 2010 AND 2011

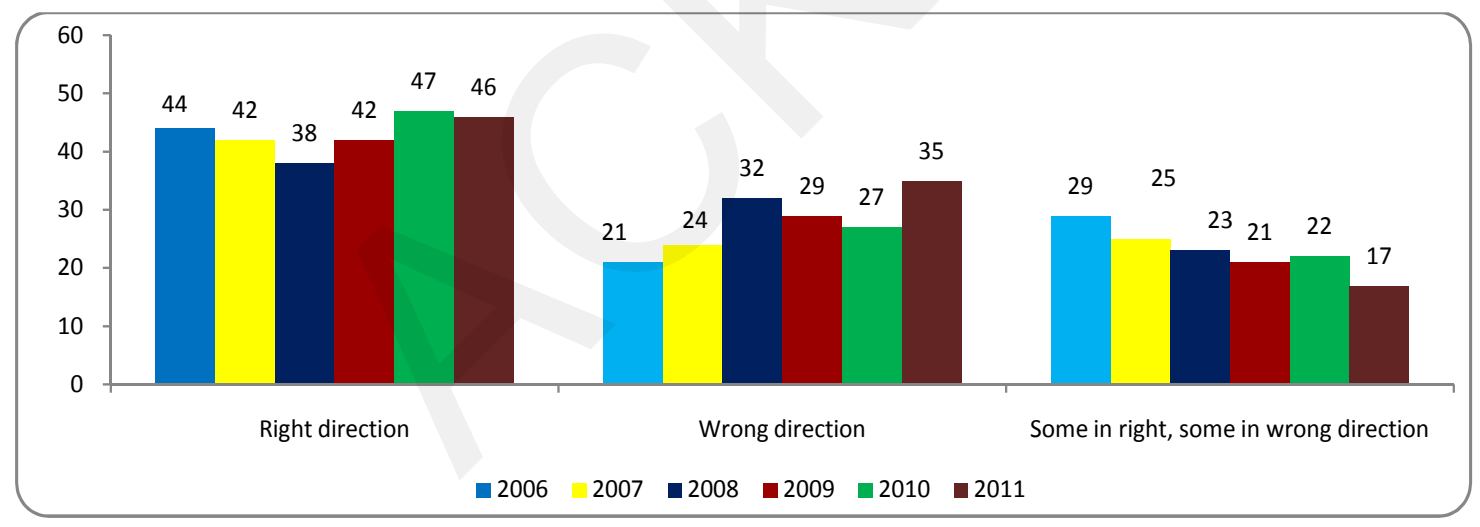

Fig 2.2

\subsection{Reasons for optimism}

Respondents who say that the country is moving in the right direction (46\% of all respondents) were asked to provide two reasons why they think so. The most commonly cited reasons are reconstruction/rebuilding $(40 \%)$ and good security (39\%), followed by improvement in the education system (16\%). Other reasons respondents stated for their optimism include having an active ANA and ANP (11\%), schools for girls have opened (10\%), good government (9\%), economic revival $(8 \%)$ and peace or end of war $(7 \%)$. 
Why do you say that things are moving in the right direction? (Q-3a\&b combined, Base 2933: Those saying right direction)

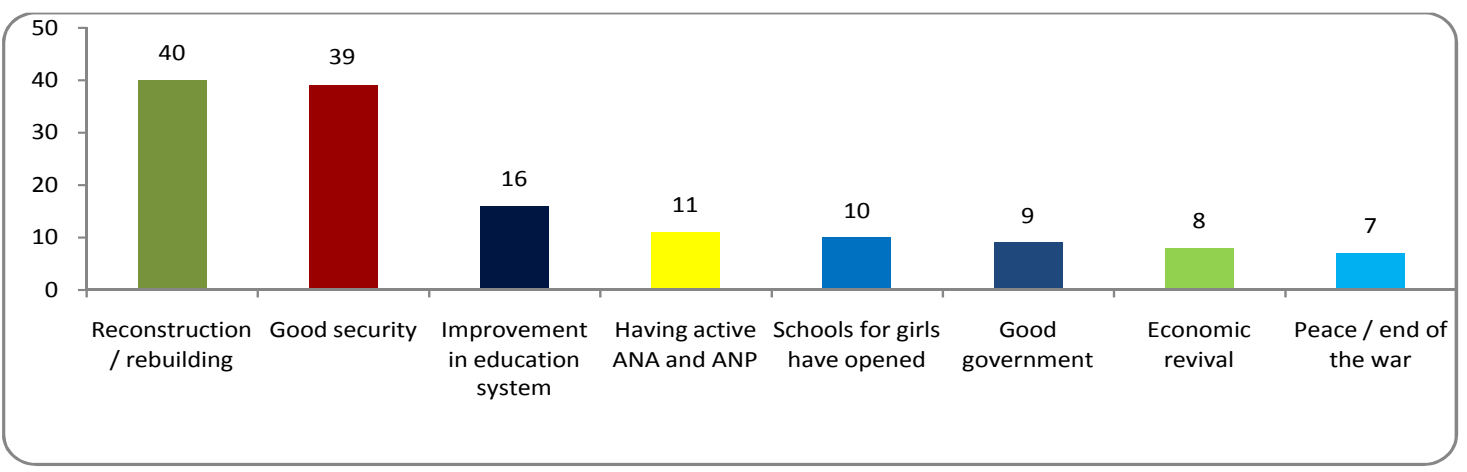

Fig 2.3

Equal numbers of respondents $(39 \%)$ in both rural and urban areas cite good security. However, more urban dwellers $(51 \%)$ than rural residents $(38 \%)$ cite reconstruction/rebuilding as a reason for saying the country is moving in the right direction.

Good security was most often cited by Tajiks (43\%), Uzbeks (46\%) and Hazaras (42\%) as a reason for optimism while Pashtuns most often mention reconstruction and rebuilding (41\%).

Most of the people in Central/Hazarajat (59\%) say that the country is moving in the right direction due to good security; this was also the most common reason given in the North West (49\%) and North East (48\%). The majority of respondents in these three regions also say that the country is moving in the right direction (see above, 2.1 Direction of the country), which again suggests that security issues continue to play a major role in respondents' overall perceptions. It is interesting to note that these regions also record the highest levels of satisfaction with government security services North East (80\%), Central Hazarajat (74\%) and North West (74\%) (see Chapter 7, 7.2 and 7.3 Satisfaction with central government performance in policy and service delivery). Reconstruction/rebuilding was the most common reason for the country moving in the right direction in the West (46\%), Central/Kabul (44\%), South East (43\%), South West (39\%) and East (38\%). It is worth mentioning that only $17 \%$ of the respondents in Central/Hazarajat cited reconstruction/rebuilding as a reason for optimism suggesting that the impact of such developments may not yet be reaching all parts of the country. Reconstruction and rebuilding is also the most commonly identified achievement of government by respondents in the West (28\%), and East (23\%) (see Chapter 7, 7.4 Important achievements and failings of the central government).

The proportion of respondents citing improvements in the education system as a reason for optimism also points to significant satisfaction with education services across the regions with around one in four citing this in the South East (24\%) and at least one in six in the North East (17\%) and Central/Kabul (17\%) regions. Improvements in the education system are also the most commonly identified achievement of government by respondents in the South East (32\%) and Central/Kabul regions (29\%), again highlighting the link that respondents perceive between the direction of progress in the country and the ability of government to provide essential services and support development (see Chapter 7, 7.4 Important achievements and failings of the central government). 
Table 2.1: Reasons given by those saying things are moving in the right direction (Q-3a\&b combined, Base 2933) BY REGION

\begin{tabular}{|c|c|c|c|c|c|c|c|c|c|}
\hline $\begin{array}{l}\text { Base: Those saying } \\
\text { right direction }\end{array}$ & $\begin{array}{c}\text { Total } \\
(\%)\end{array}$ & \begin{tabular}{|c|} 
Central/ \\
Kabul \\
$(\%)$
\end{tabular} & $\begin{array}{l}\text { East } \\
(\%)\end{array}$ & $\begin{array}{l}\text { South } \\
\text { East } \\
(\%)\end{array}$ & $\begin{array}{l}\text { South } \\
\text { West } \\
(\%)\end{array}$ & $\begin{array}{l}\text { West } \\
(\%)\end{array}$ & $\begin{array}{l}\text { North } \\
\text { East } \\
(\%)\end{array}$ & $\begin{array}{l}\text { Central/ } \\
\text { Hazarajat } \\
(\%)\end{array}$ & $\begin{array}{l}\text { North } \\
\text { West } \\
(\%)\end{array}$ \\
\hline Reconstruction/rebuilding & 40 & 44 & 38 & 43 & 39 & 46 & 34 & 17 & 45 \\
\hline Good security & 39 & 38 & 31 & 21 & 26 & 38 & 48 & 59 & 49 \\
\hline $\begin{array}{l}\text { Improvement in education } \\
\text { system }\end{array}$ & 16 & 16 & 7 & 24 & 15 & 15 & 17 & 17 & 14 \\
\hline $\begin{array}{l}\text { Having active ANA and } \\
\text { ANP }\end{array}$ & 11 & 9 & 19 & 16 & 20 & 9 & 8 & 1 & 5 \\
\hline $\begin{array}{l}\text { Schools for girls have } \\
\text { opened }\end{array}$ & 10 & 15 & 11 & 13 & 10 & 8 & 9 & 11 & 7 \\
\hline Good government & 9 & 5 & 9 & 10 & 9 & 7 & 7 & 13 & 14 \\
\hline Economic revival & 8 & 8 & 13 & 7 & 8 & 8 & 9 & 9 & 4 \\
\hline Peace/end of the war & 7 & 4 & 5 & 3 & 7 & 11 & 11 & 5 & 5 \\
\hline
\end{tabular}

Reconstruction/rebuilding and good security have been consistently identified as the two most important reasons why respondents say that the country is moving in the right direction since 2006. In 2011, the proportion of respondents citing good security slightly increased from 38\% last year to $39 \%$, while those citing reconstruction and rebuilding increased from 35\% in 2010 to $40 \%$ in 2011 . There was also an increase in those citing general improvements in the education system, from 10\% in 2010 to $16 \%$ in 2011, however the proportion of respondents who specifically cite the opening of schools for girls as a reason for saying the country is moving in the right direction dropped this year to $10 \%$ from $15 \%$ in 2010.

The significance of democracy and elections as a factor for optimism has fluctuated considerably since 2006. In 2011 only 3\% of respondents mentioned this as a reason for saying the country is moving in the right direction, compared to $7 \%$ in 2010 when the survey was conducted just before the parliamentary elections were held. The low level of reference to democracy and elections as a cause for optimism in 2011 may reflect the controversy that surrounded the 2010 parliamentary elections, which were marred by accusations of corruption. A similar drop in responses referring to democracy and elections as a reason for optimism was recorded in $2009(1 \%)$ when the survey was held during the run up to the presidential and provincial elections amidst accusations of fraud in electoral registration.

Table 2.2: Why do you say that things are moving in the right direction? (Q-3a\&b combined) COMPARISON BETWEEN 2006, 2007, 2008, 2009, 2010 AND 2011

\begin{tabular}{|l|c|c|c|c|c|c|}
\hline & $\mathbf{2 0 0 6}$ & $\mathbf{2 0 0 7}$ & $\mathbf{2 0 0 8}$ & $\mathbf{2 0 0 9}$ & $\mathbf{2 0 1 0}$ & $\mathbf{2 0 1 1}$ \\
\hline Good security & 31 & 34 & 39 & 44 & 38 & 39 \\
\hline Reconstruction/rebuilding & 21 & 39 & 32 & 36 & 35 & 40 \\
\hline Schools for girls have opened & 16 & 19 & 19 & 21 & 15 & 10 \\
\hline Democracy/elections & 10 & 9 & 7 & 1 & 7 & 3 \\
\hline Peace/end of the war & 29 & 16 & 21 & 9 & 12 & 7 \\
\hline Economic revival & 7 & 9 & 5 & 6 & 10 & 8 \\
\hline Improvement in education system & - & - & - & - & 10 & 16 \\
\hline Good government & 9 & 9 & 9 & 12 & 10 & 9 \\
\hline
\end{tabular}




\subsection{Reasons for pessimism}

Respondents who say that things are moving in the wrong direction (35\% of all respondents) were also asked to give the two main reasons why. Slightly less than half of all respondents (45\%) say insecurity, making it by far the most important reason for pessimism. This again indicates that security remains a major concern for Afghan people and a significant factor in the way they assess progress in the country. About one in six $(16 \%)$ say corruption as a reason for their pessimism, followed by bad government (15\%), unemployment $(13 \%)$ and bad economy $(10 \%)$.

Why do you say that things are moving in the wrong direction? (Q-4a\&b combined, Base 2200: Those saying wrong direction)

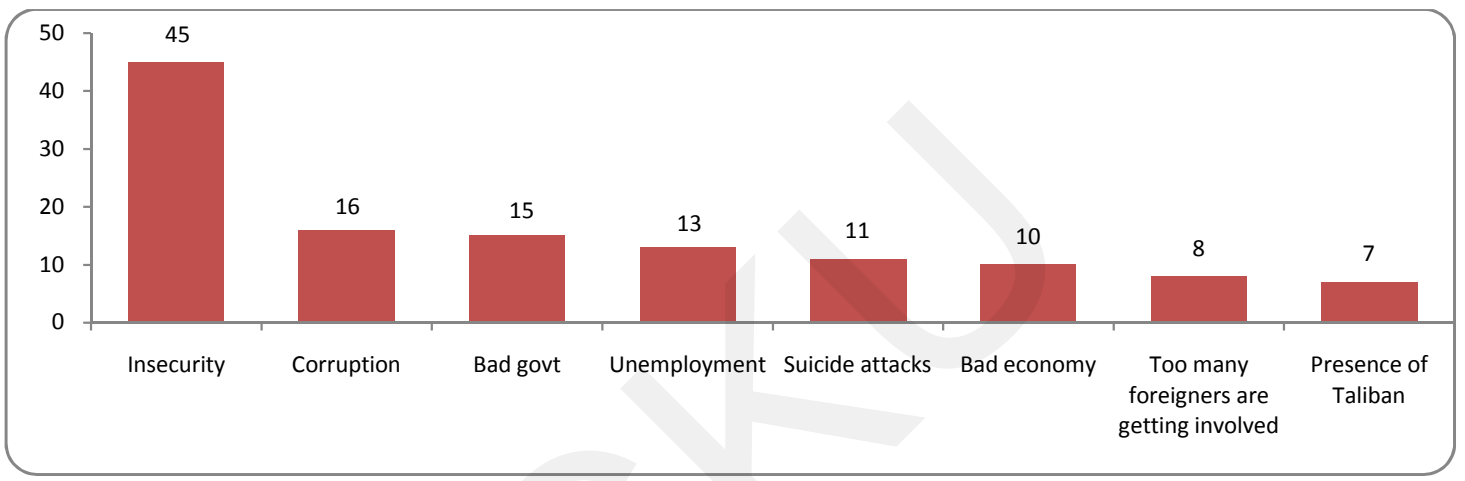

Fig 2.4

Insecurity is a major concern for all ethnic groups. However, more Pashtuns (50\%), who represent the majority of the population in the South and East of the country, give this reason for their pessimism than Hazaras (47\%), Uzbeks (42\%) and Tajiks (40\%).

The reasons for saying that the country is moving in the wrong direction in 2011 also differ significantly amongst regions. Though insecurity remains the most common reason for respondents in all regions, this is identified by the majority of respondents in the South East (56\%), East (53\%) and South West (52\%), and by under half in Central/Kabul (46\%), North West (41\%) and West (39\%), and only a third in the North East $(33 \%)$ and Central/Hazarajat $(32 \%)$. This is consistent with the finding that less than half of respondents in the South East (40\%) and East (49\%) and just over half in the South West (54\%) say that the security situation is good in their local area. These regions also record the lowest proportion of respondents who say they can move safely in their area or district (see Chapter 6, 6.1 Services and Facilities available in local areas).

This year corruption is again the second most often cited reason the country is seen to be moving in the wrong direction. Corruption is most often cited in the South East (20\%), Central/Hazarajat (19\%), East $(18 \%)$, North West $(18 \%)$ and North East (17\%). However, these figures are lower than those recorded in 2010 (see below).

The proportion of respondents citing unemployment has dropped slightly from 16\% in 2010 to $13 \%$ in 2011. However, unemployment remains a significant cause for pessimism for one in five respondents in the Central/Kabul (21\%) region and just under one in six in the North East (15\%) and South East (14\%). 
Table 2.3: Why do you say that things are moving in the wrong direction? (Q-4a\&b combined, base 2200) BY REGION

\begin{tabular}{|l|c|c|c|c|c|c|c|c|c|}
\hline \multicolumn{1}{|c|}{$\begin{array}{c}\text { Base: Those saying } \\
\text { wrong direction }\end{array}$} & $\begin{array}{c}\text { Total } \\
\mathbf{( \% )}\end{array}$ & $\begin{array}{c}\text { Central/ } \\
\text { Kabul } \\
\mathbf{( \% )}\end{array}$ & $\begin{array}{c}\text { East } \\
\mathbf{( \% )}\end{array}$ & $\begin{array}{c}\text { South } \\
\text { East } \\
\mathbf{( \% )}\end{array}$ & $\begin{array}{c}\text { South } \\
\text { West } \\
\mathbf{( \% )}\end{array}$ & $\begin{array}{c}\text { West } \\
\mathbf{( \% )}\end{array}$ & $\begin{array}{c}\text { North } \\
\text { East } \\
\mathbf{( \% )}\end{array}$ & $\begin{array}{c}\text { Central/ } \\
\text { Hazarajat } \\
\mathbf{( \% )}\end{array}$ & $\begin{array}{c}\text { North } \\
\text { West } \\
\mathbf{( \% )}\end{array}$ \\
\hline Insecurity & 45 & 46 & 53 & 56 & 52 & 39 & 33 & 32 & 41 \\
\hline Corruption & 16 & 14 & 18 & 20 & 14 & 13 & 17 & 19 & 18 \\
\hline Bad government & 15 & 15 & 13 & 13 & 16 & 15 & 17 & 15 & 21 \\
\hline Unemployment & 13 & 21 & 11 & 14 & 8 & 7 & 15 & 4 & 9 \\
\hline $\begin{array}{l}\text { Suicide attacks } \\
\text { Bad Economy }\end{array}$ & 11 & 15 & 16 & 6 & 8 & 8 & 12 & 0 & 6 \\
\hline $\begin{array}{l}\text { Too many foreigners are } \\
\text { getting involved }\end{array}$ & 10 & 14 & 11 & 7 & 4 & 9 & 13 & 8 & 10 \\
\hline \begin{tabular}{l} 
Presence of Taliban \\
\hline
\end{tabular} & 7 & 3 & 8 & 7 & 12 & 11 & 6 & 6 & 6 \\
\hline
\end{tabular}

Insecurity has been identified as the main reason for pessimism every year since 2007. In 2011, the proportion rose slightly to 45\% from 44\% in 2010 and 42\% in 2009, but is still lower than in 2008 (50\%) and 2007 (48\%). Interestingly, the proportion of respondents citing corruption significantly decreased from $27 \%$ in 2010 to $16 \%$ in 2011, which is more in line with previous years. This drop is reflected across all regions except the Central/Hazarajat where the figure almost doubled from 10\% in 2010 to $19 \%$ in 2011. The drop in the emphasis on corruption as a reason for pessimism, however, is not reflected in a fall in concern about corruption as a whole. On the contrary, the proportion of respondents who identify corruption as a major problem in their daily life continues to rise (see Chapter 8, 8.1 Corruption - major or minor problem). This may indicate that although corruption remains a serious issue, more pressing concerns influence respondents' opinions about the direction of the country.

Just over one in six respondents mention bad government as a reason for pessimism in 2011 (15\%) compared to $18 \%$ in 2010 and $25 \%$ in 2009 . Nonetheless, the figure is still higher than in $2008(12 \%)$. The proportion of respondents mentioning a bad economy (10\%), unemployment (13\%) and lack of reconstruction (4\%) are at their lowest levels since 2006. This is in line with the fall in the proportion of respondents that identify unemployment as the biggest problem facing Afghanistan; down from 28\% in 2010 to 23\% in 2011 (see Chapter 2, 2.4 Afghanistan's biggest problems: National level).

Table 2.4: Why do you say that things are moving in the wrong direction? (Q-4a\&'b combined) COMPARISON BETWEEN 2006, 2007, 2008, 2009, 2010 AND 2011

\begin{tabular}{|l|c|c|c|c|c|c|}
\multicolumn{1}{r}{ Q-4a\&b } & $\mathbf{2 0 0 6}$ & $\mathbf{2 0 0 7}$ & $\mathbf{2 0 0 8}$ & $\mathbf{2 0 0 9}$ & $\mathbf{2 0 1 0}$ & $\mathbf{2 0 1 1}$ \\
\hline Insecurity & 6 & 48 & 50 & 42 & 44 & 45 \\
\hline Bad government & 22 & 15 & 12 & 25 & 18 & 15 \\
\hline Corruption & & 13 & 19 & 17 & 27 & 16 \\
\hline Unemployment & 21 & 15 & 15 & 15 & 16 & 13 \\
\hline Bad economy & 27 & 12 & 17 & 11 & 8 & 10 \\
\hline No reconstruction & 22 & 8 & 7 & 6 & 4 & 4 \\
\hline
\end{tabular}




\subsection{Afghanistan's biggest problems: National level}

The survey of the Afghan people endeavors to measure public opinion regarding the biggest problems facing Afghanistan as a whole. Insecurity (including attacks, violence and terrorism) is identified as the biggest problem in Afghanistan by over a third of respondents (38\%). This is followed by unemployment, which is identified by $23 \%$ and corruption, cited by $21 \%$. Other major problems identified include poverty (12\%), lack of education (10\%), poor economy $(10 \%)$, presence of the Taliban $(8 \%)$, suicide attacks $(8 \%)$ and interference of foreign countries $(7 \%)$.

In your view, what is the biggest problem facing Afghanistan as a whole? (Q-5a\&b combined, Base 6348)

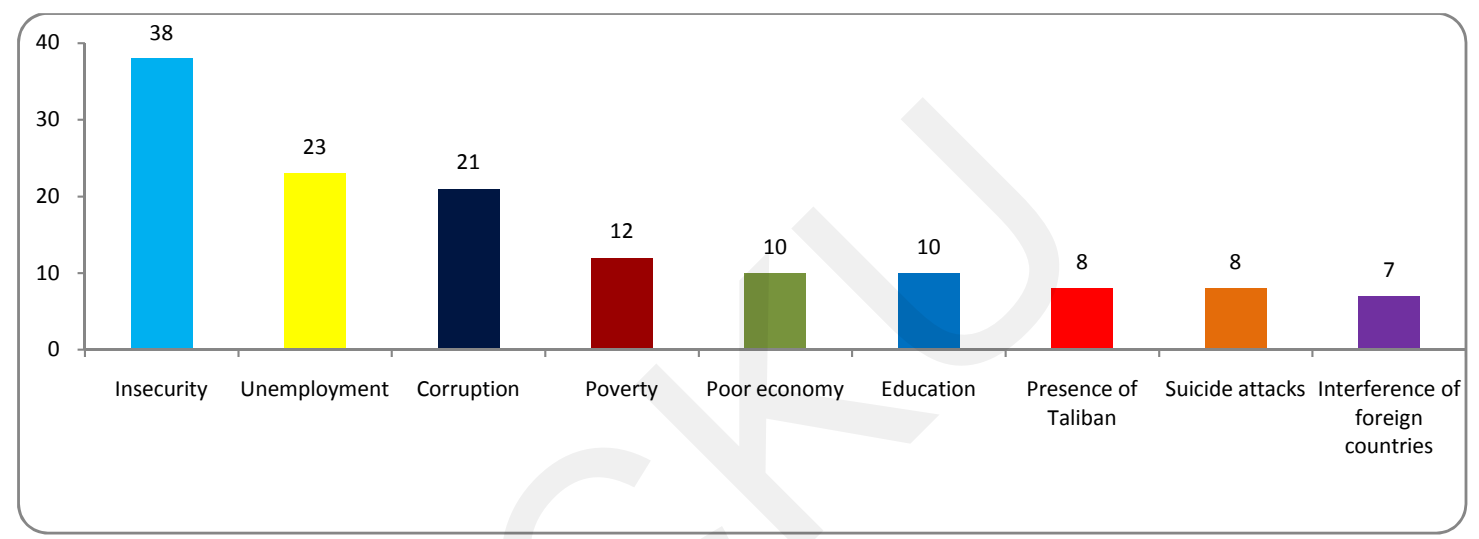

Fig. 2.5

Slightly more respondents in urban areas (39\%) identify insecurity as the biggest problem in Afghanistan than in rural areas (36\%). More Hazara (45\%), Pashtun (40\%) and Tajik (35\%) respondents than Uzbeks $(29 \%)$ identify insecurity as biggest problem in Afghanistan.

Even though insecurity is identified as the biggest problem in all the regions, it is more frequently cited in the South East (51\%), Central/Kabul (43\%), East (39\%) and West (39\%) than in other regions. A significant proportion of respondents in the Central/Kabul (34\%), North West (28\%) and North East (23\%) regions identify unemployment as the biggest problem. Corruption is identified as the biggest problem by around a third of respondents in the East (34\%) and around a quarter in the North East (26\%) and South West (25\%). These results largely reflect the reasons for pessimism given by respondents in these regions who said that the country is moving in the wrong direction (see above, 2.3 Reasons for pessimism). 
Table 2.5: In your view, what is the biggest problem facing Afghanistan as a whole? (Q-5a\&b combined, Base 6348)

\begin{tabular}{|c|c|c|c|c|c|c|c|c|c|}
\hline Base: All respondents & $\begin{array}{c}\text { Total } \\
(\%)\end{array}$ & $\begin{array}{c}\text { Central/ } \\
\text { Kabul } \\
(\%)\end{array}$ & $\begin{array}{l}\text { East } \\
(\%)\end{array}$ & $\begin{array}{c}\text { South } \\
\text { East } \\
(\%)\end{array}$ & $\begin{array}{c}\text { South } \\
\text { West } \\
(\%)\end{array}$ & $\begin{array}{l}\text { West } \\
(\%)\end{array}$ & $\begin{array}{c}\text { North } \\
\text { East } \\
(\%)\end{array}$ & $\begin{array}{c}\text { Central/ } \\
\text { Hazarajat } \\
(\%)\end{array}$ & $\begin{array}{c}\text { North } \\
\text { West } \\
(\%)\end{array}$ \\
\hline Insecurity & 38 & 43 & 39 & 51 & 34 & 39 & 26 & 36 & 31 \\
\hline Unemployment & 23 & 34 & 17 & 18 & 14 & 16 & 23 & 13 & 28 \\
\hline Corruption & 21 & 14 & 34 & 21 & 25 & 19 & 26 & 12 & 20 \\
\hline Poverty & 12 & 12 & 6 & 9 & 3 & 17 & 12 & 14 & 19 \\
\hline Poor economy & 10 & 12 & 10 & 13 & 8 & 8 & 8 & 15 & 11 \\
\hline Education & 10 & 10 & 8 & 14 & 8 & 10 & 7 & 13 & 14 \\
\hline Presence of Taliban & 8 & 5 & 6 & 4 & 5 & 14 & 8 & 9 & 14 \\
\hline Suicide attacks & 8 & 9 & 7 & 4 & 5 & 11 & 19 & $*$ & 5 \\
\hline Interference of foreign countries & 7 & 4 & 12 & 8 & 15 & 8 & 7 & 4 & 4 \\
\hline
\end{tabular}

Since 2006, insecurity and unemployment have consistently been identified as the biggest problems for the country as a whole. However, while the proportion of respondents identifying insecurity as the biggest problem in Afghanistan has remained almost the same since 2008, the proportion of respondents citing unemployment fell to $23 \%$ in 2011, which is the lowest level since the survey began in 2006 (32\% in 2006, 27\% in 2007, $31 \%$ in $2008,35 \%$ in 2009 and $28 \%$ in 2010). The proportion of respondents who identify a poor economy as the major problem facing Afghanistan also fell in 2011 to its lowest level since 2006, suggesting that Afghans view the country's economic situation more favorably than in previous years.

The proportion of respondents citing corruption has fallen to $21 \%$ in 2011 compared to $27 \%$ in 2010 , but still remains higher than in previous years (the figure was 17\% in 2009, 14\% in 2008, 16\% in 2007 and 19\% in 2006). The proportion of respondents identifying education $(10 \%)$ and poverty $(12 \%)$ as major national problems remains broadly comparable with other years.

In your view, what is the biggest problem facing Afghanistan as a whole? (Q-5a\&b combined) COMPARISON BETWEEN 2006, 2007, 2008, 2009, 2010 AND 2011

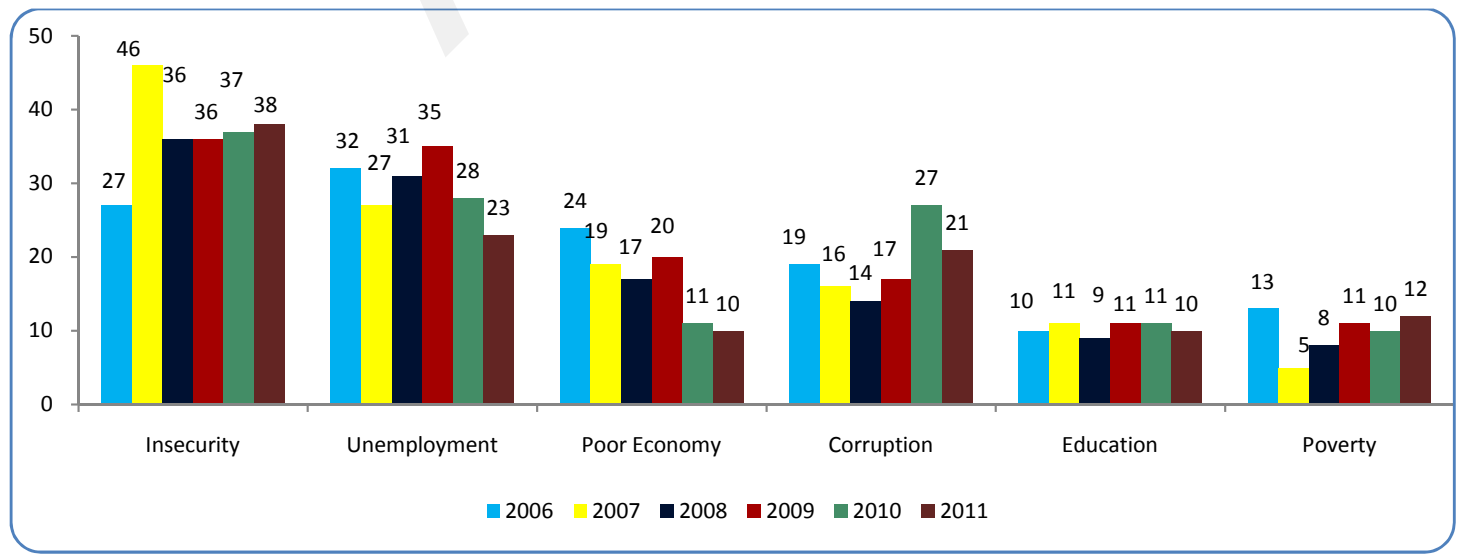

Fig 2.6 


\subsection{Afghanistan's higgest problems: Local level}

There is a difference between problems identified at the national level and those identified at the local level. The survey asked respondents about the biggest problem in their local area and asked them to cite two. While insecurity, unemployment and corruption are identified as the major problems at the national level, at the local level unemployment (28\%), electricity (23\%), and water supply $(20 \%)$ emerge as the main problems. These are followed by lack of roads (15\%), lack of education/schools/literacy (14\%), and lack of healthcare/clinics/ hospitals $(12 \%)$. Insecurity (14\%) does not emerge as predominately as other local problems, but remains a significant local problem in certain areas of the country (see below).

Unemployment is identified as one of the biggest problems at both national and local levels. Twenty-three percent of respondents identify unemployment among the top two problems at the national level and an even higher proportion $(28 \%)$ does so at the local level.

\section{What is the biggest problem in your local area? (Q-6a\&b combined, Base 6348)}

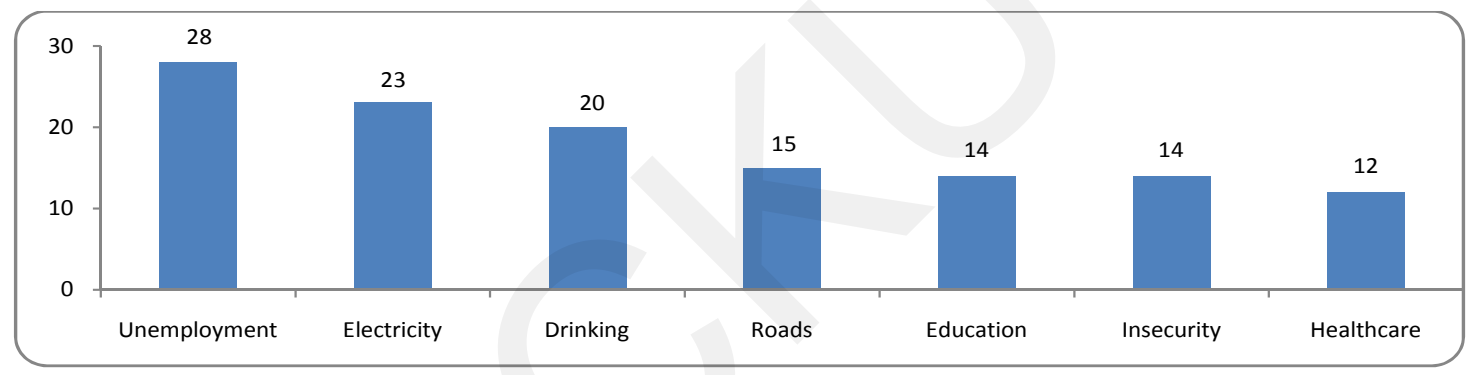

Fig. 2.7

The local problem most often cited by respondents in rural areas is unemployment (30\%), followed by electricity $(24 \%)$. While in urban areas, roads $(24 \%)$ are identified as the biggest local problem, followed by water $(23 \%)$. More than three times as many respondents in rural (16\%) as urban (5\%) areas cite insecurity as a major local problem. This is consistent with the much higher proportion of respondents who say they have experienced violence in rural (24\%) compared to urban (12\%) areas (see Chapter 3, 3.2 Experience of crime and violence).

The biggest local problems identified by respondents vary by region. Lack of employment opportunities emerges as the most important local problem in the South East (32\%), Central/Kabul (27\%) and West (27\%). Lack of electricity is cited most frequently as the most important problem in the East $(33 \%)$, North East $(30 \%)$ and South West (22\%), while water is cited in the Central/Hazarajat (33\%) and North West (34\%) regions as the biggest local problem.

Although nationally only 14\% of the respondents cite insecurity as the biggest local problem, about a third of the respondents in the South East (31\%) and a fifth in the South West (21\%) cite insecurity, making it the second biggest local problem in those regions. This is also true for 18\% in the East and $16 \%$ in the West where insecurity is identified as the third most important local problem. 
Table 2.6: What is the biggest problem in your local area? (Q-6a\&b combined, Base 6348) BY REGION

\begin{tabular}{|l|c|c|c|c|c|c|c|c|} 
& $\begin{array}{c}\text { Central/ } \\
\text { Kabul } \\
(\%)\end{array}$ & $\begin{array}{c}\text { East } \\
\mathbf{( \% )}\end{array}$ & $\begin{array}{c}\text { South } \\
\text { East } \\
(\%)\end{array}$ & $\begin{array}{c}\text { South } \\
\text { West } \\
(\%)\end{array}$ & $\begin{array}{c}\text { West } \\
(\%)\end{array}$ & $\begin{array}{c}\text { North } \\
\text { East } \\
(\%)\end{array}$ & $\begin{array}{c}\text { Central/ } \\
\text { Hazarajat } \\
(\%)\end{array}$ & $\begin{array}{c}\text { North } \\
\text { West } \\
(\%)\end{array}$ \\
\hline Unemployment & 27 & 30 & 32 & 20 & 27 & 28 & 30 & 29 \\
\hline Electricity & 18 & 33 & 16 & 22 & 24 & 30 & 12 & 27 \\
\hline Roads & 22 & 10 & 8 & 7 & 10 & 18 & 12 & 21 \\
\hline Drinking Water & 21 & 15 & 10 & 9 & 13 & 23 & 33 & 34 \\
\hline Healthcare/clinics/hospitals & 11 & 11 & 12 & 10 & 7 & 20 & 13 & 10 \\
\hline Education/schools/literacy & 9 & 14 & 18 & 12 & 15 & 14 & 20 & 19
\end{tabular}

Unemployment as a major local problem recorded a slight increase this year, rising to $28 \%$ from $26 \%$ in 2009 and 2010. However, 2011 marks the lowest proportion of respondents who identify unemployment as a major national problem.

In 2011, fewer respondents identify electricity, roads and healthcare as major local problems than in almost any previous year, suggesting that progress has been made in these areas. This is consistent with the fact that the proportion of respondents giving a positive assessment of the availability of clinics, hospitals and medicines in 2011 is the highest recorded in any year. Satisfaction with electricity supply has also shown an upward trend - from $31 \%$ in 2007 to $34 \%$ in 2009, 2010 and 2011. Identification of drinking water supply and education as major local problems remain broadly similar to previous years, however respondents continue to record the highest levels of satisfaction with these local services (see Chapter 6, 6.1 Services and Facilities available in local areas).

What is the biggest problem in your local area? (Q-6a\&b combined) COMPARISON BETWEEN 2006, 2007, 2008, 2009, 2010 AND 2011

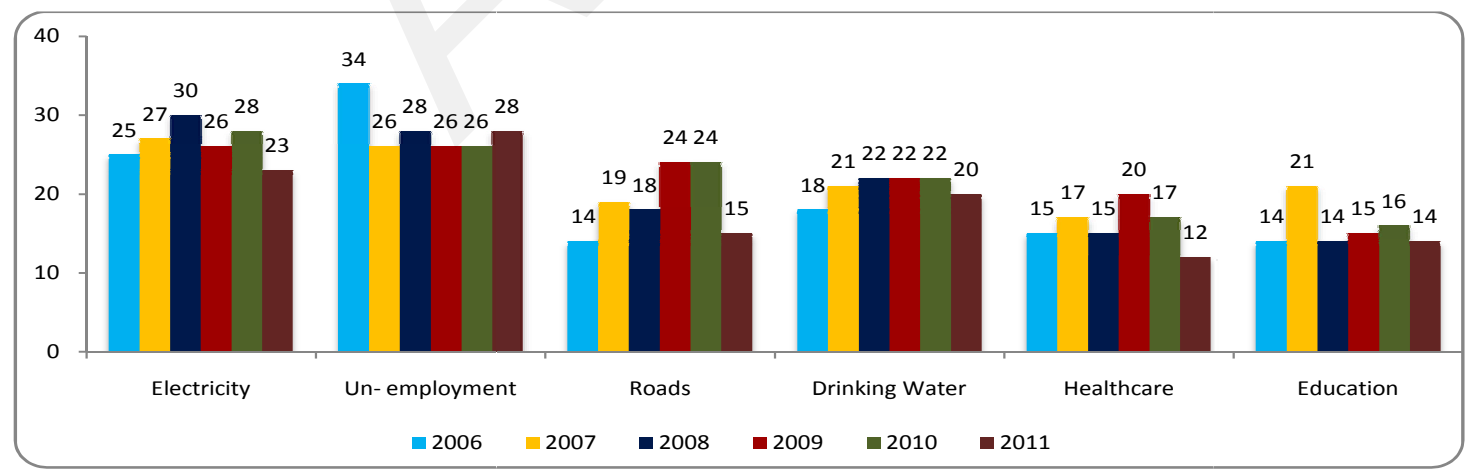

Fig 2.8 


\section{Security}

\subsection{Fear for safety}

The 2011 survey sought to gauge the perceptions of safety and security for individuals and their families. Slightly more than half $(56 \%)$ of respondents report that they often $(18 \%)$ or sometimes $(38 \%)$ fear for their personal safety or for that of their families. Another $20 \%$ say that they rarely fear for their safety while $24 \%$ say that they never do so.

The proportion of respondents who say that they often fear for their safety has been rising steadily (from $9 \%$ in 2006 to $11 \%$ in $2007,15 \%$ in $2008,16 \%$ in 2009 and $18 \%$ in 2010), but it remained steady in 2011 $(18 \%)$. The proportion who say they never do has been declining steadily since $2008(36 \%)$ to reach its lowest recorded level of $24 \%$ in 2011.

How often do you fear for your own personal safety or security or for that of your family these days? (Q-16) COMPARISON BETWEEN 2006, 2007, 2008, 2009, 2010 AND 2011

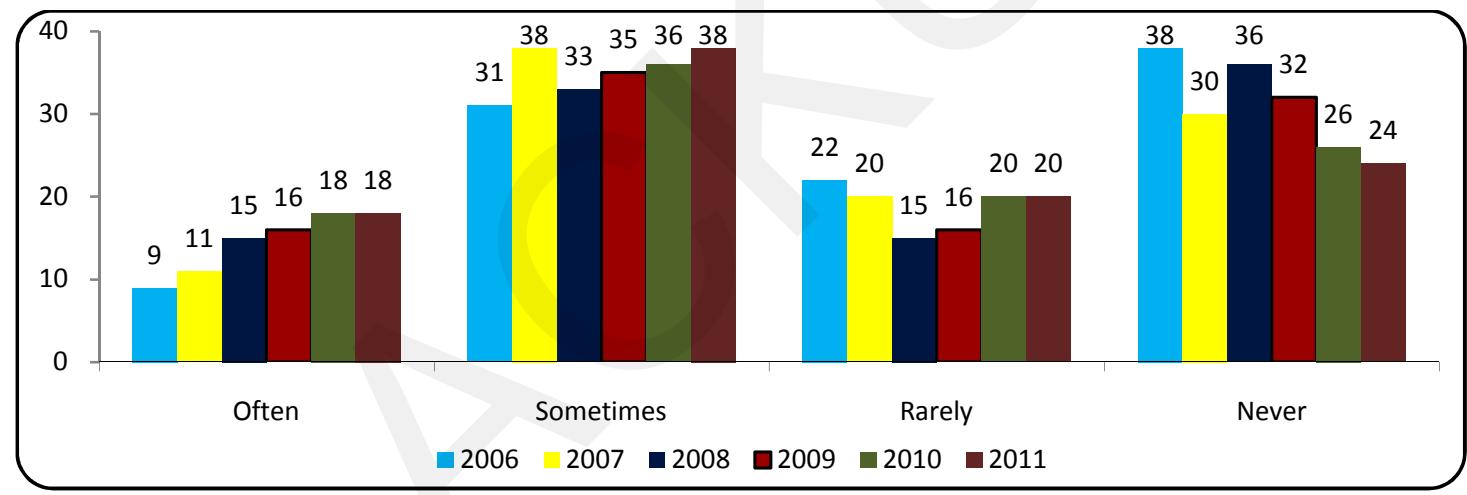

Fig. 3.1

The proportion of respondents, who report never having any fear, is highest in Central/Hazarajat $(66 \%)$ followed distantly by the North East (34\%), North West (30\%) and Central/Kabul (25\%) regions. There has been a large drop since 2010 in the two latter regions (from 45\% to 34\% in the North West and from 34\% to $25 \%$ in the Central/Kabul region), suggesting increasing concern about security. Conversely, there has also been a significant rise in the North East (from 21\% in 2010 to 34\% in 2011) suggesting an improvement in perceptions of security in this region. Indeed, in 2011 more than four fifths (84\%) of respondents in the North East say the security situation is good or very good in their local area up from $73 \%$ in 2010 (see Chapter 6, 6.1 Services and Facilities available in local areas).

On the other hand, more than $60 \%$ of respondents report often or sometimes fearing for their safety in the South East (68\%), the East (61\%) and West (62\%), and more than half in the South West (59\%), Central/ 
Kabul (56\%), North West (53\%) and North East (45\%) regions say the same. The factors that influence these perceptions may differ between regions. The South East, which records the highest proportion of respondents who report having fear for their safety, also records the lowest proportion of respondents (40\%) who judge the security situation in their local area to be positive (see Chapter 6, 6.1 Services and facilities available in local areas) and the highest incidence of crime or violence experienced by respondents (38\%). Respondents' direct experience of crime and violence is also higher in many of the regions that report high levels of fear for safety, including the South West (31\%), East (26\%), West (24\%) and North East (23\%) (see below, 3.2 Experience of crime and violence).

How often do you fear for your own personal safety or security or for that of your family these days? (Q-16, Base 6348) BY REGION

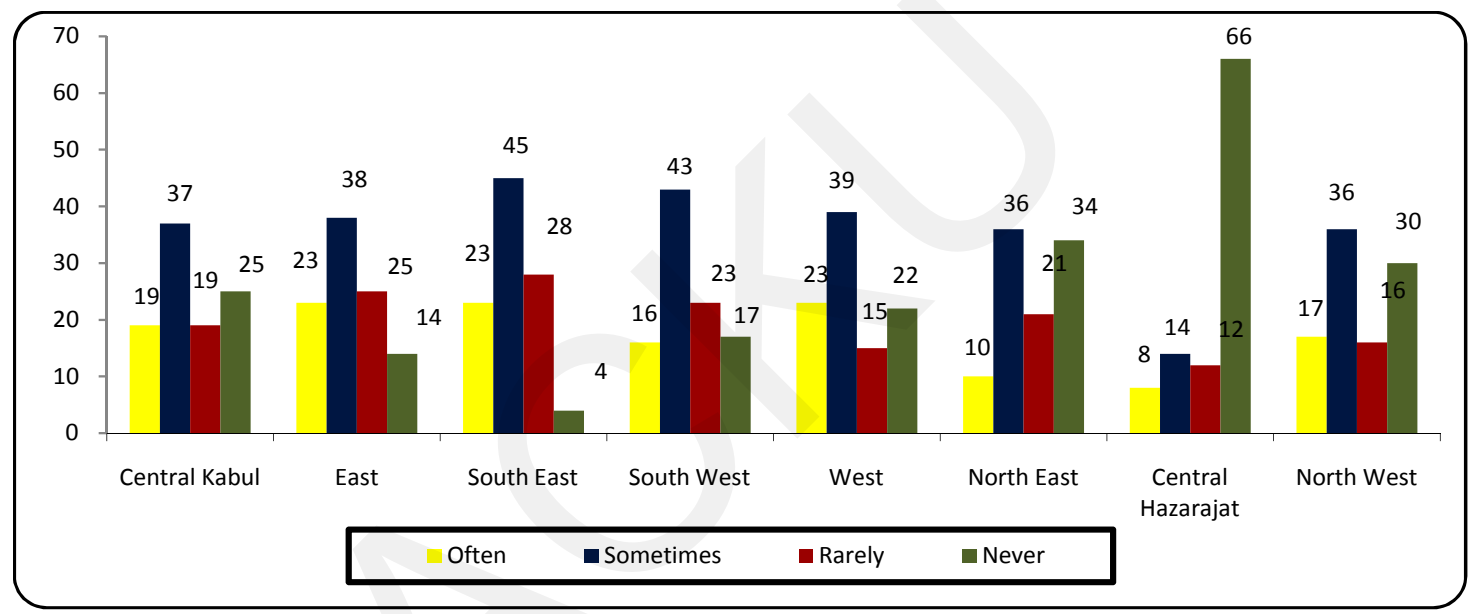

Fig 3.2

There are also differences between ethnic groups. More Uzbek (64\%) and Pashtun (60\%) respondents report often or sometimes fearing for their safety than their Tajik (51\%) and Hazara (53\%) counterparts.

\subsection{Experience of crime and violence}

The survey also sought to uncover people's actual experience of violence and crime by asking whether they, or anyone in their family, have been a victim of violence or some criminal act in their home or community in the past year. Compared to the proportion of people who report that they sometimes or often fear for their safety $(56 \%)$, the proportion of those who have actually experienced violence or crime in the past year is relatively low $(22 \%)$. However, this figure is substantially higher than that in $2010(17 \%)$. 
The proportion of respondents who say they have experienced violence or crime is twice as high in rural $(24 \%)$ as in urban (12\%) areas. This is consistent with the higher numbers of people reporting insecurity as a major local problem in rural (16\%) than in urban (5\%) areas (see Chapter2, 2.5 Afghanistan's biggest problems: Local leve).

There are also differences across regions. The highest incidence of crime or violence experienced by respondents is in the South East (38\%) followed by the South West (31\%), East (26\%), West (24\%) and North East $(23 \%)$. Moreover, there has been a marked rise in the proportion of respondents reporting that they have directly experienced violence or crime in all regions except Central/Kabul since 2010, reaching the highest levels recorded in most regions since 2008. The rise is particularly significant in the North West (15\% in 2011 compared to 6\% in 2010), East (26\% in 2011 compared to $18 \%$ in 2010), South West (31\% in 2011 compared to $25 \%$ in 2010 ) and Central/Hazarajat (7\% in 2011 compared to $2 \%$ in 2010).

Table 3.1: Proportion of those who report that they or anyone in their family have been a victim of violence or of some criminal act in their home or community in the past year (Q-17) ALL AND BY REGION, COMPARISON BETWEEN 2008, 2009, 2010 AND 2011

\begin{tabular}{|l|c|c|c|c|}
\hline & $\begin{array}{c}\mathbf{2 0 0 8} \\
\mathbf{( \% )}\end{array}$ & $\begin{array}{c}\mathbf{2 0 0 9} \\
\mathbf{( \% )}\end{array}$ & $\begin{array}{c}\mathbf{2 0 1 0} \\
\mathbf{( \% )}\end{array}$ & $\begin{array}{c}\mathbf{2 0 1 1} \\
\mathbf{( \% )}\end{array}$ \\
\hline All & 16 & 17 & 17 & $\mathbf{2 2}$ \\
\hline Central/Kabul & 13 & 12 & 11 & $\mathbf{1 1}$ \\
\hline East & 19 & 22 & 18 & $\mathbf{2 6}$ \\
\hline South East & 21 & 26 & 34 & $\mathbf{3 8}$ \\
\hline South West & 22 & 25 & 25 & $\mathbf{3 1}$ \\
\hline West & 17 & 25 & 21 & $\mathbf{2 4}$ \\
\hline North East & 15 & 12 & 20 & $\mathbf{2 3}$ \\
\hline Central /Hazarajat & 4 & 10 & 2 & $\mathbf{7}$ \\
\hline North West & 11 & 6 & 6 & $\mathbf{1 5}$ \\
\hline
\end{tabular}

Respondents who report having been a victim of violence or crime in the past year ( $22 \%$ of all respondents) were asked about the kinds of violence and crime they or som eone in their family had experienced. The most common form of violence or crime cited is physical attack or beating $(36 \%)$ followed by burglary/looting $(12 \%)$, racketeering/extortion $(10 \%)$ and theft of livestock (10\%). Around one in 12 victims of violence report violence resulting from the actions of foreign forces $(8 \%)$ and instances of pick-pocketing $(8 \%)$. 
What kind of violence or crime did you or someone in your family experience in the past year? (Q-18a, Base 1377) (\%age based on multiple responses)

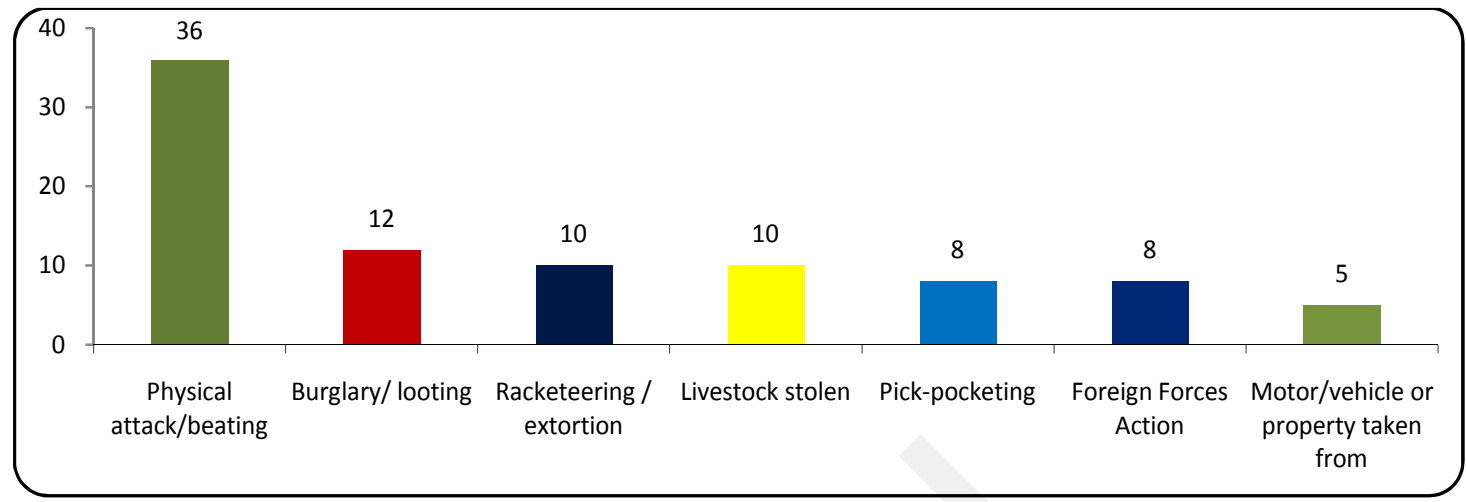

Fig. 3.3

Over a third of crime victims in rural areas $(37 \%)$ report having been victims of physical attack or beating compared to less than a third in urban areas (29\%). On the other hand, pick-pocketing is more prevalent in urban areas.

What kind of violence or crime did you or someone in your family experience in the past year? (Q-18a, Base 1377) (Percentage based on multiple responses) BY SETTLEMENT

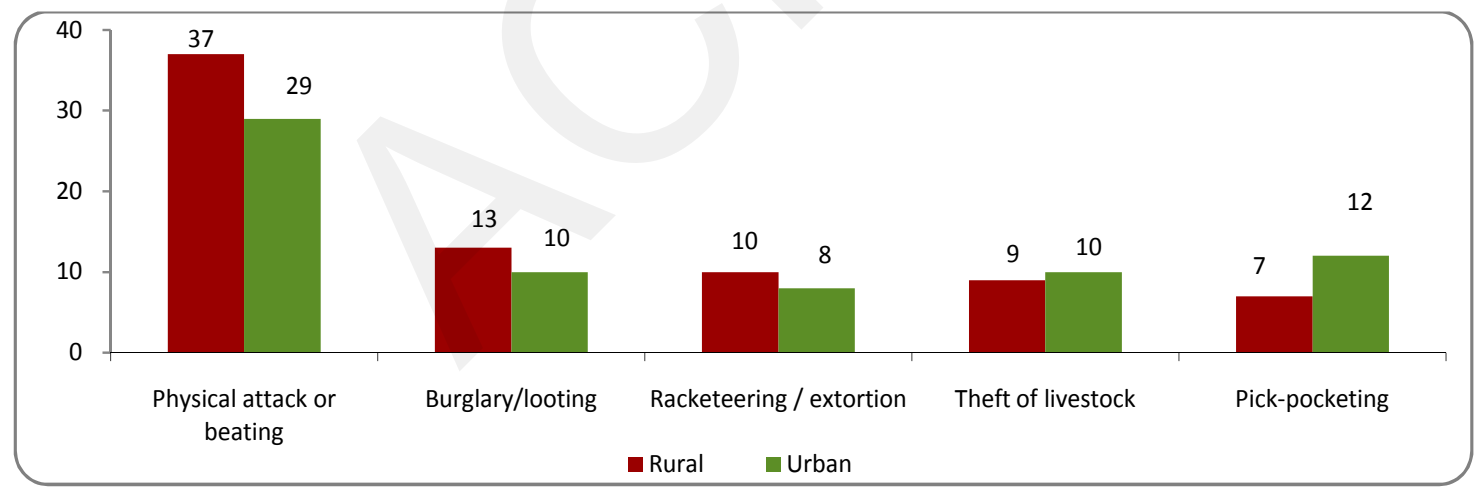

Fig. 3.4

The incidence of victimization from militants/insurgents actions has risen significantly since $2007(3 \%)$ to around one in 10 respondents in 2008 (8\%), 2009 (9\%) and 2010 (9\%), but it declined to one in 25 (4\%) in 2011. 
Table 3.2: What kind of violence or crime did you or someone in your family experience in the past year? (Q-18a) (Only militants/insurgents actions) COMPARISON BETWEEN 2007, 2008, 2009, 2010 AND 2011

Militants/Insurgent actions

2007
3

\begin{tabular}{|c|c|c|c|}
\hline 2008 & 2009 & 2010 & 2011 \\
\hline 8 & 9 & 9 & 4 \\
\hline
\end{tabular}

The incidence of victimization from militants/insurgents actions has declined significantly in most regions. The largest decrease in the incidence of victimization from militants/insurgents actions is recorded in North West (from 21\% in 2010 to zero percent in 2011). In the East (8\%), the trend remained stable and in the South East it increased slightly (from 4\% in 2010 to $5 \%$ in 2011).

Table 3.3: What kind of violence or crime did you or someone in your family experience in the past year? (Q-18a) (Militants) insurgents actions only) COMPARISON BETWEEN 2010 AND 2011 ALL AND BY REGION

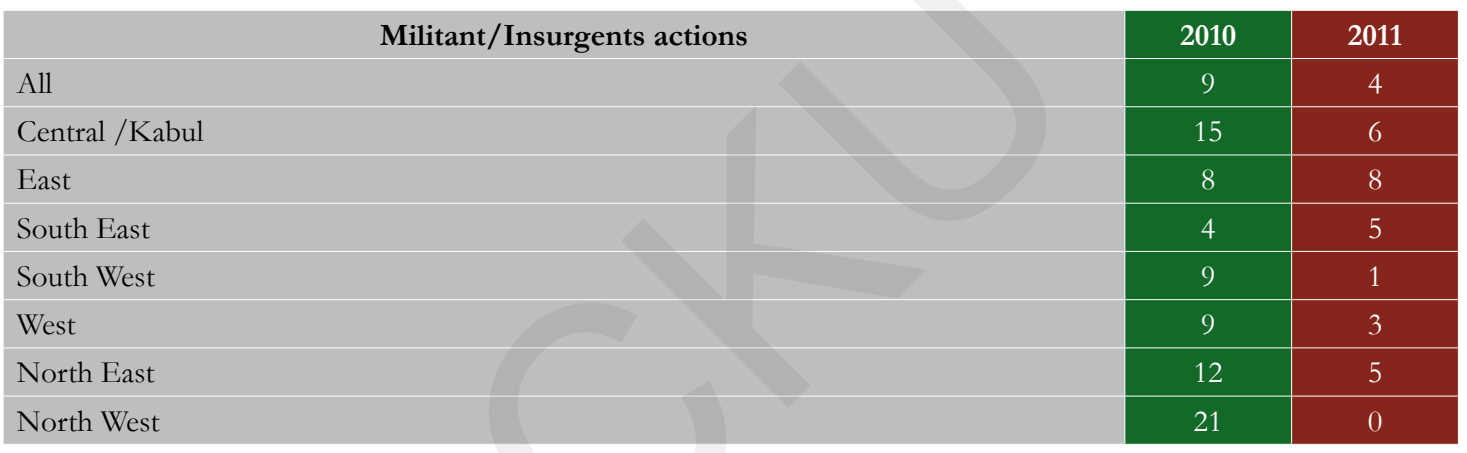

Conversely, the incidence of perceived victimization from foreign forces actions has risen from 6\% in 2010 to $8 \%$ in 2011 and is three times higher in the South West (27\%) than in any other part of the country $(9 \%$ in the South East and $\%$ in the West, North West and North East). Those reporting violence from foreign forces and police action increased in all regions in 2011 compared to 2010 with the exception of the East, where it fell from $19 \%$ to $5 \%$ and of Central/Kabul where it remained stable.

Table 3.4: What kind of violence or crime did you or someone in your family experience in the past year? (Q-18a, ) (Foreign forces actions only) COMPARISON BETWEEN 2010 AND 2011 ALL AND BY REGION

\begin{tabular}{|c|c|c|}
\hline Foreign Forces actions & 2010 & 2011 \\
\hline All & 6 & 8 \\
\hline Central/Kabul & 5 & 4 \\
\hline East & 19 & 5 \\
\hline South East & 2 & 9 \\
\hline South West & 11 & 27 \\
\hline West & 3 & 2 \\
\hline North East & 1 & 2 \\
\hline North West & 0 & 2 \\
\hline
\end{tabular}


In addition, around one in 20 respondents report violence or crime as a result of police actions in the Central/ Kabul (7\%), South East (7\%) and South West (4\%) regions.

Table 3.5: What kind of violence or crime did you or someone in your family experience in the past year? (Q-18a,) (Police actions only) COMPARISON BETWEEN 2010 AND 2011 ALL AND BY REGION

\begin{tabular}{|c|c|c|}
\hline Police actions & 2010 & 2011 \\
\hline All & 3 & 4 \\
\hline Central / Kabul & 5 & 7 \\
\hline East & 1 & 3 \\
\hline South East & 5 & 7 \\
\hline South West & 5 & 4 \\
\hline West & 2 & 3 \\
\hline North East & 7 & 1 \\
\hline Central/ Hazarajat & 0 & 0 \\
\hline North West & 0 & 3 \\
\hline
\end{tabular}

The respondents who were victims of physical attack or beating (36\% of victims of crime or violence and $8 \%$ of all respondents) were asked in a follow-up question about the kind of physical attack or beating they or their family member experienced. Thirty-five percent of them report that the incident involved their neighbors while $33 \%$ say it was a case of domestic violence (within the family). Another $6 \%$ say it was an incident involving someone else (other than a neighbor or family member) and 5\% say it was case involving relatives.

\subsection{Attitude toward reporting crime}

Those respondents who have been victims of violence or crime (22\% of all respondents) were also asked whether they reported the crime to any authority. Over half $(59 \%)$ of them say that they reported the crime while a third $(33 \%)$ say they did not. These results are comparable to previous years.

Amongst respondents who reported violence or crime (59\% of victims of crime), more men $(62 \%)$ than women (54\%) reported the violence or crime to some authority. Reporting rates also vary across the regions. More than two thirds of crime victims reported the violence or crime to some authority in the West $(67 \%)$ and North West (67\%) compared to less than half in the Central/Kabul (45\%) and South West (46\%) regions. 
You said that you've been a victim of violence or criminal act in the past year. Did you report it to any authority? (Q-19)

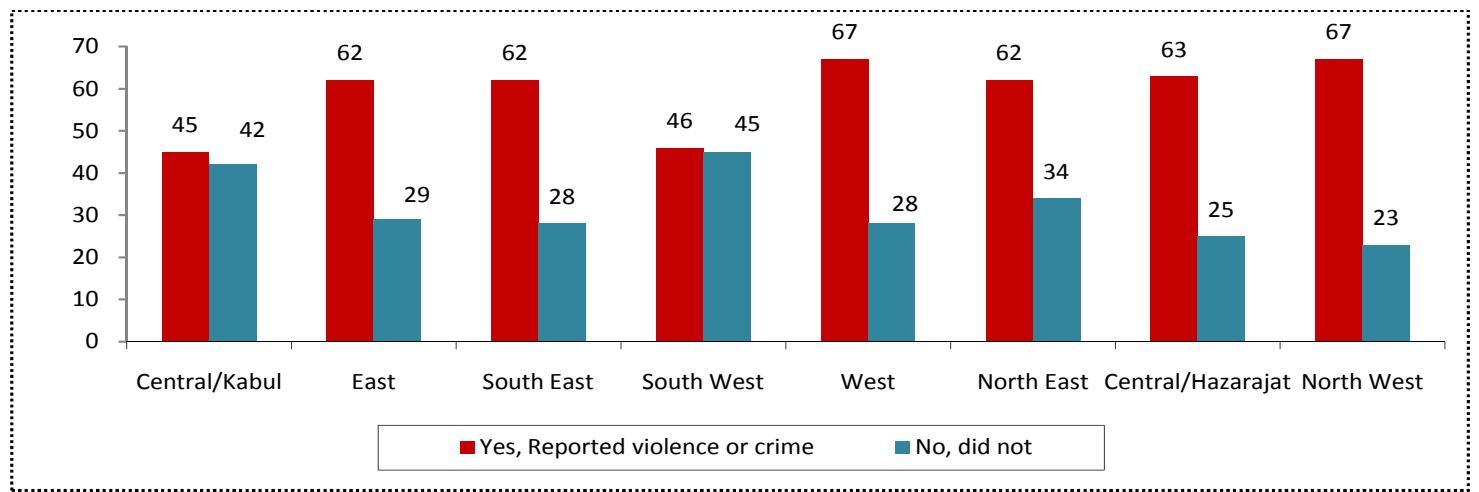

Fig 3.5

The respondents who say that they reported violence or crime $59 \%$ of victims and $13 \%$ of all the respondents) were also asked to which agency or institution they reported it. Multiple responses were possible for this question. Respondents most often reported crime to the Afghan National Police (ANP) (35\%). This may be because of the mandate of the police force and the high level of confidence respondents report in the efficiency of the ANP in arresting those who have committed crimes (see below, 3.5 Perceptions of the Afghan $\mathrm{Na}$ tional Police). Respondents also reported crime to other government agencies including the district governor/ woleswal (12\%) and the Afghan National Army (ANA) (12\%). A significant proportion said they reported the crime to informal or traditional institutions such as shura/elders (25\%), tribal leaders/maliks $(10 \%)$ and mullahs $(6 \%)$.

Respondents in urban areas who have been victims of crime are significantly more likely to report the problem to government institutions such as the ANP (52\% compared to $32 \%$ in rural areas). This may be because this institution is more often present in urban settings, and is therefore more accessible to urban residents. On the other hand, rural residents are more likely to report crime to shura/elders (26\% compared to $14 \%$ in urban areas) and mullah (7\% compared to $1 \%$ in urban areas). This is consistent with the fact that local shura and jirga still remain the most trusted and accessible conflict resolution mechanisms for Afghans, particularly in rural areas (see Chapter 10, 10.3 Perceptions on local shura and jirga). 
To what agency or institution did you report the crime? (Q-20, Base 811) ALL AND BY SETTLEMENT

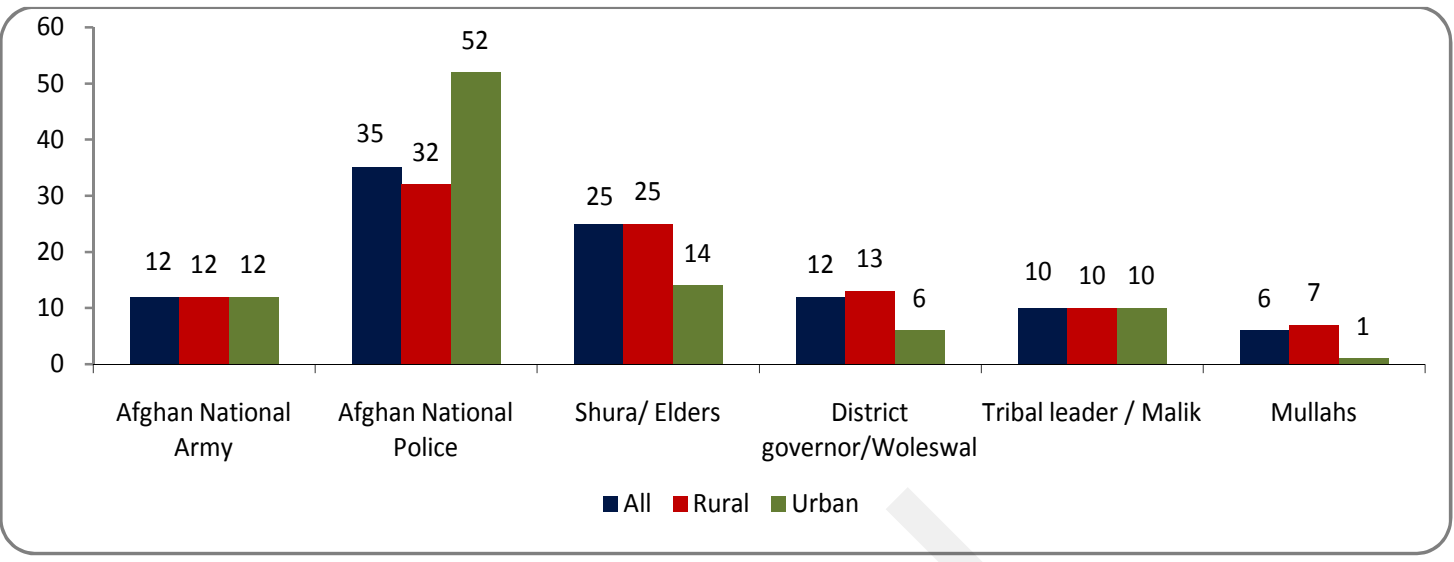

Fig. 3.6

The proportion of respondents who reported violence and crime to an authority shows significant differences across regions. Almost half of respondents in the North East (48\%), Central/Kabul (46\%) and East (40\%) regions reported a crime to the ANP, compared to around a quarter in the South East (25\%) and West (26\%). The first three regions are also the regions where the highest level of confidence in the ANP is recorded (see Chapter 7, 7.1 Confidence in public institutions).

The highest proportion of respondents who reported a crime to ANA is in the East (25\%), South East (18\%) and South West (17\%) regions. This may be because of greater presence of ANA in these regions for military operations and stabilization purposes. These are the same regions that record the highest levels of violence by foreign forces and by direct police action (see Chapter 3, 3.2 Experience of crime and violence), suggesting that the ANA may be seen as a more approachable authority to whom respondents can report crime in these regions.

The proportion of the respondents who reported a crime to a district governor/woleswal is highest in the Central/Kabul (18\%) and West (15\%) regions and lowest in the South West (5\%).

Around one third of respondents in the West (35\%), South West (30\%) and South East (29\%) and around a quarter in the North West $(25 \%)$ reported a crime to shura/elders. About one in six of the respondents in the South East (16\%), East (14\%) and one in 10 in North West (12\%) and Central/Hazarajat (10\%) regions reported a crime to the tribal leaders/maliks. Around one in 10 reported a crime to a mullah in the North West $(12 \%)$, South East $(10 \%)$ and West (9\%) regions. 
Table 3.6: To what agency or institution did you report the crime? (Q-20, Base 811) AND ALL BY REGION

\begin{tabular}{|l|c|c|c|c|c|c|c|c|c|} 
& $\begin{array}{c}\text { All } \\
(\mathbf{\%})\end{array}$ & $\begin{array}{c}\text { Central/ } \\
\text { Kabul } \\
(\%)\end{array}$ & $\begin{array}{c}\text { East } \\
\mathbf{( \% )}\end{array}$ & $\begin{array}{c}\text { South } \\
\text { East } \\
\mathbf{( \% )}\end{array}$ & $\begin{array}{c}\text { South } \\
\text { West } \\
\mathbf{( \% )}\end{array}$ & $\begin{array}{c}\text { West } \\
\mathbf{( \% )}\end{array}$ & $\begin{array}{c}\text { North } \\
\text { East } \\
\mathbf{( \% )}\end{array}$ & $\begin{array}{c}\text { Central/ } \\
\text { Hazarajat } \\
(\%)\end{array}$ & $\begin{array}{c}\text { North } \\
\text { West } \\
\mathbf{( \% )}\end{array}$ \\
\hline Afghan National Army & 12 & 6 & 25 & 18 & 17 & 6 & 6 & 0 & 7 \\
\hline Afghan National Police & 35 & 46 & 40 & 25 & 32 & 26 & 48 & 30 & 32 \\
\hline Shura/elders & 25 & 18 & 15 & 29 & 30 & 35 & 18 & 20 & 25 \\
\hline District governor/woleswal & 12 & 18 & 14 & 11 & 5 & 15 & 11 & 10 & 13 \\
\hline Tribal leader /malik & 10 & 1 & 14 & 16 & 9 & 6 & 9 & 10 & 12 \\
\hline Mullahs & 6 & 1 & 0 & 10 & 5 & 9 & 3 & 0 & 12 \\
\hline
\end{tabular}

Respondents, who have been victims of crime or violence, but said they did not report this to any authority (i.e. $33 \%$ of victims and $7 \%$ of all respondents), were asked to give the reasons for not reporting the crime. Again, multiple responses were possible. A quarter (25\%) said that they did not report the crime because it was not serious. However, about one in six victimized respondents $(16 \%)$ said that they were afraid of retaliation and one in eight $(13 \%)$ said it made no difference whether they reported or not.

Why didn't you report the crime? (Q-21, Base 452)

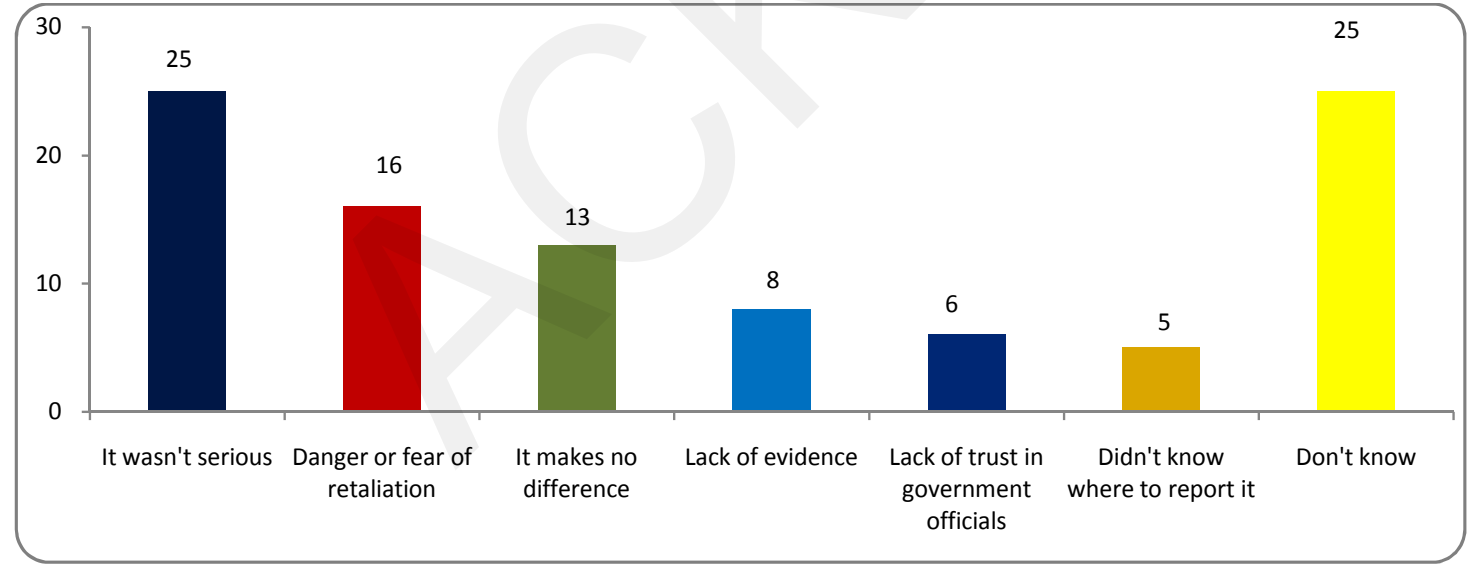

Fig. 3.7

All respondents, regardless of whether they personally experienced crime or not, were asked the hypothetical question: "If you were a victim of violence or any criminal act, how much confidence would you have that the governmental law-enforcing organizations and judicial systems would punish the guilty party?" More than half of respondents (59\%) say that they would have some level of confidence (20\% say a great deal of confidence and $39 \%$ say a fair amount of confidence). However, another $24 \%$ say they would not have very much confidence and $13 \%$ say they would have no confidence at all. 
The majority of respondents in all regions except Central/Kabul (49\%) and the South East (49\%) report overall confidence in government law enforcement agencies, with the highest levels of confidence recorded in the North East (69\%) and East (65\%).

If you were a victim of violence or any criminal act, how much confidence would you have that the governmental law-enforcing organizations and judicial systems would punish the guilty party? (Q-22, Base ALL Respondents, 6348) BY REGION

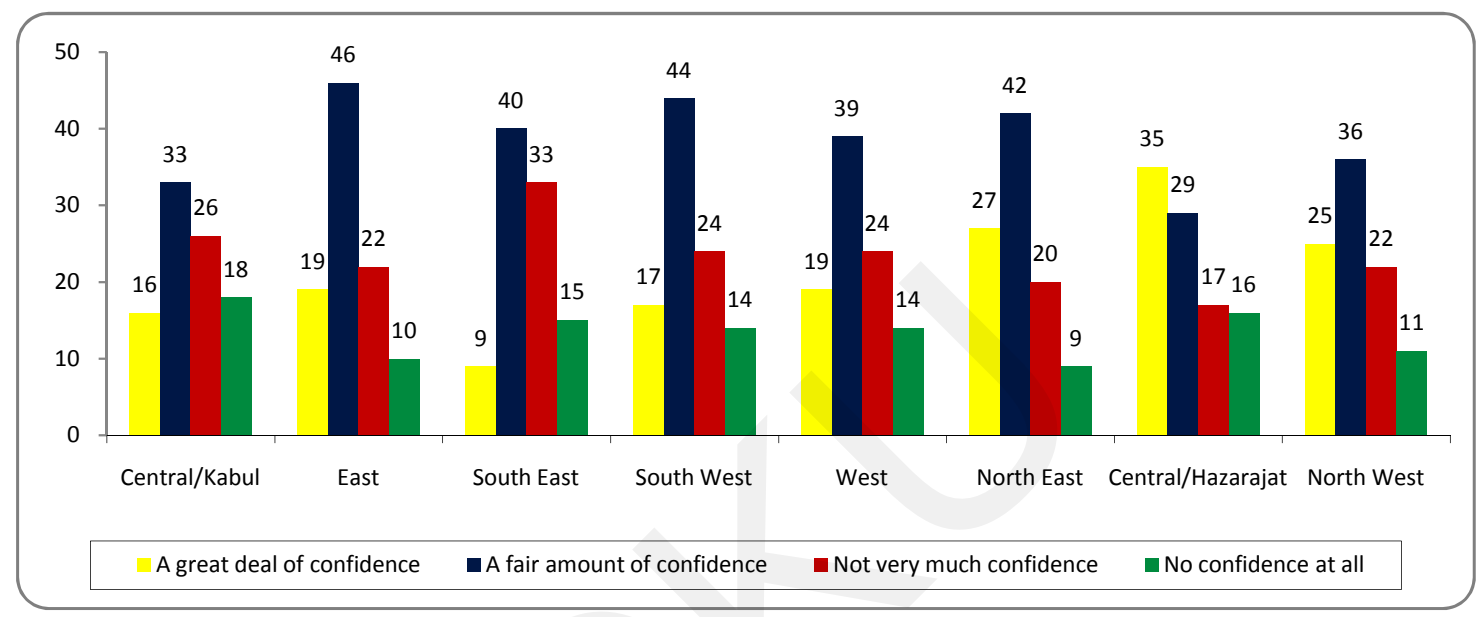

Fig. 3.8

In some regions, the level of confidence in government law enforcement agencies/institutions increased in 2011, such as South West (from 49\% in 2010 to 61\% in 2011), Central/Hazarajat (from 53\% in 2010 to $63 \%$ in 2011), East (from 58\% in 2010 to $66 \%$ in 2011), and North East (from 62\% in 2010 to $69 \%$ in 2011). However, the level of confidence in government law enforcement agencies to punish those who commit crime dropped $7 \%$ in both the Central/Kabul (from 56\% to 49\%) and North West (from 68\% to 61\%) regions.

Table 3.7: If you were a victim of violence or any criminal act, how much confidence would you have that the governmental law-enforcing organizations and judicial systems would punish the guilty party? (Q-22) COMPARISON OF 2010 AND 2011 BY REGION

\begin{tabular}{l|c|c|}
\multirow{2}{*}{} & \multirow{2}{*}{ Q22 } & \multicolumn{2}{c}{ A level of confidence } \\
\cline { 2 - 3 } & $\mathbf{2 0 1 0}$ & $\mathbf{2 0 1 1}$ \\
\hline Central/Kabul & 56 & 49 \\
\hline East & 58 & 66 \\
\hline South East & 50 & 49 \\
\hline South West & 49 & 61 \\
\hline West & 55 & 58 \\
\hline North East & 62 & 69 \\
\hline Central/Hazarajat & 53 & 63 \\
\hline North West & 68 & 61 \\
\hline
\end{tabular}


The survey also endeavored to identify what people think are the biggest causes of crime in Afghanistan. The most common causes of crime identified by respondents are unemployment (19\%) and corruption (10\%). Around one in 10 respondents identify insecurity ( $9 \%$ ) and lack of government's attention/weak government $(9 \%)$ as the biggest causes of crime.

People's views in this regard differ widely across the regions. Unemployment is the reason most frequently identified in the Central/Kabul (26\%), South West (24\%) and North East (22\%), whereas corruption is most often mentioned in the East $(16 \%)$. Insecurity is mentioned most often in the East $(13 \%)$ and South East $(13 \%)$. Lack of government attention/weak government is also highlighted in the East $(14 \%)$ and the North West $(10 \%)$

Table 3.8: What is the biggest cause of crime in Afghanistan? (Q-23, Base, 6348) ALL AND BY REGION

\begin{tabular}{|c|c|c|c|c|c|c|c|c|c|}
\hline Q-23 & $\begin{array}{c}\text { TOTAL } \\
(\%)\end{array}$ & $\begin{array}{c}\text { Central/ } \\
\text { Kabul } \\
(\%)\end{array}$ & $\begin{array}{l}\text { East } \\
(\%)\end{array}$ & $\begin{array}{c}\text { South } \\
\text { East } \\
(\%)\end{array}$ & $\begin{array}{l}\text { South } \\
\text { West } \\
(\%)\end{array}$ & $\begin{array}{l}\text { West } \\
(\%)\end{array}$ & $\left|\begin{array}{c}\text { North } \\
\text { East } \\
(\%)\end{array}\right|$ & $\begin{array}{c}\text { Central/ } \\
\text { Hazarajat } \\
\text { (\%) }\end{array}$ & $\begin{array}{c}\text { North } \\
\text { West } \\
(\%)\end{array}$ \\
\hline Unemployment & 19 & 26 & 14 & 15 & 24 & 13 & 22 & 7 & 19 \\
\hline Corruption & 10 & 9 & 16 & 9 & 8 & 10 & 9 & 9 & 10 \\
\hline Insecurity & 9 & 9 & 13 & 13 & 9 & 6 & 6 & 6 & 8 \\
\hline $\begin{array}{l}\text { Lack of government } \\
\text { attention/weak government }\end{array}$ & 9 & 9 & 14 & 9 & 4 & 7 & 9 & 7 & 10 \\
\hline Poverty & 8 & 9 & 8 & 9 & 5 & 7 & 7 & 10 & 9 \\
\hline Illiteracy & 8 & 6 & 6 & 10 & 12 & 7 & 7 & 4 & 8 \\
\hline Drugs & 4 & 3 & 2 & 5 & 1 & 7 & 4 & 7 & 6 \\
\hline Lack of law implementation & 4 & 5 & 3 & 7 & 1 & 5 & 4 & 5 & 3 \\
\hline
\end{tabular}

\subsection{Fear to participate in various activities}

The survey also measured perceptions of security by exploring whether people feel fear in participating in a range of public activities. A series of activities was read out to respondents and they were asked to say whether they would participate in these activities with some degree of fear or without fear. More than half of the respondents $(59 \%)$ say that they would have no fear participating in resolving problems in the community. While $42 \%$ of respondents say they would have no fear voting in a national election, $57 \%$ reported some level of fear to do so, including $18 \%$ who say "a lot of fear." Only $31 \%$ say they would have no fear participating in a peaceful demonstration while $66 \%$ feel some level of fear to do so, including $25 \%$ who say "a lot of fear." The results are similar in the case of running for public office. The proportion of respondents who say they would not be afraid when traveling from one part of the country to another is the lowest at $25 \%$ while three quarters of respondents (75\%) say they feel some level of fear to do so, including $29 \%$ who say "a lot of fear."

More than half of the respondents (55\%) say they would have no fear encountering an officer of the ANA, and $51 \%$ say the same about encountering an officer of the ANP. Only $23 \%$ say they would have no fear when encoun- 
tering international forces while $76 \%$ say they would have some level of fear when encountering them, including $36 \%$ who say they would have a lot of fear. Forty-eight percent say they would have some fear or a lot of fear encountering ANP officers; 44\% say they would have some fear or a lot of fear encountering an ANA officer.

Table 3.9: Public's level of fear to participate in various activities (Q-30a-h, Base 6348)

\begin{tabular}{l|c|c|c|} 
& $\begin{array}{c}\text { No fear } \\
(\mathbf{\%})\end{array}$ & $\begin{array}{c}\text { Some fear } \\
(\mathbf{\%})\end{array}$ & $\begin{array}{c}\text { A lot of fear } \\
(\mathbf{\%})\end{array}$ \\
\hline a) When participating in resolving problems in your community & 59 & 33 & 8 \\
\hline b) Voting in a national election & 42 & 39 & 18 \\
\hline c) Participating in a peaceful demonstration & 31 & 41 & 25 \\
\hline d) To run for a public office & 33 & 38 & 25 \\
\hline e) When encountering ANP officers & 51 & 34 & 14 \\
\hline f) When encountering ANA officers & 55 & 31 & 13 \\
\hline g) When traveling from one part of Afghanistan to another part of the country & 25 & 46 & 29 \\
\hline h) When encountering international forces & 23 & 40 & 36 \\
\hline
\end{tabular}

Levels of fear to participate in all forms of public activities are consistently higher in the South East, South West, East and West regions. These are also the regions where insecurity is most often identified as a major local problem (see Chapter2, 2.5 Afghanistan's biggestproblems: Local leve), and where most respondents say that the security situation is bad in their local area (see Chapter 6, 6.1 Services and facilities available in local areas).

Table 3.10: Public's level of fear (combination of some fear and a lot of fear) to participate in various activities (Q-30a-h, Base 6348) ALL AND BY REGION

\begin{tabular}{|c|c|c|c|c|c|c|c|c|c|}
\hline & $\begin{array}{l}\text { All } \\
(\%)\end{array}$ & $\begin{array}{c}\text { Central/ } \\
\text { Kabul } \\
(\%)\end{array}$ & $\begin{array}{c}\text { East } \\
(\%)\end{array}$ & $\begin{array}{c}\text { South } \\
\text { East } \\
(\%)\end{array}$ & $\begin{array}{c}\text { South } \\
\text { West } \\
(\%)\end{array}$ & $\begin{array}{l}\text { West } \\
(\%)\end{array}$ & $\begin{array}{l}\text { North } \\
\text { East } \\
(\%)\end{array}$ & $\begin{array}{l}\text { Central/ } \\
\text { Hazarajat } \\
\quad(\%)\end{array}$ & $\begin{array}{c}\text { North } \\
\text { West } \\
(\%)\end{array}$ \\
\hline $\begin{array}{l}\text { a) Participating in resolving } \\
\text { problems in your community }\end{array}$ & 41 & 37 & 41 & 48 & 55 & 48 & 29 & 32 & 35 \\
\hline b) Voting in a national election & 57 & 43 & 69 & 76 & 77 & 60 & 50 & 37 & 52 \\
\hline $\begin{array}{l}\text { c) Participating in a peaceful } \\
\text { demonstration }\end{array}$ & 66 & 60 & 70 & 80 & 72 & 69 & 64 & 47 & 66 \\
\hline d) Running for public office & 63 & 52 & 69 & 82 & 78 & 67 & 58 & 44 & 61 \\
\hline e) Encountering ANP officers & 48 & 39 & 52 & 62 & 65 & 51 & 36 & 48 & 45 \\
\hline $\begin{array}{l}\text { f) When encountering ANA } \\
\text { officers }\end{array}$ & 44 & 37 & 48 & 49 & 62 & 47 & 33 & 51 & 42 \\
\hline $\begin{array}{l}\text { g) Traveling from one part of } \\
\text { Afghanistan to another part of } \\
\text { the country }\end{array}$ & 75 & 74 & 73 & 81 & 76 & 79 & 68 & 63 & 73 \\
\hline $\begin{array}{l}\text { h) when encountering } \\
\text { international forces }\end{array}$ & 76 & 72 & 80 & 86 & 84 & 73 & 75 & 53 & 75 \\
\hline
\end{tabular}


Comparison of the results of the 2011 survey with those of previous years reveals that the proportion of people who say they fear to participate in public activities is rising over time, although there has been a fall since 2010 when the highest levels were recorded. This is consistent with the rising proportion of respondents who say they sometimes or often fear for their safety (see above 3.1 Fear for safety).

The proportion of respondents who say they would have some fear participating in resolving problems in their community has decreased from $46 \%$ in 2010 to $41 \%$ in 2011 but is still higher than in any other year since 2006. The same is true for voting in a national election, running for public office and participating in a peaceful demonstration. There is a small decrease in the levels of fear related to encountering ANP officers (from 49\% in 2007 and 2008, 50\% in 2009, and 52\% in 2010 to 48\% in 2011). Fear when travelling between different parts of the country, however, has been rising steadily since 2008 , from $61 \%$ to $69 \%$ in $2009,74 \%$ in 2010 and $75 \%$ in 2011.

Table 3.11: Public's level of fear (combination of some fear and a lot of fear) to participate in various activities (Q-30a-h) COMPARISON BETWEEN 2006, 2007, 2008, 2009, 2010 AND 2011

\begin{tabular}{l|c|c|c|c|c|c|} 
& $\begin{array}{c}\mathbf{2 0 0 6} \\
\mathbf{( \% )}\end{array}$ & $\begin{array}{c}\mathbf{2 0 0 7} \\
\mathbf{( \% )}\end{array}$ & $\begin{array}{c}\mathbf{2 0 0 8} \\
\mathbf{( \% )}\end{array}$ & $\begin{array}{c}\mathbf{2 0 0 9} \\
\mathbf{( \% )}\end{array}$ & $\begin{array}{c}\mathbf{2 0 1 0} \\
\mathbf{( \% )}\end{array}$ & $\begin{array}{c}\mathbf{2 0 1 1} \\
\mathbf{( \% )}\end{array}$ \\
\hline $\begin{array}{l}\text { a) When participating in resolving problems in your } \\
\text { community }\end{array}$ & 32 & 38 & 39 & 40 & 46 & 41 \\
\hline $\begin{array}{l}\text { b) Voting in a national election } \\
\text { c) Participating in a peaceful demonstration }\end{array}$ & 41 & 44 & 45 & 51 & 60 & 57 \\
\hline $\begin{array}{l}\text { d) To run for a public office } \\
\text { e) When encountering ANP officers }\end{array}$ & -61 & 61 & 61 & 61 & 67 & 66 \\
\hline f) When encountering ANA officers & - & 49 & 49 & 50 & 52 & 48 \\
\hline $\begin{array}{l}\text { g) When traveling from one part of Afghanistan to } \\
\text { another part of the country }\end{array}$ & - & - & - & - & - & 44 \\
\hline h) When encountering international forces & - & - & - & - & - & 76 \\
\hline
\end{tabular}

\subsection{Perceptions of the Afghan National Police}

The institution in Afghanistan that is principally responsible for ensuring security and fighting crime and violence is the Afghan National Police (ANP). The survey attempted to understand public perceptions of the ANP with regards to various dimensions such as its honesty, fairness, professionalism, efficiency to arrest criminals and capacity to act without the assistance of foreign troops. A series of statements about the ANP was read out to respondents and they were asked to state whether they agree or disagree with the statements. The responses to these statements are summarized in the table below. 
Table 3.12: Public agreement and disagreement with statements about the ANP (Q-42a-e, Base 6348)

\begin{tabular}{|c|c|c|c|c|}
\hline & $\begin{array}{l}\text { Strongly } \\
\text { agree } \\
(\%)\end{array}$ & $\begin{array}{c}\text { Agree } \\
\text { somewhat } \\
(\%)\end{array}$ & $\begin{array}{c}\text { Disagree } \\
\text { somewhat } \\
(\%)\end{array}$ & $\begin{array}{c}\text { Strongly } \\
\text { disagree } \\
(\%)\end{array}$ \\
\hline a) ANP is honest and fair with the Afghan people & 49 & 36 & 10 & 4 \\
\hline b) ANP is unprofessional and poorly trained & 20 & 36 & 29 & 15 \\
\hline $\begin{array}{l}\text { c) ANP needs the support of foreign troops and cannot } \\
\text { operate by itself }\end{array}$ & 28 & 37 & 23 & 11 \\
\hline d) ANP helps improve the security & 43 & 40 & 13 & 4 \\
\hline $\begin{array}{l}\text { e) ANP is efficient at arresting those who have } \\
\text { committed crimes so that they can be brought to justice }\end{array}$ & 35 & 40 & 17 & 7 \\
\hline
\end{tabular}

The Afghan public's assessment of the ANP is mostly positive. More than four out of five respondents agree that the ANP is honest and fair with the Afghan people (85\%) and a similar proportion of respondents say the ANP helps improve security (83\%). Three quarters of respondents $(75 \%)$ say that the ANP is efficient in arresting those who have committed crimes so they can be brought to justice. Around two thirds of respondents $(65 \%)$ say that the ANP needs the support of foreign troops and cannot operate by itself. The majority $(56 \%)$ also say that the ANP is unprofessional and poorly trained.

Overall, public perceptions of the operational capacity of the ANP have been rising over time. Fewer respondents now say that the ANP is unprofessional and poorly trained (56\% in 2011 compared to 58\% in 2009 and 2010 and $65 \%$ in 2007 and $60 \%$ in 2008) or that it needs the support of foreign troops to operate $(65 \%$ in 2011 compared to $69 \%$ in $2010,70 \%$ in $2009,69 \%$ in 2008 and $77 \%$ in 2007$)$. However, the fact that the majority of respondents still have a negative perception on these issues highlights ongoing concerns about insecurity, which is consistently identified as the most important problem facing the country (see Chapter 2, 2.4 Afghanistan's biggest problems: National level).

Table 3.13: Public agreement (strongly agree and agree somewhat) with statements about the ANP (Q-42a-e) COMPARISON BETWEEN 2007, 2008, 2009, 2010 AND 2011

a) ANP is honest and fair with the Afghan people

b) ANP is unprofessional and poorly trained

c) ANP needs the support of foreign troops and cannot operate by itself

d) ANP helps improve the security

e) ANP is efficient at arresting those who have committed crimes so that they can be brought to justice

\begin{tabular}{|c|c|c|c|c|}
\hline \multicolumn{5}{|c|}{ Agree (\%) } \\
\hline (Strongly agree \& agree somewhat) \\
\hline 2007 & 2008 & 2009 & 2010 & 2011 \\
\hline 86 & 80 & 83 & 84 & 85 \\
\hline 65 & 60 & 58 & 58 & 56 \\
\hline 77 & 69 & 70 & 69 & 65 \\
\hline 86 & 80 & 82 & 77 & 82 \\
\hline
\end{tabular}

Perceptions of the operational capacity of the ANP is similar across all ethnic groups except for the Pashtun who record significantly less positive opinions of the ANP across most dimensions. 
Table 3.14: Public agreement and disagreement with statements about the ANP (Q-42a-e, Base 6348)

\begin{tabular}{|c|c|c|c|c|c|}
\hline & \multicolumn{5}{|c|}{$\begin{array}{c}\text { Agree }(\%) \\
\text { (Strongly agree } \& \text { agree somewhat) }\end{array}$} \\
\hline & Pashtun & Tajik & Uzbek & Hazara & Other \\
\hline a) ANP is honest and fair with the Afghan people & 79 & 91 & 92 & 85 & 87 \\
\hline b) ANP is unprofessional and poorly trained & 50 & 58 & 61 & 62 & 58 \\
\hline $\begin{array}{l}\text { c) ANP needs the support of foreign troops and cannot operate } \\
\text { by itself }\end{array}$ & 61 & 65 & 65 & 77 & 67 \\
\hline d) ANP helps improve the security & 76 & 87 & 88 & 86 & 84 \\
\hline $\begin{array}{l}\text { e) ANP is efficient at arresting those who have committed crimes } \\
\text { so that they can be brought to justice }\end{array}$ & 69 & 79 & 84 & 78 & 76 \\
\hline
\end{tabular}

\subsection{Perceptions of the Afghan National Army}

The survey also sought to measure public perceptions of the other most significant national security force, the Afghan National Army (ANA). A similar series of statements about the ANA were read out to respondents and they were asked to indicate whether they agree or disagree. The responses to these statements are summarized in the table below.

Table 3.15: Public agreement and disagreement with statements about the ANA (Q-41a-d, Base 6348)

\begin{tabular}{l|c|c|c|c|} 
& $\begin{array}{c}\text { Strongly } \\
\text { agree } \\
(\%)\end{array}$ & $\begin{array}{c}\text { Agree } \\
\text { somewhat } \\
(\%)\end{array}$ & $\begin{array}{c}\text { Disagree } \\
\text { somewhat } \\
(\%)\end{array}$ & $\begin{array}{c}\text { Strongly } \\
\text { disagree } \\
(\%)\end{array}$ \\
\hline a) ANA is honest and fair with the Afghan people & 64 & 29 & 5 & 2 \\
\hline b) ANA is unprofessional and poorly trained & 16 & 28 & 32 & 23 \\
\hline $\begin{array}{l}\text { c) ANA needs the support of foreign troops and } \\
\text { cannot operate by itself }\end{array}$ & 26 & 34 & 23 & 3 \\
\hline d) ANA helps improve the security & 56 & 31 & 9 & 3 \\
\hline
\end{tabular}

Overall, the public has an even more positive assessment of the ANA than it does of the ANP. Nine out of 10 respondents (93\%) agree that the ANA is honest and fair with the Afghan people, compared to eight out of $10(85 \%)$ who say the same about the ANP. A similarly high proportion agrees that the ANA is helping to improve the security situation in the country (87\%), compared to $82 \%$ for the ANP. However, as with the ANP, a high proportion of respondents also say that the ANA needs the support of foreign troops and cannot operate by itself $(60 \%)$. Less than half of respondents $(44 \%)$ agree that the ANA is unprofessional and poorly trained.

There are significant variations since 2007 in the agreement on some statements about ANA. There has been a clear decline in the proportion of respondents who strongly agree or agree someone with the statement that the "ANA is unprofessional and poorly trained," from 62\% in 2007 to $44 \%$ in 2011 . Likewise, there has been a decline among those who hold the view that the ANA needs the support of foreign troops and cannot operate by itself - from $77 \%$ in 2007 to $60 \%$ in 2011. 


\section{Afghanistan in 2011}

Table 3.16: Public agreement (strongly agree and agree somewhat) with statements about the $A N A(Q-41 a-d) C O M P A R I-$ SON BETWEEN 2007, 2008, 2009, 2010 AND 2011

\begin{tabular}{|c|c|c|c|c|c|}
\hline & & ngly & e $(\%)$ & ewhat & \\
\hline & 2007 & 2008 & 2009 & 2010 & 2011 \\
\hline a) ANA is honest and fair with the Afghan people & 90 & 89 & 91 & 92 & 92 \\
\hline b) ANA is unprofessional and poorly trained & 62 & 55 & 52 & 52 & 44 \\
\hline $\begin{array}{l}\text { c) ANA needs the support of foreign troops and } \\
\text { cannot operate by itself }\end{array}$ & 77 & 69 & 69 & 69 & 60 \\
\hline d) ANA helps improve the security & 89 & 86 & 87 & 86 & 88 \\
\hline
\end{tabular}




\section{Reconciliation and Reintegration}

\subsection{Perceptions of the government's reconciliation efforts}

The survey asked Afghan citizens whether they support the government's peace, reconciliation and negotiation efforts with armed opposition groups. Respondents' support for peace and reconciliation remains very high. A large majority of respondents $(82 \%)$ say they approve of the government's efforts, with $41 \%$ strongly in favor and the same proportion somewhat in favor. The level of support for peace and reconciliation with armed opposition groups remained stable between 2010 and 2011. This continued high level of support suggests that a substantial proportion of the Afghan public is in favor of a political solution to the ongoing conflict in the country, rather than a purely military one.

Do you strongly agree, agree somewhat, disagree somewhat or strongly disagree with the government's reconciliation efforts and negotiations with the armed opposition? (Q-57) COMPARISON BETWEEN 2009, 2010 AND 2011

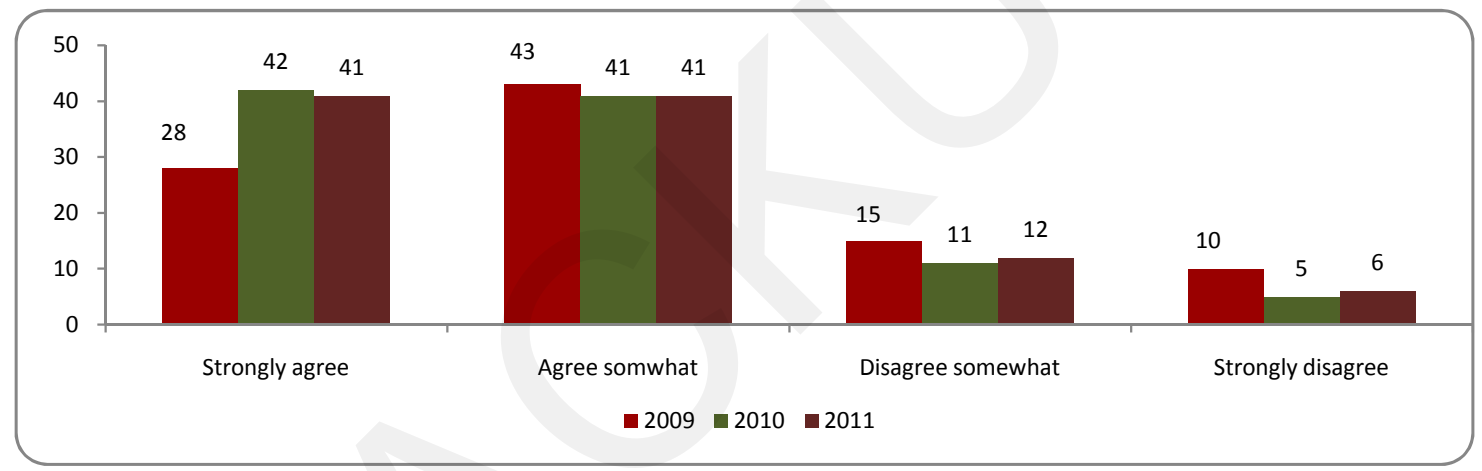

Fig. 4.1

More men are supportive of the peace, reconciliation/negotiation and reintegration efforts than women. Over four fifths of male respondents $(83 \%)$ say they agree with the peace efforts, including almost half $(46 \%)$ who strongly agree. This is true for $78 \%$ women including a third $(33 \%)$ who strongly agree. These findings could reflect a concern amongst Afghan women regarding the possible impact on women's lives that may arise through a negotiated settlement with the Taliban, whose regime imposed major restrictions on women's participation in Afghan society at all levels.

Support for the government's reconciliation, negotiation and reintregation efforts is higher amongst Pashtun (86\%), Tajik (81\%) and other ethnic groups (81\%) than it is amongst Uzbek (77\%) and Hazara (70\%) respondents.

Support for the government's peace, reconciliation efforts and a negotiation with the armed opposition is generally high in all regions, but to different degrees; support is highest in the East (89\% including 55\% who strongly support the efforts), South West (88\% including 48\% strong support) and South East (83\% including 
$41 \%$ strong support). These are also the regions where insecurity is most often identified as a major local problem (see Chapter 2, 2.5 Afghanistan's biggest problems: Local leve), and where most respondents say that the security situation is bad in their local area (see Chapter 6, 6.1 Services and Facilities available in local areas). Overall support is also high in the North East (85\%) but only 30\% of these respondents say they strongly support the reconciliation efforts. Support for reconciliation with armed groups is lowest in the Central/Hazarajat (63\%) but more than a third of respondents $(36 \%)$ disagree somewhat or strongly with the government's efforts in this regard.

Do you strongly agree, agree somewhat, disagree somewhat or strongly disagree with the government's reconciliation efforts and negotiations with the armed opposition? (Q-57, 6348) BY REGION

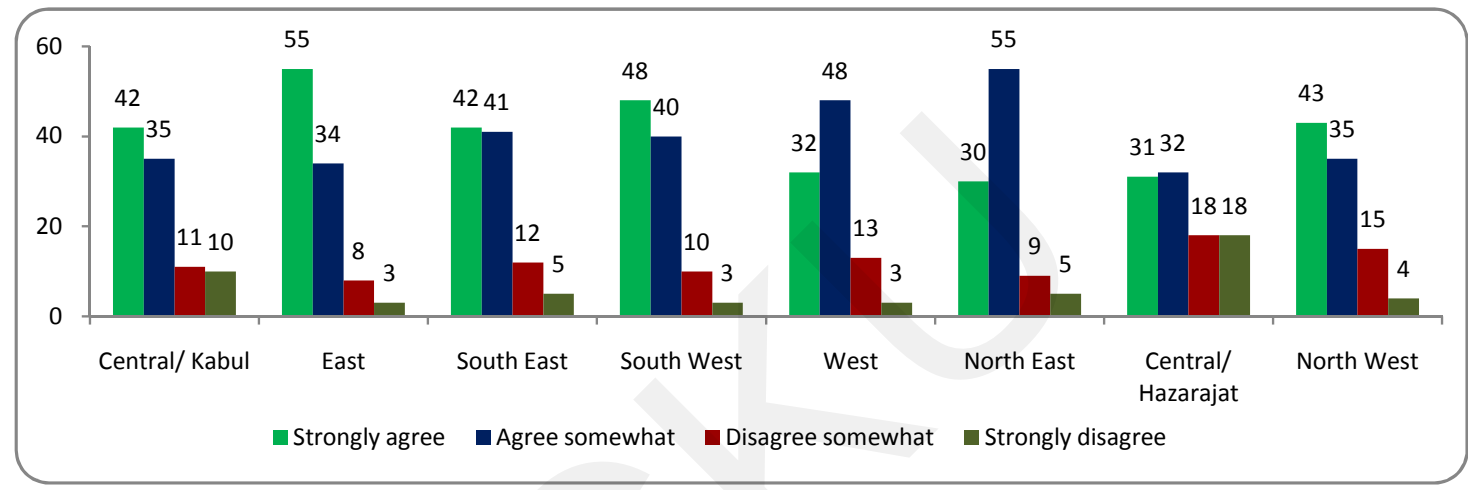

Fig. 4.2

Respondents were also asked whether they think the government's peace/reconciliation efforts and negotiations will help stabilize the country. Around three quarters (73\%) of respondents say they will. Only $23 \%$ say the government's peace/reconciliation efforts and negotiations will not stabilize the country. The figures for 2011 are very similar to those recorded in 2010.

Even though the majority of respondents in all regions say the government's peace and negotiations efforts will help stabilize the country, the proportion of those who say so is higher in the East $(80 \%)$, North East (76\%), South East (75\%), North West (75\%) and South West (74\%) than in Central/Kabul (69\%), West (68\%) and Central/Hazarajat (68\%) regions. 
Do you think the Afghan government's reconciliation efforts and negotiations will help stabilize the country? (Q-58, Base 6348) BY REGION

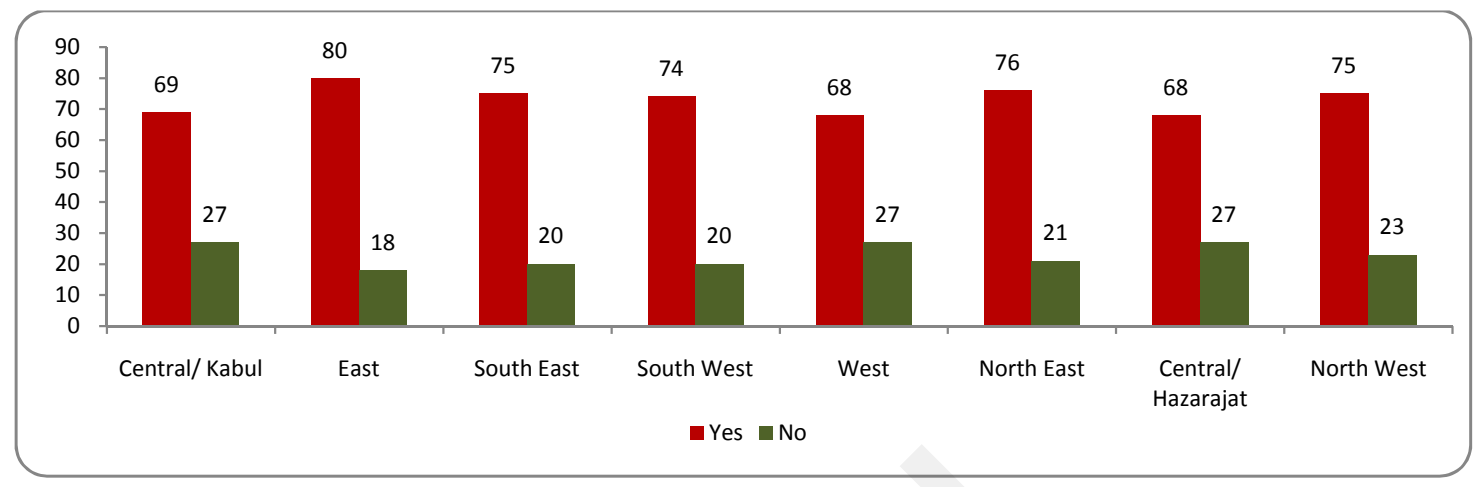

Fig. 4.3

Respondents were then asked whether they agree or disagree that those anti-government elements who lay down their arms and express willingness to reintegrate into society should be provided with government assistance, jobs and housing. Four out of five respondents (80\%) agree with this approach, including 38\% who strongly agree. Nineteen percent disagree with this approach to reintegration.

Support for the government's reintegration efforts has remained consistent since 2010 . In 2009, 71\% of respondents agreed with the provision of assistance for those who choose to lay down their arms and reintegrate into society, compared to $81 \%$ in 2010 and $80 \%$ in 2011. In 2010, 40\% strongly agreed with the peace efforts, whereas in 2011 this figure dropped slightly to 38\%. Overall disagreement with the reintegration approach remained largely the same in 2011 (19\%) as in $2010(18 \%)$.

Do you strongly agree, agree somewhat, disagree somewhat or strongly disagree that those anti-government elements who lay down arms and express willingness to reintegrate into society be provided with government assistance, jobs and housing? (Q-59) COMPARISON 2009, 2010 AND 2011

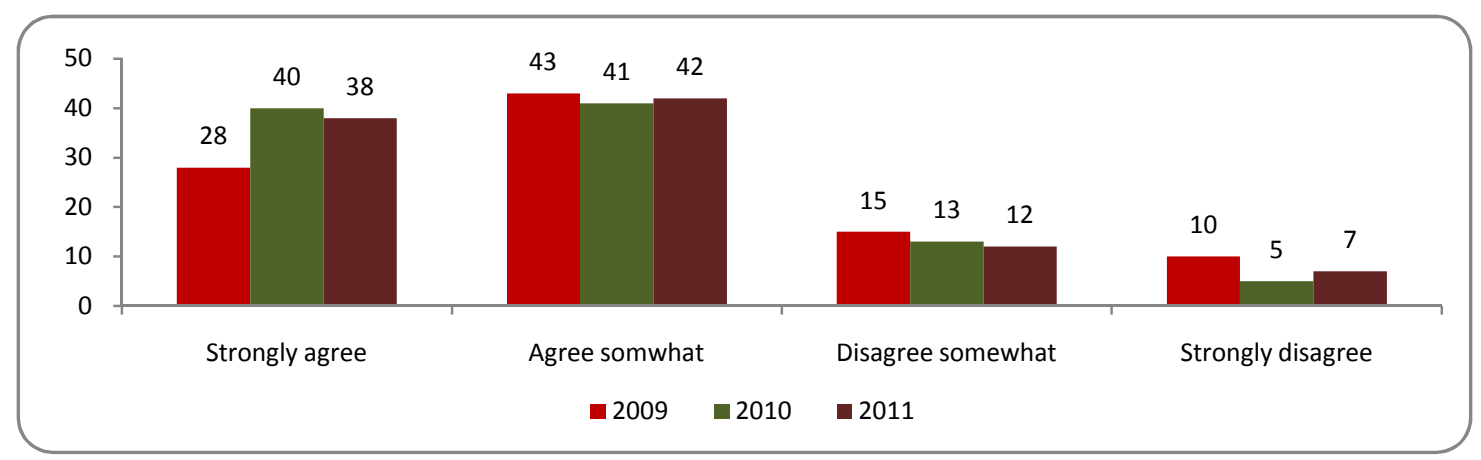

Fig. 4.4 
Support for government assistance to former armed opposition group members who choose to reintegrate is highest amongst Pashtuns (83\%, including 44\% who strongly agree) followed by other ethnic groups ( $82 \%$ including 40\% who strongly agree) and Uzbeks (81\%, including 37\% who strongly agree).

Do you strongly agree, agree somewhat, disagree somewhat or strongly disagree those anti-government elements who lay arms and express willingness to reintegrate into society to be provided government assistance, jobs and housing? (Q 59, Base 6348) BY ETHNICITY

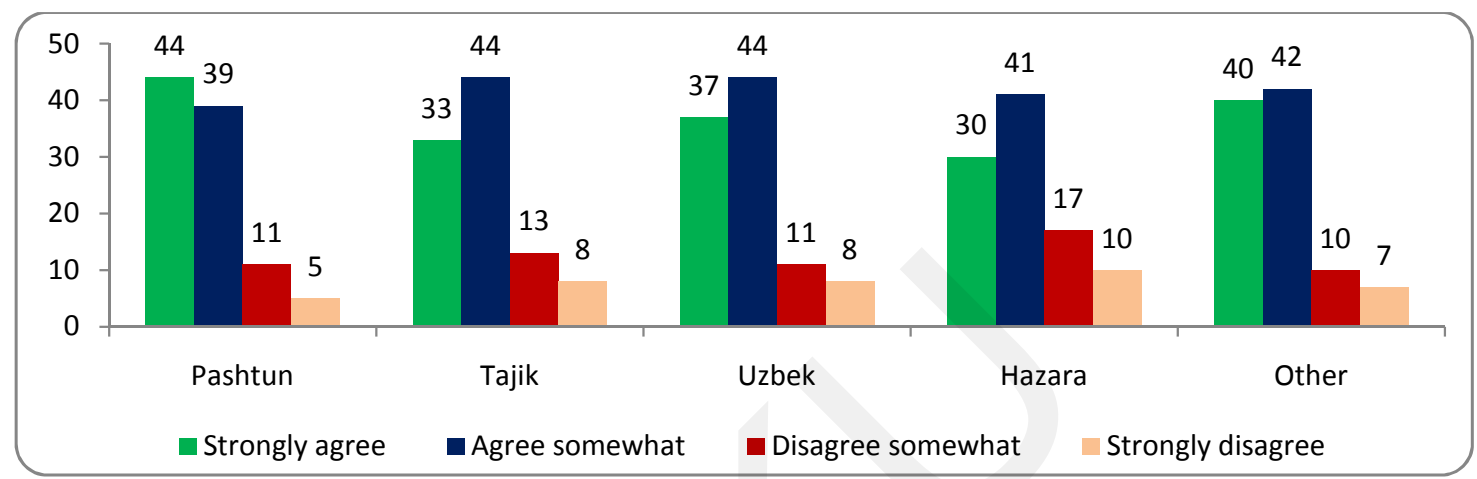

Fig. 4.5

Support at the regional level reflects the pattern seen in the responses between ethnic groups. Support is highest in the East (86\%, including 57\% who strongly agree), South West (85\%, including 39\% who strongly agree) and South East (82\%, including $42 \%$ who strongly agree) where the population is largely Pashtun, and in the North West (83\%, including 43\% who strongly agree) where the population is predominantly Uzbek. These are also the regions that record the highest levels of sympathy for armed opposition groups (see following section, 4.2 Sympathy with armed opposition groups).

Do you strongly agree, agree somewhat, disagree somewhat or strongly disagree those anti-government elements who lay down arms and express willingness to reintegrate into society to be provided government assistance, jobs and housing? (Q 59, Base 6348) BY REGION

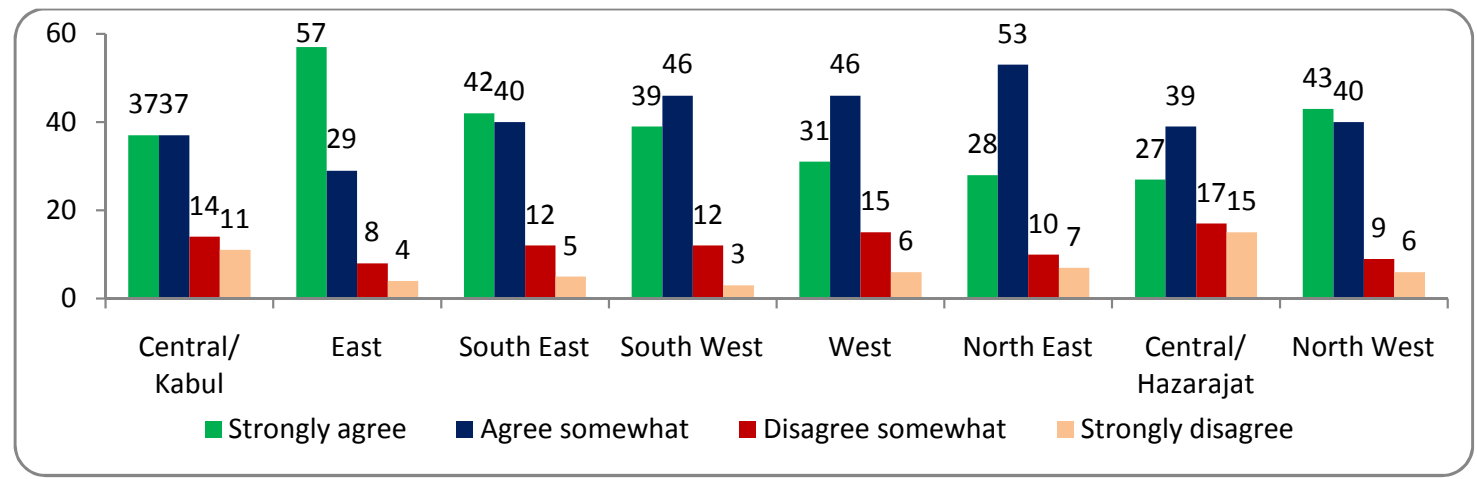

Fig. 4.6 


\subsection{Reasons why armed opposition groups fight the Afghan government}

The survey also asked Afghans why they think armed opposition groups are fighting against the Afghan government. Respondents cite many reasons, but the most common is the 'presence of foreign troops/ international community' (21\%). More respondents say this is the reason why armed opposition groups fight against the Afghan government than those who say these groups want to gain power (18\%). Another $7 \%$ say armed opposition groups are fighting the government to create insecurity, and the same proportion (7\%) say the groups are fighting because they are supported by Pakistan.

More men (24\%) than women (18\%) say that armed opposition groups fight against the Afghan government because of the presence of foreign troops/international community. In contrast, slightly more women (19\%) than men $(17 \%)$ say armed opposition groups fight the government to gain power.

In your opinion what is the reason that the armed anti-government groups are fighting against the Afghan government? $(Q-60$, Base 6348)

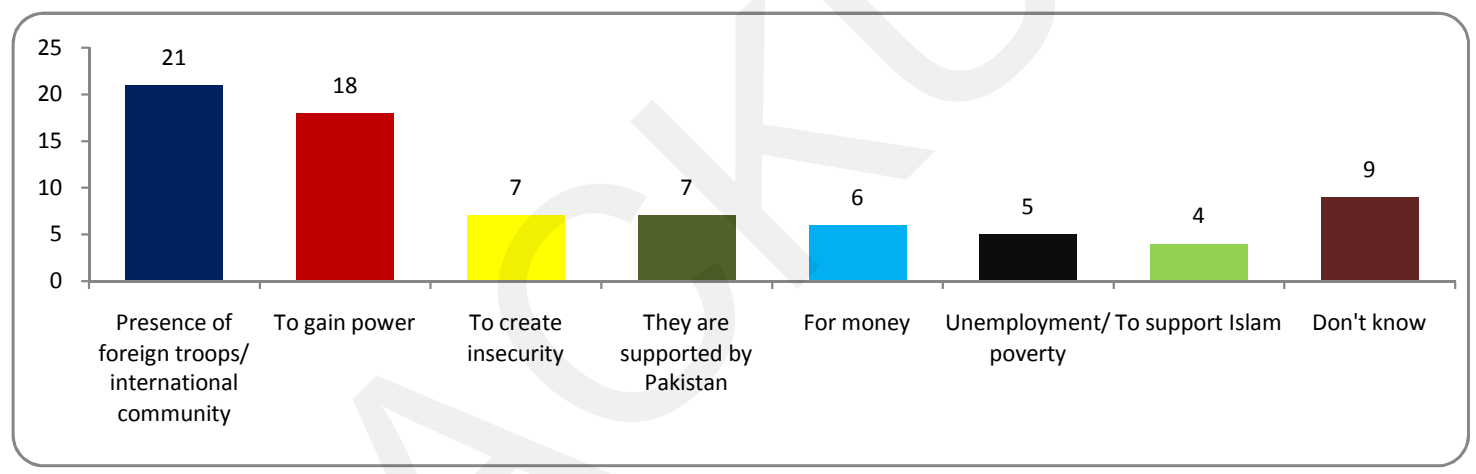

Fig. 4.7

Higher proportions of Pashtun (24\%) and Hazara (23\%) respondents say that armed opposition groups fight against the Afghan government because of the presence of foreign troops/international community, than Tajik (19\%) and Uzbek (17\%) respondents. Conversely, more Hazara (25\%) say that armed opposition groups fight against the Afghan government to gain power than Tajiks (20\%), Uzbeks (17\%) and Pashtuns (15\%).

Almost a third of respondents in the South East (32\%) say that armed opposition groups fight against the Afghan government because of the presence of foreign troops/international community. This is also true for just under a quarter in the West (24\%), East (23\%) and South West (22\%), and a fifth in the North West (20\%). The most common response in the Central/Hazarajat (26\%), North East (23\%) and Central/Kabul (21\%) regions is that armed opposition groups fight against the Afghan government to gain power. 
Table 4.1: In your opinion what is the reason that the armed anti-government groups are fighting against the Afghan government? (Q-60, Base 6348)

\begin{tabular}{|l|c|c|c|c|c|c|c|c|c|} 
& $\begin{array}{c}\text { Total } \\
(\%)\end{array}$ & $\begin{array}{c}\text { Central/ } \\
\text { Kabul } \\
(\%)\end{array}$ & $\begin{array}{c}\text { East } \\
(\mathbf{\%})\end{array}$ & $\begin{array}{c}\text { South } \\
\text { East } \\
(\%)\end{array}$ & $\begin{array}{c}\text { South } \\
\text { West } \\
(\%)\end{array}$ & $\begin{array}{c}\text { West } \\
(\%)\end{array}$ & $\begin{array}{c}\text { North } \\
\text { East } \\
(\%)\end{array}$ & $\begin{array}{c}\text { Central/ } \\
\text { Hazarajat } \\
(\%)\end{array}$ & $\begin{array}{c}\text { North } \\
\text { West } \\
(\%)\end{array}$ \\
\hline $\begin{array}{l}\text { Presence of foreign troops/ } \\
\text { international community }\end{array}$ & 21 & 18 & 23 & 32 & 22 & 24 & 17 & 14 & 20 \\
\hline To gain power & 18 & 21 & 16 & 16 & 9 & 15 & 23 & 26 & 18 \\
\hline To create insecurity & 7 & 4 & 9 & 4 & 11 & 7 & 6 & 14 & 7 \\
\hline They are supported by Pakistan & 7 & 9 & 8 & 9 & 10 & 6 & 6 & 5 & 4 \\
\hline For money & 6 & 8 & 6 & 4 & 4 & 5 & 4 & 4 & 9 \\
\hline Unemployment/poverty & 5 & 4 & 1 & 1 & 2 & 3 & 14 & 2 & 5 \\
\hline To support Islam & 4 & 7 & 4 & 4 & 5 & 3 & 2 & $*$ & 3 \\
\hline Don't know & 9 & 10 & 8 & 6 & 9 & 11 & 4 & 12 & 10 \\
\hline
\end{tabular}

\subsection{Sympathy with armed opposition groups}

The survey also endeavored to measure public sympathy toward anti-government armed groups. The survey asked all respondents the following question: "Thinking about the reasons the armed opposition used violence during the past year, would you say that you in general have a lot of sympathy, a little sympathy, or no sympathy at all for these anti-government armed opposition groups?" Twenty-nine percent of the respondents say they have some level of sympathy for the armed opposition groups, including $11 \%$ who say that they have a lot of sympathy, while the majority of respondents $(64 \%)$ say they have no sympathy at all. Sympathy for armed opposition groups has fallen significantly since 2009 when the majority of respondents $(56 \%)$ said they had some level of sympathy with their reasons for using violence, including $22 \%$ who said they had a lot of sympathy. The proportion of respondents who say they have no sympathy with armed opposition groups continues to rise from just over a third (36\%) in 2009 to over half (55\%) in 2010 and just under two thirds (64\%) in 2011.

Thinking about the reasons the armed opposition used violence during the past year, would you say that you in general have a lot of sympathy, a little sympatby, or no sympathy at all for these anti-government groups? (Q-61 a) COMPARISON 2009, 2010 and 2011

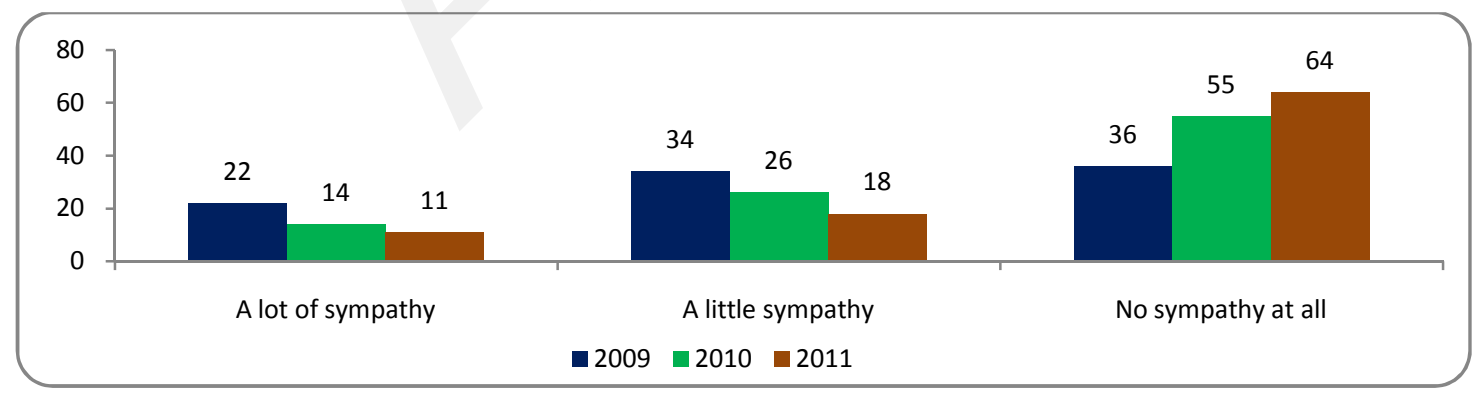

Fig. 4.8

Urban-rural settlement has a significant influence on the public's view in this matter. More urban respondents $(74 \%)$ say they have no sympathy at all for armed opposition groups compared to their rural counterparts $(61 \%)$.

Even though the majority of respondents of all ethnic groups say they have no sympathy with anti-government armed groups, the proportion of those who have some level of sympathy for such groups is significantly higher among Pashtuns (37\%), Uzbeks (30\%) and other ethnic groups (32\%). 
Thinking about the reasons the armed opposition used violence during the past year, would you say that you in general have a lot of sympathy, a little sympathy, or no sympathy at all for these armed opposition groups? (Q-61a, Base 6348) BY ETHNICITY \& SETTLEMENT

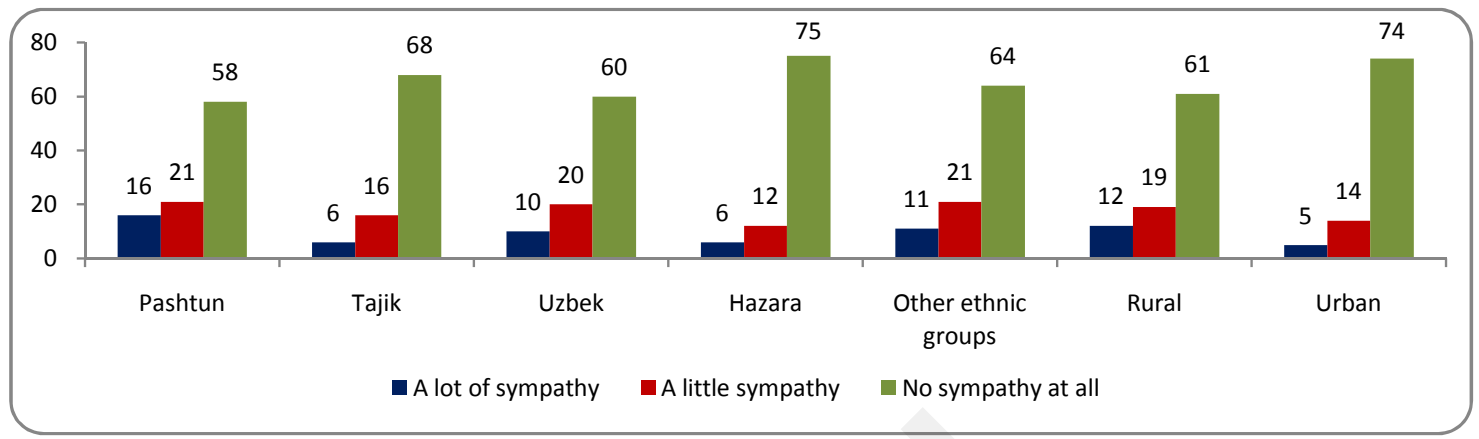

Fig. 4.9

The majority of respondents in all regions also say they have no sympathy for anti-government armed groups, but more than a third of respondents in the East (41\%), South East (41\%) and South West (37\%) say they have some level of sympathy with armed opposition groups.

However, there has been a clear drop in levels of sympathy with armed opposition groups in all regions since 2009. The decline has been most noticeable in the Central/Hazarajat (from $48 \%$ in 2009 to $10 \%$ in 2011), West (from $60 \%$ in 2009 to $25 \%$ in 2011), North East (from $50 \%$ in 2009 to $26 \%$ in 2011) and South East (from $66 \%$ in 2009 to $41 \%$ in 2011 ).

Thinking about the reasons the armed opposition used violence during the past year, would you say that you in general have a lot of sympathy, a little sympathy, or no sympathy at all for these armed opposition groups? (Q-61 a) COMBINATION OF A LOT OF SYMPATHY AND LITTLE SYMPATHY RESPONSES, BY REGION, COMPARISON BETWEEN 2009, 2010 AND 2011

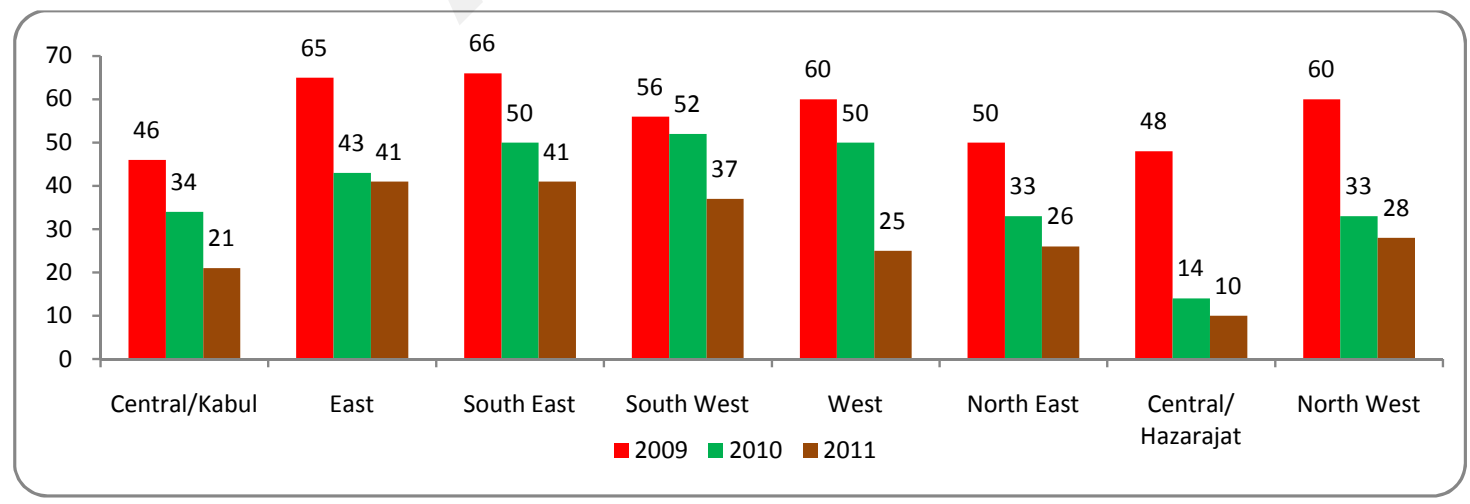

Fig. 4.10 
Respondents who said they have a lot of sympathy for the armed opposition groups (11\% of all respondents) were asked why. One third (34\%) say this is because the groups are Muslims while a slightly smaller proportion $(27 \%)$ says it is because they are Afghans. Seven percent say they have sympathy with armed opposition groups because they want to fight a holy war (jihad) while another 5\% say it is because they fight against foreign forces.

You said that you have a lot of sympathy for the armed opposition groups. Why do you say that? (Q-61b, Base 679)

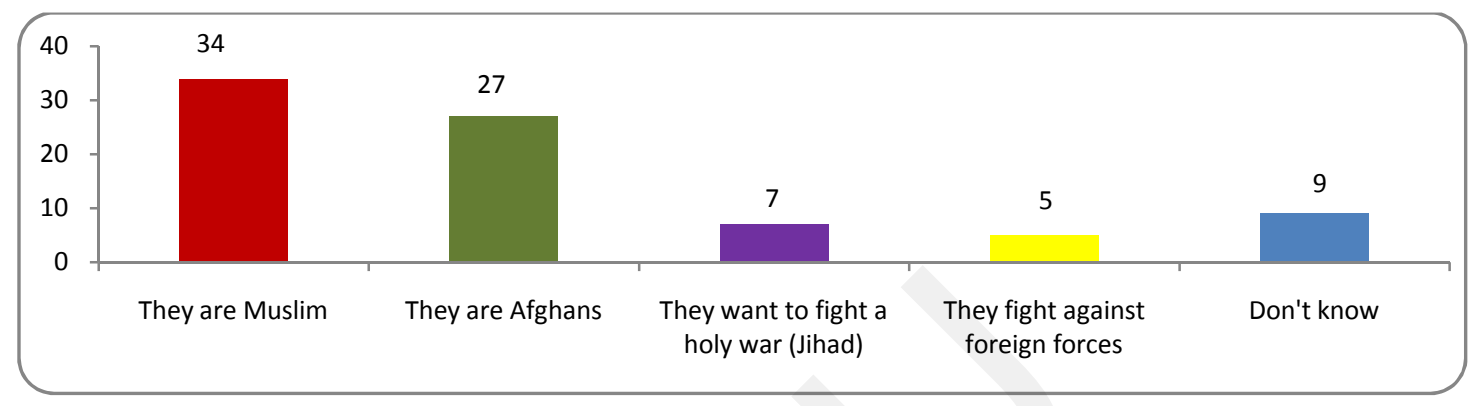

Fig. 4.11

The same question was asked to those respondents who say that they have a little sympathy with armed opposition groups (18\% of all respondents), and similar responses were recorded. Close to a third (32\%) say this is because the armed groups are Afghans and another 30\% say it is because they are Muslims.

You said that you have a little sympathy for the armed opposition groups. Why do you say that? (Q-61c, Base 1153)

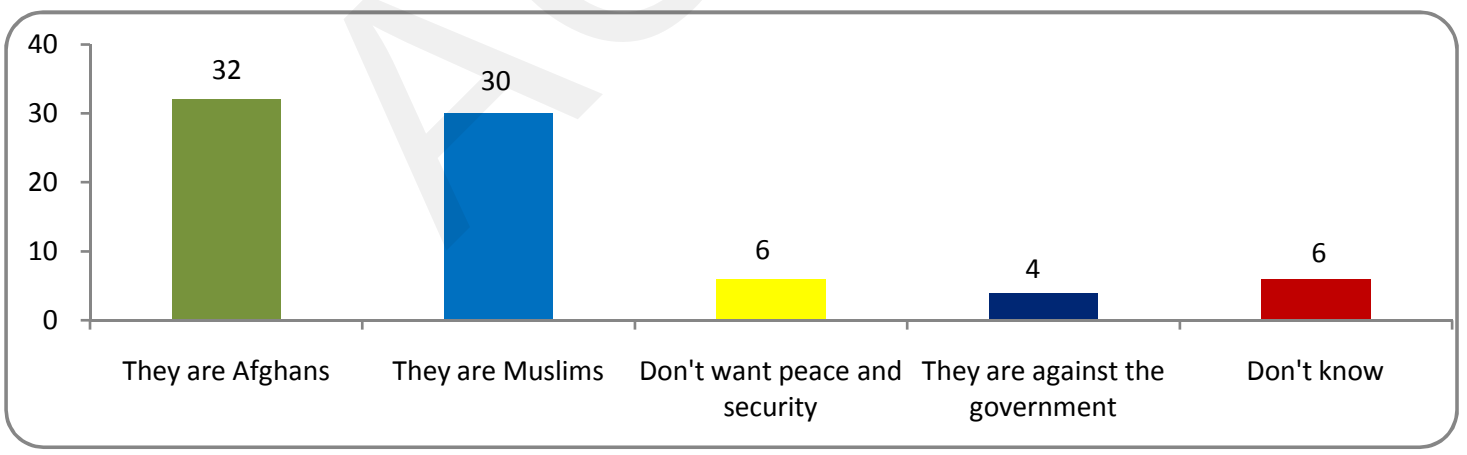

Fig. 4.12

Amongst respondents who have a little sympathy for armed opposition groups, Pashtun respondents most commonly say it is because the armed opposition groups are Muslims whereas the most common response amongst other ethnic groups is that it is because the groups are Afghans. 
You said that you have a little sympathy for the armed opposition groups. Why do you say that? (Q-61c, Base 1153) BY ETHNICITY

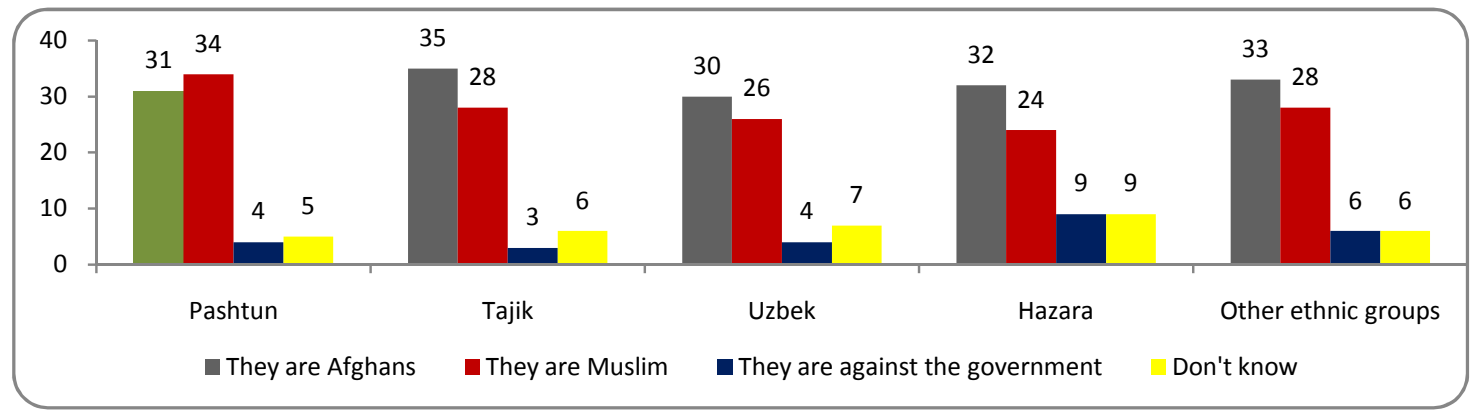

Fig. 4.13

There is variation across regions as well. In the Central/Kabul (37\%), East (36\%) and North East (36\%) regions, the most common response to why respondents had a little sympathy for armed opposition groups is because they are Afghans. Support for armed groups because they are Muslims is the most common response in the South East (38\%), South West (35\%) and North West (24\%). In the West, an equal proportion $(32 \%)$ cited both responses. Support for armed opposition groups because they are against the government is twice as high in the North West (10\%) as anywhere else in the country.

Table 4.2: You said that you have a little sympatby for the armed opposition groups. Why do you say that? (Q-61c, Base 1153) BY REGIONS

\begin{tabular}{|c|c|c|c|c|c|c|c|c|}
\hline & $\begin{array}{c}\text { Total } \\
(\%)\end{array}$ & $\begin{array}{c}\text { Central/ } \\
\text { Kabul } \\
(\%)\end{array}$ & $\begin{array}{c}\text { East } \\
(\%)\end{array}$ & $\begin{array}{c}\text { South } \\
\text { East } \\
(\%)\end{array}$ & $\begin{array}{c}\text { South } \\
\text { West } \\
(\%)\end{array}$ & $\begin{array}{c}\text { West } \\
(\%)\end{array}$ & $\begin{array}{c}\text { North } \\
\text { East } \\
(\%)\end{array}$ & $\begin{array}{c}\text { North } \\
\text { West } \\
(\%)\end{array}$ \\
\hline They are Afghans & 32 & 37 & 36 & 36 & 30 & 32 & 36 & 18 \\
\hline They are Muslims & 30 & 25 & 27 & 38 & 35 & 32 & 31 & 24 \\
\hline Don't want peace and security & 6 & 14 & 4 & 1 & 4 & 6 & 5 & 7 \\
\hline They are against the government & 4 & 3 & 5 & 5 & 3 & 2 & 3 & 10 \\
\hline Killing innocent people & 3 & 1 & 4 & 2 & 8 & 4 & 0 & 3 \\
\hline Don’t know & 6 & 9 & 7 & 5 & 2 & 5 & 5 & 7 \\
\hline
\end{tabular}

In the same way, the survey asked those respondents who said they have no sympathy at all for the armed opposition groups (64\% of all respondents) to give their reasons. The most common reason, cited by more than one third of respondents $(34 \%)$ is that armed opposition groups are killing innocent people. Around one in six $(16 \%)$ say they have no sympathy because these groups do not want peace and security. Another $12 \%$ say that these groups are oppressors while 6\% say they have no sympathy for armed groups because they are against the government. The same proportion $(6 \%)$ says that because they have no sympathy for them, the armed opposition groups work for Pakistan. 


\section{2 | Afghanistan in 2011}

You said that you have no sympathy for the armed opposition groups. Why do you say that? (Q-61d, Base 4032)

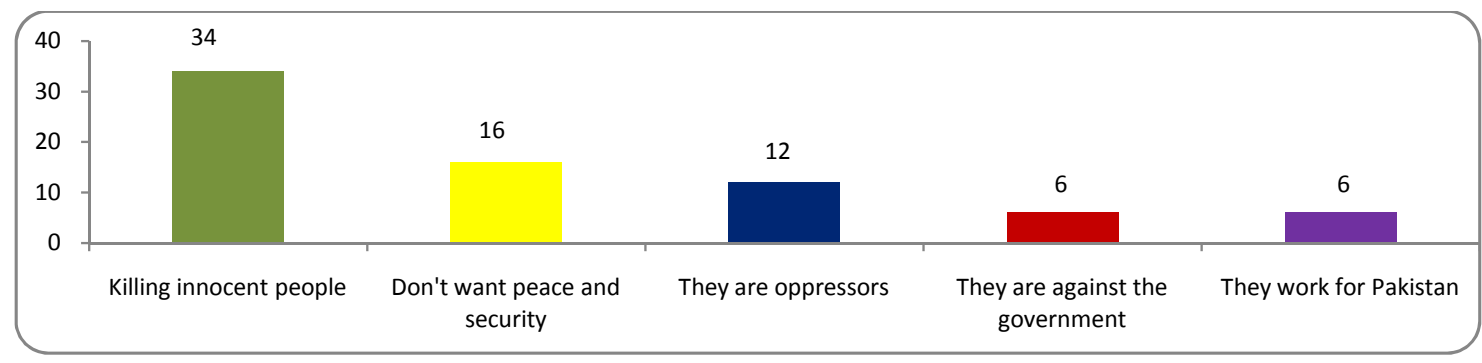

Fig. 4.14

As mentioned above, the most common reason why respondents in all regions say they do not have any sympathy toward armed opposition groups is because they kill innocent people. However, a significant proportion of respondents in East (24\%) and Central/Hazarajat (21\%) also think such groups do not want peace and security. Similarly, a sizable number of people in the Central/Kabul (16\%), West (14\%) and North East (14\%) say they have no sympathy for the armed groups because they are oppressors.

Table 4.3: You said that you have no sympathy at all for the armed opposition groups. Why do you say that? $(Q 61 d$, Base 4032) ALL AND BY REGION

\begin{tabular}{|c|c|c|c|c|c|c|c|c|}
\hline & $\begin{array}{l}\text { All } \\
(\%)\end{array}$ & \begin{tabular}{|c|} 
Central/ \\
Kabul \\
$(\%)$
\end{tabular} & $\begin{array}{l}\text { Eastern } \\
(\%)\end{array}$ & $\begin{array}{c}\text { South } \\
\text { East } \\
(\%)\end{array}$ & $\begin{array}{c}\text { South } \\
\text { Western } \\
(\%)\end{array}$ & $\begin{array}{l}\text { Western } \\
(\%)\end{array}$ & $\begin{array}{l}\text { North } \\
\text { East } \\
(\%)\end{array}$ & $\begin{array}{c}\text { Central/ } \\
\text { Hazarajat } \\
(\%)\end{array}$ \\
\hline Killing innocent people & 34 & 36 & 35 & 36 & 46 & 29 & 30 & 31 \\
\hline $\begin{array}{l}\text { They donst want peace and } \\
\text { security }\end{array}$ & 16 & 12 & 24 & 13 & 16 & 16 & 18 & 21 \\
\hline They are oppressors & 12 & 16 & 6 & 13 & 6 & 14 & 14 & 10 \\
\hline They are against the government & 6 & 6 & 4 & 6 & 1 & 9 & 6 & 14 \\
\hline They work for Pakistan & 6 & 6 & 6 & 8 & 9 & 5 & 6 & 3 \\
\hline Donst know & 3 & 4 & 3 & 4 & 2 & 3 & 2 & 4 \\
\hline
\end{tabular}




\section{Economy}

\subsection{Economic prosperity}

The survey endeavored to measure the perception of Afghan citizens about their level of economic prosperity. Respondents were asked to compare their current economic condition with their circumstances under the Taliban government (1996-2001). Forty-four percent of respondents reported that their families are more prosperous today than they were under the Taliban regime. One third (34\%) say that they are now less prosperous. Sixteen percent say that their level of economic prosperity is the same, while the remainder $(5 \%)$ report being absent during Taliban rule.

If you think about your family, would you say that today your family is more prosperous, less prosperous or about as prosperous as under the Taliban government? (Q-13, Base 6348)

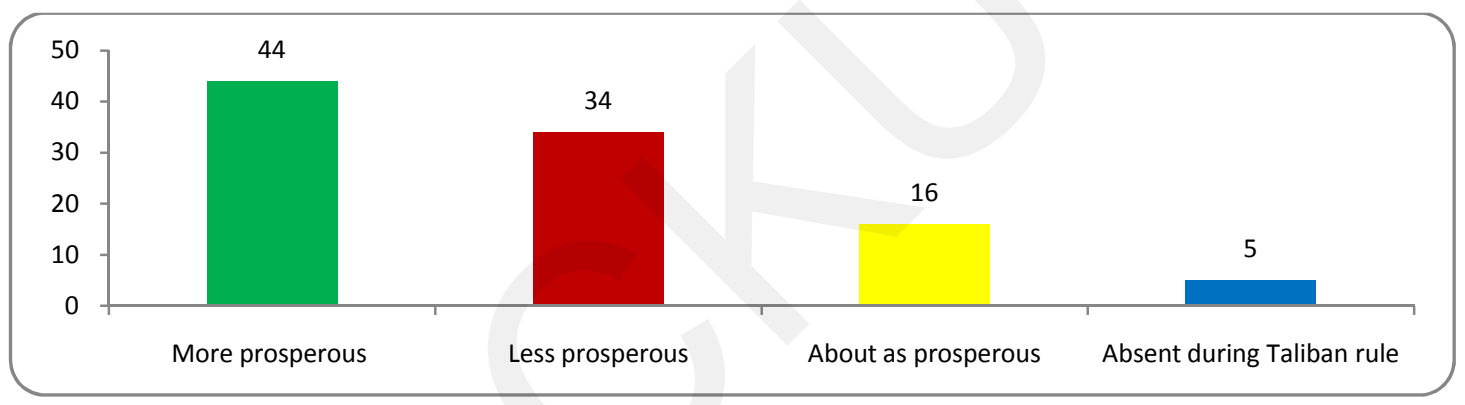

Fig 5.1

This year, as in previous years, perceptions vary between ethnic groups regarding the assessment of their current prosperity compared to the Taliban period. The majority of Hazara (59\%) and Tajik (55\%) say that their families are more prosperous today than under the Taliban regime, however, among Pashtuns only 33\% hold this view.

The majority of respondents say their families are more prosperous today in the Central/Hazarajat (67\%), North West (54\%), West (53\%), North East (51\%) and Central/Kabul (51\%) regions. Respondents who say their families are less prosperous today are mostly found in the East (45\%), South West (44\%) and South East (40\%), which are regions with predominantly Pashtun populations. 
Table 5.1: If you think about your family, would you say that today your family is more prosperous, less prosperous or about as prosperous as under the Taliban government? (Q-13, Base 6348) ALL AND BY REGIONS

\begin{tabular}{|l|c|c|c|c|c|c|c|c|c|}
\hline $\begin{array}{l}\text { Base: All } \\
\text { Respondents }\end{array}$ & $\begin{array}{c}\text { Total } \\
(\mathbf{\%})\end{array}$ & $\begin{array}{c}\text { Central/ } \\
\text { Kabul } \\
(\%)\end{array}$ & $\begin{array}{c}\text { East } \\
\mathbf{( \% )}\end{array}$ & $\begin{array}{c}\text { South } \\
\text { East } \\
(\%)\end{array}$ & $\begin{array}{c}\text { South } \\
\text { Western } \\
(\%)\end{array}$ & $\begin{array}{c}\text { West } \\
(\%)\end{array}$ & $\begin{array}{c}\text { North } \\
\text { East } \\
(\%)\end{array}$ & $\begin{array}{c}\text { Central/ } \\
\text { Hazarajat } \\
(\%)\end{array}$ & $\begin{array}{c}\text { North } \\
\text { West } \\
(\%)\end{array}$ \\
\hline More prosperous & 44 & 51 & 31 & 29 & 21 & 53 & 51 & 67 & 54 \\
\hline Less prosperous & 34 & 28 & 45 & 40 & 44 & 26 & 35 & 22 & 32 \\
\hline $\begin{array}{l}\text { About as } \\
\text { prosperous }\end{array}$ & 16 & 12 & 20 & 23 & 30 & 14 & 10 & 6 & 11 \\
\hline $\begin{array}{l}\text { Absent during } \\
\text { Taliban rule (vol.) }\end{array}$ & 5 & 8 & 4 & 8 & 4 & 6 & 4 & 4 & 2
\end{tabular}

If you think about your family, would you say that today your family is more prosperous, less prosperous or about as prosperous as under the Taliban government? (Q-13, Base 6348) BY ETHNICITY

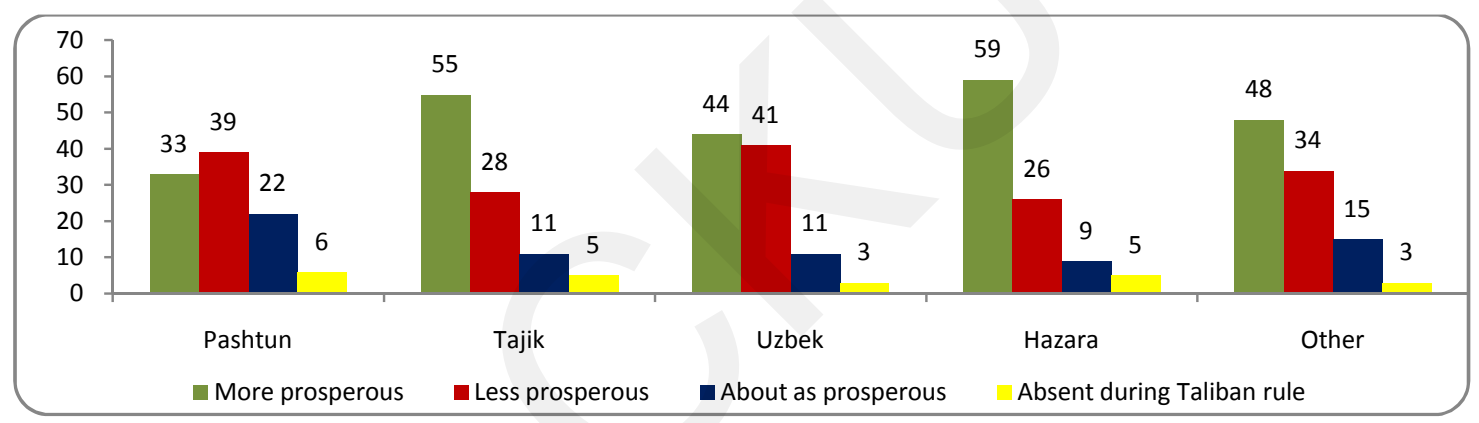

Fig 5.2

More respondents in urban (53\%) than rural (42\%) areas think that their families are more prosperous today than during the Taliban era. More than a third $(36 \%)$ of rural residents are of the opinion that they are less prosperous today than they were under the Taliban government, compared to just a quarter (25\%) of urban respondents.

If you think about your family, would you say that today your family is more prosperous, less prosperous or about as prosperous as under the Taliban government? (Q-13, Base 6348) BY SETTLEMENT

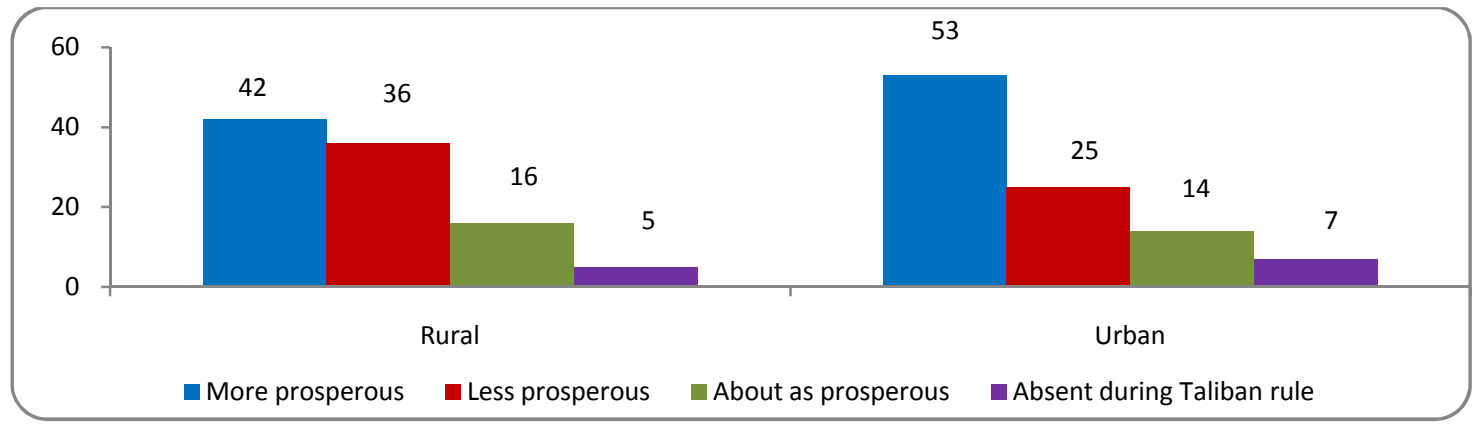

Fig 5.3 
The proportion of respondents who say they are more prosperous now compared to the period under Taliban rule went up (44\% in 2011 compared to 41\% in 2010), but it is still lower than in most previous years. In 2011, 10\% fewer respondents report that they are more prosperous today than they were under the Taliban government in comparison to the results of the 2006 (54\%) or 2009 (54\%) surveys when the highest figures were recorded. There has been a corresponding rise in the proportion of respondents who say they are less prosperous now, although the figure has fallen by $2 \%$ since 2010 . The proportion of respondents who say they are about as prosperous now as under the Taliban government has fluctuated between $12 \%$ and $16 \%$.

Table 5.2: If you think about your family, would you say that today your family is more prosperous, less prosperous or about as prosperous as under the Taliban government? (Q-13) COMPARISON BETWEEN 2006, 2007, 2008, 2009, 2010 AND 2011

\begin{tabular}{|l|c|c|c|c|c|c|}
\hline & $\begin{array}{c}\mathbf{2 0 0 6} \\
\mathbf{( \% )}\end{array}$ & $\begin{array}{c}\mathbf{2 0 0 7} \\
\mathbf{( \% )}\end{array}$ & $\begin{array}{c}\mathbf{2 0 0 8} \\
\mathbf{( \% )}\end{array}$ & $\begin{array}{c}\mathbf{2 0 0 9} \\
\mathbf{( \% )}\end{array}$ & $\begin{array}{c}\mathbf{2 0 1 0} \\
\mathbf{( \% )}\end{array}$ & $\begin{array}{c}\mathbf{2 0 1 1} \\
\mathbf{( \% )}\end{array}$ \\
\hline More prosperous & 54 & 49 & 39 & 54 & 41 & 44 \\
\hline Less prosperous & 26 & 28 & 36 & 24 & 36 & 34 \\
\hline About as prosperous & 12 & 14 & 16 & 14 & 16 & 16 \\
\hline Absent during Taliban rule & 7 & 8 & 7 & 6 & 5 & 5 \\
\hline
\end{tabular}

The proportion of respondents who say they are more prosperous today is higher in 2011 for Hazaras (59\%), Tajiks (55\%) and other ethnic groups (48\%) than it is for Uzbeks (44\%) and Pashtuns (33\%).

Table 5.3: If you think about your family, would you say that today your family is more prosperous, less prosperous or about as prosperous as under the Taliban government? (Q-13) ALL AND BY ETHNICITY

\begin{tabular}{|l|c|c|c|c|c|c|}
\hline Base: All Respondents & $\begin{array}{c}\text { Total: } \\
\mathbf{( \% )}\end{array}$ & $\begin{array}{c}\text { Pashtun } \\
\mathbf{( \% )}\end{array}$ & $\begin{array}{c}\text { Tajik } \\
\mathbf{( \% )}\end{array}$ & $\begin{array}{c}\text { Uzbek } \\
\mathbf{( \% )}\end{array}$ & $\begin{array}{c}\text { Hazara } \\
\mathbf{( \% )}\end{array}$ & $\begin{array}{c}\text { Other } \\
\mathbf{( \% )}\end{array}$ \\
\hline More prosperous & 44 & 33 & 55 & 44 & 59 & 48 \\
\hline Less prosperous & 34 & 39 & 28 & 41 & 26 & 34 \\
\hline
\end{tabular}

These perceptions could be influenced by several factors. The inability of the state or the market to generate employment is likely to be an important contributing factor. This is consistent with the finding that the majority of respondents rate the government's performance poorly in reviving/developing the economy, with more than half (53\%) judging this to be quite bad or very bad and about two thirds $(63 \%)$ saying the same regarding the creation of job opportunities (see Chapter 7, 7.3 Satisfaction with government performance). In addition, unemployment has consistently been identified as one of the biggest problems at both the national and local levels (see Chapter 2, 2.4 Afghanistan's biggest problem: National level and 2.5 Afghanistan's biggest problem: Local level). Indeed, in 2011 more than a third of respondents (37\%) say that employment opportunities in their area have gotten worse over the last year and 45\% say there has been no positive change (see next section, 5.2 Economic situation of Afghan households). 


\subsection{Economic situation of Afghan households}

The survey also endeavored to measure the economic situation of Afghan households in detail by comparing the situation of households today with their situation one year ago in terms of financial and physical wellbeing, and their access to basic services and amenities. The proportion of 2011 respondents who reported improvements in their situation during the last year is summarized in the following table.

Table 5.4: Compared to one year ago, would you say that situation for your household has gotten better, remained the same or gotten worse with respect to the following? (Q-14a-h, Base 6348)

\begin{tabular}{|l|c|c|c|} 
& $\begin{array}{c}\text { Better } \\
(\%)\end{array}$ & $\begin{array}{c}\text { The same } \\
(\%)\end{array}$ & $\begin{array}{c}\text { Worse } \\
(\%)\end{array}$ \\
\hline a) Financial wellbeing of your household & 43 & 48 & 9 \\
\hline b) Employment opportunities & 19 & 45 & 35 \\
\hline c) Availability of products in the market & 30 & 49 & 20 \\
\hline d) Quality of your food diet & 35 & 49 & 15 \\
\hline e) Physical conditions of your house/dwelling & 31 & 52 & 16 \\
\hline f) Health wellbeing of your family members & 38 & 47 & 14 \\
\hline g) Electric supply & 22 & 39 & 37 \\
\hline h) Access to schools & 46 & 43 & 10 \\
\hline
\end{tabular}

Overall, a significant proportion of respondents identify improvements in the financial wellbeing of their household (43\%) and access to schools (46\%). However, the sense of increased financial wellbeing is not shared evenly among regions. Almost half of respondents in the East (48\%), South East (47\%), North East (47\%) and Central/Hazarajat (46\%) report an improvement in their financial wellbeing in the past year. This is also true for $43 \%$ of respondents in the South West and West and $40 \%$ in the Central/Kabul region, but just over a third (34\%) report improvements in the North West. At least one in 10 respondents in the Central/ Kabul, West and North West (11\% each) report that their financial wellbeing worsened in the past year.

The highest percentage of respondents say their access to schools is better than last year (46\%) is consistent with the high level of satisfaction regarding the availability of education for children $(73 \%$ of respondents say this is quite good or very good in their local area) (see Chapter 6, 6.1 Facilities available in local areas). It is also consistent with the finding that the majority of respondents $(57 \%)$ are aware of development programs regarding education (see Chapter 6, 6.3 Knowledge of development programs).

More than a third of respondents report improvements in the health of family members $(38 \%)$ and in the quality of their food diet (35\%). Just under a third identify improvement in the availability of products in the market $(30 \%)$ and the physical condition of their house (31\%). However, only around a fifth of respondents identify improvements in the electricity supply $(22 \%)$. There is a big difference between those living in rural and urban areas: around one in six respondents $(17 \%)$ in rural areas say that the supply of electricity has gotten better, compared to $40 \%$ of respondents living in urban areas. Central/Kabul is the only region in which the largest group of respondents report that the electricity supply has improved during the past year $(36 \%$ compared to the national average of $22 \%$ ). 
Of household situations to choose from, respondents report the least improvement in employment opportunities. Just under one in five (19\%) respondents say that employment opportunities have improved compared to the last year, whereas more than a third of respondents $(37 \%)$ say that employment opportunities in their area have gotten worse in the last year versus $45 \%$ who say there has been no change. These findings are consistent with respondents' views on local services and amenities where the lowest levels of satisfaction relate to the availability of jobs and the supply of electricity (see Chapter 6, 6.2 Facilities available in local areas). This is also consistent with the identification of unemployment as one of the biggest problems at both national and local levels (see Chapter 2, 2.4 Afghanistan's biggest problem: National level and 2.5 Afghanistan's biggest problem: Local level).

The most significant improvements concern the financial wellbeing of households (from $31 \%$ who saw improvements in 2009 to $42 \%$ in 2010 and 43\% in 2011), quality of the food diet (from 23\% in 2009 to $33 \%$ in 2010 and 35\% in 2011), availability of products in the market (from 19\% in 2009, 27\% in 2010 and $30 \%$ in 2011) and the physical conditions of house/dwelling (from 20\% in 2009, 25\% in 2010 and $31 \%$ in 2011). The figures in the table below suggest that the level of material prosperity since 2009 is improving for a significant proportion of the Afghan population, with the exception of electricity supply, which has stayed almost the same.

Table 5.5: Percentage of people whose situation has gotten better compared to one year ago in various domains (Q-14a-h) COMPARISON BETWEEN 2009, 2010 AND 2011

\begin{tabular}{|l|c|c|c|} 
& $\begin{array}{c}\mathbf{2 0 0 9} \\
\mathbf{( \% )}\end{array}$ & $\begin{array}{c}\mathbf{2 0 1 0} \\
\mathbf{( \% )}\end{array}$ & $\begin{array}{c}\mathbf{2 0 1 1} \\
\mathbf{( \% )}\end{array}$ \\
\hline Financial wellbeing of your household & 31 & 42 & 43 \\
\hline Access to schools & 40 & 42 & 46 \\
\hline Health wellbeing of your family members & 32 & 35 & 38 \\
\hline Quality of your food diet & 23 & 33 & 35 \\
\hline Availability of products in the market & 19 & 27 & 30 \\
\hline Physical conditions of your house/dwelling & 20 & 25 & 31 \\
\hline Electric supply & 23 & 23 & 22 \\
\hline Employment opportunities & 11 & 17 & 19 \\
\hline
\end{tabular}

\subsection{Availability of transport means}

As another measure of economic wellbeing, respondents were asked whether their household owns any private means of transport. They were first asked whether they have a bicycle in functioning order in their household. Just over half of respondents say they have a working bicycle $(52 \%)$ and just under half say they do not (48\%). More households own bicycles in the South East (71\%) and South West (67\%), East (55\%), Central/Kabul (53\%) and West (52\%) than in the North West (43\%), North East (38\%) and Central/Hazarajat $(25 \%)$ regions. Bicycle ownership is lowest in the Central/Hazarajat where only $25 \%$ of respondents say their household has a bicycle in working order. This may be because the terrain is mountainous and therefore inappropriate for bicycle use. 
When respondents were asked whether their household owns a functioning motorcycle, slightly more than a third (39\%) say yes while $61 \%$ say they do not. Motorcycle ownership is also mentioned more frequently in rural areas $(42 \%)$ than in urban areas (28\%). Motorcycle ownership is higher amongst higher income groups. Forty percent of those in the lowest earning group (earning less than 2,000Afs per month) own motorcycles, compared to $51 \%$ of mid-level income earners (3,000 to 5,000Afs per month) and $60 \%$ of high income earners (10,000Afs or beyond per month).

Finally, respondents were asked whether their household owns a car in functioning order. Fewer than one fifth $(18 \%)$ say they do while $82 \%$ say they do not. Slightly more respondents from urban areas $(23 \%)$ than from rural areas $(17 \%)$ say their household has a car.

More respondents in the South West (39\%) say they own cars in functioning order than in the Central/Kabul (25\%), South East (23\%), Central/Hazarajat (14\%), West (13\%), East (12\%), North East (10\%) and North West $(7 \%)$ regions. Clearly, as income level rises, car ownership also increases. Only $10 \%$ of respondents in the lowest income group live in households that own cars while this is true for $30 \%$ of respondents in the highest income group.

Do you own any of the following here in your household in functioning order...Bicycle? (Q-1e, Base 6348)

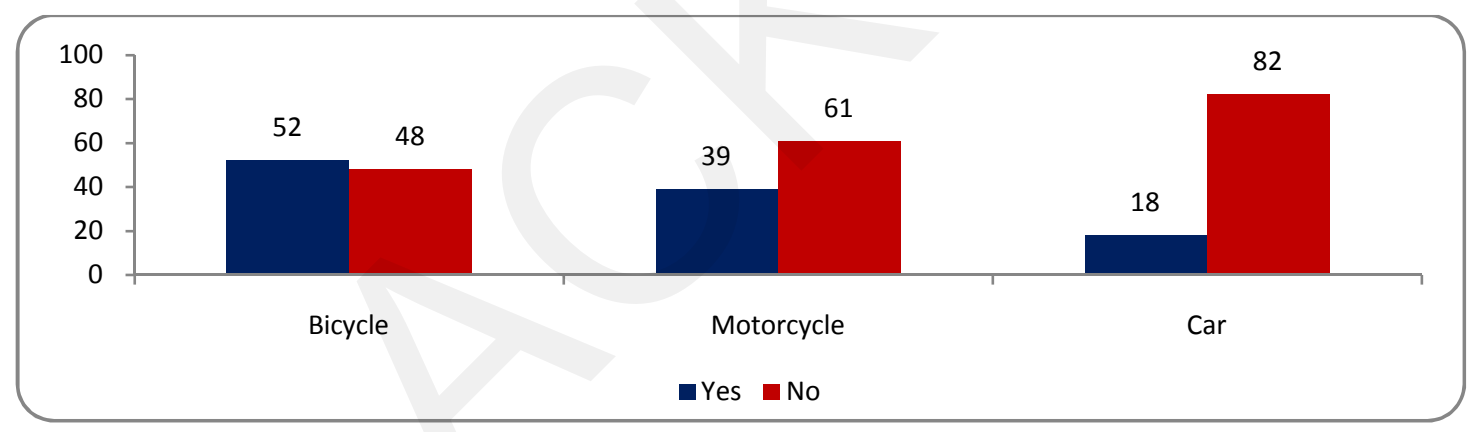

Fig 5.4

\section{4 Main source of energy for cooking and heating}

Respondents were also asked about their main source of energy for domestic use. Firewood is the most commonly used source of energy for cooking (46\%), particularly in rural areas (52\% compared to $23 \%$ for urban areas). The second most commonly used source of energy for cooking is bottled gas/LPG (21\%), which is used more in urban areas $(60 \%$ compared to $11 \%$ in rural areas). The third most commonly used cooking fuel is animal dung/manure (18\%), which is used almost exclusively in rural areas (21\% compared to $6 \%$ in urban areas).

There is some variation among regions. Firewood is the main source of energy for cooking in the East (57\%), North East (56\%), South East (54\%), South West (53\%), North West (44\%) and West (38\%). Bottled gas/ LPG is the main source of cooking fuel in the Central/Kabul region (50\%), but is also used by around one 
in five respondents in the South East (20\%) and West (20\%), and one in seven in the South West (14\%) and North West (13\%). Animal dung/manure is the most commonly used source of energy for cooking in the Central/Hazarajat $(36 \%)$ and is used by at least a quarter of respondents in the West $(27 \%)$, North West $(26 \%)$ and North East $(25 \%)$.

What is your main source of energy for cooking, what do you cook on most? (Q-15a, Base 6348) ALL AND BY SETTLEMENT

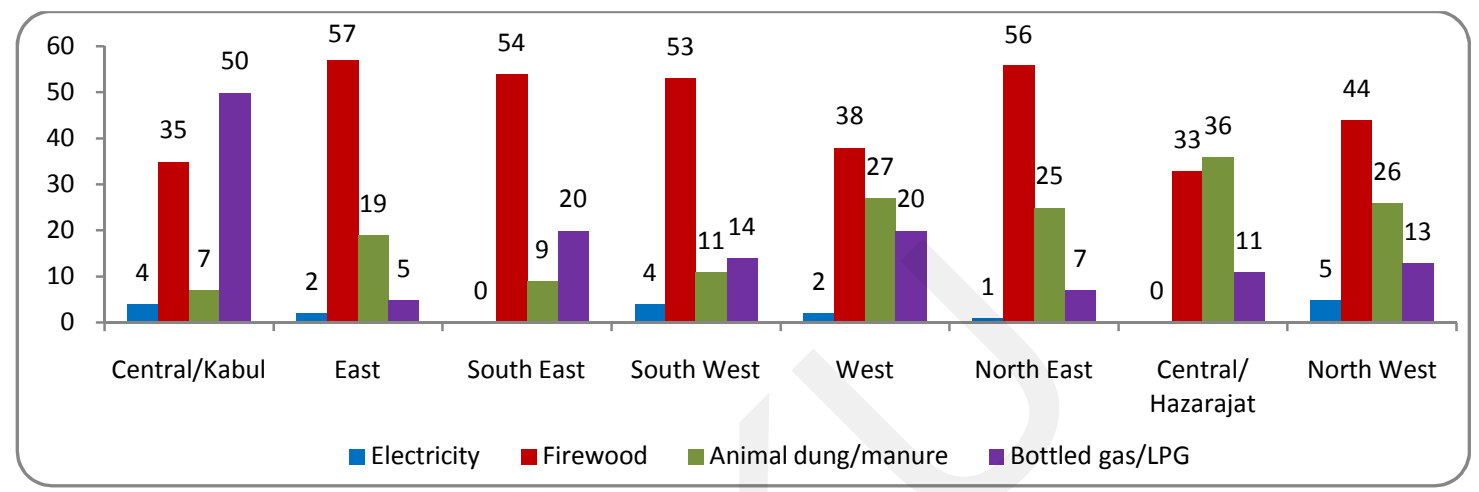

Fig 5.5

Respondents were also asked what they use to heat their houses. Firewood again is the most commonly used source of energy for heating (39\%) although it is more commonly used in urban (48\%) than rural (37\%) areas. The second most commonly used source of heating fuel is animal dung/manure $(18 \%)$ which is used more in rural $(22 \%)$ than urban $(5 \%)$ areas. The third most commonly used source of energy for heating is charcoal $(12 \%)$ which is used almost as often in urban (14\%) and rural $(11 \%)$ areas.

Table 5.6: And what do you heat your house with most, what is your main source of energy for heating? (Q-15a\&b. Base 6348)

\begin{tabular}{|c|c|c|c|c|c|c|}
\hline \multirow[b]{2}{*}{ Q-15a\&b, Base 6348} & \multicolumn{2}{|c|}{ All } & \multicolumn{2}{|c|}{ Rural } & \multicolumn{2}{|c|}{ Urban } \\
\hline & $\begin{array}{c}\text { Heating } \\
(\%)\end{array}$ & $\begin{array}{c}\text { Cooking } \\
(\%)\end{array}$ & $\begin{array}{c}\text { Heating } \\
(\%)\end{array}$ & $\begin{array}{c}\text { Cooking } \\
(\%)\end{array}$ & $\begin{array}{c}\text { Heating } \\
(\%)\end{array}$ & $\begin{array}{c}\text { Cooking } \\
(\%)\end{array}$ \\
\hline Firewood & 39 & 46 & 37 & 52 & 48 & 23 \\
\hline Animal dung/manure & 18 & 18 & 22 & 21 & 5 & 6 \\
\hline Charcoal & 12 & 3 & 11 & 3 & 14 & 2 \\
\hline Bottled Gas/LPG & 9 & 21 & 8 & 11 & 12 & 60 \\
\hline Grass or other biomass & 8 & 7 & 9 & 8 & 3 & 2 \\
\hline Coal & 7 & 2 & 7 & 3 & 8 & 1 \\
\hline Electricity & 4 & 3 & 3 & 2 & 8 & 6 \\
\hline Kerosene & 2 & 1 & 2 & * & 1 & 1 \\
\hline Diesel & 1 & 0 & 1 & $*$ & $*$ & $*$ \\
\hline
\end{tabular}




$$
\text { pe }
$$




\section{Development and Service Delivery}

\subsection{Services and facilities available in local areas}

The survey attempted to measure the current condition of basic infrastructure and essential public services that citizens can access in their local area. The table below summarizes respondents' views on a range of basic facilities available in the villages and neighborhoods where they live.

Table 6.1: Present condition of basic facilities in localities (Q-7a-i, Base 6348)

\begin{tabular}{|l|c|c|c|c|}
\hline & $\begin{array}{c}\text { Very good } \\
(\%)\end{array}$ & $\begin{array}{c}\text { Quite good } \\
(\%)\end{array}$ & $\begin{array}{c}\text { Quite Bad } \\
(\%)\end{array}$ & $\begin{array}{c}\text { Very Bad } \\
(\%)\end{array}$ \\
\hline Availability of clean drinking water & 30 & 40 & 20 & 9 \\
\hline Security situation & 28 & 41 & 20 & 10 \\
\hline Availability of education for children & 28 & 45 & 19 & 8 \\
\hline $\begin{array}{l}\text { Freedom of movement }- \text { the ability to move safely in } \\
\text { your area or district }\end{array}$ & 26 & 44 & 23 & 7 \\
\hline Availability of clinics and hospitals & 15 & 42 & 30 & 12 \\
\hline Availability of water for irrigation & 14 & 35 & 33 & 16 \\
\hline Supply of electricity & 14 & 20 & 26 & 39 \\
\hline Availability of medicine & 14 & 39 & 34 & 12 \\
\hline Availability of jobs & 7 & 24 & 42 & 28 \\
\hline
\end{tabular}

Respondents report the highest level of satisfaction with the availability of education for children, with almost three quarters $(73 \%)$ saying this is quite good or very good in their local area. A similarly high proportion of respondents say the same about the availability of clean drinking water $(70 \%)$ and freedom of movement or their ability to move safely in their area or district $(70 \%)$. More than two thirds $(69 \%)$ of respondents say the security situation is quite good or very good in the area where they live. On the other hand, people are least satisfied with the availability of jobs. More than two thirds $(70 \%)$ of respondents say the availability of jobs in their local area is quite bad or very bad. Almost two thirds (65\%) say the same about the supply of electricity.

There are significant regional variations in satisfaction with public services and infrastructure. More than four fifths of respondents say the availability of education for children is good or very good in their local area in the Central/Kabul (82\%) and Central/Hazarajat (82\%) regions. However, this percentage decreases to $76 \%$ of respondents in the North East, $74 \%$ in the North West, $73 \%$ in the East, $70 \%$ in the South East, $69 \%$ in the West and just over half of respondents in the South West (58\%).

While over four fifths of respondents in the East (82\%), South West $(80 \%)$ and South East (80\%) say the availability of clean drinking water is very good or quite good, this is true for only $73 \%$ in the Central/Kabul, $70 \%$ in the West, $62 \%$ in the North East, $59 \%$ in the Central/Hazarajat and 55\% in the North West. In the North East region, almost twice as many respondents $(63 \%)$ say the availability of water for irrigation, which is the most essential need for the agricultural economy of the country, is very good or quite good, compared to those in the North West (35\%) and Central Hazarajat regions (35\%). 
The regional variations are even starker regarding respondents' assessment of the local security situation. While over $80 \%$ of respondents in the Central/Hazarajat (85\%), Central/Kabul (84\%) and North East (83\%) and $74 \%$ in the North West say security is good or very good in their local area, this is true for only $68 \%$ of respondents in the West, $54 \%$ in the South West and less than half of respondents in the East (49\%) and South East (40\%). Similarly, the highest proportions of respondents who say they can move safely in their area or district are also recorded in the Central/Kabul (83\%), North East (82\%), Central/Hazarajat (79\%) and North West (78\%), whereas much lower proportions of respondents say this in the South East (50\%), South West (59\%), East (59\%) and West (59\%).

On the other hand, fewer than one in five respondents in the South East (14\%) and East (19\%) and less than a third in the North East (31\%), West (29\%), South West $(28 \%)$ say that the supply of electricity in their area is good despite government efforts to increase the supply from neighboring countries such as Tajikistan and Iran. The majority of respondents in the Central/Kabul region (57\%) say their local electricity supply is good and at least a third say the same in the Central/Hazarajat (44\%) and North West (36\%). A much higher proportion of residents of urban areas (66\%) report satisfaction concerning the supply of electricity than residents of rural areas $(26 \%)$.

Despite some improvement in the availability of jobs since 2008, unemployment remains one of the most pressing issues in Afghanistan. Interestingly, about half of respondents in the South West (50\%) say the availability of jobs in their local area or district is very good or quite good compared to around a third in the Central/Kabul (34\%), West (30\%), Central/Hazarajat (29\%) and East (29\%) and less than a quarter in the South East (23\%), North East (23\%) and North West (23\%).

There is less difference between regions in respondents' assessments of the availability of clinics and hospitals and medicines. However, while more than $60 \%$ say local availability of hospitals and clinics is good in the Central/Kabul (67\%), Central/Hazarajat (62\%), South West (62\%) and West $(60 \%)$ this is true for under half in the North West (46\%) and South East (48\%). Similarly, while more than $60 \%$ say local availability of medicines is good in the Central/Kabul (66\%), this is true for under half in the North West (42\%) and North East $(47 \%)$ and East (48\%). 
Table 6.2: I would like to ask you about today's conditions in the village / neighborhood where you live. Would you rate the availability of (basic facilities) as very good, quite good, quite bad or very bad in your area? (Q-7a-i, Base 6348) ALL AND BY REGION

\begin{tabular}{|l|c|c|c|c|c|c|c|c|c|}
\hline $\begin{array}{l}\text { Base: Combination of very good } \\
\text { and quite good }\end{array}$ & $\begin{array}{c}\text { All } \\
\mathbf{( \% )}\end{array}$ & $\begin{array}{c}\text { Central/ } \\
\text { Kabul } \\
\mathbf{( \% )}\end{array}$ & $\begin{array}{c}\text { East } \\
\mathbf{( \% )}\end{array}$ & $\begin{array}{c}\text { South } \\
\text { East } \\
\mathbf{( \% )}\end{array}$ & $\begin{array}{c}\text { South } \\
\text { West } \\
(\mathbf{\%})\end{array}$ & $\begin{array}{c}\text { West } \\
\mathbf{( \% )}\end{array}$ & $\begin{array}{c}\text { North } \\
\text { East } \\
\mathbf{( \% )}\end{array}$ & $\begin{array}{c}\text { Central/ } \\
\text { Hazarajat } \\
\mathbf{( \% )}\end{array}$ & $\begin{array}{c}\text { North } \\
\text { West } \\
\mathbf{( \% )}\end{array}$ \\
\hline Availability of education for children & 73 & 82 & 73 & 70 & 58 & 69 & 76 & 82 & 74 \\
\hline Availability of clean drinking water & 70 & 73 & 82 & 80 & 80 & 70 & 62 & 59 & 55 \\
\hline $\begin{array}{l}\text { Freedom of movement - the ability } \\
\text { to move safely in your area or district }\end{array}$ & 70 & 83 & 59 & 50 & 59 & 59 & 82 & 79 & 78 \\
\hline Security situation & 69 & 84 & 49 & 40 & 54 & 68 & 83 & 85 & 74 \\
\hline Availability of clinics and hospitals & 57 & 67 & 57 & 48 & 62 & 60 & 53 & 62 & 46 \\
\hline Availability of medicine & 53 & 66 & 48 & 54 & 51 & 55 & 47 & 53 & 42 \\
\hline Availability of water for irrigation & 50 & 47 & 52 & 53 & 55 & 52 & 63 & 35 & 35 \\
\hline Supply of electricity & 34 & 57 & 19 & 14 & 28 & 29 & 31 & 44 & 36 \\
\hline Availability of jobs & 30 & 34 & 29 & 23 & 50 & 30 & 23 & 29 & 23 \\
\hline
\end{tabular}

There has been a slight improvement since 2007 in the assessment of the availability of most basic facilities and public services except for water for irrigation. Availability of education for children has consistently remained the basic amenity with which most communities are satisfied. More than two thirds of respondents have judged availability to be good or very good since 2007 (72\%), (70\% in 2008, 67\% in 2009, 68\% in 2010 and $73 \%$ in 2011). The majority of respondents have also consistently judged positively the availability of clean drinking water, the local security situation and the ability to move safely in the local area. However, despite the fact that electricity supply and availability of jobs consistently record the lowest levels of satisfaction, the proportion of respondents reporting a positive assessment of the local electricity supply shows an upward trend - from 31\% in 2007 to $34 \%$ in 2011 . The same is true for the availability of jobs where the proportion of respondents who say it is good in their local area has been rising steadily since 2008 (21\%) to $24 \%$ in 2009 , $27 \%$ in 2010 and $31 \%$ in 2011 . This is consistent with the fall in the proportion of respondents that identify unemployment as the biggest problem facing Afghanistan to its lowest recorded level in 2011 (see Chapter 2, 2.4 Afghanistan's biggest problems: National level).

However, satisfaction with the availability of water for irrigation seems to be falling over time - while $59 \%$ reported being satisfied with this in 2007, only 45\% do so in 2011. 
Table 6.3: Present condition of basic facilities in localities (Q-7a-i) combination of quite good and very good responses COMPARISON BETWEEN 2007, 2008, 2009, 2010 AND 2011

\begin{tabular}{|l|c|c|c|c|c|}
\hline \multicolumn{1}{|c|}{ Development issues } & $\begin{array}{c}2007 \\
(\%)\end{array}$ & $\begin{array}{c}2008 \\
(\%)\end{array}$ & $\begin{array}{c}2009 \\
(\%)\end{array}$ & $\begin{array}{c}2010 \\
(\%)\end{array}$ & $\begin{array}{c}2011 \\
(\%)\end{array}$ \\
\hline Availability of clean drinking water & 63 & 62 & 63 & 63 & 70 \\
\hline Availability of water for irrigation & 59 & 47 & 53 & 49 & 45 \\
\hline Availability of jobs & 30 & 21 & 24 & 27 & 31 \\
\hline Supply of electricity & 31 & 25 & 34 & 34 & 34 \\
\hline Security situation & 66 & 62 & 64 & 65 & 69 \\
\hline Availability of clinics and hospitals & 56 & 51 & 49 & 46 & 57 \\
\hline Availability of medicine & - & 49 & 44 & 43 & 53 \\
\hline Availability of education for children & 72 & 70 & 67 & 68 & 73 \\
\hline $\begin{array}{l}\text { Freedom of movement - the ability to move } \\
\text { safely in your area or district }\end{array}$ & - & - & - & 63 & 70 \\
\hline
\end{tabular}

\subsection{Future expectations for infrastructure and services}

Respondents were also asked about their expectations of improvement in basic infrastructure and services in the coming year. The majority of respondents expect to see improvements in their local area in all the amenities and services mentioned. More than four fifths of respondents expect to see some level of improvement in the availability of clean drinking water $(86 \%)$ and education for children $(84 \%)$. About three quarters expect improvement in the availability of clinics and hospitals (78\%), medicines (77\%) and water for irrigation (74\%). Respondents are less optimistic about the prospects for improvements in the electricity supply (63\%) and the availability of jobs $(66 \%)$, although around two thirds still think that these will get better. However, around a third of respondents say the availability of electricity $(34 \%)$ and jobs $(33 \%)$ in their local area could get worse.

Table 6.4: What is your expectation for the availability of basic amenities in your area a year from now? Do you expect it to be much better, somewhat better, somewhat worse or much worse? (Q-8a-i)

\begin{tabular}{|l|c|c|c|c|}
\hline \multicolumn{1}{|c|}{ Development issues } & $\begin{array}{c}\text { Much } \\
\text { better }\end{array}$ & $\begin{array}{c}\text { Somewhat } \\
\text { better }\end{array}$ & $\begin{array}{c}\text { Somewhat } \\
\text { worse }\end{array}$ & $\begin{array}{c}\text { Much } \\
\text { worse }\end{array}$ \\
\hline Availability of clean drinking water & 49 & 37 & 10 & 4 \\
\hline Availability of education for children & 48 & 36 & 11 & 4 \\
\hline Security situation & 45 & 32 & 14 & 7 \\
\hline $\begin{array}{l}\text { Freedom of movement - the ability to move safely in } \\
\text { your area or district }\end{array}$ & 45 & 35 & 14 & 5 \\
\hline Availability of clinics and hospitals & 40 & 39 & 15 & 5 \\
\hline Availability of medicine & 39 & 38 & 16 & 5 \\
\hline Availability of water for irrigation & 37 & 37 & 17 & 7 \\
\hline Supply of electricity & 37 & 27 & 15 & 19 \\
\hline Availability of jobs & 36 & 30 & 21 & 12 \\
\hline
\end{tabular}




\subsection{Awareness of development programs}

International development agencies in cooperation with the government of Afghanistan have been supporting a wide variety of development projects and programs that aim to improve the wellbeing of Afghan citizens. The survey attempts to measure whether respondents are aware of any projects or programs in their local area. All respondents were asked whether they know or have heard of any development project or program in their area or district, implemented during the past 12 months. Respondents were then given a list of the kinds of development programs that might be present in their area.

More than half $(59 \%)$ of respondents say they are aware of projects relating to reconstruction/building of roads and bridges. More respondents in the South West (72\%), East (71\%), South East (62\%) and North West $(62 \%)$ say they are aware of projects relating to reconstruction/building of roads and bridges than in the Central/Hazarajat (42\%), Central/Kabul (54\%), West (54\%) and North East (54\%).

Nationally, more than half $(57 \%)$ are aware of projects belonging to education including reconstruction/ opening of schools and training teachers. However, more than two thirds of respondents in the East (68\%), South East (68\%) and North East (65\%) say they are aware of these projects compared to less than half of respondents in Central/Hazarajat (40\%) and Central/Kabul (48\%) regions.

Just under half of respondents (48\%) cite projects related to drinking water supply. Again around two thirds of respondents in the South West (68\%) and over half in the South East (56\%) and North East (52\%) say they are aware of projects relating to water supply for drinking but only a third of respondents in the Central/ Kabul (34\%) and a quarter in the Central/Hazarajat (25\%) regions say this.

Forty-four percent say they are aware of healthcare programs, such as primary health centers and regular visits of doctors but these are more commonly identified in East (54\%) and South East (49\%) than in the Central/ Hazarajat (27\%) and Central/Kabul (37\%) regions.

Awareness of reconstruction programs in agriculture (33\%) and industry $(18 \%)$ is also higher in the East (40\% for agriculture, 24\% for industry) and South West (40\% for agriculture, $28 \%$ for industry), followed by the West (40\% for agriculture, 22\% for industry) and North West (39\% for agriculture, 20\% for industry).

A little more than a quarter of respondents $(26 \%)$ countrywide say they are aware of the projects related to electricity. However, the distribution of these projects appears to differ from those related to the delivery of basic social services. While more than a third of respondents are aware of projects in the Central/Kabul (37\%), North East (33\%) and North West (31\%), this is true for less than a fifth in the West (19\%) and East $(17 \%)$ and only a tenth in the South East $(10 \%)$. These last three regions are also the same regions that report the lowest levels of satisfaction with the availability of electricity supply in their local area (See above, 6.1 Services and Facilities available in local areas).

The overall pattern that emerges suggests a heavy concentration of donor assisted development projects focusing on basic infrastructure and public services in certain areas of the country, particularly the East and South West, and to some extent the North West. Awareness of security-related projects such as those related to de-mining and demilitarization/disarmament are also highest in the South West (44\% de-mining, 30\% demilitarization), East (34\% de-mining, 32\% demilitarization) and North West (32\% de-mining, 31\% demilitarization). Humanitarian programs appear to be concentrated in these regions. Other regions, especially the Central/Hazarajat regions, appear to receive significantly less development assistance. This is likely to be due in part to donor strategies designed to link development initiatives with security-related initiatives. There does not seem to be a strong correlation between awareness of different development projects and satisfaction with the related services. 
Table 6.5: Speaking of the past 12 months, do you know of, heard of any project or program in this area, district, implemented in the following fields? Percentage of respondents who know or have heard of any development project or program implemented in their localities (Q-9Aa-l, Base 6348)

\begin{tabular}{|c|c|c|c|c|c|c|c|c|c|}
\hline "Yes" responses & $\begin{array}{l}\text { All } \\
(\%)\end{array}$ & $\begin{array}{c}\text { Central/ } \\
\text { Kabul } \\
(\%)\end{array}$ & $\begin{array}{c}\text { East } \\
(\%)\end{array}$ & $\begin{array}{c}\text { South } \\
\text { East } \\
(\%)\end{array}$ & $\begin{array}{c}\text { South } \\
\text { West } \\
(\%)\end{array}$ & $\begin{array}{l}\text { West } \\
(\%)\end{array}$ & $\begin{array}{l}\text { North } \\
\text { East } \\
(\%)\end{array}$ & $\begin{array}{l}\text { Central/ } \\
\text { Hazarajat } \\
\quad(\%)\end{array}$ & $\begin{array}{c}\text { North } \\
\text { West } \\
(\%)\end{array}$ \\
\hline $\begin{array}{l}\text { Reconstruction/building of roads, } \\
\text { bridges }\end{array}$ & 59 & 54 & 71 & 62 & 72 & 54 & 54 & 42 & 62 \\
\hline $\begin{array}{l}\text { Education (reconstruction/ open- } \\
\text { (.ing of school, more teachers, etc }\end{array}$ & 57 & 48 & 68 & 68 & 58 & 52 & 65 & 40 & 58 \\
\hline Water supply for drinking & 48 & 34 & 72 & 56 & 68 & 44 & 52 & 25 & 38 \\
\hline Water supply for irrigation & 29 & 23 & 45 & 24 & 44 & 30 & 30 & 14 & 24 \\
\hline $\begin{array}{l}\text { Healthcare (primary health center, } \\
\text { (.regular visits of doctors, etc }\end{array}$ & 44 & 37 & 54 & 49 & 58 & 36 & 46 & 27 & 46 \\
\hline Electricity supply & 26 & 37 & 17 & 10 & 23 & 19 & 33 & 26 & 31 \\
\hline $\begin{array}{l}\text { Reconstruction/programs in } \\
\text { agriculture }\end{array}$ & 33 & 24 & 40 & 32 & 40 & 40 & 24 & 23 & 39 \\
\hline $\begin{array}{l}\text { Reconstruction/programs in } \\
\text { industry }\end{array}$ & 18 & 14 & 24 & 11 & 28 & 22 & 11 & 13 & 20 \\
\hline Building new mosques & 27 & 25 & 35 & 28 & 35 & 32 & 19 & 9 & 28 \\
\hline De-mining & 31 & 27 & 38 & 30 & 44 & 26 & 27 & 15 & 32 \\
\hline Demilitarization/disarmament & 25 & 23 & 32 & 19 & 30 & 20 & 27 & 15 & 31 \\
\hline $\begin{array}{l}\text { Humanitarian programs - help in } \\
\text { food, medicines, shelter, produc- } \\
\text {.tion materials, etc }\end{array}$ & 24 & 17 & 38 & 19 & 27 & 26 & 17 & 13 & 33 \\
\hline
\end{tabular}

In order to measure public perceptions regarding who is primarily responsible for providing aid for development projects, respondents were asked who they think is responsible for these activities in various sectors. This question was only asked to those respondents who were aware of development projects in their area. The majority of respondents respond that the Afghan government is the primary agency responsible for projects to support building mosques (66\%), education (64\%) and improving the supply of electricity (59\%) and water for irrigation (51\%). The Afghan government is also seen to be the lead agency for projects related to demilitarization and disarmament (54\%), healthcare (53\%), improving drinking water supply (45\%) and reconstruction or building of roads and bridges (45\%). On the other hand, a higher proportion of respondents respond that foreign donors are mainly responsible for de-mining (43\%). An almost equal proportion say the Afghan government (38\%) and foreign donors (37\%) are responsible for humanitarian programs $(37 \%)$. 
Table 6.6: Has the Afghan government or foreign sponsors been primarily responsible for providing most of the aid for the projects? (Q-9Ba-l)

\begin{tabular}{|l|c|c|c|} 
Development fields & $\begin{array}{c}\text { Afghan gov- } \\
\text { ernment } \\
(\mathbf{\%})\end{array}$ & $\begin{array}{c}\text { Foreign } \\
\text { sponsor } \\
\mathbf{( \% )}\end{array}$ & $\begin{array}{c}\text { Both } \\
\mathbf{( \% )}\end{array}$ \\
\hline Building new mosques & 66 & 19 & 13 \\
\hline Education (reconstruction/opening of school, more teachers, etc.) & 64 & 20 & 16 \\
\hline Electricity supply & 59 & 24 & 17 \\
\hline Demilitarization/disarmament & 54 & 24 & 21 \\
\hline Healthcare (primary health center, regular visits of doctors, etc.) & 53 & 27 & 20 \\
\hline Reconstruction/programs in agriculture & 53 & 27 & 19 \\
\hline Water supply for irrigation & 51 & 29 & 20 \\
\hline Reconstruction/programs in industry & 48 & 31 & 20 \\
\hline Reconstruction/building of roads, bridges & 45 & 36 & 19 \\
\hline Water supply for drinking & 45 & 35 & 19 \\
\hline Humanitarian programs - help in food, medicines, shelter, production materials, etc. & 38 & 37 & 24 \\
\hline De-mining & 34 & 43 & 22 \\
\hline
\end{tabular}

\subsection{Development programs and public awareness of foreign aid}

Over the years, the international community and donor agencies have been supporting a wide variety of projects and programs in Afghanistan. In 2011, the survey resumed efforts to measure respondents' perceptions about the provision of aid for development projects and programs in their local area. All respondents were asked which country they think has provided the most aid for the projects they are aware of in their area or district. More than a quarter of respondents $(27 \%)$ say the United States has provided the most aid for projects implemented in their local area. This is a significant drop from previous years (48\% in 2006, 44\% in $2007,46 \%$ in 2008, 41\% in 2009). Respondents also identified Germany (7\%), Japan (6\%), India (4\%) and the United Kingdom (Britain) (2\%) as supporting projects locally, followed by China, Iran, Saudi Arabia, Turkey, Canada, France, Sweden, Provincial Reconstruction Teams (PRTs), Pakistan, Italy, Spain, Norway, Denmark, the National Solidarity Program, United Nations' agencies and Poland. One fifth of respondents (20\%) say they are not aware of any development projects in their area.

Which country do you think has provided the most aid for the projects you mentioned to have been implemented in this area, district? (Q-10, Base 4348)

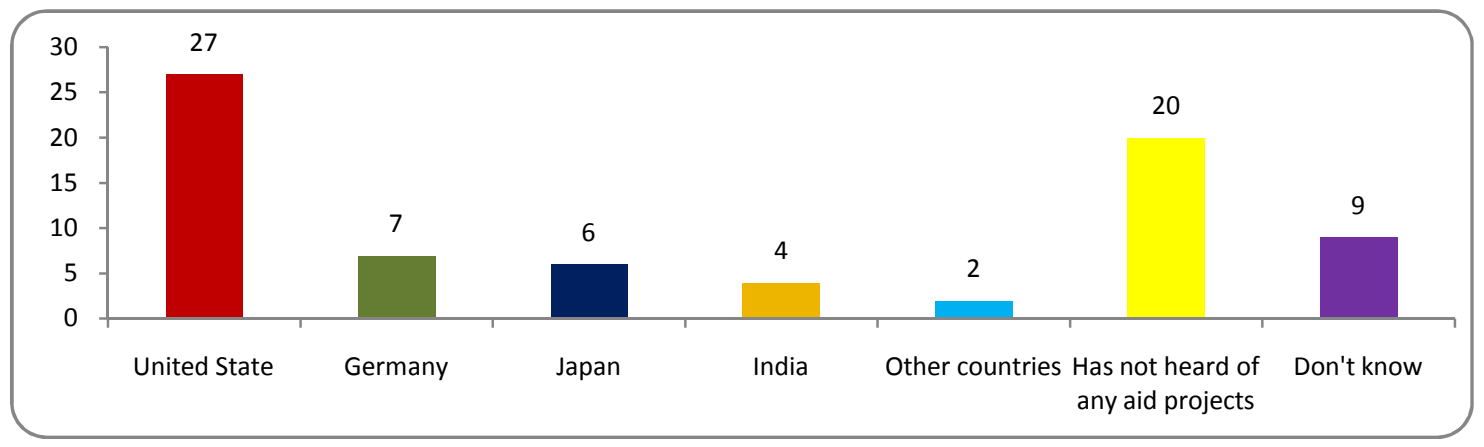

Fig 6.1 
The United States is identified as the major donor in all regions, followed by Germany, Japan and India. This is true for Afghanistan as a whole and for the regions. Germany is cited most often in the North East (22\%), where the German-led PRT is based. This is followed by Japan, which is most often cited by respondents in the East $(12 \%)$ and South West (10\%). India is most often identified in the South West (10\%) and East (8\%). The United Kingdom is identified four times more often in the South West (8\%), where British Soldiers and the UK-led PRT have been based more than in any other part of the country.

Table 6.7: Which country do you think has provided the most aid for the projects you mentioned to have been implemented in this area, district? (Q-10, Base 4348)

\begin{tabular}{|c|c|c|c|c|c|c|c|c|c|}
\hline & $\begin{array}{c}\text { Total } \\
(\%)\end{array}$ & $\begin{array}{c}\text { Central/ } \\
\text { Kabul } \\
(\%)\end{array}$ & $\begin{array}{c}\text { East } \\
(\%)\end{array}$ & $\begin{array}{c}\text { South } \\
\text { East } \\
(\%)\end{array}$ & $\begin{array}{l}\text { South } \\
\text { West } \\
(\%)\end{array}$ & $\begin{array}{l}\text { West } \\
(\%)\end{array}$ & $\begin{array}{c}\text { North } \\
\text { East } \\
(\%)\end{array}$ & $\begin{array}{c}\text { Central/ } \\
\text { Hazarjat } \\
(\%)\end{array}$ & $\begin{array}{c}\text { North } \\
\text { West } \\
(\%)\end{array}$ \\
\hline United States & 27 & 24 & 36 & 33 & 25 & 30 & 26 & 17 & 21 \\
\hline $\begin{array}{l}\text { Has not heard of any aid } \\
\text { projects }\end{array}$ & 20 & 31 & 11 & 10 & 8 & 30 & 16 & 34 & 18 \\
\hline Donst know (vol.) & 9 & 13 & 4 & 11 & 4 & 6 & 8 & 15 & 8 \\
\hline Germany & 7 & 2 & 6 & 5 & 2 & 2 & 22 & 1 & 8 \\
\hline Japan & 6 & 4 & 12 & 5 & 10 & 3 & 4 & 8 & 7 \\
\hline India & 4 & 2 & 8 & 3 & 10 & 5 & 2 & 5 & 1 \\
\hline $\begin{array}{l}\text { United Kingdom } \\
\text { (Britain) }\end{array}$ & 2 & 1 & 2 & 1 & 8 & 1 & 1 & $*$ & 1 \\
\hline China & 2 & 1 & 2 & 1 & 1 & 2 & 2 & 3 & 2 \\
\hline Iran & 2 & 1 & $*$ & 1 & 2 & 2 & 2 & 3 & 3 \\
\hline Saudi Arabia & 2 & 2 & 1 & 3 & 3 & 1 & 2 & 1 & 1 \\
\hline Turkey & 2 & 5 & 1 & 1 & 1 & 0 & * & 0 & 4 \\
\hline Canada & 2 & 1 & 1 & 1 & 9 & $*$ & $*$ & 0 & * \\
\hline France & 2 & 3 & 3 & 1 & * & * & 1 & 3 & 2 \\
\hline Sweden & 2 & 1 & 3 & 3 & 0 & 0 & 2 & 0 & 6 \\
\hline $\begin{array}{l}\text { Provincial } \\
\text { Reconstruction Team }\end{array}$ & 2 & 2 & 2 & 3 & 2 & 2 & 1 & 0 & $*$ \\
\hline
\end{tabular}




\section{Governance}

\subsection{Confidence in public institutions}

Confidence of the people in public institutions is a measure of public trust in government and other important governance institutions. Survey respondents were asked about the confidence they have in a range of public institutions and organizations. The list was read out and respondents were asked to state how much confidence they have in each institution to perform its job. Public confidence in the various organizations and institutions listed is shown in the table below.

Table 7.1: Do you have a great deal of confidence, a fair amount of confidence, not very much confidence, or no confidence at all in the following institutions? (Q-40a-t)

\begin{tabular}{|l|c|c|c|c|c|c|}
\hline \multicolumn{7}{c}{ Confidence (\%) } \\
& \multicolumn{7}{c}{ (Great deal + Fair amount) } \\
\hline & 2006 & $\mathbf{2 0 0 7}$ & $\mathbf{2 0 0 8}$ & $\mathbf{2 0 0 9}$ & $\mathbf{2 0 1 0}$ & $\mathbf{2 0 1 1}$ \\
\hline Afghan National Army & 87 & 88 & 89 & 91 & 91 & $\mathbf{9 3}$ \\
\hline Afghan National Police & 86 & 83 & 82 & 84 & 79 & $\mathbf{8 3}$ \\
\hline Religious leaders & - & - & - & - & - & $\mathbf{7 4}$ \\
\hline Electronic media such as radio, TV & 84 & 74 & 76 & 70 & 71 & $\mathbf{7 2}$ \\
\hline Community shuras/ jirgas & - & 71 & 69 & 67 & 66 & $\mathbf{7 0}$ \\
\hline Newspapers, print media & 77 & 62 & 63 & 62 & 57 & $\mathbf{6 9}$ \\
\hline Community development councils & - & 64 & 65 & 64 & 61 & $\mathbf{6 8}$ \\
\hline Provincial councils & - & 69 & 65 & 62 & 62 & $\mathbf{6 7}$ \\
\hline Provincial government & - & - & - & - & - & $\mathbf{6 7}$ \\
\hline Provincial development committee & - & - & - & - & - & $\mathbf{6 4}$ \\
\hline Parliament & - & - & - & - & 59 & $\mathbf{6 2}$ \\
\hline Public administration & - & 61 & 55 & 57 & 57 & $\mathbf{6 2}$ \\
\hline Independent Elections Commission & 65 & - & 57 & 67 & 54 & $\mathbf{5 9}$ \\
\hline International NGOs & 57 & 65 & 64 & 66 & 54 & $\mathbf{5 6}$ \\
\hline Government ministers & - & 58 & 51 & 53 & 54 & $\mathbf{5 6}$ \\
\hline Government justice system & 38 & 48 & 46 & 46 & 48 & $\mathbf{5 5}$ \\
\hline Municipality & - & 48 & 42 & 46 & 46 & $\mathbf{5 5}$ \\
\hline National NGOs & 57 & 59 & 62 & 61 & 55 & $\mathbf{5 4}$ \\
\hline Political parties & 44 & 39 & 43 & 47 & 43 & $\mathbf{4 7}$ \\
\hline Local militias & 31 & 33 & 36 & 37 & 34 & $\mathbf{3 6}$ \\
\hline
\end{tabular}


The survey reveals that the highest levels of public confidence are still enjoyed by the Afghan National Army (ANA), with $93 \%$ of respondents saying they have a fair amount or a great deal of confidence in this body. The second highest level of confidence is recorded for the Afghan National Police (ANP), with 83\% of respondents expressing some level of confidence in them. Since 2006, these two institutions have consistently secured the highest levels of public confidence. However, while public confidence in the ANA has been rising over time (from 87\% in 2006 to $93 \%$ in 2011), public confidence in the ANP has been largely stable.

These findings are consistent with responses showing that a significant majority of respondents think the ANA (88\%) and the ANP (84\%) help improve security, and that the ANP is efficient at arresting those who have committed crimes so that they can be brought to justice (76\%) (see Chapter 3, 3.5: Perceptions of the ANP, and 3, 3.6: Perceptions of the $A N A$ ). They are also consistent with the relatively high levels of satisfaction with the performance of government in providing security (62\%) as the ANA and the ANP represent the largest and most visible government security services (see below 7.3 Satisfaction with central government performance in policy and service delivery). The higher level of confidence expressed in the ANA is also consistent with the lower level of corruption encountered in this organization compared to the ANP (see Chapter 8, 8.2 Payment of bribes).

At the same time, $42 \%$ of respondents say they would have some or a lot of fear encountering an ANA officer, and $43 \%$ say they would have some or a lot of fear encountering an ANP officer.

Table 7.2: Cross-tabulation of the proportion of respondents who have great deal or fair amount of confidence on $A N A$ and $A N P$ with those respondents who have no fear, some fear or a lot of fear when encountering $A N A$ and $A N P$ officer $(Q-40 a$ versus $30 f$ and $40 b$ versus 30 )

\begin{tabular}{|l|c|c|}
\hline 40a Crosstab 30f (Base - 5848) and 40b Crosstab 30e (Base - 5207) & $\begin{array}{c}\text { Confidence } \\
\text { in ANA }\end{array}$ & $\begin{array}{c}\text { Confidence } \\
\text { in ANP }\end{array}$ \\
\hline No Fear & 58 & 57 \\
\hline A lot or some fear & 42 & 43 \\
\hline
\end{tabular}

This may also be a reflection of the high proportion of respondents $(68 \%)$ who agree that it is generally not acceptable to talk negatively about the government in public where this is more relevant to the security forces (see Chapter 9, 9.4 Democratic spirit of the government).

This year, religious leaders were added to the list as they have an important presence in Afghan society. They obtained the third highest levels of public confidence, after the ANA and the ANP. About three quarters of respondents (74\%) say that they have some level of confidence in religious leaders. This is also consistent with the view of respondents that local religious leaders should be regularly consulted for solving local problems (see Chapter 9, 9.8 Involvement of Religious Leaders) and the perception that religious leaders serve the interests of Afghan society rather than their own when making decisions (see Chapter 9, 9.4 Consideration of the public interest when making decisions and policies). 
Public confidence in electronic media such as radio and TV is also high $(72 \%)$. However, confidence levels have been falling since 2006 when the figure was $84 \%$. More than two thirds $(69 \%)$ of respondents say they have confidence in newspapers and print media. This is the highest level of confidence in print media recorded since 2007, but it is still lower than that recorded in $2006(77 \%)$.

In 2011, a majority of respondents reported some level of confidence in both national (54\%) and international (56\%) NGOs, which is similar to the figures recorded last year. Between 2007 and 2009, confidence in national NGOs stabilized at around $60 \%$, and confidence in international NGOs at around $65 \%$, but these figures decreased significantly in 2010 and 2011. Representative bodies continue to enjoy the confidence of around two thirds of respondents, including community shura and jirgas (70\%), provincial councils (67\%), community development councils (CDC) (68\%), and parliament (62\%). This year the level of confidence in representative bodies increased in comparison to 2010. Confidence in community shura and jirga was up 4\% (from 66\% in 2010 to $70 \%$ in 2011), provincial councils was up 5\% (from 62\% in 2010 to 67\% in 2011), CDCs was up 7\% (from 61\% in 2010 to $68 \%$ in 2011) and parliament was up 3\% (from 59\% in 2010 to $62 \%$ in 2011). This is consistent with respondents' increased satisfaction in the good job these institutions are doing (see below, 7.5 Satisfaction with the performance of local government and 7.9 Role of community development councils).

Just under two thirds $(62 \%)$ of respondents expressed confidence in public administration, which is the highest level of confidence recorded since 2007 . The majority of respondents $(56 \%)$ say they have confidence in government ministers. This is consistent with the generally high levels of satisfaction with central government performance in most regions (See below 7.2 Satisfaction with the performance of the central government and 7.3 Satisfaction with central government performance in policy and service delivery). It is also consistent with the perception that government employees mostly consider the public interest rather than their own interests when making decisions (see Chapter 9, 9.4 Consideration of the public interest when making decisions and policies).

In 2011, confidence in the government justice system also reached its highest level since 2006. For the first time, a majority of respondents (55\%) say they have some level of confidence in the system. This finding corroborates the increase in positive assessments of the quality and performance of state courts (see Chapter 10, 10.2 Perceptions of the state courts).

The same is true for local government institutions. In 2011, for the first time, a majority (55\%) of respondents say they have confidence in municipalities, which is the highest level of confidence recorded to date. This is consistent with an increase in satisfaction with the performance of municipal authorities amongst urban respondents in 2011 (See below, 7.5 Satisfaction with the performance of local government). The data for 2011 also shows an increase in the level of confidence in provincial councils $(67 \%)$ which reaches its highest level since 2008, although it remains slightly lower than in 2007 (69\%). This rise in confidence concurs with a similar rise in reported satisfaction in the performance of provincial government since 2008 (see Chapter 7, 7.5 Satisfaction with the performance of local government). In fact, levels of confidence toward most public institutions have risen this year.

Despite the crisis in the parliamentary elections, which has not yet been completely resolved, this year recorded an increase in confidence toward the Independent Elections Commission (IEC) (from 54\% in 2010 to $59 \%$ in 2011). However, this figure remains well below the $67 \%$ confidence level recorded in 2009 . 
Confidence in political parties increased slightly in 2011 (47\%) from 2010 (43\%) to revert to the highest level of confidence recorded in 2009. However, political parties still record the second lowest level of public confidence among all the institutions listed. There has been a generally negative perception of political parties in Afghanistan since the 1980s. Recent electoral processes in Afghanistan appear to have done little to increase either the image of the political parties or the confidence of the public toward Afghan political parties.

Local militias are the institutions that consistently receive the lowest level of confidence from the Afghan public, with just over a third of respondents (36\%) expressing some confidence in them. This is consistent with the finding that $29 \%$ of respondents say they have some level of sympathy for armed opposition groups (see Chapter 4: 4.3 Sympathy with armed opposition groups). However, while sympathy for armed opposition groups has been falling consistently over time, this year, there is a slight increase in the level of public confidence towards local militias as in the case with other organizations and institutions. The low level of confidence in local militias may be informed by the reported perception that armed opposition groups are killing innocent people and do not want peace and security (see Chapter 4: 4.3 Sympathy with armed opposition groups).

\subsection{Satisfaction with the performance of the central government}

When asked to assess the way the national government is carrying out its responsibilities, nearly three quarters (73\%) of respondents give a positive assessment, including 18\% who say that the government is doing a very good job and 55\% who say it is doing quite a good job. Overall, satisfaction with the performance of the national government has remained more or less stable since 2009. Dissatisfaction with the central government has also remained steady since 2009 (26\%) and 2010 (25\%) when compared to $2011(25 \%)$

Thinking of the national government, how do you feel about the way it is carrying out its responsibilities? (Q-43) COMPARISON BETWEEN 2007, 2008, 2009, 2010 AND 2011

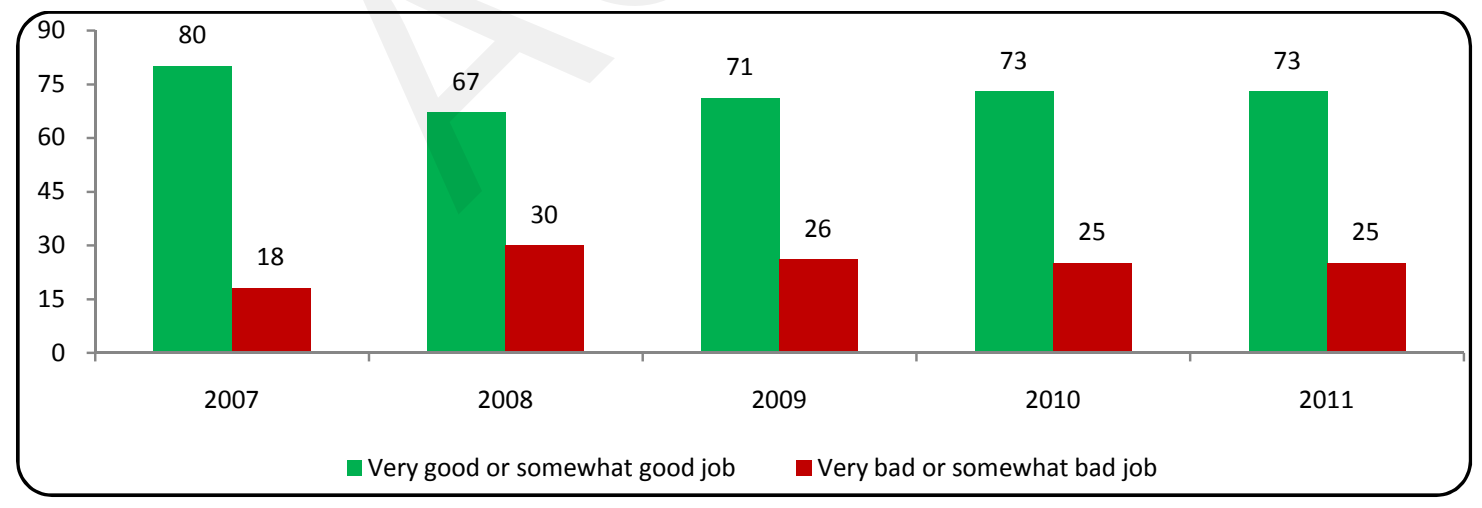

Fig 7.1 
Respondents in rural areas $(75 \%)$ are more likely than those in urban areas $(68 \%)$ to say that the national government is doing a good job. More respondents in the lowest income group who earn less than 2000 Afs per month $(80 \%)$ than those in higher income groups (on average $71 \%$ ) say that the national government is doing a very good or a somewhat good job

The 2011 survey records the highest levels of positive assessments of national government performance since 2008 in all regions except the South East, North West and Central/Kabul.

Satisfaction is highest in the North East (82\%). This is followed by East (80\%), West (77\%), North West $(77 \%)$ and Central/Hazarajat (77\%). These are also the regions that record the highest levels of satisfaction with the performance of the national government for the provision of basic services sSee below, 7.3 Satisfaction with central government performance in policy and service delivery). Assessments of overall government performance are lowest in the South East (61\%) and Central/Kabul (66\%). In these regions, around one third of respondentk say the national government is performing poorly 38\% in the South East Centeral Kabul.

Satisfaction with national government performance has been rising steadily in some regions such as the West (from 61\% in 2008, 68\% in 2009, 72\% in 2010 and 77\% in 2011), the South West (from 61\% in 2008, 59\% in 2009, 69\% in 2010 and $72 \%$ in 2011) and the Central/Hazarajat (from 64\% in 2008, 61\% in 2009, 68\% in 2010 and $77 \%$ in 2011). However, there has been a significanl decline in positive assessments in 2011 in the North West (77\% in 2011 from 84\% in 2010, 82\% in 2009 and 81\% in 2008) and to a lesser extent in the South East (61\% in 2011 from 65\% in 2010, 63\% in 2009 and 56\% in 2008) and Central/Kabul (66\% in 2011 from $68 \%$ in $2010,68 \%$ in 2009 and $62 \%$ in 2008$)$.

Table 7.3: Thinking of thl nationantgovernment, how do you feel about the way it is carrying out its responsibilities? (Q-43) ALL AND BY REGION - COMPARISON BETWEN, 2008, 2009, 2010 AND 2011

\begin{tabular}{|l|c|c|c|c|} 
& \multicolumn{5}{c|}{ Very good or somewhat good job } \\
\cline { 2 - 6 } & $\begin{array}{c}\mathbf{2 0 0 8} \\
\mathbf{( \% )}\end{array}$ & $\begin{array}{c}\mathbf{2 0 0 9} \\
\mathbf{( \% )}\end{array}$ & $\begin{array}{c}\mathbf{2 0 1 0} \\
\mathbf{( \% )}\end{array}$ & $\begin{array}{c}\mathbf{2 0 1 1} \\
\mathbf{( \% )}\end{array}$ \\
\hline All & 67 & 71 & 73 & 73 \\
\hline Central/Kabul & 62 & 68 & 68 & 66 \\
\hline East & 74 & 86 & 78 & 80 \\
\hline South East & 56 & 63 & 65 & 61 \\
\hline South West & 61 & 59 & 69 & 72 \\
\hline West & 61 & 68 & 72 & 77 \\
\hline North East & 79 & 75 & 76 & 82 \\
\hline Central/Hazarajat & 64 & 61 & 68 & 77 \\
\hline North West & 81 & 82 & 84 & 77 \\
\hline
\end{tabular}




\subsection{Satisfaction with central government performance in policy and service delivery}

The survey asked people about the performance of the national government in specific areas such as education, healthcare, creating job opportunities, reviving/developing the economy, maintaining relations with neighboring countries and the international community, fighting corruption and providing security.

The government's performance is judged most positively with regard to the provision of basic public services such as education, healthcare and security. Eighty-five percent of respondents say the government is doing either a somewhat good job or a very good job in providing education. Sixty-eight percent say the same about the provision of healthcare and a similar proportion $(62 \%)$ and have the same view about the provision of security. The majority of respondents also give a positive assessment of government performance in maintaining relations with the international community (61\%) and neighboring countries $(55 \%)$.

Table 7.4a: Perceptions of the performance of the national government in specific areas (Q-44a-h, Base 6348)

\begin{tabular}{|c|c|c|}
\hline \multirow{2}{*}{ Q-44 A-H base 6348} & \multicolumn{2}{|c|}{$\begin{array}{c}\text { Very good or } \\
\text { somewhat good job }\end{array}$} \\
\hline & $\begin{array}{c}2010 \\
(\%)\end{array}$ & $\begin{array}{l}2011 \\
(\%)\end{array}$ \\
\hline Education & 85 & 85 \\
\hline Healthcare system & 63 & 68 \\
\hline Security & 62 & 62 \\
\hline Maintaining relations with international community & - & 61 \\
\hline Maintaining relations with neighboring countries & 57 & 55 \\
\hline Reviving/developing the economy & 43 & 46 \\
\hline Creating job opportunities & 33 & 36 \\
\hline Fighting corruption & 29 & 35 \\
\hline
\end{tabular}

On the other hand, only around a third of respondents say the government is doing a good job in fighting corruption (35\%) and creating job opportunities $(36 \%)$ and under half say the same about the government's performance in reviving/developing the economy (46\%). Indeed, the majority of respondents say that the government is doing a bad job in fighting corruption (64\%), creating jobs (64\%) and reviving/developing the economy $(52 \%)$. However, even in these areas that have the least positive assessments, satisfaction with government performance has risen slightly since 2010. These findings are consistent with respondents' views of the availability of basic services and amenities in their local area, showing that they are most satisfied with the availability of education for children and the security situation, but least satisfied with the availability of jobs (see Chapter 6, 6.2 Facilities available in local area). This suggests that the public's assessment of the government's performance is closely related to the ability of the government to provide basic public services at the local level. 
Respondents in urban areas give a more positive assessment of the performance of the national government than those in rural areas regarding the provision of basic services such as education ( $88 \%$ of urban and $84 \%$ of rural respondents), healthcare (74\% of urban, $66 \%$ of rural respondents) and security (63\% of urban and $61 \%$ of rural respondents).

Across the country, the most positive assessments of government performance in almost all domains are reported in the North West, with the exception of security, maintaining relations with neighboring countries and reviving/developing the economy. The highest levels of satisfaction regarding the provision of security are recorded in the North East (80\%), Central/Hazarajat (74\%) and the North West (73\%). It is significant that in all three of these regions, along with the South West, the majority of respondents think that the country is going in the right direction (see Chapter 2, 2.1 Direction of the country).

Table 7.4b: Perceptions of the performance of the national government in specific areas (Q-44a-h, Base 6348) ALL AND BY REGION

\begin{tabular}{|l|c|c|c|c|c|c|c|c|c|}
\hline \multicolumn{1}{|c|}{$\begin{array}{l}\text { Very good or } \\
\text { somewhat good job }\end{array}$} & $\begin{array}{c}\text { All } \\
\mathbf{( \% )}\end{array}$ & $\begin{array}{c}\text { Central/ } \\
\text { Kabul } \\
(\%)\end{array}$ & $\begin{array}{c}\text { East } \\
(\mathbf{\%})\end{array}$ & $\begin{array}{c}\text { South } \\
\text { East } \\
(\%)\end{array}$ & $\begin{array}{c}\text { South } \\
\text { West } \\
(\%)\end{array}$ & $\begin{array}{c}\text { West } \\
(\%)\end{array}$ & $\begin{array}{c}\text { North } \\
\text { East } \\
(\%)\end{array}$ & $\begin{array}{c}\text { Central/ } \\
\text { Hazarajat } \\
(\%)\end{array}$ & $\begin{array}{c}\text { North } \\
\text { West } \\
(\%)\end{array}$ \\
\hline Education & 85 & 90 & 90 & 79 & 72 & 89 & 84 & 90 & 85 \\
\hline $\begin{array}{l}\text { Healthcare system } \\
\text { Creating job opportunities }\end{array}$ & 68 & 70 & 72 & 60 & 61 & 69 & 67 & 63 & 72 \\
\hline $\begin{array}{l}\text { Maintaining relations with } \\
\text { neighboring countries }\end{array}$ & 55 & 55 & 57 & 50 & 53 & 51 & 63 & 50 & 61 \\
\hline $\begin{array}{l}\text { Maintaining relations with } \\
\text { international community }\end{array}$ & 61 & 58 & 61 & 54 & 50 & 58 & 66 & 63 & 69 \\
\hline $\begin{array}{l}\text { Reviving/developing the } \\
\text { economy }\end{array}$ & 46 & 37 & 52 & 43 & 54 & 45 & 47 & 47 & 47 \\
\hline $\begin{array}{l}\text { Fighting corruption } \\
\text { Security }\end{array}$ & 35 & 30 & 37 & 25 & 38 & 32 & 35 & 48 & 44 \\
\hline
\end{tabular}

\subsection{Important achievements and failings of the central government}

The survey asked respondents to identify the most important achievements of the central government in the past two years. The achievements cited most frequently are a better education system $(26 \%)$, reconstruction $(26 \%)$ and establishing peace and security (20\%). The achievements of government identified by respondents are broadly similar to the reasons for optimism given by respondents who say that the country is moving in the right direction (see Chapter 2, 2.2 Reasons for optimism), suggesting that respondents believe government plays a critical role in leading the country toward positive development. These findings are also consistent with the positive assessment of the availability of education and the security situation in local areas (see Chapter 6, 6.2 Facilities available in local area) and the high levels of satisfaction with central government performance in relation to education (which has the highest level of satisfaction) and security (which has the third highest level of 
satisfaction) (see above, 7.3 Satisfaction with central government performance in policy and service delivery). However, one in ten respondents (10\%) say they cannot identify any achievements of central government in the last year.

What in your opinion is the most important achievement of the central government in the past two years? (Q-54a\&b, Base 6348) (Percentages based on multiple responses)

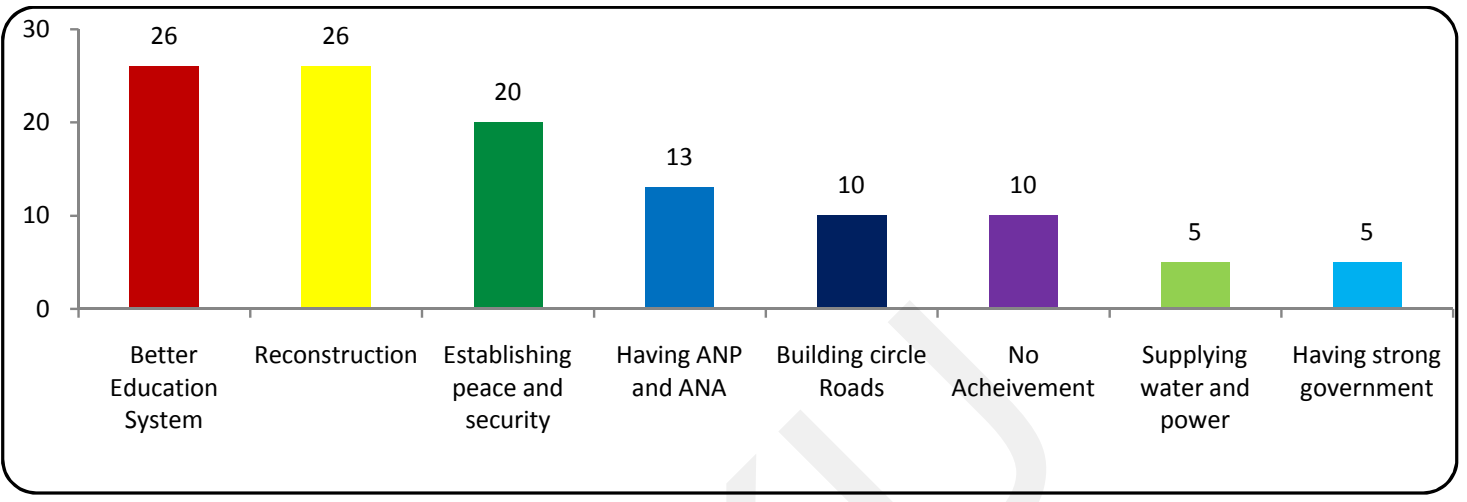

Fig. 7.2

Improvements in the education system are most often cited as the most important achievement of the current government in the South East (32\%), Central/Kabul (29\%) and Central/Hazarajat (29\%) regions. Reconstruction is the government achievement reported most often in the North West (33\%), West (28\%) and East $(23 \%)$. Establishing peace and security is the achievement most often identified in the North East where it is cited by close to a third (32\%) of respondents. Having the ANP and ANA is most often reported in the South West where it is identified by about a quarter $(24 \%)$ of respondents. However, almost one in five respondents $(19 \%)$ in the Central/Kabul region say they cannot identify any achievements by the national government.

Table 7.5: What in your opinion is the mostimportant achievement of the current government in the past few years? And what is next? (Q-54a\&b, Base 6348) (Percentages based on multiple responses) ALL AND BY REGION

\begin{tabular}{|c|c|c|c|c|c|c|c|c|c|}
\hline$Q-45 a \& b$ & $\begin{array}{l}\text { All } \\
(\%)\end{array}$ & $\begin{array}{c}\text { Central/ } \\
\text { Kabul } \\
(\%)\end{array}$ & $\begin{array}{l}\text { East } \\
(\%)\end{array}$ & $\begin{array}{c}\text { South } \\
\text { East } \\
(\%)\end{array}$ & $\begin{array}{c}\text { South } \\
\text { West } \\
(\%)\end{array}$ & $\begin{array}{l}\text { West } \\
(\%)\end{array}$ & $\begin{array}{c}\text { North } \\
\text { East } \\
(\%)\end{array}$ & $\begin{array}{c}\text { Central/ } \\
\text { Hazarajat } \\
(\%)\end{array}$ & $\begin{array}{c}\text { North } \\
\text { West } \\
(\%)\end{array}$ \\
\hline Better education system & 26 & 29 & 20 & 32 & 23 & 25 & 27 & 29 & 25 \\
\hline Reconstruction & 26 & 26 & 23 & 23 & 21 & 28 & 29 & 21 & 33 \\
\hline Establishing peace and security & 20 & 12 & 20 & 10 & 18 & 27 & 32 & 23 & 24 \\
\hline Having ANP and ANA & 13 & 9 & 22 & 18 & 24 & 12 & 13 & 7 & 7 \\
\hline Building circle roads & 10 & 11 & 8 & 15 & 11 & 5 & 6 & 4 & 13 \\
\hline No achievement & 10 & 19 & 3 & 8 & 13 & 8 & 7 & 10 & 5 \\
\hline Having strong government & 5 & 2 & 11 & 4 & 6 & 5 & 5 & 6 & 4 \\
\hline Supplying water and power & 5 & 9 & 3 & 4 & 2 & 3 & 3 & 3 & 6 \\
\hline
\end{tabular}


The survey also asked respondents to identify the most important failings of the central government in the past two years. The failings most frequently identified are insecurity (identified by $32 \%$ of respondents), administrative corruption (25\%) and lack of job opportunities (14\%). More than one in 10 respondents identify weak government (13\%), failure to stop suicide attacks (11\%) and failure to remove the Taliban (10\%), while $8 \%$ mention a weak economy as significant government failings. The issues identified as failings of the central government closely mirror the reasons given by respondents who believe that the country is moving in the wrong direction (see Chapter 2, 2.3 Reasons for pessimism). However, security is given greater emphasis than corruption as a government failure in 2011, while this was the opposite in 2010. A quarter of respondents $(25 \%)$ say they cannot specifically identify any government failures.

Table 7.6: What in your opinion is the most important failing of the central government in the past two years? And what is next? (Q-55a\&b, Base 6348) (Percentages based on multiple responses)

\begin{tabular}{|c|c|}
\hline Q-55a\&b & $\begin{array}{c}\text { Total } \\
(\%)\end{array}$ \\
\hline Insecurity & 32 \\
\hline Administrative corruption & 25 \\
\hline Lack of job opportunities & 14 \\
\hline Weak government & 13 \\
\hline Suicide attacks & 11 \\
\hline Removing Taliban & 10 \\
\hline Weak economy & 8 \\
\hline Removing drugs & 6 \\
\hline Foreign forces in the country for long time & 5 \\
\hline Bad education system & 5 \\
\hline Donıt know & 25 \\
\hline
\end{tabular}

Security issues are identified as both an achievement and a failing of the government: this is likely due to the variation in the security conditions in different parts of the country. The inability to ensure security is identified as a central government failing by at least half of respondents in the South East (51\%), more than a third in the Central/Kabul (40\%) and East (35\%), and over a quarter in the West $(27 \%)$ and Central/Hazarajat $(27 \%)$ regions. This corresponds with the low levels of satisfaction with the provision of security recorded in the South East where only $36 \%$ of respondents say the government is doing a good job.

Specific security-related issues that are highlighted in different regions include failure of government to prevent or stop suicide attacks, most often reported in the North East (18\%) and Central/Kabul (12\%) regions and the regions most often targeted by suicide attacks. One in 10 respondents also cited government's failure to prevent suicide attacks in the East (10\%), South West (10\%) and West (10\%), which are also regions that are 
often affected by such attacks. Failure to remove the Taliban is mentioned by a sizeable proportion of respondents as a failing of the government in the North West (21\%), in the West (15\%) and Central/Hazarajat (15\%) regions. These are also amongst the regions that register the lowest levels of sympathy with armed opposition groups, along with the North East and Central/Kabul regions (see Chapter 4, 4.3 Sympathy with armed opposition groups). Administrative corruption is cited most frequently as the most important failing of the central government in the East (33\%), North East (31\%), South West (24\%) and North West (25\%). Weak government in general is also identified by at least one in ten respondents in all regions (between $11 \%$ and 15\%).

The lack of job opportunities is mentioned by a significant proportion in the Central/Kabul (21\%), North West (17\%) and North East (15\%) regions.

Table 7.7: What in your opinion is the most important failing of the central government in the past two years? And what is next? (Q-55a\&b, Base 6348) (Percentages based on multiple responses) ALL AND BY REGION

\begin{tabular}{|c|c|c|c|c|c|c|c|c|c|}
\hline Q-55a\&b & $\begin{array}{c}\text { Total } \\
(\%)\end{array}$ & $\begin{array}{c}\text { Central/ } \\
\text { Kabul } \\
(\%)\end{array}$ & $\begin{array}{c}\text { East } \\
(\%)\end{array}$ & $\begin{array}{c}\text { South } \\
\text { East } \\
(\%)\end{array}$ & $\begin{array}{c}\text { South } \\
\text { West } \\
(\%)\end{array}$ & $\begin{array}{l}\text { West } \\
(\%)\end{array}$ & $\begin{array}{c}\text { North } \\
\text { East } \\
(\%)\end{array}$ & $\begin{array}{c}\text { Central/ } \\
\text { Hazarajat } \\
(\%)\end{array}$ & $\begin{array}{c}\text { North } \\
\text { West } \\
(\%)\end{array}$ \\
\hline $\begin{array}{l}\text { Administrative } \\
\text { corruption }\end{array}$ & 25 & 22 & 33 & 27 & 24 & 21 & 31 & 21 & 25 \\
\hline Insecurity & 32 & 40 & 35 & 51 & 25 & 27 & 18 & 27 & 26 \\
\hline $\begin{array}{l}\text { Lack of job } \\
\text { opportunities }\end{array}$ & 14 & 21 & 13 & 14 & 7 & 8 & 15 & 10 & 17 \\
\hline Weak government & 13 & 12 & 15 & 11 & 12 & 14 & 15 & 15 & 13 \\
\hline Weak economy & 8 & 9 & 6 & 9 & 6 & 11 & 9 & 8 & 8 \\
\hline Removing Taliban & 10 & 6 & 7 & 6 & 7 & 15 & 7 & 15 & 21 \\
\hline Removing drugs & 6 & 4 & 2 & 5 & 9 & 7 & 5 & 4 & 10 \\
\hline Bad education system & 5 & 4 & 8 & 4 & 3 & 6 & 2 & 8 & 7 \\
\hline $\begin{array}{l}\text { Foreign forces in the } \\
\text { country for long time }\end{array}$ & 5 & 4 & 5 & 6 & 8 & 2 & 5 & 1 & 5 \\
\hline Suicide attacks & 11 & 12 & 10 & 6 & 10 & 10 & 18 & $*$ & 8 \\
\hline Donıt know & 25 & 29 & 21 & 20 & 40 & 34 & 17 & 36 & 24 \\
\hline
\end{tabular}

The proportion of respondents unable or unwilling to identify any failure of the government is higher in the South West (40\%), Central/Hazarajat (36\%) and West (34\%) regions.

\subsection{Satisfaction with the performance of local government}

Respondents were asked to assess the performance of the local government in their area, which includes provincial councils, municipalities and district councils. 
Four fifths of respondents (80\%) assess their provincial government positively, including $29 \%$ who say that the provincial government is doing a very good job. Positive assessments of provincial governments have been gradually rising since 2008 (from $74 \%$ in 2008 to $75 \%$ in 2009, 78\% in 2010 and $80 \%$ in 2011, which is equal to the highest figure recorded in 2007 (80\%).

Turning to your provincial government, do you think that overall it is doing a very good job, somewhat good job, somewhat bad job or a very bad job? (Q-45a, Base 6348) COMPARISON OF 2007, 2008, 2009, 2010 AND 2011

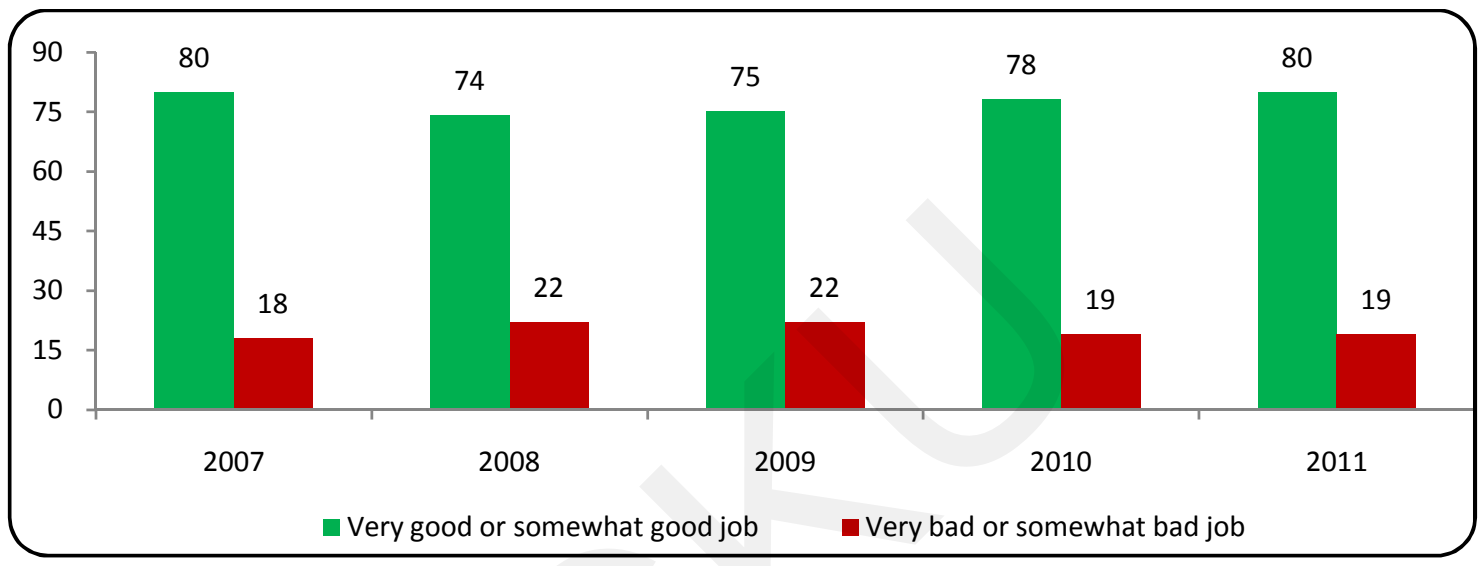

Fig 7.3

However, assessments of the performance of the provincial government vary between regions. The overall assessment of the performance of provincial government is positive in all regions; at least four fifths of respondents say their provincial government is doing a good job in the North West (88\%), North East (84\%), Central/Hazarajat (83\%), West (82\%), East (80\%) and Central/Kabul $(80 \%)$ regions. However, fewer say this in the South West $(70 \%)$ and South East $(72 \%)$.

Assessments of the performance of the provincial government have been gradually improving in most regions since 2009. However, satisfaction with provincial government has been falling over this period in the East (from 85\% in 2009 to $77 \%$ in 2010 and 80\% in 2011) and the South East (from $76 \%$ in 2009 to $70 \%$ in 2010 and 72\% in 2011). Yet, despite this overall trend, positive assessments rose in 2011 compared to 2010 in all regions except the Central/Kabul and South West where they remained stable. This is consistent with the general rise in public confidence in government institutions recorded in 2011, including in provincial councils (see above, 7.1 Confidence in public institutions). 
Table 7.8: Turning to your provincial government, do you think that overall it is doing a very good job, somewhat good job, somewhat bad job or a very bad job? (Q-45a, Base 6348) COMPARISON OF 2009, 2010 AND 2011 BY REGION

\begin{tabular}{|c|c|c|c|}
\hline \multirow{2}{*}{ Q-45a, Base 6348} & \multicolumn{3}{|c|}{$\begin{array}{c}\text { Very good or } \\
\text { somewhat good job }\end{array}$} \\
\hline & $\begin{array}{r}2009 \\
(\%) \\
\end{array}$ & $\begin{array}{r}2010 \\
(\%) \\
\end{array}$ & $\begin{array}{l}2011 \\
(\%)\end{array}$ \\
\hline Central/Kabul & 72 & 80 & 80 \\
\hline East & 85 & 77 & 80 \\
\hline South East & 76 & 70 & 72 \\
\hline South West & 62 & 70 & 70 \\
\hline West & 76 & 77 & 82 \\
\hline North East & 78 & 78 & 84 \\
\hline Central/Hazarajat & 69 & 74 & 83 \\
\hline North West & 81 & 87 & 88 \\
\hline
\end{tabular}

The survey also asked about the performance of municipal and district authorities. People living in urban areas (21\% of all respondents) were only asked the question pertaining to municipal authorities. About two thirds $(64 \%)$ of urban respondents say that the municipal authority in their local area is doing a good job, including $20 \%$ who say it is doing a very good job. Over a quarter $(27 \%)$ of respondents give a negative assessment of the performance of the municipality in their locality, including $7 \%$ who say that it is doing a very bad job.

The most positive assessments of the performance of municipal authorities are in the Central/Kabul (70\%), South West (69\%) and South East (66\%) regions. In the East, the majority of respondents say the municipal government is doing quite a good job (51\%) but very few people say it is doing a very good job (2\%). On the other hand, the highest levels of dissatisfaction are also recorded in the East $(36 \%)$, along with the North West (36\%) and South East (34\%) and South West (31\%).

It is worth noting that the proportion of respondents who are unable or unwilling to answer this question is very high in the Central/Hazarajat (43\%), and significant in the North East (29\%), North West (17\%) and West $(13 \%)$ regions. 
[URBAN RESIDENTS ONLY] Turning to elements of the mMunicipal authorities, do you think that overall it is doing a very good job, somewhat good job, somewhat bad job or a very bad job? (45b, Base - 1365) BY REGION

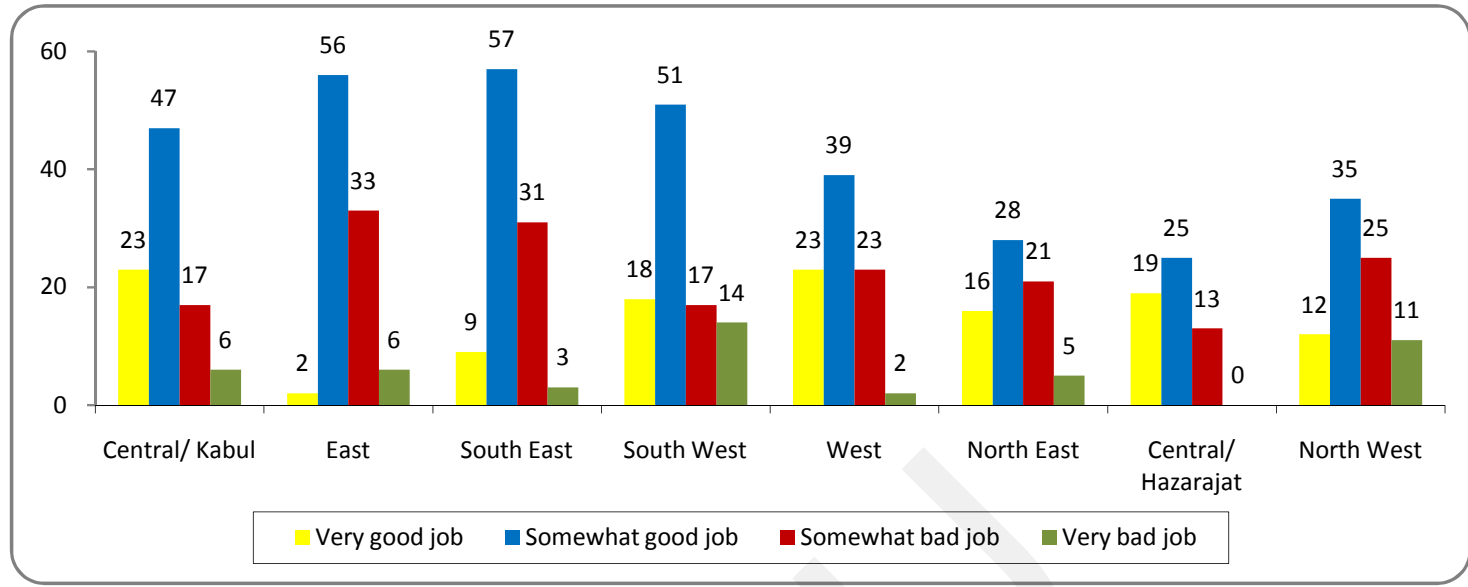

Fig 7.4

At the national level, the overall level of satisfaction with the performance of municipal authorities has significantly increased in 2011 (63\%) compared to 2010 (53\%). However, satisfaction with municipal authorities has fluctuated significantly in recent years in different regions. Satisfaction with municipal authorities rose since 2010 in the South West (from 44\% in 2010 to 66\% in 2011), Central/Kabul (from 59\% in 2010 to $71 \%$ in 2011), and to a lesser extent in the North East (from 42\% in 2010 to 44\% in 2011), but fell in all other regions, with the largest drops in the East (from 83\% in 2010 to 58\% in 2011) ${ }^{1}$, North West (from 68\% in 2010 and $47 \%$ in 2011), and South East (from $78 \%$ in 2010 to $66 \%$ in 2011).

Table 7.9: [URBAN RESIDENTS ONLY] Turning to elements of the Municipal authorities, do you think that overall it is doing a very good job, somewhat good job, somewhat bad job or a very bad job? Sum of very and somewhat good job (45b) COMPARISON OF 2007, 2008, 2009, 2010 AND 2011 ALL AND BY REGION

\begin{tabular}{|c|c|c|c|c|c|}
\hline \multirow[b]{2}{*}{ Q- 45b } & \multicolumn{5}{|c|}{ Very Good or somewhat good job } \\
\hline & $\begin{array}{l}2007 \\
(\%)\end{array}$ & $\begin{array}{c}2008 \\
(\%)\end{array}$ & $\begin{array}{l}2009 \\
(\%)\end{array}$ & $\begin{array}{l}2010 \\
(\%)\end{array}$ & $\begin{array}{l}2011 \\
(\%)\end{array}$ \\
\hline All & 57 & 50 & 58 & 53 & 63 \\
\hline Central/ Kabul & 64 & 50 & 50 & 59 & 71 \\
\hline East & 59 & 50 & 71 & 78 & 66 \\
\hline South East & 48 & 60 & 71 & 78 & 66 \\
\hline South West & 58 & 58 & 55 & 44 & 69 \\
\hline West & 53 & 31 & 56 & 66 & 62 \\
\hline North East & 67 & 44 & 62 & 42 & 44 \\
\hline Central/Hazarajat & 28 & - & 56 & 6 & 44 \\
\hline North West & 67 & 63 & 88 & 68 & 47 \\
\hline
\end{tabular}

\footnotetext{
1 The figure for the central Hazarajat in 2010 was statistically insignificant due to the small sample size of urban residents in this region.
} 
The survey asked a similar question about the performance of local authorities to people living in rural areas (79\% of all respondents). Sixty-seven percent of respondents rate the performance of their local authorities positively, which is a little higher than for municipal authorities in urban areas (63\%). However, $28 \%$ of respondents say the local authority in their locality is doing a bad job.

The largest proportions of respondents who say that their local authority is doing a good job are in the North West (74\%), North East (74\%) and East (73\%). The highest levels of dissatisfaction, where more than a third of respondents say that their local authorities are doing a bad job, are recorded in the South East (39\%) and South West (35\%), Central/Hazarajat (32\%) and Central/Kabul (29\%) regions.

[RURAL RESIDENTS ONLY] Turning to elements of the local authorities, do you think that overall it is doing a very good job, somewhat good job, somewhat bad job or a very bad job? (Q 45c, Base-4983) BY REGION

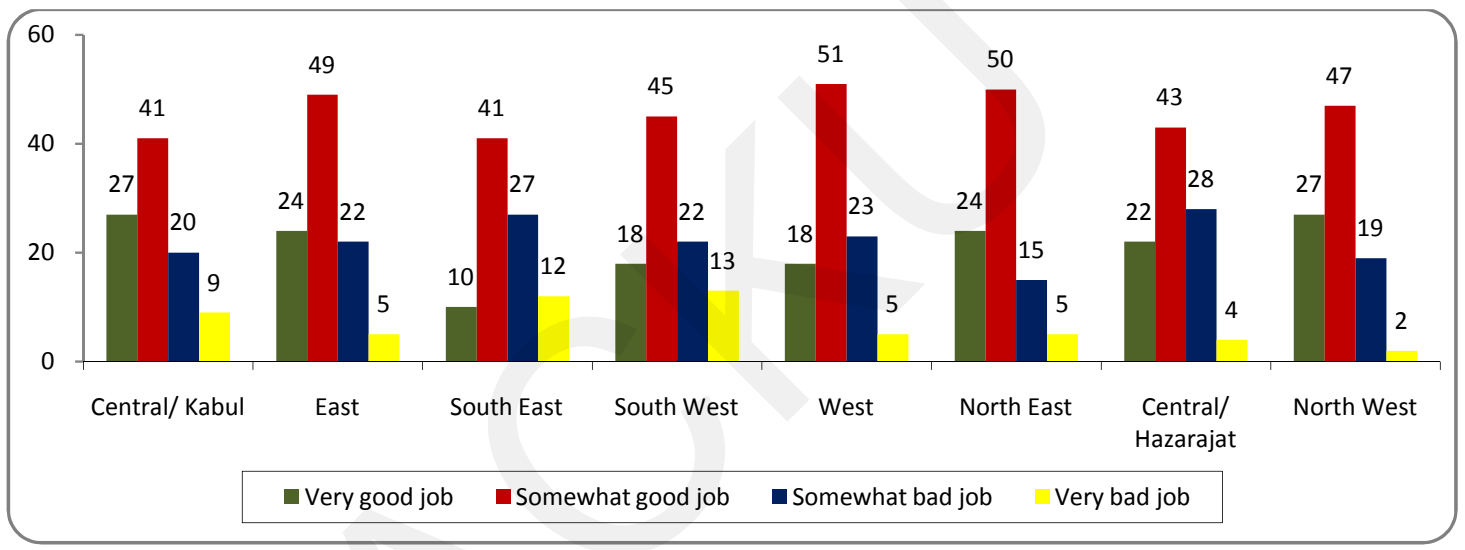

Fig 7.5

Positive assessments of the performance of local authorities increased in all regions in 2011 compared to 2010 with the exception of the Central/Hazarajat, where satisfaction declined from $71 \%$ in 2010 to $65 \%$ in 2011) and the North West (from 76\% in 2010 to 74\% in 2011). The most significant rises are in the South West (from 44\% in 2010 to $62 \%$ in 2011) and South East (from 45\% in 2010 to $52 \%$ in 2011). 
Table 7.10: [RURAL RESIDENTS ONLY] Turning to elements of the local authorities, do you think that overall it is doing a very good job, somewhat good job, somewhat bad job or a very bad job? Sum of very good and somewhat good job - $(Q-$ 45c) COMPARISON OF 2008, 2009, 2010 AND 2011 ALL AND BY REGION

\begin{tabular}{|l|c|c|c|c|}
\hline & \multicolumn{5}{c|}{ Very good or somewhat good job } \\
\cline { 2 - 6 } & $\begin{array}{c}\mathbf{2 0 0 8} \\
\mathbf{( \% )}\end{array}$ & $\begin{array}{c}\mathbf{2 0 0 9} \\
\mathbf{( \% )}\end{array}$ & $\begin{array}{c}\mathbf{2 0 1 0} \\
\mathbf{( \% )}\end{array}$ & $\begin{array}{c}\mathbf{2 0 1 1} \\
\mathbf{( \% )}\end{array}$ \\
\hline All & 61 & 69 & 67 & 63 \\
\hline Central/Kabul & 76 & 73 & 62 & 68 \\
\hline East & 54 & 77 & 65 & 73 \\
\hline South East & 76 & 60 & 45 & 52 \\
\hline South West & 59 & 50 & 44 & 62 \\
\hline West & 81 & 67 & 59 & 69 \\
\hline North East & 53 & 76 & 68 & 74 \\
\hline Central/Hazarajat & 85 & 58 & 71 & 65 \\
\hline North West & 64 & 81 & 76 & 74 \\
\hline
\end{tabular}

On the whole, public perceptions of the performance of different levels of government reveal that people are most positive about the performance of their provincial government, followed by the national government and rural district authorities. They are least satisfied with the performance of municipalities, though here too the assessments for 2011 (63\%) have registered a positive increase compared to 2007 (57\%). This mirrors the levels of public confidence recorded for these different institutions, which are highest for provincial councils $(67 \%)$ followed by national government institutions such as parliament $(62 \%)$ and the public administration $(62 \%)$ and lowest for municipal authorities (55\%). This correlation reinforces the clear link between performance and public trust in government institutions (see above, 7.1 Confidence in public institutions).

Table 7.11: Proportions of respondents who say the national government, provincial government, municipality and local authorities are doing a good job (combination of very good job and somewhat good job) (Q-43 and 45 a,berc) COMPARISON BETWEEN 2007, 2008, 2009, 2010 AND 2011

\begin{tabular}{|l|c|c|c|c|c|}
\hline \multirow{2}{*}{ National government } & $\begin{array}{c}\mathbf{2 0 0 7} \\
\mathbf{( \% )}\end{array}$ & $\begin{array}{c}\mathbf{2 0 0 8} \\
\mathbf{( \% )}\end{array}$ & $\begin{array}{c}\mathbf{2 0 0 9} \\
\mathbf{( \% )}\end{array}$ & $\begin{array}{c}\mathbf{2 0 1 0} \\
\mathbf{( \% )}\end{array}$ & $\begin{array}{c}\mathbf{2 0 1 1} \\
\mathbf{( \% )}\end{array}$ \\
\hline Provincial government & 80 & 67 & 71 & 73 & 73 \\
\hline Municipal authority & 80 & 74 & 75 & 78 & 80 \\
\hline Local authority & 57 & 50 & 58 & 54 & 63 \\
\hline
\end{tabular}




\subsection{Role of elected representative bodies}

The survey sought to examine people's perceptions of elected representative bodies including parliament and members of parliament (MPs) at the national level, provincial councils (PC) at the provincial level and community development councils (CDC) that operate at villages and community level in rural areas.

To assess perceptions of the responsiveness of national level representatives to the needs of the people, respondents were asked whether they agree or disagree with the statement: "The parliament is addressing the major problems of people in our country." Overall, more than two thirds of respondents $(70 \%)$ agree with this statement, including $28 \%$ who strongly agree. However, just under a third of respondents $(28 \%)$ disagree, including about one in 10 (9\%) who disagrees strongly. These findings are broadly similar to those recorded in $2009^{2}$.

Do you agree or disagree with the statement: "The parliament is addressing the major problems of people in our country"? (Q-50a, Base 6348)

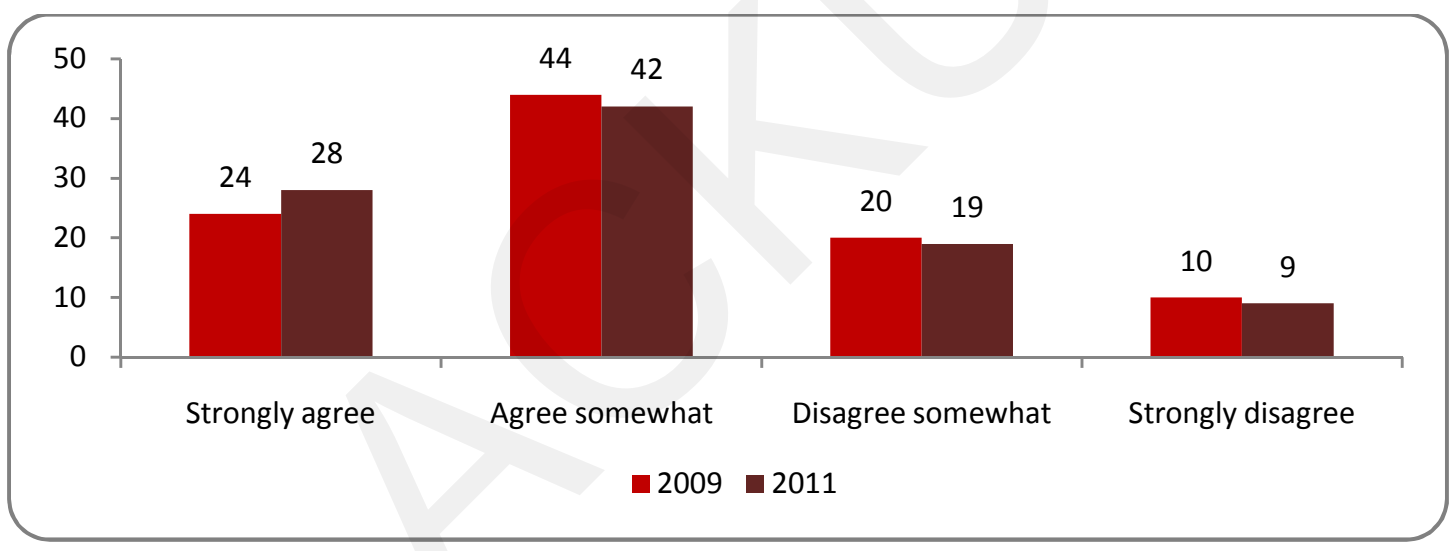

Fig. 7.6

More rural $(72 \%)$ than urban $(63 \%)$ respondents say the parliament is addressing the major problems of the country. Levels of agreement are particularly high in the Central/Hazarajat (87\%), East (78\%), North West $(75 \%)$ and North East (71\%), while disagreement is highest in the South West (34\%), Central/Kabul (32\%), South East (32\%) and West (30\%) regions.

2 This question was not asked in 2010 survey. 
Table 7.12: Do you agree or disagree with the statement: "The parliament is addressing the major problems of people in our country"? (Q-50a, Base 6348) BY REGION

\begin{tabular}{|l|c|c|c|c|}
\hline Central/Kabul & $\begin{array}{c}\text { Strongly } \\
\text { agree }\end{array}$ & $\begin{array}{c}\text { Agree } \\
\text { somewhat }\end{array}$ & $\begin{array}{c}\text { Disagree } \\
\text { somewhat }\end{array}$ & $\begin{array}{c}\text { Strongly } \\
\text { disagree }\end{array}$ \\
\hline East & 25 & 41 & 18 & 14 \\
\hline South East & 31 & 47 & 18 & 4 \\
\hline South West & 25 & 41 & 22 & 10 \\
\hline West & 29 & 36 & 24 & 10 \\
\hline North East & 21 & 47 & 22 & 8 \\
\hline Central/Hazarajat & 31 & 40 & 21 & 7 \\
\hline North West & 44 & 43 & 6 & 5 \\
\hline
\end{tabular}

The majority of respondents (59\%) also agree with the statement: "My MP is addressing the major problems of my constituency in the parliament," including about one in five (19\%) who strongly agrees. However, more than a third of respondents (39\%) disagree with this statement.

Do you agree or disagree with the statement: "My MP is addressing the major problems of my constituency in the parliament"? (Q-50b, Base 6348)

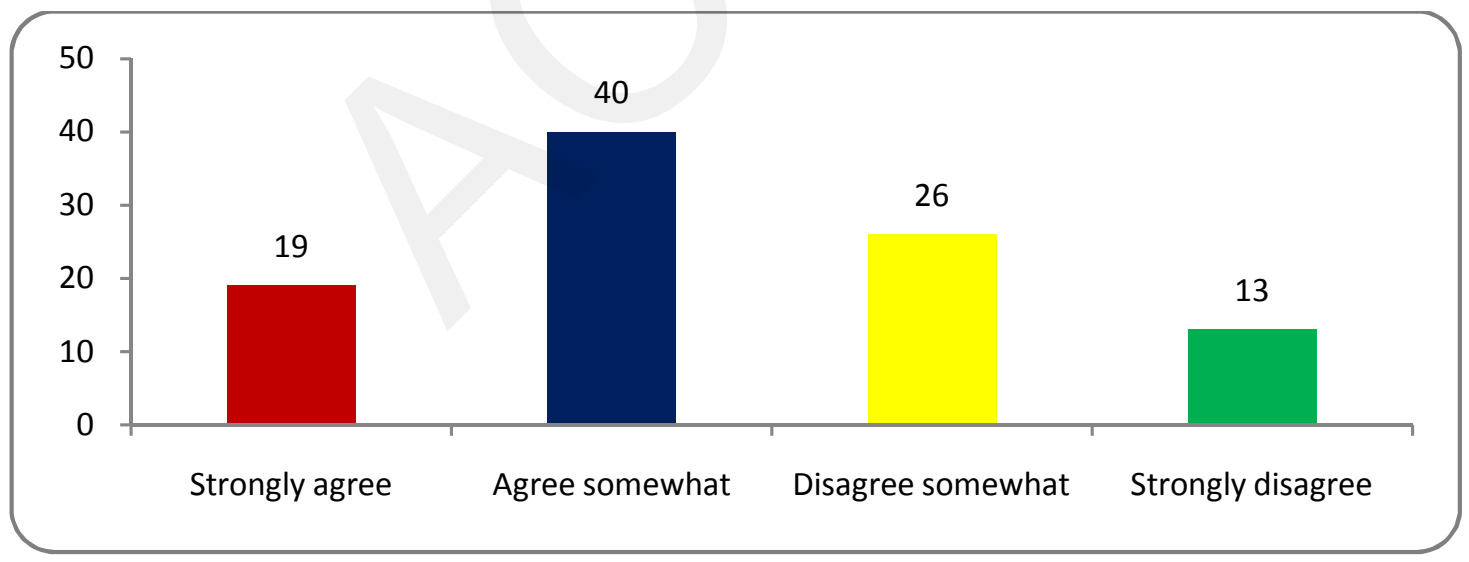

Fig. 7.7 
More rural respondents $(62 \%)$ say their MP is addressing the major problems of their constituency in the parliament than their urban counterparts $(51 \%)$.

Again, the highest levels of agreement with this statement are in the East (71\%), Central/Hazarajat (67\%) and the North West (65\%), which are also the regions that report the highest levels of satisfaction with the responsiveness of parliament to the needs of the country as a whole. On the other hand, nearly half of respondents in the Central/Kabul (47\%) region and significant proportions in the South East (41\%), West (41\%), North East (38\%) and South West (37\%) disagree with this statement.

Do you agree or disagree with the statement: "My MP is addressing the major problems of my constituency in the parliament"? (Q-50b, Base 6348) BY REGION

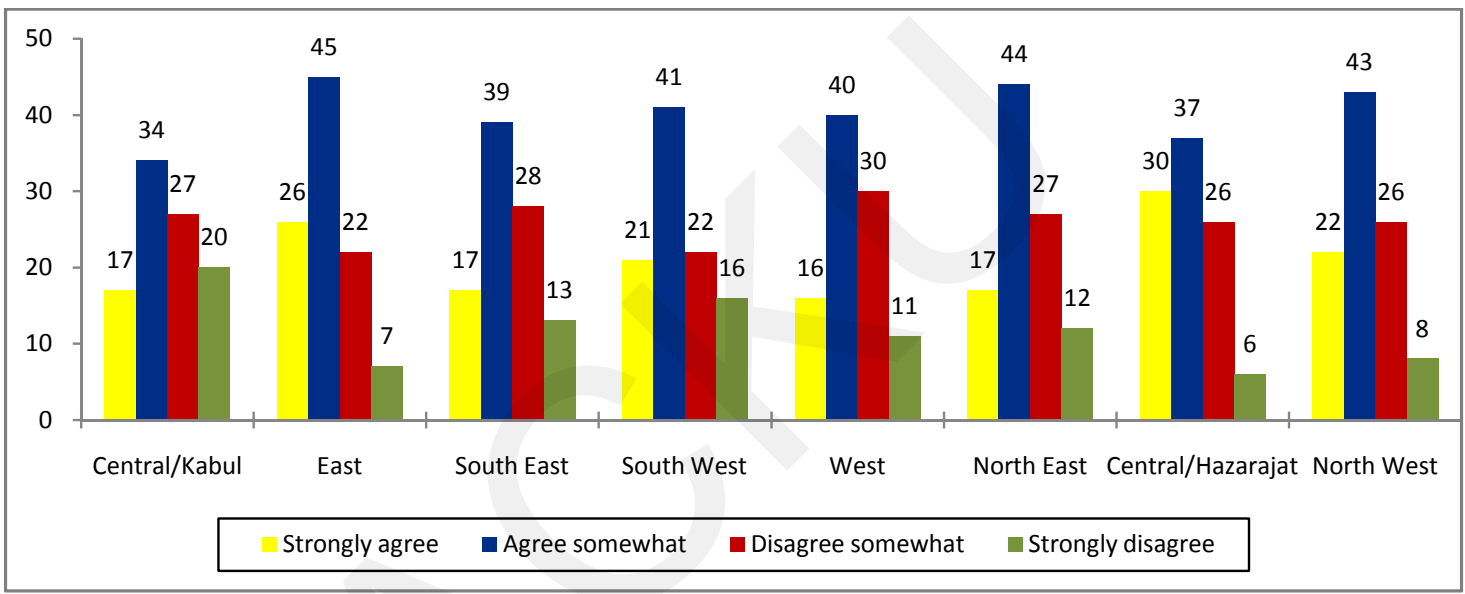

Fig. 7.8

Overall, levels of satisfaction with the performance of MPs in addressing the major problems of their constituencies in the parliament have fallen steadily since 2006, suggesting increasing disenchantment with the ability of MPs to address local problems through the parliamentary system. However, there has been very little change since 2009. 
Do you agree or disagree with the statement, "My MP is addressing the major problems of my constituency in the parliament"? (Q-50b) COMPARISON BETWEEN 2006, 2007, 2008, 2009 AND 2011

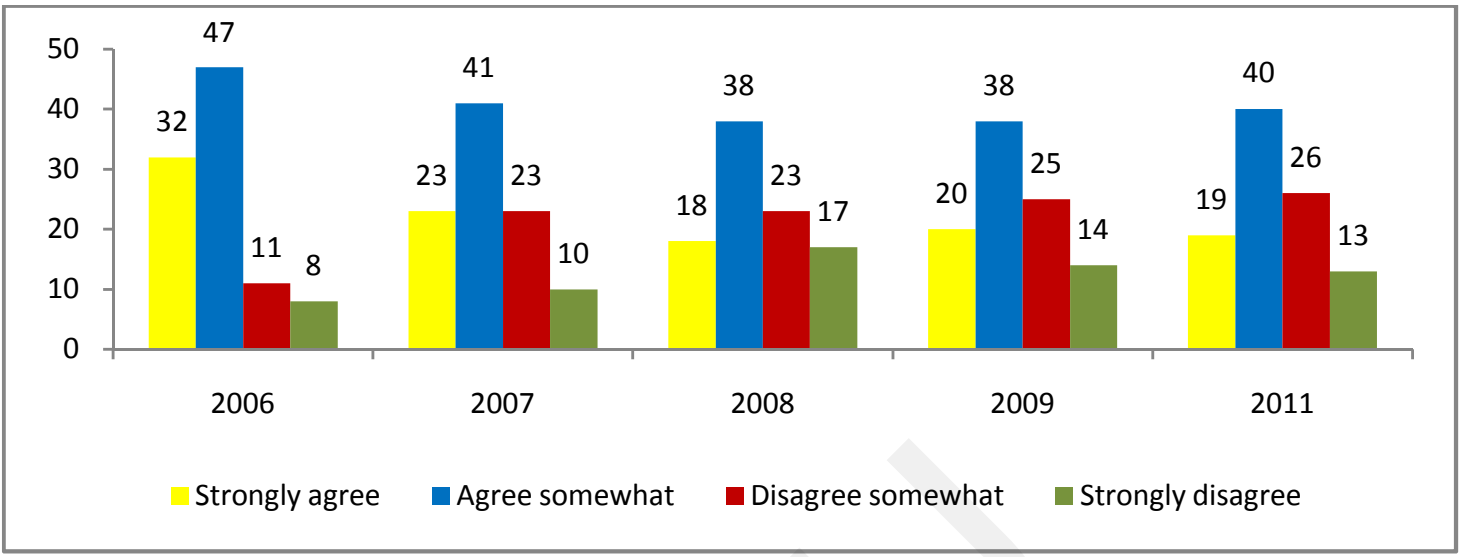

Fig. 7.9

The majority of respondents (59\%) agree with the statement: "My provincial council member is addressing the major problems of my community," including more than one in five $(22 \%)$ who strongly agrees. However, $40 \%$ disagree with this statement.

Do you agree or disagree with the statement "My provincial council member is addressing the major problems of my community"? (Q-50c, Base-6348)

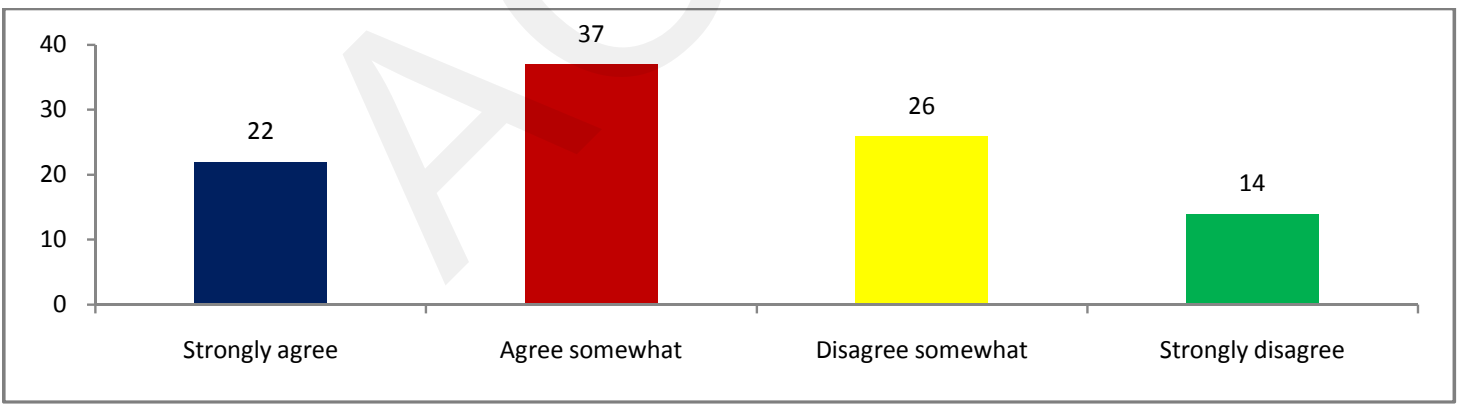

Fig. 7.10

The highest levels of agreement are in the Central/Hazarajat (72\%), North West (67\%) and East (65\%), which are also the regions that report the highest levels of satisfaction with the responsiveness of parliament and of MPs at national level. However, nearly half of respondents in the Central/Kabul (48\%) and South East (47\%) regions, and significant proportions in the West (39\%), North East (40\%) and South West (37\%) disagree with this statement. 
Do you agree or disagree with the statement, "My provincial council member is addressing the major problems of my community"? (Q-50c, Base-6348) BY REGION

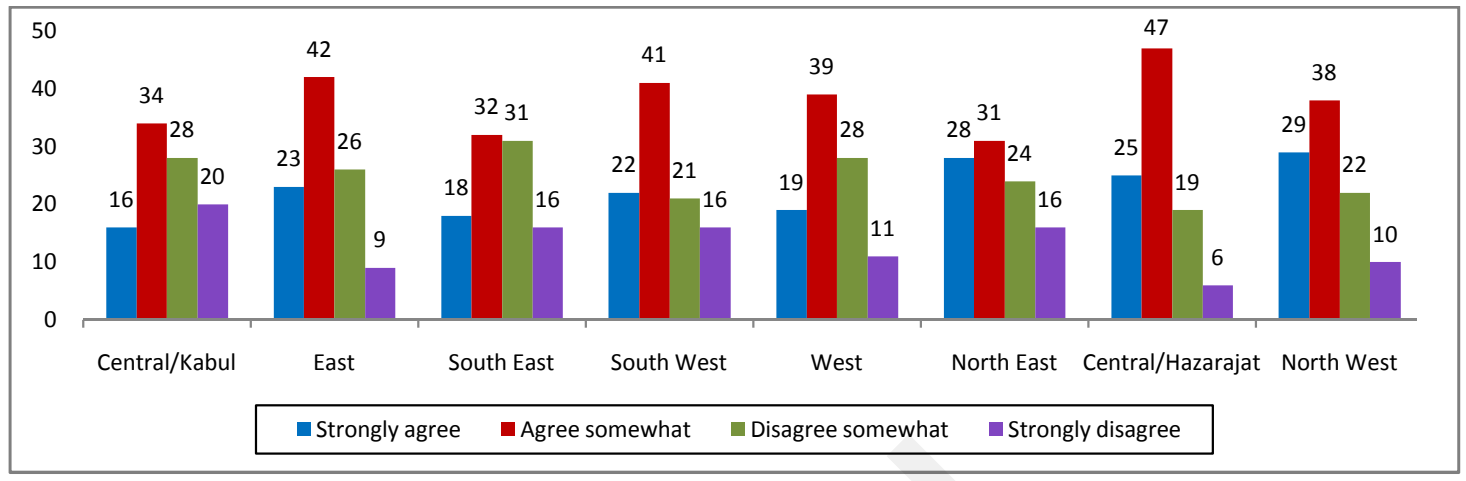

Fig. 7.11

\subsection{Contacts with members of parliament (MPs)}

The survey sought to examine in greater detail, people's perceptions of the responsiveness of members of parliament in addressing problems in their constituencies by looking at their involvement in resolving local problems experienced by individuals and communities. Respondents were asked: "Have you ever contacted your MP for help in solving any of your personal or local problems?" Only around one in five respondents (20\%) reports ever having contacted their MP for help of this kind. Men (24\%) are more likely than women (15\%) to have contacted their MP for help in solving any of their personal or local problems. Respondents living in villages (23\%) are twice as likely to have done so as those living in urban areas (11\%). Contact with MPs for this purpose is most frequently reported by respondents in the South East (28\%) and East (28\%) of the country.

Have you ever contacted your MP for help in solving any of your personal or local problems? (Q-46, Base 6348)

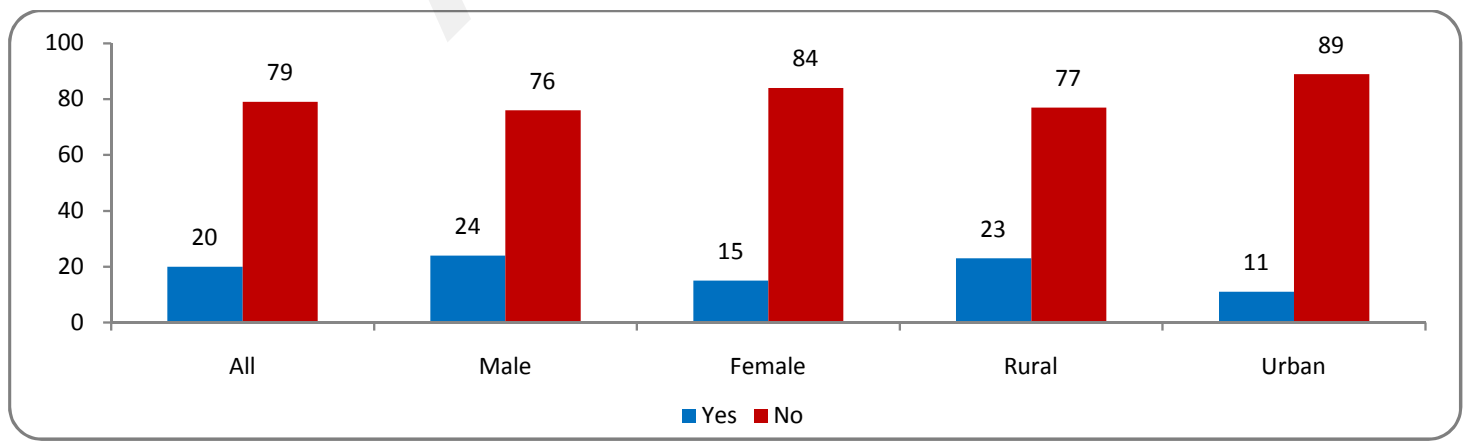

Fig. 7.12 
Around twice as many respondents report contacting their MP for help in solving problems in $2011(20 \%)$ than in previous years: 2006 (11\%), 2007 (8\%), 2008 (9\%) and $2009(12 \%)$.

Table 7.13: Have you ever contacted your MP for help in solving any of your personal or local problems? (Q-46) COMPARISON BETWEEN 2006, 2007, 2008, 2009 AND 2011

\begin{tabular}{|l|c|c|c|c|c|} 
& 2006 & $\mathbf{2 0 0 7}$ & $\mathbf{2 0 0 8}$ & $\mathbf{2 0 0 9}$ & $\begin{array}{c}\mathbf{2 0 1 1} \\
\mathbf{( \% )}\end{array}$ \\
\hline Yes & 11 & 8 & 9 & 12 & 20 \\
\hline No, did not contact & 87 & 89 & 88 & 85 & 79 \\
\hline
\end{tabular}

Those respondents who had contacted their MP for help in solving local problems ( $20 \%$ of all respondents) were then asked whether their MPs tried to help to resolve the problem. Two thirds of respondents $(68 \%)$ say the MP tried to help, while 31\% say they did not. This finding seems consistent with the proportion of respondents who agree that their MP is addressing the major problems of their constituency in the parliament $(59 \%)$ (see above, 7.6 Role of elected representatives). More rural (69\%) than urban (54\%) respondents say their MP tried to help resolve the problem.

Did the member of parliament try to help to resolve the problem? (Filtered, asked if answered Yes in Q - 46) (Q-47, Base 1262)

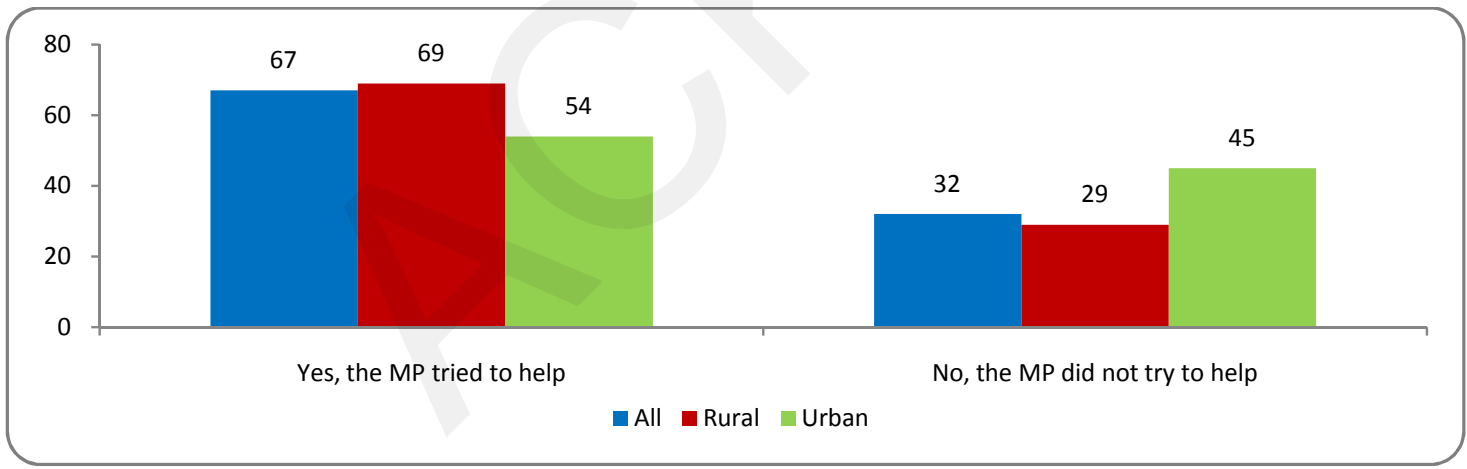

Fig 7.13

The highest proportions of respondents who say their MP tried to help resolve the problem are in the North West (82\%), Central/Hazarajat (82\%), East (73\%), South West $(70 \%)$ and West $(68 \%)$ regions. On the other hand, nearly half of respondents in the North East (46\%) and $40 \%$ in the East say their MPs did not try to help resolve the problem. 
Did the member of parliament try to help to resolve the problem? (Filtered, asked if answered Yes in Q - 46) (Q47, Base 1262)

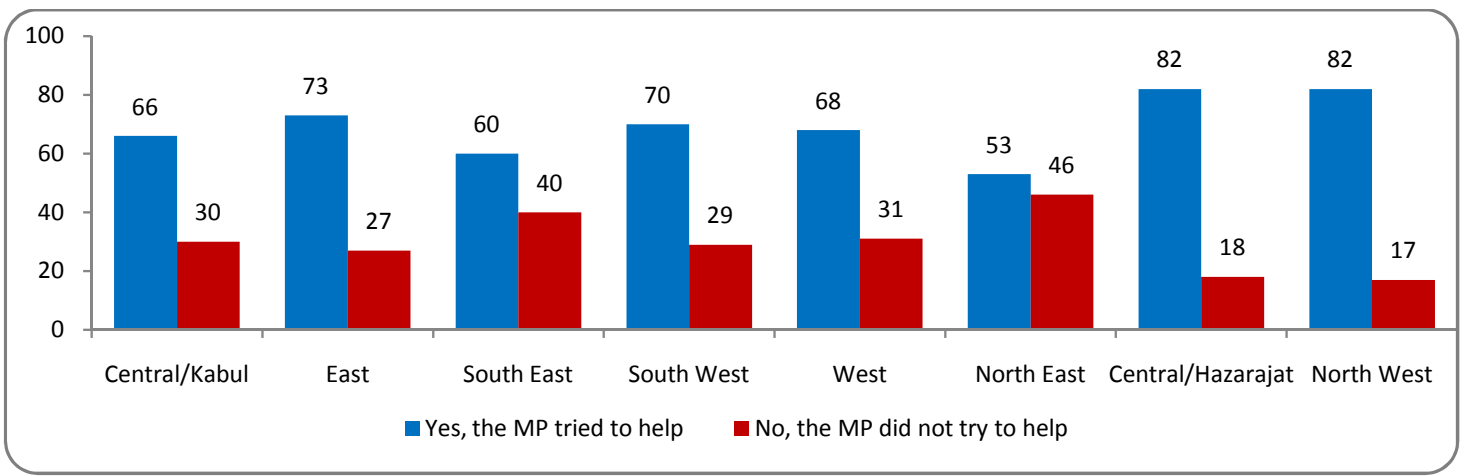

Fig. 7.14

\subsection{Contacts with provincial council representatives}

Respondents were asked the same question about contacting a representative of the provincial council for help in solving personal or local problems. Again, three quarters of respondents $(75 \%)$ have not done this, however about a quarter $(24 \%)$ say they have contacted a PC representative for assistance. This figure has almost doubled in 2011 (24\%) compared to 2006 (12\%), 2007 (11\%), $2008(11 \%)$ and $2009(15 \%)^{3}$.

Table 7.14: Now let's talk about the provincial councils. Have you ever contacted a representative on the provincial council for help in solving any of your personal or local problems? (Q-48) COMPARISON BETWEEN 2006, 2007, 2008, 2009 AND 2011

\begin{tabular}{|l|c|c|c|c|c|}
\hline \multirow{2}{*}{ Yes } & $\begin{array}{c}2006 \\
\mathbf{( \% )}\end{array}$ & $\begin{array}{c}2007 \\
\mathbf{( \% )}\end{array}$ & $\begin{array}{c}2008 \\
\mathbf{( \% )}\end{array}$ & $\begin{array}{c}2009 \\
(\mathbf{\%})\end{array}$ & $\begin{array}{c}2011 \\
\mathbf{( \% )}\end{array}$ \\
\hline No, did not contact & 12 & 11 & 11 & 15 & 24 \\
\hline
\end{tabular}

Male respondents $(28 \%)$ are more likely to have contacted a member of the PC than are female respondents $(18 \%)$. Again, respondents living in rural areas $(27 \%)$ are more than twice as likely to have contacted a PC member as those living in urban areas (11\%). 
Now let's talk about the provincial councils. Have you ever contacted a representative on the Provincial Council for help in solving any of your personal or local problems? (Q-48, Base 6348) ALL AND BY GENDER AND SETTLEMENT

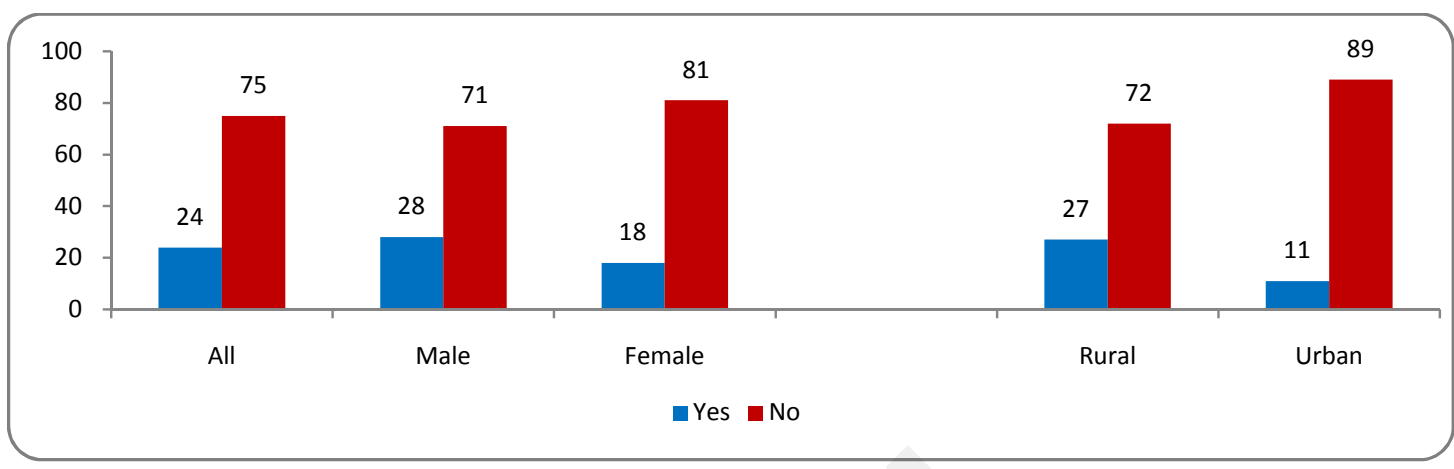

Fig. 7.15

Respondents were further asked whether, when asked for assistance, the PC representative tried to help resolve the problem. More than two thirds of respondents (69\%) say their PC representative tried to help, which is a similar proportion to those who said the same about their MP (67\%). About one third (31\%) said the PC representative did not try to assist.

Did the provincial council try to help to resolve the problem? (Filtered, asked if answered Yes in Q - 48) (Q-49, Base 1499)

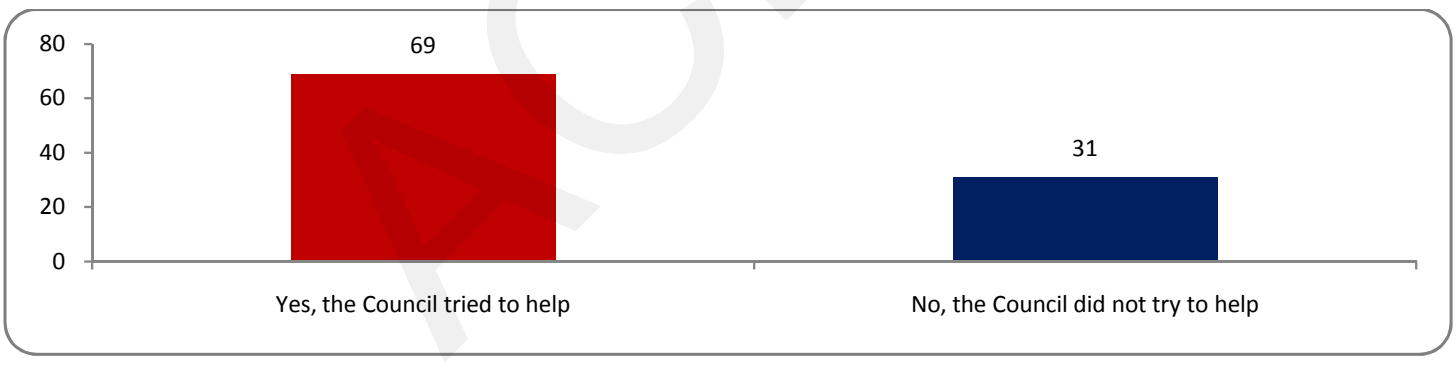

Fig. 7.16

Perceptions of the responsiveness of PC members vary across the regions. The highest proportion of respondents who say their PC member tried to help resolve the problem are in the West $(80 \%)$, North West (77\%), Central/Kabul (74\%) and South West (70\%) regions. 
Did the provincial council try to help to resolve the problem? (Filtered, asked if answered Yes in Q - 48) (Q-49, Base 1499) BY REGION

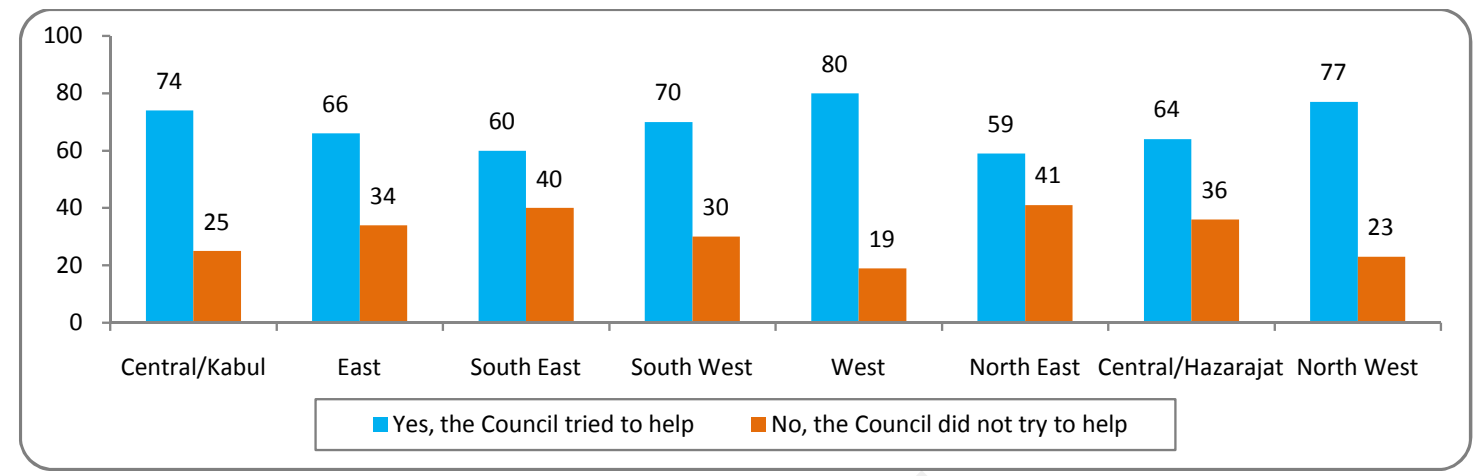

Fig. 7.17

\subsection{Role of community development councils}

Community development councils (CDCs) were established as part of the National Solidarity Program as elected community development governance bodies in rural areas. CDCs currently cover 27,907 rural communities, accounting for 72 percent of villages ${ }^{4}$ across Afghanistan, with plans to achieve full national coverage over time. The role of CDCs is defined in a Ministry of Rural Rehabilitation and Development ratified bylaw that states they will "provide the social and development foundation at community level and be responsible for implementation and supervision of development projects and liaison between the communities and government and non-government organizations." Current government policy indicates that CDCs are likely to play the role of village councils provided for in the Afghan Constitution until appropriate legislation is passed and elections are held to formally constitute such bodies.

The survey attempted to measure public awareness and views about CDCs. Respondents received a brief explanation about CDCs and were then asked whether they were aware of such institutions in their neighborhood. Half of respondents (50\%) say they are aware of a CDC in their area, while just under half (48\%) say they are not. Awareness of CDCs is significantly higher among men (55\%) than amongst women (43\%). As CDCs operate more in rural areas, it does not come as a surprise that awareness of them is more than twice as high amongst rural respondents (56\%) as amongst urban dwellers $(27 \%)$.

The level of public awareness of CDCs varies across regions. About two thirds of respondents say they are aware of a CDC in their local area in the North East (65\%) and North West $(62 \%)$. However, this is true for only around a third of respondents in Central/Kabul (32\%) region.

\footnotetext{
4 Source: National Solidarity Program, Afghanistan website [Accessed 23August 2011] www.nspafghanistan.af
} 
Are you aware of an institution called a community development council formed in your neighborhood/settlement? (Q-51, Base 6348) BY REGION

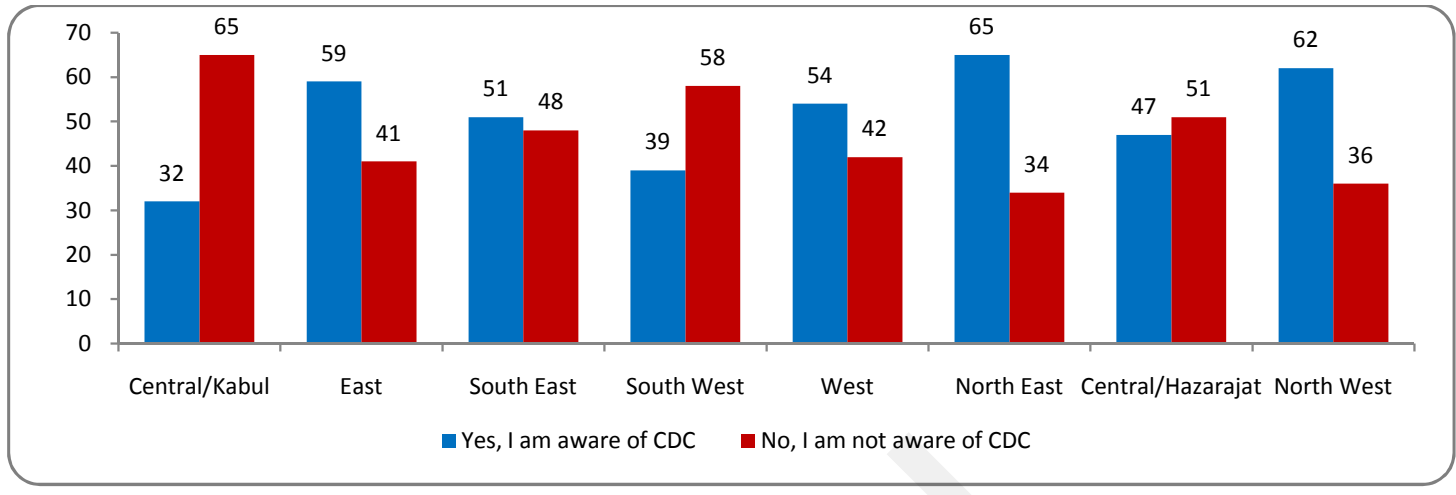

Fig 7.18

Moreover, across the country as a whole, awareness of CDCs has been steadily rising in recent years. Although only around a third of respondents said they were aware of CDCs in $2006(37 \%)$ and 2007 (32\%), 50\% say they are aware of CDCs in 2011.

Are you aware of an institution called a community development council formed in your neighborhood/ settlement? (Q-91) COMPARISON BETWEEN 2006, 2007, 2008, 2009 AND 2011

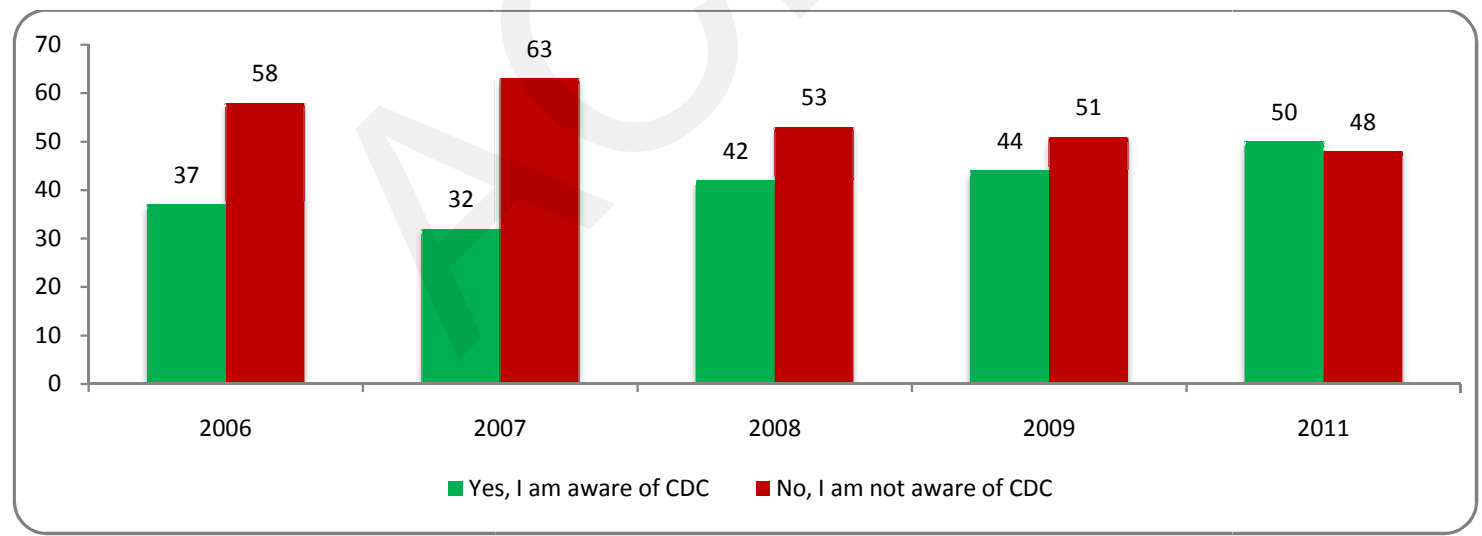

Fig. 7.19

Respondents who are aware of a CDC in their neighborhood (50\% of all respondents) were also asked to indicate which social groups are members of the CDC. A list of groups was read out and respondents were asked to say whether these groups are represented on the CDC in their area. Traditional local leaders are most often mentioned as members of CDCs. Around four fifths of respondents say that elders of the local shura/ jirga $(84 \%)$ or a local malik/khan (71\%) are members of their local CDC. Many respondents mention other 
influential members of the community such as mullahs (58\%) and local teachers (47\%). Less than a third of respondents say local commanders $(28 \%)$ are members of the CDC. However, a significant proportion of respondents also indicate that their local CDC includes representation of less powerful social groups such as farmers (45\%), shopkeepers (39\%) and landless agricultural workers (37\%). Under a quarter $(23 \%)$ of respondents say that women are represented on their local CDC. Twenty-three percent mention public officials from the municipality or district administration amongst the members of their local CDC. These findings are broadly similar to those in 2007, 2008 and 2009.

Table 7.15: Percentage of the people who think that there is a representation of various groups in the council (Q-52a-k, Base-3172)

\section{Group}

Elders of the local shura/jirga

Local malik/khan

Mullah

Local teacher

Farmers

Shopkeepers

Landless agricultural workers

Local commanders

Women

Officials from municipal/district administration

Doctor

\begin{tabular}{|c|c|}
\hline \multicolumn{2}{|c|}{$\begin{array}{c}\text { Representation } \\
(\%)\end{array}$} \\
\hline $\mathbf{2 0 1 0}$ & $\mathbf{2 0 1 1}$ \\
\hline 77 & 84 \\
\hline 71 & 71 \\
\hline 56 & 58 \\
\hline 48 & 47 \\
\hline 45 & 45 \\
\hline 40 & 39 \\
\hline 36 & 37 \\
\hline 32 & 28 \\
\hline 27 & 23 \\
\hline 23 & 23 \\
\hline 19 & 21 \\
\hline
\end{tabular}

These same respondents were also asked about their level of satisfaction with the job their local CDC is doing. Overall, four out of five of respondents $(81 \%)$ say they are satisfied with the performance of their local CDC, including $29 \%$ who are very satisfied. Only around one in six (14\%) of respondents expressed some level of dissatisfaction. The level of satisfaction increased slightly in 2011 compared to 2009.

How satisfied are you with the job this community development council is doing? (Q-53, Base- 3172)

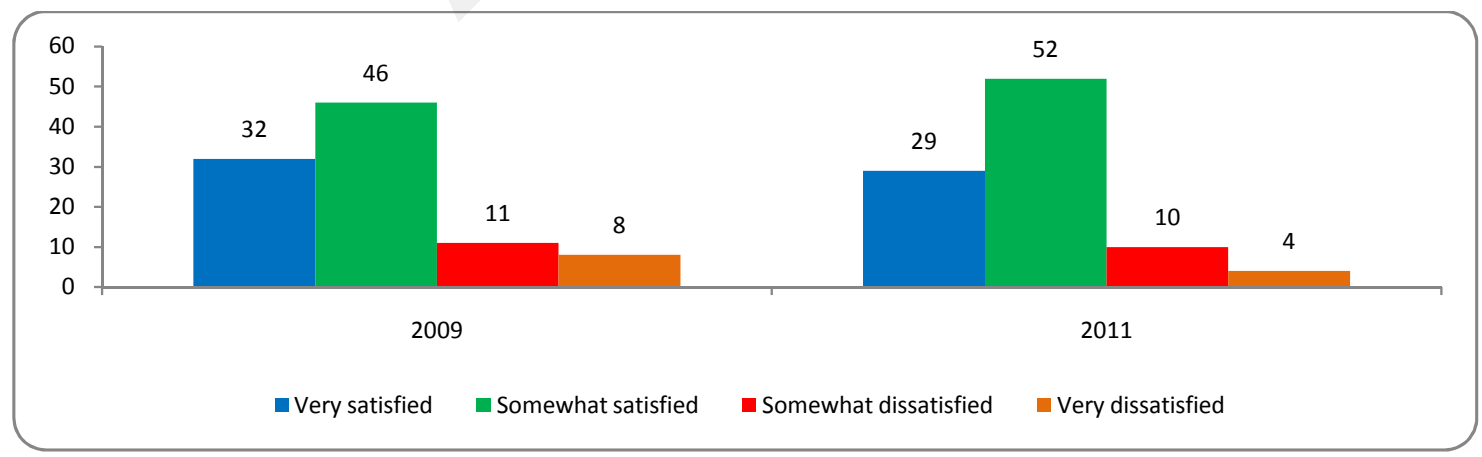

Fig 7.20 


\section{Corruption}

\subsection{Corruption - major or minor problem}

Given the fact that respondents consistently identify corruption as one of the biggest problems facing Afghanistan (see Chapter 2, 2.4 Afghanistan's biggest problems: National leve) and that the level of corruption in public institutions is an important measure of government performance, the survey endeavored to measure public perceptions of the prevalence of corruption in various facets of life and at different levels of government in Afghanistan. Respondents were asked whether they think corruption is a major problem, a minor problem or no problem at all in their daily life, their neighborhood, their local authorities, their provincial government and in Afghanistan as a whole.

The survey shows that the majority of Afghans think that corruption is a major problem in all facets of life and at all levels of government. In addition, as in previous years, the perception of the prevalence of corruption rises with the level of the institution. Just under half of respondents say corruption is a major problem in their neighborhood (47\%), while a little more than half say the same about corruption in their daily life $(56 \%)$ and in their local authorities $(56 \%)$. Around two thirds say that corruption is a major problem in their provincial government (64\%), whereas around three quarters think that corruption is a major problem in Afghanistan as a whole (76\%). However, less than one in seven say that corruption is not a problem at all in their neighborhood $(14 \%)$ or in their daily life $(12 \%)$. One in 10 say there is no problem with corruption in their local authority $(10 \%)$ and around one in 20 say corruption is not a problem in their provincial government $(7 \%)$ or in Afghanistan as a whole (5\%).

Table 8.1: Please tell me whether you think that corruption is a major problem, a minor problem or no problem at all in the following area (Q-26a-e, Base 6348)

\begin{tabular}{|c|c|c|c|}
\hline & $\begin{array}{c}\text { Major } \\
\text { Problem } \\
\quad(\%)\end{array}$ & $\begin{array}{c}\text { Minor } \\
\text { Problem } \\
(\%)\end{array}$ & $\begin{array}{c}\text { Not a } \\
\text { Problem } \\
(\%)\end{array}$ \\
\hline a) In your daily life & 56 & 31 & 12 \\
\hline b) In your neighborhood & 47 & 38 & 14 \\
\hline c) In your local authorities & 56 & 33 & 10 \\
\hline d) In your provincial government & 64 & 27 & 7 \\
\hline e) In Afghanistan as a whole & 76 & 18 & 5 \\
\hline
\end{tabular}

There is some variation in the perception of corruption across regions. The proportion of respondents, who say that corruption is a major problem in Afghanistan as a whole, is highest in the Central/Kabul (84\%) and South East (79\%) regions. The Central/Kabul region also records the highest proportion of respondents who say that corruption is a major problem at provincial government $(74 \%)$ and local authority $(65 \%)$ levels. The 
perception of corruption as a major problem in daily life is highest in the East (74\%) followed by Central/ Kabul (64\%). Perceptions of corruption as a major problem at the local level are lowest in the West, where less than half of respondents say this is true in their local authorities (44\%) and in daily life (41\%) and just over a third say corruption is a major problem in their neighborhood $(35 \%)$. Perceptions of corruption as a major problem in provincial government are lowest in Central/Hazarajat (51\%), South West (56\%) and West $(58 \%)$. The proportion of respondents who say that corruption is a problem in Afghanistan as a whole is also lowest in Central/Hazarajat (59\%) and South West (58\%)

Table 8.2: Please tell me whether you think that corruption is a major problem, a minor problem or no problem at all in the following area (Q-26a-e, Base 6348) ALL AND BY REGION. Major Problem responses

\begin{tabular}{|l|c|c|c|c|c|c|c|c|c|}
\hline $\begin{array}{c}\text { Corruption is a } \\
\text { Major Problem: } \\
\text { Level }\end{array}$ & $\begin{array}{c}\text { Total } \\
\mathbf{( \% )}\end{array}$ & $\begin{array}{c}\text { Central/ } \\
\text { Kabul } \\
(\%)\end{array}$ & $\begin{array}{c}\text { East } \\
\mathbf{( \% )}\end{array}$ & $\begin{array}{c}\text { South } \\
\text { East } \\
(\mathbf{\%})\end{array}$ & $\begin{array}{c}\text { South } \\
\text { West } \\
(\%)\end{array}$ & $\begin{array}{c}\text { West } \\
\mathbf{( \% )}\end{array}$ & $\begin{array}{c}\text { North } \\
\text { East } \\
\mathbf{( \% )}\end{array}$ & $\begin{array}{c}\text { Central/ } \\
\text { Hazarajat } \\
(\%)\end{array}$ & $\begin{array}{c}\text { North } \\
\text { West } \\
\mathbf{( \% )}\end{array}$ \\
\hline Daily life & 56 & 64 & 74 & 54 & 51 & 41 & 55 & 49 & 56 \\
\hline Neighborhood & 47 & 57 & 59 & 48 & 45 & 35 & 43 & 36 & 45 \\
\hline Local authorities & 56 & 65 & 61 & 60 & 49 & 44 & 55 & 46 & 52 \\
\hline Provincial government & 64 & 74 & 63 & 69 & 56 & 58 & 64 & 51 & 62 \\
\hline Afghanistan as a whole & 76 & 84 & 70 & 79 & 58 & 73 & 83 & 59 & 77 \\
\hline
\end{tabular}

This pattern is consistent with previous years. The perception of corruption in Afghanistan as a whole has remained consistently high (around three fourths) since 2006. The proportion of respondents that identify corruption as a major problem in their provincial government has fluctuated slightly over the last few years. By contrast, perceptions of corruption as a major problem at the local authority level has been rising since 2007 (from 48\% to 53\% in 2008 and 2009, but remains the same in 2011 (56\%) as in 2010 (56\%). Similarly, a steadily increasing proportion of respondents say that corruption is a major problem in daily life; in 2006, $42 \%$ thought so while in 2011 the figure has reached $56 \%$.

Table 8.3: Percentage of the people who think corruption is a major problem in various facets of life and levels of government (Q-26a-e) COMPARISON BETWEEN 2006, 2007, 2008, 2009, 2010 AND 2011

\begin{tabular}{|l|c|c|c|c|c|c|}
\hline Corruption is a Major Problem: & $\begin{array}{c}\mathbf{2 0 0 6} \\
\mathbf{( \% )}\end{array}$ & $\begin{array}{c}\mathbf{2 0 0 7} \\
\mathbf{( \% )}\end{array}$ & $\begin{array}{c}\mathbf{2 0 0 8} \\
\mathbf{( \% )}\end{array}$ & $\begin{array}{c}\mathbf{2 0 0 9} \\
\mathbf{( \% )}\end{array}$ & $\begin{array}{c}\mathbf{2 0 1 0} \\
\mathbf{( \% )}\end{array}$ & $\begin{array}{c}\mathbf{2 0 1 1} \\
\mathbf{( \% )}\end{array}$ \\
\hline In your daily life & 42 & 47 & 51 & 53 & 55 & 56 \\
\hline In your neighborhood & 40 & 43 & 48 & 50 & 50 & 47 \\
\hline In your local authorities & - & 48 & 53 & 53 & 56 & 56 \\
\hline In your provincial government & 66 & 60 & 63 & 61 & 65 & 64 \\
\hline In Afghanistan as a whole & 77 & 74 & 76 & 76 & 76 & 76 \\
\hline
\end{tabular}


The survey attempted to further explore trends in public perceptions of corruption by asking respondents to compare the level of corruption now with one year ago. More than half of respondents (55\%) say the amount of corruption has increased in Afghanistan as whole while 44\% say this about corruption in the provincial government. Around a third of respondents (34\%) think that corruption has increased in their local authorities and in their daily lives (30\%) and around a quarter say this is true in their neighborhood (24\%). The findings suggest that respondents are more likely to identify an increase in corruption in domains where they perceive corruption to be generally high. While around a quarter of respondents say that corruption has decreased in the last year in their neighborhood $(26 \%)$ and in daily life $(23 \%)$, fewer than one in five say this about their local authorities (19\%) or their provincial government (14\%) and only one in $10(11 \%)$ say there has been a decrease in corruption in Afghanistan as a whole in the last year.

Table 8.4: Percentage of the people who think the amount of corruption has increased in various facets of life and levels of government (Q-27a-e, Base 6348)

\section{Amount of corruption has:}
a) In your daily life
b) In your neighbourhood
c) In your local authorities
d) In your provincial government
e) In Afghanistan as a whole

\begin{tabular}{|c|c|c|}
\hline $\begin{array}{c}\text { Increased } \\
(\mathbf{\%})\end{array}$ & $\begin{array}{c}\text { Stayed the same } \\
(\mathbf{\%})\end{array}$ & $\begin{array}{c}\text { Decreased } \\
(\mathbf{\%})\end{array}$ \\
\hline 30 & 46 & 23 \\
\hline 24 & 49 & 26 \\
\hline 34 & 45 & 19 \\
\hline 44 & 40 & 14 \\
\hline 55 & 32 & 11 \\
\hline
\end{tabular}

Perceptions of an increase in corruption in provincial government are highest in the North West $(49 \%)$ and North East (48\%), and the same is true for Afghanistan as whole (61\% in the North East, 60\% in the North West).

Table 8.5: Compared to a year ago, do you think the amount of corruption overall in various facets of life and levels of government has increased, stayed the same or decreased? (Q-27a-e, Base 6348) ALL AND BY REGION

\begin{tabular}{|c|c|c|c|c|c|c|c|c|c|}
\hline $\begin{array}{c}\text { Corruption has } \\
\text { increased: } \\
\text { Level }\end{array}$ & $\begin{array}{c}\text { Total } \\
(\%)\end{array}$ & $\begin{array}{c}\text { Central/ } \\
\text { Kabul } \\
(\%)\end{array}$ & $\begin{array}{c}\text { East } \\
(\%)\end{array}$ & $\begin{array}{c}\text { South } \\
\text { East } \\
(\%)\end{array}$ & $\begin{array}{l}\text { South } \\
\text { West } \\
(\%)\end{array}$ & $\begin{array}{l}\text { West } \\
(\%)\end{array}$ & $\begin{array}{c}\text { North } \\
\text { East } \\
(\%)\end{array}$ & $\begin{array}{c}\text { Central/ } \\
\text { Hazarajat } \\
(\%)\end{array}$ & $\begin{array}{c}\text { North } \\
\text { West } \\
(\%)\end{array}$ \\
\hline Daily Life & 30 & 32 & 47 & 28 & 28 & 14 & 30 & 32 & 31 \\
\hline Neighborhood & 24 & 27 & 40 & 22 & 27 & 14 & 18 & 13 & 28 \\
\hline Local authorities & 34 & 36 & 46 & 36 & 29 & 23 & 35 & 21 & 40 \\
\hline Provincial government & 44 & 46 & 46 & 47 & 39 & 36 & 48 & 23 & 49 \\
\hline Afghanistan as a whole & 55 & 58 & 50 & 54 & 44 & 51 & 61 & 44 & 60 \\
\hline
\end{tabular}


When this question is examined longitudinally, an interesting trend is revealed. The proportion of respondents who say corruption has increased over the last year at the level of daily life has been steadily rising, from $21 \%$ in 2007 and $24 \%$ in 2006 and 2008 to 30\% in 2011. On the other hand, the proportion who think corruption has increased at the level of provincial government and in Afghanistan as a whole in the last year has declined slightly: In 2006, half (50\%) of respondents said corruption in their provincial government had increased in the last year whereas only $44 \%$ say this in 2011. Similarly, in 2006, 60\% said corruption was increasing in Afghanistan as a whole, compared to $55 \%$ who say so in 2011.

Table 8.6: Percentage of the people who think the amount of corruption has increased in various facets of life and levels of government (Q-27a-e) COMPARISON BETWEEN 2006, 2007, 2008, 2009, 2010 AND 2011

\begin{tabular}{|l|c|c|c|c|c|c|}
\hline $\begin{array}{c}\text { Corruption has increased in } \\
\text { the last year }\end{array}$ & $\begin{array}{c}\mathbf{2 0 0 6} \\
\mathbf{( \% )}\end{array}$ & $\begin{array}{c}\mathbf{2 0 0 7} \\
\mathbf{( \% )}\end{array}$ & $\begin{array}{c}\mathbf{2 0 0 8} \\
\mathbf{( \% )}\end{array}$ & $\begin{array}{c}\mathbf{2 0 0 9} \\
\mathbf{( \% )}\end{array}$ & $\begin{array}{c}\mathbf{2 0 1 0} \\
\mathbf{( \% )}\end{array}$ & $\begin{array}{c}\mathbf{2 0 1 1} \\
\mathbf{( \% )}\end{array}$ \\
\hline In your daily life & 24 & 21 & 24 & 23 & 27 & 30 \\
\hline In your neighborhood & 28 & 21 & 25 & 24 & 24 & 24 \\
\hline In your local authorities & - & 31 & 33 & 32 & 34 & 34 \\
\hline In your provincial government & 50 & 45 & 45 & 41 & 44 & 44 \\
\hline In Afghanistan as a whole & 60 & 57 & 57 & 54 & 53 & 55 \\
\hline
\end{tabular}

The proportion of respondents who think corruption has decreased in the last year has remained mostly stable for most facets of life, although there has been a rise in the proportion of those who say corruption at the neighborhood level has decreased in the previous year (from 18\% in 2006, 22\% in 2007, 21\% in 2008, $22 \%$ in $2009,23 \%$ in 2010 to $26 \%$ in 2011).

Table 8.7: Percentage of the people who think the amount of corruption has decreased in various facets of life and levels of government (Q-27a-e) COMPARISON BETWEEN 2006, 2007, 2008, 2009, 2010 AND 2011

\begin{tabular}{|l|c|c|c|c|c|c|}
\hline $\begin{array}{c}\text { Corruption has decreased in } \\
\text { the last year }\end{array}$ & $\begin{array}{c}\mathbf{2 0 0 6} \\
\mathbf{( \% )}\end{array}$ & $\begin{array}{c}\mathbf{2 0 0 7} \\
\mathbf{( \% )}\end{array}$ & $\begin{array}{c}\mathbf{2 0 0 8} \\
\mathbf{( \% )}\end{array}$ & $\begin{array}{c}\mathbf{2 0 0 9} \\
\mathbf{( \% )}\end{array}$ & $\begin{array}{c}\mathbf{2 0 1 0} \\
\mathbf{( \% )}\end{array}$ & $\begin{array}{c}\mathbf{2 0 1 1} \\
\mathbf{( \% )}\end{array}$ \\
\hline In your daily life & 24 & 22 & 27 & 23 & 23 & 23 \\
\hline In your neighborhood & 18 & 22 & 21 & 22 & 23 & 26 \\
\hline In your local authorities & - & 17 & 15 & 17 & 17 & 19 \\
\hline In your provincial government & 12 & 14 & 11 & 14 & 13 & 14 \\
\hline In Afghanistan as a whole & 10 & 11 & 9 & 9 & 11 & 11 \\
\hline
\end{tabular}

\subsection{The forms of corruption}

The survey asked respondents to identify the kind of corruption that affects them the most. More than one third $(39 \%)$ of respondents says that administrative corruption affects them the most. This is followed by 
bribes $(17 \%)$, moral corruption $(13 \%)^{1}$, corruption by police or in police headquarters $(8 \%)$ and corruption in court $(7 \%)$.

The proportion of respondents who cite administrative corruption as the type of corruption that affects them most is higher in rural (41\%) than in urban (31\%) areas. The same is true for bribes (14\% in rural, $9 \%$ in urban areas), corruption in the police ( $9 \%$ rural, $5 \%$ urban), corruption in court (7\% rural, $4 \%$ urban) and corruption in the education systems (5\% rural, $4 \%$ urban). On the other hand, moral corruption is of greater concern for urban $(22 \%)$ than for rural respondents $(15 \%)$.

Please, tell me what kind of corruption affects you personally the most? Please give me two examples? (Q-24a\&6, Base 6348, Combination of multiple responses) ALL AND BY SETTLEMENT

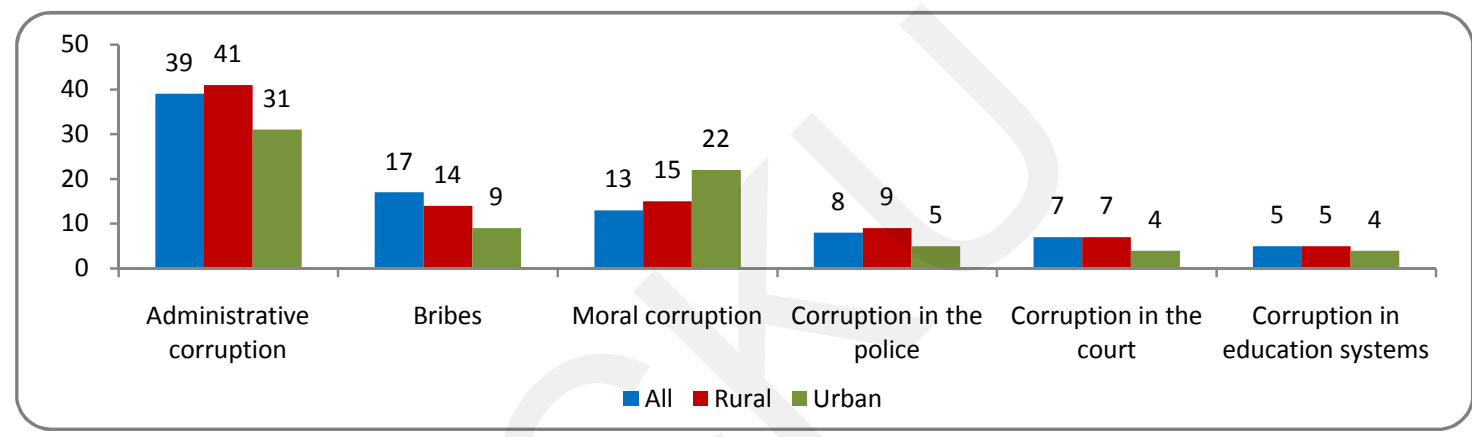

Fig. 8.1

Perceptions differ by region. Administrative corruption is mentioned by a relatively higher proportion of people in the South West (46\%), North East (45\%), West (44\%) and East (43\%). Bribe taking is mentioned most by respondents in the South West (28\%), Central/Kabul (21\%) and East (19\%), while moral corruption is most often mentioned in the North East (27\%) and West (24\%). Corruption in the police is mentioned by almost twice as many respondents in the South East (16\%) than in any other part of the country (between $4 \%$ and $9 \%)$. One in 10 respondents in the South East (10\%), North East (10\%) and North West (10\%) regions also say corruption in the court is the form of corruption the most affects them personally. The proportion of respondents who say they are most affected by corruption in the education system is highest in the Central/ Hazarajat (9\%), North West $(9 \%)$ and East $(8 \%)$ regions.

\footnotetext{
${ }^{1}$ Moral corruption includes anti-social behavior and other actions, which are considered against the norms of Afghan Society. The Pashto word used for this is Akblaqi Fasaad and the Dari word used for this is Fasaad-e-Akblaqi, which also means unethical behavior.
} 
Table 8.8: On another subject, please, tell me what kind of corruption affects you personally the most? Please give me two examples? (Q-24a\&6, Base 6348, Combination of multiple responses) BY REGION AND ALL

\begin{tabular}{|c|c|c|c|c|c|c|c|c|c|}
\hline Kind of Corruption & $\begin{array}{c}\text { All } \\
(\%)\end{array}$ & $\begin{array}{c}\text { Central/ } \\
\text { Kabul } \\
(\%)\end{array}$ & $\begin{array}{l}\text { East } \\
(\%)\end{array}$ & $\begin{array}{c}\text { South } \\
\text { East } \\
(\%)\end{array}$ & $\begin{array}{l}\text { South } \\
\text { West } \\
(\%)\end{array}$ & $\begin{array}{l}\text { West } \\
(\%)\end{array}$ & $\begin{array}{c}\text { North } \\
\text { East } \\
(\%)\end{array}$ & $\begin{array}{c}\text { Central/ } \\
\text { Hazarajat } \\
(\%)\end{array}$ & $\begin{array}{c}\text { North } \\
\text { West } \\
(\%)\end{array}$ \\
\hline $\begin{array}{l}\text { Administrative } \\
\text { corruption }\end{array}$ & 39 & 32 & 43 & 41 & 46 & 44 & 45 & 29 & 32 \\
\hline Bribes & 17 & 21 & 19 & 14 & 28 & 15 & 8 & 16 & 13 \\
\hline Moral corruption & 13 & 8 & 4 & 16 & 1 & 24 & 27 & 15 & 6 \\
\hline Corruption in the police & 8 & 7 & 5 & 16 & 6 & 4 & 9 & 7 & 8 \\
\hline Corruption in the court & 7 & 5 & 8 & 10 & 5 & 3 & 10 & 0 & 10 \\
\hline $\begin{array}{l}\text { Corruption in education } \\
\text { systems }\end{array}$ & 5 & 3 & 8 & 5 & 2 & 2 & 6 & 9 & 9 \\
\hline
\end{tabular}

\subsection{Payment of bribes}

The survey also attempted to measure respondents' personal experience of corruption in various facets of public life by asking how often in the past year they had to give cash or a gift, or perform a favor for a government official. Survey findings show that a substantial proportion of respondents had no contact with officials in the institutions mentioned (between 31\% and 52\%) which means that they were not in a position to experience corruption directly. The situations in which respondents most frequently encountered corruption in the form of an obligation to pay a bribe are in access to public healthcare services (38\%), contacts with the Afghan National Police (35\%) and in the judiciary/courts (35\%). More than a third of respondents also report encountering corruption when applying for jobs (34\%) and receiving official documents (34\%). The lowest experience of bribery is recorded for contact with the Afghan National Army (20\%) although this is still the experience of one in five respondents. 
Table 8.9: Whenever you have contacted government officials, how often in the past year have you had to give cash, a gift or perform a favor for an official? (Q-28a-j, Base 6348)

\begin{tabular}{|c|c|c|c|c|c|c|}
\hline Institution & $\begin{array}{c}\text { In all } \\
\text { cases } \\
(\%)\end{array}$ & $\begin{array}{c}\text { Most } \\
\text { cases } \\
(\%)\end{array}$ & $\begin{array}{c}\text { Isolated } \\
\text { Cases } \\
(\%)\end{array}$ & $\begin{array}{c}\text { Bribes paid (sum } \\
\text { of All, Most, and } \\
\text { Isolated Cases) } \\
(\%)\end{array}$ & $\begin{array}{c}\text { No } \\
\text { bribes } \\
\text { paid } \\
(\%)\end{array}$ & $\begin{array}{l}\text { No contact } \\
\text { with } \\
\text { officials } \\
(\%)\end{array}$ \\
\hline Public healthcare service & 3 & 13 & 22 & 38 & 30 & 31 \\
\hline Afghan National Police & 4 & 12 & 19 & 35 & 30 & 35 \\
\hline When applying for a job & 4 & 13 & 17 & 34 & 24 & 41 \\
\hline Judiciary/courts & 6 & 13 & 16 & 35 & 20 & 44 \\
\hline To receive official documents & 6 & 12 & 16 & 34 & 22 & 43 \\
\hline $\begin{array}{l}\text { Admissions to schools/ } \\
\text { university }\end{array}$ & 3 & 10 & 14 & 27 & 32 & 40 \\
\hline Officials in the municipality & 6 & 11 & 13 & 30 & 23 & 47 \\
\hline State electricity supply & 3 & 9 & 13 & 25 & 27 & 46 \\
\hline Customs office & 4 & 10 & 12 & 26 & 22 & 52 \\
\hline Afghan National Army & 3 & 7 & 10 & 20 & 38 & 42 \\
\hline
\end{tabular}

When considering only those respondents who had contact with the institutions listed, it becomes clear that for many basic public services such as accessing healthcare, applying for jobs, receiving official documents and dealing with the police or the courts, respondents encountered some level of corruption at least half of the time.

Levels of corruption experienced by respondents across the regions vary significantly. The proportion of respondents who report having paid a bribe to an official in the last year is highest in almost all mentioned services in the East followed by the South West, the North West, Central/Hazarajat and South East regions. 
Table 8.10: Whenever you have contacted government officials, how often in the past year have you had to give cash, a gift or perform a favor for an official? (Q-28a-j, Base 6348) ALL AND BY REGION

\begin{tabular}{|l|c|c|c|c|c|c|c|c|c|}
\hline Q- 28a-j, Bribe paid & $\begin{array}{c}\text { Total } \\
(\mathbf{\%})\end{array}$ & $\begin{array}{c}\text { Central/ } \\
\text { Kabul } \\
\mathbf{( \% )}\end{array}$ & $\begin{array}{c}\text { East } \\
\mathbf{( \% )}\end{array}$ & $\begin{array}{c}\text { South } \\
\text { East } \\
(\mathbf{\%})\end{array}$ & $\begin{array}{c}\text { South } \\
\mathbf{W e s t} \\
\mathbf{( \% )}\end{array}$ & $\begin{array}{c}\text { West } \\
\mathbf{( \% )}\end{array}$ & $\begin{array}{c}\text { North } \\
\text { East } \\
\mathbf{( \% )}\end{array}$ & $\begin{array}{c}\text { Central/ } \\
\text { Hazarajat } \\
\mathbf{( \% )}\end{array}$ & $\begin{array}{c}\text { North } \\
\text { West } \\
\mathbf{( \% )}\end{array}$ \\
\hline To receive official documents & 38 & 23 & 50 & 43 & 47 & 30 & 25 & 36 & 38 \\
\hline Judiciary/courts & 35 & 19 & 59 & 45 & 42 & 27 & 34 & 37 & 37 \\
\hline When applying for a job & 34 & 23 & 53 & 43 & 42 & 28 & 29 & 35 & 38 \\
\hline Afghan National Police & 35 & 20 & 50 & 55 & 44 & 28 & 31 & 39 & 36 \\
\hline Public healthcare service & 34 & 28 & 50 & 58 & 43 & 32 & 31 & 36 & 41 \\
\hline Admissions to schools/ & 27 & 20 & 47 & 36 & 34 & 20 & 17 & 34 & 26 \\
\hline university & 30 & 19 & 47 & 24 & 46 & 26 & 27 & 31 & 35 \\
\hline Officials in the municipality & 25 & 14 & 47 & 28 & 41 & 21 & 17 & 25 & 27 \\
\hline Customs office & 26 & 19 & 41 & 20 & 34 & 22 & 21 & 28 & 35 \\
\hline State electricity supply & 20 & 10 & 37 & 23 & 28 & 18 & 11 & 26 & 23 \\
\hline Afghan National Army & & & & & & & & 26 \\
\hline
\end{tabular}

Levels of corruption experienced in the different government institutions are slightly higher in 2011 compared to 2010. Indeed, the experience of corruption reported by respondents in 2011 is the highest or equivalent to the highest for any year to date for all listed institutions. These findings are consistent with the rising proportion of respondents who say corruption has increased over the last year in their daily life (see above, 8.1 Corruption - major or minor problem). These findings also help to explain why corruption continues to be identified as the third biggest problem facing Afghanistan (see Chapter 2, 2.4 Afghanistan's biggest problems: National level), and the second biggest reason for pessimism amongst those who say that the country is moving in the wrong direction (see Chapter 2, 2.3 Reasons for pessimism). It also sheds light on the reasons why failure to tackle administrative corruption is identified as the most important failing of central government (see Chapter 7, 7.4 Important achievements and failings of the central government).

Table 8.11: Percentage of the people who have corruption-related experience - sum of all cases, most cases and isolated cases (Q-28a-j) COMPARISON BETWEEN 2006, 2007, 2008, 2009, 2010 AND 2011

\begin{tabular}{|l|c|c|c|c|c|c|}
\hline & $\begin{array}{c}\mathbf{2 0 0 6} \\
\mathbf{( \% )}\end{array}$ & $\begin{array}{c}\mathbf{2 0 0 7} \\
\mathbf{( \% )}\end{array}$ & $\begin{array}{c}\mathbf{2 0 0 8} \\
\mathbf{( \% )}\end{array}$ & $\begin{array}{c}\mathbf{2 0 0 9} \\
\mathbf{( \% )}\end{array}$ & $\begin{array}{c}\mathbf{2 0 1 0} \\
\mathbf{( \% )}\end{array}$ & $\begin{array}{c}\mathbf{2 0 1 1} \\
\mathbf{( \% )}\end{array}$ \\
\hline To receive official documents & - & 24 & 24 & 28 & 28 & 38 \\
\hline Judiciary/courts & 35 & 23 & 23 & 29 & 29 & 35 \\
\hline When applying for a job & - & 26 & 25 & 30 & 30 & 34 \\
\hline Afghan National Police & 36 & 24 & 21 & 28 & 32 & 35 \\
\hline Public healthcare service & 38 & 30 & 26 & 31 & 33 & 34 \\
\hline Admissions to schools/university & - & 17 & 16 & 21 & 24 & 27 \\
\hline Officials in the municipality & 26 & 19 & 17 & 22 & 22 & 30 \\
\hline Customs office & 20 & 12 & 14 & 17 & 20 & 25 \\
\hline State electricity supply & 24 & 22 & 17 & 23 & 22 & 26 \\
\hline Afghan National Army & - & 11 & 10 & 13 & 17 & 20 \\
\hline
\end{tabular}




\subsection{Government efforts to fight corruption}

The survey also attempted to measure what respondents thought about the government's efforts to fight corruption - whether the government is doing too much, about right or not enough. Only $17 \%$ of respondents say the government is doing too much in fighting corruption while $43 \%$ say it is doing about right. More than a third of respondents $(37 \%)$ say it is not doing enough to fight corruption.

While the greatest proportion of respondents in rural areas (43\%) think that the government is doing about right in fighting corruption, most respondents in urban areas (45\%) think that the government is not doing enough in fighting corruption. This corroborates the pessimistic view of respondents when asked whether they think the government is doing a good or bad job in fighting corruption (see Chapter 7, 7.3 - Satisfaction with central government performance in policy and service delivery).

Do you think that the government is doing too much, about right, or not enough to fight corruption? (Q-29, Base 6348) ALL AND BY SETTLEMENT

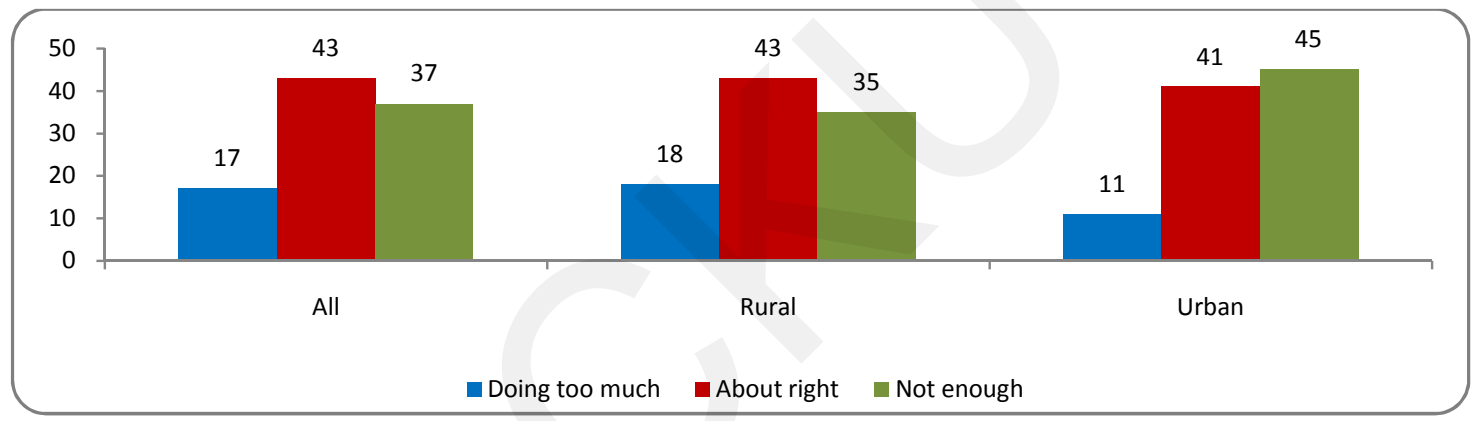

Fig 8.2

Perceptions of respondents vary across the regions on government efforts to fight corruption. The largest proportion of respondents in the Central/Kabul (46\%), South East (46\%) and Central/Hazarajat (41\%) regions think the government is not doing enough to fight corruption. This is likely to be influenced by the fact that the Central/Kabul and South East regions record amongst the highest proportion of respondents who say that corruption is a major problem across most levels of government (see above, 8.1 Corruption - major or minor problem). However, most respondents in the East (49\%) - which records the highest level of bribe payments across all services surveyed - say the government is doing about right in fighting corruption, and the same is true in the South East (49\%), North East (49\%) and West (42\%). These results seem to confirm the finding that respondent's lives are affected more by administrative corruption than bribe taking, affecting respondents' perceptions of the government's efforts to fight corruption. 
Do you think that the government is doing too much, about right or not enough to fight corruption? (Q-29, Base 6348) ALL AND BY REGION

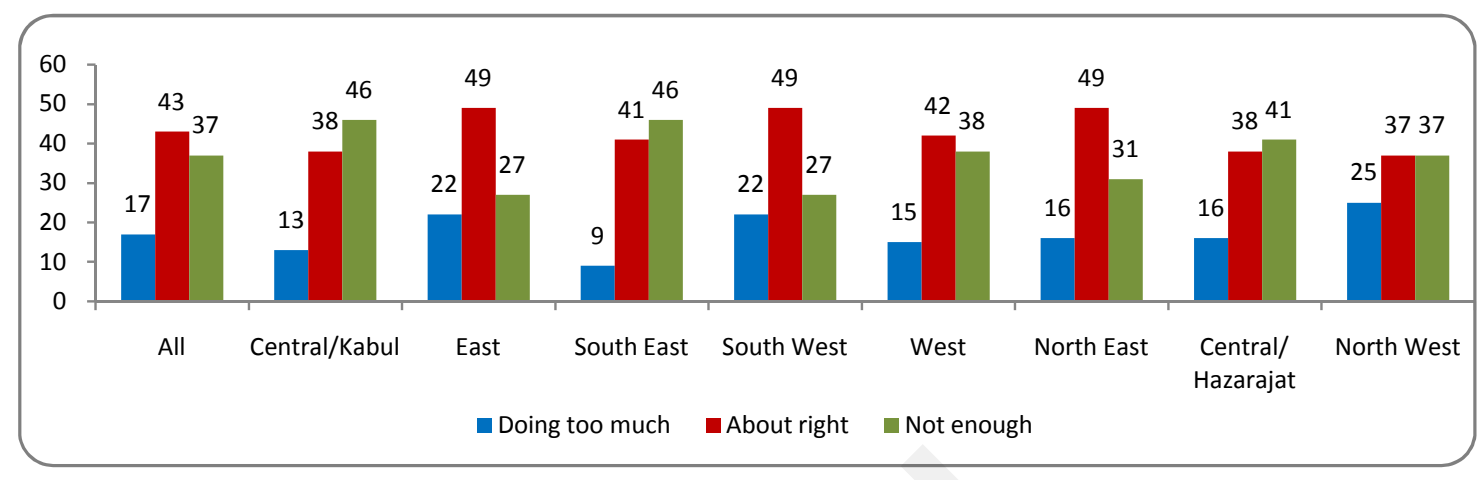

Fig 8.3 


\section{Political Participation}

\subsection{Freedom of expression}

The survey sought to measure public opinion on freedom of expression, one of the most important characteristics of democracy. It began by asking whether people feel that they can freely express their opinions and why they do, or do not.

Respondents were first asked whether people feel safer, as safe as before or less safe to freely express their opinions in their local area compared to one year ago. More than a quarter $(26 \%)$ of respondents says they feel safer to express their opinions, but one fifth (20\%) say they feel less safe. Almost half (48\%) of respondents say they feel as safe as before to express their opinions.

The differences between ethnic groups are largely reflected at the regional level. The Central/Hazarajat, with a majority Hazara population, is the region that records the highest proportion of residents saying it is safer now to freely express their opinions compared to one year back, with just under half $(49 \%)$ of respondents who say this. On the other hand, more than a quarter $(27 \%)$ of respondents in the South East, which has a largely Pashtun population, say it is less safe to freely express their opinions compared to one year ago. This is also true for at least a fifth of respondents in the East (23\%), North East (21\%), Central/Kabul (21\%) and South West $(20 \%)$ regions.

In comparison to one year ago, do people in the area where you live feel safer, as safe as before or less safe to freely express their opinions? (Q-31, Base 6348) ALL AND BY REGION

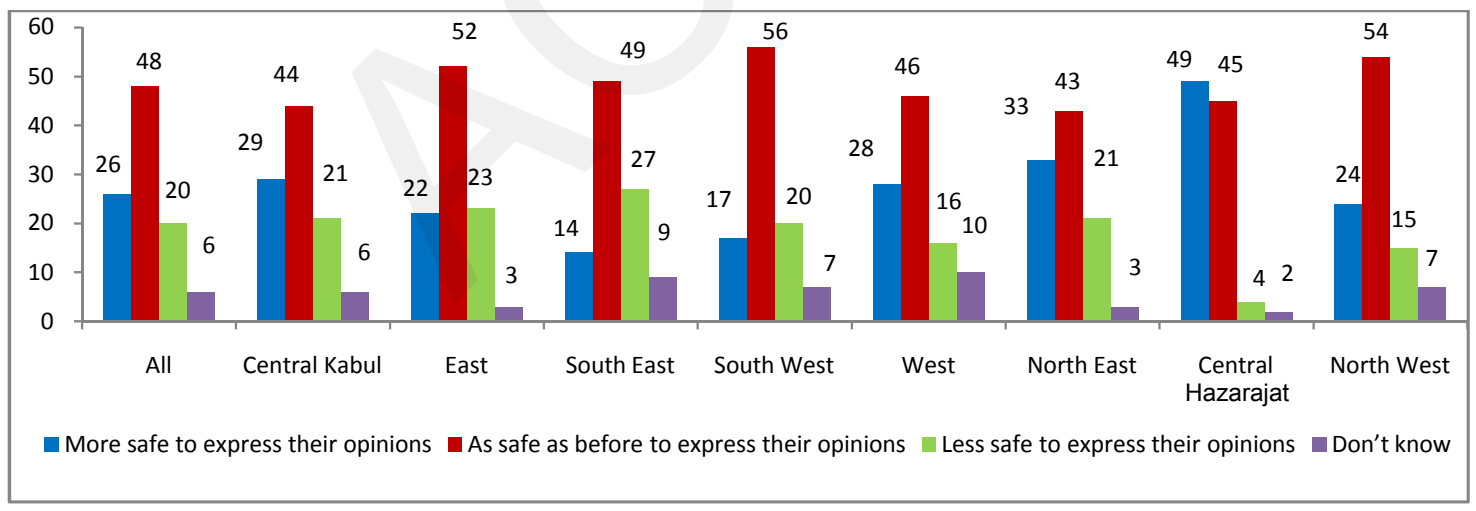

Fig 9.1

In 2011, there has been a significant increase in the proportion of respondents who say that they feel less safe to express their political opinions in their areas since 2010 (up from $17 \%$ to $20 \%$ ). 
Table 9.1: In comparison to one year ago, do people in the area where you live feel safer, as safe as before or less safe to freely express their opinions? (Q-31) COMPARISON BETWEEN 2010 AND 2011

\section{Q-31}

\begin{tabular}{|c|c|}
\hline $\begin{array}{c}2010 \\
(\%)\end{array}$ & $\begin{array}{c}2011 \\
(\%)\end{array}$ \\
\hline 25 & 26 \\
\hline 49 & 48 \\
\hline 17 & 20 \\
\hline 6 & 6 \\
\hline
\end{tabular}

Respondents who say that people feel safer to express their opinions in their local area (26\% of all respondents) were then asked what changes or reasons have made this possible. Respondents were asked to give two reasons. More than half $(56 \%)$ say this is because security conditions are good in their area, while just under half $(47 \%)$ say this is due to the guarantee of freedom of speech. Seventeen percent attribute this to peace and democracy. This suggests that local security conditions play a significant role in making people feel safer to express their opinions, as does the legal guarantee of freedom of expression.

What changes compared with the past, or reasons, do you think have made most people to feel safe to express their opinions in the area where you live? (Q-32a\&b combined, Base 1645)

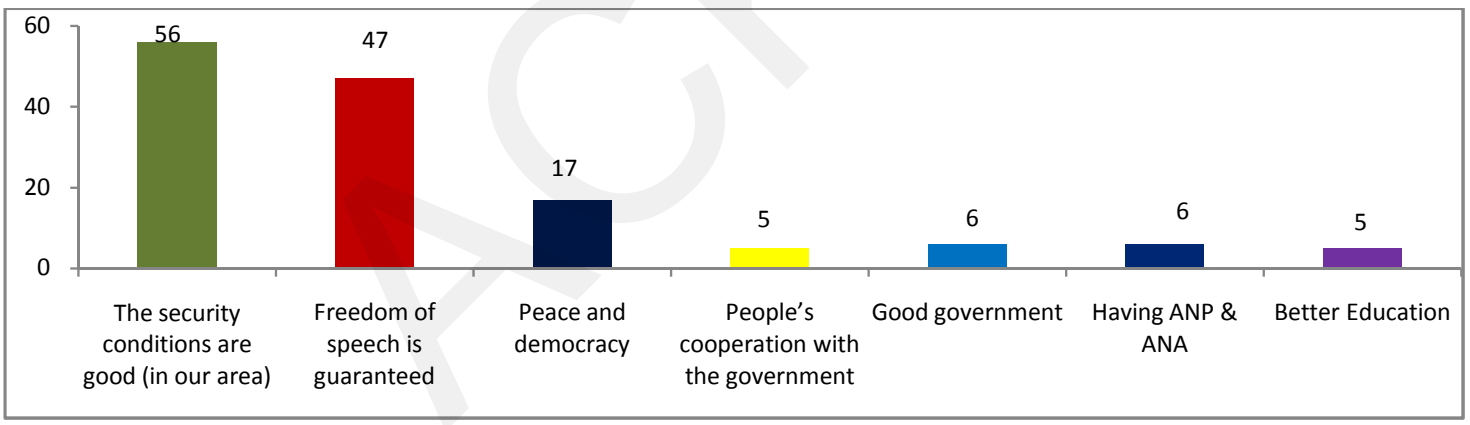

Fig 9.2

The proportion of respondents who cite good security conditions as the reason why people feel safer to express their opinions is highest in the Central/Hazarajat (68\%), North West (68\%), South West (65\%) and North East (64\%), but the guarantee of freedom of speech is the most common response given by respondents in the Central/Kabul (56\%) and West (53\%) regions. 
Table 9.2: What changes compared with the past, or reasons, do you think have made most people to feel safe to express their opinions in the area where you live? (Q-32a\&'b combined, Base 1645) ALL AND BY REGION

\begin{tabular}{|l|c|c|c|c|c|c|c|c|c|}
\hline \multicolumn{1}{|c|}{ Q-32a\&b } & $\begin{array}{c}\text { All } \\
\mathbf{( \% )}\end{array}$ & $\begin{array}{c}\text { Central/ } \\
\text { Kabul } \\
(\%)\end{array}$ & $\begin{array}{c}\text { East } \\
\mathbf{( \% )}\end{array}$ & $\begin{array}{c}\text { South } \\
\text { East } \\
(\%)\end{array}$ & $\begin{array}{c}\text { South } \\
\text { West } \\
(\%)\end{array}$ & $\begin{array}{c}\text { West } \\
(\%)\end{array}$ & $\begin{array}{c}\text { North } \\
\text { East } \\
(\%)\end{array}$ & $\begin{array}{c}\text { Central/ } \\
\text { Hazarajat } \\
(\%)\end{array}$ & $\begin{array}{c}\text { North } \\
\text { West } \\
(\%)\end{array}$ \\
\hline $\begin{array}{l}\text { Security conditions are good } \\
\text { (in our area) }\end{array}$ & 56 & 51 & 48 & 45 & 65 & 44 & 64 & 68 & 68 \\
\hline $\begin{array}{l}\text { Freedom of speech is } \\
\text { guaranteed }\end{array}$ & 47 & 56 & 48 & 42 & 28 & 53 & 45 & 28 & 48 \\
\hline $\begin{array}{l}\text { Peace and democracy } \\
\text { People's cooperation with the }\end{array}$ & 5 & 13 & 22 & 19 & 9 & 23 & 19 & 8 & 21 \\
\hline $\begin{array}{l}\text { government } \\
\text { Good government }\end{array}$ & 6 & 2 & 10 & 2 & 14 & 9 & 7 & 6 & 4 \\
\hline $\begin{array}{l}\text { Having ANP and ANA } \\
\text { Better education }\end{array}$ & 6 & 11 & 10 & 4 & 8 & 1 & 6 & 6 & 3 \\
\hline
\end{tabular}

Trend analysis reveals that the legal guarantee of freedom of speech was the most common reason given for people feeling safer to express their opinions in 2007, 2008 and 2009. This year, like last year, the most common reason given is that the local security situation is good.

Table 9.3: What changes compared with the past, or reasons, do you think have made most people to feel safe to express their opinions in the area where you live? (Q-32a\&'b combined) COMPARISON BETWEEN 2007, 2008, 2009, 2010 AND 2011

\section{Q-32a\&b}

The security conditions are good (in our area)

Freedom of speech is guaranteed

Peace and democracy

People's cooperation with the government

Good government

Having ANP and ANA

Better education

Don't know

\begin{tabular}{|c|c|c|c|c|}
\hline $\begin{array}{c}2007 \\
(\%)\end{array}$ & $\begin{array}{c}\mathbf{2 0 0 8} \\
\mathbf{( \% )}\end{array}$ & $\begin{array}{c}\mathbf{2 0 0 9} \\
\mathbf{( \% )}\end{array}$ & $\begin{array}{c}\mathbf{2 0 1 0} \\
\mathbf{( \% )}\end{array}$ & $\begin{array}{c}\mathbf{2 0 1 1} \\
\mathbf{( \% )}\end{array}$ \\
\hline 45 & 42 & 37 & 54 & 56 \\
\hline 60 & 60 & 55 & 32 & 47 \\
\hline 26 & 14 & 14 & 10 & 17 \\
\hline 0 & 0 & 1 & 7 & 5 \\
\hline 0 & 3 & 11 & 6 & 6 \\
\hline 0 & - & 1 & 6 & 6 \\
\hline 0 & 0 & 4 & 2 & 5 \\
\hline 2 & 36 & 3 & 6 & 2 \\
\hline
\end{tabular}

Respondents who say that people feel less safe to express their opinions in their area (15\% of all respondents) were further asked why this is the case. They were also asked to name two reasons. Security issues account for the majority of responses including fear for personal safety $(32 \%)$, bad security conditions $(37 \%)$, presence of the Taliban (26\%) and presence of warlords $(6 \%)$. The absence of a guarantee of freedom of expression from the government also features amongst responses $(18 \%)$. Seven percent of respondents mention the government's indifference to public opinion as a barrier to free speech. Social limitations on women's freedom of expression are also mentioned by $10 \%$ of respondents. 


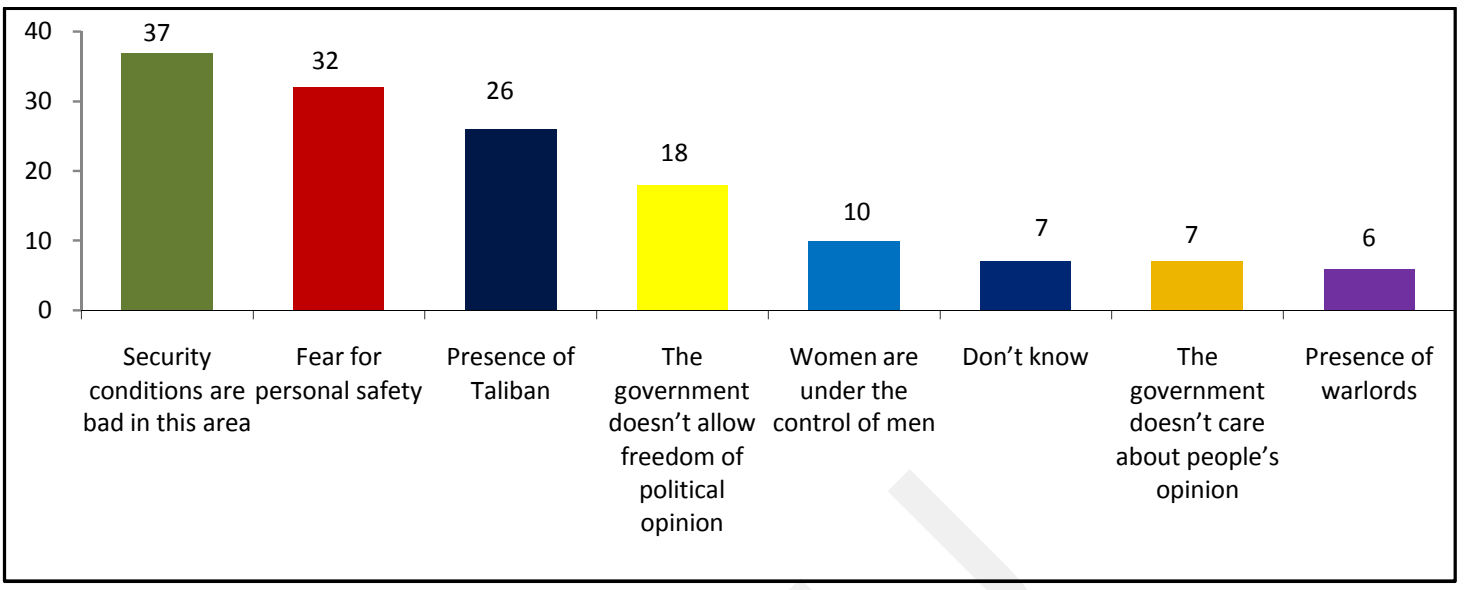

Fig 9.3

Slightly more respondents in urban (36\%) than rural (31\%) areas say they feel less safe to express their political opinions because of fears for personal safety. Conversely, the proportion of respondents who cite the presence of Taliban as the reason for not having freedom to express their political opinion is almost twice as high in rural areas $(28 \%)$ compared to urban areas $(14 \%)$.

Regional variations are also significant. The majority of respondents who say they feel less safe to express their opinions now in the South East (51\%) say this is because security conditions are bad in their area. This is also true for $43 \%$ of respondents in the Central/Kabul region, 39\% in the East and 31\% in the North West. In addition, fear for personal safety is also the most common reason cited by respondents in the North East (41\%), South West (38\%) and West (35\%). The presence of the Taliban is cited most in the East (35\%), West (33\%), South East (32\%) and South West (27\%) regions. However, the Taliban is also reported as an impediment to freedom of expression by around a fifth of respondents in all other regions except the Central/Hazarajat. The presence of warlords is cited by more respondents in the Central/Hazarajat $(20 \%)^{1}$ compared to other regions (between 1\% and 11\%). Around a quarter of respondents in the South East (25\%) and North West $(24 \%)$ say they have less freedom to express their political opinion because of government censorship, and this is true for around a fifth of respondents in the East (21\%) Central/Kabul (19\%) and South West (18\%).

\footnotetext{
1 Sample size in this region for this answer is very small (10 respondents) and therefore not statistically significant.
} 
Table 9.4: Why don't people in your area have the freedom to express their political opinions? (Q-33a\&b combined, Base 1249) ALL AND BY REGION

\begin{tabular}{|c|c|c|c|c|c|c|c|c|c|}
\hline Q-33a\&b & $\begin{array}{l}\text { All } \\
(\%)\end{array}$ & $\begin{array}{c}\text { Central/ } \\
\text { Kabul } \\
(\%)\end{array}$ & $\begin{array}{r}\text { East } \\
(\%)\end{array}$ & $\begin{array}{l}\text { South } \\
\text { East } \\
(\%)\end{array}$ & $\begin{array}{l}\text { South } \\
\text { West } \\
(\%)\end{array}$ & $\begin{array}{l}\text { West } \\
(\%)\end{array}$ & $\begin{array}{c}\text { North } \\
\text { East } \\
(\%)\end{array}$ & $\begin{array}{l}\text { Central/ } \\
\text { Hazarajat } \\
\quad(\%)\end{array}$ & $\begin{array}{c}\text { North } \\
\text { West } \\
(\%)\end{array}$ \\
\hline $\begin{array}{l}\text { Security conditions are bad } \\
\text { in this area }\end{array}$ & 37 & 43 & 39 & 51 & 30 & 31 & 26 & 30 & 33 \\
\hline Fear for personal safety & 32 & 31 & 33 & 21 & 38 & 35 & 41 & 20 & 28 \\
\hline Presence of Taliban & 26 & 20 & 35 & 32 & 27 & 33 & 21 & 0 & 19 \\
\hline $\begin{array}{l}\text { Government doesn't } \\
\text { allow freedom of political } \\
\text { opinion }\end{array}$ & 18 & 19 & 21 & 25 & 18 & 9 & 12 & 10 & 24 \\
\hline $\begin{array}{l}\text { Women are under the } \\
\text { control of men }\end{array}$ & 10 & 11 & 16 & 13 & 6 & 4 & 9 & 10 & 9 \\
\hline $\begin{array}{l}\text { Government doesn't care } \\
\text { about people's opinion }\end{array}$ & 7 & 9 & 8 & 7 & 5 & 6 & 8 & 20 & 7 \\
\hline Presence of warlords & 6 & 1 & 9 & 8 & 8 & 9 & 4 & 20 & 11 \\
\hline Don't know & 7 & 6 & 3 & 9 & 2 & 9 & 10 & 10 & 8 \\
\hline
\end{tabular}

Trend analysis suggests that since 2006 bad security conditions and fear for safety have consistently been the two most important reasons why people feel they have less freedom to express their political opinion in the previous year. The proportion of respondents who cite the presence of the Taliban as the reason why people feel less safe to express their opinions has been rising steadily since 2008 (from $15 \%$, to $21 \%$ in 2009, $24 \%$ in 2010 and 26\% in 2011), surpassing the highest figure previously recorded in 2007 (25\%). In 2011, more respondents cite government censorship as a reason for feeling less safe to express their opinions than in previous years (18\% compared to $11 \%$ in $2010,12 \%$ in 2009 and $15 \%$ in 2008), but this is still lower than the figure recorded in 2007 (22\%). More than twice as many respondents are unable or unwilling to answer this question in 2011 (19\%) compared to previous years (between 3\% and 8\%). This finding in itself seems consistent with the significant rise in the proportion of respondents who say they feel less safe to express their opinions freely in 2011 (see above). 
Table 9.5: Why don't people in your area have the freedom to express their political opinions? (Q-33a\& b combined) COMPARISON BETWEEN 2006, 2007, 2008, 2009, 2010 AND 2011

\begin{tabular}{|c|c|c|c|c|c|c|}
\hline & $\begin{array}{c}2006 \\
(\%)\end{array}$ & $\begin{array}{c}2007 \\
\mathbf{( \% )}\end{array}$ & $\begin{array}{c}2008 \\
(\%)\end{array}$ & $\begin{array}{c}2009 \\
(\%)\end{array}$ & $\begin{array}{c}2010 \\
(\%)\end{array}$ & $\begin{array}{c}2011 \\
(\%)\end{array}$ \\
\hline Security conditions are bad & 40 & 36 & 38 & 29 & 25 & 37 \\
\hline Fear for safety & 30 & 34 & 41 & 34 & 34 & 32 \\
\hline Presence of Taliban & 16 & 25 & 18 & 21 & 24 & 26 \\
\hline Government does not allow freedom of political opinions & 17 & 22 & 15 & 12 & 11 & 18 \\
\hline Women are under the control of men & 4 & 4 & 10 & 9 & 7 & 10 \\
\hline Presence of warlords & 33 & 18 & 8 & 7 & 6 & 6 \\
\hline Donst know & 3 & 3 & 4 & 4 & 8 & 19 \\
\hline
\end{tabular}

\subsection{Personal efficacy: ability to influence government decisions}

The survey attempted to measure perceptions of personal efficacy in political participation. Personal efficacy refers to the degree of influence people think someone like them can have over government decisions through participation in political processes (both formal and informal). More than half (53\%) of respondents say they feel they can have a significant degree of influence over government decisions, including $15 \%$ who say a lot of influence and 38\% saying some influence. Around a quarter (23\%) say they cannot have any influence at all.

How much influence do you think someone like you can have over government decisions? (Q-34, Base 6348)

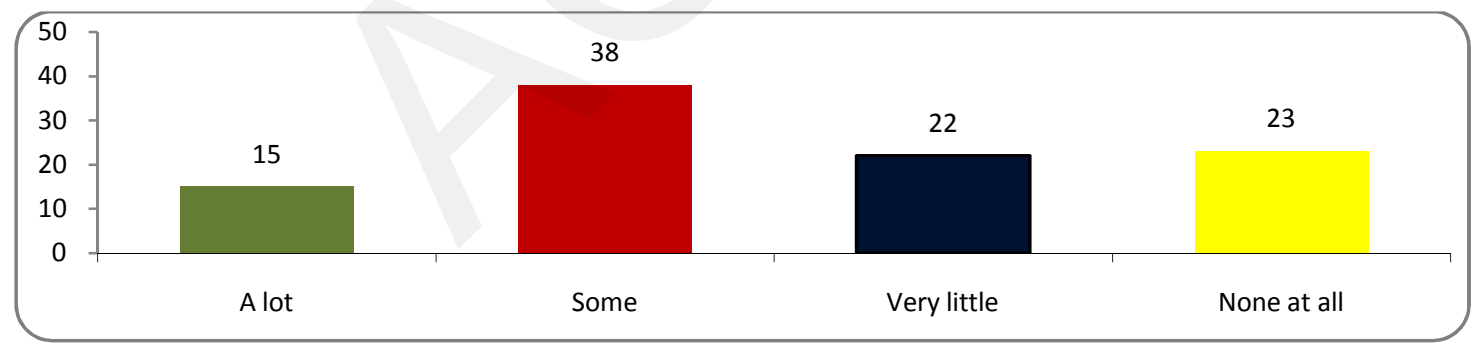

Fig 9.4

The highest levels of confidence in their ability to influence government decisions are recorded by respondents in the South West (63\%), East (60\%), North East (57\%), Central/Hazarajat (56\%) and North West $(54 \%)$ where the majority say they can have some level of influence. Conversely, more than half of respondents in the South East (52\%) and Central/Kabul (50\%) regions say they can have little or no influence over government decisions, including more than a quarter who say they can have "no influence at all" $(29 \%$ in Central/Kabul, $27 \%$ in South East). 
How much influence do you think someone like you can have over government decisions? (Q-34, Base 6348) BY REGION

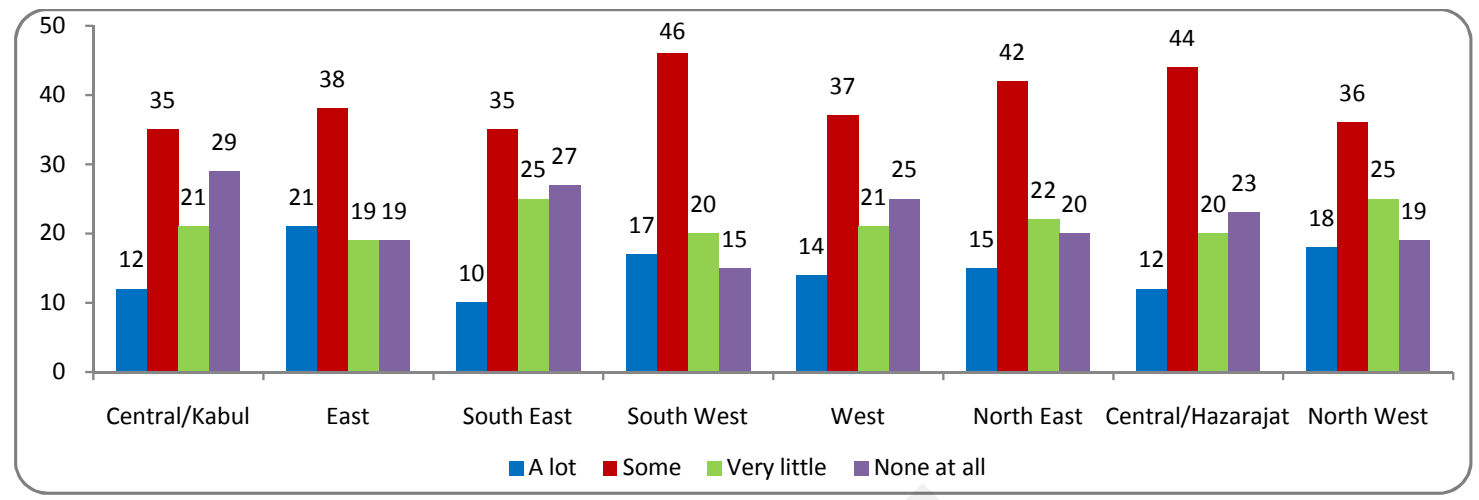

Fig 9.5

The proportion of respondents who say they can have "a lot" or "some" influence over government decisions has been declining steadily over time. Those who say that someone like them can have influence over government decisions has declined from 66\% in 2008 to 56\% in 2009, 54\% in 2010 and 53\% in 2011. Conversely, the proportions of respondents who say they can have very little influence or no influence at all has also been rising since 2008, although the percentage still remains lower than in 2006.

Table 9.6: How much influence do you think someone like you can have over government decisions - a lot, some, very little or none at all? (Q-34) COMPARISON BETWEEN 2006, 2007, 2008, 2009, 2010 AND 2011

\begin{tabular}{|l|c|c|c|c|c|c|}
\hline \multicolumn{1}{|c|}{ Influence over government decisions $(\mathbf{Q}-\mathbf{3 4})$} & $\begin{array}{c}2006 \\
\mathbf{( \% )}\end{array}$ & $\begin{array}{c}\mathbf{2 0 0 7} \\
\mathbf{( \% )}\end{array}$ & $\begin{array}{c}\mathbf{2 0 0 8} \\
\mathbf{( \% )}\end{array}$ & $\begin{array}{c}\mathbf{2 0 0 9} \\
\mathbf{( \% )}\end{array}$ & $\begin{array}{c}\mathbf{2 0 1 0} \\
\mathbf{( \% )}\end{array}$ & $\begin{array}{c}\mathbf{2 0 1 1} \\
\mathbf{( \% )}\end{array}$ \\
\hline Sum of some and lot of influence & 47 & 53 & 66 & 56 & 54 & 53 \\
\hline Sum of very little and no influence at all & 49 & 42 & 30 & 38 & 43 & 45 \\
\hline
\end{tabular}

\subsection{Consideration of the public interest when making decisions and policies}

The survey also sought to examine public perceptions of whether various institutions consider the public interest or their own interests when they make decisions and policies. The following table summarizes the findings. 
Table 9.7: Thinking of officials, do you believe that people employed in the following institutions are driven in their work mainly to serve the interests of the Afghan society, or mainly to serve their own interests? (Q-39a-h, Base 6348)

\begin{tabular}{|l|c|c|c|}
\hline & $\begin{array}{c}\text { 'Afghans } \\
\text { interests } \\
(\mathbf{\%})\end{array}$ & $\begin{array}{c}\text { Their own } \\
\text { interests } \\
(\%)\end{array}$ & $\begin{array}{c}\text { Both } \\
\mathbf{( \% )}\end{array}$ \\
\hline Religious leaders & 45 & 34 & 18 \\
\hline Government employee & 44 & 38 & 18 \\
\hline Member of parliament & 33 & 40 & 25 \\
\hline Officials in the court & 32 & 45 & 21 \\
\hline Ministers in the government & 31 & 47 & 21 \\
\hline Officials in international NGOs & 28 & 47 & 23 \\
\hline Officials in donors' institutions & 28 & 45 & 25 \\
\hline Officials in national NGOs & 25 & 49 & 24 \\
\hline
\end{tabular}

Almost half of respondents (45\%) say religious leaders consider Afghan public interest when making decisions and policies. This finding is consistent with the high levels of public confidence in religious leaders (see Chapter 7, 7.1 Confidence on public institutions) and the support for consultation with religious leaders on local problems (see Chapter 9, 9.11 Involvement of religious leaders). A similar proportion (44\%) say government employees consider the public's interest rather than their own interests when making decisions and policies.

For all other groups and institutions cited, a higher proportion of respondents believe that decisions and policies are made for their own interests rather than the public interest. Perceptions that institutions act in their own interests rather than the public's interest are highest for officials in national NGOs (49\%), international NGOs (47\%) and officials in donor institutions (45\%).

Responses to this question vary across the regions. The proportion of respondents who think religious leaders mainly serve the interests of Afghan society is highest in the North East (52\%), East (50\%) and West (46\%). More than one third of respondents in the North West (41\%), Central/Kabul (38\%), Central/Hazarajat $(38 \%)$ and West (37\%) regions think that religious leaders look after their own interests first.

Nationally, less than a third of respondents (33\%) say MPs take account of the Afghan public's interests, and $40 \%$ say the same about ministers in the government. This is true at a regional level as well. More than one third of respondents in the West (43\%), North East (35\%), Central/Hazarajat (35\%) and North West (35\%) regions say that government ministers consider the Afghan public interests when making decisions and policies. The proportion of respondents who say MPs look after the Afghan public's interests is also highest in these regions (43\% in the North East, $40 \%$ in the West). 
On the other hand, $43 \%$ of respondents in the West and just over a third in the North East (35\%), Central/ Hazarajat (35\%) and North West (35\%) say government ministers consider the Afghan public's interest when they make decisions and policies. Similarly, the highest proportion of respondents who think MPs consider the public interest rather than their own interests are also found in the North West (43\%), West (40\%), North East $(36 \%)$ and Central/Hazarajat (33\%).

The majority of respondents say that government employees serve the public interest rather than their own interests in the North West (57\%) and North East (53\%), yet less than half say the same in the West (47\%), Central/Hazarajat (46\%) and East (43\%). Less than half of the respondents say officials in the courts in the West (48\%), in the North East (38\%) in the North West (36\%) and in Central/Hazarajat (35\%) serve the public's interest, while the majority of respondents in the East (54\%), Central/Kabul (51\%) and South East $(50 \%)$ say that court employees serve their own interests first.

The levels of confidence in national NGOs to act in the Afghan public's interest in decision and policymaking is highest in the North East (31\%), East (29\%), West (29\%) and South West (28\%). Confidence in international NGOs to make decisions in the public interest is highest in the Central/Kabul (54\%), North West $(54 \%)$ and West (50\%) regions. Perceptions that officials in donor institutions consider the public interest first is highest in the North East (39\%), followed by the Central/Hazarajat (33\%), West (31\%), North West (31\%) and East (30\%) regions.

Table 9.8: Proportion of respondents who believe that people employed in the following institutions are driven in their work mainly to serve the interests of the Afghan society (Q-39a-h, Base 6348) ALL AND BY REGION

\begin{tabular}{|c|c|c|c|c|c|c|c|c|c|}
\hline$Q-39 a-h$ & $\begin{array}{r}\text { All } \\
(\%)\end{array}$ & $\begin{array}{c}\text { Central/ } \\
\text { Kabul } \\
(\%)\end{array}$ & $\begin{array}{c}\text { East } \\
(\%)\end{array}$ & $\begin{array}{c}\text { South } \\
\text { East } \\
(\%)\end{array}$ & $\begin{array}{c}\text { South } \\
\text { West } \\
(\%)\end{array}$ & $\begin{array}{l}\text { West } \\
(\%)\end{array}$ & $\begin{array}{c}\text { North } \\
\text { East } \\
(\%)\end{array}$ & $\begin{array}{c}\text { Central/ } \\
\text { Hazarajat } \\
(\%)\end{array}$ & $\begin{array}{c}\text { North } \\
\text { West } \\
(\%)\end{array}$ \\
\hline Religious leaders & 45 & 37 & 50 & 40 & 56 & 46 & 52 & 41 & 40 \\
\hline Government employees & 44 & 38 & 43 & 32 & 31 & 48 & 53 & 46 & 57 \\
\hline Members of parliament & 33 & 29 & 30 & 22 & 31 & 40 & 36 & 33 & 43 \\
\hline Officials in the court & 32 & 26 & 23 & 21 & 31 & 48 & 38 & 35 & 36 \\
\hline $\begin{array}{l}\text { Ministers in the } \\
\text { government }\end{array}$ & 31 & 27 & 26 & 21 & 25 & 43 & 35 & 35 & 35 \\
\hline $\begin{array}{l}\text { Officials in international } \\
\text { NGOs }\end{array}$ & 28 & 23 & 35 & 16 & 29 & 30 & 33 & 26 & 30 \\
\hline $\begin{array}{l}\text { Officials in donor } \\
\text { institutions }\end{array}$ & 28 & 21 & 30 & 20 & 29 & 31 & 39 & 33 & 31 \\
\hline Officials in Afghan NGOs & 25 & 20 & 29 & 18 & 28 & 29 & 31 & 24 & 23 \\
\hline
\end{tabular}




\subsection{Democratic spirit of the government}

The survey also explored perceptions of the commitment of the Afghan government to core democratic principles. Respondents were asked whether they agree or disagree with a number of statements related to the application of democratic principles. The first statement sought to test whether respondents believe that the government is responsive to the opinions and concerns of ordinary people. Respondents were asked if they agree or disagree with the statement, "I don't think the government cares much about what people like me think." More than three quarters of respondents (78\%) agree with this statement including 37\% who strongly agree. Only $21 \%$ disagree with the statement.

More than eight out of 10 respondents in the North West (87\%), Central/Hazarajat (84\%), Central/Kabul $(84 \%)$ and East $(80 \%)$ regions agree with this statement and the same is true for more than three quarters in the South East (79\%) and North West (78\%) regions. A smaller majority of respondents agree with this statement in the South West (57\%) region.

Do you agree with "I don't think that the government cares much about what people like me think."? (Q-12a, Base - 6348) ALL AND BY REGION

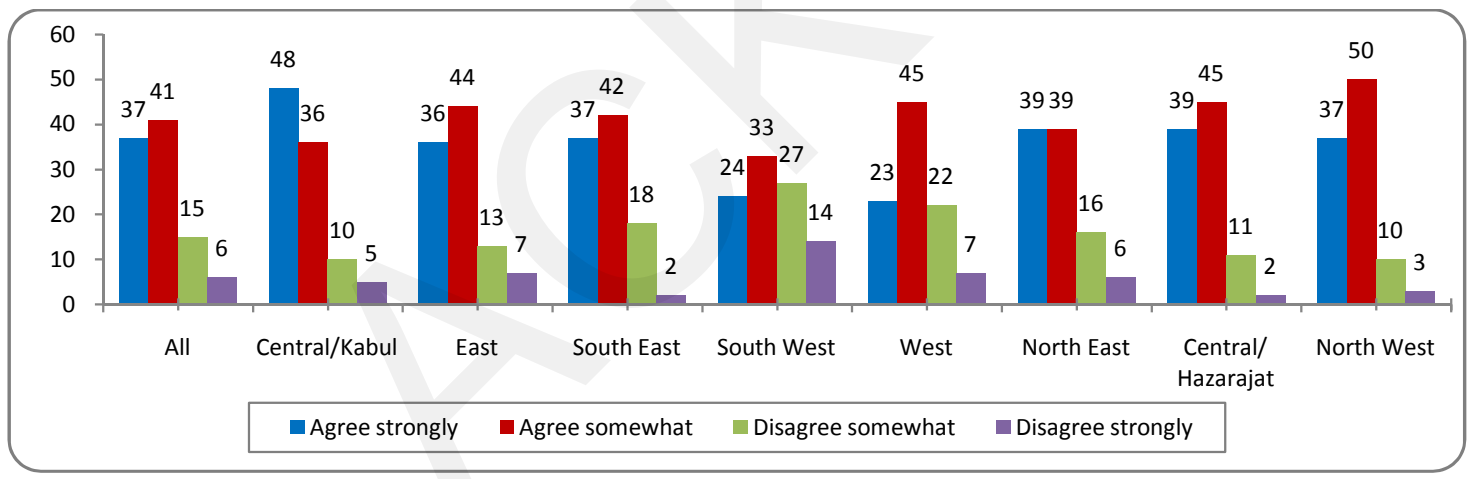

Fig 9.6

Respondents were then asked whether, "It is generally not acceptable to talk negatively about the Government in public." More than two thirds of respondents (68\%) agree with this statement, including 29\% who strongly agree. Just under a third of respondents $(31 \%)$ disagree.

Around three quarters of respondents in the East (77\%), Central/Kabul (70\%), South West (70\%), and Central/Hazarajat $(70 \%)$ regions agree that it is not acceptable to criticize the government. The highest levels of disagreement with this statement are recorded in the North West (37\%), West (34\%), South East (34\%) and North East (33\%). 
Do you agree with "It is generally not acceptable to talk negatively about the government in public?" (Q-12b, Base All respondents 6348) ALL AND BY REGION

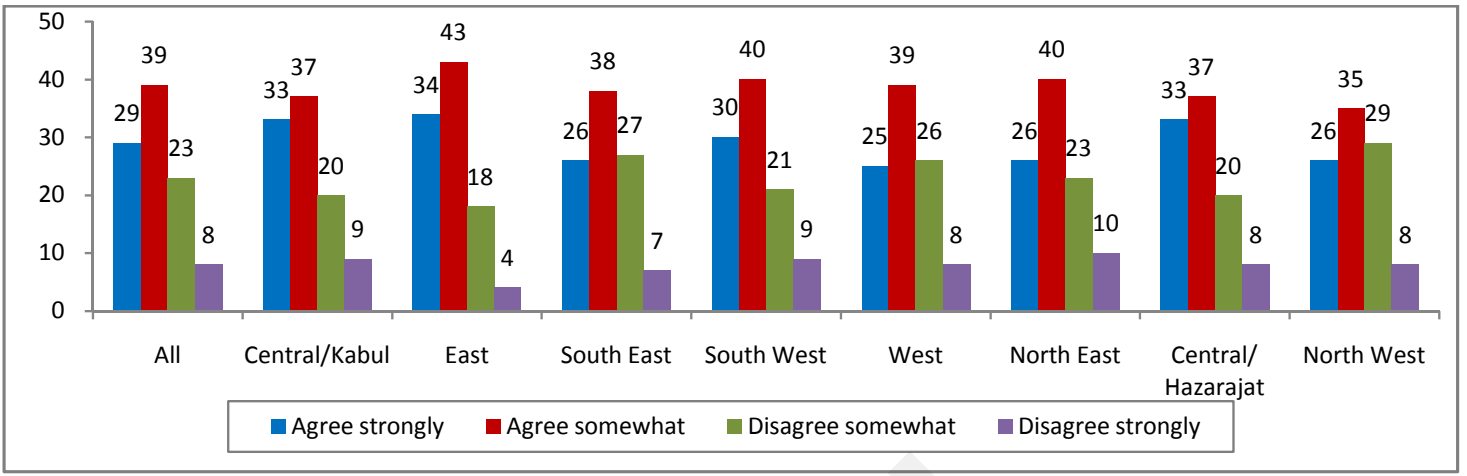

Fig 9.7

Respondents were also asked their opinion on the statement, "It is a good thing that the government should allow peaceful opposition." More than four out of five respondents (81\%) agree with this statement. This is true for all regions except for the South West (79\%) and the West (68\%). At least one in five respondents disagrees that the government should allow peaceful opposition in the West (24\%) and South West (20\%).

Please tell me if you agree with the statement, "It is a good thing that the government should allow peaceful opposition." (Q-56a, Base All Respondents 6348) ALL AND BY REGION

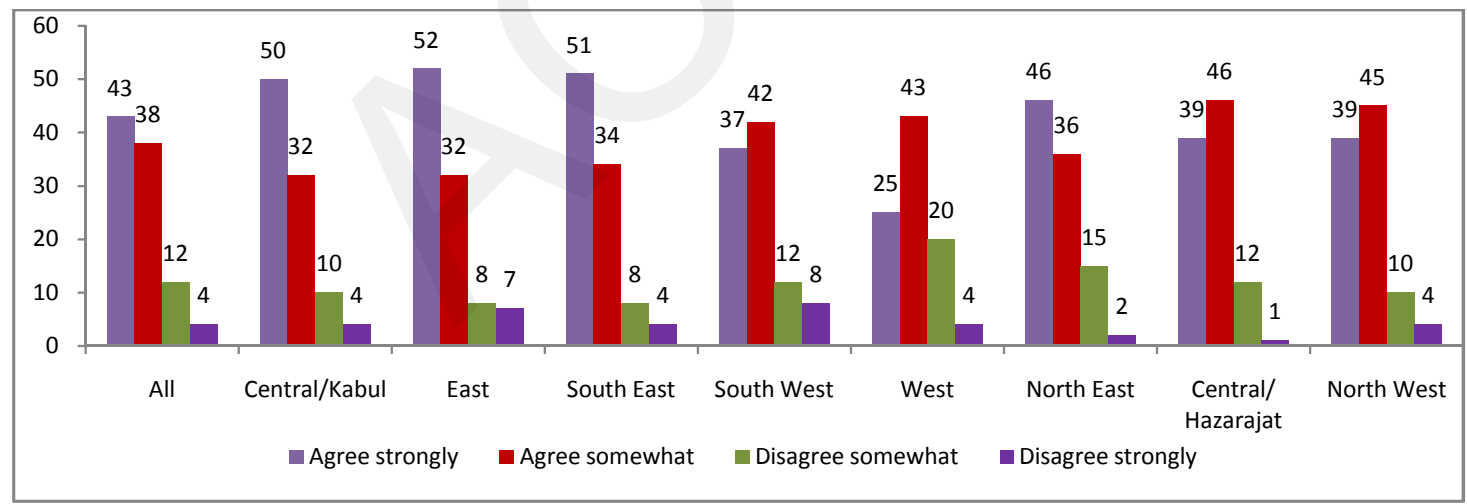

Fig 9.8

Respondents were then read the statement, "Everyone should have equal rights under the law, regardless of their gender, ethnicity or religion," and asked for their opinion. More than four fifths $(82 \%)$ of respondents agree with this statement. This is true for all regions except for the West (75\%), South West (69\%) and Central/Hazarajat (68\%). More than a quarter of respondents in the Central/Hazarajat (31\%) and South West $(29 \%)$ and just under a quarter in the West (24\%) disagree with this statement. 
Please tell me if you agree with "Everyone should have equal rights under the law, regardless of their gender, ethnicity or religion." (Q-56b, Base All Respondents 6348) ALL AND BY REGION

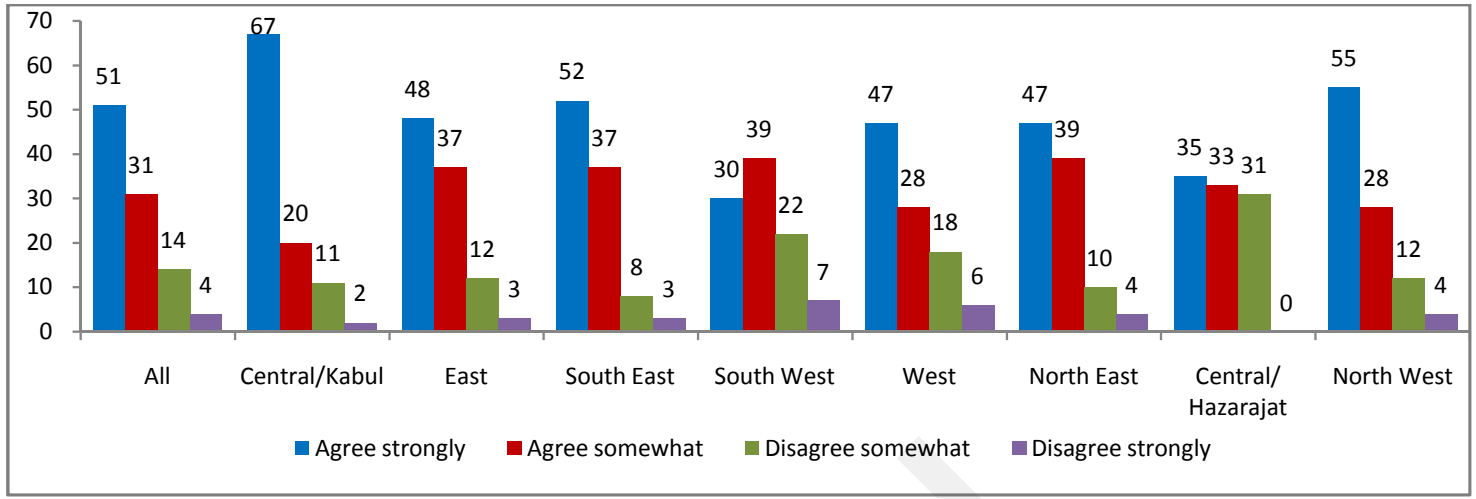

Fig 9.9

Levels of agreement with these statements have fluctuated over time. The proportion of respondents who say that the government does not care about the views of people like them has remained relatively stable since 2006. However, there is an increase in 2011 of respondents who agree that it is unacceptable to talk negatively about the government (from $62 \%$ in 2010 to $68 \%$ in 2011). This finding is consistent with the significant increase in the proportion of respondents who say that they feel less safe to express their political opinions in their areas since 2010.(see above: 9.1 Freedom of expression).

Support for allowing peaceful opposition fell slightly in 2011 (81\%) after an increase in 2010 (up from 77\% in 2009 to $83 \%$ in 2010). This may be a reflection of the increased number of demonstrations held across the country, which in some cases, turned violent.

However, there has been a drop in the proportion of respondents who agree that everyone should have equal rights under the law regardless of their gender, ethnicity and religion over time. In 2006 and 2007, 90\% of respondents said they agree with this statement. However, this fell to just over $80 \%$ in the following years and remains around this level in 2011 (82\%). This finding corroborates another finding of the survey that indicates there is a noticeable decline between 2006 and 2011 in the proportion of the people who think that women should be allowed to work outside the home (71\% in 2006 and 62\% in 2011) (see Chapter 11 Women and Society, Table 11.5). 
Table 9.9: Proportion of those who agree (combination of strongly agree and agree somewhat) toward the statements related to democratic spirit of the government (Q-12a-b and Q-56a-b) COMPARISON BETWEEN 2006, 2007, 2008, 2009, 2010 AND 2011

\begin{tabular}{|c|c|c|c|c|c|c|}
\hline & $\begin{array}{l}2006 \\
(\%)\end{array}$ & $\begin{array}{l}2007 \\
(\%)\end{array}$ & $\begin{array}{c}2008 \\
(\%)\end{array}$ & $\begin{array}{c}2009 \\
(\%)\end{array}$ & $\begin{array}{l}2010 \\
(\%)\end{array}$ & $\begin{array}{l}2011 \\
(\%)\end{array}$ \\
\hline $\begin{array}{l}\text { I don't think that the government cares much about what } \\
\text { people like me think }\end{array}$ & 77 & 79 & 76 & 74 & 74 & 78 \\
\hline $\begin{array}{l}\text { It is generally not acceptable to talk negatively about the } \\
\text { government in public }\end{array}$ & - & 69 & 62 & 61 & 62 & 68 \\
\hline $\begin{array}{l}\text { It is a good thing that the government should allow peace- } \\
\text { ful opposition }\end{array}$ & 84 & 81 & 78 & 77 & 83 & 81 \\
\hline $\begin{array}{l}\text { Everyone should have equal rights under the law, regardless } \\
\text { of their gender, ethnicity or religion }\end{array}$ & 90 & 90 & 84 & 80 & 81 & 82 \\
\hline
\end{tabular}

\subsection{Attitudes toward participation in democratic processes}

The survey also sought respondents' views on the principles that guide their own participation in democratic processes. They were first asked to what extent they agree or disagree with the statement, "A person should vote the way his or her community votes, not how they feel individually." The majority of respondents $(56 \%)$ say they agree with this statement, while $42 \%$ say that voting should be a matter of individual choice.

However, levels of support for this statement vary between regions. More than $60 \%$ of respondents agree that people should vote the way the community votes in the East (68\%), South West (63\%) and Central/ Hazarajat (61\%) regions, and the majority say the same in the South East (57\%), North East (57\%) and North West $(55 \%)$. The majority in the West $(52 \%)$, however, say that voting should be a matter of personal choice and $48 \%$ say the same in the Central/Kabul region.

Please tell me if you agree with "A person should vote the way his or her community votes, not how they feel individually." (Q-56c, Base All Respondents 6348) ALL AND BY REGION

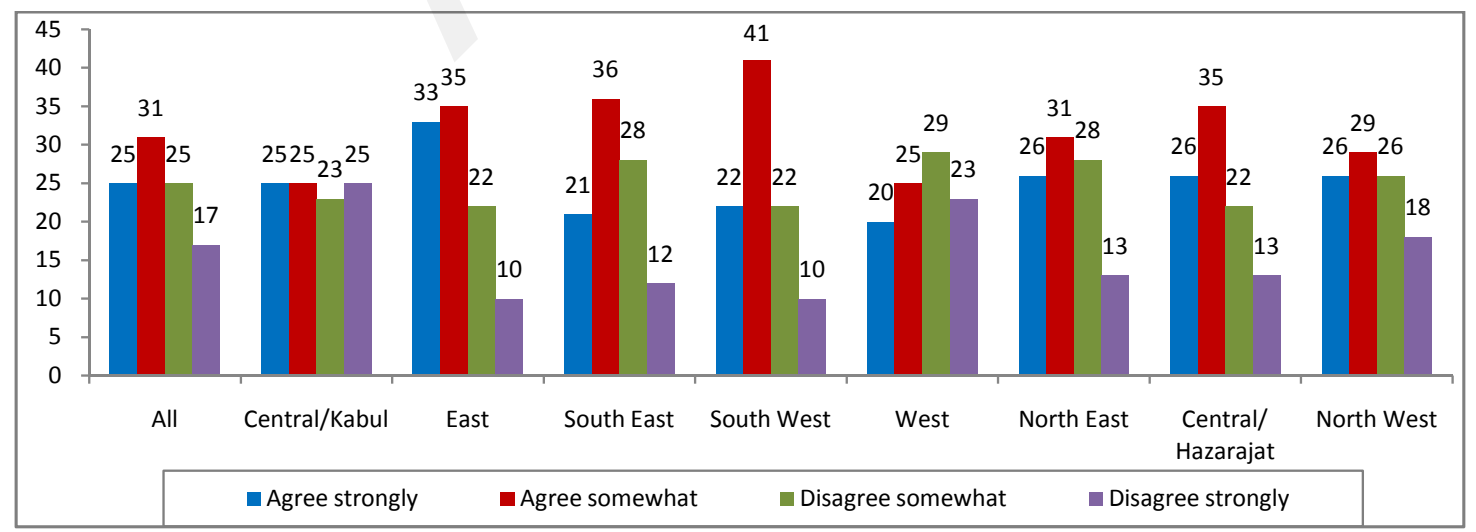

Fig 9.10 
Over time, there has been a gradual decrease in agreement with the statement, "A person should vote the way his or her community votes, not how they feel individually" (from 65\% in 2008 to 59\% in 2009, 57\% in 2010 and $55 \%$ in 2011). In 2011, more people than in any previous year say they believe that voting is a question of individual preference, not what the community prefers.

Table 9.10: Public agreement (combination of strongly agree and agree somewhat) with various democratic principles (Q-56-c) COMPARISON BETWEEN 2008, 2009 AND 2010

\begin{tabular}{|c|c|c|c|}
\hline $\begin{array}{c}2008 \\
(\%)\end{array}$ & $\begin{array}{c}2009 \\
(\%)\end{array}$ & $\begin{array}{c}2010 \\
(\%)\end{array}$ & $\begin{array}{c}2011 \\
(\%)\end{array}$ \\
\hline 65 & 59 & 57 & 55 \\
\hline
\end{tabular}

\subsection{Perceptions of democracy}

Afghan political actors and the international community have worked to restore democratic government in Afghanistan since the fall of the Taliban in 2001. For this reason, since 2004, the survey has sought to examine how Afghans understand and perceive democracy and how these perceptions are changing over time.

In order to ascertain whether Afghans think they will gain any perceptible benefits from the introduction of democracy to the country, respondents were asked to identify the most important thing that democracy in Afghanistan will bring them personally. They were allowed to give more than one response. Forty-three percent of respondents identify peace and a similar proportion say freedom $(42 \%)$ as the greatest personal benefits they expect from democracy. These responses highlight the expectation of many Afghans that the consolidation of democracy will bring freedom, peace and prosperity.

More than one in five respondents $(22 \%)$ specifically cite Islamic democracy as the most important thing that democracy in Afghanistan will bring to them personally, highlighting the importance respondents place on the integration of democratic practices and values with other core values in Afghan society. Significant numbers of respondents also identify aspects of good governance and the rule of law as benefits they expect to gain from democracy. These include government of the people (21\%), rights and law (20\%), less corruption (16\%), women's rights $(15 \%)$, better government $(10 \%)$ and elections $(9 \%)$. Around one in six respondents cite material benefits such as prosperity $(17 \%)$. The lowest perceived benefits of democracy are recorded among the Pashtuns while all other ethnic groups are more optimistic in identifying what democracy will bring for them. 
Table 9.11: What, if anything, is the most important thing that democracy in Afghanistan will bring you personally? (Percentages based on multiple responses) (Q-62, Base 6348)

\begin{tabular}{|l|c|c|c|c|c|c|}
\hline \multicolumn{1}{|c|}{ Q - 62, Base 6348 } & $\begin{array}{c}\text { All } \\
\mathbf{( \% )}\end{array}$ & $\begin{array}{c}\text { Pashtun } \\
(\mathbf{\%})\end{array}$ & $\begin{array}{c}\text { Tajik } \\
\mathbf{( \% )}\end{array}$ & $\begin{array}{c}\text { Uzbek } \\
(\mathbf{\%})\end{array}$ & $\begin{array}{c}\text { Hazara } \\
\mathbf{( \% )}\end{array}$ & $\begin{array}{c}\text { Other } \\
(\mathbf{\%})\end{array}$ \\
\hline Peace & 43 & 35 & 50 & 46 & 46 & 44 \\
\hline Freedom & 42 & 32 & 50 & 46 & 50 & 48 \\
\hline Islamic democracy & 22 & 18 & 27 & 24 & 26 & 20 \\
\hline Government of the people & 21 & 14 & 27 & 25 & 25 & 29 \\
\hline Rights and law & 20 & 17 & 21 & 23 & 22 & 23 \\
\hline Prosperity & 17 & 11 & 21 & 27 & 21 & 19 \\
\hline Less corruption & 16 & 11 & 19 & 24 & 21 & 18 \\
\hline Women's rights & 15 & 10 & 18 & 18 & 23 & 17 \\
\hline Better government services & 10 & 8 & 12 & 14 & 10 & 12 \\
\hline Elections & 9 & 7 & 12 & 13 & 7 & 9
\end{tabular}

There are some differences among income groups regarding the potential benefits of democracy. Nearly twice as many respondents with low income (less than 2000Afs a month) cite prosperity (20\%) than do those with higher income levels (10,000Afs and above) (11\%). Higher proportions in the lower income group also cite more intangible benefits such as women's rights (24\% compared to $13 \%$ in the highest income group), freedom (49\% compared to $39 \%$ of high income earners), peace (44\% compared to $39 \%$ ) and government of the people ( $23 \%$ compared to $18 \%)$.

Table 9.12: What, if anything, is the most important thing that democracy in Afghanistan will bring you personally? (Percentages based on multiple responses) (Q-62, Base 6348) ALL AND BY HOUSEHOLD INCOME GROUPS

\begin{tabular}{|c|c|c|c|c|c|c|}
\hline Base: All respondents & $\begin{array}{l}\text { All } \\
(\%)\end{array}$ & $\begin{array}{c}\text { Less than } \\
2,000 \text { Afs } \\
(\%)\end{array}$ & $\begin{array}{c}2,001- \\
3,000 \text { Afs } \\
(\%)\end{array}$ & $\begin{array}{c}3,001-5,000 \text { Afs } \\
\text { (incl. refused and } \\
\text { DK) } \\
(\%)\end{array}$ & $\begin{array}{c}5,001-10,000 \\
\text { Afs } \\
(\%)\end{array}$ & $\begin{array}{l}10,001+ \\
\text { Afs } \\
(\%)\end{array}$ \\
\hline Freedom & 42 & 49 & 49 & 44 & 38 & 39 \\
\hline Peace & 42 & 44 & 45 & 42 & 44 & 39 \\
\hline Islamic democracy & 26 & 20 & 23 & 23 & 23 & 21 \\
\hline Government of the people & 21 & 23 & 25 & 21 & 22 & 18 \\
\hline Rights and law & 18 & 17 & 22 & 21 & 20 & 18 \\
\hline Prosperity & 17 & 20 & 20 & 19 & 19 & 11 \\
\hline Less corruption & 17 & 15 & 18 & 16 & 18 & 14 \\
\hline Womenss rights & 15 & 24 & 18 & 15 & 14 & 13 \\
\hline Better government services & 12 & 9 & 12 & 10 & 11 & 10 \\
\hline Elections & 9 & 7 & 10 & 10 & 11 & 7 \\
\hline
\end{tabular}


Regions with majority Pashtun populations (the East, South West and South East) record the lowest proportions of respondents who identify any of the potential benefits of democracy.

Table 9.13: What, if anything, is the most important thing that democracy in Afghanistan will bring you personally? (Percentages based on multiple responses) (Q-62, Base 6348) ALL AND BY REGION

\begin{tabular}{|l|c|c|c|c|c|c|c|c|c|}
\hline & $\begin{array}{c}\text { All } \\
\mathbf{( \% )}\end{array}$ & $\begin{array}{c}\text { Central/ } \\
\text { Kabul } \\
\mathbf{( \% )}\end{array}$ & $\begin{array}{c}\text { East } \\
\mathbf{( \% )}\end{array}$ & $\begin{array}{c}\text { South } \\
\text { East } \\
\mathbf{( \% )}\end{array}$ & $\begin{array}{c}\text { South } \\
\text { West } \\
\mathbf{( \% )}\end{array}$ & $\begin{array}{c}\text { West } \\
\mathbf{( \% )}\end{array}$ & $\begin{array}{c}\text { North } \\
\text { East } \\
\mathbf{( \% )}\end{array}$ & $\begin{array}{c}\text { Central/ } \\
\text { Hazarajat } \\
\mathbf{( \% )}\end{array}$ & $\begin{array}{c}\text { North } \\
\text { West } \\
(\mathbf{\%})\end{array}$ \\
\hline Peace & 43 & 39 & 26 & 34 & 37 & 50 & 55 & 39 & 51 \\
\hline Freedom & 42 & 39 & 28 & 30 & 25 & 51 & 58 & 59 & 53 \\
\hline Islamic democracy & 22 & 24 & 13 & 23 & 7 & 28 & 32 & 27 & 20 \\
\hline Government of the people & 21 & 21 & 7 & 17 & 8 & 28 & 31 & 22 & 30 \\
\hline Rights and law & 20 & 17 & 18 & 15 & 15 & 23 & 23 & 19 & 24 \\
\hline Prosperity & 17 & 10 & 7 & 12 & 6 & 22 & 36 & 29 & 23 \\
\hline Less corruption & 16 & 13 & 6 & 13 & 9 & 22 & 28 & 21 & 20 \\
\hline Women's rights & 15 & 15 & 9 & 10 & 4 & 22 & 18 & 18 & 23 \\
\hline Better government services & 10 & 11 & 7 & 7 & 6 & 9 & 13 & 7 & 16 \\
\hline Elections & 9 & 5 & 8 & 6 & 3 & 11 & 21 & 10 & 10 \\
\hline
\end{tabular}

Peace and freedom have consistently been the most commonly cited benefits and the most important expectations of democracy identified by survey respondents since 2006. It is significant that the proportion of respondents who identify peace as a potential benefit of democracy has been rising steadily since 2007, reaching its highest recorded level in 2011 (from 31\% in 2007, 35\% in 2008, 41\% in 2009 and 43\% in 2011). This finding suggests that the respondents link a democratic system to security, which is increasingly important to them. This is consistent with the increasing proportion of respondents who say that they often fear for their safety (see Chapter 3: 3.1 Fear for safety) and who identify insecurity as the main reason for saying the country is moving in the wrong direction (see Chapter 2:2.3 Reasons for pessimism).

On the other hand, the proportion of respondents who say that democracy will bring less corruption has been falling over the same period (from 22\% in 2007 and 23\% in 2008 to $17 \%$ in 2009 and $16 \%$ in 2011). This finding is consistent with the increasing proportion of respondents who say that corruption is a major problem in daily life and that corruption has increased in the last year (see Chapter 8: 8.1 Corruption-major or minor problem), suggesting that democracy has so far failed to deliver the reduction in corruption originally hoped for. 
Table 9.14: What, if anything, is the most important thing that democracy in Afghanistan will bring you personally? (Percentages based on multiple responses) (Q-62) COMPARISON BETWEEN 2006, 2007, 2008, 2010 AND 2011

\begin{tabular}{|c|c|c|c|c|c|}
\hline$Q-62$ & $\begin{array}{c}2006 \\
(\%)\end{array}$ & $\begin{array}{c}2007 \\
(\%)\end{array}$ & $\begin{array}{c}2008 \\
(\%)\end{array}$ & $\begin{array}{c}2010 \\
(\%)\end{array}$ & $\begin{array}{l}2011 \\
(\%)\end{array}$ \\
\hline Peace & 38 & 31 & 35 & 41 & 43 \\
\hline Freedom & 42 & 34 & 33 & 50 & 42 \\
\hline Islamic democracy & 30 & 20 & 19 & 23 & 22 \\
\hline Government of the people & 29 & 22 & 19 & 19 & 21 \\
\hline Rights and law & 33 & 23 & 19 & 24 & 20 \\
\hline Prosperity & 21 & 17 & 16 & 15 & 17 \\
\hline Less corruption & - & 22 & 23 & 17 & 16 \\
\hline Women's rights & 23 & 17 & 16 & 21 & 15 \\
\hline Better government services & - & - & - & - & 10 \\
\hline Elections & - & - & - & - & 9 \\
\hline
\end{tabular}

When asked how satisfied or dissatisfied they are with the way democracy works in Afghanistan, more than two thirds of respondents $(69 \%)$ say they are satisfied, including one fifth $(20 \%)$ who are very satisfied. However, over a quarter of respondents $(29 \%)$ say they are either somewhat or very dissatisfied.

Over three quarters of respondents in Central/Hazarajat (78\%), West (76\%) and North West (75\%), and more than two thirds in the East (69\%), South West (69\%) and North East (69\%) say they are satisfied with the way democracy is working in the country. Forty percent of respondents in the South East say they are dissatisfied with the way democracy is working in Afghanistan, and the same is true for around a third in the Central/Kabul (34\%) and North East (31\%) regions.

On the whole, how satisfied or dissatisfied are you with the way democracy works in Afghanistan? (Q-35, Base - 6348) ALL AND BY REGION

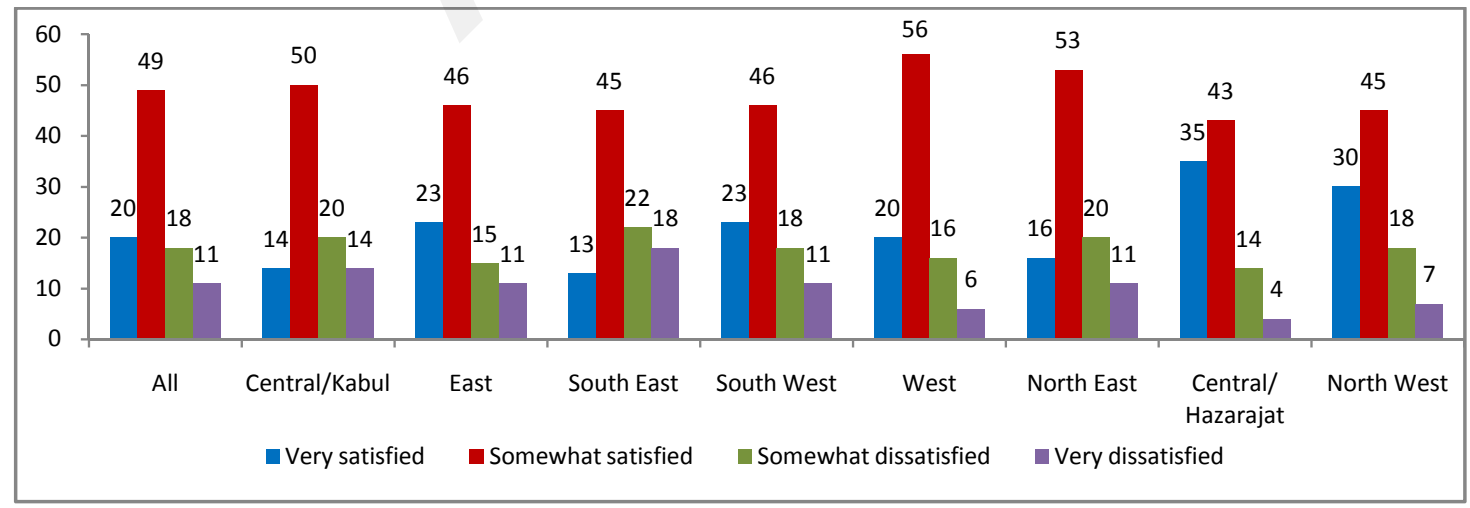

Fig 9.11 
Since 2008 overall levels of satisfaction with the way democracy works in the country have remained stable (69\% in 2011, 68\% in 2009, 68\% in 2011). However, there has been a steady rise in those who say they are dissatisfied (from $21 \%$ in 2006 to $25 \%$ in 2007 to $27 \%$ in 2008, 28\% in 2009 and $29 \%$ in 2011).

Table 9.15: On the whole, how satisfied or dissatisfied are you with the way democracy works in Afghanistan? (Q-35) COMPARISON BETWEEN 2006, 2007, 2008, 2009 AND 2011

\begin{tabular}{|l|c|c|c|c|c|}
\multicolumn{1}{|c|}{ Q-35 } & $\begin{array}{c}2006 \\
(\mathbf{2})\end{array}$ & $\begin{array}{c}\mathbf{2 0 0 7} \\
\mathbf{( \% )}\end{array}$ & $\begin{array}{c}\mathbf{2 0 0 8} \\
\mathbf{( \% )}\end{array}$ & $\begin{array}{c}\mathbf{2 0 0 9} \\
\mathbf{( \% )}\end{array}$ & $\begin{array}{c}\mathbf{2 0 1 1} \\
\mathbf{( \% )}\end{array}$ \\
\hline Somewhat and very satisfied & 76 & 73 & 68 & 68 & 69 \\
\hline Somewhat and very dissatisfied & 21 & 25 & 27 & 28 & 29 \\
\hline
\end{tabular}

\subsection{Involvement of religious leaders}

The survey also attempted to examine public opinion regarding the involvement of religious leaders in government decision-making. Respondents were offered two alternative viewpoints, "Some people argue that local religious leaders should be regularly consulted on the problems facing an area while others argue that politics and religion should not mix," and asked which is closer to their view. More than two thirds (70\%) of respondents say that religious leaders should be consulted, while just over a quarter $(27 \%)$ say that politics and religion should not mix. More men (72\%) than women $(66 \%)$, and more rural $(70 \%)$ than urban $(66 \%)$ respondents say that religious leaders should be consulted on local problems.

The majority of respondents in all regions are in favor of consulting with religious leaders, Support for such consultation is highest in the Central/Hazarajat (76\%) and East $(75 \%)$ and lowest in the West (66\%), North East (67\%) and South West (68\%).

Some people say that local religious leaders should be regularly consulted on the problems facing an area while others think that politics and religion should not mix. Which is closer to your view? (Q-63, Base-6348) ALL AND BY REGION

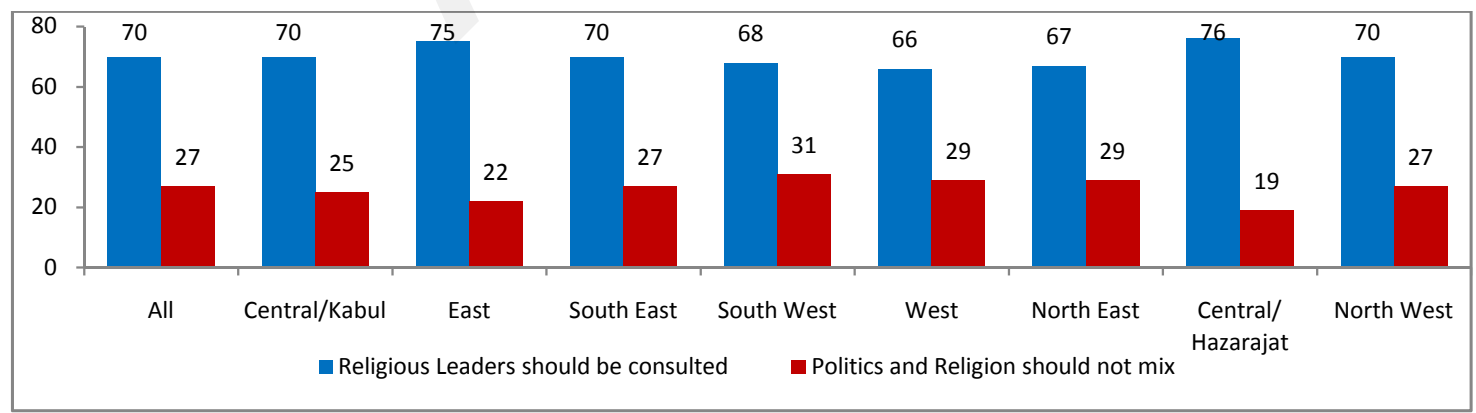

Fig 9.12 
The proportion of respondents who say religious leaders should be consulted has increased over time (from $61 \%$ in 2006 and $60 \%$ in 2007 to $69 \%$ in $2008,67 \%$ in 2009 and $70 \%$ in 2011). ${ }^{2}$ There has been a corresponding decrease over the same period in the proportion of respondents who say they think politics and religion should not mix (from 37\% in 2006 and 36\% in 2007 to 26\% in 2008 and 27\% in 2009 and 2011). These findings suggest that an increasing number of people in Afghanistan see the involvement of religious leaders as one of the ways to strengthen governance in the country.

Table 9.16: Some people say that local religious leaders should be regularly consulted on the problems facing an area while others think that politics and religion should not mix. Which is closer to your view? (Q-63) COMPARISON BETWEEN 2006, 2007, 2008, 2009 AND 2011

\begin{tabular}{|l|c|c|c|c|c|}
\multicolumn{1}{|c|}{ Q-63 } & $\begin{array}{c}\mathbf{2 0 0 6} \\
\mathbf{( \% )}\end{array}$ & $\begin{array}{c}\mathbf{2 0 0 7} \\
\mathbf{( \% )}\end{array}$ & $\begin{array}{c}\mathbf{2 0 0 8} \\
\mathbf{( \% )}\end{array}$ & $\begin{array}{c}\mathbf{2 0 0 9} \\
\mathbf{( \% )}\end{array}$ & $\begin{array}{c}\mathbf{2 0 1 1} \\
\mathbf{( \% )}\end{array}$ \\
\hline Religious leaders should be consulted & 61 & 60 & 69 & 67 & 70 \\
\hline Politics and religion should not mix & 37 & 36 & 26 & 27 & 27 \\
\hline
\end{tabular}

\subsection{Perceptions of the $\mathbf{2 0 1 0}$ parliamentary elections}

Respondents were asked whether they thought the 2010 parliamentary elections were free and fair. Before asking this question, respondents were briefed about what the terms "free" and "fair" mean. In an electoral context "free" means that all people have the chance to vote as they wish. "Fair" means that all candidates and parties follow the rules and are given equal access to public channels of communication and that votes are counted correctly and not manipulated.

Nearly half (49\%) of respondents say that the 2010 parliamentary elections were free and fair, while an almost equal proportion $(46 \%)$ say they were not.

The majority of respondents from all the ethnic communities, except Pahtun, say past parliamentary elections were free and fair. Just under half of Pashtun respondents (49\%) say the 2010 parliamentary elections were not free and fair.

Around two thirds of respondents in the Central/Hazarajat (65\%) and North West (61\%), and a majority in the North East (54\%) and West (52\%) regions say that the election was free and fair. However most respondents in the other regions say they were not.

2 This question was not asked in 2010 
Do you think the past presidential election was free and fair? (Q-64, Base 6348) BY REGION

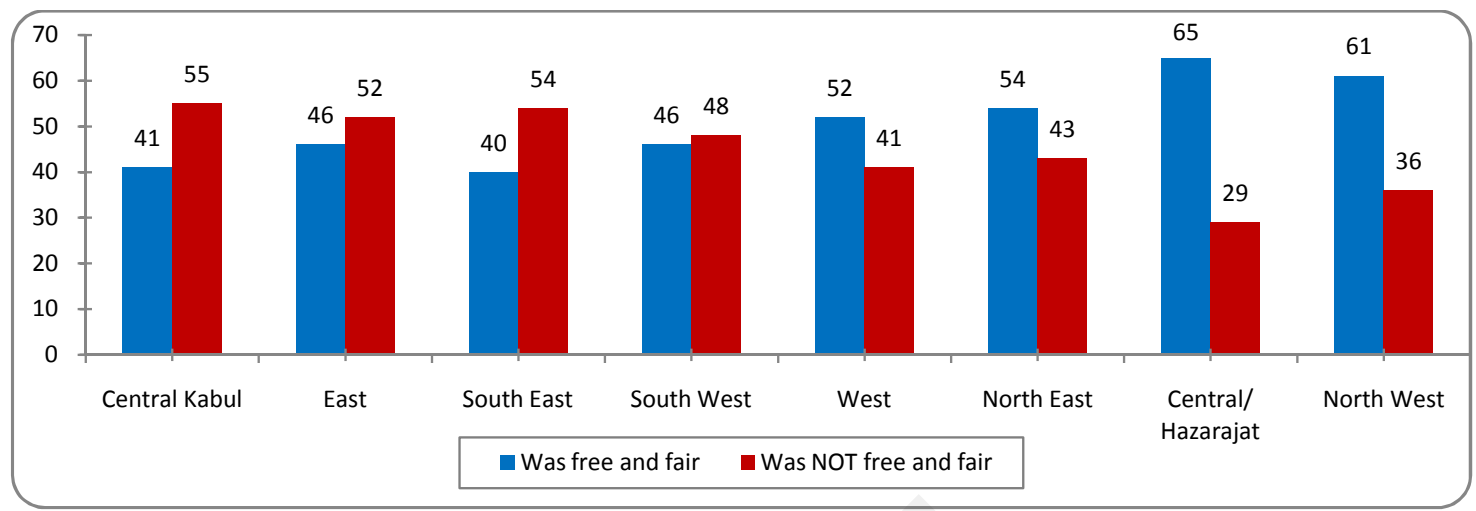

Fig. 9.13

Respondents who said that the 2010 parliamentary elections were not free and fair ( $46 \%$ of all respondents) were then asked why, in their view, this was the case. The most common reason identified is buying of votes $(41 \%)$ followed by cheating in the vote count (34\%). Small proportions of respondents also cited the reasons of men voting on behalf of women (7\%), husbands not letting their wives vote (4\%) and intimidation against voters or party activists $(5 \%)$.

Buying of votes was identified most frequently in the South West (52\%) followed by the Central/Hazarajat (47\%), Central/Kabul (42\%) and West (41\%) regions. Irregularities in vote counting was the most frequently identified reason in the East (41\%) and was also cited by at least a third of respondents who said the elections were not free and fair in the North West (36\%), Central/ Kabul (35\%), South East (35\%) and North East $(35 \%)$ regions.

Twelve percent of respondents in the South East identified men voting on behalf of women followed by $9 \%$ in the North West and 8\% in the East and West. Husbands not letting their wives vote was identified slightly more often in the West (6\%) and Central/Hazarajat (6\%) than in other regions (between 3\% and 4\%)

Intimidation of voters or party activists was cited by almost twice as many respondents in the West (10\%) as in other regions (between $0 \%$ and $7 \%$ ). 
Table 9.17: (Filtered). You said that you think that the election was not free and fair. What makes you think so? (Q-65, Base-2943) ALL AND BY REGION

\begin{tabular}{|c|c|c|c|c|c|c|c|c|c|}
\hline & $\begin{array}{l}\text { All } \\
(\%)\end{array}$ & $\begin{array}{c}\text { Central/ } \\
\text { Kabul } \\
(\%)\end{array}$ & $\begin{array}{l}\text { East } \\
(\%)\end{array}$ & $\begin{array}{c}\text { South } \\
\text { East } \\
(\%)\end{array}$ & $\begin{array}{c}\text { South } \\
\text { West } \\
(\%)\end{array}$ & $\begin{array}{l}\text { West } \\
(\%)\end{array}$ & $\begin{array}{c}\text { North } \\
\text { East } \\
(\%)\end{array}$ & $\begin{array}{c}\text { Central/ } \\
\text { Hazarajat } \\
(\%)\end{array}$ & $\begin{array}{c}\text { North } \\
\text { West } \\
(\%)\end{array}$ \\
\hline Buying of votes & 41 & 42 & 33 & 38 & 52 & 41 & 39 & 47 & 38 \\
\hline Cheating in the vote count & 34 & 35 & 41 & 35 & 31 & 25 & 35 & 28 & 36 \\
\hline Men voted on behalf of women & 7 & 4 & 8 & 12 & 6 & 8 & 7 & 5 & 9 \\
\hline $\begin{array}{l}\text { Intimidation against voters or } \\
\text { party activists }\end{array}$ & 5 & 3 & 5 & 7 & 4 & 10 & 6 & 0 & 6 \\
\hline Husbands not letting wives vote & 4 & 4 & 4 & 4 & 2 & 6 & 4 & 6 & 3 \\
\hline Don't know & 3 & 2 & 3 & 2 & 3 & 4 & 2 & 2 & 3 \\
\hline
\end{tabular}

The survey also sought to gauge public perceptions of who is running elections in Afghanistan. Two thirds $(66 \%)$ of respondents report that the elections are run by the Independent Election Commission while another 23\% say elections are run by the government. Seven percent say elections are run by the international community and $2 \%$ say they are run by a special court.

There is some variation if this question is disaggregated by ethnic communities. Even though a majority of all groups say the elections were run by the Independent Election Commission, a higher proportion of Uzbeks report this (78\%) than do Hazaras (68\%), other ethnic groups (68\%), Tajiks (67\%) and Pashtuns (63\%).

Who is running elections in Afghanistan? (Q-65, Base- 6348) BY ETHNICITY

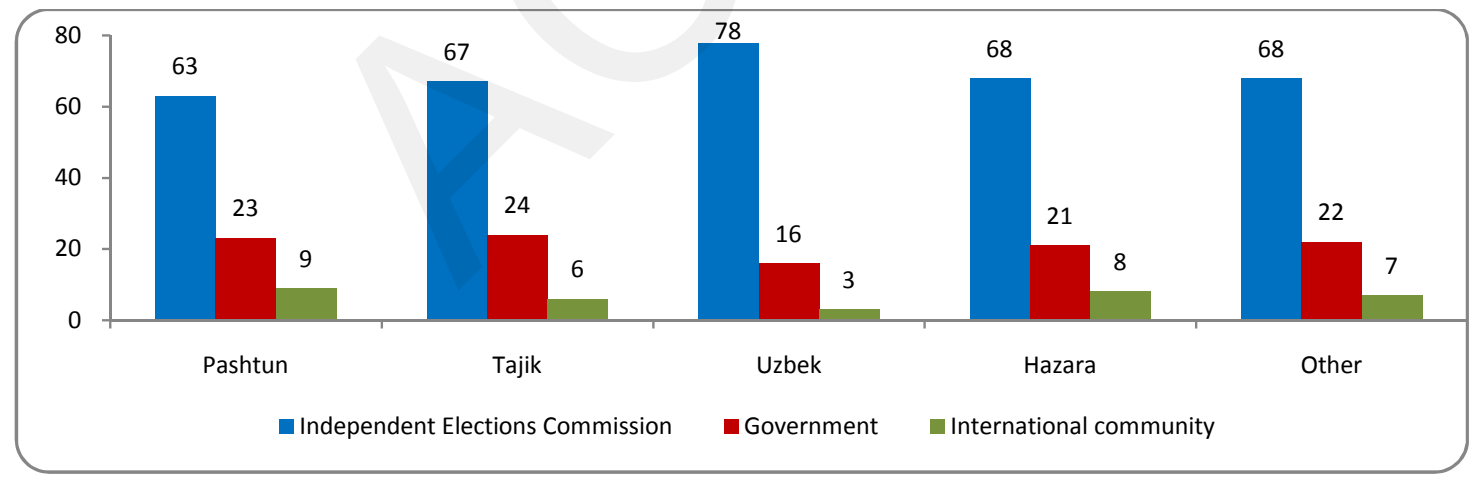

Fig. 9.14

The Independent Election Commission was identified as the body running elections in Afghanistan by more than three quarters of respondents in the North East (76\%) and around two thirds in all other regions (between $63 \%$ and 69\%), except the West (58\%). Some 30\% of respondents in the West, $29 \%$ in the North West and $25 \%$ in the East say the government runs elections. The highest proportion of respondents who say the international community conducts elections in Afghanistan is found in the South West, where 12\% say this. 
In your opinion, who is running elections in Afghanistan? (Q-66, Base-6348) BY REGION

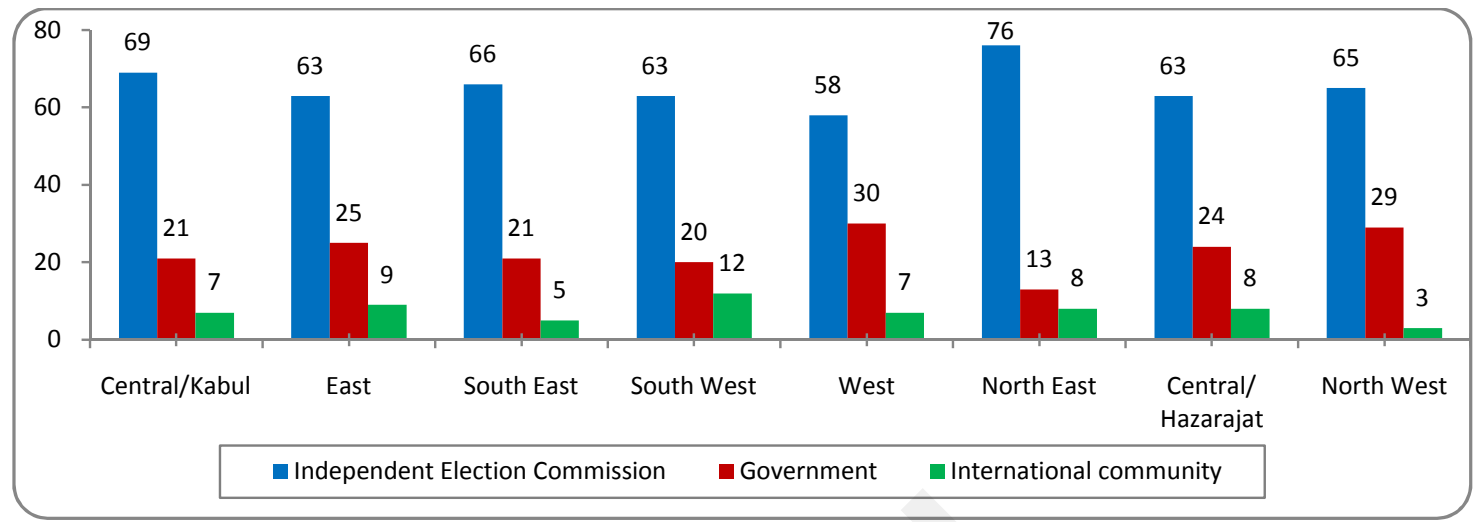

Fig 9.15

\subsection{Elections as a method for choosing leaders}

Respondents were also asked their opinions about the use of elections to select leaders in Afghanistan. A series of statements was read out to respondents and they were asked to say whether they agree or disagree with each of them. The first statement was, "We should choose our leaders in this country through regular, open and honest elections." Ninety percent of respondents agree with this statement, including 67\% who strongly agree and 23\% agree who agree somewhat. More than $90 \%$ of respondents agree with this statement in all regions except the West (86\%) and South West (80\%). Levels of disagreement are almost twice as high in the South West (20\%) as in any other regions (between $5 \%$ and $12 \%$ ).

Table 9.18: We should choose our leaders in this com.....y through regular, open and honest elections (Q-37a, Base 6348) ALL AND BY REGION

\begin{tabular}{|l|c|c|c|c|c|c|c|c|c|} 
& $\begin{array}{c}\text { All } \\
(\%)\end{array}$ & $\begin{array}{c}\text { Central/ } \\
\text { Kabul } \\
(\%)\end{array}$ & $\begin{array}{c}\text { East } \\
(\%)\end{array}$ & $\begin{array}{c}\text { South } \\
\text { East } \\
(\%)\end{array}$ & $\begin{array}{c}\text { South } \\
\text { West } \\
(\%)\end{array}$ & $\begin{array}{c}\text { West } \\
(\%)\end{array}$ & $\begin{array}{c}\text { North } \\
\text { East } \\
(\%)\end{array}$ & $\begin{array}{c}\text { Central/ } \\
\text { Hazarajat } \\
(\%)\end{array}$ & $\begin{array}{c}\text { North } \\
\text { West } \\
(\%)\end{array}$ \\
\hline Agree somewhat and strongly & 90 & 92 & 95 & 92 & 80 & 86 & 91 & 94 & 92 \\
\hline $\begin{array}{l}\text { Disagree somewhat and } \\
\text { strongly }\end{array}$ & 9 & 8 & 5 & 7 & 20 & 12 & 7 & 6 & 8 \\
\hline
\end{tabular}

The following statement was then read out, "Since elections sometimes produce bad results, we should adopt other methods for choosing this country's leaders." A majority of respondents (52\%) disagree with this statement including $21 \%$ who strongly disagree and 31\% who disagree somewhat. This finding confirms support for elections as the best way to select leaders. Two thirds of urban respondents $(66 \%)$ disagree with the idea of using alternative methods, while this is true for just under half of rural respondents (48\%). The majority of Uzbeks (61\%) and respondents from other ethnic groups (59\%) support the use of alternative methods 
to select leaders whereas the majority of Pashtun (56\%), Tajik (52\%) and Hazara (52\%) respondents say they prefer elections.

Since elections sometimes produce bad results, we should adopt other methods for choosing this country's leaders (Q-37b, Base6348) ALL AND BY SETTLEMENT AND ETHNICITY

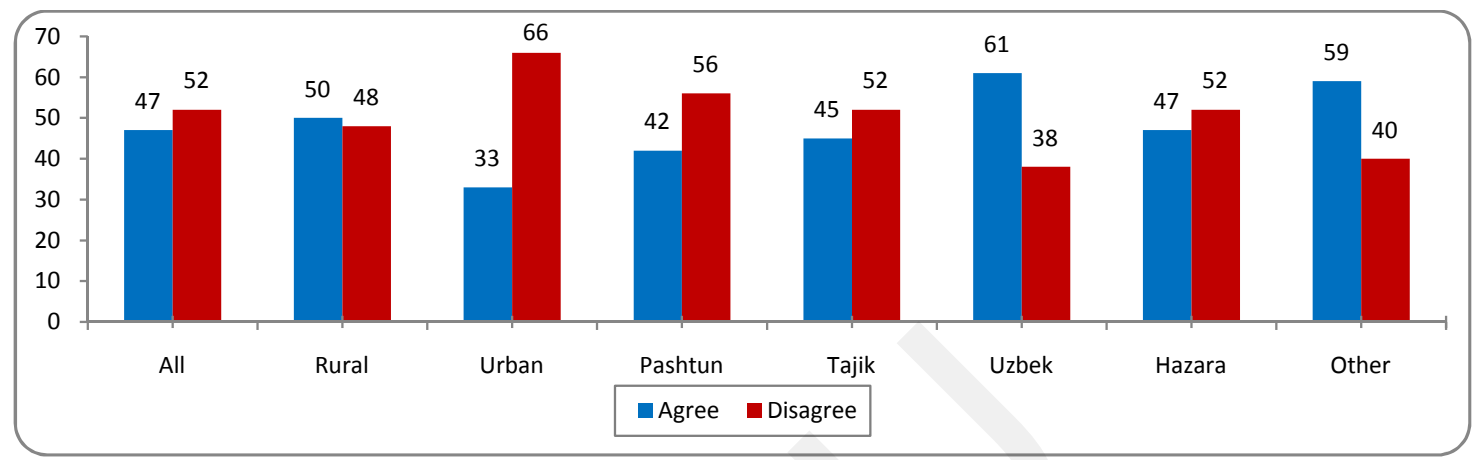

Fig 9.16

Nearly three quarters of respondents in the Central/Hazarajat (73\%) say they are in favor of using alternative means to select leaders, and this is also true for the majority of respondents in the North East (62\%), North West $(61 \%)$ and West (59\%). The majority of respondents, however, prefer elections for this purpose in the South East (70\%), Central/Kabul (69\%), East (62\%) and South West (50\%) regions.

Table 9.19: Since elections sometimes produce bad results, we should adopt other methods for choosing this country's leaders (Q37b, Base-6348) ALL AND BY REGION

\begin{tabular}{|l|c|c|c|c|c|c|c|c|c|} 
& $\begin{array}{c}\text { All } \\
(\mathbf{\%})\end{array}$ & $\begin{array}{c}\text { Central/ } \\
\text { Kabul } \\
\mathbf{( \% )}\end{array}$ & $\begin{array}{c}\text { East } \\
\mathbf{( \% )}\end{array}$ & $\begin{array}{c}\text { South } \\
\text { East } \\
(\mathbf{\%})\end{array}$ & $\begin{array}{c}\text { South } \\
\text { West } \\
(\mathbf{\%})\end{array}$ & $\begin{array}{c}\text { West } \\
\mathbf{( \% )}\end{array}$ & $\begin{array}{c}\text { North } \\
\text { East } \\
\mathbf{( \% )}\end{array}$ & $\begin{array}{c}\text { Central/ } \\
\text { Hazarajat } \\
\mathbf{( \% )}\end{array}$ & $\begin{array}{c}\text { North } \\
\text { West } \\
(\mathbf{\%})\end{array}$ \\
\hline Agree & 47 & 29 & 37 & 27 & 48 & 59 & 62 & 73 & 61 \\
\hline Disagree & 52 & 69 & 62 & 70 & 50 & 38 & 36 & 27 & 39 \\
\hline
\end{tabular}

\subsection{Perceptions of political parties}

The survey also sought to explore perceptions of political parties. Respondents were asked, "Political parties are usually established and serve the interests of various strata of society. At present, the interests of which one of the following do you think the political parties in our country serve the most?" One fourth of respondents $(25 \%)$ say political parties mostly serve the interest of the country as a whole, while $19 \%$ say they serve the interests of broad layers of society. Another 18\% say that parties serve regional interests, $14 \%$ say parties serve group/personal interests and 13\% say they serve ethnic interests. Some 5\% say that parties serve corporate interests (like those of farmers, workers, businessmen, etc.) and $4 \%$ say they serve local interests. 
Political parties are usually established and serve the interests of various strata of society. At present, the interests of which one of the following do you think the political parties in our country serve the most? (Q-36, Base- 6348)

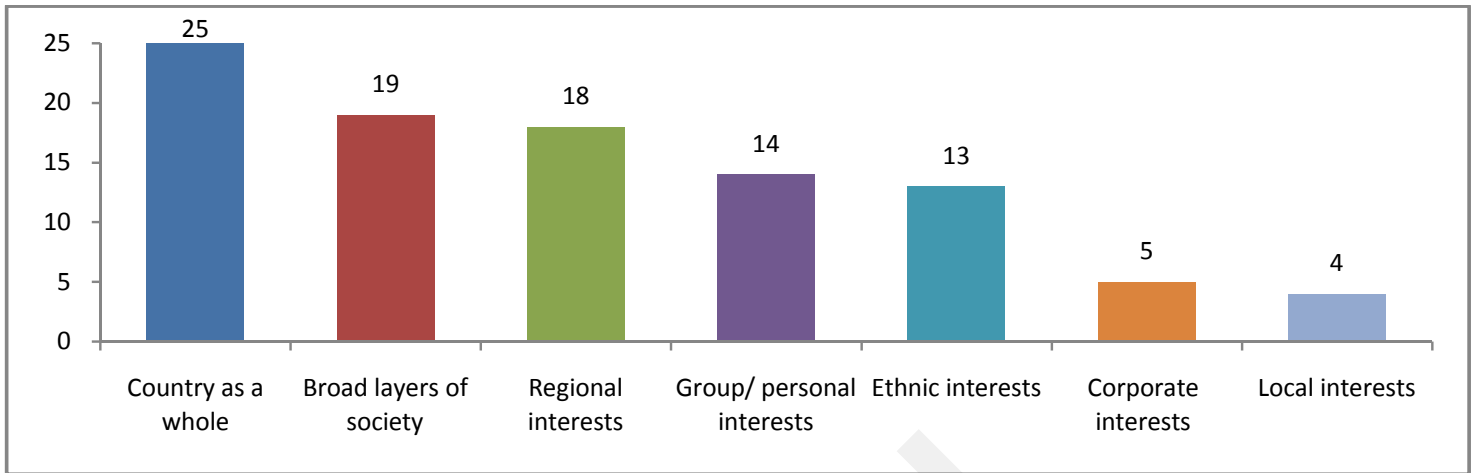

Fig 9.17

In almost all regions, respondents mostly say that political parties represent a broad spectrum of public interests. The view that political parties serve the interest of the country as a whole is the most common response in the North West (31\%) East (28\%), South West (36\%), North East (26\%) and South East (20\%). Similarly, the most common response in the Central/Hazarajat (26\%) and Central/Kabul (21\%) regions is that political parties serve the interests of broad layers of society. In the West, the most common view expressed by respondents is that political parties serve regional interests $(22 \%)$, and this same view is held by just under a fifth of respondents in all other regions (between 15\% and 19\%). A similar proportion of respondents say that political parties serve group/personal interests in the South East (19\%), East (18\%), Central/Kabul (17\%), Central/Hazarajat $(16 \%)$ and West $(15 \%)$, but less than one in 10 respondents in the North East $(9 \%)$, North West $(8 \%)$ and South West $(8 \%)$ say they feel this way.

Table 9.20: Political parties are usually established and serve the interests of various strata of society. At present, the interests of which one of the following, do you think, the political parties in our country serve the most? (Q-36, Base- 6348) ALL AND BY REGION

\begin{tabular}{|c|c|c|c|c|c|c|c|c|c|}
\hline & $\begin{array}{r}\text { All } \\
(\%)\end{array}$ & $\begin{array}{c}\text { Central/ } \\
\text { Kabul } \\
(\%)\end{array}$ & $\begin{array}{c}\text { East } \\
(\%)\end{array}$ & $\begin{array}{c}\text { South } \\
\text { East } \\
(\%)\end{array}$ & $\begin{array}{c}\text { South } \\
\text { West } \\
(\%)\end{array}$ & $\begin{array}{l}\text { West } \\
(\%)\end{array}$ & $\begin{array}{c}\text { North } \\
\text { East } \\
(\%)\end{array}$ & $\begin{array}{c}\text { Central/ } \\
\text { Hazarajat } \\
(\%)\end{array}$ & $\begin{array}{c}\text { North } \\
\text { West } \\
(\%)\end{array}$ \\
\hline Country as a whole & 25 & 20 & 28 & 20 & 36 & 18 & 26 & 23 & 31 \\
\hline Broad layers of society & 19 & 21 & 18 & 12 & 16 & 19 & 23 & 26 & 20 \\
\hline Regional interests & 18 & 16 & 15 & 19 & 17 & 22 & 18 & 16 & 19 \\
\hline Group/personal interest & 14 & 17 & 18 & 19 & 8 & 15 & 9 & 16 & 8 \\
\hline Ethnic interests & 13 & 15 & 11 & 16 & 11 & 15 & 13 & 12 & 12 \\
\hline $\begin{array}{l}\text { Corporate interests (like those of } \\
\text { farmers, workers, businessmen, } \\
\text { etc.) }\end{array}$ & 5 & 4 & 5 & 6 & 7 & 3 & 6 & 4 & 6 \\
\hline Local interests & 4 & 3 & 3 & 5 & 4 & 4 & 4 & 2 & 4 \\
\hline
\end{tabular}


Respondents were also asked if they agree or disagree with the statement, "Political parties create division and confusion; it is therefore unnecessary to have many political parties in Afghanistan." Around two thirds $(68 \%)$ of respondents say they agree with this statement including $37 \%$ who strongly agree and $20 \%$ who agree somewhat. Just under a third (31\%) say they disagree including 20\% who disagree somewhat (20\%) and $11 \%$ who strongly disagree. A higher proportion of urban $(75 \%)$ than rural $(66 \%)$ residents say they agree with this statement.

Around three quarters of respondents in the East (76\%) and Central/Kabul (74\%), and around two thirds in the South East (67\%), North West (67\%) and West (66\%) agree that political parties create division and confusion; it is therefore unnecessary to have many political parties in Afghanistan. However, disagreement with this statement is highest in South West (45\%) and Central/Hazarajat (39\%) regions.

Table 9.21: Political parties create division and confusion; it is therefore unnecessary to have many political parties in Afghanistan (Q-37c, Base-6348) ALL AND BY REGION

\begin{tabular}{|l|c|c|c|c|c|c|c|c|c|} 
& $\begin{array}{c}\text { All } \\
(\mathbf{\%})\end{array}$ & $\begin{array}{c}\text { Central/ } \\
\text { Kabul } \\
(\mathbf{\%})\end{array}$ & $\begin{array}{c}\text { East } \\
(\mathbf{\%})\end{array}$ & $\begin{array}{c}\text { South } \\
\text { East } \\
(\%)\end{array}$ & $\begin{array}{c}\text { South } \\
\text { West } \\
(\%)\end{array}$ & $\begin{array}{c}\text { West } \\
(\mathbf{\%})\end{array}$ & $\begin{array}{c}\text { North } \\
\text { East } \\
(\%)\end{array}$ & $\begin{array}{c}\text { Central/ } \\
\text { Hazarajat } \\
(\%)\end{array}$ & $\begin{array}{c}\text { North } \\
\text { West } \\
(\mathbf{\%})\end{array}$ \\
\hline Agree somewhat and strongly & 68 & 74 & 76 & 67 & 54 & 66 & 67 & 59 & 67 \\
\hline $\begin{array}{l}\text { Disagree somewhat and } \\
\text { strongly }\end{array}$ & 31 & 24 & 24 & 31 & 45 & 31 & 33 & 39 & 32 \\
\hline
\end{tabular}

Respondents were also asked whether they agree or disagree with the following statement, "Many political parties are needed to make sure that Afghans have real choices in who governs them." Forty-three percent of respondents say they agree with this statement, including $19 \%$ who strongly agree and $24 \%$ who agree somewhat. However the majority (55\%) of respondents disagree, including $29 \%$ who disagree somewhat and $26 \%$ who strongly disagree.

The majority of respondents in the Central/Hazarajat (61\%) North West (51\%) and South West (51\%) say that political parties are needed to make sure that Afghans have real choices in who governs them. More than two thirds in the Central/Kabul (68\%) regions and the majority in the South East (62\%), East (59\%) and North East (52\%) disagree with this statement. In the West, opinions are almost equally shared between those who agree that political parties are needed to provide choice (47\%) and those who disagree (49\%). 
Political parties are needed to make sure that Afghans have real choices in who governs them (Q-37d, Base-6348) ALL AND BY REGION

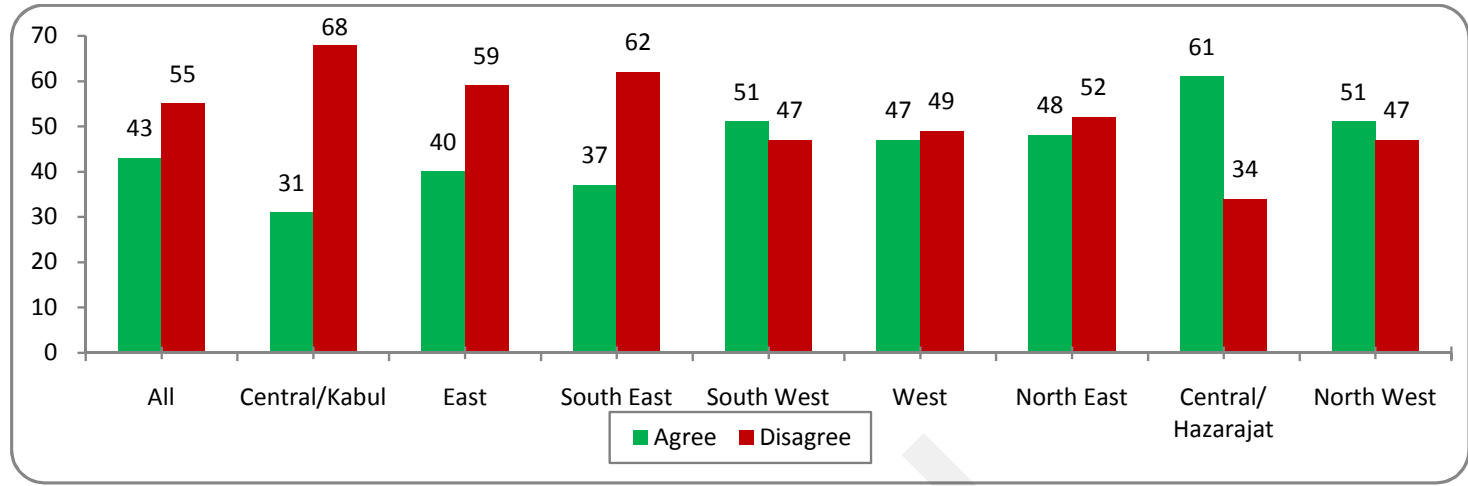

Fig 9.18

\subsection{Constitutional responsibilities of the president and parliament}

The survey sought to examine public views on the constitutional balance of power between the president and parliament. Respondents were asked whether they agree or disagree with the following statement, "Members of parliament represent the people; therefore they should make laws for this country, even if the president does not agree." Overall, more than two thirds (70\%) of respondents say they agree (including 39\% who say they strongly agree) and 28\% say they disagree (including $9 \%$ who say they strongly disagree). More than two thirds of respondents agree with this statement in the Central/Kabul (75\%), East (74\%), North West (72\%), South East (71\%), North East (70\%) and Central/Hazarajat (68\%). Forty percent in the South West and $32 \%$ in the West disagree.

Table 9.22: Members of parliament represent the people; therefore they should make laws for this country, even if the president does not agree (Q-37e, Base- 6348) BY REGION

\begin{tabular}{|l|c|c|c|c|c|c|c|c|c|}
\hline & $\begin{array}{c}\text { All } \\
(\%)\end{array}$ & $\begin{array}{c}\text { Central/ } \\
\text { Kabul } \\
(\%)\end{array}$ & $\begin{array}{c}\text { East } \\
(\%)\end{array}$ & $\begin{array}{c}\text { South } \\
\text { East } \\
(\%)\end{array}$ & $\begin{array}{c}\text { South } \\
\text { West } \\
(\%)\end{array}$ & $\begin{array}{c}\text { West } \\
(\%)\end{array}$ & $\begin{array}{c}\text { North } \\
\text { East } \\
(\%)\end{array}$ & $\begin{array}{c}\text { Central/ } \\
\text { Hazarajat } \\
(\%)\end{array}$ & $\begin{array}{c}\text { North } \\
\text { West } \\
(\%)\end{array}$ \\
\hline $\begin{array}{l}\text { Agree somewhat and } \\
\text { strongly }\end{array}$ & 70 & 75 & 74 & 71 & 57 & 64 & 70 & 68 & 72 \\
\hline $\begin{array}{l}\text { Disagree somewhat } \\
\text { and strongly }\end{array}$ & 28 & 22 & 25 & 28 & 40 & 32 & 28 & 26 & 27 \\
\hline
\end{tabular}

Then respondents were asked their opinion on the statement, "Since the president represents all of us, he should pass laws without worrying about what parliament thinks." Forty-three percent of respondents say they agree with this statement while the majority (55\%) disagree. More urban (66\%) than rural (53\%) re- 
spondents disagree with this statement. At least half of respondents agree with this statement in the Central/ Hazarajat (54\%), North East (53\%), North West (51\%) and West (50\%) regions. The majority disagree in Central/Kabul (70\%), South East (64\%) and East (56\%) regions.

Table 9.23: Since the president represents all of us, he should pass laws without worrying about what parliament thinks (Q37f, Base- 6348) ALL AND BY REGION

\begin{tabular}{|l|c|c|c|c|c|c|c|c|c|} 
& $\begin{array}{c}\text { All } \\
(\%)\end{array}$ & $\begin{array}{c}\text { Central/ } \\
\text { Kabul } \\
(\%)\end{array}$ & $\begin{array}{c}\text { East } \\
(\%)\end{array}$ & $\begin{array}{c}\text { South } \\
\text { East } \\
(\%)\end{array}$ & $\begin{array}{c}\text { South } \\
\text { West } \\
(\%)\end{array}$ & $\begin{array}{c}\text { West } \\
(\%)\end{array}$ & $\begin{array}{c}\text { North } \\
\text { East } \\
(\%)\end{array}$ & $\begin{array}{c}\text { Central/ } \\
\text { Hazarajat } \\
(\%)\end{array}$ & $\begin{array}{c}\text { North } \\
\text { West } \\
(\%)\end{array}$ \\
\hline Agree somewhat and strongly & 43 & 28 & 44 & 34 & 47 & 50 & 53 & 54 & 51 \\
\hline Disagree somewhat and strongly & 55 & 70 & 56 & 64 & 48 & 45 & 46 & 43 & 49 \\
\hline
\end{tabular}

The survey then sought to examine public opinion regarding the limitations of presidential power within the country's legal framework. The statement, “Since the president was elected to lead the country, he should not be bound by laws or court decisions that he thinks are wrong" was read aloud and respondents were asked whether they agree or disagree with this. Sixty-one percent of respondents agree with the statement while over a third (38\%) disagree. The highest levels of agreement with this statement are reported in the East $(72 \%)$, North East (69\%), North West (62\%) and Central/Kabul (62\%) regions. A significant proportion, however, disagrees with the statement in the South East (49\%), South West (44\%), West (41\%) and North West (37\%).

Table 9.24: Since the president was elected to lead the country, he should not be bound by laws or court decisions that he thinks are wrong (Q-37g, Base-6348) ALL AND BY REGION

\begin{tabular}{|l|c|c|c|c|c|c|c|c|c|} 
& $\begin{array}{c}\text { All } \\
(\mathbf{\%})\end{array}$ & $\begin{array}{c}\text { Central/ } \\
\text { Kabul } \\
(\mathbf{\%})\end{array}$ & $\begin{array}{c}\text { East } \\
\mathbf{( \% )}\end{array}$ & $\begin{array}{c}\text { South } \\
\text { East } \\
(\%)\end{array}$ & $\begin{array}{c}\text { South } \\
\text { West } \\
(\%)\end{array}$ & $\begin{array}{c}\text { West } \\
\mathbf{( \% )}\end{array}$ & $\begin{array}{c}\text { North } \\
\text { East } \\
(\%)\end{array}$ & $\begin{array}{c}\text { Central/ } \\
\text { Hazarajat } \\
(\%)\end{array}$ & $\begin{array}{c}\text { North } \\
\text { West } \\
(\%)\end{array}$ \\
\hline Agree somewhat and strongly & 61 & 62 & 72 & 50 & 50 & 53 & 69 & 57 & 62 \\
\hline Disagree somewhat and strongly & 38 & 35 & 28 & 49 & 44 & 41 & 31 & 38 & 37 \\
\hline
\end{tabular}

Respondents were then asked to indicate whether they agree or disagree with the opposite statement, "The president must always obey the laws and the courts, even if he thinks they are wrong." Half of respondents $(50 \%)$ agree with the statement, while just under half (47\%) disagree. More respondents in rural areas (53\%) agree with this statement than do people in urban areas (38\%). The majority of respondents in all regions agree with the statement except in the Central/Kabul and East where the majority disagree. 
Table 9.25: The president must always obey the laws and the courts, even if he thinks they are wrong (Q-37h, Base- 6348) ALL AND BY REGION

\begin{tabular}{|c|c|c|c|c|c|c|c|c|c|}
\hline & $\begin{array}{l}\text { All } \\
(\%)\end{array}$ & $\begin{array}{c}\text { Central/ } \\
\text { Kabul } \\
(\%)\end{array}$ & $\begin{array}{c}\text { East } \\
(\%)\end{array}$ & $\begin{array}{c}\text { South } \\
\text { East } \\
(\%)\end{array}$ & $\begin{array}{c}\text { South } \\
\text { West } \\
(\%)\end{array}$ & $\begin{array}{l}\text { West } \\
(\%)\end{array}$ & $\begin{array}{c}\text { North } \\
\text { East } \\
(\%)\end{array}$ & $\begin{array}{c}\text { Central/ } \\
\text { Hazarajat } \\
(\%)\end{array}$ & $\begin{array}{c}\text { North } \\
\text { West } \\
(\%)\end{array}$ \\
\hline $\begin{array}{l}\text { Agree somewhat and } \\
\text { strongly }\end{array}$ & 50 & 42 & 41 & 53 & 57 & 49 & 54 & 66 & 53 \\
\hline $\begin{array}{l}\text { Disagree somewhat and } \\
\text { strongly }\end{array}$ & 47 & 55 & 58 & 45 & 39 & 45 & 45 & 29 & 46 \\
\hline
\end{tabular}

The survey also sought to measure the Afghan public opinion regarding constitutional limitations of the presidential term of office. Respondents were asked their view on the statement, "The constitution should limit the president to serving a maximum of two terms in office." Nearly three quarters of respondents $(73 \%)$ expressed their agreement with this statement, including strongly agree (41\%) and agree somewhat $(32 \%)$. The majority of respondents in all regions agree with this statement although $42 \%$ disagree in the South West region.

Table 9.26: The constitution should limit the president to serving a maximum of two terms in office (Q-37i, Base- 6348) ALL AND BY REGION

\begin{tabular}{|c|c|c|c|c|c|c|c|c|c|}
\hline & $\begin{array}{l}\text { All } \\
(\%)\end{array}$ & $\begin{array}{c}\text { Central/ } \\
\text { Kabul } \\
(\%)\end{array}$ & $\begin{array}{c}\text { East } \\
(\%)\end{array}$ & $\begin{array}{c}\text { South } \\
\text { East } \\
(\%)\end{array}$ & $\begin{array}{c}\text { South } \\
\text { West } \\
(\%)\end{array}$ & $\begin{array}{l}\text { West } \\
(\%)\end{array}$ & $\begin{array}{l}\text { North } \\
\text { East } \\
(\%)\end{array}$ & $\begin{array}{c}\text { Central/ } \\
\text { Hazarajat } \\
(\%)\end{array}$ & $\begin{array}{c}\text { North } \\
\text { West } \\
(\%)\end{array}$ \\
\hline $\begin{array}{l}\text { Agree somewhat and } \\
\text { strongly }\end{array}$ & 73 & 78 & 78 & 73 & 52 & 61 & 79 & 75 & 78 \\
\hline $\begin{array}{l}\text { Disagree somewhat and } \\
\text { strongly }\end{array}$ & 24 & 20 & 21 & 26 & 42 & 28 & 19 & 21 & 20 \\
\hline
\end{tabular}

Respondents were then asked for their views on the opposite statement, "There should be no constitutional limit on how long the president can serve." Only $35 \%$ of respondents say they agree with this statement while $60 \%$ say they disagree. The level of disagreement is significantly higher among urban respondents (70\%) than among rural (59\%) respondents. Levels of disagreement are particularly high in the Central/Kabul (74\%), North West (64\%), East (65\%) and South East (64\%). The Central/Hazarajat is the only region where the majority of respondents $(59 \%)$ agree with the statement. 
Table 9.27: There should be no constitutional limit on how long the president can serve (Q-37j, Base- 6348) ALL AND BY REGION

\begin{tabular}{|c|c|c|c|c|c|c|c|c|c|}
\hline & $\begin{array}{l}\text { All } \\
(\%)\end{array}$ & $\begin{array}{c}\text { Central/ } \\
\text { Kabul } \\
(\%)\end{array}$ & $\begin{array}{l}\text { East } \\
(\%)\end{array}$ & $\begin{array}{c}\text { South } \\
\text { East } \\
(\%)\end{array}$ & $\begin{array}{c}\text { South } \\
\text { West } \\
(\%)\end{array}$ & $\begin{array}{l}\text { West } \\
(\%)\end{array}$ & $\begin{array}{c}\text { North } \\
\text { East } \\
(\%)\end{array}$ & $\begin{array}{c}\text { Central/ } \\
\text { Hazarajat } \\
(\%)\end{array}$ & $\begin{array}{c}\text { North } \\
\text { West } \\
(\%)\end{array}$ \\
\hline $\begin{array}{l}\text { Agree somewhat and } \\
\text { strongly }\end{array}$ & 35 & 24 & 33 & 34 & 40 & 43 & 38 & 59 & 35 \\
\hline $\begin{array}{l}\text { Disagree somewhat and } \\
\text { strongly }\end{array}$ & 60 & 74 & 65 & 64 & 52 & 46 & 58 & 35 & 64 \\
\hline
\end{tabular}

Taken together, the answers to these questions give some insights into public opinion regarding the constitutional powers and mandates of the president and parliament. Responses to the first two questions show that the majority of respondents feel that it is parliament that should take the leading role in making laws for the country, and that the president should not be able to impede parliament from carrying out this role $(70 \%)$. A minority of respondents (43\%) say that the president should be able to pass laws without taking into account the views of parliament. The highest levels of support for the president to make laws without considering parliament are found in the Central/Hazarajat (54\%), North East (53\%), North West (51\%) and West (50\%).

Responses to the two questions that followed reveal significant support for the idea that the president should be able to act outside of the national legal and judicial framework (61\%). Just half of respondents say that the president should exercise his powers within the legal framework of the country and be bound by decisions made by the courts (50\%). This may be due to the low levels of confidence that respondents have in the judicial system compared to other public institutions (see Chapter 7; 7.1 Confidence in public institutions). The highest levels of support for the idea that the president should be considered above the law are found in the East $(72 \%)$ followed again by the North East (69\%) and North West (62\%) and in the Central/Kabul $(62 \%)$ regions.

Responses to the final two questions confirm significant support for the existence of constitutional limitations on the presidential mandate. Nearly three quarters of respondents nationally support a constitutional limitation of two terms of office for the president. Only 35\% of respondents say that there should be no limit to the number of terms a president can serve. The highest levels of support for unlimited presidential terms of office are found in the Central/Hazarajat (59\%), West (43\%) and South West (40\%). Around a third of Uzbeks (33\%) and Tajiks (32\%) believe that the president's term should be limited, however 36\% of Pashtuns, $38 \%$ of Hazaras and $45 \%$ of respondents from other ethnic groups think that there should be no constitutional limit on how long the president can serve.

At a national level, there is agreement for constitutional limitations to the length of the president's mandate and the presidential role in lawmaking. Yet beyond this, the majority of respondents say the president should be free to act without constraints from the legal and judicial system. There is no clear regional dimension to these views, however there is a divergence between ethnic groups. 
Table 9.28: Agreement with statements related to the constitutional roles of the president and parliament (Q37e-j, TOTAL AGREE RESPONSES, (Base- 6348) ALL AND BY REGION

\begin{tabular}{|c|c|c|c|c|c|c|c|c|c|}
\hline & $\begin{array}{l}\text { All } \\
(\%)\end{array}$ & $\begin{array}{c}\text { Central/ } \\
\text { Kabul } \\
(\%)\end{array}$ & $\begin{array}{c}\text { East } \\
(\%)\end{array}$ & $\begin{array}{c}\text { South } \\
\text { East } \\
(\%)\end{array}$ & $\begin{array}{c}\text { South } \\
\text { West } \\
(\%)\end{array}$ & $\begin{array}{l}\text { West } \\
(\%)\end{array}$ & $\begin{array}{c}\text { North } \\
\text { East } \\
(\%)\end{array}$ & $\begin{array}{c}\text { Central/ } \\
\text { Hazarajat } \\
(\%)\end{array}$ & $\begin{array}{c}\text { North } \\
\text { West } \\
(\%)\end{array}$ \\
\hline $\begin{array}{l}\text { MPs should make laws for this country, even if the } \\
\text { president does not agree }\end{array}$ & 70 & 75 & 74 & 71 & 57 & 64 & 70 & 68 & 72 \\
\hline $\begin{array}{l}\text { The president should pass laws without worrying about } \\
\text { what parliament thinks }\end{array}$ & 43 & 28 & 44 & 34 & 47 & 50 & 53 & 54 & 51 \\
\hline $\begin{array}{l}\text { The president should not be bound by laws or court } \\
\text { decisions that he thinks are wrong }\end{array}$ & 61 & 62 & 72 & 50 & 50 & 53 & 69 & 57 & 62 \\
\hline $\begin{array}{l}\text { The president must always obey the laws and the courts, } \\
\text { even if he thinks they are wrong }\end{array}$ & 50 & 42 & 41 & 53 & 57 & 49 & 54 & 66 & 53 \\
\hline $\begin{array}{l}\text { The constitution should limit the president to serving a } \\
\text { maximum of two terms }\end{array}$ & 73 & 78 & 78 & 73 & 52 & 61 & 79 & 75 & 78 \\
\hline $\begin{array}{l}\text { There should be no constitutional limit on how long the } \\
\text { president can serve }\end{array}$ & 35 & 24 & 33 & 34 & 40 & 43 & 38 & 59 & 35 \\
\hline
\end{tabular}

Respondents were also asked about the most important responsibility of their members of parliament. A series of statements related to responsibility of MPs was read out to respondents and they were asked to choose among those statements. Thirty-three percent of respondents say their MPs' most important job is to make laws for the good of the country while $29 \%$ say it is to listen to constituents and represent their needs. Twenty-six percent say delivering jobs or development is a MP's most important responsibility. A relatively higher proportion of respondents in urban areas (39\%) say MPs are responsible for making laws for the good of the country compared to their rural counterparts $(31 \%)$.

Members of parliament have various responsibilities. Which of the following do you think is the most important responsibility of your member of parliament? (Q-38, Base- 6348) ALL AND BY SETTELMENT

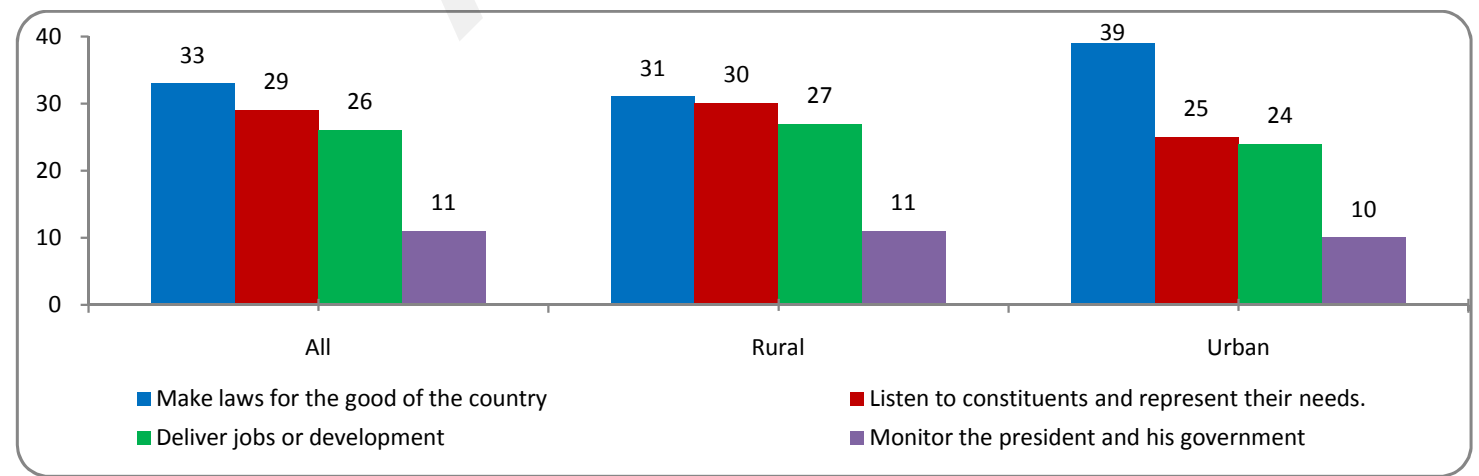

Fig 9.19 
The responses for this question varied according to region. Most respondents identify making laws for the good of the country as the most important responsibility of MPs in the Central/Kabul (42\%), West (32\%), North East (35\%) and North West (35\%), while most respondents in the East (48\%), South East (32\%) and South West $(40 \%)$ identify listening to constituents and representing their needs. In Central/Hazarajat, the most commonly identified responsibility of MPs (35\%) is delivery of jobs and development.

Table 9.29: Members of the parliament have various responsibilities. Which of the following do you think is the most important responsibility of your member of parliament? (Q-38, Base-6348) ALL AND BY REGION

\begin{tabular}{|l|c|c|c|c|c|c|c|c|c|} 
& $\begin{array}{c}\text { All } \\
\mathbf{( \% )}\end{array}$ & $\begin{array}{c}\text { Central/ } \\
\text { Kabul } \\
(\mathbf{\%})\end{array}$ & $\begin{array}{c}\text { East } \\
\mathbf{( \% )}\end{array}$ & $\begin{array}{c}\text { South East } \\
\mathbf{( \% )}\end{array}$ & $\begin{array}{c}\text { South } \\
\text { West } \\
\mathbf{( \% )}\end{array}$ & $\begin{array}{c}\text { West } \\
\mathbf{( \% )}\end{array}$ & $\begin{array}{c}\text { North } \\
\text { East } \\
\mathbf{( \% )}\end{array}$ & $\begin{array}{c}\text { Central/ } \\
\text { Hazarajat } \\
\mathbf{( \% )}\end{array}$ & $\begin{array}{c}\text { North } \\
\text { West } \\
\mathbf{( \% )}\end{array}$ \\
\hline $\begin{array}{l}\text { Listen to constituents } \\
\text { and represent their } \\
\text { needs }\end{array}$ & 29 & 20 & 48 & 32 & 40 & 26 & 24 & 18 & 29 \\
$\begin{array}{l}\text { Deliver jobs or } \\
\text { development }\end{array}$ & 26 & 25 & 19 & 25 & 30 & 31 & 28 & 35 & 22 \\
\hline $\begin{array}{l}\text { Make laws for the } \\
\text { good of the country }\end{array}$ & 33 & 42 & 23 & 29 & 23 & 32 & 35 & 29 & 35 \\
\hline $\begin{array}{l}\text { Monitor the president } \\
\text { and his government }\end{array}$ & 11 & 11 & 9 & 13 & 6 & 8 & 13 & 13 & 12 \\
\hline
\end{tabular}




$$
\text { pe }
$$




\section{Justice Systems}

\subsection{Dispute resolution}

The survey sought to examine public opinion of formal and informal institutions for resolving disputes within communities. Respondents were asked if, in the past year, their community has had a dispute they could not resolve themselves and therefore had to ask for help or cooperation from others. A quarter of respondents $(25 \%)$ report that their community has had such a dispute within the past year, while the majority $(73 \%)$ say they did not. More rural respondents $(28 \%)$ report taking community disputes for resolution outside the community than their urban counterparts $(16 \%)$. Around a third of respondents report taking a community dispute for resolution elsewhere in the South East (33\%), West (31\%), East (29\%) and North East (27\%), around a quarter say they did this in the North West $(25 \%)$ and South West $(24 \%)$ and around a fifth in the Central/ Hazarajat (21\%). Use of dispute resolution mechanisms is the lowest in the Central/Kabul region (17\%).

Sometimes people and communities have problems, related to an issue that concerns everybody in their area, that they can't resolve on their own and so they bave to ask for the help of a government or a non-government person, group or agency. In the past 1 year, has your community bad such a problem in your area that you had to ask. for help or cooperation to resolve? (Q-67, Base6348) BY REGION

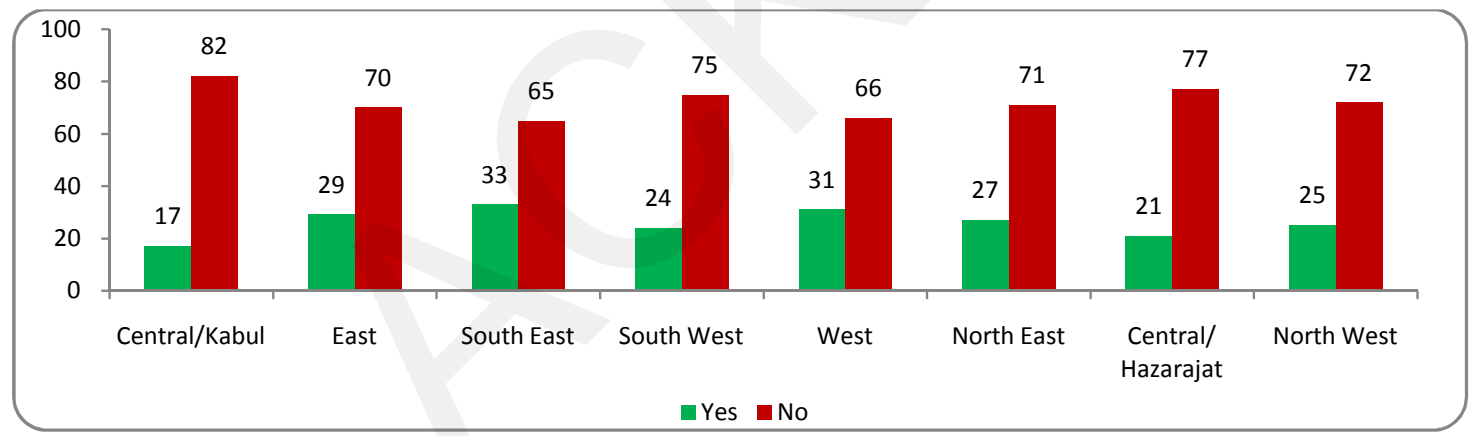

Fig. 10.1

Trend analysis shows that the incidence of community disputes taken for resolution elsewhere has increased over time. In 2007, 16\% of respondents reported that their community had taken a dispute for resolution elsewhere in the last year. This figure has risen to $25 \%$ in 2011. 
Sometimes people and communities have problems, related to an issue that concerns everybody in their area, that they can't resolve on their own and so they have to ask for the help of a government or a non-government person, group or agency. In the past 1 year, has your community had such a problem in your area that you had to ask. for help or cooperation to resolve? Q-67 (COMPARISON BETWEEN 2007, 2008, 2009, 2010 AND 2011)

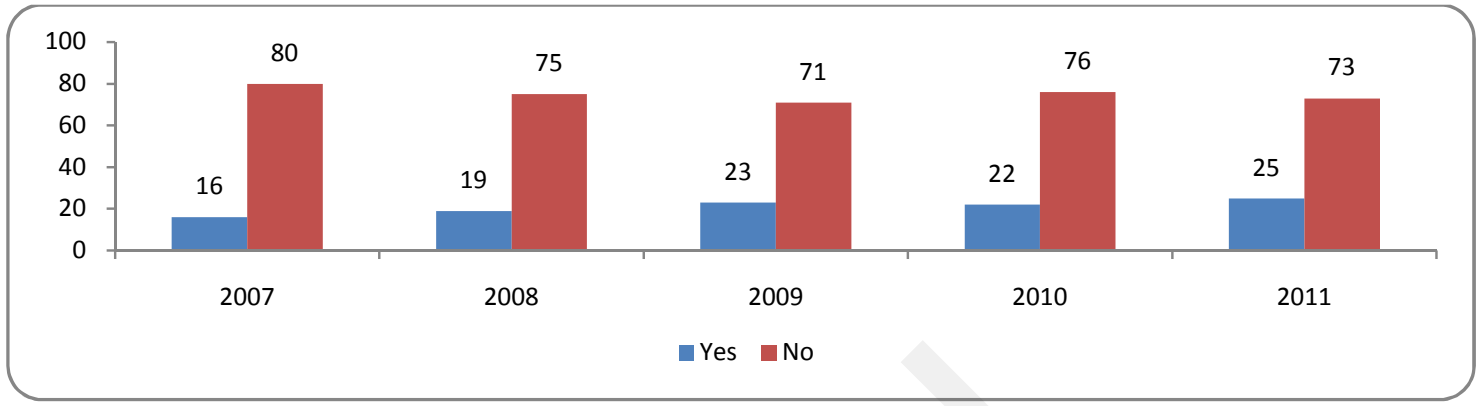

Fig. 10.2

Respondents who took community disputes for resolution elsewhere ( $25 \%$ of all the respondents) were further asked about the nature of the problem. The most frequently identified problems were disputes over land, reported by around a fifth $(21 \%)$ of those who had sought assistance with dispute resolution. Problems related to public infrastructure were also commonly cited including disputes related to lack of water and electricity $(18 \%)$ and reconstruction of roads and bridges (7\%). Security problems were cited by $7 \%$, and a further $5 \%$ specifically cited robbery/burglary. Around one in 20 respondents cited problems within or between social groups including tribal problems $(6 \%)$ and family problems (8\%). Legal disputes were cited by 5\%.

Disputes over land have regularly been the most common reason for communities to seek dispute resolution (28\% in 2007, 21\% in 2010 and $21 \%$ in 2011), although in 2009 disputes related to lack of water and electricity were at the top of the list $(21 \%)$.

The 2011 survey findings show that community disputes over land are most common in the East (34\%), followed by the South West (27\%), West (25\%), Central/Kabul (24\%) and South East (20\%) regions, and infrastructure problems related to lack of water and electricity are most often reported in the North East $(37 \%)$ and North West (18\%). 
Table 10.1: What kind of problem was/is that? (Q-68, Base 1603) ALL AND BY REGION

\begin{tabular}{|c|c|c|c|c|c|c|c|c|c|}
\hline Q- 68 & $\begin{array}{l}\text { All } \\
(\%)\end{array}$ & $\begin{array}{c}\text { Central/ } \\
\text { Kabul } \\
(\%)\end{array}$ & $\begin{array}{c}\text { East } \\
(\%)\end{array}$ & $\begin{array}{c}\text { South } \\
\text { East } \\
(\%)\end{array}$ & $\begin{array}{c}\text { South } \\
\text { West } \\
(\%)\end{array}$ & $\begin{array}{l}\text { West } \\
(\%)\end{array}$ & $\begin{array}{c}\text { North } \\
\text { East } \\
(\%)\end{array}$ & $\begin{array}{c}\text { Central/ } \\
\text { Hazarajat } \\
(\%)\end{array}$ & $\begin{array}{c}\text { North } \\
\text { West } \\
(\%)\end{array}$ \\
\hline Dispute over land & 21 & 24 & 34 & 20 & 27 & 25 & 14 & 14 & 12 \\
\hline Lack of water and electricity & 18 & 14 & 9 & 17 & 16 & 11 & 37 & 13 & 18 \\
\hline Security problems & 7 & 8 & 8 & 7 & 8 & 9 & 5 & 0 & 5 \\
\hline Robbery and burglary & 5 & 6 & 4 & 3 & 6 & 5 & 7 & 0 & 6 \\
\hline $\begin{array}{l}\text { Reconstruction of roads and } \\
\text { bridges }\end{array}$ & 7 & 10 & 1 & 11 & 4 & 4 & 7 & 17 & 7 \\
\hline $\begin{array}{l}\text { Building schools and } \\
\text { kindergartens }\end{array}$ & 4 & 3 & 2 & 9 & 1 & 2 & 3 & 15 & 3 \\
\hline Tribal problems & 6 & 2 & 6 & 9 & 2 & 12 & 3 & 2 & 7 \\
\hline Family problems & 8 & 6 & 13 & 6 & 10 & 11 & 5 & 4 & 10 \\
\hline Economic problems & 2 & 3 & 0 & 0 & 1 & 2 & 1 & 8 & 6 \\
\hline Legal disputes & 5 & 6 & 9 & 5 & 5 & 6 & 4 & 4 & 2 \\
\hline
\end{tabular}

The survey findings show that respondents' views differ across ethnic groups and income groups. Disputes over land are more often reported by Hazaras (22\%) followed by Uzbeks (19\%), but less by Pashtuns (16\%). Disputes related to lack of water and electricity are more often reported by Pashtun respondents $(25 \%)$. Relatively more Pashtuns (8\%) also report security problems than do, for instance, Uzbeks (1\%). A relatively high proportion of Pashtuns (11\%) also cite family-related problems whereas tribal problem are more often identified by Hazara's (12\%) compared to other communities. Economic problems are cited by a sizeable number of Uzbeks $(8 \%)$.

More middle income households (earning between 5,000-10,000 Afs a month [23\%] cite disputes related to electricity and water compared to those in the highest income bracket $[10,000+$ Afs a month] $(13 \%)$.

Table 10.2: What kind of problem was/is that? (Q-68, Base 1603) ALL AND BY ETHNICITY

\begin{tabular}{|l|c|c|c|c|c|c|}
\hline \multicolumn{1}{|c|}{ Q- 68 } & $\begin{array}{c}\text { All } \\
\mathbf{( \% )}\end{array}$ & $\begin{array}{c}\text { Pashtun } \\
\mathbf{( \% )}\end{array}$ & $\begin{array}{c}\text { Tajik } \\
\mathbf{( \% )}\end{array}$ & $\begin{array}{c}\text { Uzbek } \\
\mathbf{( \% )}\end{array}$ & $\begin{array}{c}\text { Hazara } \\
(\mathbf{\%})\end{array}$ & $\begin{array}{c}\text { Other } \\
(\mathbf{\%})\end{array}$ \\
\hline Dispute over land & 21 & 16 & 18 & 19 & 22 & 17 \\
\hline Lack of water and electricity & 18 & 25 & 18 & 18 & 18 & 23 \\
\hline Security problems & 7 & 8 & 6 & 1 & 6 & 7 \\
\hline Robbery and burglary & 5 & 3 & 8 & 7 & 2 & 7 \\
\hline $\begin{array}{l}\text { reconstruction of roads and } \\
\text { bridges }\end{array}$ & 7 & 6 & 8 & 3 & 8 & 8 \\
\hline Building schools and kindergartens & 4 & 5 & 2 & 4 & 7 & 0 \\
\hline Tribal problems & 6 & 4 & 7 & 7 & 12 & 8 \\
\hline Family problems & 8 & 11 & 6 & 9 & 3 & 10 \\
\hline Economic problems & 2 & 1 & 2 & 8 & 4 & 1 \\
\hline Legal disputes & 5 & 5 & 6 & 3 & 7 & 4 \\
\hline
\end{tabular}


Respondents who had taken disputes for resolution (25\% of all the respondents) were then asked who they approached or asked to solve the problem. Respondents were asked to name up to three institutions. The largest proportions of respondents say they took their disputes to a local shura or jirga for resolution (66\%). A substantial proportion also say they took their disputes to local government institutions such as district authorities (35\%), local malik/khans (28\%) and the provincial governor/authorities (17\%). More then quarter of respondents approached the Afghan National Police (ANP) (28\%) and 14\% approached the Afghan National Army (ANA). Other influential local people and institutions that were approached to assist with dispute resolution include mullahs $(23 \%)$ and community development councils (16\%). Seventeen percent of respondents approached a government agency. Only a small number of respondents approached external agencies such as NGOs $(6 \%)$, provincial reconstruction teams (PRT) $(2 \%)$, foreign forces $(2 \%)$ or a specialized national institution like the Human Rights Commission (3\%). Only 1\% report taking community disputes to friends and family for resolution.

Table 10.3: Who did you approach/ ask to solve the problem? (Q-69a,b and c, Base 1603)

\begin{tabular}{l} 
Elders of the local shura/jirga \\
District authorities \\
Malik/khan \\
Afghan National Police \\
Mullah \\
Provincial governor/authorities \\
Government agency/office \\
Community development council \\
Afghan National Army \\
Member of parliament \\
NGO \\
\hline Human Rights Commission \\
Provincial reconstruction team (PRT) \\
Foreign forces \\
Friends and family
\end{tabular}

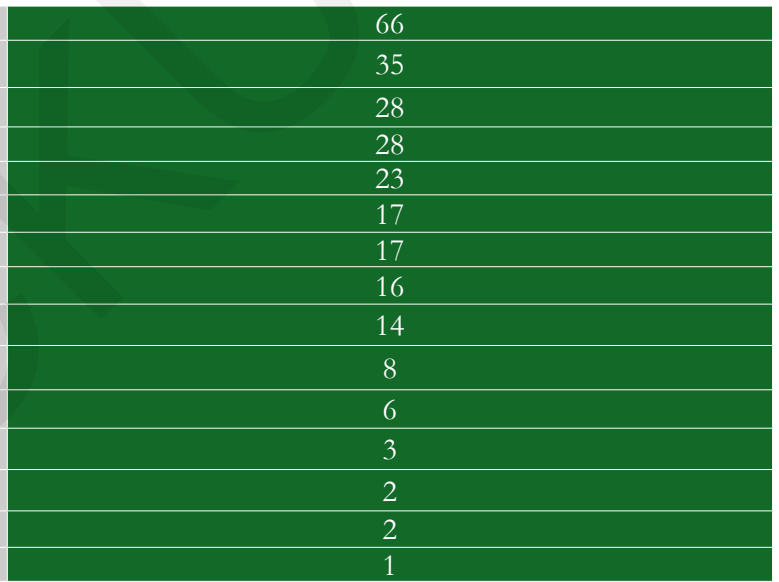

Disputes over land, which are the most common form of disputes taken for resolution, were addressed to a wide variety of institutions including mullah (25\%), malik/khan (25\%), shura/jirga (24\%), government agencies $(22 \%)$, the ANP $(22 \%)$, district authorities (20\%), provincial governor $(18 \%)$. These findings suggest that respondents more frequently address such disputes to the institutions that are the closest to their local community.

Aside from disputes over land, the most common issues taken to shura/jirga are disputes over lack of water and electricity (19\%) and family problems (9\%). The same is true for malik/khans and mullahs, who are also most frequently approached with disputes about lack of water and electricity ( $22 \%$ for maliks, $14 \%$ for mullahs) and family problem (10\% for maliks, $13 \%$ for mullahs). 
Local government and government agencies are most commonly approached with community disputes over public service provision, including lack of water and electricity (23\% approached provincial governors, $21 \%$ approached district authorities and 19\% approached government agencies). The same is true for reconstruction of roads and bridges (10\% approached provincial governors, $6 \%$ approached district authorities and $7 \%$ approached government agencies). However, a small proportion of respondents also approached district authorities to address social problems including tribal problems $(8 \%)$ and security problems $(8 \%)$.

The ANP is most often approached with security problems (14\%), followed by robbery and burglary $(12 \%)$.

A small proportion of respondents say they referred legal disputes to a dispute resolution mechanism, with almost equal numbers taking such disputes to the different institutions identified (between $4 \%$ and $8 \%$ ).

Table10.4: What kind of problem was that? (Q-68 by Q69, Base 1603) BY PLACE APPROACHED TO SOLVE THE PROBLEM

\begin{tabular}{|c|c|c|c|c|c|c|c|}
\hline & $\begin{array}{c}\text { Shura/ } \\
\text { Jirga } \\
(\%)\end{array}$ & $\begin{array}{l}\text { Government } \\
\text { Agency } \\
(\%)\end{array}$ & $\begin{array}{c}\text { ANP } \\
(\%)\end{array}$ & $\begin{array}{l}\text { Malik/ } \\
\text { Khan } \\
(\%)\end{array}$ & $\begin{array}{l}\text { Provincial } \\
\text { Governor } \\
\quad(\%)\end{array}$ & $\begin{array}{l}\text { District } \\
\text { Auth. } \\
(\%)\end{array}$ & $\begin{array}{c}\text { Mullah } \\
(\%)\end{array}$ \\
\hline Lack of water and electricity & 19 & 16 & 7 & 22 & 23 & 21 & 14 \\
\hline \multirow{3}{*}{$\begin{array}{l}\text { Dispute over land } \\
\text { Reconstruction of roads and } \\
\text { bridges } \\
\text { Robbery and burglary }\end{array}$} & 24 & 22 & 22 & 25 & 18 & 20 & 25 \\
\hline & 6 & 7 & 4 & 5 & 10 & 6 & 4 \\
\hline & 5 & 4 & 12 & 5 & 2 & 5 & 5 \\
\hline Tribal problem & 6 & 3 & 7 & 6 & 6 & 8 & 9 \\
\hline Security problems & 5 & 5 & 14 & 5 & 6 & 8 & 4 \\
\hline Family problem & 9 & 6 & 8 & 10 & 5 & 5 & 13 \\
\hline Legal disputes & 6 & 6 & 6 & 6 & 4 & 4 & 8 \\
\hline
\end{tabular}

Respondents who approached a government agency/office to resolve community problems were asked which agency/office that was. Around a quarter say they approached the district governor $(24 \%)$ or the courts $(24 \%)$. Around one in 20 say they approached the provincial governor $(7 \%)$, the police $(5 \%)$, the directorate of water and power (5\%), the Ministry of Rural Rehabilitation and Development (MRRD) (5\%) or the municipality (5\%). A very small proportion contacted the Independent Human Rights Commission (2\%). 
You said you contacted a government agency/ office to resolve your problem. Which government agency/office is that? $(Q-70$, Base- 270)

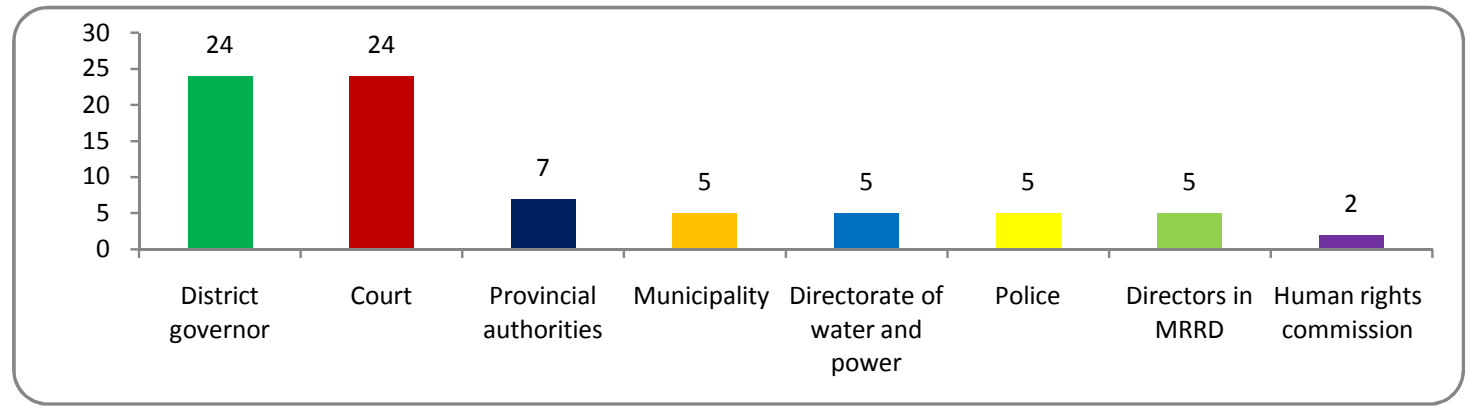

Fig. 10.3

Respondents who had taken community disputes for resolution ( $25 \%$ of all the respondents) were then asked whether the problem for which they sought help has been resolved. More than half $(56 \%)$ report that the problem has been resolved, while just over a third (36\%) say the problem is still pending resolution and $7 \%$ say they don't know.

There are also differences between regions. Over two thirds of respondents report that their problem has been resolved in the South West (72\%) and East (67\%). This is also true for the majority of respondents in the West (60\%), South East (58\%), North West (54\%) and Central/Kabul (46\%). However, the majority in the North East (50\%) and Central/Hazarajat (50\%) regions say their disputes are still pending resolution.

Has this problem been resolved or it's still pending resolution? (Filtered, Q-71, Base 1603) BY REGION

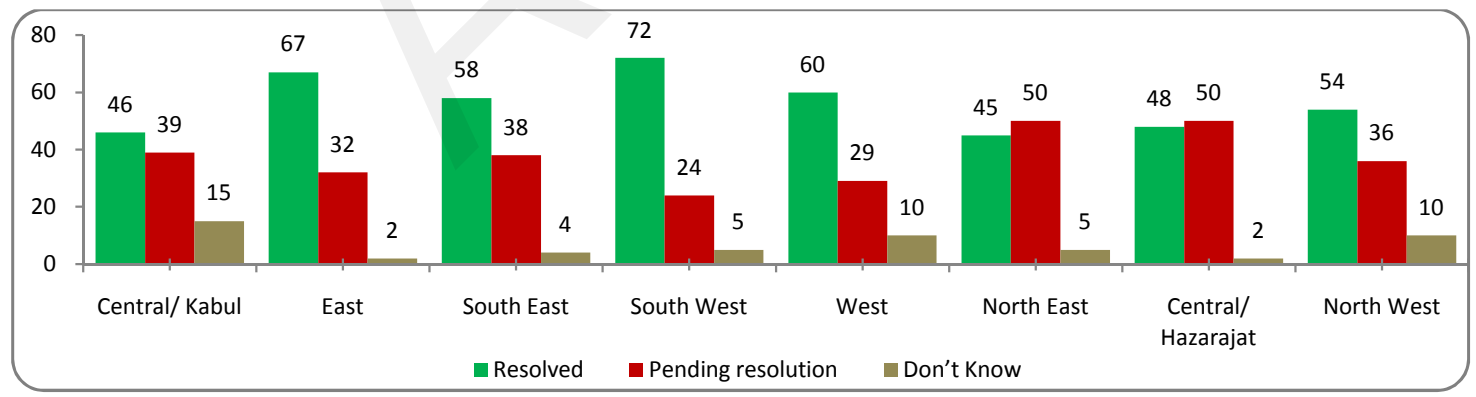

Fig. 10.4

In examining resolution rates for disputes taken to different institutions, it becomes clear that dispute resolution mechanisms that are strongly anchored in local communities are amongst the most effective in resolving disputes. Around two thirds of respondents who submitted disputes to mullahs $(70 \%)$ and malik $/ \mathrm{khans}$ $(64 \%)$ say their dispute has been resolved, and this is also true for the majority who took their dispute to local shura and jirga (59\%). 
The Afghan National Police (ANP), which has a specific mandate for addressing crime and security problems, also has a high success rate with $62 \%$ of those who took community disputes to the ANP saying these have now been resolved.

Local government institutions that have wide mandates have somewhat lower resolution rates, although the majority of respondents who took disputes to government agencies (52\%) and district authorities (51\%), still report that their dispute was resolved. The majority of those who took their dispute to the higher administrative level of the provincial governor say their dispute is still pending resolution (51\%).

Table 10.5: Has this problem been resolved or it is still pending resolution? (Q-71, Base 1603) BY PLACE APPROACHED TO SOLVE THE PROBLEM

\begin{tabular}{|l|c|c|c|c|c|c|c|}
\hline & $\begin{array}{c}\text { Shura/ } \\
\text { Jirga } \\
(\%)\end{array}$ & $\begin{array}{c}\text { Government } \\
\text { Agency } \\
(\%)\end{array}$ & $\begin{array}{c}\text { ANP } \\
(\%)\end{array}$ & $\begin{array}{c}\text { Malik/ } \\
\text { Khan } \\
(\%)\end{array}$ & $\begin{array}{c}\text { Provincial } \\
\text { Governor } \\
(\%)\end{array}$ & $\begin{array}{c}\text { District } \\
\text { Auth. } \\
(\%)\end{array}$ & Mullah \\
\hline Resolved & 59 & 52 & 62 & 64 & 47 & 51 & 70 \\
\hline Pending resolution & 34 & 47 & 31 & 30 & 51 & 44 & 24 \\
\hline Don't know & 6 & 2 & 7 & 5 & 2 & 6 & 7 \\
\hline
\end{tabular}

Respondents who say that the problem was resolved were further asked how long it took to resolve. Almost two thirds (64\%) say their community dispute was resolved within a month including $28 \%$ who say within one week, $29 \%$ who say within one month and $7 \%$ who say their dispute was resolved within one day. However, more than a third of respondents (35\%) report much longer time frames for resolution including 18\% who say more than three months, $10 \%$ who say more than six months and $7 \%$ who say more than one year.

Respondents were asked whether, in the past two years, they personally had a dispute or a formal case that they could not settle with another party and had to go to a state court or village/neighborhood-based shura/ jirga to resolve it. Around one in five respondents (20\%) report having taken a dispute for resolution to one of these bodies. A higher proportion of men (23\%) than women (15\%) report taking a dispute for resolution to one of these bodies. Likewise, more rural $(22 \%)$ than urban $(11 \%)$ residents report doing so. Individuals' use of these dispute resolution mechanisms is highest in the South East (31\%), and East (31\%), followed by the South West (25\%), West (23\%), and North East (20\%). Less than one in six respondents say they took a dispute to one of these bodies for resolution in the Central/Hazarajat (15\%) and North West (14\%) and less than one in 10 say they did this in the Central/Kabul region (9\%). 
In the past two years have you had a dispute or a formal case that you couldn't settle with the other party and had to go to a state court or village/ neighborhood-based shura/jirga to resolve it? (Q-73, Base 6348) BY REGION

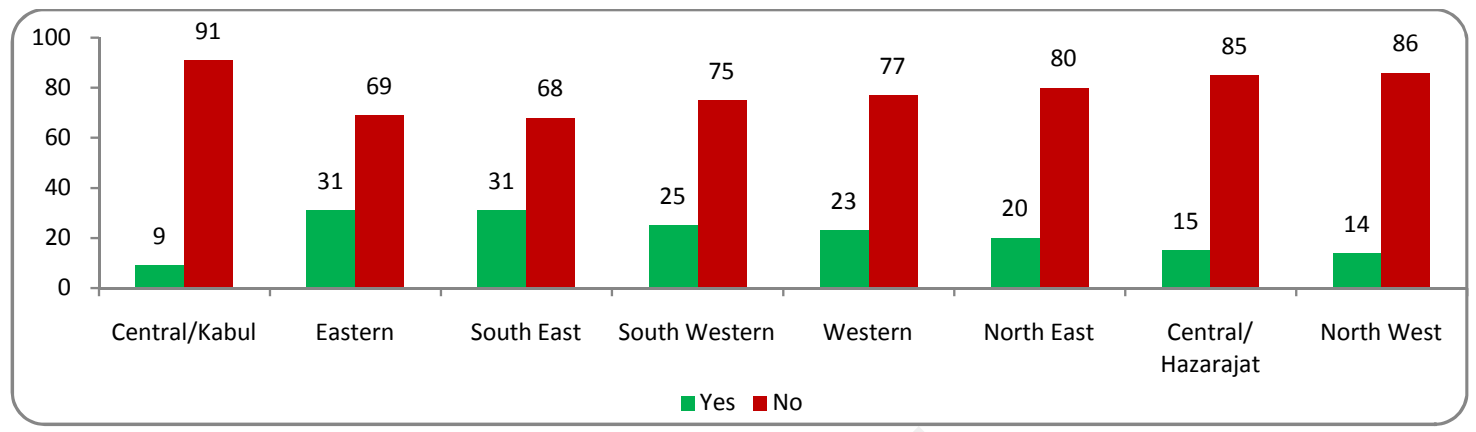

Fig. 10.5

Regardless of where they had taken their personal case, respondents were asked what kind of case or dispute they had taken for resolution. More than half of cases were disputes over land (59\%) which is by far the most common cause of contention (see above). Property disputes other than land were the second most common cause $(9 \%)$, followed by commercial disputes $(8 \%)$, robbery/burglary $(8 \%)$ and physical assault $(8 \%)$.

What kind of a case or dispute was it? (Q-74, Base 1250)

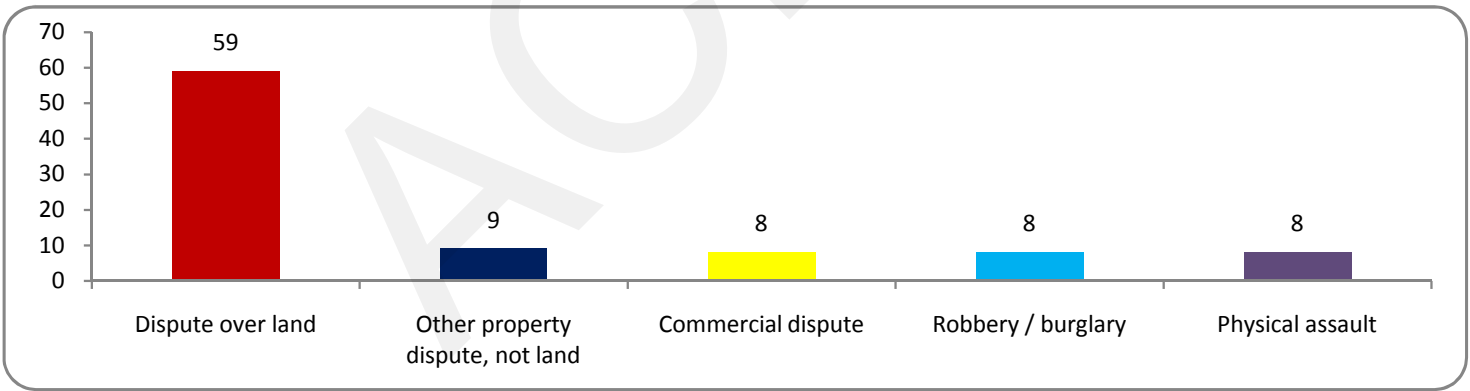

Fig. 10.6

Since 2007, disputes over land have consistently been the most common kind of dispute taken for resolution (from $48 \%$ in 2007, 47\% in 2008, 52\% in 2009 and 59\% in 2011). There has been very little variation in the kinds of cases brought to these bodies for resolution in recent years. 
Table 10.6: What kind of a case or dispute was it? (Q-74) COMPARISON BETWEEN 2007, 2008, 2009 AND 2011

\begin{tabular}{|l|c|c|c|c|}
\hline \multicolumn{1}{|c|}{ Q- $\mathbf{7 4}$} & $\begin{array}{c}\mathbf{2 0 0 7} \\
\mathbf{( \% )}\end{array}$ & $\begin{array}{c}\mathbf{2 0 0 8} \\
\mathbf{( \% )}\end{array}$ & $\begin{array}{c}\mathbf{2 0 0 9} \\
\mathbf{( \% )}\end{array}$ & $\begin{array}{c}\mathbf{2 0 1 1} \\
\mathbf{( \% )}\end{array}$ \\
\hline Dispute over land & 48 & 47 & 52 & 59 \\
\hline Other property disputes, not land & 14 & 9 & 11 & 9 \\
\hline Commercial disputes & 9 & 7 & 8 & 8 \\
\hline Robbery and burglary & 9 & 8 & 6 & 8 \\
\hline Physical assault & 10 & 12 & 8 & 8 \\
\hline Murder & 4 & 5 & 4 & 3 \\
\hline Divorce & 4 & 6 & 4 & 3 \\
\hline Pick-pocketing & 2 & 1 & 2 & 1 \\
\hline
\end{tabular}

Personal disputes over land are more commonly taken for resolution among rural $(60 \%)$ than urban $(45 \%)$ respondents, whereas all other types of disputes are cited slightly more often in urban areas.

Table 10.7: What kind of a case or dispute was it? (Q-74, Base 1250) BY SETTLEMENT

\begin{tabular}{|c|c|c|c|}
\hline Q-74, Base 1250 & $\begin{array}{c}\text { Total } \\
(\%)\end{array}$ & $\begin{array}{c}\text { Village } \\
(\%)\end{array}$ & $\begin{array}{c}\text { Urban } \\
(\%)\end{array}$ \\
\hline Dispute over land & 59 & 60 & 45 \\
\hline Other property dispute, not land & 9 & 8 & 12 \\
\hline Commercial dispute & 8 & 8 & 9 \\
\hline Robbery/burglary & 8 & 7 & 13 \\
\hline Physical assault & 8 & 7 & 11 \\
\hline
\end{tabular}

Respondents who had taken personal disputes for resolution ( $20 \%$ of all respondents) were then asked where they had taken their case. Almost equal proportions say they took the case to a shura or jirga (43\%), and to a state court (41\%) One in eight respondents $(12 \%)$ report taking their case to both institutions.

There has been little variation in the proportions of respondents taking their disputes to the different dispute resolutions mechanisms since 2008 , although fewer respondents report using both mechanisms $(17 \%$ in 2008 , compared to $12 \%$ in 2011). 
Table 10.8: Where have you taken this case or dispute? (Q-75, Base 1250) COMPARISON BETWEEN 2008, 2009, AND 2011

\begin{tabular}{|l|c|c|c|} 
& $\mathbf{2 0 0 8}$ & $\begin{array}{c}\mathbf{2 0 0 9} \\
\mathbf{( \% )}\end{array}$ & $\begin{array}{c}\mathbf{2 0 1 1} \\
\mathbf{( \% )}\end{array}$ \\
\hline State court & 39 & 38 & 41 \\
\hline Village, neighborhood-based shura/jirga & 42 & 47 & 43 \\
\hline Both & 17 & 10 & 12 \\
\hline
\end{tabular}

Most respondents living in urban areas report that they took their case to state courts (45\%), while most in rural areas say they approached local shura or jirga (44\%). More respondents took their disputes to local shura/jirga in all regions except the South West (55\% took their dispute to state courts, 38\% to shura/jirga) and North West (45\% to state courts $38 \%$ to shura/jirga) ${ }^{1}$.

Table 10.9: Where have you taken this case or dispute? (Q-75, Base 1250) BY REGION

\begin{tabular}{|l|c|c|c|c|c|c|c|}
\hline & $\begin{array}{c}\text { Central/ } \\
\text { Kabul } \\
(\mathbf{\%})\end{array}$ & $\begin{array}{c}\text { East } \\
\mathbf{( \% )}\end{array}$ & $\begin{array}{c}\text { South } \\
\text { East } \\
(\mathbf{\%})\end{array}$ & $\begin{array}{c}\text { South } \\
\text { West } \\
\mathbf{( \% )}\end{array}$ & $\begin{array}{c}\text { West } \\
\mathbf{( \% )}\end{array}$ & $\begin{array}{c}\text { North } \\
\text { East } \\
(\mathbf{\%})\end{array}$ & $\begin{array}{c}\text { North } \\
\text { West } \\
(\mathbf{\%})\end{array}$ \\
\hline State court & 33 & 43 & 39 & 55 & 41 & 29 & 45 \\
\hline Village, neighborhood-based-shura/jirga & 47 & 44 & 51 & 38 & 43 & 43 & 36 \\
\hline Both & 15 & 10 & 7 & 5 & 11 & 20 & 16 \\
\hline
\end{tabular}

Respondents who have taken their personal case to a state court (11\% of all respondents), were asked a follow-up question regarding their use of professional legal services. Almost equal numbers report they pleaded their case alone or were helped by friends or relatives (43\%) or they used the professional legal services of a lawyer (42\%). Twelve percent used both professional legal services and the help of friends and relatives.

The figure for the Central Hazarajat is considered statistically irrelevant due to the insignificant number of respondents (33) who took disputes to these bodies. 
When taking a case to a state court or being a party in settling case in a state court, have you used any professional legal services (from a lawyer) or you pleaded your case alone or helped by friends/ relatives? (Q-76, Base 664)

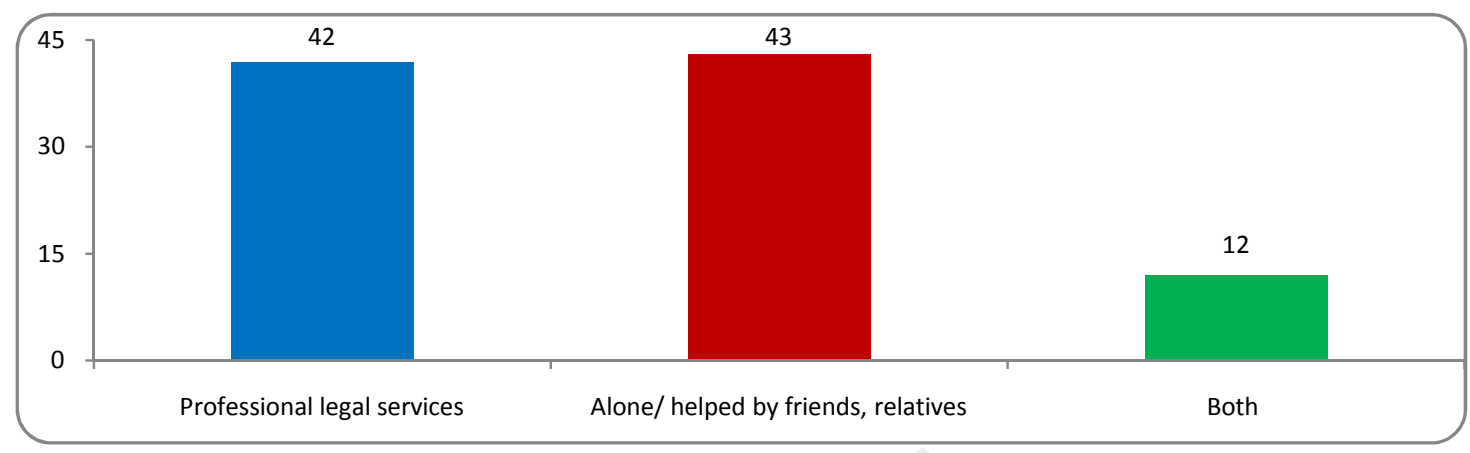

Fig. 10.7

The proportion of those who used legal services has grown over the last few years from 35\% in 2007, 22\% in $2008,39 \%$ in 2009 and $42 \%$ in 2011.

Respondents who contacted shura/jirga to resolve their problems ( $9 \%$ of all respondents) were asked what made them decide to take their personal dispute to this body instead of the state court. More than a quarter of respondents $(26 \%)$ say this is because local shura/jirga resolve disputes efficiently. Twenty-one percent say it is because of corruption in government courts and 16\% say they preferred this mechanism because shura/jirga are honest. Ten percent say they preferred to take their case to shura/jirga because local elders are members.

All respondents, whether or not they had taken a dispute for resolution in the last year, were asked how satisfied they are with the available disputes resolution mechanisms/services in their area. Three quarters $(75 \%)$ of respondents say they are satisfied (including $25 \%$ who say they are very satisfied) while $21 \%$ say they are not.

How satisfied you are with the available disputes resolution mechanisms/services in your area? (Q-78, Base 6348)

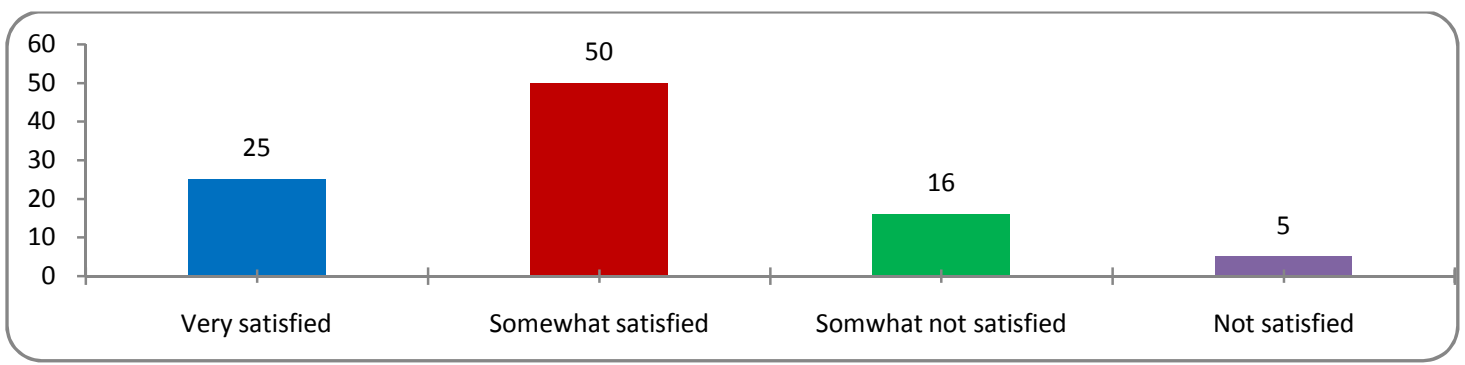

Fig. 10.8 
Levels of satisfaction with available dispute resolution mechanisms are highest in the North East (82\%) and East (81\%), followed by the Central/Kabul (75\%), Central/Hazarajat (75\%), North West (75\%), West (74\%), South West (71\%) and South East (71\%).

How satisfied you are with the available dispute resolution mechanisms/services in your area? (Q-78, Based 6348) BY REGION

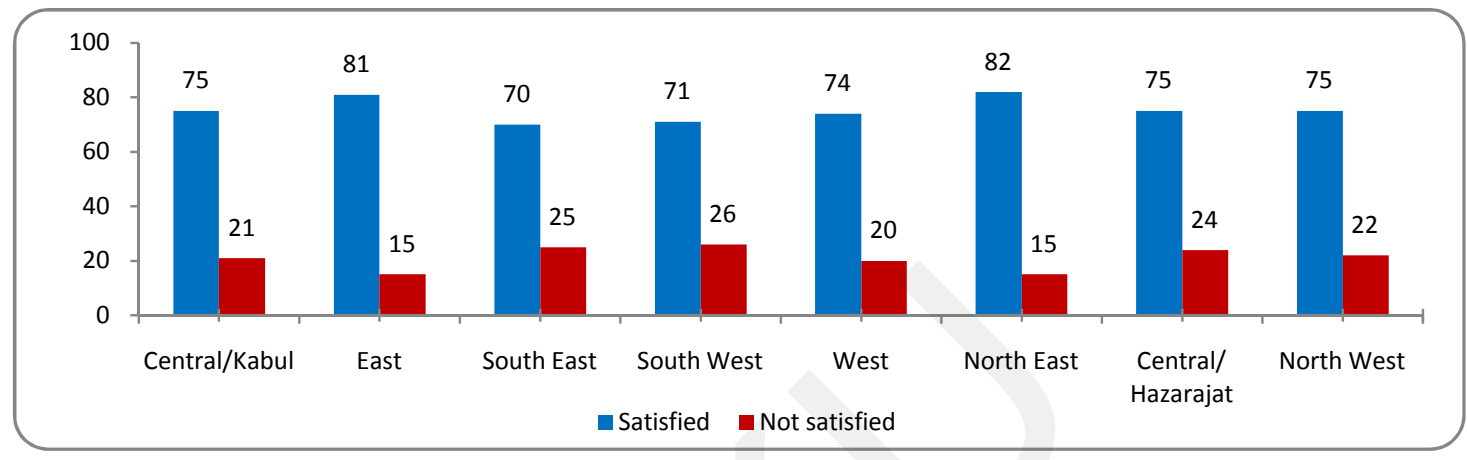

Fig. 10.9

All respondents, who had taken a personal dispute for resolution during the past two years $(20 \%$ of all respondents), were then asked how satisfied they are with the available dispute resolution mechanisms or services in their area. Over four fifths of them (83\%) say they are satisfied with the shura/jirga including 35\% who say they are very satisfied. Seventy-eight percent say they are satisfied with the state court including $21 \%$ who say they are very satisfied. As in previous years, respondents are more satisfied with shura/jirga than with state courts.

Table10.10: How satisfied you are with the available disputes resolution mechanisms/services in your area? (Q-78 and Q-75 cross tabulation) BY PLACE WHERE THE CASE OR DISPUTE WAS TAKEN

\begin{tabular}{|l|c|c|c|}
\hline & $\begin{array}{c}\text { State Court } \\
(\mathbf{\%})\end{array}$ & $\begin{array}{c}\text { Shura/Jirga } \\
\mathbf{( \% )}\end{array}$ & $\begin{array}{c}\text { Both } \\
(\mathbf{\%})\end{array}$ \\
\hline Somewhat and very satisfied & 78 & 83 & 73 \\
\hline Somewhat and very dissatisfied & 20 & 14 & 25
\end{tabular}

\subsection{Perceptions of state courts}

To measure public perceptions of state courts, a series of statements related to the qualities and performance of these institutions a were read out and respondents were asked to say whether they agree or disagree. Levels of agreement with each of the statements are shown in the table below. 
Table 10.11 Percentage of respondents who agree (combination of strongly agree and somewhat agree) with various statements related to state courts (Q-79a-g, Base 6348)

\section{Q-79a-g, Base 6348}

a) State courts are accessible to me

b) State courts are fair and trusted

c) State courts are not corrupt compared to other institutions

d) State courts follow the local norms and values of our people

e) State courts are effective at delivering justice

f) State courts resolve cases timely and promptly

g) State courts treat men and women equally

\begin{tabular}{c|c|c|c|}
$\begin{array}{c}\text { Strongly } \\
\text { agree } \\
(\%)\end{array}$ & $\begin{array}{c}\text { Agree } \\
\text { somewhat } \\
(\mathbf{\%})\end{array}$ & $\begin{array}{c}\text { Disagree } \\
\text { somewhat } \\
(\%)\end{array}$ & $\begin{array}{c}\text { Strongly } \\
\text { disagree } \\
(\%)\end{array}$ \\
\hline 33 & 44 & 16 & 6 \\
\hline 16 & 43 & 29 & 11 \\
\hline 17 & 39 & 29 & 12 \\
\hline 17 & 40 & 29 & 12 \\
\hline 19 & 39 & 27 & 12 \\
\hline 13 & 34 & 32 & 19 \\
\hline 23 & 39 & 23 & 11 \\
\hline
\end{tabular}

The most positive assessment of state courts relates to accessibility. The survey shows that more than three quarters of respondents (77\%) feel that state courts are accessible to them including 33\% who agree strongly with this statement. However, just under a quarter $(22 \%)$ say they cannot access state courts easily. The majority also say state courts treat men and women equally (62\%), are fair and trusted (59\%), are effective at delivering justice (58\%), follow local norms and values (57\%) and are not corrupt compared to other institutions $(56 \%)$. However, less than half of respondents say that state courts resolve cases promptly (47\%).

The proportion of respondents who say that state courts are accessible to them rises somewhat with level of education. Just over three quarters of respondents who never went to school (76\%) or who studied to sixth grade $(77 \%)$ or ninth grade $(78 \%)$ agree with this statement compared to over four fifths of respondents $(82 \%)$ who studied to tenth grade or above. More urban respondents also agree that state courts are accessible to them $(84 \%)$ than their rural counterparts $(76 \%)$, and more men $(80 \%)$ than women $(75 \%)$ say the same.

Do you agree or disagree with "State courts are accessible to me"? (Q-79a, Base 6348) BY GENDER AND SETTLEMENT

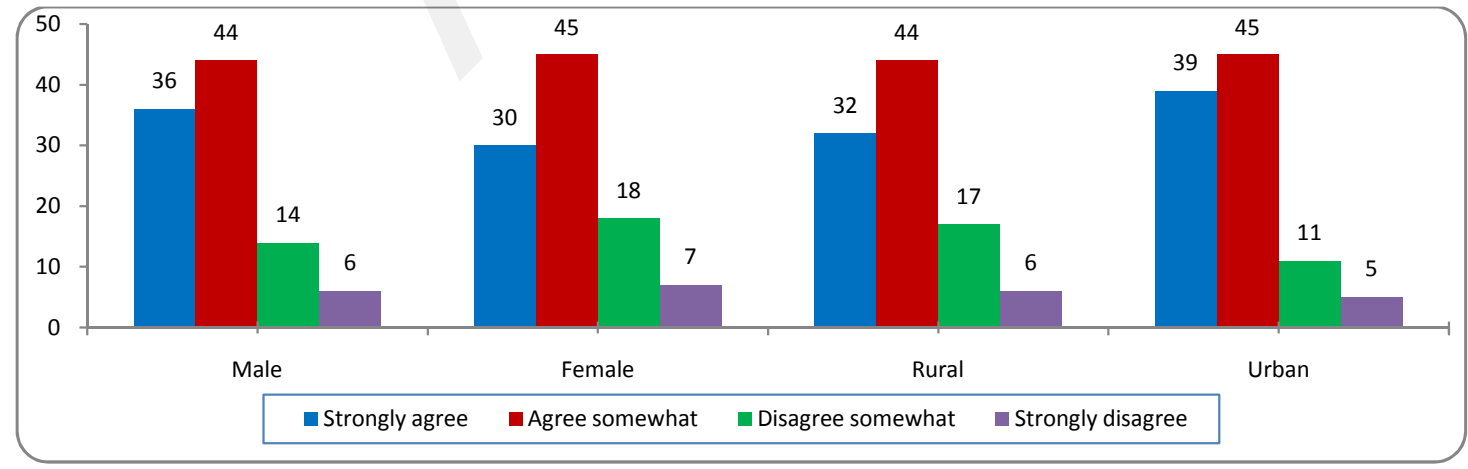

Fig 10.10 
Satisfaction with the performance of state courts is highest across almost all domains in the Central/ Hazarajat, North West and North East, which are also the regions that report the highest levels of satisfaction with government performance and public service delivery in general (see Chapter 7, 7.3 Satisfaction with central government performance in policy and service delivery). Satisfaction with state courts is lowest across almost all domains in the South West and South East.

Table 10.12: Percentage of respondents who agree (combination of strongly agree and somewhat agree) with various statements related to state courts (Q-79a-g, Base 6348) BY REGION

\begin{tabular}{|c|c|c|c|c|c|c|c|c|}
\hline Q-79a-g & $\begin{array}{c}\text { Central/ } \\
\text { Kabul } \\
(\%)\end{array}$ & $\begin{array}{c}\text { East } \\
(\%)\end{array}$ & $\begin{array}{l}\text { South } \\
\text { East } \\
(\%)\end{array}$ & $\begin{array}{l}\text { South } \\
\text { West } \\
(\%)\end{array}$ & $\begin{array}{l}\text { West } \\
(\%)\end{array}$ & $\begin{array}{l}\text { North } \\
\text { East } \\
(\%)\end{array}$ & $\begin{array}{l}\text { Central/ } \\
\text { Hazarajat } \\
(\%)\end{array}$ & $\begin{array}{l}\text { North } \\
\text { West } \\
(\%)\end{array}$ \\
\hline State courts are accessible to me & 81 & 88 & 60 & 66 & 73 & 81 & 92 & 85 \\
\hline State courts are fair and trusted & 60 & 57 & 46 & 51 & 57 & 64 & 66 & 65 \\
\hline $\begin{array}{l}\text { State courts are not corrupt } \\
\text { compared to others }\end{array}$ & 57 & 55 & 39 & 51 & 58 & 61 & 60 & 68 \\
\hline $\begin{array}{l}\text { State courts follow the local } \\
\text { norms and values of our people }\end{array}$ & 59 & 58 & 41 & 53 & 56 & 62 & 60 & 67 \\
\hline $\begin{array}{l}\text { State courts are effective at } \\
\text { delivering justice }\end{array}$ & 58 & 59 & 43 & 53 & 58 & 63 & 62 & 69 \\
\hline $\begin{array}{l}\text { State courts resolve cases timely } \\
\text { and promptly }\end{array}$ & 46 & 49 & 27 & 47 & 48 & 54 & 56 & 56 \\
\hline $\begin{array}{l}\text { State courts treat men and } \\
\text { women equally }\end{array}$ & 62 & 65 & 45 & 52 & 59 & 72 & 69 & 71 \\
\hline
\end{tabular}

Satisfaction with the performance of state courts across all the listed dimensions shows a small improvement in 2011 compared to the past three years, reaching again the highest levels recorded in 2007, except with respect to their ability to resolve cases promptly. Less than half of respondents (47\%) agree with this statement in 2011 , compared to $51 \%$ in 2007.

Table 10.13: Proportion of those who agree with the following statements about state courts (Q-79a-f) COMPARISON BETWEEN 2007, 2008, 2009 ,2010 AND 2011

\begin{tabular}{|c|c|c|c|c|c|}
\hline & $\begin{array}{l}2007 \\
(\%)\end{array}$ & $\begin{array}{c}2008 \\
(\%)\end{array}$ & $\begin{array}{l}2009 \\
(\%)\end{array}$ & $\begin{array}{l}2010 \\
(\%)\end{array}$ & $\begin{array}{c}2011 \\
(\%)\end{array}$ \\
\hline a) State courts are accessible to me & 78 & 68 & 68 & 73 & 77 \\
\hline b) State courts are fair and trusted & 58 & 50 & 50 & 53 & 59 \\
\hline c) State courts are not corrupt compared to other institutions & 56 & 47 & 47 & 49 & 56 \\
\hline $\begin{array}{l}\text { d) State courts follow the local norms and values of our } \\
\text { people }\end{array}$ & 57 & 50 & 49 & 51 & 57 \\
\hline e) State courts are effective at delivering justice & 58 & 52 & 51 & 54 & 58 \\
\hline f) State courts resolve cases timely and promptly & 51 & 38 & 40 & 42 & 47 \\
\hline
\end{tabular}

\subsection{Perceptions of local shura and jirga}

To gauge public perception of informal justice mechanisms, respondents were asked about the quality and 
performance of local shura and jirga in the same manner as they were asked about state courts. Levels of agreement with each of the statements are summarized in the table below.

Table 10.14: Perceptions of the qualities and performance of local shura/jirga (Q-80a-f, Base 6348)

\begin{tabular}{|l|c|c|c|c|}
\multicolumn{1}{|c|}{$(\mathbf{Q}-\mathbf{8 0 a - f , ~ B a s e ~ 6 3 4 8 )}$} & $\begin{array}{c}\text { Strongly } \\
\text { agree } \\
\mathbf{( \% )}\end{array}$ & $\begin{array}{c}\text { Agree } \\
\text { somewhat } \\
\mathbf{( \% )}\end{array}$ & $\begin{array}{c}\text { Disagree } \\
\text { somewhat } \\
\mathbf{( \% )}\end{array}$ & $\begin{array}{c}\text { Strongly } \\
\text { disagree } \\
\mathbf{( \% )}\end{array}$ \\
\hline a) Local shura/jirga are accessible to me & 48 & 39 & 10 & 3 \\
\hline b) Local shura/jirga are fair and trusted & 33 & 46 & 16 & 4 \\
\hline $\begin{array}{l}\text { c) Local shura/jirga follow the local norms and values } \\
\text { of our people. }\end{array}$ & 33 & 44 & 18 & 4 \\
\hline d) Local shura/jirga are effective at delivering justice & 33 & 42 & 19 & 4 \\
\hline e) Local shura/jirga resolve cases timely and promptly & 29 & 44 & 20 & 5 \\
\hline f)Local shura/jirga should include women as members & 32 & 40 & 18 & 8 \\
\hline
\end{tabular}

The most positive assessment of local shura and jirga relates to their accessibility. More than four fifths $(87 \%)$ of respondents agree that shura/jirga are accessible to them (87\%), compared to just over three quarters who say the same about state courts $(78 \%)$. More than three quarters agree that local shura/jirga are fair and trusted $(79 \%)$, follow local norms and values $(77 \%)$ and are effective at delivering justice (75\%). Just under three quarters say that shura/jirga resolve cases promptly $(73 \%)$. The survey also shows that a significant majority of respondents $(72 \%)$ say that local shura/jirga should include women as members.

As is the case for the formal justice system, more men (88\%) than women (84\%) say local shura/jirga are accessible to them. However, unlike for state courts, more rural respondents $(88 \%)$ agree with this statement than urban residents $(81 \%)$.

Positive assessments of local shura/jirga are highest across most domains in the North East, North West and East, but lowest in the South East, West and South West.

Table 10.15: Percentage of respondents who agree (combination of strongly agree and somewhat agree) with various statement related to shura/jirga (Q-80a-f, Base 6348)

\begin{tabular}{|l|c|c|c|c|c|c|c|c|}
\hline \multicolumn{1}{|c|}{ Q-65a-e, Base $\mathbf{6 4 6 7}$} & $\begin{array}{c}\text { Central } \\
\text { Kabul } \\
\mathbf{( \% )}\end{array}$ & $\begin{array}{c}\text { East } \\
\mathbf{( \% )}\end{array}$ & $\begin{array}{c}\text { South } \\
\text { East } \\
\mathbf{( \% )}\end{array}$ & $\begin{array}{c}\text { South } \\
\text { West } \\
\mathbf{( \% )}\end{array}$ & $\begin{array}{c}\text { West } \\
\mathbf{( \% )}\end{array}$ & $\begin{array}{c}\text { North } \\
\text { East } \\
\mathbf{( \% )}\end{array}$ & $\begin{array}{c}\text { Central } \\
\text { Hazarajat } \\
\mathbf{( \% )}\end{array}$ & $\begin{array}{c}\text { North } \\
\text { West } \\
\mathbf{( \% )}\end{array}$ \\
\hline a) Are accessible to me & 85 & 92 & 81 & 81 & 82 & 93 & 92 & 90 \\
\hline $\begin{array}{l}\text { b) Are fair and trusted } \\
\text { c) Follow the local norms } \\
\text { and values of our people }\end{array}$ & 78 & 84 & 72 & 76 & 71 & 89 & 74 & 82 \\
\hline $\begin{array}{l}\text { d) Are effective at delivering } \\
\text { justice }\end{array}$ & 80 & 74 & 66 & 73 & 65 & 86 & 74 & 77 \\
$\begin{array}{l}\text { e) Resolve cases timely and } \\
\text { promptly }\end{array}$ & 74 & 78 & 65 & 69 & 66 & 82 & 75 & 78 \\
\hline $\begin{array}{l}\text { f) Local shura/jirga should } \\
\text { include women as members }\end{array}$ & 76 & 70 & 64 & 63 & 65 & 80 & 76 & 78 \\
\hline
\end{tabular}


As with state courts, satisfaction with the performance of local shura/jirga across all dimensions shows a small improvement in 2011 compared to the past three years. The exception concerns accessibility: in 2011 the proportion of respondents who say that local shura/jirga are accessible to them is the highest to date $(87 \%)$.

Table 10.16: Proportion of those who agree with the following statements about shura/jirga (Q-80a-e) COMPARISON BETWEEN 2007, 2008, 2009, 2010 AND 2011

a) Local shura/jirga are accessible to me

b) Local shura/jirga are fair and trusted

c) Local shura/jirga follow the local norms and values of our people.

d) Local shura/jirga are effective at delivering justice

e) Local shura/jirga resolve cases timely and promptly

2007
$\mathbf{( \% )}$
83
78
76
76
72

\begin{tabular}{|c|}
\hline $\begin{array}{c}2008 \\
(\%)\end{array}$ \\
\hline 76 \\
\hline 70 \\
\hline 69 \\
\hline 69 \\
\hline 59
\end{tabular}

\begin{tabular}{|c|c|c|}
\hline $\begin{array}{c}\mathbf{2 0 0 9} \\
(\%)\end{array}$ & $\begin{array}{c}2010 \\
(\%)\end{array}$ & $\begin{array}{c}\mathbf{2 0 1 1} \\
\mathbf{( \% )}\end{array}$ \\
\hline 79 & 86 & 87 \\
\hline 72 & 73 & 79 \\
\hline 70 & 70 & 77 \\
\hline 69 & 69 & 75 \\
\hline 64 & 66 & 73 \\
\hline
\end{tabular}

The table below compares respondents' assessments of state courts and local shura/jirga. On all five counts the traditional justice system is seen to perform better than the modern state justice system.

Table 10.17: Percentage of respondents who agree (combination of strongly agree and somewhat agree) with various statement related to state courts and shura/jirga (Q-79 and Q-80, Base 6348)

\begin{tabular}{|l|c|c|}
\hline & \multicolumn{2}{|c|}{ Agree } \\
\cline { 2 - 3 } & State Court & $\begin{array}{c}\text { Shura/Jirga } \\
(\%)\end{array}$ \\
\hline Are accessible to me & $\mathbf{( \% )}$ & 87 \\
\hline Are fair and trusted & 77 & 79 \\
\hline Follow the local norms and values of our people & 59 & 75 \\
\hline Are effective at delivering justice & 57 & 73 \\
\hline Resolve cases timely and promptly & 58 & 72 \\
\hline
\end{tabular}

Overall, these results demonstrate that many Afghans continue to view traditional dispute resolution mechanisms such as shura and jirga more positively than they do the modern formal justice system such as state courts. These findings corroborate the higher levels of public confidence recorded for shura and jirga $(70 \%)$ than for the state justice system (55\%) (see Chapter 7, 7.1: Confidence with various institutions). 


\section{Women in Society}

\subsection{Biggest problems faced by women}

The survey sought to examine the problems faced by women in Afghan society. All respondents were asked to identify the biggest problems women face in their local area. A quarter of respondents (25\%) identify lack of education and/or illiteracy as the biggest problem faced by women. Another $15 \%$ cite the lack of rights, including women's rights, $9 \%$ say domestic violence and $8 \%$ of respondents cite forced marriage/dowry, general healthcare and poverty. Around one in 20 respondents say that women can't leave their home $(6 \%)$, women are under the control of men $(6 \%)$ and have experienced pregnancy-related healthcare problems $(5 \%)$.

\section{What are the biggest problems facing women in this area today? (Q-81, Base 6348) BY ALL RESPONDENTS}

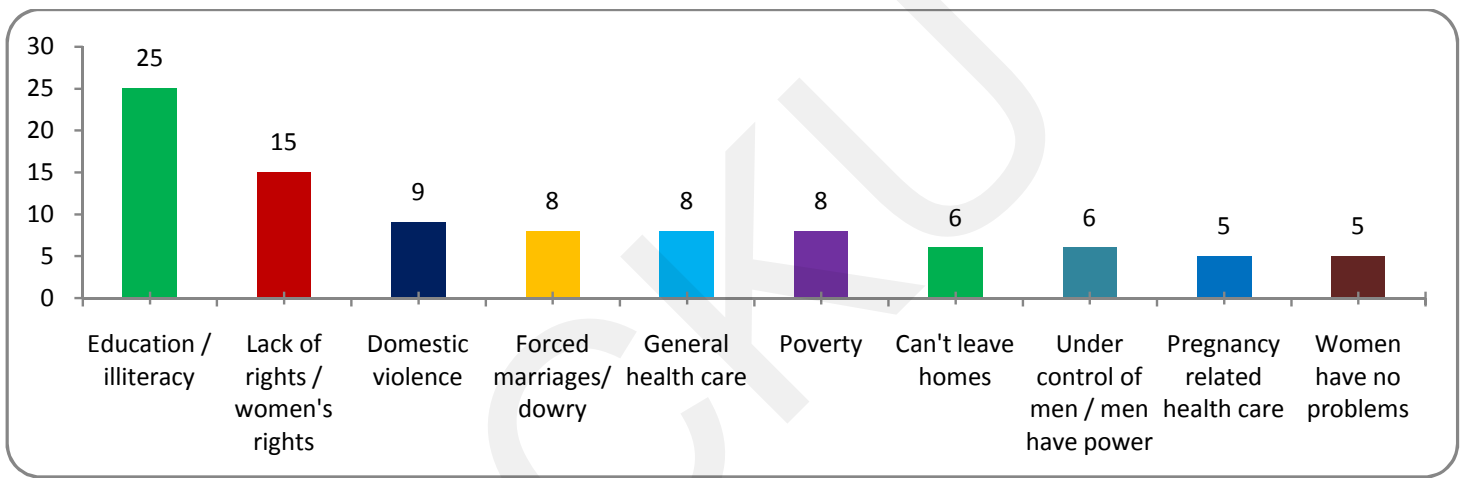

Fig. 11.1

A slightly higher proportion of respondents in urban (28\%) than rural (24\%) areas identify illiteracy and lack of education as the biggest problem facing women in their areas. Lack of education and illiteracy are also identified as the biggest problem facing women in all regions, with the exception of the South West. At least a quarter of respondents identify a lack of education and illiteracy as the biggest problem facing women in Central/Hazarajat (33\%), Central/Kabul(30\%), North West (28\%) and West (27\%) regions.

Lack of rights, including women's rights, is the most commonly identified problem for women in the South West $(21 \%)$. This is also cited by at least one in six respondents in the Central/Hazarajat (17\%), West $(17 \%)$, East (16\%), South East (15\%) and North West (15\%).

Issues of domestic violence are cited most often in the South East (12\%), South West (11\%) and North East $(11 \%)$, and respondents particularly identified forced marriages/dowry in the West $(14 \%)$.

Poverty is identified by slightly more respondents in the North East $(10 \%)$ and North West (10\%) than by those in other regions (between 5\% and 9\%). A higher proportion of respondents in the East (14\%) identify general healthcare to be the biggest problem facing women compared to those in other regions (between 3\% and $11 \%)$. 
Table 11.1: What are the biggest problems facing women in this area today? (Q-81, Base 6348) ALL AND BY REGION

\begin{tabular}{|l|c|c|c|c|c|c|c|c|c|} 
& $\begin{array}{c}\text { All } \\
\mathbf{( \% )}\end{array}$ & $\begin{array}{c}\text { Central/ } \\
\text { Kabul } \\
(\mathbf{\%})\end{array}$ & $\begin{array}{c}\text { East } \\
\mathbf{( \% )}\end{array}$ & $\begin{array}{c}\text { South } \\
\text { East } \\
\mathbf{( \% )}\end{array}$ & $\begin{array}{c}\text { South } \\
\text { West } \\
\mathbf{( \% )}\end{array}$ & $\begin{array}{c}\text { West } \\
\mathbf{( \% )}\end{array}$ & $\begin{array}{c}\text { North } \\
\text { East } \\
\mathbf{( \% )}\end{array}$ & $\begin{array}{c}\text { Central/ } \\
\text { Hazarajat } \\
\mathbf{( \% )}\end{array}$ & $\begin{array}{c}\text { North } \\
\text { West } \\
\mathbf{( \% )}\end{array}$ \\
\hline Education/illiteracy & 25 & 30 & 24 & 20 & 16 & 27 & 24 & 33 & 28 \\
\hline Lack of rights/women's rights & 15 & 11 & 16 & 15 & 21 & 17 & 11 & 17 & 15 \\
\hline Domestic violence & 9 & 6 & 8 & 12 & 11 & 8 & 11 & 5 & 8 \\
\hline Forced marriages/dowry & 8 & 5 & 6 & 9 & 5 & 14 & 10 & 4 & 10 \\
\hline Poverty & 8 & 8 & 6 & 7 & 5 & 8 & 10 & 9 & 10 \\
\hline General healthcare & 8 & 7 & 14 & 9 & 11 & 3 & 10 & 7 & 6 \\
\hline Can't leave home & 6 & 6 & 9 & 7 & 7 & 6 & 6 & 9 & 6 \\
\hline $\begin{array}{l}\text { Under control of men/ men } \\
\text { have power }\end{array}$ & 6 & 5 & 9 & 7 & 7 & 3 & 4 & 8 & 5 \\
\hline Pregnancy-related healthcare & 5 & 2 & 6 & 7 & 4 & 4 & 7 & 3 & 4 \\
\hline
\end{tabular}

Since 2006, lack of education and illiteracy have consistently been identified as the biggest problems for women in Afghanistan, although the figure has fallen significantly since 2009 (from 49\% to 31\% in 2010 and $25 \%$ in 2011). In 2011, a higher proportion of respondents identify the lack of women's rights as a major problem facing women than in 2010 (15\% compared to 7\% in 2010) but this is still lower than previous years (24\% in 2006, 23\% in 2008, 24\% in 2009 and $21 \%$ in 2009). The same is also true for domestic violence $(9 \%$ in 2011 compared to $7 \%$ in $2010,11 \%$ in $2009,12 \%$ in $2008,15 \%$ in 2007 and $23 \%$ in 2006). The identification of pregnancy-related healthcare as a major problem for Afghan women remained steady at 5\% since 2009 . At the same time, there has been a significant decline in the proportion of respondents who identify forced marriages and dowry as a major problem (from $24 \%$ in 2006, to $14 \%$ in $2007,11 \%$ in $2008,7 \%$ in $2009,5 \%$ in 2010 and $8 \%$ 2011). It is significant to note that the identification of a lack of job opportunities for women, which has been steadily increasing between 2007 (19\%), 2008 (24\%), 2009 (28\%) and 2010 (15\%), fell to just $2 \%$ in 2011 . It's interesting to note that only $1 \%$ responded that they were unwilling to answer this question in 2011, compared to 2008 (23\%), 2009 (15\%) and 2010 (13\%).

Table 11.2: What are the biggest problems facing women in this area today? (Q-81) COMPARISON BETWEEN 2006, 2007, 2008, 2009, 2010 and 2011

\begin{tabular}{|l|c|c|c|c|c|c|} 
& $\mathbf{2 0 0 6}$ & $\mathbf{2 0 0 7}$ & $\mathbf{2 0 0 8}$ & $\mathbf{2 0 0 9}$ & $\mathbf{2 0 1 0}$ & $\mathbf{2 0 1 1}$ \\
\hline Education/illiteracy & 41 & 48 & 45 & 49 & 31 & 25 \\
\hline Lack of rights/women's rights & 24 & 23 & 24 & 21 & 7 & 15 \\
\hline Domestic violence & 23 & 15 & 12 & 11 & 7 & 9 \\
\hline Forced marriages/dowry & 24 & 14 & 11 & 7 & 5 & 8 \\
\hline General healthcare & 18 & 10 & 9 & 10 & 3 & 8 \\
\hline Poverty & 16 & 10 & 12 & 11 & 2 & 8 \\
\hline Can't leave home & 14 & 9 & 11 & 8 & 3 & 6 \\
\hline Under control of men/men have power & 16 & 7 & 2 & 3 & 2 & 6 \\
\hline Pregnancy related healthcare & 0 & 7 & 4 & 5 & 5 & 5 \\
\hline Lack of job opportunities for women & 2 & 19 & 24 & 28 & 15 & 2 \\
\hline Security & 7 & 4 & 5 & 6 & 2 & 2 \\
\hline Don't know & 0 & 3 & 23 & 15 & 13 & 1 \\
\hline
\end{tabular}


Respondents were also asked if there is an organization, institution or authority in their area where women can go to have their problem(s) resolved. Less than one in five respondents (19\%) say such an organization exists while over three quarters $(77 \%)$ say there is no such organization in their area. Four percent say they don't know. There are no significant differences between men and women and between rural and urban respondents. More than a quarter of respondents in the West (28\%) and East (27\%), and at least a fifth in the North West (21\%) and North East (20\%) say there is such an organization or institution in their area. But this is true for only $16 \%$ in the South East, $15 \%$ in the Central/Kabul, 14\% in the South West and 12\% in the Central/Hazarajat regions.

Is there an organization, institution or authority in your area where women can go to have their problem(s) resolved? (Q-82a, Base 6348) BY REGION

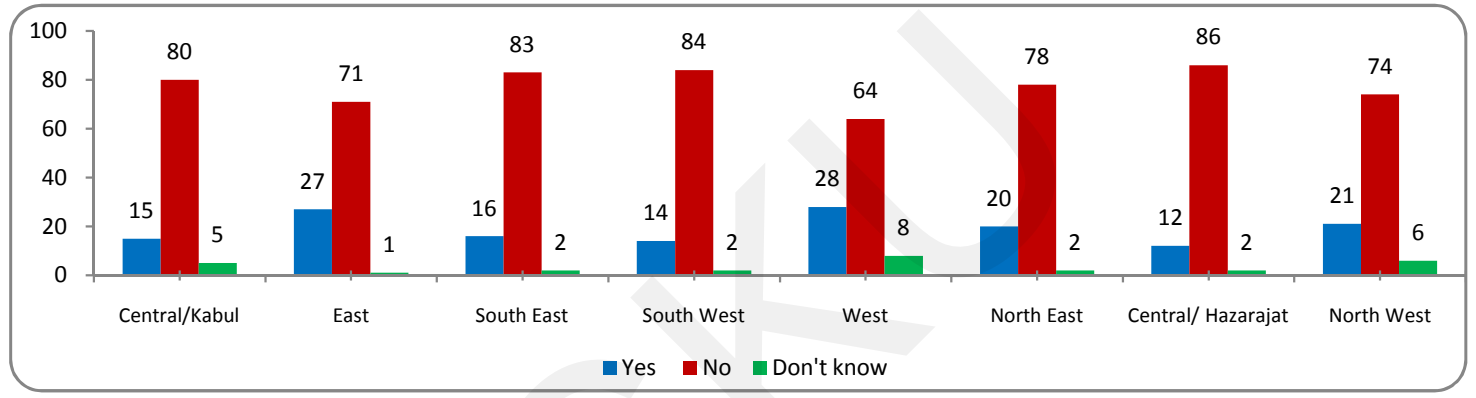

Fig 11.2

Respondents who say there is an organization or institution where women can go to solve their problems (19\% of all respondents) were asked to name the concerned organization or institution. Multiple responses were possible. Almost a quarter (23\%) of respondents identify the Directorate of Women's Affairs, and 18\% identify a women's shura. At least one in eight respondents identify institutions that deal in general with rights issues or with problem solving including the human rights office $(13 \%)$, district office $(12 \%)$ and village shura/elder's shura $(12 \%)$. A small proportion of respondents identify the courts $(5 \%)$ as a potential institution where women can resolve their problems.

Nearly twice as many respondents in urban (36\%) as rural (19\%) areas identify the Directorate of Women's Affairs as a place where women can go to solve their problems. This institution is identified equally by men 
$(23 \%)$ and women (23\%). The Human Rights Office is also identified by more respondents in urban $(22 \%)$ than rural $(10 \%)$ areas. The courts are mentioned by three times as many urban $(6 \%)$ as rural $(2 \%)$ respondents although the numbers remain small. More respondents in urban areas (25\%) also identify women's shura than do rural residents (17\%). District offices, on the other hand, are identified by many more rural $(15 \%)$ than urban $(2 \%)$ respondents, as we would expect since district offices principally exist in rural areas. Twice as many rural respondents (14\%) cite village shura/elder's shura as a place where women can resolve their problems, than those living in urban areas $(7 \%)$.

(Filtered, if 'yes' in Q-82a) What organization, institution or authority is that? (Q-82b, Base 1228) BY ALL AND SETTELMENT

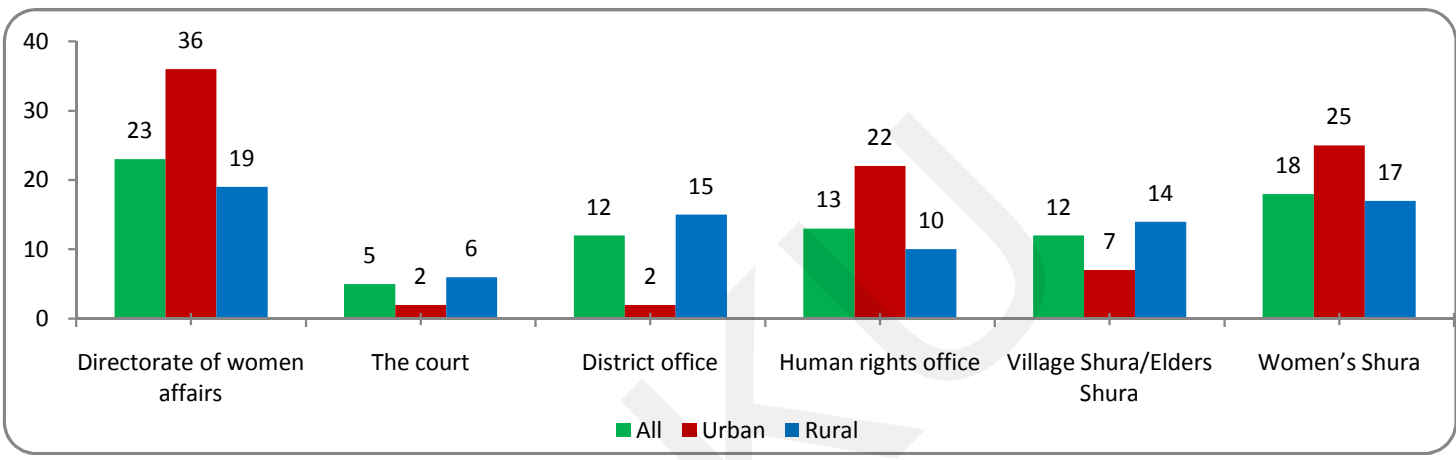

Fig 11.3

Pashtun (28\%) and Tajik (27\%) respondents most frequently identify the Directorate of Women's Affairs as the institution to which women can turn to resolve their problems. Hazara respondents most frequently identify village shura/elder's shura (21\%) while Uzbeks give equal weight to district offices and women's shura ( $22 \%$ to each). Respondents from other ethnic groups most often say women's shura (37\%).

(Filtered, if 'yes' in Q-82a) What organization, institution or authority is that? (Q-82b, Base 1228) BY ETHNICITY

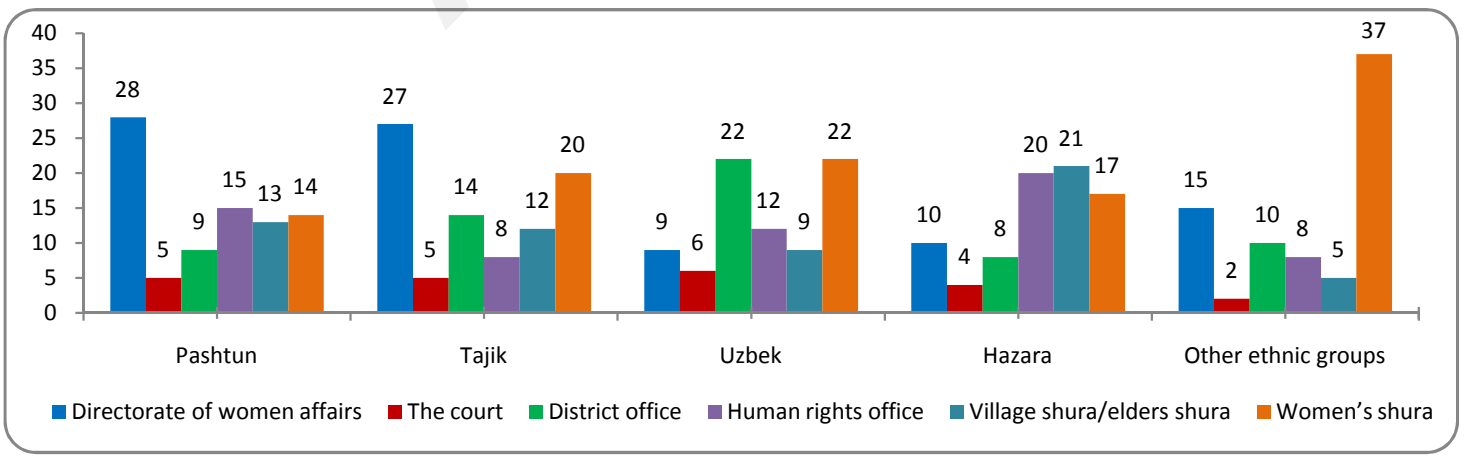

Fig. 11.4 
Forty-one percent of respondents in the South West identify the Directorate of Women's Affairs as a place for women to resolve their problems, and at least a quarter do the same in the Central/Kabul (30\%), East (27\%), and South East (25\%) and 22\% in the West. Women's shura are most commonly identified in the North West (29\%), North East (26\%) and West (20\%). Village shura/elder's shura are also most often identified in the North East (22\%) and West (19\%). District offices are identified by just under one in five respondents in the North West (18\%) and North East (17\%). The majority of respondents in the Central/Hazarajat (50\%) cite the Human Rights Office as a place for women to resolve their problems, and this institution is also cited by around a fifth of respondents in the South East (19\%) and East (19\%). The courts are also identified twice as often in the South East (7\%) and East (6\%), along with the Central/Kabul (6\%) and North West (6\%) as in other parts of the country (between $0 \%$ and $3 \%$ ).

Table 11.3: (Filtered, if 'yes' in Q-82a) What organization, institution or authority is that? (Q-82b, Base 1228) BY REGION

\begin{tabular}{|l|c|c|c|c|c|c|c|c|}
\hline & $\begin{array}{c}\text { Central/ } \\
\text { Kabul } \\
(\mathbf{\%})\end{array}$ & $\begin{array}{c}\text { East } \\
\mathbf{( \% )}\end{array}$ & $\begin{array}{c}\text { South } \\
\text { East } \\
\mathbf{( \% )}\end{array}$ & $\begin{array}{c}\text { South } \\
\text { West } \\
\mathbf{( \% )}\end{array}$ & $\begin{array}{c}\text { West } \\
\mathbf{( \% )}\end{array}$ & $\begin{array}{c}\text { North } \\
\text { East } \\
\mathbf{( \% )}\end{array}$ & $\begin{array}{c}\text { Central/ } \\
\text { Hazarajat } \\
\mathbf{( \% )}\end{array}$ & $\begin{array}{c}\text { North } \\
\text { West } \\
\mathbf{( \% )}\end{array}$ \\
\hline Directorate of Women's Affairs & 30 & 27 & 25 & 41 & 22 & 14 & 8 & 13 \\
\hline Women's shura & 16 & 5 & 12 & 17 & 20 & 26 & 15 & 29 \\
\hline Village shura/elder's shura & 8 & 11 & 15 & 5 & 19 & 22 & 4 & 5 \\
\hline District office & 10 & 11 & 9 & 3 & 11 & 17 & 4 & 18 \\
\hline Human rights office & 11 & 19 & 20 & 17 & 6 & 6 & 50 & 12 \\
\hline The court & 6 & 7 & 6 & 3 & 3 & 3 & 0 & 6
\end{tabular}

\subsection{Attitudes toward gender equality: women and education}

The survey also sought to gauge public opinion on the issue of gender equality. The first issue explored relates to gender equality in education. Respondents were asked whether they agree with the statement, "Women should have equal opportunities like men in education." Over four fifths (85\%) of respondents say they agree with this statement, including 50\% who strongly agree. Only $14 \%$ disagree with the statement. This finding closely matches with that of 2010. These responses are also broadly consistent with the high level of public agreement for equal rights under the law, regardless of gender, ethnicity or religion (81\%) (see Chapter 9, 9.5: Democratic spirit of government).

A higher proportion of women (91\%) than men (81\%) support equal opportunities for women in education. Urban residents (91\%, including 65\% who strongly agree) are also more likely to support equal educational opportunities for women compared to their rural counterparts ( $84 \%$ including $46 \%$ who strongly agree). 
Some people say that women should have equal opportunities like men in education. Do you agree or disagree with this opinion? (Q-67, Base 6467) BY GENDER AND SETTLEMENT

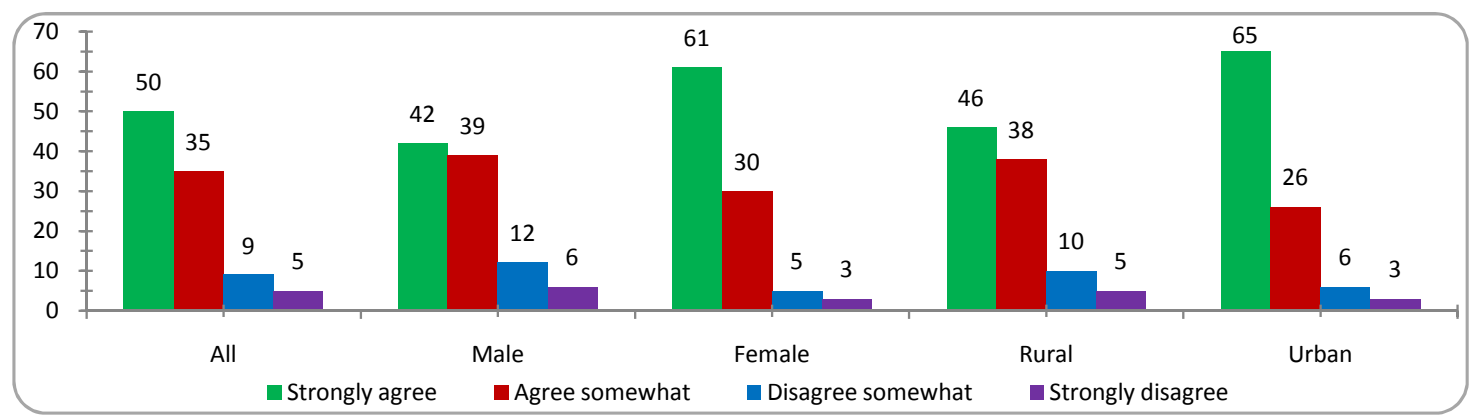

Fig. 11.5

There are variations between ethnic groups as well. A higher proportion of Pashtuns $(20 \%)$ and other ethnic groups $(17 \%)$ disagree with the statement that women should have equal opportunities like men in education, while less than one in 10 Tajik (8\%), Hazara (8\%) and Uzbek (9\%) hold that view.

Table 11.4: Some people say that women should have equal opportunities like men in education. Do you agree or disagree with this opinion? (Q- 83, Based 6348) BY ETHNICITY

\begin{tabular}{|l|c|c|c|c|c|c|}
\hline & All & Pashtun & Tajik & Uzbek & Hazara & Other \\
\hline Agree somewhat and strongly & 85 & 79 & 91 & 91 & 91 & 83 \\
\hline Disagree somewhat and strongly & 14 & 20 & 8 & 9 & 8 & 17 \\
\hline
\end{tabular}

At least $90 \%$ of respondents say they support equal educational opportunities for women in the Central/ Hazarajat (96\%), Central/Kabul (90\%) and North East (90\%), and this is true for more than four fifths in the East (88\%), South East (87\%), West (87\%) and North West (87\%) regions, but this falls to 61\% in the South West where more than a third $(38 \%)$ of respondents oppose equal educational opportunities for women, three times more than in other regions (between $4 \%$ and $13 \%$ ).

Table 11.5: Some people say that women should have equal opportunities like men in education. Do you agree or disagree with this opinion? (Q- 83, Based 6348) BY REGION

\begin{tabular}{|l|c|c|c|c|c|c|c|c|}
\hline & $\begin{array}{c}\text { Central/ } \\
\text { Kabul } \\
(\%)\end{array}$ & $\begin{array}{c}\text { East } \\
(\mathbf{\%})\end{array}$ & $\begin{array}{c}\text { South } \\
\text { East } \\
(\%)\end{array}$ & $\begin{array}{c}\text { South } \\
\text { West } \\
(\%)\end{array}$ & $\begin{array}{c}\text { West } \\
(\%)\end{array}$ & $\begin{array}{c}\text { North } \\
\text { East } \\
(\%)\end{array}$ & $\begin{array}{c}\text { Central/ } \\
\text { Hazarajat } \\
(\%)\end{array}$ & $\begin{array}{c}\text { North } \\
\text { West } \\
(\%)\end{array}$ \\
\hline Agree somewhat and strongly & 90 & 88 & 87 & 61 & 87 & 90 & 96 & 87 \\
\hline Disagree somewhat and strongly & 9 & 11 & 13 & 38 & 12 & 9 & 4 & 12 \\
\hline
\end{tabular}




\subsection{Attitudes toward gender equality: women and employment}

Respondents were also asked to give their opinion on gender equality in relation to employment opportunities. They were asked whether they think women should be allowed to work outside the home. Just under two thirds $(62 \%)$ say women should be allowed to work outside the home while just over one third (35\%) say they should not.

Survey findings show that there is a significant difference between men and women's attitudes in this regard. More than three quarters of female respondents $(79 \%)$ say women should be allowed to work outside the home compared with just half $(50 \%)$ of men who think so. Likewise, significantly more urban respondents agree with the statement $(77 \%)$ than do their rural counterparts $(58 \%)$.

Some people say that women should be allowed to work outside the home. What is your opinion about this? (Q-84, Base 6348) BY GENDER AND SETTLEMENT

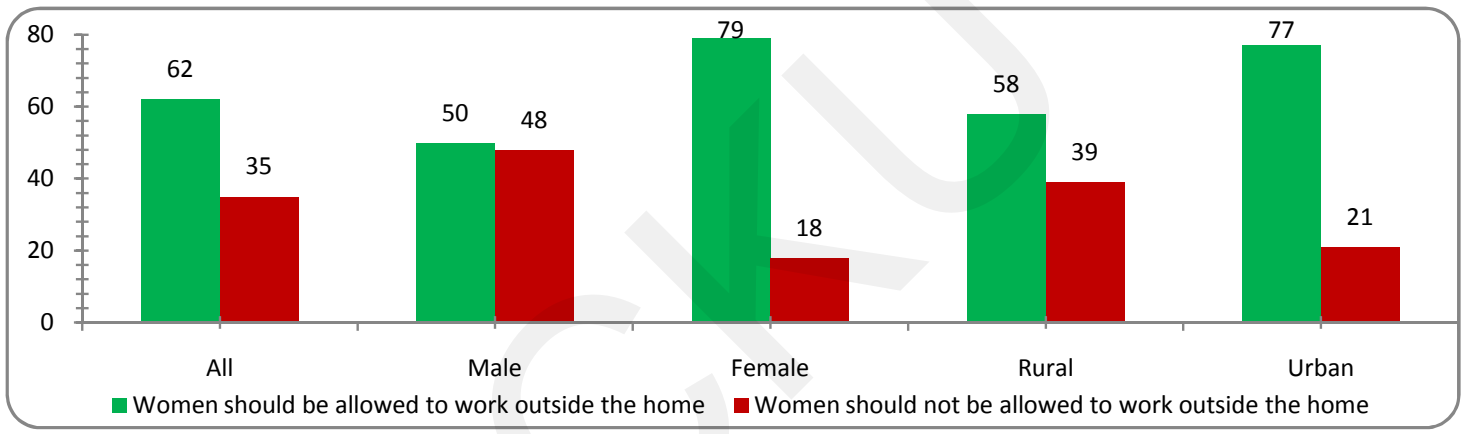

Fig. 11.6

Between ethnic communities, support for women being allowed to work outside the home is strongest among Hazaras (76\%) followed by Tajiks (71\%) and Uzbeks (68\%). There is relatively low support for the idea that women should be allowed to work outside their homes among Pashtuns (52\%) and other ethnic groups (59\%).

Some people say that women should be allowed to work outside the home. What is your opinion about this? (Q-84, Base 6348) BY ETHNICITY

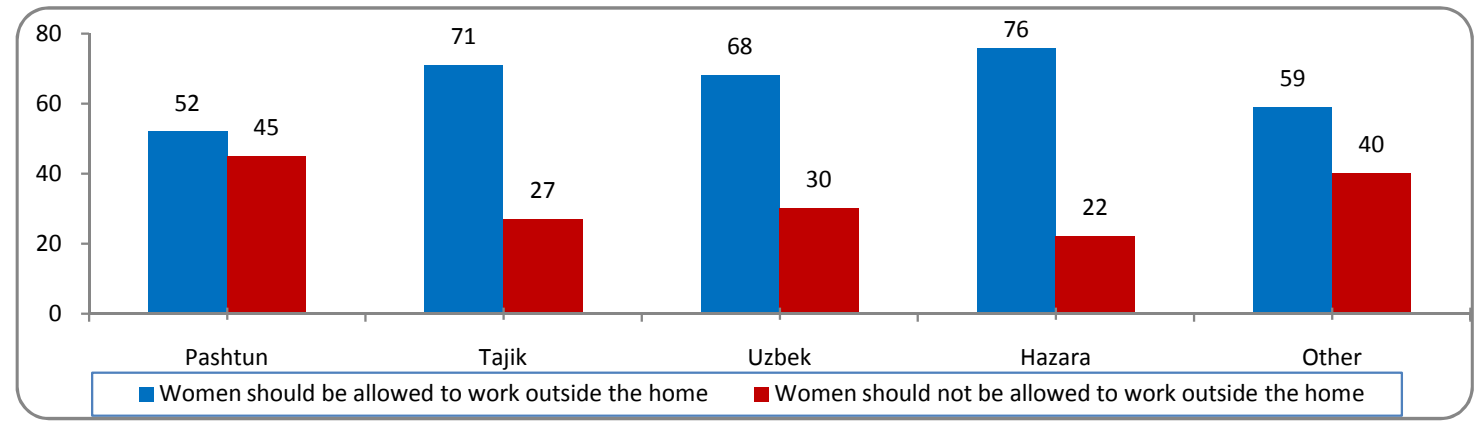

Fig.11.7 
As with support for equality in education, the highest levels of support for women working outside the home are in the Central/Hazarajat (79\%), Central/Kabul (73\%), North West (69\%), North East (65\%) and West $(60 \%)$ regions. Opposition is highest in the South West (59\%) but also significant in the East (43\%) and South East $(42 \%)$.

Table 11.6: Some people say that women should be allowed to work outside the home. What is your opinion about this? (Q-84, Base 6348) BY REGION

\begin{tabular}{|l|c|c|c|c|c|c|c|c|} 
& $\begin{array}{c}\text { Central/ } \\
\text { Kabul } \\
(\%)\end{array}$ & $\begin{array}{c}\text { East } \\
(\%)\end{array}$ & $\begin{array}{c}\text { South } \\
\text { East } \\
(\%)\end{array}$ & $\begin{array}{c}\text { South } \\
\text { West } \\
(\%)\end{array}$ & $\begin{array}{c}\text { West } \\
(\%)\end{array}$ & $\begin{array}{c}\text { North } \\
\text { East } \\
(\%)\end{array}$ & $\begin{array}{c}\text { Central/ } \\
\text { Hazarajat } \\
(\%)\end{array}$ & $\begin{array}{c}\text { North } \\
\text { West } \\
(\%)\end{array}$ \\
\hline $\begin{array}{l}\text { Women should be allowed to work outside } \\
\text { the home }\end{array}$ & 73 & 56 & 56 & 39 & 60 & 65 & 79 & 69 \\
\hline $\begin{array}{l}\text { Women should not be allowed to work } \\
\text { outside the home }\end{array}$ & 24 & 43 & 42 & 59 & 36 & 33 & 19 & 28 \\
\hline
\end{tabular}

Although nationally the majority of respondents have consistently supported the view that women should be allowed to work outside the home, there has been a steady decline in the proportion of people who agree with this (from $71 \%$ in 2006, 70\% in 2007, 69\% in 2008, 67\% in 2009, 64\% in 2010 and $62 \%$ in 2011). Similarly, opposition to women working outside the home has risen from just over a quarter of respondents in 2006 $(27 \%)$ to a third $(35 \%)$ in 2011.

Table 11.7: Some people say that women should be allowed to work outside the home. What is your opinion about this? (Q84) COMPARISON BETWEEN 2006, 2007, 2008, 2009, 2010 AND 2011

\begin{tabular}{|l|c|c|c|c|c|c|} 
& $\begin{array}{c}2006 \\
(\%)\end{array}$ & $\begin{array}{c}2007 \\
(\mathbf{\%})\end{array}$ & $\begin{array}{c}\mathbf{2 0 0 8} \\
\mathbf{( \% )}\end{array}$ & $\begin{array}{c}\mathbf{2 0 0 9} \\
(\mathbf{\%})\end{array}$ & $\begin{array}{c}\mathbf{2 0 1 0} \\
\mathbf{( \% )}\end{array}$ & $\begin{array}{c}\mathbf{2 0 1 1} \\
\mathbf{( \% )}\end{array}$ \\
\hline Women should be allowed to work outside the home & 71 & 70 & 69 & 67 & 64 & 62 \\
\hline Women should not be allowed to work outside the home & 27 & 28 & 27 & 29 & 33 & 35 \\
\hline
\end{tabular}

One of the reasons why support for women working outside the home is decreasing may be related to the increase in safety concerns in many areas. This can be seen in the increasing proportion of respondents who say sometimes or often they fear for their personal safety and that of their family (see Chapter 3, 3.1 Fear for safety).

Respondents' views on women's independence to work outside the home closely mirror their views on equal opportunity in education. For example, $85 \%$ of respondents agree and somewhat agree that women should have equal opportunity in education, while $81 \%$ of respondents strongly agree that women should be allowed to work outside the home. Similarly, $14 \%$ of respondents strongly and somewhat disagree that women should have equal opportunity in education, while $17 \%$ say that women should not be allowed to work outside the home. 
Table11.8: Some people say that women should be allowed to work outside the home. What is your opinion about this? (Q-84, Base 6348)

\begin{tabular}{|l|c|c|c|c|} 
& $\begin{array}{c}\text { Strongly } \\
\text { agree } \\
(\%)\end{array}$ & $\begin{array}{c}\text { Agree } \\
\text { somewhat } \\
(\%)\end{array}$ & $\begin{array}{c}\text { Disagree } \\
\text { somewhat } \\
(\%)\end{array}$ & $\begin{array}{c}\text { Strongly } \\
\text { disagree } \\
(\%)\end{array}$ \\
\hline Women should be allowed to work outside the home & 81 & 53 & 23 & 11 \\
\hline Women should not be allowed to work outside the home & 17 & 44 & 74 & 86 \\
\hline
\end{tabular}

Respondents were also asked whether they think women should be allowed to stand up for their individual rights. More than three quarters of respondents (79\%) say they should. Only 19\% disagree. More women $(84 \%)$ than men $(74 \%)$ say women should be allowed to stand up for their individual rights, as do more respondents in urban $(86 \%)$ than rural $(77 \%)$ areas.

There is also variation between regions. Support for women standing up for their individual rights is highest in the Central/Kabul (86\%), North West (84\%), East (80\%), North East (80\%), Central/Hazarajat (80\%) and South East (79\%) regions. However, at least a third of respondents in the South West $(33 \%)$ and a quarter in the West $(25 \%)$ say women should not be allowed to stand up for their individual rights.

Please tell me if you agree with "Women should be allowed to stand up for their individual rights." (Q56d, Base All Respondents 6348) ALL AND BY REGION

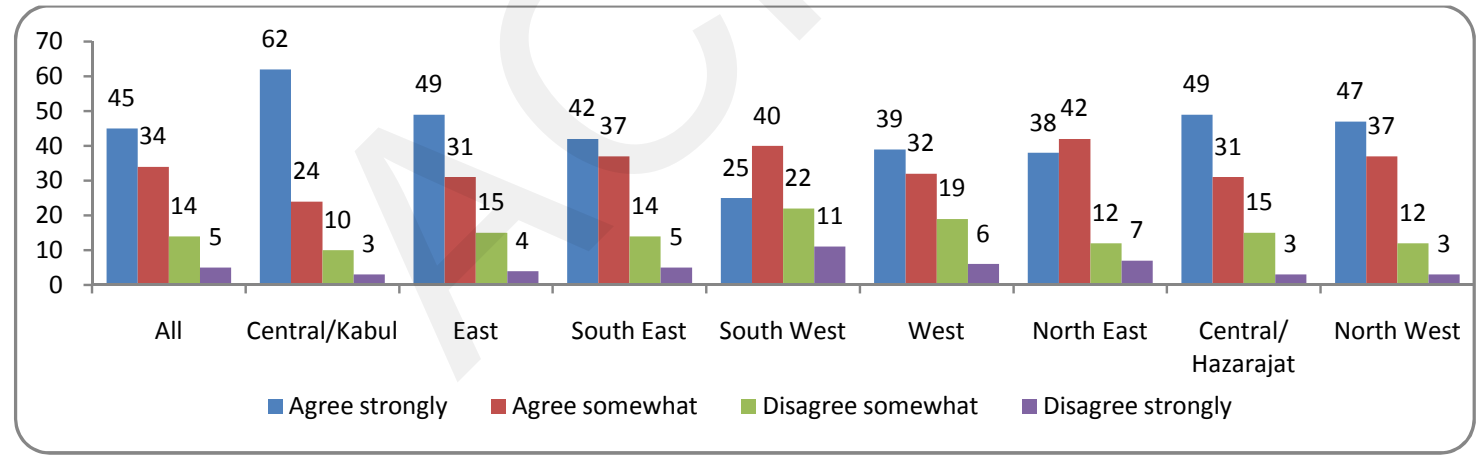

Fig 11.8

\subsection{Women's political participation}

The survey attempted to ascertain whether respondents' views on gender equality in general carry through into support for women's electoral participation. Respondents were asked whether they agree or disagree that men cannot vote in place of women and that women must vote themselves. More than four fifths $(85 \%)$ of respondents say they agree with this statement, including 52\% who strongly agree. Just over one in $10(11 \%)$ respondents disagrees with the statement. 
More women (88\%) than men $(83 \%)$ agree that women should vote themselves. Similarly, more urban residents $(88 \%)$ agree that women must vote themselves than their rural counterparts $(85 \%)$.

There are more significant differences in views between ethnic groups. At least eight out of 10 Uzbek (92\%), Tajik (89\%), Hazara (88\%) and other ethnic group (86\%) respondents agree with the statement that women must vote themselves compared to $80 \%$ of Pashtun respondents.

In the election, everyone must vote and go to the polls themselves. Men cannot vote in place of women. Women must vote themselves. What do you think about this statement? Do you agree or disagree? (Q- 88, Base 6348) BY ETHNICITY

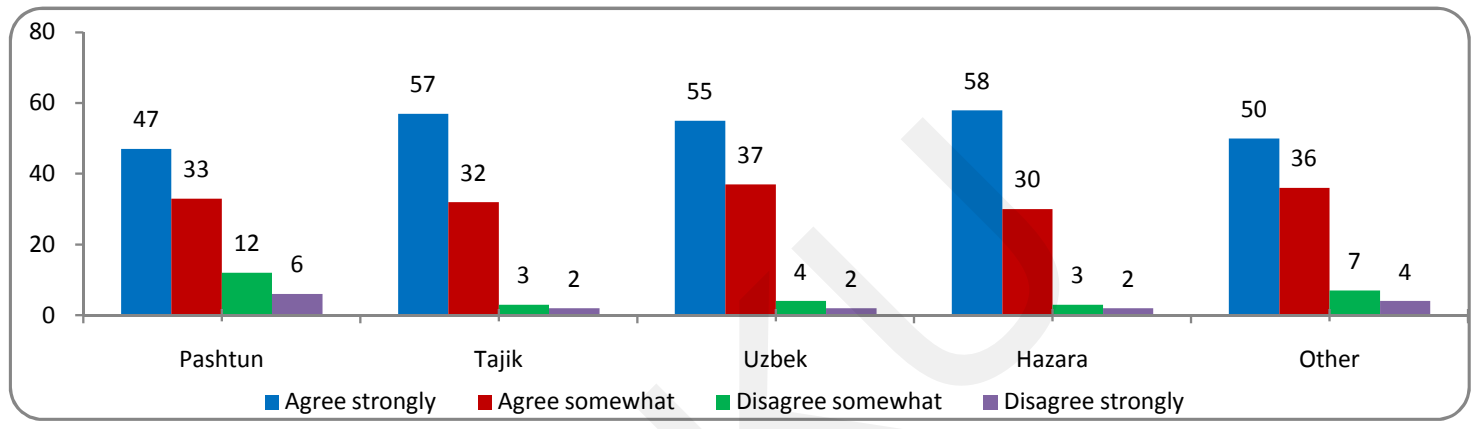

Fig.11.9

Respondents were asked whether, if women vote, they should decide for themselves how to vote or whether they should receive advice from men. Just over half of respondents (51\%) say that women should decide for themselves while just over a quarter $(28 \%)$ say men should advise them. Around a fifth $(21 \%)$ say women should decide for themselves but in consultation with men. This shows that close to half of the respondents $(49 \%)$ believe that men should somehow be involved in women's decision-making process.

The majority of women (58\%), but less than half of men (45\%), say that women should decide for themselves. More urban $(65 \%)$ than rural (47\%) respondents say women should decide for themselves on how to vote. Similarly, a higher proportion of respondents with higher education $(62 \%)$ say that women should decide for themselves, than respondents who never went to school (48\%). More respondents aged 18-24 (55\%) also say this compared to those over 55 (49\%). Conversely more than a third of male respondents $(34 \%)$ say that women should be advised by men compared to under a fifth of female respondents (19\%). A similar proportion of women $(23 \%)$ and men (19\%) say that women should decide in consultation with men. 
If women vote, do you think that women should decide for themselves or should they receive advice from men? (Q-87, Base 6348) BY ALL, GENDER AND SETTLEMENT

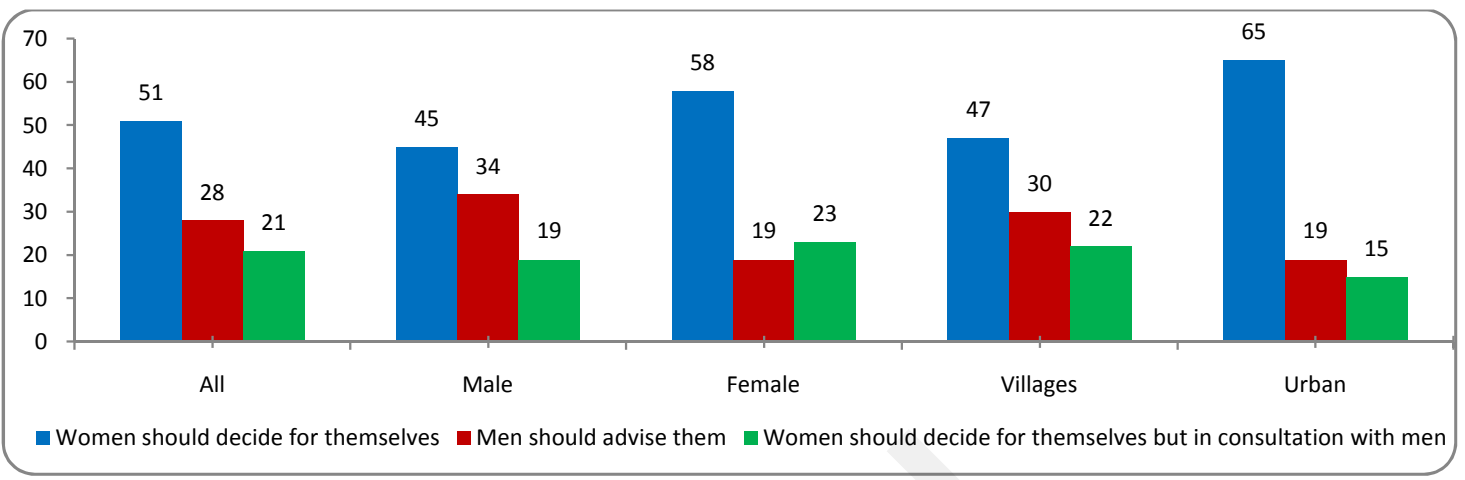

Fig. 11.10

Opinions differ among ethnic communities in this regard. Nearly two thirds of Hazaras $(65 \%)$ and the majority of Tajiks (56\%), other ethnic groups (55\%) and Uzbeks (54\%), say that women should decide for themselves, but this is true for only $41 \%$ of Pashtun respondents. More Pashtuns (31\%) say men should advise women on their decisions followed by Uzbeks (28\%), other ethnic groups (28\%) and Tajiks (26\%), while only $19 \%$ of Hazaras say this. Again while more than a quarter (27\%) of Pashtun respondents say women should decide for themselves but in consultation with men, this is true for only $17 \%$ of Tajik, $16 \%$, of Uzbek and other ethnic groups and $15 \%$ of Hazara respondents..

If women vote, do you think that women should decide for themselves or should they receive advice from men? (Q-87, Base 6348) BY ETHNICITY

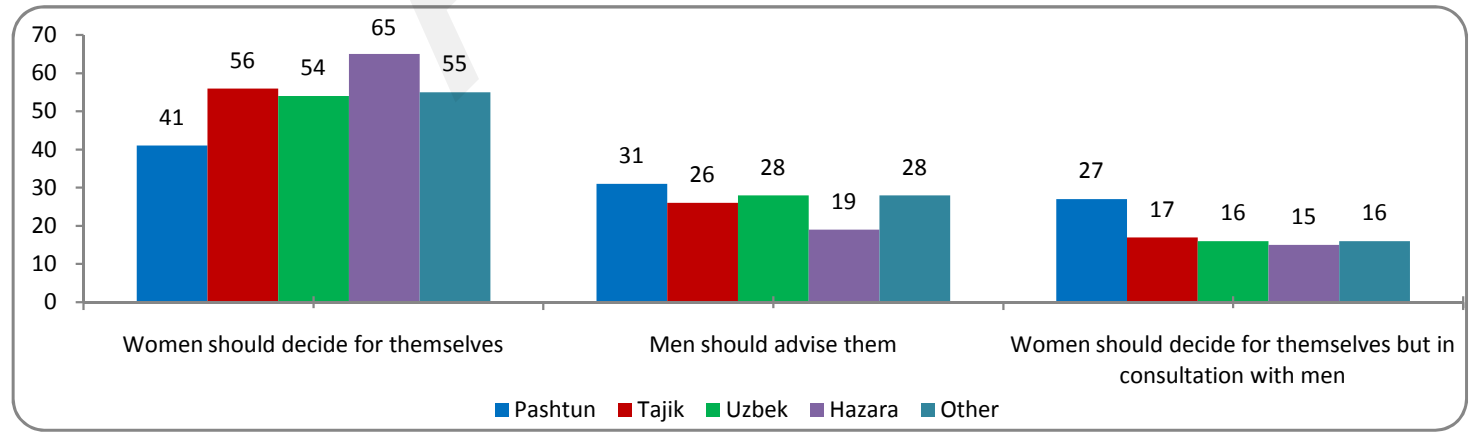

Fig. 11.11 
Opinions also vary across the regions. The majority of respondents in the Central/ Hazarajat (78\%) agree that women should decide for themselves, followed by $62 \%$ in Central/Kabul, 56\% in North West and 55\% in North East. A significant proportion of residents in the South West (45\%) and West (33\%) say that men should advise women how to vote while significant proportions of respondents in the East $(35 \%)$, South East $(31 \%)$ and South West $(26 \%)$ say that women should decide for themselves but in consultation with men.

Table 11.9: If women vote, do you think that women should decide for themselves or should they receive advice from men? (Q87, Base 6348)-BY REGION

\begin{tabular}{|c|c|c|c|c|c|c|c|c|}
\hline & $\begin{array}{c}\text { Central/ } \\
\text { Kabul } \\
(\%)\end{array}$ & $\begin{array}{l}\text { East } \\
(\%)\end{array}$ & $\begin{array}{c}\text { South } \\
\text { East } \\
(\%)\end{array}$ & $\begin{array}{l}\text { South } \\
\text { West } \\
(\%)\end{array}$ & $\begin{array}{l}\text { West } \\
(\%)\end{array}$ & $\begin{array}{c}\text { North } \\
\text { East } \\
(\%)\end{array}$ & $\begin{array}{c}\text { Central/ } \\
\text { Hazarajat } \\
(\%)\end{array}$ & $\begin{array}{c}\text { North } \\
\text { West } \\
(\%)\end{array}$ \\
\hline Women should decide for themselves & 62 & 41 & 40 & 28 & 49 & 55 & 78 & 56 \\
\hline Men should advise them & 21 & 22 & 28 & 45 & 33 & 27 & 13 & 29 \\
\hline $\begin{array}{l}\text { Women should decide for themselves } \\
\text { but in consultation with men }\end{array}$ & 17 & 35 & 31 & 26 & 17 & 18 & 9 & 14 \\
\hline
\end{tabular}

Respondents' views on women's independence in voting clearly correlate with their views on equal opportunities in education. Analysis shows that $66 \%$ of respondents who strongly agree that women should have equal opportunities in education also say that women should decide for themselves how to vote. On the other hand, $60 \%$ of those who strongly disagree that women should have equal educational opportunities to men also say that men should advise them on their decisions and also $20 \%$ say women should decide for themselves but in consultation with men.

Table 11.10: If women vote, do you think that women should decide for themselves or should they receive advice from men?(Q-87, Base 6348) BY OPINIONS REGARDING WHETHER WOMEN SHOULD HAVE EQUAL OPPORTUNITIES LIKE MEN IN EDUCATION (Q-83)

\begin{tabular}{|c|c|c|c|c|}
\hline & $\begin{array}{c}\text { Strongly } \\
\text { agree } \\
(\%)\end{array}$ & $\begin{array}{c}\text { Agree } \\
\text { somewhat } \\
(\%)\end{array}$ & $\begin{array}{c}\text { Disagree } \\
\text { somewhat } \\
(\%)\end{array}$ & $\begin{array}{c}\text { Strongly } \\
\text { disagree } \\
(\%)\end{array}$ \\
\hline Women should decide for themselves & 66 & 41 & 23 & 18 \\
\hline Men should advise them & 16 & 35 & 49 & 60 \\
\hline $\begin{array}{l}\text { Women should decide for themselves but in } \\
\text { consultation with men }\end{array}$ & 18 & 24 & 26 & 20 \\
\hline
\end{tabular}

Similarly, respondents' view on women's independence in voting also correlate with their views regarding whether women should be allowed to work outside home. For example, $62 \%$ of respondents who think women should be allowed to work outside the home also say that women should decide how to vote for themselves. On the other hand, $45 \%$ of those who think women should not be allowed to work outside the home also think that men should advise them on how to vote. 
Table 11.11: If women vote, do you think that women should decide for themselves or should they receive advice from men? (Q-87, Base 6348) BY OPINIONS REGARDING WHETHER WOMEN SHOULD BE ALLOWED TO WORK OUTSIDE HOME (Q84)

\begin{tabular}{|l|c|c|}
\hline & $\begin{array}{c}\text { Women should be allowed to } \\
\text { work outside home (\%) }\end{array}$ & $\begin{array}{c}\text { Women should not be allowed } \\
\text { to work outside home (\%) }\end{array}$ \\
\hline Women should decide for themselves how to vote & 62 & 30 \\
\hline $\begin{array}{l}\text { Men should advise them } \\
\begin{array}{l}\text { Women should decide for themselves but in } \\
\text { consultation with men }\end{array}\end{array}$ & 18 & 45 \\
\hline
\end{tabular}

\subsection{Women and political leadership}

The survey sought to assess public attitudes to women in political leadership roles and posed a series of questions related to women playing leadership roles in politics. Respondents were first asked whether they think political leadership positions should be mostly for men, mostly for women or whether both men and women should have equal representation at the leadership level. Forty-five percent of respondents say that both men and women should have equal representation, while $44 \%$ say that leadership positions should be mostly for men. Only $10 \%$ say that leadership positions should be mostly for women.

There is a big discrepancy in the opinions of male and female respondents on this issue. The survey shows that women have a much stronger belief in equality of representation than do their male counterparts. Almost twice as many women $(61 \%)$ as men $(33 \%)$ say there should be equal representation in political leadership. More than half of men (58\%) believe that political leadership positions should be mostly for men, while only around one in eight $(13 \%)$ female respondents say that leadership positions should be mostly for women.

Just under half $(47 \%)$ of respondents in rural areas say that leadership positions should be mostly for men, compared to a third (33\%) of those in urban areas. In urban areas, the majority of respondents (59\%) say that men and women should have equal representation in political leadership, while only $41 \%$ in rural areas say this. 
Do you think that political leadership positions should be mostly for men, mostly for women, or do you think that both men and women should have equal representation in the political leadership? (Q-85, Base 6348)BY ALL, GENDER AND SETTLEMENT

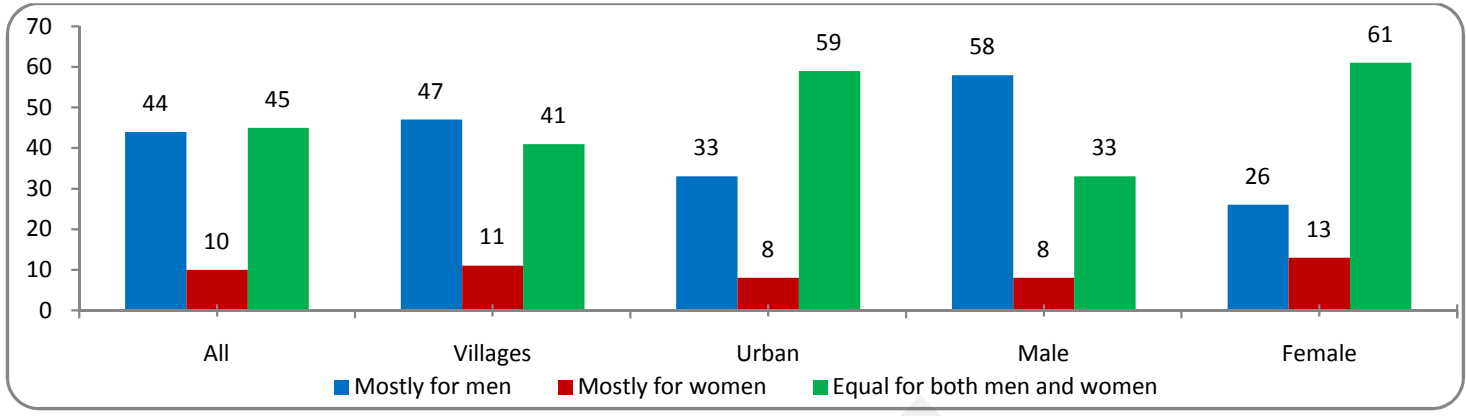

Fig. 11.12

The survey findings also show that opinions vary between ethnic groups. The majority of Pashtun respondents $(52 \%)$ say leadership positions should be for men, while most Hazara (63\%) and Tajik (53\%) respondents say leadership positions should be for both men and women. Uzbeks and respondents from other ethnic groups are divided in this regard.

Support for equal representation of men and women in political leadership positions is highest in the Central/ Hazarajat (69\%), followed by the Central/Kabul (58\%) and West (52\%) regions. The majority of respondents in the South West $(66 \%)$ say that leadership positions should be for men only, and this is also true for just under half of respondents in the South East (47\%), East (47\%), North East (45\%) and North West (45\%). These are also mostly the regions that register higher levels of opposition to women working outside the home (see above 11.3 Attitudes toward gender equality: women and employment).

Do you think that political leadership positions should be mostly for men, mostly for women, or do you think that both men and women should have equal representation in the political leadership? (Q-85, Base 6348) BY REGION

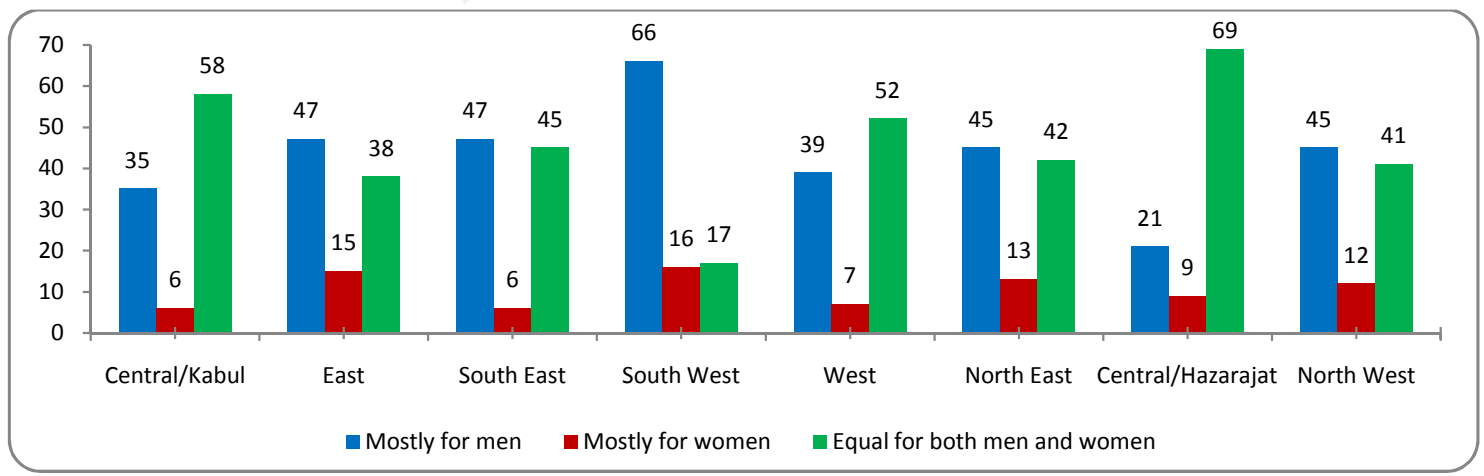

Fig. 11.13 
Survey results in 2011 show that support for equal representation of men and women in political leadership positions has been declining steadily since 2008 (from 51\% in 2007 and 2008 to 47\% in 2009, 46\% in 2010 and $45 \%$ in 2011 years). Support for political leadership positions mostly for men has been rising over the same period. Support for political leadership positions being for women has remained basically stable since 2008.

Table 11.12: Do you think that political leadership positions should be mostly for men, mostly for women, or do you think that both men and women should have equal representation in the political leadership? (Q-85)COMPARISON BETWEEN 2006, 2007, 2008, 2009, 2010 AND 2011

\begin{tabular}{|l|c|c|c|c|c|c|}
\multicolumn{1}{|c|}{ Q-85 } & $\begin{array}{c}\mathbf{2 0 0 6} \\
\mathbf{( \% )}\end{array}$ & $\begin{array}{c}\mathbf{2 0 0 7} \\
\mathbf{( \% )}\end{array}$ & $\begin{array}{c}\mathbf{2 0 0 8} \\
\mathbf{( \% )}\end{array}$ & $\begin{array}{c}\mathbf{2 0 0 9} \\
\mathbf{( \% )}\end{array}$ & $\begin{array}{c}\mathbf{2 0 1 0} \\
\mathbf{( \% )}\end{array}$ & $\begin{array}{c}\mathbf{2 0 1 1} \\
\mathbf{( \% )}\end{array}$ \\
\hline Equal for both men and women & 50 & 51 & 51 & 47 & 46 & 45 \\
\hline Mostly for men & 37 & 21 & 35 & 39 & 40 & 44 \\
\hline Mostly for women & 12 & 27 & 10 & 10 & 11 & 10 \\
\hline
\end{tabular}

\subsection{Women in representative roles}

In order to further examine public attitudes regarding women in political leadership roles, the survey also asked respondents whether they are opposed to being represented by a woman on various representative bodies from the local to the national level. The majority of respondents say they have no objection to being represented by a woman on any of these bodies. There is little difference between the responses of men and women on this issue. Only slightly more men say they would oppose being represented by a woman in one or more of these governance institutions compared to their female counterparts. The responses are shown in the table below.

Table 11.13: Are you opposed to a woman representing you in the following institutions? (Q-86a-e, Base 6348)

\begin{tabular}{|l|c|c|c|c|c|c|} 
& Yes & No & \multicolumn{2}{|c|}{ Male } & \multicolumn{2}{|c|}{ Female } \\
\cline { 4 - 7 } & $\mathbf{( \% )}$ & $\mathbf{( \% )}$ & Yes & No & Yes & No \\
\hline a) National parliament & 45 & 54 & 48 & 54 & 41 & 58 \\
\hline b) In your provincial council & 41 & 58 & 44 & 55 & 38 & 61 \\
\hline c) In your community development councils & 38 & 60 & 41 & 58 & 35 & 63 \\
\hline d) In your district development assembly & 37 & 61 & 39 & 59 & 34 & 63 \\
\hline e) In your local shura or jirga & 37 & 61 & 40 & 58 & 34 & 64 \\
\hline
\end{tabular}

Respondents express the least opposition to being represented by a woman in their district development assembly (61\% say they have no objection) and their local shura or jirga $(61 \%)$, followed by their community development council (60\%) and provincial council (58\%). Just under half of respondents say they are opposed to being represented by a woman in the national parliament (45\%). 
At the regional level, the proportions of respondents who say they have no objection to being represented by a woman in any of the institutions mentioned are highest in the Central/Hazarajat and South West. The high level of support in Central/Hazarajat for women taking representative roles is consistent with the fact that the majority of respondents in all regions say they have no objection to being represented by a woman in a local shura or jirga, community development council, district development assembly or provincial council. Less than half of respondents in the South East (45\%) and East (43\%) say they do not object to being represented by a woman in the national parliament.

Table 11.14: Are you opposed to a woman representing you the following institutions? (Q-86a-e, Base 6348) NO Responses - BY REGION

\begin{tabular}{|l|c|c|c|c|c|c|c|c|}
\hline & $\begin{array}{c}\text { Central/ } \\
\text { Kabul } \\
(\%)\end{array}$ & $\begin{array}{c}\text { East } \\
(\%)\end{array}$ & $\begin{array}{c}\text { South } \\
\text { East } \\
(\%)\end{array}$ & $\begin{array}{c}\text { South } \\
\text { West } \\
(\%)\end{array}$ & $\begin{array}{c}\text { West } \\
(\%)\end{array}$ & $\begin{array}{c}\text { North } \\
\text { East } \\
(\%)\end{array}$ & $\begin{array}{c}\text { Central/ } \\
\text { Hazarajat } \\
(\%)\end{array}$ & $\begin{array}{c}\text { North } \\
\text { West } \\
(\%)\end{array}$ \\
\hline National parliament & 55 & 43 & 45 & 57 & 56 & 55 & 70 & 56 \\
\hline Provincial council & 58 & 51 & 55 & 61 & 57 & 55 & 75 & 61 \\
\hline Community development council & 59 & 61 & 63 & 65 & 56 & 58 & 74 & 60 \\
\hline District development assembly & 59 & 60 & 59 & 65 & 61 & 60 & 66 & 63 \\
\hline Local shura or jirga & 60 & 60 & 60 & 66 & 62 & 57 & 73 & 61 \\
\hline
\end{tabular}

Support for female representation fell in all of the identified institutions in 2009, which was an election year for provincial councils, with the most significant drop in the proportion of respondents who said they have no objection to being represented by a woman at the provincial council level. Support for female representation also remained relatively low in 2010, which was a year for parliamentary elections. However, in 2011 support for women in representative political roles has risen again to levels closer to those recorded in 2007 and 2008.

Table 11.15: Proportion of respondents who are not opposed to being represented by a woman in the following organizations 'not opposed' responses only - (Q-86a-e) COMPARISON BETWEEN 2007, 2008, 2009, 2010 AND 2011

\begin{tabular}{|l|c|c|c|c|c|} 
& $\begin{array}{c}\mathbf{2 0 0 7} \\
\mathbf{( \% )}\end{array}$ & $\begin{array}{c}\mathbf{2 0 0 8} \\
\mathbf{( \% )}\end{array}$ & $\begin{array}{c}\mathbf{2 0 0 9} \\
\mathbf{( \% )}\end{array}$ & $\begin{array}{c}\mathbf{2 0 1 0} \\
\mathbf{( \% )}\end{array}$ & $\begin{array}{c}\mathbf{2 0 1 1} \\
\mathbf{( \% )}\end{array}$ \\
\hline a) In national parliament & 55 & 57 & 50 & 49 & 54 \\
\hline b) In your provincial council & 58 & 59 & 49 & 51 & 58 \\
\hline c) In your community development councils & 58 & 58 & 52 & 55 & 60 \\
\hline d) In your district development assembly & 59 & 57 & 54 & 56 & 61 \\
\hline e) In your local shura or jirga & 56 & 58 & 53 & 56 & 61 \\
\hline
\end{tabular}




\section{Access to Information}

Since 2006, the survey has been exploring how Afghan people access and receive information. This year, the survey again examined listenership of radio, viewership of television, readership of newspapers/magazines and ownership of various types of communications technologies. It also measured the availability of communications facilities such as radio, television, fixed phone lines, mobile phones and computers in households and assessed their preferences for receiving information through these and other channels including informal community networks.

\subsection{Access to communications technology}

Radio is the most accessible media for Afghan households. More than four fifths (81\%) of respondents say they have a functioning radio in their household. There is a small difference in access to radio between rural $(83 \%)$ and urban $(73 \%)$ areas. Other communications technologies, however, are much more accessible to urban residents than to those living in rural areas. Survey findings show that $66 \%$ of respondents say they have a functioning mobile phone in their households. This is true for $88 \%$ of urban households but only $60 \%$ of rural households. Less than half of respondents $(42 \%)$ report that they own a TV but this is the case for around four fifths $(81 \%)$ of urban respondents compared to a third $(32 \%)$ in rural areas. Only a small proportion of Afghan households own a computer (9\%); this is true for nearly four times more urban respondents $(22 \%)$ than their rural counterparts $(6 \%)$. Ownership of fixed phone lines remains rare in Afghanistan.

Table 12.1: Proportion of respondents who have the following communications technologies in functioning order in their housebolds (Q-1, Base 6348) ALL, RURAL AND URBAN SETTLEMENT

\begin{tabular}{|l|c|c|c|}
\hline Radio & $\begin{array}{c}\text { All } \\
(\%)\end{array}$ & $\begin{array}{c}\text { Rural } \\
(\%)\end{array}$ & $\begin{array}{c}\text { Urban } \\
(\%)\end{array}$ \\
\hline Mobile phone & 81 & 83 & 73 \\
\hline TV & 66 & 60 & 88 \\
\hline Computer & 42 & 32 & 81 \\
\hline
\end{tabular}

Ownership of all kinds of communications technology rises with both income and educational levels. Almost all households (87\%) in the highest income group (earning over 10,000 Afs a month) own a radio, but this is true for just over two thirds (73\%) of households in the lower earning brackets (earning under 2,000 Afs). This disparity indicates the ongoing challenges in providing information through technological means to the poorer segments of Afghan society.

A higher proportion of people own TV sets, mobile phones and computers in the Central/Kabul, which is also the region where satisfaction with the electricity supply is higher than any other region. Radio ownership 
is highest in the South East (95\%), East (94\%) and South West (93\%). and is lowest in the Central/Hazarajat $(57 \%)$ and North West $(69 \%)$ regions. The majority of respondents say they have access to television in their household in the Central/Kabul region (69\%) and this is true for just under half in the West (47\%) and North West (44\%). Again, these findings are consistent with the high levels of access to electricity supply in these regions. Mobile telephone penetration is also highest in the Central/Kabul region (87\%) followed by the East (81\%), South East (74\%) and North West (68\%). The Central/Kabul region also has a significantly higher proportion of households that own a computer (21\%) followed by the South East $(12 \%)$ region.

Table 12.2: Regional comparison of ownership of communications technologies (Q-1, Base 6348)

\begin{tabular}{|l|c|c|c|c|c|c|c|c|}
\hline & $\begin{array}{c}\text { Central/ } \\
\text { Kabul } \\
(\mathbf{\%})\end{array}$ & $\begin{array}{c}\text { East } \\
\mathbf{( \% )}\end{array}$ & $\begin{array}{c}\text { South } \\
\text { East } \\
(\mathbf{\%})\end{array}$ & $\begin{array}{c}\text { South } \\
\text { West } \\
(\mathbf{\%})\end{array}$ & $\begin{array}{c}\text { West } \\
(\%)\end{array}$ & $\begin{array}{c}\text { North } \\
\text { East } \\
(\%)\end{array}$ & $\begin{array}{c}\text { Central/ } \\
\text { Hazarajat } \\
(\%)\end{array}$ & $\begin{array}{c}\text { North } \\
\text { West } \\
(\%)\end{array}$ \\
\hline Radio & 79 & 94 & 95 & 93 & 75 & 77 & 57 & 69 \\
\hline TV set & 69 & 21 & 31 & 22 & 47 & 31 & 40 & 44 \\
\hline Mobile phone & 87 & 81 & 74 & 45 & 47 & 55 & 51 & 68 \\
\hline Computer & 21 & 6 & 12 & 5 & 8 & 2 & 6 & 6
\end{tabular}

Ownership of functioning radios has declined slightly over time despite the fact that radio continues to be the most accessible form of communications technology in Afghanistan (from 88\% in 2007 to 84\% in 2008, to between $81 \%$ and $82 \%$ between 2009 and 2011). On the other hand, the proportion of respondents who own a television set has risen steadily (from 37\% in 2007 to 38\% in 2008, 41\% in 2009 and 2010 and 42\% in 2011). The most dramatic increase has been seen in mobile phone ownership, which has risen from $42 \%$ in 2007 to $66 \%$ in 2011. Computer ownership is also rising. The proportion of respondents who report that they own a computer has almost doubled since 2008 (5\% to 9\% in 2010 and 2011).

Table 12.3: Proportion of respondents who have the following communications technologies in functioning order in their housebolds (Q-1) COMPARISON BETWEEN 2007, 2008, 2009 ,2010 AND 2011

\begin{tabular}{|l|c|c|c|c|c|} 
& $\begin{array}{c}2007 \\
(\%)\end{array}$ & $\begin{array}{c}2008 \\
(\%)\end{array}$ & $\begin{array}{c}2009 \\
(\%)\end{array}$ & $\begin{array}{c}2010 \\
(\%)\end{array}$ & $\begin{array}{c}2011 \\
(\%)\end{array}$ \\
\hline Radio & 88 & 84 & 81 & 82 & 81 \\
\hline Mobile phone & 42 & 40 & 52 & 59 & 66 \\
\hline TV set & 37 & 38 & 41 & 41 & 42 \\
\hline Computer & - & 5 & 6 & 9 & 9 \\
\hline
\end{tabular}

\subsection{Radio listenership}

The survey sought to examine the use of different media. Respondents were first asked whether they listen to radio programs. A large majority $(79 \%)$ say they listen to radio programs while $21 \%$ say they do not. More 
men $(85 \%)$ than women $(71 \%)$ listen to the radio; likewise, more rural residents $(81 \%)$ listen to the radio than urban residents $(69 \%)$.

Do you listen to radio programs? (W-1, Base 6348)

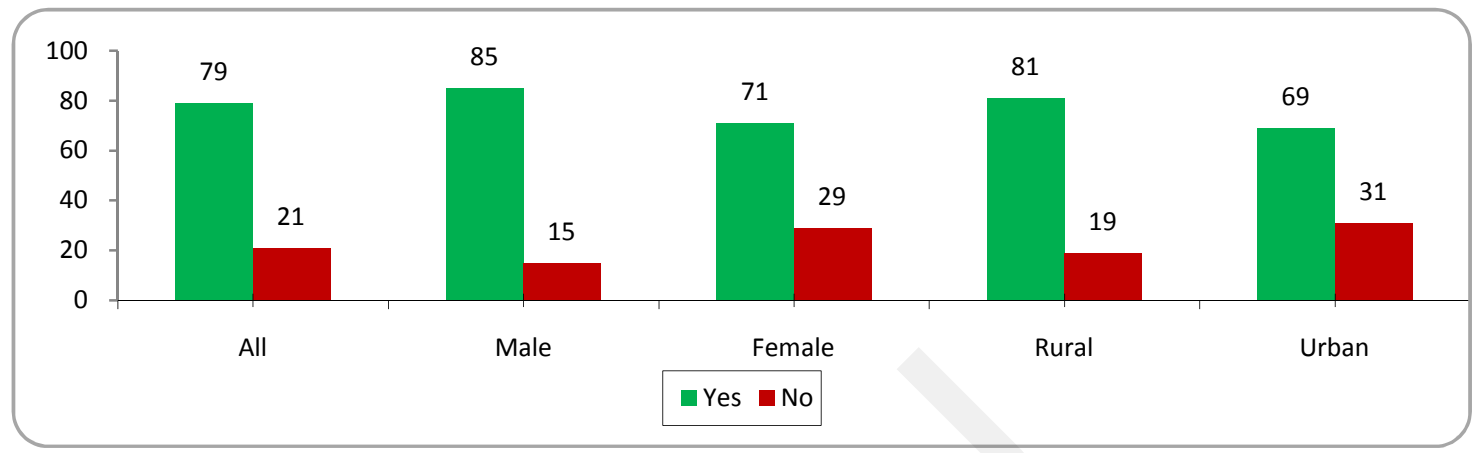

Fig 12.1

Radio listenership is lower in low income households. Seventy percent of households in the lowest earning group (earning less than 2000 Afs a month) say they listen to radio programs, while $84 \%$ of those in the highest earning bracket (earning more than 10,000 Afs) say the same. This is consistent with radio ownership figures, which are correspondingly higher $(87 \%)$ for households with higher incomes than for those in the lowest income bracket (73\%) (see above 12.1 Access to communications technology).

Radio ownership affects listenership at the regional level as well. Respondents in the South East report the highest levels of radio ownership (95\%) and are those who listen to the radio the most (93\%). The lowest proportion of radio ownership is in Central/Hazarajat (57\%) and North West (69\%) regions. These are also the regions that record the lowest radio listenership (54\% in the Central/Hazarajat and $66 \%$ in the North West).

Table 12.4: Comparison of ownership and listenership of radio (Q-1a \& W-1, Base6348) AND ALL BY REGION

\begin{tabular}{|l|c|c|c|c|c|c|c|c|c|}
\hline All percentage & $\begin{array}{c}\text { All } \\
(\%)\end{array}$ & $\begin{array}{c}\text { Central/ } \\
\text { Kabul } \\
(\%)\end{array}$ & $\begin{array}{c}\text { East } \\
\mathbf{( \% )}\end{array}$ & $\begin{array}{c}\text { South } \\
\text { East } \\
(\%)\end{array}$ & $\begin{array}{c}\text { South } \\
\text { West } \\
(\%)\end{array}$ & $\begin{array}{c}\text { West } \\
(\%)\end{array}$ & $\begin{array}{c}\text { North } \\
\text { East } \\
(\%)\end{array}$ & $\begin{array}{c}\text { Central } \\
\text { Hazarajat } \\
(\%)\end{array}$ & $\begin{array}{c}\text { North } \\
\text { West } \\
(\%)\end{array}$ \\
\hline Radio Ownership & 81 & 79 & 94 & 95 & 93 & 75 & 77 & 57 & 69 \\
\hline Radio Listenership & 79 & 76 & 93 & 93 & 92 & 72 & 77 & 54 & 66 \\
\hline
\end{tabular}

\subsection{Television viewership}

The survey then asked about television viewership. Respondents were asked whether they watch television programs. The majority (59\%) say they do not watch television programs while $41 \%$ say that they do. Television viewership is much higher in urban $(81 \%)$ than rural $(31 \%)$ areas. This is consistent with much higher 
levels of television ownership and access to electricity supply in urban areas. Unlike the radio, more women $(48 \%)$ than men $(36 \%)$ report that they watch TV.

Do you watch television programs? (W-2, Base 6348)

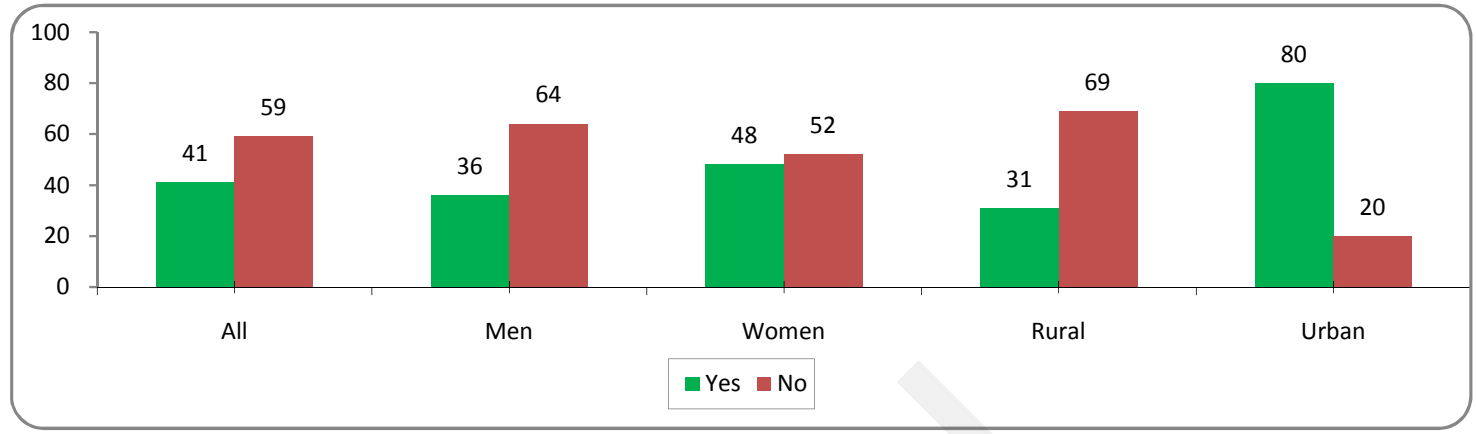

Fig 12.2

Viewership of television rises steadily with both income and educational level. About half (49\%) of the households in the highest income group watch television, but this is true for less than one third (31\%) of households in the lowest earning group. Television viewership is also more common among respondents who have completed tenth grade and higher (59\%) compared to those who never went to school (36\%). This is consistent with the higher levels of television ownership amongst these groups (see above 12.1 Access to communications technology).

Again, television viewership is highest in areas where more people own television sets. The Central/Kabul region records the highest ownership of televisions (69\%) and the highest television viewership (66\%). On the other hand, at least three quarters of respondents in the South West $(77 \%)$ do not watch television, largely because $78 \%$ don't own a television set.

Table 12.5: Comparison of ownership of TV set and viewership of television (Q-1bङW2, Base 6348) AND ALL BY REGION

\begin{tabular}{|l|c|c|c|c|c|c|c|c|c|}
\hline \multicolumn{1}{|c|}{ Q-1b \& W2 } & $\begin{array}{c}\text { All } \\
(\%)\end{array}$ & $\begin{array}{c}\text { Central/ } \\
\text { Kabul } \\
(\%)\end{array}$ & $\begin{array}{c}\text { East } \\
(\%)\end{array}$ & $\begin{array}{c}\text { South } \\
\text { East } \\
(\%)\end{array}$ & $\begin{array}{c}\text { South } \\
\text { West } \\
(\%)\end{array}$ & $\begin{array}{c}\text { West } \\
(\%)\end{array}$ & $\begin{array}{c}\text { North } \\
\text { East } \\
(\%)\end{array}$ & $\begin{array}{c}\text { Central } \\
\text { Hazarajat } \\
(\%)\end{array}$ & $\begin{array}{c}\text { North } \\
\text { West } \\
(\%)\end{array}$ \\
\hline Ownership of TV set & 42 & 69 & 21 & 31 & 22 & 47 & 31 & 40 & 44 \\
\hline Viewership of TV & 41 & 66 & 21 & 31 & 23 & 46 & 31 & 37 & 46 \\
\hline
\end{tabular}




\subsection{Sources of information for news and current events}

The survey also endeavored to ascertain how respondents prefer to receive news and information. Respondents were first asked to identify the main source from which they get news and information. Just under half $(45 \%)$ identify radio as their main information source, while over a quarter $(28 \%)$ say TV. One in five respondents (20\%) receives news and information from friends, family and neighbors. A small proportion of respondents say they get information from mosques $(6 \%)$ or newspapers $(1 \%)$.

There is significant variation between urban and rural areas. About two thirds of respondents in urban areas $(68 \%)$ most often use television as the preferred source for news and information, compared to about one in six $(17 \%)$ of their rural counterparts. In contrast, at least twice as many respondents in rural areas use radio (53\% compared to $17 \%$ in urban areas), friends and family ( $23 \%$ compared to $11 \%$ in urban areas), and mosques (6\% compared to $3 \%$ in urban areas) to get news and information.

Which of the following sources do you use most often for news and information? (W-3, Base 6348)

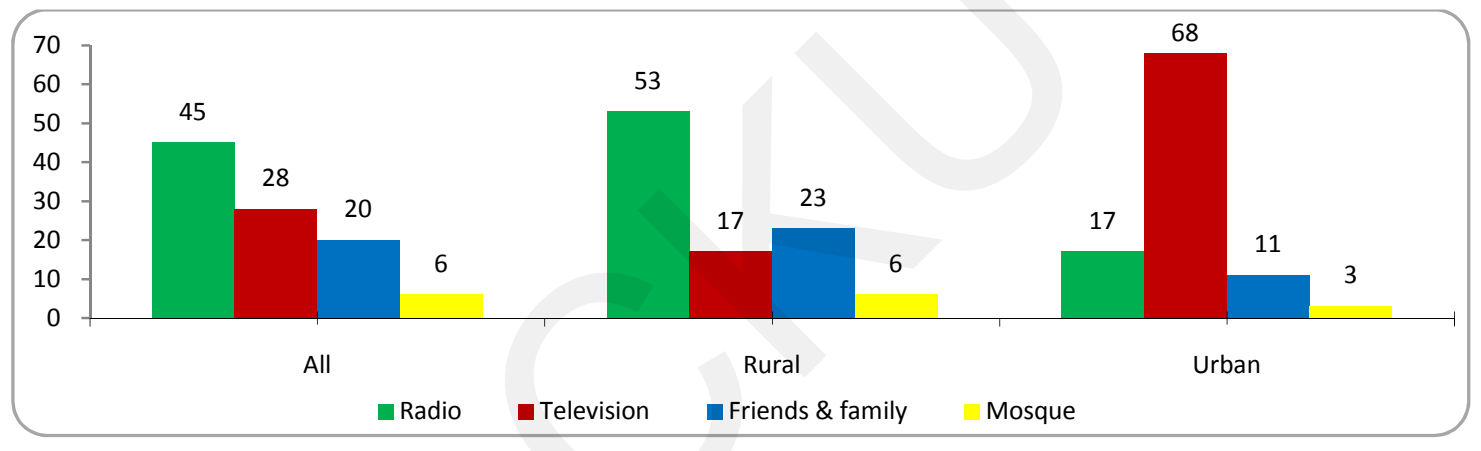

Fig 12.3

More men (52\%) than women (36\%) identify radio as their main source of information, whereas more women $(35 \%)$ than men $(23 \%)$ report that television is their preferred source of information. Women $(26 \%)$ are significantly more likely than men $(16 \%)$ to identify family and friends as their source for getting news and information.

The survey also found that respondents who never went to school (47\%) are more likely to use radio as their source of information compared to respondents with higher educational levels (38\%). However, respondents with higher educational levels $(46 \%)$ are more likely to use television compared to those respondents who never went to school $(22 \%)$. Those with lower levels of education also tend to rely more on family, friends and neighbors to get information. Significantly, more respondents who never went to school $(24 \%)$ say they get their information this way, than those who completed primary school (19\%), attended high school (12\%) or completed secondary or higher education $(11 \%)$. 
There are large differences across regions on the sources most often used to access news and information. Radio use for this purpose is highest in the East (74\%), South West (58\%) and South East (53\%), but is also used by more than a third of respondents in Central/Kabul (35\%) and North West (32\%) regions. Not surprisingly, the highest proportion of respondents mentioning television as their source of news and information is in the Central/Kabul region (52\%). This is the only region where more respondents get their news and information from television than radio. It is also the region that records the lowest use of friends and family (11\%) and the mosque $(2 \%)$ as sources of news and information. Friends and family constitute the most important source of news and information in Central/Hazarajat region (29\%) although this is significantly lower than in 2010 (48\%). This region also records the lowest level of radio ownership. Around one in 10 respondents uses mosques as a source of news and information in the West (10\%), North West (8\%) and South East (8\%) regions.

Table 12.6: Which of the following sources do you use most often for news and information? (W-3, Base 6348) AND ALL BY REGION

\begin{tabular}{|l|c|c|c|c|c|c|c|c|c|} 
& Total & $\begin{array}{c}\text { Central/ } \\
\text { Kabul }\end{array}$ & East & $\begin{array}{c}\text { South } \\
\text { East }\end{array}$ & $\begin{array}{c}\text { South } \\
\text { West }\end{array}$ & West & $\begin{array}{c}\text { North } \\
\text { East }\end{array}$ & $\begin{array}{c}\text { Central } \\
\text { Hazarajat }\end{array}$ & $\begin{array}{c}\text { North } \\
\text { West }\end{array}$ \\
\hline Radio & 45 & 33 & 74 & 53 & 58 & 40 & 49 & 35 & 32 \\
\hline Television & 28 & 52 & 10 & 15 & 10 & 29 & 22 & 29 & 33 \\
\hline Friends and family & 20 & 11 & 12 & 23 & 27 & 20 & 23 & 29 & 26 \\
\hline Mosque & 6 & 2 & 2 & 8 & 5 & 10 & 5 & 5 & 8 \\
\hline
\end{tabular}

Although radio has remained the most common source of information since 2006, the proportion of respondents who say radio is their main source of information has been falling over this period, from 55\% in 2006 to $45 \%$ in 2011 . On the other hand, the proportion of respondents who identify TV as their main source of news and information has been steadily rising from $22 \%$ in 2006 to $28 \%$ in 2011. Surprisingly, those who cite friends and family as their main source of information has also risen over this period, from 15\% in 2006 to $20 \%$ in 2011. Three times more respondents also say they get their news and information from religious leaders (mosques) in 2010 and 2011 (6\%) than in previous years (between 1\% and 2\%).

Table 12.7: Which of the following sources do you use most often for news and information? (W-3, Base 6348) COMPARISON BETWEEN 2006, 2007, 2008, 2009, 2010 AND 2011

\begin{tabular}{|l|c|c|c|c|c|c|}
\hline & $\mathbf{2 0 0 6}$ & $\mathbf{2 0 0 7}$ & $\mathbf{2 0 0 8}$ & $\mathbf{2 0 0 9}$ & $\mathbf{2 0 1 0}$ & $\mathbf{2 0 1 1}$ \\
\hline Radio & 55 & 54 & 51 & 47 & 46 & 45 \\
\hline TV & 22 & 26 & 21 & 25 & 28 & 28 \\
\hline Friends and family & 15 & 14 & 18 & 18 & 19 & 20 \\
\hline Religious leaders (mosques) & 2 & 1 & 2 & 2 & 6 & 6 \\
\hline
\end{tabular}




\section{Appendix 1: Target Demographics}

A total of 6348 respondents were surveyed in the study, out of which 4983 (78\%) were from rural areas and 1365 (22\%) were from urban areas. Of all respondents interviewed, 57\% were male and 43\% were female. The following tables provide demographic and socio-economic details of the respondents including a ruralurban breakdown. They also provide the employment status, occupation, educational status, income status and marital status of the respondents.

\section{Gender and Region}

\begin{tabular}{|c|c|c|c|}
\hline \multirow{2}{*}{ Characteristics } & All & Rural & Urban \\
\hline & 6348 & 4983 & 1365 \\
\hline Gender & $(\%)$ & $(\%)$ & $(\%)$ \\
\hline Male & 57 & 59 & 51 \\
\hline Female & 43 & 41 & 49 \\
\hline Region & $\%$ & $\%$ & $\%$ \\
\hline Central/Kabul & 22 & 14 & 54 \\
\hline East & 10 & 11 & 4 \\
\hline South East & 11 & 13 & 2 \\
\hline South West & 11 & 12 & 8 \\
\hline West & 13 & 15 & 9 \\
\hline North East & 15 & 16 & 10 \\
\hline Central/Hazarajat & 3 & 4 & 1 \\
\hline North West & 14 & 15 & 12 \\
\hline
\end{tabular}

\section{Employment Status and Age Group}

\begin{tabular}{|c|c|c|c|}
\hline \multirow{2}{*}{ Characteristics } & \multirow{2}{*}{$\begin{array}{c}\text { All } \\
6348\end{array}$} & \multirow{2}{*}{$\begin{array}{c}\text { Rural } \\
4983\end{array}$} & \multirow{2}{*}{$\begin{array}{c}\text { Urban } \\
1365\end{array}$} \\
\hline & & & \\
\hline Employment & $(\%)$ & $(\%)$ & $(\%)$ \\
\hline Working & 47 & 49 & 40 \\
\hline Retired & 2 & 1 & 2 \\
\hline Housewife & 37 & 36 & 41 \\
\hline Student & 7 & 7 & 10 \\
\hline Unemployed & 7 & 7 & 8 \\
\hline Age Group & $\%$ & $\%$ & $\%$ \\
\hline $18-24$ & 25 & 24 & 27 \\
\hline $25-34$ & 26 & 26 & 26 \\
\hline $35-44$ & 21 & 24 & 22 \\
\hline $45-54$ & 16 & 16 & 15 \\
\hline $65+$ & 6 & 5 & 6 \\
\hline
\end{tabular}




\section{Main Occupation}

\begin{tabular}{|l|c|c|c|}
\hline \multicolumn{1}{|c}{ Main Occupation } & All & Rural & Urban \\
\hline Base: Currently working and retired respondents & $\mathbf{3 0 8 4}$ & $\mathbf{2 5 1 6}$ & $\mathbf{5 6 8}$ \\
\hline Farmer (own land / tenant farmer) & $\mathbf{( \% )}$ & $\mathbf{( \% )}$ & $\mathbf{( \% )}$ \\
\hline Farm labourer (others land) & 35 & 40 & 13 \\
\hline Labourer, domestic, or unskilled worker & 12 & 14 & 5 \\
\hline Informal sales/ business & 8 & 7 & 13 \\
\hline Skilled worker/artisan & 7 & 7 & 8 \\
\hline Government office - clerical worker & 13 & 12 & 17 \\
\hline Private office - clerical worker & 3 & 3 & 5 \\
\hline Government office - executive/manager & 1 & 1 & 3 \\
\hline Private office - executive/manager & 2 & 1 & 5 \\
\hline Self-employed professional & 1 & 1 & 3 \\
\hline Small business owner & 4 & 3 & 8 \\
\hline School teacher & 6 & 5 & 8 \\
\hline University teacher & 5 & 4 & 6 \\
\hline Military/Police & $*$ & $*$ & 1 \\
\hline Don't know & 2 & 2 & 4 \\
\hline
\end{tabular}

\section{Farming Land}

\begin{tabular}{|l|c|c|c|}
\hline \multicolumn{1}{|c|}{ Farming Land } & All & Rural & Urban \\
\hline Base: Farmers who own land or tenant farmers & $\mathbf{1 0 8 0}$ & $\mathbf{1 0 0 9}$ & $\mathbf{7 1}$ \\
\hline & $\mathbf{( \% )}$ & $\mathbf{( \% )}$ & $\mathbf{( \% )}$ \\
\hline Less than 1 Jerib & 10 & 10 & 12 \\
\hline 1 - 2 Jerib & 26 & 27 & 13 \\
\hline 2.1 - 3 Jerib & 27 & 27 & 22 \\
\hline More than 3 Jerib & 35 & 34 & 48 \\
\hline Don't know & 2 & 2 & 4 \\
\hline
\end{tabular}

* Jerib: One Jerib is equal to one fifth of a hectare.

\section{Educational Status}

\begin{tabular}{|l|c|c|c|}
\hline \multicolumn{1}{|c|}{ Educational Status } & All & Rural & Urban \\
\hline & $\mathbf{6 3 4 8}$ & $\mathbf{4 9 8 3}$ & $\mathbf{1 3 6 5}$ \\
\hline Never went to school & $\mathbf{( \% )}$ & $\mathbf{( \% )}$ & $\mathbf{( \% )}$ \\
\hline Primary School, incomplete & 58 & 61 & 45 \\
\hline Primary School, complete & 9 & 10 & 9 \\
\hline Secondary education, incomplete & 6 & 6 & 5 \\
\hline Secondary education, complete & 6 & 5 & 7 \\
\hline High School & 4 & 3 & 4 \\
\hline University education or above & 13 & 11 & 20 \\
\hline
\end{tabular}


Stability indicator

\begin{tabular}{|l|c|c|c|}
\hline Base: If given the opportunity will you leave & All & Rural & Urban \\
\hline Afghanistan and live somewhere else? & $\mathbf{6 3 4 8}$ & 4983 & $\mathbf{1 3 6 5}$ \\
\hline & $\mathbf{( \% )}$ & $\mathbf{( \% )}$ & $\mathbf{( \% )}$ \\
\hline Yes & 34 & 33 & 36 \\
\hline No & 65 & 65 & 64 \\
\hline
\end{tabular}

\section{Spoken Languages}

\begin{tabular}{|c|c|c|c|}
\hline \multirow{2}{*}{ Languages spoken } & All & Rural & Urban \\
\hline & 6348 & 4983 & 1365 \\
\hline & $(\%)$ & $(\%)$ & $(\%)$ \\
\hline Pashto & 49 & 50 & 44 \\
\hline Dari & 76 & 72 & 91 \\
\hline Uzbeki & 11 & 12 & 7 \\
\hline Turki & 2 & 3 & $*$ \\
\hline Urdu & 2 & 2 & 3 \\
\hline English & 4 & 2 & 8 \\
\hline Arabic & 1 & 1 & $*$ \\
\hline Balochi & 1 & 1 & * \\
\hline
\end{tabular}

\section{Marital Status}

\begin{tabular}{|c|c|c|c|}
\hline \multirow{2}{*}{ Marital Status } & All & Rural & Urban \\
\hline & 6348 & 4983 & 1365 \\
\hline & $(\%)$ & $(\%)$ & $(\%)$ \\
\hline Single & 19 & 18 & 23 \\
\hline Married & 80 & 81 & 76 \\
\hline Widower/ Widow & 2 & 2 & 2 \\
\hline
\end{tabular}

\section{Ethnicity Status}

\begin{tabular}{|c|c|c|c|}
\hline \multirow{2}{*}{ Ethnicity } & All & Rural & Urban \\
\hline & 6348 & 4983 & 1365 \\
\hline Base: all respondents & $(\%)$ & $(\%)$ & $(\%)$ \\
\hline Pashtun & 41 & 44 & 32 \\
\hline Tajik & 32 & 28 & 46 \\
\hline Uzbek & 9 & 9 & 6 \\
\hline Hazara & 11 & 11 & 11 \\
\hline Turkmen & 2 & 2 & $*$ \\
\hline Baloch & 1 & 1 & $*$ \\
\hline
\end{tabular}


178 | Afghanistan in 2011

\begin{tabular}{|l|l|l|l|}
\hline Kirghiz & $*$ & $*$ & $*$ \\
\hline Nuristani & 1 & 1 & $*$ \\
\hline Aimak & 1 & 1 & 1 \\
\hline Arab & 1 & 1 & 2 \\
\hline Pashaye & $*$ & 1 & $*$ \\
\hline Sadat & 1 & $*$ & 1 \\
\hline Qazelbash & $*$ & $*$ & 1 \\
\hline
\end{tabular}

\section{Average Monthly Household Income}

\begin{tabular}{|c|c|c|c|}
\hline \multirow{3}{*}{ Income } & All & Rural & Urban \\
\hline & 6348 & 4983 & 1365 \\
\hline & $(\%)$ & $(\%)$ & $(\%)$ \\
\hline Less than 2,000 Afs & 9 & 10 & 5 \\
\hline $2,001-3,000$ Afs & 17 & 18 & 12 \\
\hline $3,001-5,000$ Afs & 18 & 19 & 16 \\
\hline $5,001-10,000$ Afs & 31 & 32 & 31 \\
\hline $10,001-15,000$ Afs & 12 & 11 & 15 \\
\hline $15,001-20,000$ Afs & 7 & 6 & 12 \\
\hline $20,001-25,000$ Afs & 2 & 2 & 4 \\
\hline $25,001-40,000$ Afs & 1 & 1 & 2 \\
\hline More then $40,000 \mathrm{Afs}$ & $*$ & $*$ & 1 \\
\hline
\end{tabular}




\section{Appendix 2: Methodology}

\section{Distribution of sampling points by region and urban/rural strata}

The survey was conducted among 6348 respondents in a single wave. Fieldwork for the survey was conducted by the Afghan Center for Socio-economic and Opinion Research (ACSOR-Surveys), Kabul, between July 2 and August 1, 2011 by a team of 589 trained interviewers (259 women and 330 men). The survey consisted of in-person interviews with a random, representative sample of 6348 Afghan citizens, 18 years of age and over and resident in Afghanistan.

The survey included both urban and rural respondents in all provinces of Afghanistan. The Sheharwali (municipal administration in Afghanistan) defines the urban population as those living within municipal boundaries. By default, the rural population comprises those who are living outside the municipal limits. Rural areas are defined neither in terms of population density nor remoteness.

The country is divided into eight geographical regions covering all 34 provinces. The sample was distributed proportional to geographic and residential characteristics of the population in each province. Within each province, districts were selected by first listing them by size of population and then applying a random selection method from this list.

For provinces with low population density, such as Samangan, Logar, Zabul, Urozgan, Nimroz, Panjshir and Nooristan, five interviews per sampling point were conducted, rather than eight as in other provinces, to offer broader geographic distribution.

The margin of sampling error is calculated at a cumulative of $+/-4.1$ percent at 95 percent confidence interval. The stochastic error is $+/-2.4$ percent while the systemic error is $+/-1.7$ percent. The systemic error appears because of the areas not accessible for surveying this year. The systemic error percentage is based on the retrospective calculation of the contribution of the inaccessible areas in the data for 2008 .

\section{Selection of sampling points and replacement of sampling Points}

The interviews were completed using multi-stage random sampling. Due to local cultural traditions, the sample was first divided into male and female sub-samples. Each region, province and further strata was allocated an equal number of male and female respondents per sampling points. Field researchers of the appropriate gender were allocated to conduct the interviews for each sub-sample. However, in 2011, in two provinces, Paktika and Zabul, the deteriorated security situation restricted the freedom of movement, making it unsafe to employ female interviewers. This meant that no women were included in the sample in these provinces.

Moreover, in 2011, there were restrictions on the movement of survey researchers. A number of districts in the country could not be surveyed because of inaccessibility due to logistical problems, natural disasters and security. Overall 166 of the 876 sampling points had to be replaced. The replacements were made by selecting other sampling points in the same region. The instability and frequent fighting in some provinces caused 95 of the sampling points across the country ( $57 \%$ of the total replacements) to be adjusted or replaced to keep 
interviewers out of areas affected by active violence. This has slightly decreased from 2010 when 138 sampling points (65\% of total replacements) had to be replaced for security reasons. The regions most severely affected by these restrictions are the South East (23 replacements), East (20 replacements), Central/Kabul (17 replacements), and North West (16 replacements). There were eight replacements due to security made in South West, seven in the North East, four in West, and zero in Central/Hazarjat regions. In regions with significant numbers of sampling points had to be changed for security reasons individual provinces with the most changed included Kunarha (15 replacements) in the East, Ghazni (12 replacements) in the South East, and Balkh (eight replacements) in the North West.

Replacement of the sampling points and the reason for replacement is described in the following table.

\begin{tabular}{|c|c|c|c|c|}
\hline Province & SP & Projected District/Village & Replaced with & Reason \\
\hline \multirow{6}{*}{ 1.Kabul } & 99 & FATAH KHAIL. Village & Shah Mardan. Village & $\begin{array}{l}\text { No village with this name } \\
\text { was found }\end{array}$ \\
\hline & 101 & PAITAWA. Village & Bitini. Village & $\begin{array}{l}\text { No village with this name } \\
\text { was found }\end{array}$ \\
\hline & 105 & Surubi. District & Char Asiab. District & $\begin{array}{l}\text { The district is controlled } \\
\text { by Taliban }\end{array}$ \\
\hline & 105 & PUSHT BAZAR. Village & Qaria Khair Abad. Village & $\begin{array}{l}\text { The village is under } \\
\text { control of Taliban }\end{array}$ \\
\hline & 106 & FARMAN BAIG. Village & Timor China. Village & $\begin{array}{l}\text { The village is under } \\
\text { control of Taliban }\end{array}$ \\
\hline & 110 & DAKU SUFLA. Village & Marki. Village & $\begin{array}{l}\text { No village with this name } \\
\text { was found }\end{array}$ \\
\hline \multirow[t]{2}{*}{ 2. Kapisa } & 111 & Tagab. District & Kohistan. District & $\begin{array}{l}\text { The district is controlled } \\
\text { by Taliban }\end{array}$ \\
\hline & 112 & Tagab. District & Koh Band. District & $\begin{array}{l}\text { The district is controlled } \\
\text { by Taliban }\end{array}$ \\
\hline \multirow{8}{*}{ 3. Parwan } & 125 & $\begin{array}{l}\text { SHAMAQ TOOPDARA. } \\
\text { Village }\end{array}$ & Qalai Safid. Village & $\begin{array}{l}\text { There was few houses in } \\
\text { this village }\end{array}$ \\
\hline & 126 & Kohi Safi. District & Surkhi parsa. District & $\begin{array}{l}\text { The district is controlled } \\
\text { by Taliban }\end{array}$ \\
\hline & 127 & Kohi Safi. District & Salang. District & $\begin{array}{l}\text { The district is controlled } \\
\text { by Taliban }\end{array}$ \\
\hline & 127 & KHAM BAIYE. Village & Samoch Shah Mir. Village & $\begin{array}{l}\text { No transportation way for } \\
\text { vehicles }\end{array}$ \\
\hline & 128 & MOUSA KHAIL. Village & Sahadullah. Village & $\begin{array}{l}\text { People didn't allow to } \\
\text { interview }\end{array}$ \\
\hline & 129 & DAHI CHANAR. Village & Qalai Saheb Zada. Village & $\begin{array}{l}\text { No transportation way for } \\
\text { vehicles }\end{array}$ \\
\hline & 139 & SEYEL KUNDI. Village & Se Kotal. Village & $\begin{array}{l}\text { No village with this name } \\
\text { was found }\end{array}$ \\
\hline & 140 & DENAR KHAIL. Village & Qalandar Khail. Village & $\begin{array}{l}\text { People didn't allow to } \\
\text { interview }\end{array}$ \\
\hline 10. Nangarhar & 183 & $\begin{array}{l}\text { MURGHAN KALAY. } \\
\text { Village }\end{array}$ & Baba Kalai. Village & $\begin{array}{l}\text { The village is under } \\
\text { control of Taliban }\end{array}$ \\
\hline
\end{tabular}




\begin{tabular}{|c|c|c|c|c|}
\hline \multirow{15}{*}{ 12. Kunarha } & 197 & QALA WARAK. Village & Zor Asmar. Village & $\begin{array}{l}\text { The village is under } \\
\text { control of Taliban }\end{array}$ \\
\hline & 198 & CHIM BANDA. Village & Miagano Kalai. Village & $\begin{array}{l}\text { The village is under } \\
\text { control of Taliban }\end{array}$ \\
\hline & 199 & MEYAL. Village & Bargam Kalai. Village & $\begin{array}{l}\text { The village is under } \\
\text { control of Taliban }\end{array}$ \\
\hline & 200 & NELI GUL. Village & Managi Kalai. Village & $\begin{array}{l}\text { The village is under } \\
\text { control of Taliban }\end{array}$ \\
\hline & 201 & SAWADA BANDA. Village & Madrak. Village & $\begin{array}{l}\text { The village is under } \\
\text { control of Taliban }\end{array}$ \\
\hline & 201 & Darai Pich. District & $\begin{array}{l}\text { Shigal-wa-Sheltan. } \\
\text { District }\end{array}$ & $\begin{array}{l}\text { The district is controlled } \\
\text { by Taliban }\end{array}$ \\
\hline & 202 & Darai Pich. District & Marawura. District & $\begin{array}{l}\text { The district is controlled } \\
\text { by Taliban }\end{array}$ \\
\hline & 202 & NARAIZA. Village & Zobono Kalai. Village & $\begin{array}{l}\text { The village is under } \\
\text { control of Taliban }\end{array}$ \\
\hline & 203 & KANDO. Village & Wali Qala. Village & $\begin{array}{l}\text { The village is under } \\
\text { control of Taliban }\end{array}$ \\
\hline & 205 & QALAWOL. Village & Sakrai. Village & $\begin{array}{l}\text { The village is under } \\
\text { control of Taliban }\end{array}$ \\
\hline & 206 & TANGI. Village & Khas Kamp. Village & $\begin{array}{l}\text { The village is under } \\
\text { control of Taliban }\end{array}$ \\
\hline & 207 & LODLAM. Village & Nem Kalai. Village & $\begin{array}{l}\text { The village is under } \\
\text { control of Taliban }\end{array}$ \\
\hline & 208 & LORAH BILA. Village & Delwara. Village & $\begin{array}{l}\text { The village is under } \\
\text { control of Taliban }\end{array}$ \\
\hline & 209 & KADO. Village & $\begin{array}{l}\text { Saheb Zadagano Kalai } \\
\text { Narang. Village }\end{array}$ & $\begin{array}{l}\text { The village is under } \\
\text { control of Taliban }\end{array}$ \\
\hline & 210 & KHORAH GASH. Village & Shiri Kalai. Village & $\begin{array}{l}\text { The village is under } \\
\text { control of Taliban }\end{array}$ \\
\hline \multirow{3}{*}{ 11. Laghman } & 214 & MANO KALA. Village & Fateh Khan. Village & $\begin{array}{l}\text { The village is under } \\
\text { control of Taliban }\end{array}$ \\
\hline & 216 & HAIDAR BANDA. Village & Baloch Abad. Village & $\begin{array}{l}\text { No village with this name } \\
\text { was found }\end{array}$ \\
\hline & 220 & HAL HAJEG. Village & Kukhi. Village & $\begin{array}{l}\text { No village with this name } \\
\text { was found }\end{array}$ \\
\hline \multirow{3}{*}{ 13. Nooristan } & 228 & DINGOR. Village & Teleren. Village & $\begin{array}{l}\text { The village is under } \\
\text { control of Taliban }\end{array}$ \\
\hline & 923 & Waigal. District & Noor Gram. District & $\begin{array}{l}\text { The district is controlled } \\
\text { by Taliban }\end{array}$ \\
\hline & 924 & Waigal. District & Barg-i-Matal. District & $\begin{array}{l}\text { The district is controlled } \\
\text { by Taliban }\end{array}$ \\
\hline
\end{tabular}




\begin{tabular}{|c|c|c|c|c|}
\hline \multirow{4}{*}{ 4. Wardak } & 240 & MIRAN KHAIL. Village & Allah Yar Khail. Village & $\begin{array}{l}\text { The village is under } \\
\text { control of Taliban }\end{array}$ \\
\hline & 244 & $\begin{array}{l}\text { KHAN JAN KHAIL. } \\
\text { Village }\end{array}$ & Deh Hayat. Village & $\begin{array}{l}\text { The village is under } \\
\text { control of Taliban }\end{array}$ \\
\hline & 245 & QOUL KAMRAN. Village & Kan Ezat. Village & $\begin{array}{l}\text { The village is under } \\
\text { control of Taliban }\end{array}$ \\
\hline & 246 & DARA ZEYARAT. Village & Qalai Malik. Village & $\begin{array}{l}\text { The village is under } \\
\text { control of Taliban }\end{array}$ \\
\hline \multirow{6}{*}{ 5. Logar } & 252 & Azra. District & Pull Alam. District & $\begin{array}{l}\text { The district is controlled } \\
\text { by Taliban }\end{array}$ \\
\hline & 253 & Azra. District & Pull Alam. District & $\begin{array}{l}\text { The district is controlled } \\
\text { by Taliban }\end{array}$ \\
\hline & 268 & Charkh. District & Baraki Barak. District & $\begin{array}{l}\text { The district is controlled } \\
\text { by Taliban }\end{array}$ \\
\hline & 929 & Charkh. District & $\begin{array}{l}\text { Mohamad Agha. } \\
\text { District }\end{array}$ & $\begin{array}{l}\text { The district is controlled } \\
\text { by Taliban }\end{array}$ \\
\hline & 930 & Charkh. District & $\begin{array}{l}\text { Mohamad Agha. } \\
\text { District }\end{array}$ & $\begin{array}{l}\text { The district is controlled } \\
\text { by Taliban }\end{array}$ \\
\hline & 931 & Charkh. District & $\begin{array}{l}\text { Mohamad Agha. } \\
\text { District }\end{array}$ & $\begin{array}{l}\text { The district is controlled } \\
\text { by Taliban }\end{array}$ \\
\hline \multirow{12}{*}{ 6. Ghazni } & 271 & Zanakhan. District & Jaghuri. District & $\begin{array}{l}\text { The district is controlled } \\
\text { by Taliban }\end{array}$ \\
\hline & 272 & Zanakhan. District & Jaghuri. District & $\begin{array}{l}\text { The district is controlled } \\
\text { by Taliban }\end{array}$ \\
\hline & 279 & WALI DAD. Village & Qaracha. Village & $\begin{array}{l}\text { The village is under } \\
\text { control of Taliban }\end{array}$ \\
\hline & 283 & JANJAL ANDARI. Village & Chuni. Village & $\begin{array}{l}\text { The village is under } \\
\text { control of Taliban }\end{array}$ \\
\hline & 285 & Andar. District & Qarabagh. District & $\begin{array}{l}\text { The district is controlled } \\
\text { by Taliban }\end{array}$ \\
\hline & 286 & Andar. District & Ghazni. District & $\begin{array}{l}\text { The district is controlled } \\
\text { by Taliban }\end{array}$ \\
\hline & 287 & Andar. District & Ghazni. District & $\begin{array}{l}\text { The district is controlled } \\
\text { by Taliban }\end{array}$ \\
\hline & 288 & Andar. District & Nawur. District & $\begin{array}{l}\text { The district is controlled } \\
\text { by Taliban }\end{array}$ \\
\hline & 302 & Giro. District & Muqur. District & $\begin{array}{l}\text { The district is controlled } \\
\text { by Taliban }\end{array}$ \\
\hline & 303 & Giro. District & Malestan. District & $\begin{array}{l}\text { The district is controlled } \\
\text { by Taliban }\end{array}$ \\
\hline & 304 & Nawa. District & Waghaz. District & $\begin{array}{l}\text { The district is controlled } \\
\text { by Taliban }\end{array}$ \\
\hline & 305 & Nawa. District & $\begin{array}{l}\text { Khawaja Umary. } \\
\text { District }\end{array}$ & $\begin{array}{l}\text { The district is controlled } \\
\text { by Taliban }\end{array}$ \\
\hline
\end{tabular}




\begin{tabular}{|c|c|c|c|c|}
\hline \multirow{6}{*}{ 7. Paktia } & 307 & Zurmat. District & Jaji. District & $\begin{array}{l}\text { The district is controlled } \\
\text { by Taliban }\end{array}$ \\
\hline & 308 & Zurmat. District & Said Karam. District & $\begin{array}{l}\text { The district is controlled } \\
\text { by Taliban }\end{array}$ \\
\hline & 309 & Zurmat. District & Gardez. District & $\begin{array}{l}\text { The district is controlled } \\
\text { by Taliban }\end{array}$ \\
\hline & 310 & Zurmat. District & Chamkani. District & $\begin{array}{l}\text { The district is controlled } \\
\text { by Taliban }\end{array}$ \\
\hline & 321 & Waza Zadram. District & Shwak. District & $\begin{array}{l}\text { The district is controlled } \\
\text { by Taliban }\end{array}$ \\
\hline & 322 & Waza Zadram. District & Ahmad Aba. District & $\begin{array}{l}\text { The district is controlled } \\
\text { by Taliban }\end{array}$ \\
\hline 8. Paktika & 335 & Waza Khwah. District & Sar Rawza. District & $\begin{array}{l}\text { The district is controlled } \\
\text { by Taliban }\end{array}$ \\
\hline \multirow{4}{*}{ 9. Khost } & 341 & Sabari. District & Tanai. District & $\begin{array}{l}\text { The district is controlled } \\
\text { by Taliban }\end{array}$ \\
\hline & 342 & Sabari. District & Musa kheil. District & $\begin{array}{l}\text { The district is controlled } \\
\text { by Taliban }\end{array}$ \\
\hline & 351 & Spera. District & Gurbuz. District & $\begin{array}{l}\text { The district is controlled } \\
\text { by Taliban }\end{array}$ \\
\hline & 352 & Spera. District & Bak. District & $\begin{array}{l}\text { The district is controlled } \\
\text { by Taliban }\end{array}$ \\
\hline \multirow{2}{*}{ 27. Helmand } & 371 & Bughran. District & Kajaki. District & $\begin{array}{l}\text { The district is controlled } \\
\text { by Taliban }\end{array}$ \\
\hline & 372 & Bughran. District & Garm Seir. District & $\begin{array}{l}\text { The district is controlled } \\
\text { by Taliban }\end{array}$ \\
\hline \multirow{3}{*}{ 28. Kandahar } & 388 & $\begin{array}{l}\text { PUPAL ZAY KALAY. } \\
\text { Village }\end{array}$ & Azim Kala. Village & $\begin{array}{l}\text { No village with this name } \\
\text { was found }\end{array}$ \\
\hline & 403 & $\begin{array}{l}\text { JANGAL SAR HAJI } \\
\text { SHADI ZAI. Village }\end{array}$ & Kabuli Ha. Village & $\begin{array}{l}\text { The village is under } \\
\text { control of Taliban }\end{array}$ \\
\hline & 413 & WALY KALAY. Village & Loi Kariz. Village & $\begin{array}{l}\text { No village with this name } \\
\text { was found }\end{array}$ \\
\hline \multirow{2}{*}{ 23. Badghis } & 442 & Jawand. District & Ab-Kamari. District & $\begin{array}{l}\text { The district is controlled } \\
\text { by Taliban }\end{array}$ \\
\hline & 443 & Jawand. District & Qala-i-Now. District & $\begin{array}{l}\text { The district is controlled } \\
\text { by Taliban }\end{array}$ \\
\hline \multirow{5}{*}{ 26. Nimroz } & 449 & Khashroad. District & Zaranj. District & $\begin{array}{l}\text { The district is controlled } \\
\text { by Taliban }\end{array}$ \\
\hline & 450 & Khashroad. District & Zaranj. District & $\begin{array}{l}\text { The district is controlled } \\
\text { by Taliban }\end{array}$ \\
\hline & 451 & Khashroad. District & Char Burjak. District & $\begin{array}{l}\text { The district is controlled } \\
\text { by Taliban }\end{array}$ \\
\hline & 452 & Khashroad. District & $\begin{array}{l}\text { Asl-i-chakhansoor. } \\
\text { District }\end{array}$ & $\begin{array}{l}\text { The district is controlled } \\
\text { by Taliban }\end{array}$ \\
\hline & 453 & Khashroad. District & Kang. District & $\begin{array}{l}\text { The district is controlled } \\
\text { by Taliban }\end{array}$ \\
\hline
\end{tabular}




\begin{tabular}{|c|c|c|c|c|}
\hline 24. Herat & 496 & QALA GHOCHI. Village & Jalalabad. Village & $\begin{array}{l}\text { No village with this name } \\
\text { was found }\end{array}$ \\
\hline \multirow{9}{*}{ 14. Badakhshan } & 531 & HAWZA KAN. Village & Galki. Village & $\begin{array}{l}\text { No village with this name } \\
\text { was found }\end{array}$ \\
\hline & 535 & Raghastan. District & Urgo. District & $\begin{array}{l}\text { No transportation way for } \\
\text { vehicles }\end{array}$ \\
\hline & 536 & Raghastan. District & Darayeem. District & $\begin{array}{l}\text { No transportation way for } \\
\text { vehicles }\end{array}$ \\
\hline & 545 & Sheghnan. District & Khash. District & $\begin{array}{l}\text { No transportation way for } \\
\text { vehicles }\end{array}$ \\
\hline & 546 & Sheghnan. District & Yaftel Sufla. District & $\begin{array}{l}\text { No transportation way for } \\
\text { vehicles }\end{array}$ \\
\hline & 547 & Shiki. District & Tashkan. District & $\begin{array}{l}\text { No transportation way for } \\
\text { vehicles }\end{array}$ \\
\hline & 548 & Shiki. District & Faiz Abad. District & $\begin{array}{l}\text { No transportation way for } \\
\text { vehicles }\end{array}$ \\
\hline & 549 & Khwahan. District & Zebak. District & $\begin{array}{l}\text { No transportation way for } \\
\text { vehicles }\end{array}$ \\
\hline & 550 & Khwahan. District & Yamgan. District & $\begin{array}{l}\text { No transportation way for } \\
\text { vehicles }\end{array}$ \\
\hline \multirow{9}{*}{ 15. Takhar } & 555 & QHAZNICHAI. Village & Momin Abad. Village & $\begin{array}{l}\text { No village with this name } \\
\text { was found }\end{array}$ \\
\hline & 557 & ABDULLAH JAN. Village & Shaikh Abad. Village & $\begin{array}{l}\text { No village with this name } \\
\text { was found }\end{array}$ \\
\hline & 563 & $\begin{array}{l}\text { KHOWJA DAIRWAN. } \\
\text { Village }\end{array}$ & Nanwa. Village & $\begin{array}{l}\text { No transportation way for } \\
\text { vehicles }\end{array}$ \\
\hline & 564 & YAFERY. Village & Wardgan. Village & $\begin{array}{l}\text { No village with this name } \\
\text { was found }\end{array}$ \\
\hline & 569 & JADRAN. Village & Jee Ahmad. Village & $\begin{array}{l}\text { The village is under } \\
\text { control of Taliban }\end{array}$ \\
\hline & 571 & $\begin{array}{l}\text { TOOTAK ARAB HA. } \\
\text { Village }\end{array}$ & Shori. Village & $\begin{array}{l}\text { People didn't allow to } \\
\text { interview }\end{array}$ \\
\hline & 572 & CHAKARAN. Village & Mazar Shaikh. Village & $\begin{array}{l}\text { No village with this name } \\
\text { was found }\end{array}$ \\
\hline & 579 & $\begin{array}{l}\text { KHOWJA SABARHAN. } \\
\text { Village }\end{array}$ & Namdab Payen. Village & $\begin{array}{l}\text { No transportation way for } \\
\text { vehicles }\end{array}$ \\
\hline & 580 & ZOLLAN DARAH. Village & Aji Ramazan. Village & $\begin{array}{l}\text { No transportation way for } \\
\text { vehicles }\end{array}$ \\
\hline
\end{tabular}




\begin{tabular}{|c|c|c|c|c|}
\hline \multirow{9}{*}{ 16. Baghlan } & 584 & WALI UZBEK HA. Village & Kampodna. Village & $\begin{array}{l}\text { No village with this name } \\
\text { was found }\end{array}$ \\
\hline & 587 & $\begin{array}{l}\text { KHOWJA KHAZAR. } \\
\text { Village }\end{array}$ & Niaz Afghan. Village & $\begin{array}{l}\text { No transportation way for } \\
\text { vehicles }\end{array}$ \\
\hline & 593 & JANDAR BAI. Village & Kuhna Masjed. Village & $\begin{array}{l}\text { No village with this name } \\
\text { was found }\end{array}$ \\
\hline & 594 & MARK KHOLA. Village & $\begin{array}{l}\text { Naw Abad Sar Joy. } \\
\text { Village }\end{array}$ & $\begin{array}{l}\text { No transportation way for } \\
\text { vehicles }\end{array}$ \\
\hline & 595 & SEE JAREYBA. Village & Surkh Kotel. Village & $\begin{array}{l}\text { No village with this name } \\
\text { was found }\end{array}$ \\
\hline & 597 & ARBAB HUSSAIN. Village & Bikzad. Village & $\begin{array}{l}\text { No village with this name } \\
\text { was found }\end{array}$ \\
\hline & 598 & KHOSHKAK. Village & Sang Shorakh. Village & $\begin{array}{l}\text { No transportation way for } \\
\text { vehicles }\end{array}$ \\
\hline & 599 & QAREQ SAI. Village & $\begin{array}{l}\text { Sang Surakh Bala. } \\
\text { Village }\end{array}$ & $\begin{array}{l}\text { No transportation way for } \\
\text { vehicles }\end{array}$ \\
\hline & 605 & ARCHA GAK. Village & Gari. Village & $\begin{array}{l}\text { No village with this name } \\
\text { was found }\end{array}$ \\
\hline \multirow{8}{*}{ 17. Kunduz } & 612 & $\begin{array}{l}\text { KUNAM KHOURD } \\
\text { GANICHAI. Village }\end{array}$ & Sea Sad Qabili. Village & $\begin{array}{l}\text { The village is under } \\
\text { control of Taliban }\end{array}$ \\
\hline & 616 & PARCHA-DASHT. Village & Shaftalo Bagh. Village & $\begin{array}{l}\text { No village with this name } \\
\text { was found }\end{array}$ \\
\hline & 621 & $\begin{array}{l}\text { PAHLAWAN QESHLAQ. } \\
\text { Village }\end{array}$ & $\begin{array}{l}\text { Anjam Jal Arabia. } \\
\text { Village }\end{array}$ & $\begin{array}{l}\text { The village is under } \\
\text { control of Taliban }\end{array}$ \\
\hline & 622 & SOBHANI. Village & $\begin{array}{l}\text { Esmayel Qeshlaq. } \\
\text { Village }\end{array}$ & $\begin{array}{l}\text { No transportation way for } \\
\text { vehicles }\end{array}$ \\
\hline & 632 & Dasht-i-Archi. District & Kunduz. District & $\begin{array}{l}\text { The district is controlled } \\
\text { by Taliban }\end{array}$ \\
\hline & 633 & Dasht-i-Archi. District & Khan Abad. District & $\begin{array}{l}\text { The district is controlled } \\
\text { by Taliban }\end{array}$ \\
\hline & 634 & Dasht-i-Archi. District & Char Darah. District & $\begin{array}{l}\text { The district is controlled } \\
\text { by Taliban }\end{array}$ \\
\hline & 635 & Dasht-i-Archi. District & Ali Abad. District & $\begin{array}{l}\text { The district is controlled } \\
\text { by Taliban }\end{array}$ \\
\hline
\end{tabular}




\begin{tabular}{|c|c|c|c|c|}
\hline \multirow{9}{*}{ 18. Balkh } & 656 & $\begin{array}{l}\text { BARTARID BAR BALA. } \\
\text { Village }\end{array}$ & $\begin{array}{l}\text { Maulana Jalaludin. } \\
\text { Village }\end{array}$ & $\begin{array}{l}\text { The village is under } \\
\text { control of Taliban }\end{array}$ \\
\hline & 658 & HALQA JAR. Village & Zara Wana. Village & $\begin{array}{l}\text { The village is under } \\
\text { control of Taliban }\end{array}$ \\
\hline & 660 & SAIGHAN. Village & Qaria Qadim. Village & $\begin{array}{l}\text { The village is under } \\
\text { control of Taliban }\end{array}$ \\
\hline & 661 & $\begin{array}{l}\text { DAHAN CHAK AB. } \\
\text { Village }\end{array}$ & Charkhab. Village & $\begin{array}{l}\text { The village is under } \\
\text { control of Taliban }\end{array}$ \\
\hline & 663 & JANGAL SADDIQ. Village & Zadian Mahajer. Village & $\begin{array}{l}\text { The village is under } \\
\text { control of Taliban }\end{array}$ \\
\hline & 664 & $\begin{array}{l}\text { NOW SHAHR LALE ZAI. } \\
\text { Village }\end{array}$ & Zoli. Village & $\begin{array}{l}\text { The village is under } \\
\text { control of Taliban }\end{array}$ \\
\hline & 666 & $\begin{array}{l}\text { FOLADA KHALCHE. } \\
\text { Village }\end{array}$ & Sar Aab. Village & $\begin{array}{l}\text { The village is under } \\
\text { control of Taliban }\end{array}$ \\
\hline & 673 & KATA GARDAN. Village & Hanifa Tu. Village & $\begin{array}{l}\text { The village is under } \\
\text { control of Taliban }\end{array}$ \\
\hline & 677 & SANG JALAB. Village & Senjitak. Village & $\begin{array}{l}\text { No transportation way for } \\
\text { vehicles }\end{array}$ \\
\hline \multirow{2}{*}{ 20. Juzjan } & 703 & Darzab. District & Mangajak. District & $\begin{array}{l}\text { The district is controlled } \\
\text { by Taliban }\end{array}$ \\
\hline & 704 & Darzab. District & Mardyan. District & $\begin{array}{l}\text { The district is controlled } \\
\text { by Taliban }\end{array}$ \\
\hline \multirow{5}{*}{ 21. Sar-i-Pul } & 722 & Kohistanat. District & Sar-i-Pul. District & $\begin{array}{l}\text { The district is controlled } \\
\text { by Taliban }\end{array}$ \\
\hline & 723 & Kohistanat. District & Sangcharak. District & $\begin{array}{l}\text { The district is controlled } \\
\text { by Taliban }\end{array}$ \\
\hline & 724 & Kohistanat. District & Suzma Qala. District & $\begin{array}{l}\text { The district is controlled } \\
\text { by Taliban }\end{array}$ \\
\hline & 725 & Kohistanat. District & Sayad. District & $\begin{array}{l}\text { The district is controlled } \\
\text { by Taliban }\end{array}$ \\
\hline & 729 & $\begin{array}{l}\text { KHOWJA SHAH TOOT. } \\
\text { Village }\end{array}$ & Tar Balaq. Village & $\begin{array}{l}\text { No transportation way for } \\
\text { vehicles }\end{array}$ \\
\hline \multirow{2}{*}{ 22. Faryab } & 752 & Kohistan. District & Qaisar. District & $\begin{array}{l}\text { The district is controlled } \\
\text { by Taliban }\end{array}$ \\
\hline & 753 & Kohistan. District & $\begin{array}{l}\text { Khan-i-Charbagh. } \\
\text { District }\end{array}$ & $\begin{array}{l}\text { The district is controlled } \\
\text { by Taliban }\end{array}$ \\
\hline
\end{tabular}




\begin{tabular}{|c|c|c|c|c|}
\hline \multirow{6}{*}{ 31. Ghor } & 777 & KASHKAR. Village & Bahari Alia. Village & $\begin{array}{l}\text { No transportation way for } \\
\text { vehicles }\end{array}$ \\
\hline & 778 & KHAK MULLAH. Village & Kabulak. Village & $\begin{array}{l}\text { No village with this name } \\
\text { was found }\end{array}$ \\
\hline & 779 & MOGHUL GHAR. Village & Sar Aia. Village & $\begin{array}{l}\text { No village with this name } \\
\text { was found }\end{array}$ \\
\hline & 784 & CHAKAR TOO. Village & Sukhta. Village & $\begin{array}{l}\text { The village is under } \\
\text { control of Taliban }\end{array}$ \\
\hline & 791 & GUL BANA. Village & Garm Ab. Village & $\begin{array}{l}\text { The village is under } \\
\text { control of Taliban }\end{array}$ \\
\hline & 797 & MEYAN QALAK. Village & Lari. Village & $\begin{array}{l}\text { No transportation way for } \\
\text { vehicles }\end{array}$ \\
\hline \multirow{11}{*}{ 32. Bamyan } & 798 & QABIR ZAGHAK. Village & Pitab Shawqad. Village & $\begin{array}{l}\text { No transportation way for } \\
\text { vehicles }\end{array}$ \\
\hline & 799 & SULIMANY. Village & $\begin{array}{l}\text { Gardanak Pusht Bazar. } \\
\text { Village }\end{array}$ & $\begin{array}{l}\text { No village with this name } \\
\text { was found }\end{array}$ \\
\hline & 800 & SEYA BOMAK. Village & Tatarak. Village & $\begin{array}{l}\text { No transportation way for } \\
\text { vehicles }\end{array}$ \\
\hline & 802 & LADOWI BALA. Village & Siah Khak. Village & $\begin{array}{l}\text { No village with this name } \\
\text { was found }\end{array}$ \\
\hline & 803 & SHEENA. Village & Kham. Village & $\begin{array}{l}\text { No village with this name } \\
\text { was found }\end{array}$ \\
\hline & 804 & SORKH QALA. Village & Now Gaday. Village & $\begin{array}{l}\text { No village with this name } \\
\text { was found }\end{array}$ \\
\hline & 807 & ZARD ALOGAK. Village & $\begin{array}{l}\text { Bagh Mira Payeen. } \\
\text { Village }\end{array}$ & $\begin{array}{l}\text { No transportation way for } \\
\text { vehicles }\end{array}$ \\
\hline & 808 & SAR QALA. Village & Naw Abad. Village & $\begin{array}{l}\text { No transportation way for } \\
\text { vehicles }\end{array}$ \\
\hline & 809 & JOWL GAN. Village & Dehan Ghaz. Village & $\begin{array}{l}\text { No village with this name } \\
\text { was found }\end{array}$ \\
\hline & 810 & SAYWAK. Village & Kata Khak. Village & $\begin{array}{l}\text { No transportation way for } \\
\text { vehicles }\end{array}$ \\
\hline & 811 & KHOSH QOUL. Village & Aboka. Village & $\begin{array}{l}\text { No village with this name } \\
\text { was found }\end{array}$ \\
\hline \multirow{5}{*}{ 33. Daikondi } & 819 & BARIK JOWI. Village & Nomraz. Village & $\begin{array}{l}\text { No village with this name } \\
\text { was found }\end{array}$ \\
\hline & 821 & BUZ MURDA. Village & Naw Joi. Village & $\begin{array}{l}\text { There was few houses in } \\
\text { this village }\end{array}$ \\
\hline & 824 & MIRA ZARAK. Village & Ghara Lech. Village & $\begin{array}{l}\text { No village with this name } \\
\text { was found }\end{array}$ \\
\hline & 824 & Kujran. District & Neli. District & $\begin{array}{l}\text { No transportation way for } \\
\text { vehicles }\end{array}$ \\
\hline & 825 & Kujran. District & Kitti. District & $\begin{array}{l}\text { No transportation way for } \\
\text { vehicles }\end{array}$ \\
\hline
\end{tabular}




\begin{tabular}{|c|c|c|c|c|}
\hline \multirow{7}{*}{ 34. Panjshir } & 902 & QOULANDOR. Village & Qalai Esfandyar. Village & $\begin{array}{l}\text { People didn't allow to } \\
\text { interview }\end{array}$ \\
\hline & 903 & TAM ZAR. Village & Pai Chenar. Village & $\begin{array}{l}\text { People didn't allow to } \\
\text { interview }\end{array}$ \\
\hline & 905 & $\begin{array}{l}\text { DARWESH KHAIL. } \\
\text { Village }\end{array}$ & Gulestan. Village & $\begin{array}{l}\text { Malik didn't allow to } \\
\text { interview }\end{array}$ \\
\hline & 907 & $\begin{array}{l}\text { NIYAZ BAIG KHAIL. } \\
\text { Village }\end{array}$ & Aziz Baig Khail. Village & $\begin{array}{l}\text { This village was surveyed } \\
\text { before }\end{array}$ \\
\hline & 908 & SATARYA. Village & Tela Kan. Village & $\begin{array}{l}\text { People didn't allow to } \\
\text { interview }\end{array}$ \\
\hline & 911 & KHAWAK. Village & Busi. Village & $\begin{array}{l}\text { This village was surveyed } \\
\text { before }\end{array}$ \\
\hline & 913 & $\begin{array}{l}\text { PARYAN KOR KASHTE. } \\
\text { Village }\end{array}$ & Aqeb. Village & $\begin{array}{l}\text { This village was surveyed } \\
\text { before }\end{array}$ \\
\hline
\end{tabular}

\section{Selection of starting points within each sampling point}

The settlements within districts were selected at random by the field director. Each sampling point was assigned a starting point and given direction. The starting points were recognizable locations like mosques, schools, bazaars, etc. within each of the selected settlements for the survey.

\section{Household Selection}

In urban areas, from the given starting point the interviewer headed in the assigned direction and stopped at the third street/lane on the right hand side of his/her route. From there on, the second contacted household was the fourth house on the right from the beginning of the street. Further on, the selected household was each third inhabitable house on the right side of the interviewer's route. In apartment buildings the selection method was each fifth apartment

In rural areas, the interviewer started from the center of the village or the bazaar, mosque, etc. and went to the right selecting each third inhabitable house on his/her route. Compounds containing two or more houses behind a common wall were treated as detached houses, counting them counter-clock-wise from the gate to the compound.

\section{Respondent Selection}

After selecting a household, interviewers used a Kish grid for randomizing the target respondent within the household. Members of the household were listed with their names and ages in descending order.

\section{Respondent Substitution}

Using the Kish Grid, under no circumstances were interviewers allowed to substitute an alternate member of a household for the selected respondent. If the respondent refused to participate or was not available after callbacks, the interviewer moved on to the next household according to the random walk. 


\section{Call-backs (rate, method, and results)}

Typically interviewers were required to make two call-backs before replacing the designated respondent. Due to security-related fears in previous deployments field researchers had difficulty meeting the requirement of two call-backs prior to substitution. In this survey, while field researchers were able to complete some callbacks, the majority of the interviews were completed on the first attempt $(99.8 \%)$, and $0.2 \%$ of the interviews were completed on the second attempt. Due to the high rate of unemployment, and choosing the appropriate time of day for interviewing, completion on the first attempt is the norm in Afghanistan.

\section{Training of Interviewers}

ACSOR first held extended training sessions with supervisors and assistant supervisors on the Interviewers' Manual which covers all the main aspects and techniques of the field researchers' work. This was followed by a briefing for interviewers on the survey questionnaire. At the end of the detailed review of the questionnaire each supervisor conducted a monitored mock interview in the office, and was further assigned to conduct a pilot interview in the field.

On the next day, the completed pilot interviews were reviewed for proper administration. A briefing session was held to discuss any problems discovered during the pilot interviews. Each supervisor repeated the entire process with the interviewers in the respective province. The training typically lasted two to three days.

The briefings with supervisors were held in Kabul. Each supervisor then organized his/her own briefing sessions with the interviewers. The briefing on the main questions was conducted by the Project Manager Mr. Jameel Rahmany. The Field Manager, Mr. Mirwais Rahimi, reviewed the sampling procedures. Mr. Matthew Warshaw provided guidance and monitored the sessions in Kabul, and The Asia Foundation staff and consultants attended briefings as well. Issues emphasized during the briefing were: a) proper household and respondent selection, b) review of the questionnaire content, c) appropriate interviewing techniques, and d) conducting pilot interviews to master logic and concept of questions. 


\section{Refusals/Non-Contacts/Completed Interviews}

\begin{tabular}{|c|c|c|c|}
\hline \multicolumn{4}{|c|}{ SURVEY MANAGEMENT SECTION } \\
\hline \multirow[t]{3}{*}{ ACSOR Code } & AAPOR Code & Description & \\
\hline & $1.0 / 1.10$ & Completed Interviews & 6348 \\
\hline & & Average Survey Length (minutes) & 40 \\
\hline \multicolumn{4}{|c|}{ UNKNOWN HOUSEHOLD ELIGIBILITY } \\
\hline & 3.170 & $\begin{array}{l}\text { Unable to Reach/Unsafe Area (This comes from the replaced } \\
\text { sampling points and inaccessible district list) }\end{array}$ & 1505 \\
\hline 2 & 3.130 & No one at home after three visits & 385 \\
\hline 3 & 4.100 & No adults $(18+)$ after three visits & 279 \\
\hline 4 & 4.500 & Non-Residential or empty house & 153 \\
\hline & & Total Unknown Household & 2322 \\
\hline \multicolumn{4}{|l|}{ NON-CONTACTS } \\
\hline 1 & 2.230 & Door or gate locked and no one came to open it & 45 \\
\hline 6 & 2.200 & Respondent long -term absence / for the field work period & 223 \\
\hline 13 & & Selected respondent not available for interview & 93 \\
\hline & & Total Non-Contacts & 361 \\
\hline \multicolumn{4}{|l|}{ REFUSALS } \\
\hline 7 & 2.111 & Outright refusal at the door & 181 \\
\hline 8 & 2.112 & Not feeling informed to answer the questions & 122 \\
\hline 9 & 2.112 & $\begin{array}{l}\text { Respondent got angry because of a question } \\
\text { and aborted interview }\end{array}$ & 28 \\
\hline 10 & 2.112 & Prefers head of the house to be interviewed & 92 \\
\hline 11 & 2.112 & In a hurry/ No time & 79 \\
\hline & 2.112 & $\begin{array}{l}\text { Selected respondent initial refusal Cumulative } \\
\text { (sums all } 2.112>\text { codes) }\end{array}$ & 199 \\
\hline & & Total Refusals & 502 \\
\hline \multicolumn{4}{|l|}{ OTHER } \\
\hline 12 & 2.32 & Physically or mentally unable & 10 \\
\hline 5 & 2.332 & Respondent unable to complete interview in languages available & 10 \\
\hline & & Total Other & 20 \\
\hline \multicolumn{4}{|c|}{ DISPOSITION RATES } \\
\hline RATE & & FORMULA/CALCULATION & PERCENT \\
\hline \multicolumn{3}{|c|}{ Value for estimated proportion of cases of unknown eligibility that are eligible } & 0.941 \\
\hline Response Rate 3 & & $\mathrm{I} /(\mathrm{I})+(\mathrm{R}+\mathrm{NC}+\mathrm{O})+\mathrm{e}(\mathrm{UH}+\mathrm{UO})$ & 0.674 \\
\hline Cooperation Rate 3 & & $\mathrm{I} /(\mathrm{I}+\mathrm{R})$ & 0.927 \\
\hline Refusal Rate 2 & & $\mathrm{R} /(\mathrm{I})+(\mathrm{R}+\mathrm{NC}+\mathrm{O})+\mathrm{e}(\mathrm{UH}+\mathrm{UO})$ & 0.053 \\
\hline Contact Rate 2 & & $(\mathrm{I}+\mathrm{R}+\mathrm{O}) /(\mathrm{I})+(\mathrm{R}+\mathrm{NC}+\mathrm{O})+\mathrm{e}(\mathrm{UH}+\mathrm{UO})$ & 0.730 \\
\hline
\end{tabular}




\section{Quality Control Methods}

After the return of the questionnaires from the field, most of the completed questionnaires were subject to logical control for proper administration.

Actual interviewing was monitored directly by a supervisor for $3.2 \%$ of the sample. Another $28.6 \%$ of the completed interviews were back-checked by a supervisor in person. $7.4 \%$ of the completed interviews were back-checked from ACSOR's central office, whilst $4.2 \%$ of the completed interviews were back-checked by The Asia Foundation. The issues verified during in person back-checks included proper household and respondent selection and correct recording of answers to five randomly selected questions from the main body of the questionnaire.

In total, 198 interviews were rejected due to the low quality of interviewers' work. Out of these, 13 interviews were deleted due to over 40\% 'don't know' answers in the substantive and demographic sections, 21 interviews were deleted for over $90 \%$ similarities in answers of all respondents of an interviewer, and other 164 interviews were deleted due to over $90 \%$ similarities in the substantive body. Also, the following sampling points from Badakhshan and Ghor provinces were found to be of poor quality and were re-done: Sampling Points 527, 529, 534, 541, 543, 544, 550, 546, 777, 783, 784, and 796.

\section{Weighting}

The data set includes a weight to adjust for over-sampling and under-sampling at the provincial level. The data was weighted to be representative of national population distribution according to the population statistics available from the Afghan Central Statistics Office. Below is the entire list of weights assigned to rural and urban areas by province.

\begin{tabular}{|l|c|c|}
\hline \multirow{2}{*}{ Province } & \multicolumn{2}{c|}{ Weighting Factor } \\
\cline { 2 - 3 } Kabul & Rural & Urban \\
\hline Kapisa & 1.04960527 & 1.01929409 \\
\hline Parwan & 1.08364889 & . \\
\hline Wardak & 1.07108699 & 1.04015543 \\
\hline Logar & 1.03098762 &. \\
\hline Ghazni & 0.94277263 & . \\
\hline Paktia & 1.05450044 & 1.02404789 \\
\hline Paktika & 0.99122528 & 0.96260004 \\
\hline Khost & 1.03932980 &. \\
\hline Ningarhar & 1.25518589 & 1.21893782 \\
\hline Laghman & 1.04574839 & 1.01554859 \\
\hline Kunar & 1.07476080 &. \\
\hline Nooristan & 0.98053965 &. \\
\hline
\end{tabular}


192 | Afghanistan in 2011

\begin{tabular}{|c|c|c|}
\hline Badakhshan & 1.00841324 & 0.97929163 \\
\hline Takhar & 0.99305388 & 0.96437583 \\
\hline Baghlan & 1.07967249 & 1.04849301 \\
\hline Kunduz & 1.09587197 & 1.06422467 \\
\hline Balkh & 1.02838736 & 0.99868892 \\
\hline Samangan & 0.87107597 & 0.84592048 \\
\hline Juzjan & 1.11694329 & 1.08468748 \\
\hline Sar-i-Pul & 1.01553623 & 0.98620892 \\
\hline Faryab & 1.08999779 & 1.05852013 \\
\hline Badghis & 1.15973120 & . \\
\hline Herat & 1.05427677 & 1.02383068 \\
\hline Farah & 1.06376718 & 1.03304702 \\
\hline Nimroz & 0.43538345 & 0.42281016 \\
\hline Helmand & 1.00528463 & 0.97625337 \\
\hline Kandahar & 1.02869026 & 0.99898308 \\
\hline Zabul & 0.77482813 & 0.75245215 \\
\hline Uruzghan & 0.88741000 & 0.86178280 \\
\hline Ghor & 1.13663556 & . \\
\hline Bamyan & 0.97688676 & 0.94867559 \\
\hline Panjshir & 0.33778361 & . \\
\hline Dehkondi & 1.00528463 & 0.97625337 \\
\hline
\end{tabular}




\section{Appendix 3: Interview Questionnaire}

\section{Region}

\begin{tabular}{|c|c|}
\hline Base: All respondents 6348 & $(\%)$ \\
\hline Central/Kabul & 22 \\
\hline Eastern & 10 \\
\hline South East & 11 \\
\hline South Western & 11 \\
\hline Western & 13 \\
\hline North East & 15 \\
\hline Central/Hazarjat & 3 \\
\hline North West & 14 \\
\hline
\end{tabular}

\section{Geographic Code}

\begin{tabular}{l} 
Village \\
Town \\
City \\
Metro (Kabul) \\
\hline
\end{tabular}

\section{Province}

\begin{tabular}{|c|c|c|}
\hline & Base: All respondents 6348 & $(\%)$ \\
\hline Kabul & & 14 \\
\hline Kapisa & & 2 \\
\hline Parwan & & 3 \\
\hline Wardak & & 2 \\
\hline Logar & & 2 \\
\hline Ghazni & & 5 \\
\hline Paktia & & 2 \\
\hline Paktika & & 2 \\
\hline Khost & & 2 \\
\hline Ningarhar & & 6 \\
\hline Laghman & & 2 \\
\hline Kunar & & 2 \\
\hline Nooristan & & 1 \\
\hline Badakhshan & & 4 \\
\hline
\end{tabular}




\begin{tabular}{|l|l|}
\hline Takhar & 4 \\
\hline Baghlan & 3 \\
\hline Kunduz & 4 \\
\hline Balkh & 5 \\
\hline Samangan & 1 \\
\hline Juzjan & 2 \\
\hline Sar-i-Pul & 2 \\
\hline Faryab & 4 \\
\hline Badghis & 2 \\
\hline Herat & 7 \\
\hline Farah & 2 \\
\hline Nimroz & 1 \\
\hline Helmand & 4 \\
\hline Kandhar & 4 \\
\hline Zabul & 1 \\
\hline Uruzgan & 1 \\
\hline Ghor & 3 \\
\hline Bamyan & 2 \\
\hline Panjshir & 2 \\
\hline Dikundi & 1 \\
\hline
\end{tabular}

\section{NOTE TO INTERVIEWERS:}

REMEMBER THAT THIS IS A CONVERSATION. MAKE THE RESPONDENT COMFORTABLE. MAKE EYE CONTACT.

DO NOT TRY TO LEAD THE RESPONDENT DURING THE INTERVIEW OR GET THE “DESIRED” ANSWERS FROM THEM. MAKE SURE YOU TELL THEM THAT THERE ARE NO RIGHT OR WRONG ANSWERS, YOU JUST WANT THEIR OPINIONS.

DURING THE INTERVIEW, BE POLITE BUT INQUISITIVE. DO NOT ACCEPT ONE-WORD ANSWERS. DRAW OUT RESPONDENTS TO GIVE DETAILED RESPONSES BY FURTHER PROBING - SAY: “WHY DO YOU SAY THAT?” "ANYTHING ELSE?” “TELL ME MORE.”

Asalaam-u-Alikum, I am from ACSOR-Surveys, an independent research organization. We regularly conduct surveys among people like you to find out what you feel about issues of public interest. ACSOR-Surveys has no relation to the government. I just want to ask you some questions about "matters of interest to Afghans". I am interested in your opinion. Your answers will be kept confidential and your name will not be given to anyone and your views will be analyzed along with those of thousands of others. 
W-1. Do you listen to radio programs?

Base: All respondents 6348

Yes

No

W-2. Do you watch television programs?

Base: All respondents 6348

Yes

No

W-3. Which of the following sources do you use most often for news and information?

\begin{tabular}{|c|c|c|}
\hline & Base: All respondents 6348 & $\%$ \\
\hline Television & & 28 \\
\hline Radio & & 45 \\
\hline Newspaper & & 1 \\
\hline Internet & -2 & * \\
\hline Mosque & 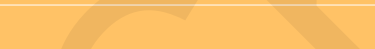 & 6 \\
\hline Friends and family & 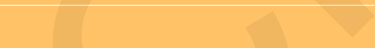 & 20 \\
\hline Other sources & & * \\
\hline Refused & . & * \\
\hline Don’t know & 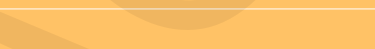 & * \\
\hline
\end{tabular}

Q-1. Do you own any of the following here in your household in functioning order?

\begin{tabular}{|l|c|c|c|c|}
\hline \multicolumn{1}{|c|}{ Base: All respondents $\mathbf{6 3 4 8}$} & Yes & No & Refused & Don't Know \\
\hline a) Radio & $\mathbf{( \% )}$ & $\mathbf{( \% )}$ & $\mathbf{( \% )}$ & $\mathbf{( \% )}$ \\
\hline b) TV set & 81 & 19 & & \\
\hline c) Fixed phone line & 42 & 58 & & \\
\hline d) Mobile phone & $*$ & 99 & & $*$ \\
\hline e) Bicycle & 66 & 34 & & $*$ \\
\hline f) Motorcycle & 52 & 48 & $*$ & $*$ \\
\hline g) Computer & 39 & 61 & $*$ & $*$ \\
\hline h) Car & 9 & 90 & $*$ & $*$ \\
\hline
\end{tabular}


Q-2. Generally speaking, do you think things in Afghanistan today are going in the right direction, or do you think they are going in the wrong direction?

\begin{tabular}{|l|c|}
\hline \multicolumn{1}{|c|}{ Base: All respondents $\mathbf{6 3 4 8}$} & $\mathbf{( \% )}$ \\
\hline Right direction & 46 \\
\hline Wrong direction & 35 \\
\hline Some in right, some in wrong direction & 17 \\
\hline Refused & $*$ \\
\hline Don't know & 2
\end{tabular}

Q-3a. (Filtered. If '1' in Q-2): Why do you say that things are moving in the right direction? (Do NOT read codes. Write down answer)

Write $1^{\text {st }}$ Mention:

Q-3b. (Filtered. If '1' in Q-2): Why else? (Do NOT read codes. Write down answer) Write 2nd Mention:

[Do not print list in final questionnaire]

\begin{tabular}{|c|c|c|}
\hline \multirow[t]{2}{*}{ Base: Right direction 2933} & $\begin{array}{c}\text { Q-3a. } \\
1^{\text {st }} \text { mention }\end{array}$ & $\begin{array}{c}\text { Q-3a \& b. } \\
1^{\text {st }} \& 2^{\text {nd }} \text { mention }\end{array}$ \\
\hline & $(\%)$ & $(\%)$ \\
\hline Peace / end of the war & 4 & 7 \\
\hline Disarmament & 1 & 2 \\
\hline Good security & 26 & 39 \\
\hline Reconstruction / rebuilding & 25 & 40 \\
\hline Free movement / travel possible & 1 & 2 \\
\hline Economic revival & 3 & 8 \\
\hline Freedom / free speech & 2 & 4 \\
\hline Democracy / elections & 1 & 3 \\
\hline Schools for girls have opened & 5 & 10 \\
\hline Women can now work & * & 1 \\
\hline Women have more freedom & 1 & 1 \\
\hline Refugees return & * & $*$ \\
\hline Good government & 5 & 9 \\
\hline International assistance & 1 & 3 \\
\hline Reduction in level of administrative corruption & 1 & 2 \\
\hline Reduction in poppy cultivation & * & 1 \\
\hline Having active ANA and ANP & 5 & 11 \\
\hline Removing terrorism & $*$ & 1 \\
\hline
\end{tabular}




\begin{tabular}{|c|c|c|}
\hline Having legal constitution & 1 & 1 \\
\hline More attention to human rights & $*$ & 1 \\
\hline Road reconstruction & 2 & 5 \\
\hline Clinics have been built & $*$ & 1 \\
\hline Development of agriculture & $*$ & 1 \\
\hline More job opportunities available & 2 & 5 \\
\hline Development of healthcare system in genera & 1 & 2 \\
\hline Having Parliament & * & 1 \\
\hline More electricity supply than before & $*$ & 1 \\
\hline National unity & 1 & 2 \\
\hline Respecting Islam & $*$ & * \\
\hline Removing Taliban & 1 & 3 \\
\hline Better treatment of addicts & $*$ & $*$ \\
\hline Improvement in education system & 7 & 16 \\
\hline Good communication system & * & * \\
\hline Clean drinking water & * & 1 \\
\hline Better relations with foreign countries & 1 & 2 \\
\hline prevention/Elimination of crimes & $*$ & * \\
\hline Establishing high Peace Jirga/Shura & 1 & 1 \\
\hline Foreign forces leaving Afghanistan & 1 & 1 \\
\hline Mining of natural resources & & * \\
\hline Prevention/Elimination of suicide attacks & $*$ & * \\
\hline Donıt know (vol.) & 1 & 1 \\
\hline
\end{tabular}

Q-4a. (Filtered. If "Wrong direction" in Q-2): Why do you say that things are moving in the wrong direction? (Do NOT read codes. Write down answer)

Write $1^{\text {st }}$ Mention:

Q-4b. (Filtered. If '2' in Q-2): Why else? (Do NOT read codes. Write down answer)

Write $2^{\text {nd }}$ Mention:

[Do not print list in final questionnaire]

\section{Base: Wrong direction 2200}

No reconstruction has happened

There is no progress

Lack of aid / no development assistance

\begin{tabular}{|c|c|}
\hline $\begin{array}{c}\text { Q-4a. } \\
\mathbf{1}^{\text {st }} \text { mention }\end{array}$ & $\begin{array}{c}\text { Q-4a } \boldsymbol{~} \mathrm{b} . \\
\mathbf{1}^{\text {st }} \boldsymbol{\boldsymbol { Q }} \mathbf{2}^{\text {nd }} \text { mention }\end{array}$ \\
\hline $\mathbf{( \% )}$ & $\mathbf{( \% )}$ \\
\hline 3 & 4 \\
$*$ & 1 \\
\hline 1 & 2 \\
\hline
\end{tabular}




\begin{tabular}{|c|c|c|}
\hline Bad economy & 5 & 10 \\
\hline Poor education system & 2 & 4 \\
\hline Too many foreigners are getting involved & 4 & 8 \\
\hline Foreign aid causes problems & * & 1 \\
\hline Western influence is too great & 1 & 1 \\
\hline There is danger to Islam & $*$ & 1 \\
\hline Neighboring countries cause problems & 1 & 2 \\
\hline Bad government & 8 & 15 \\
\hline Corruption & 7 & 16 \\
\hline Poor leadership & 2 & 4 \\
\hline There is unemployment & 4 & 13 \\
\hline Presence of Taliban & 4 & 7 \\
\hline $\begin{array}{l}\text { Lack of coordination between ISAF/ Coalition forces and ANP/ANA } \\
\text { during fights with AGE }\end{array}$ & 2 & 3 \\
\hline Administrative corruption & 2 & 4 \\
\hline Insecurity & 33 & 45 \\
\hline Disarmament didnıt take place & $*$ & $*$ \\
\hline Presence of warlords & $*$ & 1 \\
\hline People disillusioned with the government & $*$ & * \\
\hline Increase in drug trade & 1 & 2 \\
\hline High prices & 1 & 3 \\
\hline Innocent people being killed & 2 & 5 \\
\hline Kidnapping of children & $*$ & $*$ \\
\hline Ethnic problems & 1 & 2 \\
\hline Lack of shelter & $*$ & $*$ \\
\hline Water \& Power supply problems & $*$ & 1 \\
\hline Too much luxury & $*$ & $*$ \\
\hline Suicide attacks & 6 & 11 \\
\hline Unfair elections & $*$ & $*$ \\
\hline Terrorism & 1 & 1 \\
\hline Lack of freedom of speech & $*$ & $*$ \\
\hline Healthcare problems & $*$ & 1 \\
\hline Injustice in the country & 2 & 4 \\
\hline Lack of unity & $*$ & 1 \\
\hline Lack of communication system & - & $*$ \\
\hline Women's rights & $*$ & 1 \\
\hline Transportation problems & $*$ & $*$ \\
\hline Increase in crimes & $*$ & 1 \\
\hline Lack of implementation of the law & 1 & 2 \\
\hline Lack of attention to agriculture & $*$ & $*$ \\
\hline Pakistan's rocket attacks on Afghanistan & * & 1 \\
\hline High pollution levels & * & * \\
\hline Weak Parliament & - & $*$ \\
\hline
\end{tabular}


Other

Donst know (vol.) 4 4

Q-5a. (ASK ALL) In your view, what is the biggest problem facing Afghanistan as a whole? (Do NOT read codes. Write down answer)

Write 1st Mention:

Q-5b. And after that, what is the next biggest problem? (Do NOT read codes. Write down answer

Write 2nd Mention:

[Do not print list in final questionnaire]

\begin{tabular}{|c|c|c|}
\hline Base: All respondents 6348 & $\begin{array}{c}\text { Q-5a. } \\
\text { First problem } \\
(\%)\end{array}$ & $\begin{array}{c}\text { Q-5b. } \\
\text { Next problem } \\
(\%)\end{array}$ \\
\hline Insecurity / attacks / violence/ terrorism & 26 & 12 \\
\hline Presence of warlords & 1 & 1 \\
\hline Presence of Taliban & 4 & 4 \\
\hline Poor Economy & 5 & 5 \\
\hline Poverty & 6 & 6 \\
\hline Unemployment & 10 & 13 \\
\hline Reconstruction / rebuilding & * & 1 \\
\hline Education / schools / literacy & 5 & 6 \\
\hline Government / weak government / central authority & 3 & 3 \\
\hline Corruption & 12 & 10 \\
\hline Scarcity of electricity & 2 & 2 \\
\hline Roads & * & 1 \\
\hline Health care / clinics / hospitals & * & 1 \\
\hline Drinking water & * & 1 \\
\hline Water for irrigation & * & 1 \\
\hline High prices & 2 & 3 \\
\hline Lack of (proper) shelter & $*$ & * \\
\hline Drugs smuggling & 2 & 2 \\
\hline Crime & 1 & 1 \\
\hline Interference of foreign countries & 4 & 4 \\
\hline Lack of production companies & * & * \\
\hline Tribal issues/ Partisanship & $*$ & $*$ \\
\hline Agricultural problems & * & * \\
\hline Transportation problems & $*$ & * \\
\hline Lack of foreign assistance & * & * \\
\hline Lack of efficient ANA and ANP & 1 & 1 \\
\hline Returnees' problems & * & $*$ \\
\hline Disrespect to our culture & * & $*$ \\
\hline
\end{tabular}


Kidnapping of children

Innocent people being killed

No problems

Too much luxury

Low salary for the government employees

No freedom

Irresponsible armed people

No attention to women's rights

Injustice

Suicide attacks

Disrespect for Islamic laws

Existence of private prisons

Lack of national unity

Discriminations

Interference of Pakistan

Interference of Iran

Lack of respect for elders

Municipalities not doing their job well

Presence of foreign troops

Lack of natural gas

Lack of mines/Lack of mining for natural resources

Unfair elections

Weak judiciary system

Weak Parliament

Roadside bombings

Foreign forces' air-strikes

Lack of fuel

Pollution

Population levels are too high

Refused (vol.)

Donst know (vol.)

\begin{tabular}{|c|c|}
\hline$*$ & 1 \\
\hline * & 1 \\
\hline$*$ & $*$ \\
\hline$*$ & $*$ \\
\hline$*$ & $*$ \\
\hline$*$ & $*$ \\
\hline * & $*$ \\
\hline$*$ & $*$ \\
\hline 1 & 1 \\
\hline 5 & 4 \\
\hline$*$ & 1 \\
\hline$*$ & $*$ \\
\hline 2 & 3 \\
\hline$*$ & 1 \\
\hline$*$ & 1 \\
\hline$*$ & $*$ \\
\hline$*$ & \\
\hline * & * \\
\hline 1 & 1 \\
\hline$*$ & $*$ \\
\hline * & * \\
\hline$*$ & * \\
\hline$*$ & * \\
\hline$*$ & * \\
\hline$*$ & $*$ \\
\hline$*$ & * \\
\hline * & \\
\hline$*$ & * \\
\hline$*$ & * \\
\hline$*$ & * \\
\hline 1 & 8 \\
\hline
\end{tabular}

Q-6a. (ASK ALL) What is the biggest problem in your local area? (Do NOT Read codes. Write down answer)

Write 1st Mention:

Q-6b. And what is the next biggest problem in your local area? (Do NOT Read codes. Write down answer and then code in the second column below)

Write 2nd Mention:

[Do not print list in final questionnaire] 


\section{Base: All respondents 6348}

Insecurity / attacks / violence

Presence of warlords

Taliban

Poor Economy

Poverty

Unemployment

Reconstruction / rebuilding

Education / schools / literacy

Government / weak government / central authority

Corruption

Electricity

Roads

Health care / clinics / hospitals

Water

High prices

Lack of (proper) shelter

Drugs smuggling

Crime

Transportation problems

Lack of agricultural tools / equipment

No problems

Presence of foreigners

Natural disasters

Lack of foreign assistance

Kidnapping of children

Innocent people being killed

Ethnic problems

Water for irrigation

Returnees' problems

Women's rights

Addiction to drugs

Lack of communication system

Lack of bakeries

Interference of Pakistan

Lack of entertainment opportunities

Municipalities not doing their job well

Lack of mosques

People not feeling responsible

Lack of industrial projects

Injustice

Gas

Arbakis (Armed groups supported by the government)

Lack of unity
Q-6a.

First problem in the area

(\%)

9

1

1

3

5

15

2

7

1

1

12

8

5

11

3

1

1

1

*

\section{*}

1

1

1

1

\section{*}

1

2

2

\section{*}

\section{*}

$$
\text { * }
$$

$*$

*

-

2

*

*

*

*

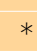

$*$

)

N

Next problem in the area

(\%)

14

2

3

6

9

28

4

14

2

3

23

15

12

20

7

1

1

3

1

1

1

1

1

$*$

$*$

1

3

4

*

1

*

$*$

$*$

*

$*$

3

*

$*$

$*$

1

$*$

$*$

$*$ 


\section{2 | Afghanistan in 2011}

\begin{tabular}{|l|l|l|l}
\hline Lack of banking system & - & $*$ \\
\hline Too much freedom & - & $*$ \\
\hline Pollution & 1 & 1 \\
\hline Moral corruption & $*$ & $*$ \\
\hline Lack of fuel & $*$ & $*$ \\
\hline Lack of ANA and ANP & $*$ & $*$ \\
\hline Lack of law implementation & $*$ & $*$ \\
\hline Presence of foreign forces/searching houses & $*$ & $*$ \\
\hline Roadside bombs & $*$ & $*$ \\
\hline Elections & $*$ & $*$ \\
\hline Population levels are too high & $*$ \\
\hline Refused (vol.) & $*$ & $*$ \\
\hline Donst know (vol.) & 1 & $*$ \\
\hline
\end{tabular}

Q-7. I would like to ask you about today's conditions in the village/neighborhood where you live. Would you rate (insert item here) as very good, quite good, quite bad, or very bad in your area?

\begin{tabular}{l|c|c|c|c|c|c|}
\hline \multicolumn{1}{|c|}{ Base: All respondents $\mathbf{6 3 4 8}$} & VG & QG & QB & VB & Ref. & DK \\
\hline & $\mathbf{( \% )}$ & $\mathbf{( \% )}$ & $\mathbf{( \% )}$ & $\mathbf{( \% )}$ & $\mathbf{( \% )}$ & $\mathbf{( \% )}$ \\
\hline a) The availability of clean drinking water & 30 & 40 & 20 & 9 & $*$ & $*$ \\
\hline b) The availability of water for irrigation & 14 & 35 & 33 & 16 & $*$ & 2 \\
\hline c) The availability of jobs & 7 & 24 & 42 & 28 & $*$ & $*$ \\
\hline d) The supply of electricity & 14 & 20 & 26 & 39 & $*$ & 1 \\
\hline e) The security situation & 28 & 41 & 20 & 10 & $*$ & 1 \\
\hline f) The availability of clinics and hospitals & 15 & 42 & 30 & 12 & $*$ & $*$ \\
\hline g) The availability of medicine & 14 & 39 & 34 & 12 & $*$ & $*$ \\
\hline h) The availability of education for children & 28 & 45 & 19 & 8 & $*$ & $*$ \\
\hline $\begin{array}{l}\text { i) Your freedom of movement-the ability to } \\
\text { move safely in your area or district }\end{array}$ & 26 & 44 & 23 & 7 & $*$ & $*$ \\
\hline
\end{tabular}


Q-8. What is your expectation for (insert item here) in your area a year from now? Do you expect it to be much better, somewhat better, somewhat worse, or much worse?

\begin{tabular}{|l|c|c|c|c|c|c|}
\hline \multicolumn{1}{|c|}{ Base: All respondents $\mathbf{6 3 4 8}$} & MB & SB & SW & MW & Ref. & DK \\
\hline & $\mathbf{( \% )}$ & $\mathbf{( \% )}$ & $\mathbf{( \% )}$ & $\mathbf{( \% )}$ & $\mathbf{( \% )}$ & $\mathbf{( \% )}$ \\
\hline a) The availability of clean drinking water & 49 & 37 & 10 & 4 & & 1 \\
\hline b) The availability of water for irrigation & 37 & 37 & 17 & 7 & $*$ & 2 \\
\hline c) The availability of jobs & 36 & 30 & 21 & 12 & $*$ & 2 \\
\hline d) The supply of electricity & 37 & 27 & 15 & 19 & $*$ & 2 \\
\hline e) The security situation & 45 & 32 & 14 & 7 & $*$ & 2 \\
\hline f) The availability of clinics and hospitals & 40 & 39 & 15 & 5 & $*$ & 1 \\
\hline g) The availability of medicine & 39 & 38 & 16 & 5 & $*$ & 1 \\
\hline h) The availability of education for children & 48 & 36 & 11 & 4 & $*$ & 1 \\
\hline i) Your freedom of movement-the ability to & 45 & 35 & 14 & 5 & $*$ & 2 \\
move safely in your area or district & & & & & & 2
\end{tabular}

Q-9a. (ASK ALL) Various projects and programs have been implemented or are being implemented in some places of our country. Speaking of the past 12 months, do you know of, heard of any project or program in this area, district, implemented in the following fields?

Q-9b. (If answered "Yes", Code 1, in Q-9a, ASK) Has the Afghan Government or Foreign sponsors been primarily responsible for providing most of the aid for the projects?

\begin{tabular}{|c|c|c|c|c|c|c|c|c|}
\hline Q-9a. Aware of project & Yes & No & Ref/DK & $\begin{array}{l}\text { Q-9b Who has } \\
\text { provided the most } \\
\text { aid for the project? }\end{array}$ & $\begin{array}{c}\text { Afghan } \\
\text { Gov. }\end{array}$ & $\begin{array}{l}\text { Foreign } \\
\text { Sponsor }\end{array}$ & Both & $\begin{array}{l}\text { Ref/ } \\
\text { DK }\end{array}$ \\
\hline Base: 6348 & $(\%)$ & $(\%)$ & $(\%)$ & Base: varied & $(\%)$ & $(\%)$ & $(\%)$ & $(\%)$ \\
\hline $\begin{array}{l}\text { a) Reconstruction/ } \\
\text { building of roads, } \\
\text { bridges }\end{array}$ & 59 & 40 & * & $\begin{array}{l}\text { a) Reconstruction/ } \\
\text { building of roads, } \\
\text { bridges }\end{array}$ & 45 & 36 & 19 & $*$ \\
\hline $\begin{array}{l}\text { b) Water supply for } \\
\text { drinking }\end{array}$ & 48 & 51 & $*$ & $\begin{array}{l}\text { b) Water supply for } \\
\text { drinking }\end{array}$ & 45 & 35 & 19 & $*$ \\
\hline $\begin{array}{l}\text { c) Water supply for } \\
\text { irrigation }\end{array}$ & 29 & 70 & 1 & $\begin{array}{l}\text { c) Water supply for } \\
\text { irrigation }\end{array}$ & 51 & 29 & 20 & 1 \\
\hline d) Electricity supply & 26 & 73 & 1 & d) Electricity supply & 59 & 24 & 17 & 1 \\
\hline $\begin{array}{l}\text { e) Healthcare (primary } \\
\text { health center, regular } \\
\text { visits of doctors, etc.) }\end{array}$ & 44 & 55 & 1 & $\begin{array}{l}\text { e) Healthcare (primary } \\
\text { health center, regular } \\
\text { visits of doctors, etc.) }\end{array}$ & 53 & 27 & 20 & 1 \\
\hline $\begin{array}{l}\text { f) Education } \\
\text { (reconstruction/openingof } \\
\text { school, more teachers etc.) }\end{array}$ & 57 & 42 & $*$ & $\begin{array}{l}\text { f) Education } \\
\text { (reconstruction/ } \\
\text { opening of school, } \\
\text { more teachers etc.) }\end{array}$ & 64 & 20 & 16 & 1 \\
\hline g) De-mining & 31 & 68 & 1 & g) De-mining & 34 & 43 & 22 & 1 \\
\hline
\end{tabular}




\begin{tabular}{|c|c|c|c|c|c|c|c|c|}
\hline $\begin{array}{l}\text { h) Demilitarization / } \\
\text { disarmament }\end{array}$ & 25 & 74 & 1 & $\begin{array}{l}\text { h) Demilitarization / } \\
\text { disarmament }\end{array}$ & 54 & 24 & 21 & 1 \\
\hline $\begin{array}{l}\text { i) Reconstruction/ } \\
\text { programs in agriculture }\end{array}$ & 33 & 66 & 1 & $\begin{array}{l}\text { i) Reconstruction/ } \\
\text { programs in agriculture }\end{array}$ & 53 & 27 & 19 & 1 \\
\hline $\begin{array}{l}\text { j) Reconstruction/ } \\
\text { programs in industry }\end{array}$ & 18 & 81 & 1 & $\begin{array}{l}\text { j) Reconstruction/ } \\
\text { programs in industry }\end{array}$ & 48 & 31 & 20 & 1 \\
\hline k) Building new mosques & 27 & 72 & 1 & $\begin{array}{l}\text { k) Building new } \\
\text { mosques }\end{array}$ & 66 & 19 & 13 & 1 \\
\hline $\begin{array}{l}\text { 1) Humanitarian } \\
\text { programs - help in } \\
\text { food, medicines, shelter, } \\
\text { production materials etc. }\end{array}$ & 24 & 75 & 1 & $\begin{array}{l}\text { l) Humanitarian } \\
\text { programs - help } \\
\text { in food, medicines, } \\
\text { shelter, production } \\
\text { materials etc. }\end{array}$ & 38 & 37 & 24 & 1 \\
\hline m) Other & $*$ & 100 & * & m) Other & 72 & 23 & 5 & \\
\hline
\end{tabular}

Q-10. Which country do you think has provided the most aid for the projects you mentioned to have been implemented in this area, district? (Single response) [Do Not Read List]

Write country:

Q-11. Which other countries have provided aid for the projects in your area, district? PROBE: Any other? (Multiple response) [Do Not Read List]

Write down all that apply, then code:

DO NOT SHOW CODE LIST IN THE DARI OR PASHTO QQ

\begin{tabular}{|l|c|c|}
\multicolumn{1}{c}{ Countries provided aid to projects } & $\begin{array}{c}\text { Q-10. Which country } \\
\text { provided most aid }\end{array}$ & Q-11. which other country \\
\hline Base: $\mathbf{6 3 4 8}$ & $\mathbf{( \% )}$ & $\mathbf{( \% )}$ \\
\hline USA & 27 & 15 \\
\hline United Kingdom (Britain) & 2 & 3 \\
\hline Germany & 7 & 9 \\
\hline Japan & 6 & 11 \\
\hline India & 4 & 7 \\
\hline Pakistan & 1 & 1 \\
\hline China & 2 & 3 \\
\hline Iran & 2 & 3 \\
\hline Saudi Arabia & 2 & 3 \\
\hline Turkey & 2 & 3 \\
\hline
\end{tabular}




\begin{tabular}{|c|c|c|}
\hline Italy & 1 & 2 \\
\hline Korea & * & 1 \\
\hline Canada & 2 & 2 \\
\hline France & 2 & 4 \\
\hline Sweden & 2 & 2 \\
\hline Spain & 1 & $*$ \\
\hline Australia & $*$ & $*$ \\
\hline Norway & 1 & 1 \\
\hline Bangladesh & $*$ & * \\
\hline Holland & $*$ & $*$ \\
\hline Denmark & 1 & $*$ \\
\hline Hungary & $*$ & $*$ \\
\hline Uzbekistan & $*$ & $*$ \\
\hline Tajikistan & $*$ & 1 \\
\hline Belgium & $*$ & $*$ \\
\hline Turkmenistan & $*$ & $*$ \\
\hline Russia & * & 1 \\
\hline Switzerland & $*$ & * \\
\hline Finland & $*$ & $*$ \\
\hline PRT team & 2 & 1 \\
\hline Lithuania & $*$ & * \\
\hline National Solidarity Program & 1 & 1 \\
\hline Foreign countries & * & * \\
\hline WFP & * & * \\
\hline World Bank & $*$ & * \\
\hline UN agencies & 1 & 1 \\
\hline Indonesia & * & * \\
\hline Kuwait & $*$ & * \\
\hline Ibn-e-Sena Foundation & $*$ & * \\
\hline Egypt & $*$ & * \\
\hline DAKAR agency & * & * \\
\hline Red Cross & * & * \\
\hline Foreign NGOs & $*$ & 1 \\
\hline Poland & 1 & * \\
\hline Austria & $*$ & * \\
\hline
\end{tabular}




\section{6 | Afghanistan in 2011}

\begin{tabular}{|c|c|c|}
\hline UNICEF & * & $*$ \\
\hline Agha Khan foundation & * & * \\
\hline European countries in general & * & * \\
\hline Philippines & $*$ & * \\
\hline HABITAT & * & $*$ \\
\hline Malaysia & $*$ & * \\
\hline Mexico & * & $*$ \\
\hline Bayat foundation & * & $*$ \\
\hline The Czech Republic & * & * \\
\hline Care organization & * & * \\
\hline Jordon & * & * \\
\hline Sri Lanka & * & * \\
\hline Albania & * & * \\
\hline IRD & * & * \\
\hline IRC & * & * \\
\hline IOM & * & * \\
\hline GFP & $*$ & * \\
\hline Has not heard of any aid projects / aid & 20 & 20 \\
\hline Don’t know (vol.) & 9 & 22 \\
\hline
\end{tabular}

Q-12. Turning to another subject, tell me, do you strongly agree, agree somewhat, disagree somewhat or strongly disagree with the following statements?

\section{Base: All respondents 6348}

a) I don't think that the government cares much about what people like me think

b) It is generally not acceptable to talk negatively about the Government in public

\begin{tabular}{|c|c|c|c|c|c|}
\hline SA & AS & DS & SD & Ref. & DK \\
\hline $\mathbf{( \% )}$ & $\mathbf{( \% )}$ & $\mathbf{( \% )}$ & $\mathbf{( \% )}$ & $\mathbf{( \% )}$ & $\mathbf{( \% )}$ \\
\hline 37 & 41 & 15 & 6 & $*$ & 1 \\
\hline 29 & 39 & 23 & 8 & $*$ & 1 \\
\hline
\end{tabular}


Q-13. (ASK ALL) Now I would like to ask you a few questions about the economy of Afghanistan. If you think about your family, would you say that today your family is more prosperous, less prosperous, or about as prosperous as under the Taliban government?

\begin{tabular}{|l|c|}
\hline \multicolumn{1}{|c|}{ Base: All respondents $\mathbf{6 3 4 8}$} & (\%) \\
\hline More prosperous & 44 \\
\hline Less prosperous & 34 \\
\hline About as prosperous under the Taliban Govt. & 16 \\
\hline Absent during Taliban rule & 5 \\
\hline Refused & $*$ \\
\hline Don't know & 1
\end{tabular}

Q-14. Compared to one year ago, would you say that situation for your household has gotten better, remained the same or gotten worse with respect to the following?

\begin{tabular}{|l|c|c|c|c|c|}
\hline \multicolumn{1}{|c|}{ Base: All respondents $\mathbf{6 3 4 8}$} & Better & The same & Worse & Ref. & DK \\
\hline a) Financial well-being of your household & $\mathbf{( \% )}$ & $\mathbf{( \% )}$ & $\mathbf{( \% )}$ & $\mathbf{( \% )}$ & $\mathbf{( \% )}$ \\
\hline b) Employment opportunities & 43 & 48 & 9 & & $*$ \\
\hline c) Availability of products in the market & 19 & 45 & 35 & $*$ & 1 \\
\hline d) Quality of your food diet & 30 & 49 & 20 & $*$ & 1 \\
\hline e) Physical conditions of your house/dwelling & 35 & 49 & 15 & $*$ & 1 \\
\hline f) Health well-being of your family members & 31 & 52 & 16 & $*$ & 1 \\
\hline g) Electric supply & 22 & 47 & 14 & $*$ & 1 \\
\hline h) Access to schools & 46 & 43 & 10 & $*$ & 1 \\
\hline
\end{tabular}

Q-15a. (ASK ALL) What is your main source of energy for cooking, what do you cook on most? (Code in the first column below)

Q-15b. And what do you heat your house with most, what is your main source of energy for heating? (Code in the second column)

\begin{tabular}{|c|c|c|}
\hline \multirow[t]{2}{*}{ Base: All 6348} & $\begin{array}{c}\text { Q-15a. } \\
\text { Main source of cooking }\end{array}$ & $\begin{array}{c}\text { Q-15b. } \\
\text { Main source of heating }\end{array}$ \\
\hline & $(\%)$ & $(\%)$ \\
\hline Electricity & 3 & 4 \\
\hline Firewood & 46 & 39 \\
\hline Coal & 2 & 7 \\
\hline Animal dung/ manure & 18 & 18 \\
\hline Grass or other biomass & 7 & 8 \\
\hline Charcoal & 3 & 12 \\
\hline Kerosene & 1 & 2 \\
\hline
\end{tabular}




\begin{tabular}{|l|c|c|}
\hline \multicolumn{1}{|c|}{ Bottled gas/LPG } & 21 & 9 \\
\hline Diesel & $*$ & 1 \\
\hline Petrol & - & $*$ \\
\hline Refused (volunteered only) & - & $*$ \\
\hline
\end{tabular}

Q-16. How often do you fear for your own personal safety or security or for that of your family these days? Often, sometimes, rarely, or never?

\begin{tabular}{|c|c|}
\hline Base: All respondents 6348 & $(\%)$ \\
\hline Often & 18 \\
\hline Sometimes & 38 \\
\hline Rarely & 20 \\
\hline Never & 24 \\
\hline Refused & $*$ \\
\hline Don't know & * \\
\hline
\end{tabular}

Q-17. Have you or has anyone in your family been a victim of violence or of some criminal act in your home or community in the past year?

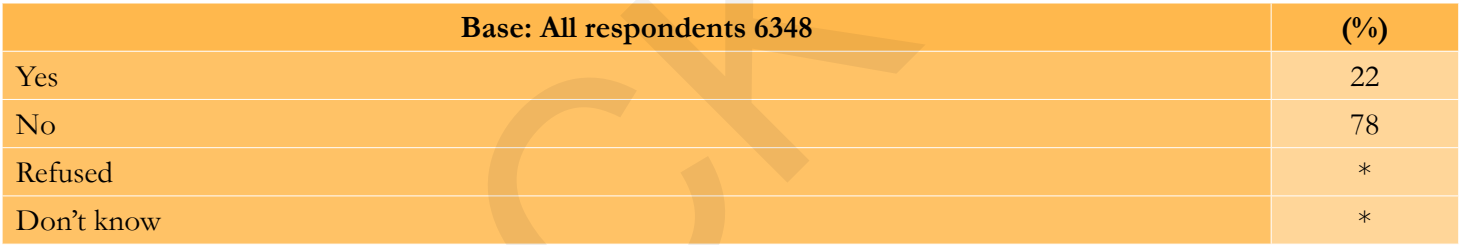

Q-18a. (Filtered. Ask if answered '1' in Q-17) What kind of violence or crime did you or someone in your family experience in the past year? READ LIST (Multiple Response)

\begin{tabular}{|l|c|}
\hline \multicolumn{1}{|c|}{ Base: Victims 1377} & $(\mathbf{\%})$ \\
\hline Physical attack or beating & 36 \\
\hline Racketeering / extortion & 10 \\
\hline Burglary/looting & 12 \\
\hline Pick-pocketing & 8 \\
\hline Motor vehicle theft / Property taken from your vehicle or parts of the vehicle stolen & 5 \\
\hline Kidnapping & 4 \\
\hline Livestock stolen & 10 \\
\hline Militants/Insurgent actions & 4 \\
\hline Police actions & 4 \\
\hline
\end{tabular}




\begin{tabular}{|l|l|}
\hline Army actions & 1 \\
\hline Foreign forces actions & 8 \\
\hline Murder & $*$ \\
\hline Suicide attacks & $*$ \\
\hline Other & 2 \\
\hline Refused & 1 \\
\hline Don't know & 1 \\
\hline
\end{tabular}

Q18b. (Filtered. Ask if answered 1 "physical attack or beating" in Q-18a) Was this physical attack or beating a case of domestic violence (within the family), a case with a neighbor, a case involving relative, or was it involving someone else? (Single Response)

\section{Base: Victims Physical attack or beating 1377}

\section{$(\%)$}

Case of domestic violence (within the family)

Case with neighbor

Case with relative

13

Case with someone else

Donst Know
2

Q-19. (Filtered. Ask if answered 'yes' in Q-17) You said that you've been a victim of violence or some criminal act in the past year. Did you report it to any authority?

\begin{tabular}{|c|c|c|}
\hline & Base: Victims 1377 & $(\%)$ \\
\hline Yes & & 59 \\
\hline No & & 33 \\
\hline Refused & & $*$ \\
\hline Don't know & & 8 \\
\hline
\end{tabular}


Q-20. (Filtered. Ask if answered "Yes" in Q-19) To what agency or institution did you report the crime? (Multiple Response) [Do Not Read Responses, Record All That Respondent Mentions, Specify If Other Mentioned]

\begin{tabular}{|c|c|}
\hline Base: Reported 811 & $(\%)$ \\
\hline Afghan National Army & 12 \\
\hline Afghan National Police & 35 \\
\hline Shura/ Elders & 25 \\
\hline Local militia (police) & 2 \\
\hline Tribal leader / Malik & 10 \\
\hline Local Commander or Warlord & 1 \\
\hline Mullah Saheb & 6 \\
\hline Local PRT & * \\
\hline Afghanistan Independent Human Rights Commission & 1 \\
\hline District Governor/ Woleswal & 12 \\
\hline Provincial authority & 3 \\
\hline Central Government & * \\
\hline Public prosecutor & 1 \\
\hline Courts & 1 \\
\hline Press or other media & * \\
\hline Taliban & $*$ \\
\hline My family & $*$ \\
\hline Don’t know & 3 \\
\hline
\end{tabular}

Q-21. (Ask if answered "No" in Q-19) Why didn't you report the crime? (Multiple Response) [Do Not Read Responses, Record All That Respondent Mentions, Specify If Other Mentioned] Write Down All Mentioned By Respondent, Code

\begin{tabular}{|c|c|}
\hline Base: Didn't report 452 & $(\%)$ \\
\hline It makes no difference & 13 \\
\hline Danger or fear of retaliation & 16 \\
\hline Lack of evidence & 8 \\
\hline It wasn't serious & 25 \\
\hline Didn't know where to report it & 5 \\
\hline Lack of trust on government officials & 6 \\
\hline Lack of legal counsel & 1 \\
\hline Refused & * \\
\hline Don’t know & 25 \\
\hline
\end{tabular}


Q-22. If you were a victim of violence or any criminal act, how much confidence would you have that the governmental law-enforcing organizations and judicial systems would punish the guilty party? (Read Out Answers)

\begin{tabular}{|c|c|}
\hline Base: All respondents 6348 & $(\%)$ \\
\hline A great deal of confidence & 20 \\
\hline A fair amount of confidence & 39 \\
\hline Not very much confidence & 24 \\
\hline No confidence at all & 13 \\
\hline Refused & $*$ \\
\hline Don't know & 4 \\
\hline
\end{tabular}

Q-23. (Ask all) In your view, what is the biggest cause of crime in Afghanistan? (Open-ended question. Write down answer)

Write Reason:

\begin{tabular}{|l|c|}
\hline \multicolumn{1}{|c|}{ Base: All respondents $\mathbf{6 3 4 8}$} & $\mathbf{( \% )}$ \\
\hline Taliban & 4 \\
\hline Terrorism & 1 \\
\hline Unemployment & 19 \\
\hline Corruption & 10 \\
\hline Drugs & 4 \\
\hline Poverty & 8 \\
\hline Illiteracy & 8 \\
\hline Existence of irresponsible armed groups & 2 \\
\hline Insecurity & 9 \\
\hline Lack of reconstruction & $*$ \\
\hline Lack of Govt. attention/ weak Govt. & 9 \\
\hline Pakistan's interference & 1 \\
\hline Lack of law implementation & 4 \\
\hline Having a weak/low-paid police & 1 \\
\hline Discriminations & 3 \\
\hline Returnees & $*$ \\
\hline Western countries & $*$ \\
\hline Presence of international forces & 4 \\
\hline Rapes & $*$ \\
\hline Kidnapping children & 4 \\
\hline Murders & 2 \\
\hline
\end{tabular}




\begin{tabular}{|l|c|}
\hline Robberies & 1 \\
\hline Powerful people misusing their power & $*$ \\
\hline Poorly protected borders & $*$ \\
\hline Criminals released without punishment & 1 \\
\hline Family problems & $*$ \\
\hline Suicide attacks & 1 \\
\hline Arbakis & 1 \\
\hline Business disputes & - \\
\hline Refused & $*$ \\
\hline Donıt know & 4 \\
\hline
\end{tabular}

Q-24. On another subject, please, tell me what kind of corruption affects you personally the most? Please give me two examples? (Open-ended. Write down up to two responses)
a)
98. Refused 99. Don’t Know
b)
98. Refused 99. Don't Know

\section{Base: 6348}

Administrative corruption

Corruption in the electricity directorate

Corruption in the Ministry of Social Affairs

Corruption in the municipality

Corruption in the police/police headquarters

Corruption in the court

Corruption in education systems

Corruption in the passport dept

Corruption in the CSO

Corruption in the customs bureau

Corruption in the parliament

Corruption in the Haji (pilgrimage) department

Corruption in the public health department

Corruption in the agriculture directorate

Corruption in the traffic department

Corruption in the attorney general office

Corruption in the directorate of MRRD

Corruption in the directorate of women affairs

Corruption in the district offices

\section{Q-24a. 1st} mentioned

(\%)

27

1

*

1

4

3

3

$*$

*

1

$*$

*

1

*

$*$

1

*

*

1
Q-24b. 1st \& 2nd mentioned

(\%)

39

1

1

2

8

7

5

*

*

1

1

*

2

*

1

1

*

*

2 
Corruption in the provincial office

Corruption in the ANA

Corruption in the Ministry of Finance

Corruption in the banks

Corruption in the red crescent society

Corruption in the private sectors

Corruption in the in the Ministry of Interior

Corruption in the Ministry of Justice

Corruption in the Ministry of Transport

Corruption in the Ministry of Defense

Corruption in the Ministry of Commerce

Corruption in the Ministry of Economy

Corruption in the press

Corruption in the directorate of communication

Corruption in the in the human rights commission office

Corruption in the provincial Shura

Corruption in the directorate of immigrants

Corruption in the airlines companies

Corruption in the directorate of prisons

Corruption in the directorate of martyrs and disabled persons

Suicide attacks

Fighting in the country

Presence of Taliban and Al-Qaeda

Corruption among warlords

Robbery

Criminal corruption

Political corruption

Lack of law/ not implemented

Lack of government attention

Unemployment

Illiteracy

Lack of knowledge in the society

Moral corruption

Injustice in the society

Sexual abuse

Lack of government employees attention to their jobs

Poverty

Drug traffic

Foreign bad behavior

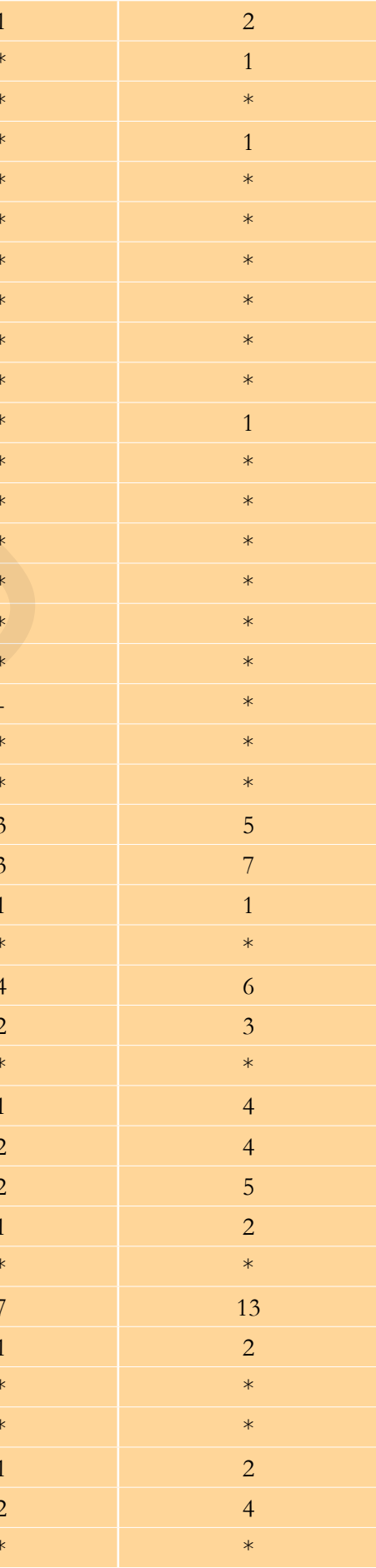




\begin{tabular}{|c|c|c|}
\hline Bribes & 10 & 17 \\
\hline Ethnic problems & 2 & 4 \\
\hline Anti-Islamic performances & $*$ & $*$ \\
\hline None & 1 & 1 \\
\hline Lack of attention peoples/women〉s rights & * & 1 \\
\hline Misusing power & * & 1 \\
\hline Robbing mines & * & * \\
\hline Corruption among foreign forces/organizations & 1 & 2 \\
\hline Corruption among people & 1 & 2 \\
\hline Social corruption & 1 & 1 \\
\hline Land disputes & * & * \\
\hline Family violence & 1 & 1 \\
\hline High prices & $*$ & * \\
\hline Lack of clean drinking water & - & * \\
\hline Corruption in the elections & $*$ & * \\
\hline Kidnapping children & 1 & 1 \\
\hline Pakistan $>$ interference & * & $*$ \\
\hline Cultural corruption & $*$ & * \\
\hline Corruption in the reconstruction process as a whole & - & * \\
\hline Lack of shelter & * & $*$ \\
\hline Violence against civilians & & * \\
\hline Corruption in gaining government jobs & * & * \\
\hline Lack of water & - & $*$ \\
\hline Refused & * & $*$ \\
\hline Donst know & 4 & 4 \\
\hline
\end{tabular}

Q-25. And, what is the most unacceptable form of corruption that affects the country? (Open-ended)

Write down

98. Refused 99. Don't Know

Base: All 6348

Administrative corruption

Corruption in the electricity directorate

Corruption in the Ministry of Social Affairs

Corruption in the municipality

Corruption in the police/police headquarters

Corruption in the court

Corruption in education systems

Corruption in the passport dept 
Corruption in the CSO

Corruption in the customs bureau

Corruption in the parliament

Corruption in the Hajj (pilgrimage) department

Corruption in the public health department

Corruption in the agriculture directorate

Corruption in the traffic department

Corruption in the attorney general office

Corruption in the directorate of MRRD

Corruption in the directorate of women affairs

Corruption in the district offices

Corruption in the provincial office

Corruption in the ANA

Corruption in the Ministry of Finance

Corruption in the banks

Corruption in the red crescent society

Corruption in the private sectors

Corruption in the in the Ministry of Interior

Corruption in the Ministry of Justice

Corruption in the Ministry of Transport

Corruption in the Ministry of Defense

Corruption in the Ministry of Commerce

Corruption in the Ministry of Economic

Corruption in the press

Corruption in the directorate of communication

Corruption in the in the human rights commission office

Corruption in the provincial Shura

Corruption in the directorate of immigrants

Corruption in the directorate of prisons

Corruption in the directorate of martyrs and disabled persons

Suicide attacks

Fighting in the country

Presence of Taliban and Al-Qaeda

Corruption among warlords

Robbery

Criminal corruption

Political corruption

Lack of law/ not implemented

Lack of government attention 


\section{6 | Afghanistan in 2011}

\begin{tabular}{|c|c|}
\hline Unemployment & 1 \\
\hline Illiteracy & 1 \\
\hline Lack of knowledge in the society & $*$ \\
\hline Moral corruption & 4 \\
\hline Injustice in the society & 1 \\
\hline Sexual abuse & * \\
\hline Lack of government employees attention to their jobs & $*$ \\
\hline Poverty & 1 \\
\hline Drug traffic & 3 \\
\hline Foreign bad behavior & * \\
\hline Bribes & 8 \\
\hline Ethnic problems & 2 \\
\hline Anti-Islamic performances & * \\
\hline None & 1 \\
\hline Lack of attention peopless/womenss rights & * \\
\hline Misusing power & $*$ \\
\hline Robbing mines & * \\
\hline Corruption among foreign forces/organizations & 1 \\
\hline Corruption among people & 1 \\
\hline Social corruption & $*$ \\
\hline Land disputes & * \\
\hline Family violence & $*$ \\
\hline High prices & * \\
\hline Corruption in the elections & * \\
\hline Kidnapping children & * \\
\hline Pakistanss interference & * \\
\hline Cultural corruption & * \\
\hline Corruption in the reconstruction process as a whole & $*$ \\
\hline Lack of shelter & * \\
\hline Violence against civilians & * \\
\hline All kinds of corruption is acceptable & * \\
\hline Corruption in gaining government jobs & $*$ \\
\hline Refused & * \\
\hline Donst know & 8 \\
\hline
\end{tabular}


Q-26. Please tell me whether you think that corruption is a major problem, a minor problem, or no problem at all in the following areas. (Circle '8' for Refused or '9' for Don't Know, if volunteered.)

\begin{tabular}{|l|c|c|c|c|c|}
\hline \multicolumn{1}{|c|}{ Base: All respondents 6348 } & $\begin{array}{c}\text { Major } \\
\text { Problem }\end{array}$ & $\begin{array}{c}\text { Minor } \\
\text { Problem }\end{array}$ & $\begin{array}{c}\text { Not a } \\
\text { Problem }\end{array}$ & Refused & Don't know \\
\hline a) In your daily life & $\mathbf{( \% )}$ & $\mathbf{( \% )}$ & $\mathbf{( \% )}$ & $\mathbf{( \% )}$ & $\mathbf{( \% )}$ \\
\hline b) In your neighborhood & 56 & 31 & 12 & $*$ & 1 \\
\hline c) In your local authorities & 47 & 38 & 14 & $*$ & 1 \\
\hline d) In your provincial government & 56 & 33 & 10 & $*$ & 1 \\
\hline e) In Afghanistan as a whole & 64 & 27 & 7 & $*$ & 1 \\
\hline
\end{tabular}

Q-27. Compared to a year ago, do you think the amount of corruption overall in ... (Read out options below one by one) has increased, stayed the same or decreased?

\begin{tabular}{|l|c|c|c|c|c|}
\hline \multicolumn{1}{|c|}{ Base: All respondents $\mathbf{6 3 4 8}$} & Increased & $\begin{array}{c}\text { Stayed the } \\
\text { same }\end{array}$ & Decreased & Refused & Don't know \\
\hline & $\mathbf{( \% )}$ & $\mathbf{( \% )}$ & $\mathbf{( \% )}$ & $\mathbf{( \% )}$ & $\mathbf{( \% )}$ \\
\hline a) In your daily life & 30 & 46 & 23 & $*$ & 1 \\
\hline b) In your neighborhood & 24 & 49 & 26 & $*$ & 1 \\
\hline c) In your local authorities & 34 & 45 & 19 & $*$ & 2 \\
\hline d) In your provincial government & 44 & 40 & 14 & $*$ & 2 \\
\hline e) In Afghanistan as a whole & 55 & 32 & 11 & $*$ & 2 \\
\hline
\end{tabular}

Q-28. Whenever you have contacted government officials, how often in the past year have you had to give cash, a gift or perform a favor for an official? If you had contacts with such officials in the past year, was it in all cases, most of the cases, in isolated or in no cases? How about your contacts with.... (Rotate items on the list)

\begin{tabular}{|l|c|c|c|c|c|c|c|}
\hline \multicolumn{1}{|c|}{ Base: All respondents $\mathbf{6 3 4 8}$} & $\begin{array}{c}\text { In all } \\
\text { cases }\end{array}$ & $\begin{array}{c}\text { Most } \\
\text { cases }\end{array}$ & $\begin{array}{c}\text { Isolated } \\
\text { cases }\end{array}$ & $\begin{array}{c}\text { No } \\
\text { cases }\end{array}$ & $\begin{array}{c}\text { Had no } \\
\text { contacts }\end{array}$ & Ref. & DK \\
\hline a) Officials in the Municipality & $\mathbf{( \% )}$ & $\mathbf{( \% )}$ & $\mathbf{( \% )}$ & $\mathbf{( \% )}$ & $\mathbf{( \% )}$ & $\mathbf{( \% )}$ & $\mathbf{( \% )}$ \\
\hline b) Customs office & 4 & 11 & 13 & 23 & 47 & $*$ & 1 \\
\hline c) Afghan National Police & 4 & 12 & 19 & 30 & 35 & $*$ & $*$ \\
\hline d) Afghan National Army & 3 & 7 & 10 & 38 & 42 & $*$ & 1 \\
\hline e) Judiciary / courts & 6 & 13 & 16 & 20 & 44 & $*$ & 1 \\
\hline f) State electricity supply & 3 & 9 & 13 & 27 & 46 & $*$ & 1 \\
\hline g) Public healthcare service & 3 & 13 & 22 & 30 & 31 & $*$ & $*$ \\
\hline h) When applying for a job & 4 & 13 & 17 & 24 & 41 & $*$ & 1 \\
\hline i) Admissions to schools/university & 3 & 10 & 14 & 32 & 40 & $*$ & 1 \\
\hline j) To receive official documents & 6 & 12 & 16 & 22 & 43 & $*$ & 1 \\
\hline
\end{tabular}


Q-29. Do you think that the Government is doing too much, about right, or not enough to fight corruption?

\begin{tabular}{|c|c|}
\hline Base: All 6348 & $(\%)$ \\
\hline Too much & 17 \\
\hline About right & 43 \\
\hline Not enough & 37 \\
\hline Refused & $*$ \\
\hline Donst know & 3 \\
\hline
\end{tabular}

Q-30. Now I will read you six different activities that you could participate in. Please, tell me, whether you would participate in the following activities with 'no fear', 'some fear' or a 'lot of fear'?

\section{Base: All respondents 6348}

a) When participating in resolving problems in your community

b) Voting in a national election

c) Participating in a peaceful demonstration

d) To run for a public office

e) When encountering ANP officers

f) When encountering ANA

g) When traveling from one part of Afghanistan to another part of the country

h) When encountering international forces

\begin{tabular}{|c|c|c|c|c|}
\hline $\begin{array}{c}\text { No } \\
\text { fear }\end{array}$ & $\begin{array}{c}\text { Some } \\
\text { fear }\end{array}$ & $\begin{array}{c}\text { A lot of } \\
\text { fear }\end{array}$ & Refused & $\begin{array}{c}\text { Don't } \\
\text { know }\end{array}$ \\
\hline $\mathbf{( \% )}$ & $\mathbf{( \% )}$ & $\mathbf{( \% )}$ & $\mathbf{( \% )}$ & $\mathbf{( \% )}$ \\
\hline 59 & 33 & 8 & $*$ & 1 \\
\hline 42 & 39 & 18 & $*$ & $*$ \\
\hline 31 & 41 & 25 & $*$ & 1 \\
\hline 33 & 38 & 25 & 1 & 2 \\
\hline 51 & 34 & 14 & $*$ & 1 \\
\hline 55 & 31 & 13 & $*$ & 1 \\
\hline 25 & 46 & 29 & $*$ & 1 \\
\hline 23 & 40 & 36 & $*$ & 1 \\
\hline
\end{tabular}

Q-31. In comparison to one year ago, do people in the area where you live feel more safe, as safe as before, or less safe to freely express their opinions?

\section{Base: All respondents 6348}

More safe to express their opinions

As safe as before to express their opinions

Less safe to express their opinions

Refused

Don't know 
Q-32. [ASK if Code 1 "more safe" in Q31] What changes compared with the past, or reasons, do you think have made most people to feel safe to express their opinions in the area where you live? (Pre-coded. Do NOT read out. Write down the main answer and code to the list)

a. First Mention:

b. Second Mention:

Do not print code list and use only in office with coders

\begin{tabular}{|c|c|c|}
\hline \multirow[t]{2}{*}{ Base: More safe 1645} & $\begin{array}{c}\text { Q-32a } \\
1^{\text {st }} \text { mentioned }\end{array}$ & $\begin{array}{c}\text { Q-32a \& b } \\
\text { Cumulative }\end{array}$ \\
\hline & $(\%)$ & $(\%)$ \\
\hline The removal of local militias & 1 & 2 \\
\hline Freedom of speech is guaranteed & 31 & 47 \\
\hline The security conditions are good (in our area) & 38 & 56 \\
\hline Having (working) parliament and local Shuras & 1 & 2 \\
\hline Peace and democracy & 6 & 17 \\
\hline Presence of ISAF / Coalition forces & 1 & 1 \\
\hline Presence of CDC & $*$ & 1 \\
\hline Presence of PC & 1 & 1 \\
\hline (Respect for) Human rights & 2 & 3 \\
\hline Disarmament & - & * \\
\hline Reconstruction & 1 & 3 \\
\hline Freedom of press is guaranteed & 1 & 2 \\
\hline Having a legal constitution & 1 & 3 \\
\hline Corruption has decreased & $*$ & 1 \\
\hline More attention to women's rights & $*$ & 1 \\
\hline Good Government & 3 & 6 \\
\hline Better education & 2 & 5 \\
\hline Better Justice system & $*$ & * \\
\hline Taliban removal & 2 & 4 \\
\hline People's cooperation with the Government & 2 & 5 \\
\hline Having ANP and ANA & 3 & 6 \\
\hline Better economic situation & * & 1 \\
\hline Increase in the level of people's awareness & 1 & 1 \\
\hline Islamic party led by Gulbudin Hekmatyar has been removed & $*$ & * \\
\hline Unity among people & 1 & 2 \\
\hline Don’t know & 2 & 2 \\
\hline
\end{tabular}




\section{0 | Afghanistan in 2011}

Q-33. [ASK if code 3 "less safe" in Q31] Why don't people in your area have the freedom to express their political opinions? (Pre-coded. Do NOT read out. Write down up top answer and code to the list)

a. First Mention:

b. Second Mention:

Do not print code list and use only in office with coders

\begin{tabular}{|c|c|c|}
\hline \multirow[t]{2}{*}{ Base: Less safe 1249} & Q-33a & $\begin{array}{l}\text { Q-33a\&b } \\
\text { cumulative }\end{array}$ \\
\hline & $(\%)$ & $(\%)$ \\
\hline Fear for personal safety & 22 & 32 \\
\hline Women are under the control of men & 5 & 10 \\
\hline Security conditions are bad in this area & 24 & 37 \\
\hline Presence of Taliban in the area & 13 & 26 \\
\hline Presence of warlords & 3 & 6 \\
\hline The Government doesn't allow freedom of political opinions & 9 & 18 \\
\hline No real democracy & 1 & 3 \\
\hline No disarmament & * & 1 \\
\hline Fear from Coalition/foreign forces & 1 & 3 \\
\hline Ethnic discrimination & 2 & 3 \\
\hline Elders / Mullahs don't allow freedom of opinions & 1 & 1 \\
\hline Lack of awareness of legal rights & 1 & 1 \\
\hline Not interested in/Lack of information about politics & 1 & 1 \\
\hline The Government doesn't care about people's opinion & 3 & 7 \\
\hline Existence of smugglers & * & * \\
\hline Lack of education & 2 & 3 \\
\hline Fear from police & 2 & 4 \\
\hline Fear from Malik & 1 & 1 \\
\hline Corruption & 1 & 1 \\
\hline Afraid of family members & 1 & 1 \\
\hline Other & - & * \\
\hline Refused & 1 & 1 \\
\hline Don’t Know & 7 & 7 \\
\hline
\end{tabular}


Q-34. (Ask all) How much influence do you think someone like you can have over government decisions - a lot, some, very little, or none at all?

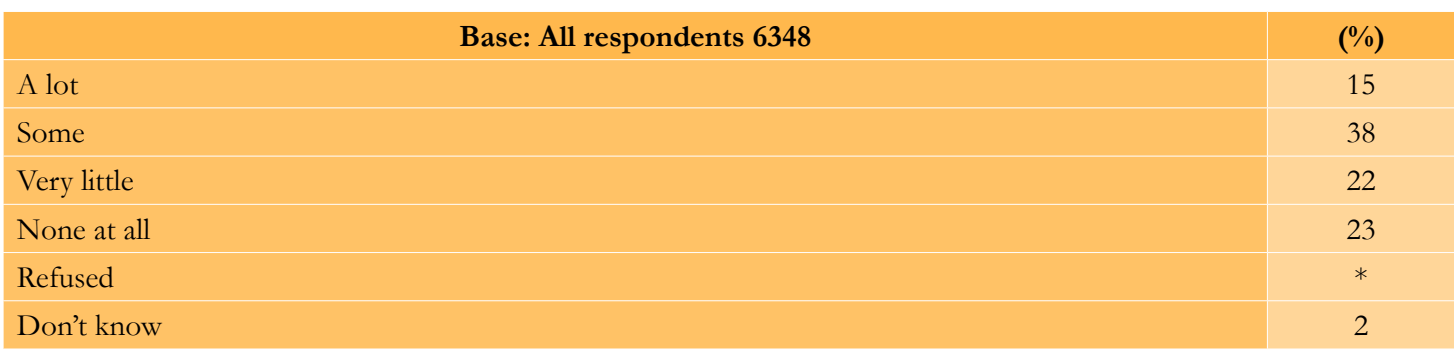

Q-35. On the whole, how satisfied or dissatisfied are you with the way democracy works in Afghanistan. Are you...

\begin{tabular}{|c|c|}
\hline Base: All respondents 6348 & $(\%)$ \\
\hline Very satisfied & 20 \\
\hline Somewhat satisfied & 49 \\
\hline Somewhat dissatisfied & 18 \\
\hline Very dissatisfied & 11 \\
\hline Refused & $*$ \\
\hline Don't know & 2 \\
\hline
\end{tabular}

Q-36. Political parties are usually established and serve the interests of various strata of society. At present, the interests of which one of the following, do you think, the political parties in our country serve the most?

\begin{tabular}{|l|c|}
\hline \multicolumn{1}{|c|}{ Base: All Respondents $\mathbf{6 3 4 8}$} & $\mathbf{( \% )}$ \\
\hline Country as a whole & 25 \\
\hline Broad layers of society & 19 \\
\hline Regional interests & 18 \\
\hline Corporate interests (like those of farmers, workers, businessmen, etc.) & 5 \\
\hline Ethnic interests & 13 \\
\hline Local interests & 4 \\
\hline Group/personal interests & 14 \\
\hline Refused (vol.) & $*$ \\
\hline Donst know (vol.) & 3 \\
\hline
\end{tabular}


Q-37. Now I will read some democratic statements, for each statement please tell me if you agree or disagree (read out statement, wait for response and then ask); strongly or somewhat?

\begin{tabular}{|c|c|c|c|c|c|c|}
\hline \multirow{2}{*}{ Base: All 6348} & SA & AS & DS & SD & Refused & DK \\
\hline & $(\%)$ & $(\%)$ & $(\%)$ & $(\%)$ & $(\%)$ & $(\%)$ \\
\hline $\begin{array}{l}\text { We should choose our leaders in this country through regular, open } \\
\text { and honest elections }\end{array}$ & 67 & 23 & 6 & 3 & $*$ & 1 \\
\hline $\begin{array}{l}\text { Since elections sometimes produce bad results, we should adopt other } \\
\text { methods for choosing this country's leaders }\end{array}$ & 19 & 28 & 31 & 21 & $*$ & 2 \\
\hline $\begin{array}{l}\text { Political parties create division and confusion; it is therefore } \\
\text { unnecessary to have many political parties in Afghanistan }\end{array}$ & 37 & 31 & 20 & 11 & $*$ & 1 \\
\hline $\begin{array}{l}\text { Many political parties are needed to make sure that Afghans have real } \\
\text { choices in who governs them }\end{array}$ & 19 & 24 & 29 & 26 & $*$ & 1 \\
\hline $\begin{array}{l}\text { Members of Parliament represent the people; therefore they should } \\
\text { make laws for this country, even if the President does not agree }\end{array}$ & 39 & 31 & 19 & 9 & $*$ & 2 \\
\hline $\begin{array}{l}\text { Since the President represents all of us, he should pass laws without } \\
\text { worrying about what Parliament thinks }\end{array}$ & 18 & 25 & 32 & 23 & $*$ & 2 \\
\hline $\begin{array}{l}\text { Since the President was elected to lead the country, he should not be } \\
\text { bound by laws or court decisions that he thinks are wrong }\end{array}$ & 30 & 31 & 23 & 15 & $*$ & 2 \\
\hline $\begin{array}{l}\text { The President must always obey the laws and the courts, even if he } \\
\text { thinks they are wrong }\end{array}$ & 22 & 28 & 27 & 20 & $*$ & 2 \\
\hline $\begin{array}{l}\text { Constitution should limit the president to serving a maximum of two } \\
\text { terms in office }\end{array}$ & 41 & 32 & 17 & 7 & 1 & 3 \\
\hline $\begin{array}{l}\text { There should be no constitutional limit on how long the president can } \\
\text { serve }\end{array}$ & 15 & 20 & 30 & 30 & $*$ & 3 \\
\hline
\end{tabular}

Q-38. Members of the Parliament have various responsibilities. Which of the following do you think is the most important responsibility of your Member of Parliament?

\begin{tabular}{|l|c|}
\hline \multicolumn{1}{|c|}{ Base: All Respondents } & (\%) \\
\hline Listen to constituents and represent their needs. & 29 \\
\hline Deliver jobs or development & 26 \\
\hline Make laws for the good of the country & 33 \\
\hline Monitor the president and his government & 11 \\
\hline Other & $*$ \\
\hline Refused & $*$ \\
\hline Donst know & 1 \\
\hline
\end{tabular}


Q-39. Thinking of officials, do you believe that people employed in the following institutions are driven in their work mainly to serve the interests of the Afghan society, or mainly to serve their own interests?

\begin{tabular}{|l|c|c|c|c|c|}
\hline \multicolumn{1}{|c|}{ Base: All 6348 } & $\begin{array}{c}\text { Afghan } \\
\text { society }\end{array}$ & $\begin{array}{c}\text { Their own } \\
\text { interests }\end{array}$ & Both & Refused & $\begin{array}{c}\text { Don't } \\
\text { Know }\end{array}$ \\
\hline Government employees & 44 & 38 & 18 & $*$ & $*$ \\
\hline Ministers in the Government & 31 & 47 & 21 & $*$ & 1 \\
\hline Officials in the Court & 32 & 45 & 21 & $*$ & 1 \\
\hline Members of the Parliament & 33 & 40 & 25 & $*$ & 1 \\
\hline Officials in International NGOs & 28 & 47 & 23 & $*$ & 2 \\
\hline Officials in Afghan NGOs & 25 & 49 & 24 & $*$ & 1 \\
\hline Officials in Donor Institutions & 28 & 45 & 25 & $*$ & 2 \\
\hline Religious Leaders & 45 & 34 & 19 & $*$ & 2 \\
\hline
\end{tabular}

Q-40. I would like to ask you about some officials, institutions and organizations in our country. I will read these out to you. As I read out each, please tell me how much confidence you have in each of the institutions and organizations and officials to perform their jobs. Do you have a great deal of confidence, a fair amount of confidence, not very much confidence, or no confidence at all in..

\begin{tabular}{|c|c|c|c|c|c|c|}
\hline Base: All 6348 & $\begin{array}{c}\text { Great } \\
\text { deal }\end{array}$ & $\begin{array}{c}\text { Fair } \\
\text { amount }\end{array}$ & $\begin{array}{l}\text { Not } \\
\text { much }\end{array}$ & $\begin{array}{c}\text { No } \\
\text { Confide. }\end{array}$ & Refused & D K \\
\hline a) Afghan National Army & 66 & 27 & 5 & 2 & & $*$ \\
\hline b) Afghan National Police & 46 & 37 & 13 & 5 & & $*$ \\
\hline c) Political parties & 12 & 35 & 33 & 19 & * & 1 \\
\hline $\begin{array}{l}\text { d) The Government Justice } \\
\text { system }\end{array}$ & 13 & 41 & 30 & 15 & $*$ & 1 \\
\hline e) Government Ministers & 17 & 40 & 28 & 14 & * & 1 \\
\hline $\begin{array}{l}\text { f) Independent Election } \\
\text { commission }\end{array}$ & 21 & 38 & 25 & 15 & $*$ & 1 \\
\hline g) Public administration & 18 & 44 & 27 & 10 & $*$ & 1 \\
\hline h) the Municipality & 17 & 38 & 27 & 15 & * & 2 \\
\hline i) Local militias & 11 & 25 & 28 & 34 & $*$ & 2 \\
\hline $\begin{array}{l}\text { j) Community Development } \\
\text { Councils }\end{array}$ & 22 & 45 & 22 & 9 & $*$ & 1 \\
\hline k) Provincial Councils & 23 & 43 & 23 & 10 & * & 1 \\
\hline $\begin{array}{l}\text { 1) Provincial Development } \\
\text { Committees }\end{array}$ & 20 & 44 & 25 & 9 & $*$ & 2 \\
\hline m) Provincial Government & 25 & 42 & 23 & 10 & * & 1 \\
\hline
\end{tabular}




\begin{tabular}{|l|l|l|l|l|l|}
\hline n) Parliament & 25 & 36 & 25 & 13 & $*$ \\
\hline o) Community Shuras / Jirgas & 27 & 42 & 21 & 8 & $*$ \\
\hline p) National NGOs & 15 & 39 & 32 & 13 & $*$ \\
\hline q) International NGOs & 17 & 39 & 30 & 13 & $*$ \\
\hline r) Electronic media such as radio, & 32 & 40 & 18 & 8 & $*$ \\
\hline TV & & & & 1 \\
\hline s) Newspapers, print media & 29 & 40 & 19 & 9 & $*$ \\
\hline t) Religious Leaders & 39 & 35 & 17 & 8 & $*$ \\
\hline
\end{tabular}

Q-41. I'm going to read some statements to you about ANA. Please tell me if you agree with each. (Read out statement, wait for response and then ask): Strongly Agree, Agree Somewhat, Disagree Somewhat pr Strongly Disagree?

\begin{tabular}{|c|c|c|c|c|c|c|}
\hline \multirow{2}{*}{ Base: All respondents 6348} & SA & AS & DS & SD & Refused & DK \\
\hline & $(\%)$ & $(\%)$ & $(\%)$ & $(\%)$ & $(\%)$ & $(\%)$ \\
\hline a) ANA is honest and fair with the Afghan people. & 64 & 29 & 5 & 2 & & $*$ \\
\hline b) ANA is unprofessional and poorly trained. & 16 & 28 & 32 & 23 & * & 1 \\
\hline $\begin{array}{l}\text { c) ANA needs the support of foreign troops and } \\
\text { cannot operate by itself. }\end{array}$ & 26 & 34 & 23 & 16 & $*$ & 1 \\
\hline d) ANA helps improve the security & 56 & 31 & 9 & 3 & - & 1 \\
\hline
\end{tabular}

Q-42 I'm going to read some statements to you about ANP. Please tell me if you agree with each. (Read out statement, wait for response and then ask): Strongly Agree, Agree Somewhat, Disagree Somewhat pr Strongly Disagree??

\section{Base: All respondents 6348}

a) ANP is honest and fair with the Afghan people.

b) ANP is unprofessional and poorly trained.

c) ANP needs the support of foreign troops and cannot operate by itself.

d) ANP helps improve the security

e) ANP is efficient at arresting those who have committed crimes so that they can be brought to justice

\begin{tabular}{|c|c|c|c|c|c|}
\hline SA & AS & DS & SD & Refused & DK \\
\hline $\mathbf{( \% )}$ & $\mathbf{( \% )}$ & $\mathbf{( \% )}$ & $\mathbf{( \% )}$ & $\mathbf{( \% )}$ & $\mathbf{( \% )}$ \\
\hline 49 & 36 & 10 & 4 & & $*$ \\
\hline 20 & 36 & 29 & 15 & $*$ & 1 \\
\hline 28 & 37 & 23 & 11 & $*$ & 1 \\
\hline 43 & 40 & 13 & 4 & $*$ & 1 \\
\hline 35 & 40 & 17 & 7 & $*$ & 1 \\
\hline
\end{tabular}


Q-43. Thinking of the National Government, how do you feel about the way it is carrying out its responsibilities? Is it doing a very good job, somewhat good job, somewhat bad job or a very bad job?

\begin{tabular}{|c|c|}
\hline Base: All respondents 6348 & $(\%)$ \\
\hline Very good job & 18 \\
\hline Somewhat good job & 55 \\
\hline Somewhat bad job & 18 \\
\hline Very bad job & 7 \\
\hline Refused & * \\
\hline Don't know & 1 \\
\hline
\end{tabular}

Q-44. And speaking of particular aspects of its work, do you think the National Government is doing a very good job, somewhat good job, somewhat bad job or a very bad job in the following fields? (Ask for each on the list)

\begin{tabular}{|l|c|c|c|c|c|c|}
\hline \multicolumn{1}{|c|}{ Base: All respondents $\mathbf{6 3 4 8}$} & VG & SG & SB & VB & Refused & DK \\
\hline & $\mathbf{( \% )}$ & $\mathbf{( \% )}$ & $\mathbf{( \% )}$ & $\mathbf{( \% )}$ & $\mathbf{( \% )}$ & $\mathbf{( \% )}$ \\
\hline a) Education & 41 & 44 & 12 & 3 & $*$ & $*$ \\
\hline b) Healthcare system & 17 & 50 & 26 & 6 & $*$ & $*$ \\
\hline c) Creating job opportunities & 9 & 28 & 39 & 25 & $*$ & $*$ \\
\hline d) Maintaining relations with neighboring countries & 14 & 41 & 30 & 12 & $*$ & 2 \\
\hline e) International community & 15 & 46 & 28 & 9 & $*$ & 2 \\
\hline f) Reviving/Developing the economy & 10 & 36 & 34 & 18 & $*$ & 1 \\
\hline g) Fighting corruption & 9 & 26 & 34 & 30 & $*$ & 1 \\
\hline h) Security & 23 & 39 & 24 & 13 & $*$ & 1 \\
\hline
\end{tabular}

Q-45. Turning to elements of the local government, do you think that overall it is doing a very good job, somewhat good job, somewhat bad job or a very bad job?

\begin{tabular}{|l|c|c|c|c|c|c|}
\hline \multicolumn{1}{|c|}{ Base: All respondents $\mathbf{6 3 4 8}$} & VG & SG & VB & SB & Refused & DK \\
\hline & $\mathbf{( \% )}$ & $\mathbf{( \% )}$ & $\mathbf{( \% )}$ & $\mathbf{( \% )}$ & $\mathbf{( \% )}$ & $\mathbf{( \% )}$ \\
\hline a) Provincial Government & 29 & 51 & 14 & 5 & $*$ & 1 \\
\hline $\begin{array}{l}\text { b) Municipal authorities } \\
\text { (urban residents only 1365) }\end{array}$ & 20 & 44 & 20 & 7 & & 10 \\
\hline $\begin{array}{l}\text { c) Local authorities } \\
\text { (rural residents only 4983) }\end{array}$ & 21 & 46 & 21 & 7 & $*$ & 4 \\
\hline
\end{tabular}




\section{6 | Afghanistan in 2011}

Q-46. Have you ever contacted your Member of Parliament (MP) for help in solving any of your personal or local problems?

\begin{tabular}{|l|c|c|}
\hline & Base: All respondents 6348 & $(\mathbf{0})$ \\
\hline Yes & 20 & 79 \\
\hline No & $*$ & $*$ \\
\hline Refused & 1 & \\
\hline Don't know & & 1 \\
\hline
\end{tabular}

Q-47. (Filtered. Ask if answered 'Yes' in Q-46) Did the Member of Parliament (MP) try to help to resolve the problem?

\begin{tabular}{|c|c|}
\hline Base: contacted 1271 & $(\%)$ \\
\hline Yes, the MP tried to help & 68 \\
\hline No, the MP did not try to help & 31 \\
\hline Refused & * \\
\hline Don't know & 1 \\
\hline
\end{tabular}

Q-48. (ASK ALL) Now let's talk about Provincial Councils. Have you ever contacted a representative on the Provincial Council for help in solving any of your personal or local problems?

\begin{tabular}{|c|c|}
\hline \multicolumn{2}{|c|}{ Base: All respondents 6348} \\
\hline Yes & 24 \\
\hline No & 75 \\
\hline Refused & 1 \\
\hline Don't know & 1 \\
\hline
\end{tabular}

Q-49. (Filtered. Ask if answered 'Yes' in Q-48) Did the Provincial Council try to help to resolve the problem?

\begin{tabular}{|l|c|}
\hline \multicolumn{1}{|c|}{ Base: contacted $\mathbf{1 4 9 9}$} & $\mathbf{( \% )}$ \\
\hline Yes, the Council tried to help & 69 \\
\hline No, the Council did not try to help & 31 \\
\hline Refused & $*$ \\
\hline Don't know & $*$ \\
\hline
\end{tabular}


Q-50. (ASK ALL) Now I will read some statements about our elected representatives. For each statement, tell me if you strongly agree. Agree somewhat, disagree somewhat or strongly disagree (Read out statement, wait for response and then ask):

\begin{tabular}{l|c|c|c|c|c|c|}
\multicolumn{1}{|c|}{ Base: All $\mathbf{6 3 4 8}$} & SA & AS & DS & SD & Refused & DK \\
\hline & $\mathbf{( \% )}$ & $\mathbf{( \% )}$ & $\mathbf{( \% )}$ & $\mathbf{( \% )}$ & $\mathbf{( \% )}$ & $\mathbf{( \% )}$ \\
\hline $\begin{array}{l}\text { a) The Parliament is addressing the major problems of } \\
\text { people in our country }\end{array}$ & 28 & 42 & 19 & 9 & $*$ & 1 \\
\hline $\begin{array}{l}\text { b) My MP is addressing the major problems of my } \\
\text { constituency in Parliament }\end{array}$ & 19 & 40 & 26 & 13 & $*$ & 2 \\
\hline $\begin{array}{l}\text { c) My Provincial Council member is addressing the major } \\
\text { problem of my community }\end{array}$ & 22 & 37 & 26 & 14 & $*$ & 2 \\
\hline
\end{tabular}

Q-51.Community Development Councils have been established as part of the National Solidarity Program and members of the Council are representatives of various groups in your community. Tell me, are you aware of such an institution formed in your neighborhood/settlement?

\begin{tabular}{|l|c|}
\multicolumn{1}{|c|}{ Base: All respondents $\mathbf{6 3 4 8}$} & $\mathbf{( \% )}$ \\
\hline Yes, aware of CDC in the neighborhood/settlement & 50 \\
\hline No, not aware of CDC in neighborhood & 48 \\
\hline Refused & $*$ \\
\hline Don't know & 2 \\
\hline
\end{tabular}

Q-52.(Filter. Ask if answered 'Yes' in Q-51) Which of the following groups are members of the Community Development Council in your neighborhood/settlement? Ask for each and code

\begin{tabular}{|l|c|c|c|c|}
\hline \multicolumn{1}{|c|}{ Base: } & Yes & No & Refused & DK \\
\hline & $\mathbf{( \% )}$ & $\mathbf{( \% )}$ & $\mathbf{( \% )}$ & $\mathbf{( \% )}$ \\
\hline a) Local Malik / Khan & 71 & 27 & $*$ & 2 \\
\hline b) Elders of the local shura/jirga & 84 & 15 & $*$ & 1 \\
\hline c) Mullah & 58 & 40 & $*$ & 2 \\
\hline d) Local commanders & 28 & 69 & $*$ & 2 \\
\hline e) Women & 23 & 75 & $*$ & 2 \\
\hline f) Local teacher & 47 & 51 & $*$ & 2 \\
\hline g) Doctor & 21 & 61 & $*$ & 18 \\
\hline h) Officials from municipal/district administration & 24 & 72 & $*$ & 3 \\
\hline i) Ordinary farmers & 45 & 53 & $*$ & 2 \\
\hline j) Landless agricultural workers & 37 & 61 & $*$ & 2 \\
\hline k) Shopkeepers & 39 & 58 & $*$ & 3 \\
\hline
\end{tabular}


Q-53. (Filtered. Ask if 'yes` in Q-51) How satisfied are you with the job this Community Development Council is doing? Are you...

\begin{tabular}{|c|c|}
\hline Base: aware of CDC 3172 & $(\%)$ \\
\hline Very satisfied & 29 \\
\hline Somewhat satisfied & 52 \\
\hline Somewhat dissatisfied & 10 \\
\hline Very dissatisfied & 4 \\
\hline Don't know & 5 \\
\hline
\end{tabular}

Q-54. What in your opinion is the most important achievement of the central government in the past two years? And what is next? (Open-ended. Write down first two mentions]

a) 98. Refused 99. Don't Know

b) 98. Refused 99. Don't Know

\begin{tabular}{|c|c|c|}
\hline \multirow[t]{2}{*}{ Base: All respondents 6348} & $\begin{array}{c}\text { Q-54a } \\
1^{\text {st }} \text { mentioned }\end{array}$ & $\begin{array}{l}\text { Q-54 a \& b } \\
\text { Cumulative }\end{array}$ \\
\hline & $(\%)$ & $(\%)$ \\
\hline No achievements & 10 & 10 \\
\hline Establishing peace and security & 12 & 20 \\
\hline Better education system & 14 & 26 \\
\hline Reconstruction & 15 & 26 \\
\hline Elections & 2 & 3 \\
\hline Improving communication system & $*$ & 1 \\
\hline Attracting foreign aid & 1 & 2 \\
\hline Having a good relationship with foreign countries & 1 & 2 \\
\hline Having ANP and ANA & 8 & 13 \\
\hline Improving economy & 2 & 4 \\
\hline Improving healthcare system & 1 & 4 \\
\hline Improving media & * & $*$ \\
\hline Having Parliament & 2 & 3 \\
\hline Freedom of speech & 2 & 4 \\
\hline Having a strong government & 3 & 5 \\
\hline Creating job opportunities & 1 & 3 \\
\hline Removing poppy cultivation & 1 & 2 \\
\hline Disarmament & 1 & 1 \\
\hline Removing the Taliban and Al-Qaeda & 2 & 3 \\
\hline Observing women/human rights & 1 & 2 \\
\hline
\end{tabular}




\begin{tabular}{|c|c|c|}
\hline Removing administrative corruption & 1 & 3 \\
\hline Creating Development Councils & 1 & 1 \\
\hline Building circle roads & 6 & 10 \\
\hline Establishing Constitution & 1 & 1 \\
\hline Returnees & * & $*$ \\
\hline National unity & 1 & 1 \\
\hline Improving agriculture & 1 & 2 \\
\hline Paying attention to Islamic values & $*$ & $*$ \\
\hline Supplying water and power & 2 & 5 \\
\hline Using natural resources & $*$ & $*$ \\
\hline Establishing private sectors & $*$ & 1 \\
\hline Improving carpet exports & $*$ & $*$ \\
\hline Improving business & * & $*$ \\
\hline Sports & * & $*$ \\
\hline Transportation system & $*$ & $*$ \\
\hline Preventing Pakistan and foreign countries interference & $*$ & 1 \\
\hline Building Factories & $*$ & 1 \\
\hline Democracy & $*$ & 1 \\
\hline Building entertainment parks & * & * \\
\hline Foreign forces leaving Afghanistan & $*$ & 1 \\
\hline Creating private banks & * & * \\
\hline Creating Provincial Shura & 1 & 1 \\
\hline Creating National Solidarity programs (NSP) & $*$ & * \\
\hline Developing the handicraft trade & - & * \\
\hline Preventing suicide attacks & $*$ & * \\
\hline Preventing crimes & $*$ & * \\
\hline Negotiating with Taliban & 1 & 1 \\
\hline Demining & * & * \\
\hline Creating Arbakis & $*$ & * \\
\hline Development in stock-breeding & * & * \\
\hline Refused & $*$ & $*$ \\
\hline Donst know & 5 & 5 \\
\hline
\end{tabular}


Q- 55. And what in your opinion is the most important failing of the central government in the past two years? And what is next? (Open-ended. Write down first two mentions]

a)

b) 98. Refused 99. Don’t Know 98. Refused 99. Don't Know

\begin{tabular}{|c|c|c|}
\hline \multirow[t]{2}{*}{ Base: All respondents 6348} & $\begin{array}{c}\text { Q-55a } \\
1^{\text {st }} \text { mentioned }\end{array}$ & $\begin{array}{l}\text { Q-55 a \& b } \\
\text { Cumulative }\end{array}$ \\
\hline & $(\%)$ & $(\%)$ \\
\hline No failures & 1 & 1 \\
\hline Insecurity/continual fighting & 23 & 32 \\
\hline Bad education system & 2 & 5 \\
\hline No/ lack of reconstruction/roads/bridges & 1 & 2 \\
\hline Holding unfair elections & * & 1 \\
\hline Lack of foreign assistance & * & 1 \\
\hline Lack of/no relations with foreign countries & * & $*$ \\
\hline Weak ANA and ANP & 1 & 3 \\
\hline Weak economy & 4 & 8 \\
\hline Lack of healthcare centers & 1 & 1 \\
\hline Weak Parliament & $*$ & 1 \\
\hline Lack of freedom of speech & * & * \\
\hline Weak Government & 7 & 13 \\
\hline Lack of job opportunities & 6 & 14 \\
\hline Administrative corruption & 14 & 25 \\
\hline Fulfilling it's commitments & $*$ & $*$ \\
\hline Removing the Terrorism & 1 & 2 \\
\hline Removing the Taliban & 6 & 10 \\
\hline Removing drugs & 3 & 6 \\
\hline Preventing civilian casualties & 1 & 2 \\
\hline National unity & * & 1 \\
\hline Returnees & * & * \\
\hline Disarmament & $*$ & 1 \\
\hline Observing Islamic rules & $*$ & 1 \\
\hline Injustice & 2 & 3 \\
\hline Human rights & * & $*$ \\
\hline Keeping safe historical heritage & * & * \\
\hline Foreign forces in the country (long time) & 3 & 5 \\
\hline Shelter & * & $*$ \\
\hline Kidnappings & $*$ & 1 \\
\hline
\end{tabular}




\begin{tabular}{|l|l|l|}
\hline Water and power & 1 & 2 \\
\hline Preventing Pakistan and foreign countries interference & 2 & 4 \\
\hline Lack of unity among tribes & 2 & 3 \\
\hline High prices & 1 & 2 \\
\hline Suicide attacks & 6 & 11 \\
\hline People referring to Christianity & $*$ & $*$ \\
\hline Factories & $*$ & 1 \\
\hline Lack of attention to agriculture & $*$ & $*$ \\
\hline Lack of transparency in the government affaires & $*$ & $*$ \\
\hline Creating Arbaki forces (Armed groups supported by the & $*$ & $*$ \\
\hline government) & $*$ & 1 \\
\hline Not having good municipality & 1 & $*$ \\
\hline Lack of law implementation & $*$ & $*$ \\
\hline Negotiation with Taliban & $*$ & 2 \\
\hline Lack of mining for natural resources & 1 & 1 \\
\hline Increase in crimes/criminals released without punishment & $*$ & $*$ \\
\hline Presence of warlords & $*$ & 1 \\
\hline Violence against women & $*$ & $*$ \\
\hline Moral corruption & $*$ & $*$ \\
\hline Not consulting with people & $*$ & $*$ \\
\hline Communication problems & $*$ & 6 \\
\hline Refused & 6 & \\
\hline Don't know & & $*$ \\
\hline
\end{tabular}

Q-56. I'm going to read some ideas. Please tell me if you strongly agree, agree somewhat, disagree somewhat or strongly disagree with each. (Read out statement, wait for response and then ask):

\section{Base: All respondents 6348}

a) It is a good thing that the government should allow peaceful opposition

b) Everyone should have equal rights under the law, regardless of their gender, ethnicity or religion

c) A person should vote the way his or her community votes, not how they feel individually

d) Women should be allowed to stand up for their individual rights

\begin{tabular}{|c|c|c|c|c|c|}
\hline SA & AS & DS & SD & Refused & DK \\
\hline $\mathbf{( \% )}$ & $\mathbf{( \% )}$ & $\mathbf{( \% )}$ & $\mathbf{( \% )}$ & $\mathbf{( \% )}$ & $\mathbf{( \% )}$ \\
\hline 43 & 38 & 12 & 4 & $*$ & 2 \\
\hline 51 & 31 & 14 & 4 & $*$ & 1 \\
\hline 25 & 31 & 25 & 17 & $*$ & 2 \\
\hline 45 & 34 & 14 & 5 & $*$ & 1 \\
\hline
\end{tabular}


We are going to change the topic. "Reconciliation" refers to a process where opposing parties explore and overcome the grievance brought on during the conflict and find ways to build trust and live cooperatively with each other. "Reintegration" refers to a process when armed opposition are removed from fighting context and incorporated into a peaceful civilian life.

Q-57. Do you strongly agree, agree somewhat, disagree somewhat or strongly disagree with the Government's reconciliation efforts and negotiations with the armed opposition?

\begin{tabular}{|c|c|}
\hline Base: All respondents 6348 & $(\%)$ \\
\hline Strongly agree & 41 \\
\hline Agree somewhat & 41 \\
\hline Disagree somewhat & 12 \\
\hline Strongly disagree & 6 \\
\hline Refused & $*$ \\
\hline Don't know & 1 \\
\hline
\end{tabular}

Q-58. Do you think the Afghan Government's reconciliation efforts and negotiations will help stabilize the country?

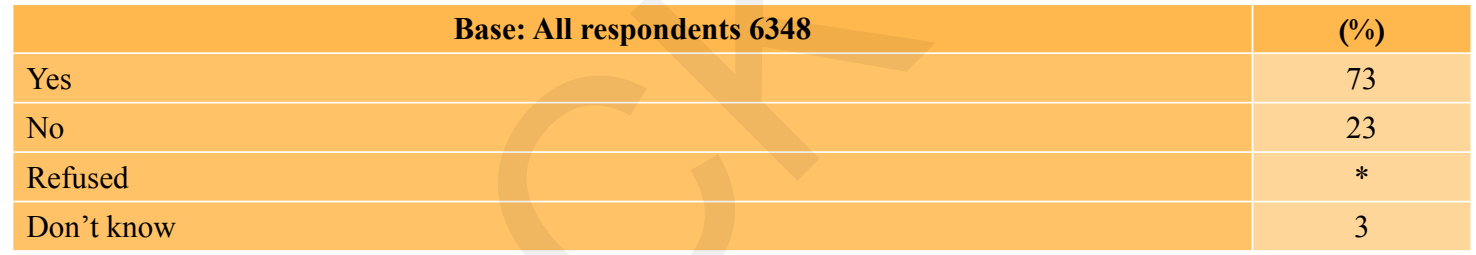

Q-59. Do you strongly agree, agree somewhat, disagree somewhat or strongly disagree those Anti-Government elements who lay down arms and express willingness to re-integrate into society to be provided government assistance, jobs and housing?

\begin{tabular}{|c|c|}
\hline Base: All respondents 6348 & $(\%)$ \\
\hline Strongly agree & 38 \\
\hline Agree somewhat & 42 \\
\hline Disagree somewhat & 12 \\
\hline Strongly disagree & 7 \\
\hline Refused & * \\
\hline Don't know & 1 \\
\hline
\end{tabular}


Q-60. In your opinion what is the reason that the armed anti-government groups are fighting against the Afghan government? (Open-ended question. Write down answer)

\begin{tabular}{|c|c|}
\hline Base: All Respondents 6348 & $(\%)$ \\
\hline They are against democracy & 1 \\
\hline Too much corruption in the government & 2 \\
\hline To gain power & 18 \\
\hline They are dissatisfied from the government & 4 \\
\hline They are against police forces & 1 \\
\hline Fighting is their way of life & 2 \\
\hline Lack of attention to their desires & 2 \\
\hline There is no reason & $*$ \\
\hline To create insecurity & 7 \\
\hline Injustice & 1 \\
\hline Ethnic problems & 1 \\
\hline To defend the country & 1 \\
\hline To support drug traffic & $*$ \\
\hline Robbery & $*$ \\
\hline Moral corruption & $*$ \\
\hline To destroy our country & $*$ \\
\hline To establish security & $*$ \\
\hline Violence against women & * \\
\hline Killing innocent people & 1 \\
\hline Freedom & $*$ \\
\hline They are not Afghan & $*$ \\
\hline For money & 6 \\
\hline Unemployment/ poverty & 5 \\
\hline Illiteracy & 3 \\
\hline Presence of foreign troops/ international community & 21 \\
\hline They are supported by Pakistan & 7 \\
\hline They are supported/motivated by foreign countries & 2 \\
\hline To support Islam & 4 \\
\hline They are against Islam & $*$ \\
\hline Refused & $*$ \\
\hline Don't know & 9 \\
\hline
\end{tabular}


Q-61a. Thinking about the reasons the armed opposition used violence during the past year, would you say that you in general have a lot of sympathy, a little sympathy, or no sympathy at all for these armed opposition groups?

\begin{tabular}{|c|c|}
\hline Base: All respondents 6348 & $(\%)$ \\
\hline A lot of sympathy & 11 \\
\hline A little sympathy & 18 \\
\hline No sympathy at all & 64 \\
\hline Refused & 2 \\
\hline Don’t know & 6 \\
\hline
\end{tabular}

Q-61b. (Filtered, ask if answered "a lot of sympathy" in Q-61a) You said that you have a lot of sympathy for the armed anti-government groups. Why do you say that?

Q-61c. (Filtered, ask if answered "a little sympathy" in Q-61a) You said that you have a little of sympathy for the armed anti-government groups. Why do you say that?

Q-61d. (Filtered, ask if answered "no sympathy at all” in Q-61a) You said that you don't have any sympathy for the armed anti-government groups. Why do you say that?

\begin{tabular}{|l|c|c|c|}
\hline \multicolumn{1}{|c|}{ Level of sympathy } & $\begin{array}{c}\text { A lot Q-61b } \\
\text { Base: } \mathbf{6 7 9}\end{array}$ & $\begin{array}{c}\text { Little Q-61c } \\
\text { Base: } \mathbf{1 1 5 3}\end{array}$ & $\begin{array}{c}\text { No Q-61d } \\
\text { Base: } \mathbf{4 0 3 2}\end{array}$ \\
\hline Donst want peace and security & $\mathbf{( \% )}$ & $\mathbf{( \% )}$ & $\mathbf{( \% )}$ \\
\hline Earn money through Islamic ways & 3 & 6 & 16 \\
\hline Killing innocent people & 2 & 2 & 1 \\
\hline They are infidels & 2 & 3 & 34 \\
\hline They are Muslim & $*$ & - & 2 \\
\hline Want to create disunity & 34 & 30 & $*$ \\
\hline They are against the government & $*$ & $*$ & 6 \\
\hline They are Afghans & 2 & 4 & 1 \\
\hline They are oppressors & 27 & 32 & 12 \\
\hline They are made to do so & 1 & 3 & $*$ \\
\hline They are robbers & $*$ & 1 & $*$ \\
\hline They are not Afghans & $*$ & $*$ & 1 \\
\hline Destroying roads and bridges & 1 & 2 & 1 \\
\hline The government mistreats the people & & $*$ & 3 \\
\hline Donst have any sympathy & $*$ & 1 & 1 \\
\hline People want peace & - & - & 1 \\
\hline Just) have (a lot of) sympathy & 1 & 1 & - \\
\hline
\end{tabular}




\begin{tabular}{l|l|l|l|}
\hline They want to fight a holy war (Jihad) & 7 & 2 & $*$ \\
\hline They work for Pakistan & 2 & 2 & 6 \\
\hline They are illiterate & $*$ & 1 & 1 \\
\hline Suicide attacks & - & $*$ & 1 \\
\hline Removing moral corruption & $*$ & $*$ & $*$ \\
\hline They are the enemy of Afghanistan & $*$ & $*$ & 2 \\
\hline They are against reconstruction & $*$ & 1 & 1 \\
\hline They are against education system & - & $*$ & $*$ \\
\hline To support poppy cultivation & - & - & $*$ \\
\hline To damage the economy & 5 & 1 & 1 \\
\hline They fight against foreign forces & & & $*$ \\
\hline They are our enemies & $*$ & $*$ & $*$ \\
\hline They are criminals & & $*$ & 1 \\
\hline They work for foreigners & $*$ & $*$ & $*$ \\
\hline They are bad people & - & 9 & 3 \\
\hline Refused & & $*$ & $*$ \\
\hline Donst know
\end{tabular}

Q-62. What, if anything, is the most important thing that democracy in Afghanistan will bring you personally? (Open ended. Multiple responses. Do Not Read Code List Write down and then code each mentioned)

\begin{tabular}{|c|c|}
\hline Base: All Respondents 6348 & $(\%)$ \\
\hline Freedom & 42 \\
\hline Rights and law & 20 \\
\hline Government of the people & 21 \\
\hline Peace & 43 \\
\hline Prosperity & 17 \\
\hline Elections & 9 \\
\hline Womenss rights & 15 \\
\hline Communism & 1 \\
\hline Islamic democracy & 22 \\
\hline Less corruption & 16 \\
\hline Better government services & 10 \\
\hline Good security & 1 \\
\hline I donst want democracy & * \\
\hline Access to more schools & $*$ \\
\hline Good relations with other countries & * \\
\hline
\end{tabular}




\section{6 | Afghanistan in 2011}

\begin{tabular}{|l|c|}
\hline More job opportunities & 1 \\
\hline Removing poppy & $*$ \\
\hline Water and power supply & 2 \\
\hline Roads & $*$ \\
\hline Nothing & 2 \\
\hline Refused & $*$ \\
\hline Donst know & 1 \\
\hline
\end{tabular}

Q-63. Now switching to local government, some people say that local religious leaders should be regularly consulted on the problems facing an area while others think that politics and religion should not mix. Which is closer to your view?

\begin{tabular}{|l|c|}
\hline \multicolumn{1}{|c|}{ Base: All respondents $\mathbf{6 3 4 8}$} & $(\mathbf{0 )}$ \\
\hline Religious leaders should be consulted & 70 \\
\hline Politics and religion should not mix & 27 \\
\hline Refused & $*$ \\
\hline Don't know & 3 \\
\hline
\end{tabular}

Q-64. Lets focus on the most recent Parliamentary election. When people talk about elections, they often describe them as free and fair. By "free" they generally mean that all people had the chance to vote as they wished. By "fair" they generally mean that all candidates/parties followed the rules and were given equal access to the public and votes were counted correctly and not manipulated. Thinking about what is meant by "free" and "fair":

Do you think the past Parliamentary election was free and fair?

\begin{tabular}{|c|c|c|}
\hline & Base: All respondents 6467 & $(\%)$ \\
\hline Was free and fair & & 49 \\
\hline Was NOT free and fair & & 46 \\
\hline Refused & & $*$ \\
\hline Don't know & & 4 \\
\hline
\end{tabular}


Q-65. (Filtered. Ask if answered "was Not free and fair" in Q-64). You said that you think that the election was not free and fair. What makes you think so? (OPEN RESPONSE, Write down response and then code after field)

\begin{tabular}{|l|c|}
\hline \multicolumn{1}{|c|}{ Base: Election was not fair and free $\mathbf{2 9 4 3}$} & $\mathbf{( \% )}$ \\
\hline Buying of votes & 41 \\
\hline Cheating in the vote count & 34 \\
\hline Husbands not letting wives vote & 4 \\
\hline Men voted on behalf of women & 7 \\
\hline Intimidation against voters or party activists & 5 \\
\hline Finding out for whom people voted without their saying & 2 \\
\hline Fraud in the election in general & 3 \\
\hline Delay in the election results & $*$ \\
\hline Foreign interference & $*$ \\
\hline There have been no elections & $*$ \\
\hline Other & $*$ \\
\hline Refused & $*$ \\
\hline Don't know & 3 \\
\hline
\end{tabular}

Q-66. (Ask All) In your opinion, who is running election in Afghanistan? (Single response)

Base: All Respondents 6348

Independent Election Commission

Government

International community

Special court

Other

Refused

Donst know

People themselves 
Q-67. Now, to change the subject. Sometimes people and communities have problems, related to an issue that concerns everybody in their area, that they can't resolve on their own and so they have to ask for the help of a government or a non-government person, group or agency. In the past 1 year, has your community had such a problem in your area that you had to ask for help or cooperation to resolve it?

\begin{tabular}{|c|c|}
\hline Base: All respondents 6467 & $(\%)$ \\
\hline Yes & 25 \\
\hline No & 73 \\
\hline Refused & $*$ \\
\hline Don't know & 2 \\
\hline
\end{tabular}

Q-68. (Filtered. Ask if answered 'Yes' in Q-67): What kind of problem was/is that? (Open-ended. Write down first mentioned answer)

\begin{tabular}{|c|c|}
\hline Base: Contact Govt. or non Govt. person 1603 & $(\%)$ \\
\hline Lack of water and electricity & 18 \\
\hline Dispute over land & 21 \\
\hline Building mosque & $*$ \\
\hline Reconstruction of roads and bridges & 7 \\
\hline Building clinics & 2 \\
\hline Building schools and kindergartens & 4 \\
\hline Robbery and burglary & 5 \\
\hline Poor transportation system & $*$ \\
\hline Economic problems & 2 \\
\hline Unemployment & 2 \\
\hline Tribal problems & 6 \\
\hline Presence of Taliban & $*$ \\
\hline Security problems & 7 \\
\hline Agricultural problems & 1 \\
\hline Murder & 1 \\
\hline Disarmament & $*$ \\
\hline Lack of shelter & 1 \\
\hline Lack of women rights & 1 \\
\hline Business problems & 1 \\
\hline Foreign forces searching houses & 1 \\
\hline Environmental problems & 1 \\
\hline Family problems & 8 \\
\hline Problems related to Government agencies & 1 \\
\hline Moral problems & $*$ \\
\hline Building shops & 1 \\
\hline
\end{tabular}




\begin{tabular}{|l|c|}
\hline Legal disputes & 5 \\
\hline Natural disaster & $*$ \\
\hline Bribe & 1 \\
\hline Traffic accidents & $*$ \\
\hline Obtaining official government documents & $*$ \\
\hline Garbage collection & $*$ \\
\hline Kidnapping & $*$ \\
\hline Poppy cultivation & $*$ \\
\hline Refused & $*$ \\
\hline Don't know & 2 \\
\hline
\end{tabular}

Q-69. (Filtered. Ask if answered 'Yes' in Q-67): Who did you approach/ask to solve the problem? (Up to Three Responses) [Do Not Read List, Write Answer Then Code Response]

Q58a. First Response:

Q58b. Second Response:

Q58c. Third Response:

Base: Contacted Govt. or non Govt. person 1396

Cumulative(a-c)

$(\%)$

Elders of the local shura/jirga

A Member of Parliament

Government agency/office

Afghan National Army

Afghan National Police

Malik / Khan

Provincial governor/ authorities

Community Development Council

District authorities

PRT

NGO

Human Rights Commission

Foreign forces

Mullah

Municipality

Friends and family

Taliban

National Solidarity Program

Don't know
66 
Q-70.(Filtered. Ask if contacted Government agency/office, in Q-69 a-c): You said you contacted a government agency/office to resolve your problem. Which government agency/office is that? (Open-ended. Write down first mentioned answer)

\begin{tabular}{|c|c|}
\hline Base: Contacted Govt. agency/office 270 & $(\%)$ \\
\hline District Governor & 24 \\
\hline Directors in MRRD & 5 \\
\hline Courts & 24 \\
\hline Ministry of Public Health & 1 \\
\hline Parliament & * \\
\hline Ministry of Education & 3 \\
\hline Municipality & 5 \\
\hline Directorate of Water and Power & 5 \\
\hline Local Shuras & 2 \\
\hline Foreign forces & * \\
\hline Police & 5 \\
\hline Provincial authorities & 7 \\
\hline Directorate of agriculture & 1 \\
\hline Human rights independent commission & 2 \\
\hline Traffic department & 1 \\
\hline Attorney general & 1 \\
\hline Directorate of pilgrimage & * \\
\hline CARE International & * \\
\hline National Soliderity Progrm & * \\
\hline Don't know & 12 \\
\hline
\end{tabular}

Q-71. (Filtered. Ask if answered 'Yes' to Q-67) Has this problem been resolved or it's still pending resolution?

\begin{tabular}{|c|c|}
\hline Base: Contacted Govt. or non Govt. person 1603 & $(\%)$ \\
\hline Resolved & 56 \\
\hline Pending resolution & 36 \\
\hline Don't know & 7 \\
\hline
\end{tabular}


Q-72. (Filtered is 'Resolved' in Q-71) How long did it take to resolve?

\begin{tabular}{|c|c|}
\hline Base: Resolved 902 & $(\%)$ \\
\hline One day & 7 \\
\hline One week & 28 \\
\hline One month & 29 \\
\hline More than three months & 18 \\
\hline More than six months & 10 \\
\hline More than one year & 7 \\
\hline Donst know (vol.) & 1 \\
\hline
\end{tabular}

Q-73. (ASK ALL) In the past two years have you had a dispute or a formal case that you couldn't settle with the other party and had to go to a State Court or village/neighborhood based Shura/Jirga to resolve it?

\begin{tabular}{|c|c|}
\hline Base: All respondents 6348 & $(\%)$ \\
\hline Yes & 20 \\
\hline No & 80 \\
\hline Refused & $*$ \\
\hline Don't know & $*$ \\
\hline
\end{tabular}

Q-74. (Filtered. Ask all with case or dispute, answer 'yes' in Q-73) What kind of a case or dispute was it? (If More Than One Case or Dispute, Ask For the Most Recent One)

\begin{tabular}{|l|c|}
\hline \multicolumn{1}{|c|}{ Base: Those with case or dispute $\mathbf{1 2 5 0}$} & $\mathbf{( \% )}$ \\
\hline Dispute over land & 59 \\
\hline Other property dispute, not land & 9 \\
\hline Commercial dispute & 8 \\
\hline Divorce & 3 \\
\hline Pick-pocketing & 1 \\
\hline Robbery / burglary & 8 \\
\hline Physical assault & 8 \\
\hline Murder & 3 \\
\hline Family problems & $*$ \\
\hline Dispute over land & $*$ \\
\hline Traffic accident & $*$ \\
\hline Other & $*$ \\
\hline Donst Know & 1 \\
\hline
\end{tabular}


Q-75. (Filtered. If answered 'Yes' to Q-73) Where have you taken this case or dispute?

Base: Those with case or dispute 1250

\begin{tabular}{|l|c|}
\hline State Court & 41 \\
\hline Village, neighborhood based Shura/Jirga & 43 \\
\hline Both & 12 \\
\hline Other & $*$ \\
\hline Refused & $*$ \\
\hline Donst Know & 4 \\
\hline
\end{tabular}

Q-76. (Filtered. If answered 'State Court', code 1, or 'Both', code '6' in Q-75) When taking a case to a State Court or being a party in settling case in a State Court, have you used any professional legal services (from a lawyer) or you pleaded your case alone or helped by friends/relatives?

\begin{tabular}{|l|c|}
\hline \multicolumn{1}{|c|}{ Base: State Court or Both $\mathbf{6 6 4}$} & $\mathbf{( \% )}$ \\
\hline Professional legal services & 42 \\
\hline Alone/ helped by friends, relatives & 43 \\
\hline Both & 12 \\
\hline Donst Know & 3 \\
\hline
\end{tabular}

Q-77. (Filtered, Ask if answered '2' VILLAGE, NEIGHBORHOOD BASED SHURA/JIRGA in Q-75) What made you decide to take your dispute to the Shura/Jirga vs State Court? (Open ended question, write down reason.)

\begin{tabular}{|l|c|}
\hline \multicolumn{1}{|c|}{ Base: Contacted village/neighborhood Shura/Jirga $\mathbf{5 3 7}$} & $\mathbf{( \% )}$ \\
\hline Because local Shuras are honest & 16 \\
\hline Are not related to the courts & 6 \\
\hline Security problems & 3 \\
\hline Land dispute & 1 \\
\hline Corruption in government courts & 21 \\
\hline Resolve disputes efficiently & 26 \\
\hline Decisions of Shuras are based on Islamic laws & 1 \\
\hline Local elders are members of the Shura & 10 \\
\hline No government courts in the area & 4 \\
\hline My family and friends recommended it & 1 \\
\hline Refused & $*$ \\
\hline Don't know & 12 \\
\hline
\end{tabular}


Q-78. (ASK ALL) How satisfied you are with the available disputes resolution mechanisms/services in your area?

\begin{tabular}{|c|c|}
\hline Base: All respondents 6348 & $(\%)$ \\
\hline Very satisfied & 25 \\
\hline Somewhat satisfied & 50 \\
\hline Somewhat not satisfied & 16 \\
\hline Not satisfied & 5 \\
\hline Refused & $*$ \\
\hline Don't know & 3 \\
\hline
\end{tabular}

Q-79. (ASK ALL) Tell me, do you strongly agree, agree somewhat, disagree somewhat, or strongly disagree with the following statements about State Courts?

\section{Base: All respondents 6348}

\begin{tabular}{|c|c|c|c|c|c|}
\hline SA & AS & DS & SD & Ref & DK \\
\hline $\mathbf{( \% )}$ & $\mathbf{( \% )}$ & $\mathbf{( \% )}$ & $\mathbf{( \% )}$ & $\mathbf{( \% )}$ & $\mathbf{( \% )}$ \\
\hline 33 & 45 & 16 & 6 & $*$ & $*$ \\
\hline 16 & 43 & 29 & 11 & $*$ & 2 \\
\hline 17 & 39 & 29 & 12 & $*$ & 2 \\
\hline 17 & 40 & 29 & 12 & $*$ & 1 \\
\hline 19 & 39 & 27 & 12 & $*$ & 2 \\
\hline 13 & 34 & 32 & 19 & $*$ & 2 \\
\hline 23 & 39 & 23 & 11 & $*$ & 3 \\
\hline
\end{tabular}

Q-80. And now let's turn to village/neighborhood based Jirgas/ Shura, Tell me do you strongly agree, agree somewhat, disagree somewhat, or strongly disagree with the following statements about the village/neighborhood based Jirgas/ Shuras?

\begin{tabular}{|l|c|c|c|c|c|c|}
\hline \multicolumn{1}{|c|}{ Base: All respondents $\mathbf{6 3 4 8}$} & SA & AS & DS & SD & Ref & DK \\
\hline & $\mathbf{( \% )}$ & $\mathbf{( \% )}$ & $\mathbf{( \% )}$ & $\mathbf{( \% )}$ & $\mathbf{( \% )}$ & $\mathbf{( \% )}$ \\
\hline a) Local jirgas, shuras are accessible to me & 48 & 39 & 10 & 3 & $*$ & 1 \\
\hline b) Local jirgas, shuras are fair and trusted & 33 & 46 & 16 & 4 & $*$ & 1 \\
\hline $\begin{array}{l}\text { c) Local jirgas, shuras follow the local norms and values of } \\
\text { our people }\end{array}$ & 33 & 44 & 18 & 4 & $*$ & 1 \\
\hline d) Local jirgas, shuras are effective at delivering justice & 33 & 42 & 19 & 4 & $*$ & 1 \\
\hline e) Local jirgas, shuras resolve cases timely and promptly & 29 & 44 & 20 & 5 & $*$ & 1 \\
\hline f) Local jirgas, shuras should include women as members & 32 & 40 & 18 & 8 & $*$ & 2 \\
\hline
\end{tabular}




\section{4 | Afghanistan in 2011}

Q-81. (ASK ALL) Now let's talk specifically about women related issues. What is the biggest problem facing women in this area today? (Code in the first column of the table below) [Do Not Read Code List]

\begin{tabular}{|c|c|}
\hline Base: All respondents 6348 & $(\%)$ \\
\hline Lack of rights / womenss rights & 15 \\
\hline Canst leave homes & 6 \\
\hline Under control of men / men have power & 6 \\
\hline Education / illiteracy & 25 \\
\hline General health care & 8 \\
\hline Pregnancy related health care & 5 \\
\hline Forced marriages/ dowry & 8 \\
\hline Domestic violence & 9 \\
\hline Poverty & 8 \\
\hline Security & 2 \\
\hline Representation in Shura/ Jirga & $*$ \\
\hline Lack of job opportunities for women & 2 \\
\hline Lack of professional courses & $*$ \\
\hline Lack of electricity and water & * \\
\hline Transportation problems & * \\
\hline Lack of Bakery for women & * \\
\hline Lack of shelter & * \\
\hline Presence of Taliban & * \\
\hline Government not paying attention to women & * \\
\hline Cultural problems & $*$ \\
\hline Freedom and democracy & * \\
\hline Lack of public baths & * \\
\hline Other & * \\
\hline Women have no problems & 5 \\
\hline Refused & * \\
\hline Donst know & 1 \\
\hline
\end{tabular}

Q-82a. Is there in your area an organization, institution, or authority, where women can go to have their problem(s) resolved?

\begin{tabular}{|c|c|}
\hline Base: All respondents 6348 & $(\%)$ \\
\hline Yes & 19 \\
\hline No & 77 \\
\hline Refused & $*$ \\
\hline Don't know & 4 \\
\hline
\end{tabular}


Q-82b. (Filtered, if answered "yes" in Q-82a) What organization, institution or authority is that?

\section{Base: Those saying there is an organization 1228}

Directorate of women affairs

The court

District office 12

Police

Government organizations in general

Attorney general

National solidarity program

Provincial office

Municipality

Balkh girls union

Human rights office

WASA organization

Women capacity building literacy organization

Agha Khan foundation

Neda-e-Zan organization

UNICEF

HABITAT

IRD

MRCECO

PRT

CARE

Red Crescent Society

Swedish organization

Village Shura/Elders Shura

Women's Shura

Religious Ulema

Refused

Don't know 
Q-83. (ASK ALL) Some people say that women should have equal opportunities like men in education. Do you agree or disagree with this opinion? (Wait for response and then ask): Strongly or somewhat?

\begin{tabular}{|c|c|}
\hline Base: All respondents 6348 & $(\%)$ \\
\hline Strongly Agree & 50 \\
\hline Agree somewhat & 35 \\
\hline Disagree somewhat & 9 \\
\hline Strongly Disagree & 5 \\
\hline Refused & * \\
\hline Don't know & 1 \\
\hline
\end{tabular}

Q-84. Some people say that women should be allowed to work outside the home. What is your opinion about this?

\section{Base: All respondents 6348}

Women should be allowed to work outside the home

Women should not be allowed to work outside the home

Refused

Don't know

Q-85. (ASK ALL) Do you think that political leadership positions should be mostly for men, mostly for women, or do you think that both men and women should have equal representation in the political leadership?

\begin{tabular}{|c|c|}
\hline & $(\%)$ \\
\hline Mostly for men & 44 \\
\hline Mostly for women & 10 \\
\hline Equal for both men and women & 45 \\
\hline Other & * \\
\hline Refused & * \\
\hline Don't know & 1 \\
\hline
\end{tabular}

Q-70. Are you opposed to a woman representing you in the following organizations?

\begin{tabular}{|l|c|c|c|c|}
\hline \multicolumn{1}{|c|}{ Base: All respondents $\mathbf{6 4 6 7}$} & Yes & No & Ref. & DK \\
\hline & $\mathbf{( \% )}$ & $\mathbf{( \% )}$ & $\mathbf{( \% )}$ & $\mathbf{( \% )}$ \\
\hline a) In National Parliament & 45 & 54 & $*$ & 1 \\
\hline b) In your Provincial Council & 41 & 58 & $*$ & 1 \\
\hline c) In your Community Development Councils & 38 & 60 & $*$ & 1 \\
\hline d) In your District Development Assembly & 37 & 61 & $*$ & 2 \\
\hline e) In your local Shura or Jirga & 37 & 61 & $*$ & 2 \\
\hline
\end{tabular}


Q-87. If women vote, do you think that women should decide for themselves or should they receive advice from men?

\begin{tabular}{|l|c|}
\multicolumn{1}{|c|}{ Base: All Respondents $\mathbf{6 3 4 8}$} & $\mathbf{( \% )}$ \\
\hline Women should decide for themselves & 51 \\
\hline Men should advise them & 28 \\
\hline Women should decide for themselves but in consultation with men & 21 \\
\hline Refused & $*$ \\
\hline Donst know & 1
\end{tabular}

Q-88. In the election, everyone must vote for themselves. Men cannot vote in place of women. Women must vote for themselves. What do you think about this statement? Do you agree or disagree? (Wait for response and then ask): Strongly or somewhat?

\begin{tabular}{|c|c|}
\hline \multicolumn{2}{|c|}{ Base: All respondents 6348} \\
\hline Strongly Agree & 52 \\
\hline Agree somewhat & 33 \\
\hline Disagree somewhat & 7 \\
\hline Strongly Disagree & 4 \\
\hline Refused & * \\
\hline Don't know & 4 \\
\hline
\end{tabular}

\section{DEMOGRAPHICS}

\section{D-1. Gender}

\begin{tabular}{|c|c|c|}
\hline & Base: All respondents 6348 & $(\%)$ \\
\hline Male & & 57 \\
\hline Female & 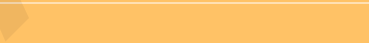 & 43 \\
\hline
\end{tabular}

D-2. (Ask All) How old were you on your last birthday? (Record actual age; if respondent refuses, please estimate)

\begin{tabular}{|c|c|}
\hline Base: All respondents 6348 & $(\%)$ \\
\hline 18-24 Years old & 25 \\
\hline 25-34 Years old & 26 \\
\hline 35-44 Years old & 21 \\
\hline 45-54 Years old & 16 \\
\hline Over 65 years & 6 \\
\hline
\end{tabular}


D-3. Are you now working, a housewife (ask only women), retired, a student, or looking for work?

\begin{tabular}{|c|c|}
\hline Base: All respondents 6348 & $(\%)$ \\
\hline Working & 47 \\
\hline Retired & 2 \\
\hline Housewife & 37 \\
\hline Student & 7 \\
\hline Unemployed & 7 \\
\hline Other & * \\
\hline Refused & $*$ \\
\hline Don't know & * \\
\hline
\end{tabular}

D-4. (Filtered. Ask if working or retired): What is your main occupation? (Write down and then code. If retired, ask for previous occupation and then code)

\begin{tabular}{|c|c|}
\hline Base: Working or retired 3084 & $(\%)$ \\
\hline Farmer (own land / tenant farmer) & 35 \\
\hline Farm laborer (othens land) & 12 \\
\hline Laborer, domestic, or unskilled worker & 8 \\
\hline Informal sales/ business & 7 \\
\hline Skilled worker/artisan & 13 \\
\hline Government Office - Clerical worker & 3 \\
\hline Private Office - Clerical worker & 1 \\
\hline Government Office - Executive/ Manager & 2 \\
\hline Private Office - Executive/ Manager & 1 \\
\hline Self employed Professional & 4 \\
\hline Small business owner & 6 \\
\hline School Teacher & 5 \\
\hline University Teacher & $*$ \\
\hline Military/ Police & 2 \\
\hline Mullah & $*$ \\
\hline Refused & $*$ \\
\hline Don't know & 1 \\
\hline
\end{tabular}


D-5. (Filtered. Ask if "Farmer in D-4) How much land do you farm?

\begin{tabular}{|c|c|}
\hline Base: Farmers 1080 & $(\%)$ \\
\hline Less than 1 Jerib & 10 \\
\hline 1 - 2 Jerib & 26 \\
\hline 2.1- 3 Jerib & 27 \\
\hline More than 3 Jerib & 35 \\
\hline Not asked & 1 \\
\hline Don't know & 2 \\
\hline
\end{tabular}

D-6. (ASK ALL) What is the highest level of school you completed? (Write down response and code)

\begin{tabular}{|l|c|}
\hline \multicolumn{1}{|c|}{ Base: All respondents $\mathbf{6 3 4 8}$} & $\mathbf{( \% )}$ \\
\hline Never went to school & 58 \\
\hline Primary School, incomplete (classes 1 to 5) & 9 \\
\hline Primary School, complete (finished class 6) & 6 \\
\hline Secondary education, incomplete (classes 7 to 8) & 6 \\
\hline Secondary education, complete (finished class 9) & 4 \\
\hline High School (classes 10 to 12) & 13 \\
\hline University education or above & 5 \\
\hline Refused & $*$ \\
\hline Don't know & $*$ \\
\hline
\end{tabular}

D-7. Tell me, if given opportunity, would leave Afghanistan and live somewhere else, or not?

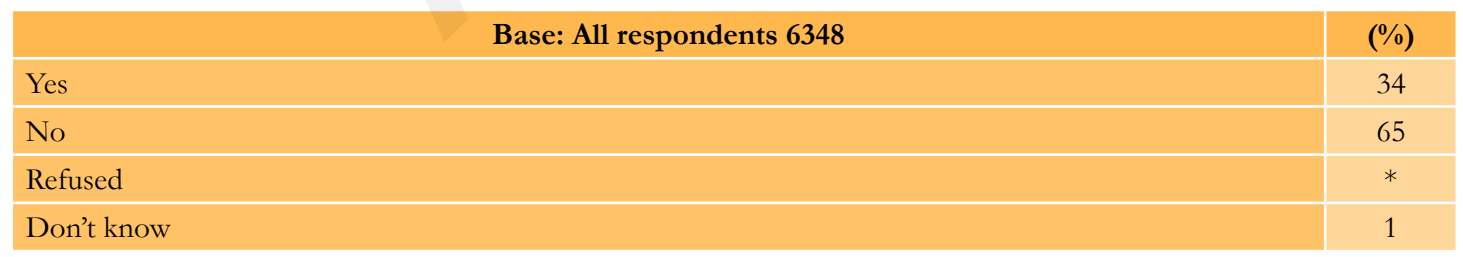




\section{0 | Afghanistan in 2011}

D-8. Which languages can you speak? (Multiple response. Code each mentioned)

\begin{tabular}{|c|c|}
\hline Base: All respondents 6348 & $(\%)$ \\
\hline Pashto & 49 \\
\hline Dari & 76 \\
\hline Uzbeki & 11 \\
\hline Turki & 2 \\
\hline Urdu & 2 \\
\hline Hindi & * \\
\hline English & 4 \\
\hline Arabic & 1 \\
\hline Russian & $*$ \\
\hline Balochi & 1 \\
\hline Pashaye & * \\
\hline Nooristani & * \\
\hline German & $*$ \\
\hline
\end{tabular}

D-9. Are you married or single?

\begin{tabular}{|c|c|}
\hline & $(\%)$ \\
\hline Single & 19 \\
\hline Married & 80 \\
\hline Widower/ Widow & 2 \\
\hline Refused & * \\
\hline Don't know & $*$ \\
\hline
\end{tabular}


D-10. Which ethnic group do you belong to? SINGLE RESPONSE ONLY

\begin{tabular}{|c|c|}
\hline Base: All respondents 6348 & $(\%)$ \\
\hline Pashtun & 41 \\
\hline Tajik & 32 \\
\hline Uzbek & 9 \\
\hline Hazara & 11 \\
\hline Turkmen & 2 \\
\hline Baloch & 1 \\
\hline Kirghiz & $*$ \\
\hline Nuristani & 1 \\
\hline Aimak & 1 \\
\hline Arab & 1 \\
\hline Pashaye & * \\
\hline Sadat & 1 \\
\hline Qazelbash & * \\
\hline
\end{tabular}

D-11. (Ask All) How many people live here at this address? (Record Number Below)

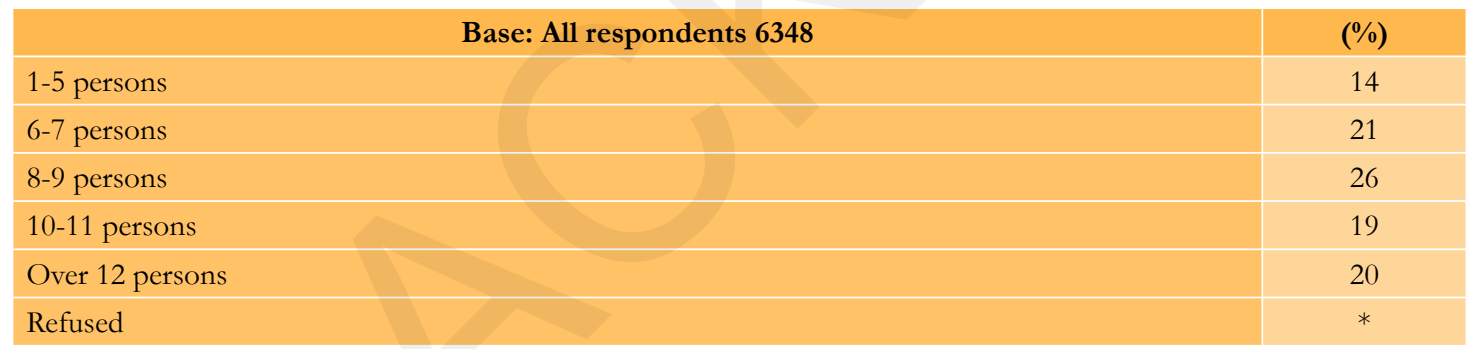

D-12. (ASK ABOUT BOTH MALES AND FEMALES) Would you tell me how many men/women are there in your household and how old is each of them? [INTERVIEWER: Write number of people for each category]

D-13a. For statistical purposes only, we need to know your average monthly household income. Will you please tell me which of the following categories best represents your average total family monthly income? (Show Card and read out) 


\section{2| Afghanistan in 2011}

\begin{tabular}{|c|c|}
\hline Base: All 6348 & $(\%)$ \\
\hline Less than 2,000 Afs & 9 \\
\hline $2,001-3,000$ Afs & 17 \\
\hline $3,001-5,000$ Afs & 18 \\
\hline $5,001-10,000 \mathrm{Afs}$ & 31 \\
\hline $10,001-15,000$ Afs & 12 \\
\hline $15,001-20,000$ Afs & 7 \\
\hline $20,001-25,000$ Afs & 2 \\
\hline $25,001-40,000$ Afs & 1 \\
\hline more then 40,000 Afs & $*$ \\
\hline Refused & $*$ \\
\hline Don't know & 1 \\
\hline
\end{tabular}

D-13b. Do female members of the family contribute to this household income?

\begin{tabular}{|c|c|c|}
\hline & Base: All respondents 6348 & $(\%)$ \\
\hline Yes & & 17 \\
\hline No & s & 83 \\
\hline Refused & & $*$ \\
\hline Don't know & $x_{2}+y^{2}$ & * \\
\hline
\end{tabular}

D-13c. [ASK IF YES AT D-13b] How much of your household's total income comes from female members of the household?

\begin{tabular}{|l|c|}
\hline \multicolumn{1}{|c|}{ Base: Female members of the family contributes to Household income $\mathbf{1 0 9 1}$} & $\mathbf{( \% )}$ \\
\hline Less than $25 \%$ (up to one quarter) & 66 \\
\hline Between $26 \%$ and $50 \%$ (up to one half) & 27 \\
\hline Between $51 \%$ and $75 \%$ (up to three quarters) & 5 \\
\hline Between $76 \%$ to $100 \%$ (more than three quarters) & 2 \\
\hline Refused & $*$ \\
\hline Don't know & 1 \\
\hline
\end{tabular}


D-14. (Interviewer code): Record number of people present for the interview:

\begin{tabular}{|c|c|}
\hline Base: & $(\%)$ \\
\hline Two & 39 \\
\hline Three & 42 \\
\hline Four & 15 \\
\hline Five & 3 \\
\hline Six & 1 \\
\hline Seven & * \\
\hline Eight & * \\
\hline Nine & $*$ \\
\hline Ten and more than ten & * \\
\hline
\end{tabular}

\section{RECORD THE TIME (USING 24 HOUR CLOCK) INTERVIEW WAS COMPLETED AND THE LENGTH OF THE INTERVIEW (M-15 AND M-16)}

\section{Read Closing Statement to the Respondent:}

“Thank you for participating in our survey. Do you have any questions? In the next few days my supervisor may contact you to evaluate the quality of my work and answer any other questions you may have. To help him do that, could I have your name and address?"

Respondent Information:

Interviewer Certification:
Name:

Address:

"I certify that I have completed this interview according to the instructions provided me by the Afghan Center for Socio-economic and Opinion Research.

Signed

Date 


\section{4 | Afghanistan in 2011}

D-15. (Interviewer code): Code household status. Based on your impressions from the dwelling of the household, the environment, the appearance of its members, please rate the living standard of this household:

\begin{tabular}{l|c|}
\hline \multicolumn{1}{|c|}{ Base: All respondents $\mathbf{6 3 4 8}$} & (\%) \\
\hline $\begin{array}{l}\text { The household is well-off; its standard is by all accounts well above the average } \\
\text { The household is enjoying a fair well-being, but generally, the features of luxury are missing, they } \\
\text { are not rich }\end{array}$ & 6 \\
\hline $\begin{array}{l}\text { The household is not denying itself the most important, vital goods of life, but the environment } \\
\text { bears indications of moderate existence; they can't indulge in any excesses }\end{array}$ & 24 \\
\hline $\begin{array}{l}\text { The household is not denying itself the most important, vital goods of life, but the physical } \\
\text { infrastructure of the household is in bad condition or in need of repair }\end{array}$ & 28 \\
\hline $\begin{array}{l}\text { Property-wise the household is more or less OK, but there is an apparent problem with incomes; } \\
\text { they are obviously surviving and living with difficulty }\end{array}$ & 21 \\
\hline The household bears all signs of poverty; living in misery, with privations & 8 \\
\hline
\end{tabular}

D-16. (Interviewer code): Which of the following statements do you think best describes the level of comprehension of the survey questionnaire by the respondent?

\begin{tabular}{|l|c|}
\hline \multicolumn{1}{|c|}{ Base: All respondents $\mathbf{6 3 4 8}$} & $\mathbf{( \% )}$ \\
\hline The respondent understood all of the questions & 66 \\
\hline The respondent understood most of the questions & 27 \\
\hline The respondent understood most of the questions but with some help & 7 \\
\hline The respondent had difficulty understanding most of the questions, even with help from me & 1 \\
\hline
\end{tabular}

D-17. (Interviewer code): Which of the following statements best describes the level of comfort or unease that the respondent had with the survey questionnaire?

\section{Base: All respondents 6348}

The respondent was comfortable (at ease) with the entire questionnaire

The respondent was comfortable with most of the questions

The respondent was comfortable with only some of the questions

The respondent was generally uncomfortable with the survey questionnaire 


\section{To Be Completed By The Supervisor:}

D-18. Was the interview subject to quality control/back-check?

\begin{tabular}{|c|c|}
\hline Base: All Respondents 6348 & $(\%)$ \\
\hline Yes & 39 \\
\hline 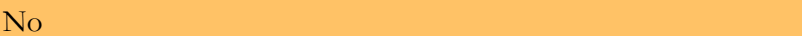 & 61 \\
\hline
\end{tabular}

D-19. Method of quality control/back-check

\begin{tabular}{|l|c|}
\hline \multicolumn{1}{|c|}{ Base: All Respondents $\mathbf{6 3 4 8}$} & $\mathbf{( \% )}$ \\
\hline Direct supervision during interview & 3 \\
\hline Back-check in person by supervisor & 29 \\
\hline Back-check from the central office & 8 \\
\hline Not applicable & 61 \\
\hline
\end{tabular}




\section{National Mood-2011}

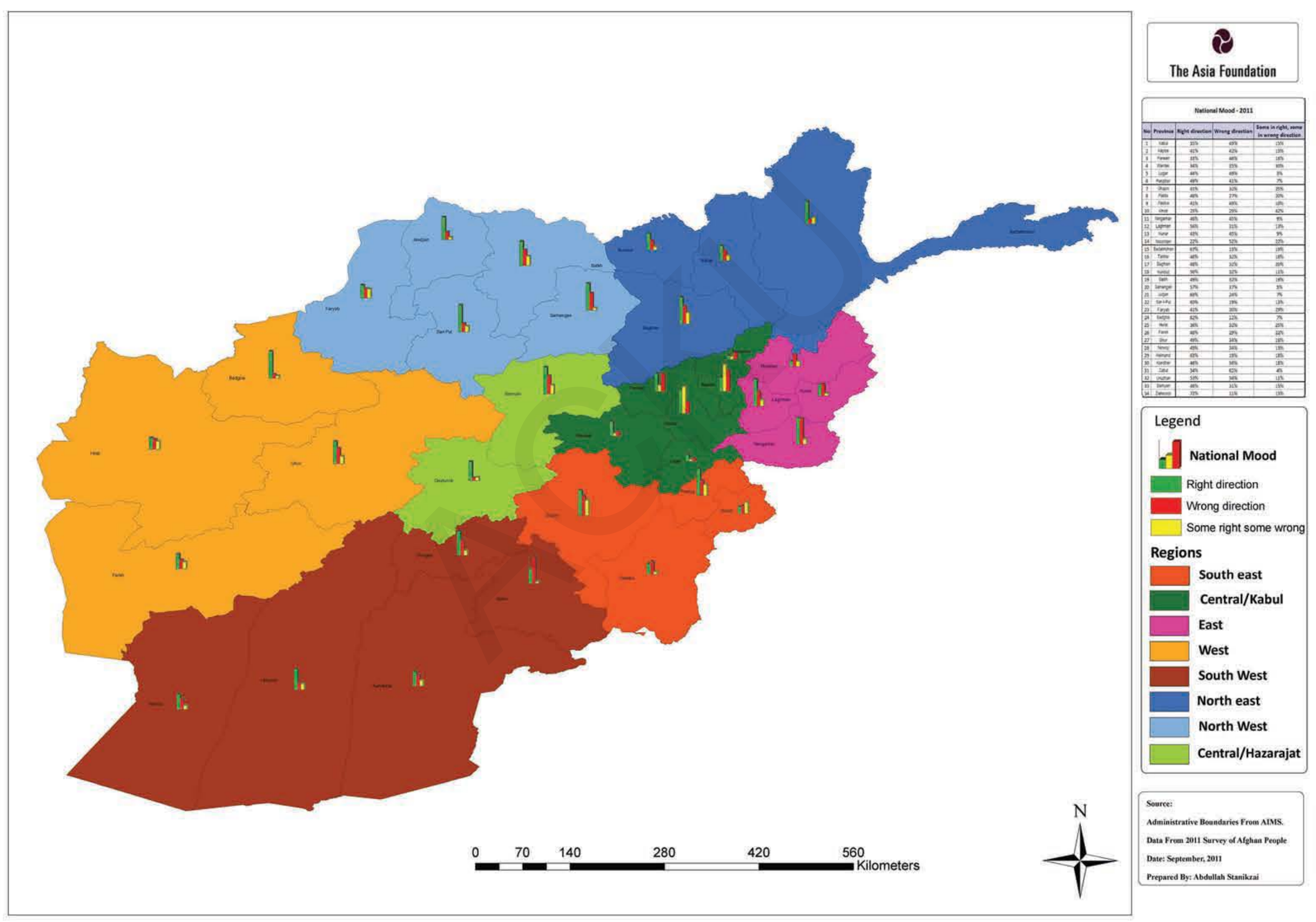


